\title{
NEW STRUCTURAL ECONOMICS FOR LESS ADVANCED COUNTRIES
}

\author{
NOWA EKONOMIA STRUKTURALNA \\ WOBEC KRA JOW MNIEJ ZAAWANSOWANYCH
}





\section{NEW STRUCTURAL ECONOMICS FOR LESS ADVANCED COUNTRIES}

Edited by: Justin Yifu Lin and Alojzy Z. Nowak

\section{NOWA EKONOMIA STRUKTURALNA WOBEC KRAJOW MNIEJ ZAAWANSOWANYCH}

Redakcja naukowa: Justin Yifu Lin i Alojzy Z. Nowak

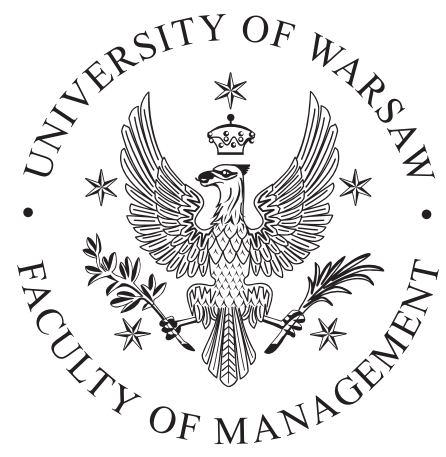


Reviewer/Recenzent: dr hab. Dariusz Milczarek, prof. UW

Centre of Europe University of Warsaw/

Centrum Europejskie Uniwersytetu Warszawskiego

Translation/Tłumaczenie: Grzegorz Grątkowski

Editorial Supervisor/Redakcja: Jerzy Jagodziński, Anita Sosnowska

Cover design/Projekt okładki: Agnieszka Miłaszewicz

(C) Copyright by Wydawnictwo Naukowe Wydziału Zarządzania Uniwersytetu Warszawskiego, Warszawa 2017

ISBN: 978-83-65402-50-9

ISBN (on-line): 978-83-65402-51-6

http://dx.doi.org/10.7172/978-83-65402-51-6.wwz.2

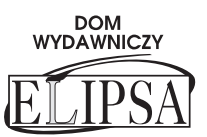

Opracowanie komputerowe, druk i oprawa:

Dom Wydawniczy ELIPSA

ul. Inflancka 15/198, 00-189 Warszawa tel./fax 2263503 01, 226351785

e-mail: elipsa@elipsa.pl,www.elipsa.pl 


\section{Table of contents}

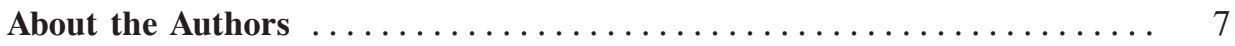

Preface (Mateusz Morawiecki) $\ldots \ldots \ldots \ldots \ldots \ldots \ldots \ldots \ldots \ldots \ldots . \ldots \ldots$

Justin Yifu Lin

New Structural Economics and industrial policies for catching-up economies ........................................ 23

Bogdan Góralczyk

Eastern-Asian development model: the growth-fostering state ......... 41

Alojzy Z. Nowak

New Structural Economics and dilemmas of the economic development . . 56

Kazimierz Ryć

The expiring real convergence process under conditions of the common market - how to counteract ........................... 69

Andrzej Sopoćko

Comparative advantage. A condition or a process? ............... 80

Grzegorz Jędrzejczak, Henryk Sterniczuk

New Structural Economics and Poland's development challenges ....... 97

\section{Marian Górski}

Macroeconomic conditions for New Structural Economics

- the case of Poland ............................... 116

Michat Kurtyka

Development of electromobility in Poland in the context of New Structural

Economics ......................................... 131

Grzegorz Tchorek

Selected development concepts and New Structural Economics.

Conclusions for electromobility in Poland ................... 147

\section{Beata Kozłowska-Chyła}

Juridical aspects of the economic position of state in the sphere

of dominium 


\section{Spis treści}

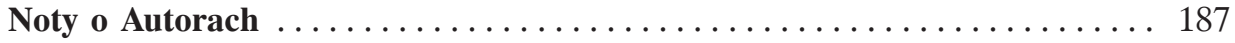

Przedmowa (Mateusz Morawiecki) .......................... 193

Justin Yifu Lin

Nowa Ekonomia Strukturalna dla gospodarek doganiajacych .......... 199

Bogdan Góralczyk

Wschodnioazjatycki model rozwojowy - państwo rozwojowe ......... 220

Alojzy Z. Nowak

Nowa Ekonomia Strukturalna a dylematy rozwoju gospodarki ......... 236

\section{Kazimierz Ryć}

Wygasanie procesu konwergencji realnej w warunkach wspólnego rynku.

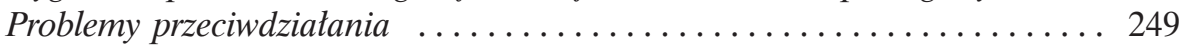

\section{Andrzej Sopoćko}

Przewaga komparatywna. Stan czy proces ..................... 259

Grzegorz Jędrzejczak, Henryk Sterniczuk

Nowa Ekonomia Strukturalna a polskie wyzwania rozwojowe ......... 275

\section{Marian Górski}

Makroekonomiczne uwarunkowania Nowej Ekonomii Strukturalnej

- przypadek Polski ......................................... 294

Michat Kurtyka

Rozwój elektromobilności w Polsce w kontekście Nowej Ekonomii

Strukturalnej ...................................... 308

Grzegorz Tchorek

Wybrane koncepcje rozwoju a Nowa Ekonomia Strukturalna.

Wnioski dla elektromobilności w Polsce ..................... 323

Beata Kozłowska-Chyła

Jurydyczne aspekty gospodarczej pozycji państwa w sferze dominium .... 345 


\section{About the Authors}

Bogdan Góralczyk - Professor in the Centre for Europe, University of Warsaw; an expert in political science and a sinologist. Former head of the Political Cabinet of the Minister of Foreign Affairs (2001-2003) and a diplomat for many years; in the years 2003-2008 Ambassador of the Republic of Poland in Thailand, Philippines and the Union of Myanmar (formerly Burma). Since 1 September 2016 Director of the Centre for Europe at the University of Warsaw. Regular commentator on TVN24 channel Biznes $i$ Świat (Business and the World) and of the Institute for Citizenship; frequent guest on TOK FM radio. Publishes, e.g., in the portal of the National Bank of Poland "Obserwator Finansowy" and at wp.pl. Author of many books and articles about China and Asia, global problems and about Hungary, such as Zmierzch i brzask. Notes z Bangkoku (Dusk and Dawn. Notes from Bangkok), Toruń 2009/2010; Chiński Feniks. Paradoksy wschodzacego mocarstwa (Chinese Phoenix. Paradoxes of the Rising Power), Warsaw 2010; Ztota Ziemia roni tzy. Esej birmański (Golden Land Sheds Tears. An Essay in Burma), Warsaw 2011; Przebudzenie smoka. Powrót Chin na scene globalna (The Dragon Awakens. China's Return to the Global Scene), Warsaw 2012; Sun Yat-sen. Misjonarz rewolucji (Sun Yat-sen. The Revolution Missionary), Warsaw 2013. Editor and co-author of the following volumes: PolskaChiny. Wczoraj, dziś, jutro (Poland-China. Yesterday, Today, Tomorrow), Torun 2010 (English version 2014); Unia Europejska jako aktor na scenie globalnej. Razem czy osobno? (European Union as an Actor in the Global Scene. Together or Apart?), Warsaw 2014 (extended English version under preparation) and European Union in the Global Scene: United or Irrelevant?, Warsaw 2015.

Lectures in Poland and abroad. Specialises in global and Asian issues (China, Burma-Myanmar, Thailand, and the Philippines), although his scope of interest also includes issues concerning the Diplomatic Protocol and cultural differences (naturally stemming from many years of his diplomatic experience and long periods spent abroad).

Marian Górski - Professor of economics; head of the Faculty of Financial Systems and of the Academic Unit for Banking and Financial Markets in the Faculty of Management, University of Warsaw. Specialised in finance, banking, macroeconomics, monetary policy. Author and co-author of many monographs and scholar articles. His academic manual entitled System Finansowy Gospodarki (Financial System in the Economy) has had three editions so far (2007; 2009; 2013). In the years 1990-1996 the Dean of the Faculty of Management, University of 
Warsaw. At present, member of the Senate of the University of Warsaw, president of the Senate Committee for budget and finance.

He has been, both in the past and at present, involved in the economic practice. In the years 1991-2005 member and president of the supervisory board of one of Poland's larger banks - BZWBK S.A. As a partner in the consulting company Premium-econ in the years 1991-2003 he advised the Minister of the State Treasury and the Minister of Economy, among others. At present member of the Council for WIBID and WIBOR reference rates which supervises the market of inter-bank deposits in Poland.

Grzegorz Jędrzejczak - doctor with a post-doctoral degree, Professor at the University of Warsaw. In the years 1989-1991 Undersecretary of State in the Ministry of Ownership Transformations responsible for the creation of the Polish capital market. In the years 1993-2013 employed in the World Bank in Washington, DC, in the Department of Private Sector Development and the Financial System of Europe and Central Asia and a representative of the World Bank in Ukraine and Azerbaijan. Member of the Supervisory Board of Polish Foundation for Management Research and IBD Business School.

Since the 1980s successfully combines scholar interests with practical activities. Areas of his interests include privatisation, the creation of regulated capital markets, the emergence of corporate culture in Poland and other countries under transformation from centrally-planned to a market economy. Important fields of his practical and analytical activities include development programmes in developing countries and the potential for support from international organisations, with particular emphasis upon the World Bank. At present specialised in issues concerning conditions for the economic policy which promotes innovativeness in middle-income countries and analyses of long-term opportunities and threats to Polish economy.

Beata Kozłowska-Chyła - doctor with a post-doctoral degree in legal science; associate professor in the Faculty of Law and Administration, University of Warsaw in the Institute of Civil Law, the Unit of Commercial Law; lecturer in the Faculty of Economic Sciences, University of Warsaw. Solicitor specialised in commercial affairs. Member of managing and supervisory boards in large joint stock companies, including companies with the State Treasury shareholding. Arbitrator recommended to the Court of Arbitration at the National Chamber of Commerce in Warsaw.

Author of many scholar publications in the fields of company law, securities law, issues of ownership transformations, privatisation of enterprises, and insurance law, e.g. Reprezentacja spótki kapitałowej w organizacji (Representation of Corporations in an Organisation), Warsaw 2015; Komentarz do Ustawy o działalności ubezpieczeniowej $i$ reasekuracyjnej (Commentary to the Insurance and Reinsurance Activities Act) (co-author), Warsaw 2017; Nowe regulacje zasad zarzadzania mieniem państwowym w zakresie powotywania i odwotywania członków organów nadzorczego i zarządzającego 
w spótkach z udziatem Skarbu Państwa (New Regulations Concerning the Principles of Management of the State Property in the Area of Appointment and Dismissal of Members of Supervisory and Managing Bodies in Companies with the State Treasury Shareholding), PUG 2/2017; Wyzwania globalizacji dla rynku ubezpieczeń (Challenges of Globalisation to the Insurance Market) (co-author), Warsaw 2016; Postępowanie administracyjne $w$ sprawie zezwolenia na wykonywanie działalności ubezpieczeniowej $i$ reasekuracyjnej - wybrane aspekty (Administrative Proceeding on the Approval for Performance of Insurance and Reinsurance Activities - Selected Aspects) (co-author), Wiadomości Ubezpieczeniowe 2/2016; Jurydyczna koncepcja podmiotowości spótki partnerskiej a status prawny jej zarzadu (Juridical Concept of Legal Personality of a Partnership and the Legal Status of its Management), Forum Prawnicze 2/2015; Zdolność prawna handlowych spótek osobowych na przyktadzie spótki partnerskiej (Legal capability of private companies based on a partner company) Forum Prawnicze 3/2015; Nieformalny zarząd spótki partnerskiej (Informal Board of Management in a Partnership), PUG 5/2015; Tryb wytaniania zarząu w spótkach zależnych od spótek Skarbu Państwa (The Procedure of Appointing the Board of Management in Companies Subsidiary to Companies of the State Treasury), Wrocław 2015; Petnomocnik w obrocie wekslowym - uwagi na tle art. 8 Prawa wekslowego (A Proxy in Bills of Exchange Trade), PUG 9/2015; Status prawny zawieszonego członka zarządu spótki akcyjnej oraz wptyw zawieszenia na strukture organizacyjna zarzadu (Legal Status of a Suspended Member of the Board of Management of a Joint-Stock Company and the Impact of Suspension Upon Changes in the Board of Management Organisational Structure), PPH 5/2015.

Michał Kurtyka - graduate of prestigious Ecole Polytechnique in Paris where he obtained the degree of engineer in 1996. Scholar in the field of quantum optics in the National Institute of Standards and Technologies near Washington (DC) where he worked under tutorship of the Nobel Prize winner in physics, William D. Phillips (who was also the promoter of Kurtyka's dissertation concerning the conditions for the formation of Bose-Einstein condensate). During his studies he was also specialised in economy, with particular emphasis upon market organisation - studies under tutorship of Professor Jean Tirole, Nobel Prize winner in economy (2014). In the area of international economy he studied in Louvain La Neuve University and obtained the master degree in Warsaw School of Economics.

Employed in the Office of the Committee for European Integration where he headed an analytical team supporting the process of negotiation on the accession to the European Union in the team of the Chief Negotiator Jan Kułakowski; directly involved in the area of transport and energy. As an advisor he co-managed projects of modernisation of Poland's largest companies and supported their adaptation to challenges of the European market. Promoter of European cooperation in the area of industrial transformation and adaptation of European industry to challenges of 
globalisation, in collaboration with European Labour University and the Dublin Foundation.

He made his doctoral defence at the University of Warsaw. Lecturer in the management of change, economy, market organisation and industrial strategy in the University of Warsaw, Collegium Civitas, Oxford Programme On Modern Poland. Co-author of the concept or implementing effective changes in an enterprise, described in the book Zarzadzanie zmiana. Od strategii do dziatania (Managing the Change: From Strategy to Action); author of the book Od restrukturyzacji do modernizacji. Opóźniona transformacja polskiego sektora elektroenergetycznego w latach 1990-2009 (From Restructuring to Modernisation. Delayed Transformation of Polish Electric Power Sector in the Years 1990-2009).

Author of the governmental programme for development of electromobility in Poland, described for the first time as concept in the book he co-wrote with Professor Leszek Jesień, New Electricity and New Cars (2013/2015), and then in the form of a document adopted by the Council of Ministers in March 2017 and entitled Plan Rozwoju Elektromobilności (Electromobility Development Plan).

Justin Yifu Lin - Professor, director of Center for New Structural Economics and honourable Dean of National School of Development at Peking University. In 1986 obtained Ph.D. in economics at the University of Chicago and in 1987 returned to China. For fifteen years performed the function of director-founder of the China Centre for Economic Research at Peking University where also worked as Professor. In the years 2008-2012 he held the office of the chief economist and Senior VicePresident of the World Bank being the first economist from any developing country to hold this office.

Corresponding fellow of the British Academy, fellow of the Academy of Sciences for the Developing World; doctor honoris causa of the Universite d'Auvergne, Fordham University, Nottingham University, City University of Hong Kong, London School of Economics, Hong Kong University of Science and Technology, University of British Colombia, Katholieke Universiteit Leuven, Open University of Hong Kong and Macao University of Science and Technology.

Author of twenty five books, including Economic Development and Transition: Thought, Strategy and Viability (2009); Demystifying the Chinese Economy (2011); New Structural Economics: A Framework for Rethinking Development and Policy (2012); The Quest for Prosperity: How Developing Countries Can Take Off (2012); Against the Consensus. Reflections on the Great Recession (2013); Going Beyond Aids: Development Cooperation for Structural Transformation (2017); Beating the Odds: Jumpstarting Developing Countries (2017).

His stimulating works inspire scholars, students, decision-makers and anybody interested in the global economy. 
Mateusz Morawiecki - On November 16, 2015, Mateusz Morawiecki was appointed to the position of the Deputy Prime Minister and the Minister of Development, and on September 28, 2016, to that of the Deputy Prime Minister, Minister of Development and Minister of Finance.

In 1998 M. Morawiecki performed the function of Deputy Director of the Department of Negotiation on the Accession in the Committee for European Integration. He was a member of the team involved in the negotiation of conditions for Poland's accession to the European Union, in the area of finance among others. Later he worked for the Bank Zachodni Group WBK (earlier with the Bank Zachodni). Since May 2007 he was the President of the Board of Management in that institution.

Mateusz Morawiecki graduated from the Faculty of History at the University of Wrocław, also completing the studies in Business Administration at Wrocław University of Science and Technology and at the Central Connecticut State University. He obtained the MBA title at Wrocław University of Economics. He is also a graduate of the University in Hamburg, University in Basel and Kellog School of Management of the Northwestern University in Evanston, USA.

His works include co-authorship of a manual in the field of the Community law and the economics of economic integration. In the years 1998-2001 he was a member of supervisory boards in the Industrial Development Agency and in Wałbrzych Energy Company. He also had a seat in Dolnośląski regional parliament during its $1^{\text {st }}$ term of office. Between 2008 and the moment of assuming the position of the Deputy Prime Minister and the Minister of Development, Morawiecki was an honorary consul of the Republic of Ireland in Poland. In 2013, he was awarded the Cross of Freedom and Solidarity and in 2015 with the Knight's Cross of the Order of Polonia Restituta.

Morawiecki speaks English and German fluently. He also communicates in Russian.

Alojzy Zbigniew Nowak - Professor of economics; graduate of SGPiS (at present, Warsaw School of Economics); in the field of economics - University of Illinois at Urbana-Champaign in the United States and Freie Universität Berlin as well as International Economics at RUCA in Antwerp; in the field of banking, finance and capital markets - Exeter University in the United Kingdom. In 1991 awarded the Rector Prize for his doctoral dissertation; in 1996 awarded the Prize of the Minister of National Education for his book entitled Banki a gospodarstwa domowe - dynamika rozwoju (Banks and Households - Dynamics of Growth).

Since 1985 employed in the Faculty of Management, University of Warsaw, where he served as the Vice-Dean for international relations and, for two terms of office, as the Dean of the Faculty. In the years 2012-2016 Vice-Rector for Research and International Relations at the University of Warsaw. At present the Dean of the Faculty of Management, University of Warsaw. 
Author of many scholar publications in Polish, English, German and Russian; laureate of many awards and prizes, member of scientific and scholar organisations and of programme councils of many magazines.

Visiting Professor in University of Cambridge; Postgraduate Business School, Grenoble, France; University of North Florida USA; Rostov University; University of North Colorado; The Catholic University of America; Freie Universität Berlin.

Kazimierz Ryć - Professor of economic sciences; employed in the Faculty of Management, University of Warsaw. Started his academic career as an assistant in the Faculty of Political Economy, headed by the prominent Polish economist Professor Oskar Lange; his doctoral dissertation was prepared under Professor Włodzimierz Brus. In the 1970s had three academic placements in France, in La Sorbonne. Co-author of the implemented concept of the popular car industry in Poland. Co-founder of the Faculty of Management, University of Warsaw - Poland's oldest - and Central and Eastern Europe's first faculty of business. Expert in the Commission for the Economic Reform; head of the Unit for Market Economy.

Vice-Dean and Dean in the Faculty of Management, University of Warsaw for many terms of office. At present lectures in macroeconomics, macroeconomic and sector-specific policy, and social policy. Tutors the procedures for doctoral degrees, involves in scholar research in two areas: macroeconomics and health care sector. Author of many publications in the field of changing consumption structure dynamics, industrial policy and problems of macroeconomic policy under conditions of supra-national integration and globalisation.

Andrzej Sopoćko - Professor since 1994 (the title awarded by the President of the Republic of Poland); employed in the Faculty of Management, University of Warsaw and in the Polish Academy of Science. One of the authors of Polish systemic transformation of the early 1990s; crucial in the process of preparation of the Anti-monopoly Act and the establishment of the Office for Competition and Consumer Protection. President of the OCCP in the years 1995-1997. Played an important role in the creation of the Warsaw Stock Exchange (initially as Member of Board, then, in the years 2003-2006, as Vice-President). Main economic advisor to the Prime Minister, Vice-Minister of Finance (in the years 2001-2003).

Author of many publications (c. 150, including 8 books). Many foreign stays and placements - three times in West Germany, three times in the USA, in Switzerland, in Russia. Awarded many awards and prizes: three times awarded by the Polish Academy of Science for the best book of the year in the field of social sciences and four times - by the Minister of Science. Raised two children and three dogs.

Henryk Sterniczuk - Professor of management and international business at the University of New Brunswick in Canada. For many years the Director of MBA at the University of New Brunswick and Professor of the Faculty of Business at the 
Pennsylvania State University in the USA. In 1990s counsellor to the Minister of Ownership Transformations and founder of the Centre for Privatisation in Poland, of the Institute for Privatisation and Management in Russia and of the International Business Institute in Ukraine, Belarus, and Kazakhstan. The President of the Supervisory Board of Polish Management Research Foundation and the President of the Scientific Council of IBD Business School.

His scholar interests also include, among other things, the social and cultural background of the process of generating innovation in post-industrial innovative societies.

Author and editor of an extensive monograph entitled Nadzór korporacyjny (Corporate Supervision) which comprehensively presents the most important issues concerning the formation, in Poland, of the principles of corporate order and best practices in companies.

Grzegorz Tchorek - doctor; associate professor in the Faculty of Management, University of Warsaw; advisor in the National Bank of Poland.

He defended his doctoral dissertation in the Faculty of Management, University of Warsaw in 2007. His thesis, entitled Teoria optymalnego obszaru walutowego a praktyka akcesyjna (The Theory of the Optimum Currency Area and the Practice of Accession) received an award from the Prime Minister in 2008.

The chief performer and co-performer of several grants implemented in the National Science Centre and in the National Bank of Poland. Author of publications in the areas of monetary integration, foreign trade, currencies exchange rates and innovativeness of enterprises.

Co-author and editor of team research projects, including the report concerning the balance of benefits and costs of the adoption of euro in Poland, prepared by the National Bank of Poland in 2009, entitled: Report on full membership of the Republic of Poland in the third stage of the Economic and Monetary Union; report concerning the assessment of competitiveness of Polish economy, prepared in 2014 (Editor-in-Chief Professor Jerzy Hausner), entitled Competitive Poland. How to Advance in Global Economic League? Recommendations and a report on the issues of innovativeness in Poland (Editors-in-Chief Professor Andrzej Sławiński and Professor Jakub Growiec) published in 2016, entitled The innovative potential of the economy: condition prospects, and of the project, implemented in the years 2012-2016, entitled The Euro introduction and competitiveness of Polish enterprises. His fields of interests include problems of European and monetary integration, international currency system, international economic relations and regional policy, and, more recently: microeconomic and sector-specific problems in the context of internationalisation of enterprises, export and direct foreign investments, competitiveness of economies and enterprise, and their innovativeness. 



\section{Preface}

After 28 years since the beginning of the systemic and economic transformation, and well over 10 years following its accession to the European Union, Poland has faced a complex challenge of having to develop consistent and comprehensive economic policy. On the one hand, such policy has to ensure the continuation of the achievements witnessed so far and enable taking advantage of them in the broadest sense. On the other hand, it has to adapt the process of the country's development to external challenges and to expectations of Polish society.

The most recent economic data indicate economic growth on a scale unprecedented in the country's history. At the end of May 2017, the rate of unemployment accounted for $7.4 \%$, i.e. the lowest in the post-1989 period. Then, a recent survey carried out by CBOS poll centre reveals that $42 \%$ of Polish people evaluate the country's current economic situation as good, this being the all-time best score. Only since the beginning of 2017, this percentage has increased by $11 \%$. Just as important is the fact that the index of financial inequalities within Polish society has finally decreased. The improvement is significant: compared to September 2015, by April 2017 the difference between the wealthiest $25 \%$ and the least well-off $25 \%$ people in Poland fell from a level of 5.9 to 4.4 !

Over the first quarter century of independence, Poland actually had no consistent economic policy. During the period before the accession to the EU, the principal purpose behind the activities undertaken was to adapt Poland's legislation and budgetary policy to requirements defined by the European Union. Then, after 2004, the country's development was largely based upon utilisation of the Community funds. Unfortunately, despite considerable efficiency with which resources earmarked to Poland were acquired (Poland managed to exploit the EU budget for the years 2007-2013 in 95\%, as shown by data made available by the European Union), these funds failed to sum up to one previously defined, overriding objective, intended to become the real vehicle driving the country's economy.

Finally, a sort of binary approach to economic theories, with total antagonism between centrally-planned and neoliberal economies, resulted in uncritical adoption, in Poland, of a development model which originated in Western European countries, with no account taken of historical and social specificity of Central and 
Eastern Europe. The fundament upon which we used to develop Polish capitalism and welfare until recently consisted of a set of rules known as the Washington Consensus. The weakness of this model was that it seriously underrated the nature - and burden, for that matter - of the post-communist reality. The classic neoliberal theory failed to really work in countries of our region, but still, it was perceived, for many years, as an inviolable axiom. In consequence, it was impossible to adapt actual needs of the country development to the policy applied.

The economic crisis of 2009 became an occasion to revise all commonly recognised economic theories. Views of such authors as Justin Yifu Lin began to gradually attract more and more attention. The effect of this shift was that any theories suggesting alleviating the edge of neoliberalism, to add elements of solidarity to it, and ideas appreciating the potential and space for a more active role of the state in the economy began to be regarded with less suspicion and more interest. Admittedly, New Structural Economics is more than just pure theory. In propagating it, Yifu Lin founds his approach upon empirical experience, also studying differences and experiences of countries which have achieved economic success without following the classic route of neoliberalism.

New Structural Economics may be described as a new economic doctrine which points out the traps faced by developing countries as they gradually approach the status of developed countries. Even more importantly, NSE indicates solutions and methods enabling middle-income countries to overcome the difficulties inherent in this specific stage of growth and to really catch up with the wealthiest countries. Polish response to that doctrine is found in the form of the Strategy for Responsible Development (SRD). This is the first document which properly considers social expectations, as well as the need to launch a new developmentfostering impulse. I believe the $21^{\text {st }}$ Century Poland should rely its existence upon a solid and sustainable economic growth achieved through re-industrialisation of the economy and healthy development of innovative small and middle-sized enterprises, accompanied by socially-sensitive and territorially balanced development, as well as upon efficient state and its institutions. All these things and intents assume an active role played by the state administration - in far-reaching opposition to laissezfaire concepts. Time has come to really appreciate the observation, presented by Professor Góralczyk, that the dogma, well-rooted in the West, about the lack of any "third way", i.e. no alternative existing for either classic capitalism or real socialism, should be overthrown as soon as possible. Yes, there is a third way. This was proven by the success of Asian tigers. Nowadays more and more Western countries attempt to benefit from that. Poland intends to become the pioneer in the field of such solutions in our region of the world. However - and just as importantly - it is not our intention to thoughtlessly emulate somebody else's solutions. Our Strategy takes complete account of Polish specific conditions and circumstances and is adapted to our needs and expectations. 
One of the most serious weaknesses of political economy in Poland after the transformation was the lack of synchronisation between the growth of GDP and the growth of wealth of all social groups in the country. The economic growth, high as it was, was not adequately experienced by families and households, thus resulting in the sense of disappointment, frustration and hostile attitudes toward political élites. It was a mistake to believe, following the statements of the Washington Consensus, that neoliberal economy would lead to alleviation of differences in the level of development. Accordingly, one should agree with the statements, put forth by Yifu Lin, where he relates per capita incomes with a stable and balanced growth. According to that theory, it is impossible for catching-up countries to really succeed, unless the entire society experiences some growth of wealth. This is why, after 25 years during which only a part of the society felt the effects of the GDP growth, the government formed by the Law and Justice party reached for social transfers unprecedented and unseen ever before. For us, it is especially important that these changes constitute no threat to the stability of public finance. What we seek to achieve, instead, is a budget which is more redistributive, but completely responsible at the same time. This way, Polish economic success is going to be truly enjoyed by the entire society.

However, the principal objective behind SRD is to reduce the differences in development through investment activity, rather than just redistribution. Small and medium-sized enterprises have the largest potential for growth. The role of the state is to provide them with the best conditions possible, to enable their healthy operation. Such an attitude may be defined as methods of state intervention which supplement the free market. In line with Professor Góralczyk's thought, we should ask ourselves a question concerning the dividing line between the state and market: how much of this and of that do we seek, and in which proportions? Of course, the state should be responsible for the careful planning of its own modernisation and for supporting a gradual, but also observable, shift toward modern technologies. Furthermore, the state should create legal provisions regulating the country's financial system and then supervise their enforcement. Justin Yifu Lin is right as he writes that large-scale infrastructural projects exceed the potential of individual companies. In this area, some form of collaboration between the state and business is necessary, with mutual autonomy being entirely retained. However, it would certainly be wrong to allow for a neoliberal vision of the state competing with the second sector. I believe there is an area for cooperation within public and private relations - a sphere in which both parties supplement each other. I would like to emphasise that as I recognise an active role of the state in the economy, at the same time I am not attributing any primary or prevalent role to it. The relationship in question is simply essential and it also benefits both sides. That's why SRD encourages to reject the stereotype of bipolarity and instead it proposes cooperation relied upon mutual trust and support. 
What should have been done while starting the pursuit aiming at catching up with developed countries was to pay attention to a serious level of social inequalities. It is never possible to build a state which is both strong and economically fair (as a deficit of either of these factors automatically undermines another and makes it wane in the long run) unless: (1) proper middle class is developed as the real fundament upon which the country and its activity relies, (2) viable and extensive home market is built, instead of increasingly expansive export, and (3) real efforts are undertaken to achieve balanced growth (both in regional and in social terms). The $500+$ programme is not only about stimulation of favourable demographic trends. It is also about eliminating extensive social stratification and real poverty in Polish families. It wouldn't be reasonable for us to expect SRD to be successful unless we first do our best to eradicate the phenomenon of the impoverishment of large social groups. And the thing which is especially significant to me: this is a programme funded thanks to the country's good economic condition - something to which labour of all Poles had contributed in the first place. From this point of view, it was even more important to implement social transfers in effect of which, for the first time since the beginning of the transformation, economic success becomes shared by the vast majority of Polish people rather than by only the wealthiest. We are all satisfied to see the success of this idea, but this very success makes the need to implement SRD even more urgent. This strategy has to become reality soon and efforts have to focus on the area which constitutes the core of any economic success - i.e. the increase of the scale of investments and development of small and medium-sized enterprises sector. At present, we reckon that the $500+$ programme ensures an adequate level of social transfers. The economy calls for even more active and greater entrepreneurship and the state is obliged to provide appropriate conditions for this to happen.

Despite the most recent economic crisis and acceptance of applying deviations from the Washington Consensus, our programme never ceases to raise much concern among neoliberals. Threats usually mentioned in this context include the intention - allegedly presented in SRD - of unreflective emulation of patterns proposed in the New Structural Economics and applied in Far Eastern countries. Let us explain, therefore, that the Strategy for Responsible Development is an original project conceived by the Government of the Republic of Poland which actually takes advantage of some advice and indications given by Justin Yifu Lin, but still adapts this author's concepts to circumstances prevailing in Central and Eastern Europe. What we reckon most valuable part in the New Structural Economics concept is its innovative approach to the state industrial policy. Creative idea of the so-called efficient quadrangle, consisting of the governing élite, state administration, society, and business, should be seen as a very precious fundament of SRD. However, its detailed contents and solutions suggested in our version include a comprehensive analysis of Polish difficulties and Polish ways to overcome the same. Without diverging much from the key assumption behind the New 
Structural Economics - that about the need for an extensive role played by the state sector and state intervention applied by experienced and well-educated personnel - we have developed a project tailor-made to Polish capabilities and expectations. Another great strength of Justin Yifu Lin's work is how he breaks through the so-called "undisputed truths" and indicates new possibilities and solutions instead. However, to translate them into practical guidelines rests already within the scope of any individual country interested. Therefore, despite the common root, it would be wrong to compare economic policy run in Asian countries with that in European ones - and, crucially - we should observe these differences between them, rather than from any theoretical dispute, really originate from geopolitical differences, regarded as something natural.

It is particularly important to ensure a smooth transition from the process of providing fair participation of the entire society in national income, towards the stage of providing incentives and support for attitudes focused on investment and growth. It isn't possible for a country to achieve sustainable economic growth unless its society is well-balanced in terms of financial wealth. The growth, no matter how strong, if only relied upon simple investment processes and not conductive to the formation of middle class, is prone to decelerate rather soon and hardly allows for a country's advance to the élite of developed countries. On the other hand, the state alone is not capable of leading to the formation of middle class strong and extensive enough. What the state can do is provide favourable conditions for the middle class to emerge. The first such condition, already in place in Poland, is to fill the gap formed by the most acute social disparities in terms of wealth. Thanks to the $500+$ programme, it became possible to eliminate the most blatant cases of impoverishment and poverty. At present, we should focus on the project which is the most difficult but also most important - upon full exploitation of Poland's and Poles' potential of the investment. It is the small and medium-sized enterprises sector that may enable the creation of strong and socially stable welfare. This is also about growth-fostering foreign investments in which Poland is regarded something more than just an assembly plant. Then, this is about increasing savings of Polish people, deposited in collective investment programmes intended to provide the real financial drive for the country's growth. It is the role of the state in the implementation of these ideas to eliminate barriers to investment, hitherto existing in the area of law. Indeed, the Ministry of Development has prepared a comprehensive reform of the economic law. Draft acts have been grouped in two packages: of "Business Constitution" and of "100 changes for companies". The latter one provides for the introduction of such solutions as shortened period of obligatory archiving of employment-related documents and their computerisation, succession for sole proprietorship companies, introduction of Simple Joint Stock Company to the law or a reform of activities of the Central Office for Measures which will become a significant partner for industrial enterprises in development of innovative solutions. The reforms planned are mainly intended to support Polish 
micro, small and medium-sized enterprises - actually, their scope will cover over 90\% of all businesses actively operating in Poland. We also attach particular importance to "Business Constitution". It is going to introduce a catalogue of fundamental principles for running business activity, as well as rules that regulate relationships between an entrepreneur and bodies of the state. The next step will be to introduce an effective but simple and transparent tax system. The existing, leaking tax system resulted in annual losses in the state budget estimated at dozens of billions PLN. Efforts undertaken by the Ministry of Finance are intended both to better sealing of the tax system and to restore fair competition, without the VAT mafia or grey zone. Along with this, we have also introduced reforms postulated by the business environment for years, including reduction of CIT to $15 \%$ for small enterprises, the introduction of investment and innovation-related relief and a reform of state treasury administration. We would like the fiscal system to be perceived as efficient and friendly but also strong and effective in enforcement from those who evade taxes, thus undermining fair competition.

An entity which plays a particularly important role in implementation of SRD is the Polish Development Fund (PFR) which integrated such bodies as the Industrial Development Agency (ARP), Bank Gospodarstwa Krajowego (BGK), Export Credit Insurance Corporation (KUKE), Polish Investment and Trade Agency (PAIH) and the Polish Agency for Enterprise Development (PARP). The priorities of the PFR group include infrastructural investments, innovations, development of entrepreneurship, export and foreign expansion of Polish business as well as handling foreign investments. Another important task of PFR is its active involvement in processes of re-polonisation of strategic sectors of the Polish economy. PFR has already invested nearly PLN 10 billion in Polish economy - without any increase of deficit or public debt. The state has a particularly important role to play in supporting Polish export. At present, foreign expansion of Polish companies reveals considerable dynamics. We have the policy of diversification of export directions in place and the total value of Polish export at the end of 2017 - according to market forecasts - may well increase twofold. The amount of PLN 60 billion is the summed value of modern, flexible instruments for financing Polish export, made available to domestic business by the Polish Development Fund (PFR) Group. This package includes, among other things, financial guarantees, insurances, export credits and the foreign expansion fund. One of the crucial changes made by the government in Poland's export policy is the creation of a new system of incentives for Polish companies which desire to become active players in the international market of mergers and takeovers. Finally, the Ministry of Development also initiated a programme of support for small and medium-sized towns. The value of that programme exceeds PLN 2.5 billion. Besides, some investments supported by the government are located outside agglomerations - actually, 23 out of $27(85 \%)$ strategic investments were made in Poland's small and medium-sized towns. Under the Fund, it is possible to obtain 
support for investments entirely financed from domestic resources or to acquire capital for own contribution to projects financed from the Community resources.

One final and important element of SRD which should be emphasised in this publication are its flagship programmes, such as Electromobility, Polish Industry Platform 4.0 or the Capital Building Platform. The already notorious concept of Electromobility certainly deserves some mention here. Firstly and most importantly, it is very wrong to regard this project as solely reduced to manufacturing of some specific number of electric passenger cars or buses. Instead, this is a programme of the future, intended to prepare Poland for the forthcoming and unavoidable great transformation in the area of transport. It includes appropriate changes to be made in Polish legislation, the creation of grant programmes, and, most of all, changes to be achieved in mentality and attitudes of Polish people towards innovations in this area. The project for the future, then - one that will certainly give rise to a lot of challenges and difficulties, but from which there is really no escape nowadays. Until recently Poland passively witnessed such initiatives, perhaps expecting ready solutions to come from other countries. This results in our country's technological backwardness compared to well-developed countries which have always paced the way well ahead of us. Today we want to make the pioneering steps, to be the first ones to face the challenges and to benefit from the cutting-edge solutions.

Poland stands in the face of new challenges. New Structural Economics and the Strategy for Responsible Development are the response. I believe the implementation of the latter policy will contribute to the achievement of solid, sustainable, socially and territorially balanced economic growth which will lead to increased welfare enjoyed by Polish families. To deliver Poland from the development standstill it not only takes the thoughtful and effective operation of public administration but - more than anything else - further development of the spirit of entrepreneurship and creativity among Polish citizens. Of course, we are witnessing a new wave approaching in the global economy. I don't really care that much about how this new wave will be called. What is much more important is that we are able to translate it into successes and wins achieved by Polish economy. I am deeply convinced we are well on our way to attaining it.

Mateusz Morawiecki

Deputy Prime Minister, Minister of Development and Minister of Finance 



\section{New Structural Economics and industrial policies for catching-up economies ${ }^{1}$}

Economic development is a process of structural transformation with continuous technological innovation and industrial upgrading, which increase labor productivity and accompanied improvements in infrastructure and institution, which reduce transaction costs. Industrial policy is essential for the government to prioritize the use of its limited resources to facilitate technological innovation and industrial upgrading by overcoming inherent externality and coordination issues in structural transformation. The industries in a middle-income country may be classified into five different types, depending on their distance to the global technology frontier: catching-up industries, leading-edge industries, comparative advantage-losing industries, short innovation cycle industries, comparative-advantage-defying strategic industries. Industrial policy should be designed accordingly.

Keywords: New Structural Economics, economic development, industrial policy.

\section{Introduction}

Academic highlights:

- The nature of economic development is a process of continuous structural change with technological innovation and industrial upgrading raising labor productivity, and with improvements in hard and soft infrastructure reducing transaction costs.

- New Structural Economics, which applies the neoclassical approach to study the determinants of economic structure and its evolution, postulates that the industrial structure in an economy is endogenous to its endowment structure.

- New Structural Economics argues that the key for development success is to have an enabling state using industrial policy to facilitate firms' entry to latent comparative-advantage industries in a competitive market by overcoming the first-mover's externality issue and coordinating the required improvements in hard and soft infrastructure to turn the latent comparative advantage industries to the nation's competitive advantages.

1 I would like to thank Slavo Radosevic for helpful comments. 
Policy highlights:

- For a middle-income country in the catching-up process, its industrial policies may be classified into five different categories based on the industry's distance to the global technological frontier, and the state may play a facilitating role accordingly:

- Industrial policy for catching up higher-income countries' industries

- Industrial policy for maintaining a leading-edge industry's technology leadership globally

- Industrial policy for leapfrogging high-income countries in short innovationcycle industries

- Industrial policy for helping firms exit from comparative advantage-losing industries

- Industrial policy for developing comparative advantage-defying, national defense-related industries.

Rapid, sustained economic growth is a modern phenomenon, emerging only in the 18th century. Before then, the average annual growth of per capita Gross Domestic Product (GDP) in Western Europe was just $0.05 \%$. At that rate, it would take an economy 1,400 years to double its per capita GDP (Maddison, 2006). From the 18th century to the mid-19th century, the annual growth of per capita GDP in Western European countries accelerated to $1 \%$, enabling it to double in just 70 years. From the mid-19th century to the present, the per capita GDP growth rate accelerated to $2 \%$ a year, shrinking the doubling time to 35 years. The impetus for accelerating growth was the Industrial Revolution of the mid-18th century: continuous technological innovations and industrial upgrading made the acceleration of labor productivity and income growth possible, which boosted per capita GDP. ${ }^{2}$

In other words, modern economic growth is a process of continuous technological innovation, which raises labor productivity in the existing industries, and industrial upgrading, which moves an economy from low value-added industries to higher valueadded ones and thus raises labor productivity as well. However, taking advantage of the potential of technologies and new industries requires well-functioning hard infrastructure to get products into large domestic and foreign markets. As the scale of trade increases, market exchanges are at arm's length, thus requiring contracts and contract-enforcing legal systems. Moreover, as the scale and risk of investment increase with the upgrading of technology and industries, the financial structure has to adapt as well. Improvements in hard and soft infrastructure reduce transaction costs for investment and trade (Kuznets, 1966; Lin and Nugent, 1995; Harrison and Rodríguez-Clare, 2010). While modern economic growth appears to be a process

2 The Industrial Revolution was still in its infancy when Adam Smith was writing An Inquiry into the Nature and Causes of the Wealth of Nations. Consequently, Smith paid little attention to technology innovation and industrial upgrading; rather, he focused on trade and specialization within given technologies and industries. 
of rising labor productivity, it is actually a process of continuous structural change in technologies, industries, and hard and soft infrastructure.

A developed country's high-income and labor productivity indicate that its technology and industry are on the global frontier. As such, it requires the indigenous invention of new technology and industry to achieve technological innovation and industrial upgrading. Inventions of new technology and industry are costly and risky. A developing country's technological innovation and industrial upgrading occur mostly behind the global technological and industrial frontier. Most of its innovation and upgrading can rely on the adoption of technology and industry that are new to the country but mature elsewhere in the world, and thus have a lower cost and risk compared with an advanced country. In other words, a developing country enjoys the latecomer advantage in technological innovation and industrial upgrading. Potentially, a developing country can grow faster than an advanced country and catch up with it.

After World War II (WWII), most countries in the developing world shattered the shackles of colonialism or semi-colonialism, starting their independent pursuit of modern economic growth. Up to 2008, only two of them moved up from low to middle income and finally to high income, and only 13 of such countries moved up from middle to high income (Agenor et al., 2012). This means that, among around 200 developing economies, most have remained trapped in a low- or middle-income status since WWII, despite the latecomer advantage. As Keynes said, 'it is ideas, not vested interests, which are dangerous for good or evil.' These countries' poor development performance reflected the failures of development ideas. In this chapter, I review the ideas embodied in two previous waves of development thinking, introduce New Structural Economics as the third wave, and propose a practical guide for formatting industrial policies in developing countries to accelerate technological innovation and industrial upgrading.

\section{Why we need to rethink development economics}

Economic theories help us understand the underlying causalities of observed economic phenomena. More than logic exercises, theories have practical relevance: economic agents - governments, firms, households, and individuals - use them to guide their actions to achieve the desired results. If existing theories fail to help us understand the underlying causalities of the observed phenomena or if decisions based on these theories fail to achieve their intended goals, we have to rethink them. Development economics needs rethinking.

Development economics is a young field in modern economics. It emerged after the Second World War to guide the reconstruction of war-ravaged countries and the nation building of newly independent former colonies. 
The first wave of development thinking was structuralism. It posited that, if a developing country wanted to catch up with developed countries in income, it needs to have the same labor productivity as developed countries. In turn, this requires developing countries to build up modern capital- and technology-intensive industries similar to those in developed countries. Yet those industries never emerged in developing countries. Why not? Economists blamed market failures arising from structural rigidities for the failure of such industries to develop spontaneously (Arndt, 1985). Structuralism recommended that governments adopt import-substitution strategies to overcome market failures through mobilizing and allocating resources to directly build those industries (Rosenstein-Rodan 1943; Prebisch, 1950).

Capitalist as well as socialist countries pursued, after WWII, the strategies advocated by structuralism (Chenery, 1961). However, countries that adopted import-substitution strategies typically experienced a pattern of rapid growth driven by large-scale investments, followed by economic crises and long periods of stagnation (Krueger and Tuncer, 1982; Lal, 1994; Pack and Saggi, 2006).

In the $1980 \mathrm{~s}$, the failure of structuralism as a catching-up guide for developing countries led to the emergence of the second wave of thinking, neoliberalism. At that time, government intervention was pervasive in developing countries, leading to rent-seeking, bribery, and embezzlement, as well as to multiple economic distortions and inefficient resource allocation. To improve economic performance and close the gap to developed countries, developing countries were advised to build a well-functioning market economy by implementing the measures referred to collectively as the 'Washington Consensus': privatization, marketization, and liberalization (Williamson, 1990). Governments were advised not to pick winners to support technological innovations and industrial upgrading.

Again, the logic seemed sound. Yet countries that applied this shock therapy often experienced economic collapse, stagnation, and frequent crises, and the gap between developing and developed countries widened further (Cardoso and Helwege, 1995). Growth rates were lower and economic crises more frequent under Washington Consensus policies in the 1980s and 1990s than under the structuralist policies of the 1960s and 1970s. Some economists referred to this period as the lost decades' for developing countries (Easterly et al., 1997; Easterly, 2001).

During this time, some economies in Asia were pursuing an entirely different development approach. From the 1950s to 1970s, Japan and the four Asian tigers - Korea, Taiwan, Singapore, and Hong Kong - grew rapidly by adopting an exportoriented development strategy, by developing initially labor-intensive, small-scale industries, and by gradually climbing the industrial ladder to larger, more capitalintensive industries with proactive government support (Amsden, 1989; Chang, 2003; Wade, 1990).

In the 1980s and 1990s, under the sway of the Washington Consensus, economists branded planned economies as less efficient than market economies and called 
for transforming them into market economies through shock therapy: removing all economic distortions by ending government interventions and by leaping in a single bound from a planned to a market economy. However, China adopted a dualtrack transition, continuing to protect and subsidize nonviable state-owned firms in the old prioritized capital-intensive industries, while liberalizing the market entry for the previously repressed labor-intensive industries. Many economists predicted such an approach would lead to rampant rent-seeking and to deteriorating resource allocation. In reality, however, economies that experienced stability and rapid growth, like Cambodia, China, and Vietnam, all followed the dual-track transition approach.

Policies based on structuralism and neoliberalism failed to achieve their goals. Nor did structuralism and neoliberalism explain the rare economic development and transition successes that did occur. A third wave of development thinking is in order.

\section{What is New Structural Economics?}

New Structural Economics, as a third wave of development thinking uses a neoclassical approach to study the determinants of economic structure and its evolution in a country's economic development, which is the nature of modern economic growth (Lin, 2011). ${ }^{3}$

What is the core hypothesis of New Structural Economics?

In brief, a country's economic structure at any given time is endogenous to its factor endowments - the amounts of capital, labor, and natural resources at that time. Countries at different development stages vary in their relative abundance of factor endowments. In developing countries, capital is generally relatively scarce, while labor and often natural resources are comparatively abundant. In developed countries, capital is relatively abundant, while labor is comparatively scarce. Although an economy's factor endowments are given at any particular period, they can change over time. New Structural Economics posits an economy's factor endowments as the starting point for development analysis because they determine an economy's total budget and relative factor prices at that time, which are two of the most important parameters in economic analysis.

Relative factor prices determine a country's comparative advantage. For example, countries with both relatively abundant labor and scarce capital would

3 By convention, the name for such studies should be 'structural economics.' The 'new' is added to distinguish it from structuralism. This practice has precedents in modern economics. For example, Douglass North, who used the neoclassical approach to study institutions in the 1960s, referred to it as 'new institutional economics' to distinguish it from the 'institutional school', which flourished in the United States in the early 20th century. 
have a comparative advantage in labor-intensive industries because production costs will be lower than in countries with relatively scarce and more expensive labor. A prerequisite to achieving a competitive advantage is for a country to develop its industries according to its comparative advantages determined by factor endowments (Porter, 1990).

In developed countries, income and labor productivity are high because the countries' relative capital abundance means that their industries and technologies are capital intensive. If a developing country wants to catch up to the income and industrial structure of developed countries, it first needs to increase the relative abundance of capital in its factor endowment structure to the level in advanced countries. The ultimate goal of economic development is to raise a country's income, the intermediate goal is to develop capital-intensive industries, and the immediate goal should be to accumulate capital quickly so that the country's comparative advantages change to more capital-intensive industries. In other words, boosting a country's income requires industrial upgrading, which in turn requires changing a country's endowment structure (Ju et al., 2015).

How can a country accumulate capital quickly? Capital comes from saving economic surpluses. If a country's industries are all consistent with its comparative advantages, as determined by its endowment structure, the country will be competitive in both domestic and international markets and generate the largest possible surplus. If all investments are made in industries that are consistent with the comparative advantages determined by a country's endowment structure, the returns to investment will be maximized and the propensity to save will be at its highest. With the largest possible surplus and the highest incentives to save, capital will be accumulated in the fastest way possible. The changes in endowment structure and comparative advantages pave the way for changes in industrial structure and the accompanying hard and soft industrial infrastructure.

Yet comparative advantage is an economic concept. How it translates into the choices of technologies and industries made by entrepreneurs? Entrepreneurs care about profits. They will invest in industries in which a country has a comparative advantage if relative factor prices reflect the relative scarcities of factors in the country's endowments (Lin, 2009; Lin and Chang, 2009). If capital is relatively scarce, the price of capital will be relatively high; if labor is relatively scarce, the price of labor (wages) will be relatively high. If the price system reflects the relative factor scarcity, profit-maximizing entrepreneurs will use a relatively inexpensive factor to substitute for a relatively expensive factor in their choice of production technologies, investing in industries that require more of a relatively inexpensive factor and less of a relatively expensive factor. A price system with these characteristics can arise only in a competitive market. Therefore, a well-functioning market is essential for the success of economic development.

Economic development is a process of structural change with continuous technological innovations, industrial upgrading, and improvement in infrastructure 
and institutions. When the factor endowment structure changes, it requires first movers to enter new industries that are consistent with changing comparative advantages. The risks for first movers are high. If they fail, they bear all the losses, and if they succeed, other firms will follow them into the industry. The resulting competition will eliminate any monopoly profit (Aghion, 2009; Romer, 1990). There is an asymmetry between the losses of failures and the gains of successes for the first movers (Hausmann and Rodrik, 2003).

No matter whether the first movers succeed or fail, they provide society with useful information. The government should encourage first movers and compensate them for the information externality they generate. Otherwise, there will be little incentive for firms to be first movers in technological innovation and industrial upgrading (Rodrik, 2004; Lin, 2009; Lin and Monga, 2011; Harrison and Rodriguez-Clare, 2010). In addition, the success or failure of first movers also depends on whether improved hard and soft infrastructure match the needs of the new industries. Improving infrastructure and institutions is beyond the capacities of individual firms. The government needs to either coordinate firms' efforts to improve infrastructure and institutions or to provide those improvements itself. Therefore, a facilitating state is also essential for economic development to happen dynamically.

New Structural Economics helps to understand why structuralism failed. The import-substitution strategy advocated by structuralism advised governments to give priority to capital- and technology-intensive industries in capital-scarce developing countries, thus defying developing countries' comparative advantages. Firms in those industries were not viable in open and competitive markets. Without government protection and subsidies, entrepreneurs would not voluntarily invest in those industries. After their establishment, the nonviable firms had to rely on the government's subsidies and protection to survive as well.

New Structural Economics also helps to understand why neoliberalism failed. In developing countries, market distortions were endogenous to the government's need to protect and subsidize nonviable firms that had been promoted by the government's previous import-substitution strategies. Eliminating protections and subsidies would doom nonviable firms, resulting in large-scale unemployment, and social and political unrest. To avoid those consequences and to continue to prop up nonviable capital-intensive industries that were still considered the cornerstone of modernization, governments had no choice but to continue its protection and subsidies. Even if the firms were privatized, soft budget constraint problems would continue. The subsidies to the nonviable firms could even increase due to the private owners having greater incentives to lobby for subsidies and protection (Lin and $\mathrm{Li}$, 2008). The new protections and subsidies were usually less efficient than the old ones, especially in the transition economies of the former Soviet Union and Eastern Europe (World Bank, 2002). In addition, neoliberalism threw the baby out with the bath water, vehemently opposing any role for governments in facilitating structural change. Chile was a typical example. A model student of Washington Consensus 
reform, Chile diligently implemented the Washington Consensus reforms in the 1980s and then removed all government protections and subsidies. Chile ranks high among developing countries on the World Bank's Doing Business Index, based on indicators of the ease of doing business and investing. However, Chile has not seen dynamic structural change for more than 30 years, and as a result, unemployment is high, income gaps have widened, and Chile remains mired in 'the middle-income trap'. New Structural Economics also justifies the gradual, dual-track approach to reform that conventional economic thought labeled the wrong approach to transition. Dualtrack reform maintains stability by providing transitory protections to nonviable firms in the old priority sectors and achieves dynamic growth by removing restrictions to entry and facilitating the development of previously repressed industries that are consistent with the country's comparative advantages. The dynamic growth of sectors consistent with comparative advantages helps the economy rapidly accumulate capital and changes the factor endowment structure. That makes some formerly nonviable firms in capital-intensive industries viable. Once firms in the new sectors are viable, the transitory protection and subsidies can be eliminated, bringing the transition to a market economy to a smooth end (Naughton, 1995; Lau et al., 2000; Subramanian and Roy, 2003; Lin, 2009; 2012 and 2013).

\section{New Structural Economics and smart industrial policy for developing countries}

Economic theories are intended not only to help people understand but also to change the world. How can the government in a developing country apply New Structural Economics to achieve dynamic structural change and catch up with highincome countries? To leverage the government's limited resources for the largest possible impact on structural change and economic growth, the government needs to know which new industries are consistent with the country's latent comparative advantages. In other words, the government should know in which industries it has low factor costs of production based on the country's endowment structure but lacks global competitiveness due to high transaction costs. Moreover, the government should know which infrastructures and institutions require improvements to reduce transaction costs to enable those new industries to thrive.

By way of explanation, New Structural Economics suggests that government should identify industries of latent comparative advantages and then provide incentives for the first movers to overcome coordinating failures in improving infrastructure and institutions to turn them into the nation's competitive advantages. Theoretically, industrial policy should be a useful instrument for the government to achieve its facilitating role. In practice, industrial policies have largely failed in developing countries, tainting their reputation in mainstream economics. But if 
the government does not facilitate the development of industries in line with the country's comparative advantage, old industries may die due to loss of comparative advantages, while new industries are unlikely to emerge spontaneously due to the lack of first movers and appropriate hard and soft infrastructure. One result would be deindustrialization. Without new industries, countries cannot achieve robust economic growth, solve the job-generation challenge, and escape the low-income or middle-income trap.

To reject the concept of industrial policy because of past failures is to miss the opportunity to understand why most industrial policies failed and to improve them in the future. They failed because in many cases the government in a developing country, with the best intentions and unaware of the endogeneity of industrial structure, tried too ambitiously to support advanced industries before the economy had the right endowment structure to make these industries into the country's comparative advantages. The firms in targeted industries were not viable in open and competitive markets, so governments had to protect and subsidize them, granting them monopoly rights, providing low-price capital, raw material, and land, or giving preferential taxes. Such distortive interventions created economic rents that stimulated rent-seeking, embezzlement, and corruption (Krueger, 1974; Krugman, 1993).

A desirable industrial policy should aim instead to facilitate the growth of industries with a latent comparative advantage, enabling them to become the country's competitive advantage in the market quickly. The latent comparative advantage refers to an industry with low factor costs of production relative to the rest of the world. This is determined by the economy's endowment structure and too high transaction costs (due to poor hard and soft infrastructure) to be competitive in domestic and international markets. Firms will be viable and the sectors competitive once the government helps the firms reduce transaction costs by overcoming coordination and externality issues to improve hard and soft infrastructure.

In addition to facilitating the growth of industries with latent comparative advantage, an industrial policy may also help firms exit from industries in which the country loses comparative advantages, or relocate to other countries with lower income and wages.

The industries in a middle-income country may be classified into five different types, depending on their distance to the global technology frontier: 1) catching-up industries, which have lower technology and value-added than similar industries in higher-income countries; 2) leading-edge industries, which are global technology frontier industries; 3) comparative advantage losing industries, which the country is about to exit due to changes in endowment structure and comparative advantages; 4) 'corner-overtaking' industries, which have short innovation cycles, allowing a middle-income country to compete directly with high-income countries; and 5) strategic industries, which go against the country's comparative advantages 
but are developed due to the need for national security. I will discuss how the government may play a facilitating role in each of the above five types of industrial policy.

\subsection{Type I: Catching up industries}

How can governments identify industries with latent comparative advantages in the process of catching up with industries in higher income countries? History offers many lessons of what to do and what to avoid.

Since the 16th and 17th centuries, successful economies have shared a common feature: industrial policies in these countries aimed to help firms enter industries that had flourished in dynamically growing and slightly more developed countries. They were able to exploit the latecomer's advantage. For example, the Netherlands was the most developed country in the world in the 16th and 17th centuries, with a highly developed wool textile industry. Britain's wool textile industry was immature by comparison. The British government implemented policies to encourage the imports of machinery and skilled workers from the Netherlands. Those policies worked. At the time, per capita income in Great Britain was $70 \%$ of the Dutch level. That meant that their endowments and comparative advantages were quite similar.

Following the Industrial Revolution, Great Britain became the most advanced economy in the world. In the late 19th century, France, Germany, and the United States used similar policies to catch up with Great Britain. Their per capita incomes at that time were already about $60-75 \%$ of Britain's (Gerschenkron, 1962). In the 1950s and 1960s, Japan imitated industries in the United States at a time when its per capita income exceeded $40 \%$ of that of the US. Later, the four Asian tigers (Korea, Taiwan, Singapore, and Hong Kong) succeeded by imitating Japan's industries. Their per capita incomes were about 30-40\% of Japan's at the time (Akamatsu, 1962; Chang, 2003; Ito, 1980; Kim, 1988).

Other countries also targeted and tried to imitate industries in the United States after the Second World War but failed. One reason was that their income levels were less than $20 \%$ of those of the US. For example, in the 1950s China targeted and tried to imitate U.S. industries even though its per capita income was just $5 \%$ of the U.S. level. With the government's efforts to build up advanced industries, China was able to test atomic and hydrogen bombs in the 1960s and launch satellites in the 1970s. These achievements came at a very high price to the economy. In 1979, when China began its transition to a market economy, its per capita income was less than one-third the average of Sub-Saharan African countries.

Drawing on the experience of successful economies and the theory of comparative advantage, I propose a new growth identification and facilitation framework for the catching-up type of industrial policy. This framework has two tracks and six steps (Lin and Monga, 2011). 


\section{Step 1. Identifying tradable goods industries}

When the government of a developing country seeks to facilitate industrial upgrading in non-resource manufacturing, it should identify the tradable goods industries in countries that have been growing dynamically for the previous 20-30 years and whose per capita income is about 100-200\% higher than its own. Although experience suggests that $100 \%$ has been a successful reference point, a larger leap could be justified because technology and industrial upgrading happen much faster today.

The tradable goods and services produced in the target countries have a good chance of being those in which the pursuing country has a latent comparative advantage. If a country has grown rapidly in the last 20-30 years, the industries in its tradable sectors must be consistent with its comparative advantage. Yet, because of rapid capital accumulation and wage increases, the industries that were consistent with the comparative advantages of the targeted country's previous factor endowment structure will soon lose their comparative advantage. The sunset industries that are about to lose their comparative advantage in the targeted country will become the sunrise industries because of latent comparative advantage in the catching-up country which has a similar endowment structure and a somewhat lower per capita GDP.

\section{Step 2. Identifying obstacles}

Among the industries identified in step 1, the government may give priority to those which some domestic firms have already entered spontaneously, and identify the obstacles impeding these firms from upgrading the quality of their products and the barriers limiting entry by other private firms. The usual barriers are related to high transaction costs. Is the primary impediment deficient infrastructure, poor logistics, inadequate financial support, or a limited pool of skilled workers? Obstacles can be identified using value-chain analysis or the growth diagnostic framework suggested by Hausmann, Rodrik, and Velasco (2008). The government can then take steps to ease those binding constraints, using randomized controlled experiments to test the effectiveness of these measures before scaling up policies at the national level (Duflo, 2004).

\section{Step 3. Encouraging firms in other, more advanced economies to relocate to the country trying to catch-up}

Some of the industries identified in Step 1 may be new to the country. The government could adopt measures to encourage firms in the targeted higher income countries to relocate to its country to take advantage of lower wages. 
The government could also establish incubation programs to catalyze the entry of domestic private firms into these industries.

\section{Step 4. Paying attention to successful businesses in new industries}

Technology changes fast, which means that there are industries today that did not exist 20 years ago. Some domestic entrepreneurs may discover new profitable opportunities that were not identified in step 1. Consider information services in India in the 1980s. In the beginning, Indian firms outsourcing to US companies used satellite communication, which was extremely expensive. The Indian government built fiber-optic systems that greatly reduced communication costs, helping Indian information service companies gain a competitive advantage over other companies in the world. When new technology brings new opportunities and domestic private firms have already discovered them, the governments should pay close attention to their success and provide support to scale up those industries. Each country may also have some unique endowments. If entrepreneurs in the country discover opportunities to use such endowments profitably, the government may also provide support to scale up those opportunities to become competitive industries.

\section{Step 5. Using special economic zones to attract domestic and foreign companies}

In developing countries with poor infrastructure and an unfriendly business environment, budget and capacity constraints prevent governments from making necessary improvements to benefit every industry in all locations of the country within a reasonable timeframe. Instead, the government can use industrial parks, export processing zones, or special economic zones to attract private domestic and foreign firms to invest in the targeted industries. Improvements in infrastructure and the business environment within these special areas can reduce transaction costs and facilitate the development of industries with latent comparative advantage. The special economic areas also have the advantage of encouraging industrial clustering, which can lower logistical costs.

\section{Step 6. Compensating pioneering firms for the externalities they generate}

The government may provide limited incentives to pioneering domestic or foreign firms that invest in industries identified in steps 1 and 4 to compensate them for the public knowledge created by their investments. The incentives should be limited in time and budget allocations because the targeted industries should have a latent comparative advantage that will enable them to become competitive in domestic and foreign markets once transaction costs fall. The incentives may be in the form of a corporate income tax holiday for a limited number of years, 
priority access to credit (in countries with financial repression), or priority access to foreign reserves for importing key equipment (in countries with capital controls). To minimize the risk of rent-seeking and political capture, the incentives should not be in the form of monopoly rent, high tariffs, or other distortions. The government may reward the firms that discovered successful new industries by themselves (see step 4 above) with a prize or other form of special recognition for their contributions to economic development.

This kind of compensation for externalities differs from the protections and subsidies of the old import-substitution strategy that aimed to help nonviable firms in priority industries stay in business. Under this new framework, the firms encouraged have low factor costs of production and are viable in the market, so their profitability can be ensured by improving their management once soft and hard infrastructure are enhanced and transaction costs lowered.

\subsection{Type II: Leading Edge Industries}

When a country reaches the middle-income stage, some of its industries may enter areas which high-income countries have exited due to limited value-added (from these high-income countries' viewpoint). In such cases, the former country becomes the highest income country in the industry worldwide and it possesses leading edge technology. One example are household appliances - such as color TVs, refrigerators, microwave ovens, and other electronic white goods - in China. For the country to maintain leadership and competitiveness in these industries, it is necessary that the firms in these industries engage in indigenous $R \& D$ for new technologies and products.

Two different kinds of activities are involved in indigenous R\&D: the development of new products and new technologies, and delivering the breakthroughs in the basic science needed for the new technologies and products. A firm can be rewarded by a patent if its efforts to develop a new product or technology are successful. Therefore, the development of new products and technology should be the firm's responsibility. However, research in basic science requires large capital inputs and is very risky, while its outputs are typically in the form of academic papers, which are public goods. Individual firms may be reluctant to do basic research.

In advanced countries such as the US, most of the industries are leading-edge industries worldwide. The basic research related to those industries is mainly carried out by either universities or research institutions, funded by the National Science Foundation, the National Institutes of Health, the Defense Department, and other government sources (Mazzucato, 2013). Similarly, basic research in other advanced economies like Japan and some European countries is also carried out by government-funded institutions. All these facts suggest that to maintain global competitiveness and leadership in its leading-edge industries, a middle-income country should adopt a similar approach to support the basic research required to 
catalyze the innovation of new technologies and products. The government should also strengthen the protection of intellectual property rights.

To be more specific, governments of middle-income countries can promote the development of new products and technologies by using fiscal allocations to set up research funds to support research institutions in related fields or to encourage cooperation between research institutions and firms in the industries. The governments can also financially support firms in the industry to set up joint research platforms, which can be used to tackle common technical bottlenecks. Firms may develop new products or technology separately, based on the breakthrough in the common technology. Lastly, the government can use procurement to help firms rapidly scale up production to reduce unit costs and increase international competitiveness.

To expand the market globally, it is essential for firms in the relevant industries to establish worldwide networks for sales, processing of products, and after-sale services. The government may help firms in this type of industries go abroad by providing personnel training, legal service, and consular protection.

\subsection{Type III: Comparative advantage-losing industries}

For labor-intensive industries, the wage is one of the most important components of the cost of production. In a rapidly growing developing country, such as China, wages will rise very quickly. Labor-intensive industries will turn from the country's comparative advantages to its sunset industries. In the face of such change, some of the firms in the labor-intensive export processing industries may upgrade to the two ends of a 'smile curve' where the added-value is higher, such as branding, R\&D, quality control, marketing, sales, etc. However, for most firms, the way out is to relocate their production to countries with lower wages, as the textile, garments, and electronic firms in Japan did in the 1960s and firms in similar industries in the Four Asian Tigers did in the 1980s. Relocating allows the firms to put their tacit knowledge in technology, management, and marketing to continual use and it also changes these firms' production from the country's GDP to the country's gross national product (GNP). Moreover, the overseas success of these firms can speed up the industrial upgrading in their home country by releasing resources for new industries and generating demand for intermediate parts or machineries used in the labor-intensive industries, which are in general more capital/technology intensive and of higher added value.

Most of the labor-intensive export processing firms are clustered. The government may use two types of policies to help these firms. The first one is to provide training on design, $\mathrm{R} \& \mathrm{D}$, and marketing, which can help some firms move up to the two ends of a 'smile curve'. The second policy is to facilitate processing firms' transfer abroad. Specific measures include offering information on host countries and training personnel needed for overseas operations, or establishing export processing 
zones together with the host governments to provide adequate infrastructure and business environments for the firms. Examples of export processing zones include Singapore's Industrial Park in Suzhou, China.

\subsection{Type IV: 'Corner overtaking' industries}

The coming of the information age creates opportunities for a developing country to compete directly with developed countries in certain industries, such as software and mobile devices, where innovations rely mainly on human capital and where the innovation cycle is relatively short (Lee, 2013). The development of a new medicine may take decades and will require billions of dollars, whereas the design of a piece of software or a mobile phone may take only a few months and be accomplished by a small team of engineers. Since the required capital input to support the innovation is relatively small, the disadvantage of a relatively capital-scarce developing country in the innovation of such types of products is, compared to a relatively capital-abundant developed country, not insurmountable. Such industries provide a developing country with the opportunity to overtake developed countries on a corner. The government in a developing country can facilitate the development of such industries by investing in the education of related human capital, setting up incubators, reinforcing the protection of property rights, encouraging venture capital, providing preferential taxes, facilitating start-ups run by creative talents at home and abroad, and using government procurement to support the production of new products.

\subsection{Type V: Strategic industries}

Every country needs national defense. National defense industries are usually characterized by high capital-intensity, long R\&D cycles, and large-scale economies. In general, such industries are not compatible with a country's comparative advantages, and especially so in the case of developing countries. However, some of those industries may be essential for national defense and the country needs to own them domestically. Firms in such industries will not be viable in an open, competitive market. Subsidies and protections from government are indispensable. The structuralist perspective discussed in section 1 of this chapter proposed the use of distortions in factor prices and of market monopolies as a means of subsidies/ protection for comparative advantage-defying advanced industries. A better approach is to subsidize these firms directly by $\mathrm{R} \& \mathrm{D}$ grants or indirectly through procurement of products. This is similar to the practices in the US and other advanced countries. In a developing country, the government's fiscal capacity to subsidize strategic industries is limited. Therefore, the choice of strategic industries should be very selective and their number should remain small. In effect, only those industries essential for national defense and having a large externality to civil industries should be chosen. 


\section{Concluding remarks}

This chapter reviewed the evolution of development economics since its formation in the wake of WWII and proposed New Structural Economics as an alternative approach. Every developing country has the potential to grow dynamically and avoid the middle-income trap. However, that can only happen if the government plays an appropriate facilitating role in a market economy by supporting the development of industries connected to the country's latent comparative advantages.

Achieving such a result will require a change in the mindset. In the first two waves of development thinking, economists used high-income countries as the reference. They examined what those countries had (capital-intensive industries) and could do well (well-functioning market) and recommended that developing countries follow suit. New Structural Economics turns this model upside down. It recommends that developing countries look at what they have now (their endowments) and what they can do well based on what they have (their comparative advantages). Governments should compensate for the externalities generated by the first movers to the industries in which the country has latent comparative advantages, and coordinate or provide improvements in hard/soft infrastructure to reduce transaction costs so that the industries in question become the nation's competitive advantages and, thus, profitable. Competitiveness will create the foundation for sustained growth, income generation, poverty reduction, and fast upgrading of endowment/industrial structure leading to a catch-up process with high-income countries. I hope that the industrial policies for the five types of industries discussed in this chapter will help governments in catching-up European countries to tap their growth potentials and achieve development success.

\section{Bibliography}

Agenor, P.R., Canuto O. and Jelenic, M. (2012). Avoiding Middle-income Growth Traps, Economic Premise, 98, 1-7.

Aghion, P. (2009). Some Thoughts on Industrial Policy and Growth. Document de Travail 2009-09. Observatoire Français des conjonctures économiques. Sciences Po. Paris. Accessed at: http://www.ofce.sciences-po.fr/pdf/dtravail/WP2009-09.pdf (14.08.2016).

Akamatsu, K. (1962). A Historical Pattern of Economic Growth in Developing Countries. Journal of Developing Economies, 1(1), 3-25.

Amsden, A.H. (1989). Asia's Next Giant. New York and Oxford: Oxford University Press. Arndt, H.W. (1985). The Origins of Structuralism. World Development, 13(2), 151-159.

Cardoso, E. and Helwege, A. (1995). Latin America's Economy. Cambridge, MA: MIT Press. Chang, H.-J. (2003). Kicking Away the Ladder: Development Strategy in Historical Perspective. London: Anthem Press. 
Chenery, H.B. 1961. Comparative Advantage and Development Policy. American Economic Review, 51(1), 18-51.

Duflo, E. (2004). Scaling Up and Evaluation. In: F. Bourguignon, B. Pleskovic (eds.), Annual World Bank Conference on Development Economics 2004. Washington, DC: World Bank.

Easterly, W. (2001). The Elusive Quest for Growth: Economists' Adventures and Misadventures in the Tropics. Cambridge, MA: MIT Press.

Easterly, W., Loayza, N. and Montiel, P.J. (1997). Has Latin America's Post-Reform Growth Been Disappointing?. World Bank Policy Research Paper 1708. World Bank, Washington, DC.

Gerschenkron, A. (1962). Economic Backwardness in Historical Perspective: A Book of Essays. Cambridge, MA: Belknap Press of Harvard University Press.

Harrison, A. and Rodríguez-Clare, A. (2010). Trade, Foreign Investment, and Industrial Policy for Developing Countries. In: D. Rodrik (ed.), Handbook of Economic Growth (vol. 5). Amsterdam: North-Holland.

Hausmann, R. and Rodrik, D. (2003). Economic Development as Self-Discovery. Journal of Development Economics, 72(2), 603-633.

Hausmann, R., Rodrik, D. and Velasco, A. (2008). Growth Diagnostics. In: N. Serra, J. Stiglitz (eds.), The Washington Consensus Reconsidered: Towards a New Global Governance. Oxford, UK: Oxford University Press.

Ito, T. (1980). Disequilibrium Growth Theory. Journal of Economic Theory, 23(3), 380-409.

Ju, J., Lin, J.Y. and Wang. Y. (2015). Endowment Structures, Industrial Dynamics, and Economic Growth. Journal of Monetary Economics, 76, 244-263.

Kim, Y.H. (1988). Higashi Ajia Kogyoka to Sekai Shihonshugi (Industrialisation of East Asia and the World Capitalism). Tokyo: Toyo Keizai Shimpo-sha.

Krueger, A. (1974). The Political Economy of Rent-Seeking Society. American Economic Review, 64(3), 291-303.

Krueger, A. and Tuncer, B. (1982). An Empirical Test of the Infant Industry Argument. American Economic Review, 72(5), 1142-52.

Krugman, P. (1993). Protection in Developing Countries. In: R. Dornbusch (ed.), Policymaking in the Open Economy: Concepts and Case Studies in Economic Performance. New York: Oxford University Press.

Kuznets, S. (1966). Modern Economic Growth: Rate, Structure and Spread. New Haven, CT: Yale University Press.

Lal, D. (1994). Against Dirigisme: The Case for Unshackling Economic Markets. San Francisco: International Center for Economic Growth, ICS Press.

Lau, L., Qian, J.Y. and Roland, G. (2000). Reform without Losers: An Interpretation of China's Dual-track Approach to Transition. Journal of Political Economy, 108(1), 120-43.

Lee, K. (2013). Schumpeterian Analysis of Economic Catch-up: Knowledge, Path Creation, and the Middle-income Trap. Cambridge, UK: Cambridge University Press.

Lin, J.Y. (2009). Economic Development and Transition: Thought, Strategy, and Viability. Cambridge, UK: Cambridge University Press.

Lin, J.Y. (2011). New Structural Economics: A Framework for Rethinking Economic Development. World Bank Research Observer, 26(2), 193-221.

Lin, J.Y. (2012). Demystifying the Chinese Economy. Cambridge, UK: Cambridge University Press.

Lin, J.Y. (2013). Against the Consensus: Reflections on the Great Recession. Cambridge, UK: Cambridge University Press. 
Lin, J.Y. and Chang, H. (2009). DPR Debate: Should Industrial Policy in Developing Countries Conform to Comparative Advantage or Defy It?. Development Policy Review, 27(5), 483-502.

Lin, J.Y. and Li, Z.Y. (2008). Policy Burden, Privatisation and Soft Budget Constraint. Journal of Comparative Economics, 36, 90-102.

Lin, J.Y. and Monga, C. (2011). DPR Debate: Growth Identification and Facilitation: The Role of the State in the Dynamics of Structural Change. Development Policy Review, 29(3), 259-310.

Lin, J.Y. and Nugent, J. (1995). Institutions and Economic Development. In: T.N. Srinivasan, J. Behrman (eds.), Handbook of Development Economics (vol. 3). Amsterdam: North Holland.

Maddison, A. (2006). The World Economy. Paris: OECD.

Mazzucato, M. (2013). The Entrepreneurial State: Debunking Public vs. Private Sector Myths. New York: Anthem Press.

Naughton, B. (1995). Growing Out of Plan: Chinese Economic Reform 1978-1993. Cambridge, UK: Cambridge University Press.

Pack, H. and Saggi, K. (2006). Is There a Case for Industrial Policy? A Critical Survey. World Bank Research Observer, 21(2), 267-97.

Porter, M.E. (1990). The Competitive Advantage of Nations. New York: Free Press.

Prebisch, R. (1950). The Economic Development of Latin America and its Principal Problems. New York: United Nations. Reprinted in: Economic Bulletin for Latin America, 7(1) (February 1962), 1-22.

Rodrik, D. (2004). Industrial Policy for the Twenty-First Century. Cambridge, MA: Harvard University.

Romer, P.M. (1990). Endogenous Technological Change. Journal of Political Economy, 98(5), S71-S102.

Rosenstein-Rodan, P. (1943). Problems of Industrialization of Eastern and Southeastern Europe. Economic Journal, 111, 202-11.

Subramanian, A. and Roy, D. (2003). Who Can Explain the Mauritian Miracle? Mede, Romer, Sachs, or Rodrik? In: D. Rodrik (ed.), In Search of Prosperity: Analytic Narratives on Economic Growth. Princeton, NJ: Princeton University Press.

Wade, R. (1990). Governing the Market. Princeton, NJ: Princeton University Press.

Williamson, J. (1990). What Washington Means by Policy Reform. In: J. Williamson (ed.), Latin American Adjustment: How Much Has Happened? Washington, DC: Institute for International Economics.

World Bank. (2002). Transition, the First Ten Years: Analysis and Lessons for Eastern Europe and Former Soviet Union. Washington, DC. 


\section{BOGDAN GÓRALCZYK}

\section{Eastern-Asian development model: the growth-fostering state}

The West has been convinced for decades that there is no alternative to classical capitalism and real socialism - no third way. After the collapse of the Cold War order, attempts were made to replicate this "no alternative" concept in the form of the dictate of markets as provided for in the neoliberal Washington Consensus. Meanwhile, East Asia has invented a combination of the market and state intervention, known as enabling state, facilitating state or "growth-fostering state". The author of this article argues and explains that the new theory by Justin Yifu Lin, referred to as New Structural Economics, cannot be fully understood without this broader context. Another claim made here is that, rather than a new economic theory, NSE is really an innovative concept of industrial policy which - unlike the industrial state model, or, more specifically, the developmental state closely tied to "Asian values" - can be applied in other catching-up economies and regions as long as they are determined to combine the market with the strong state.

Keywords: development models, industrial policy, Eastern Asia, China, emerging markets - catching-up economies.

\section{Introduction}

For several decades of the Cold War era, the world was doomed to a peculiar and unavoidable duopoly, also in economic terms: classical capitalism, roughly along the lines defined by John M. Keynes, in the United States and in Western Europe, clashing with more uniform socialist system, or state socialism, also known as "real socialism", in the USSR and the Eastern Bloc. As we know from such studies - already classical - as János Kornai's (1993), the latter model involving the domination of ideology and politics in the economy, centralisation, planning, and soft budget constraints first led to widespread deficits, then occurred economically inefficient and non-viable, and finally collapsed.

Before that, however, for a few decades, political and even academic community considered the situation binary - we had a choice between either a liberal open economy or a centrally-planned model (Bolesta, 2007, p. 105). Yet, at the turn of the 1960s, an ideological and economic alternative appeared in some part of the 
world - East Asia ${ }^{1}$. First in Japan (Bolesta, 2015, p. 24), later in some other places of the region ${ }^{2}$, and finally in China, a completely new model was established. It is this model that is discussed herein, also with reference to a new ideological and political proposal, namely Justin Yifu Lin's new theory presented in this volume.

The basic assumption and hypothesis of this study is that the new theory by J.Y. Lin can be fully and more deeply understood only in a broader context of model solutions applied previously in East Asia and that it comes as no surprise whatsoever that such a theory - concerning mainly industrial policy and, to a lesser extent, the whole economy - was conceived in the People's Republic of China (PRC). There is much evidence that it can be very useful for economically lagging emerging markets. Nonetheless - and this is the second hypothesis of this article - it is doubtful and questionable whether it might be so effectively implemented in other areas than East Asia or Southeast Asia (primarily the countries of the Association of Southeast Asian Nations - ASEAN), mainly for cultural reasons.

\section{Origins and evolution of the developmental state}

In 1982, Chalmers Johnson, a well-known American expert on East Asia and in particular on contemporary Japan, published a volume which at first caused an uproar within academic and economic circles and afterwards turned out to be a classic work, presenting a completely new phenomenon, termed developmental state (Johnson, 1982). Building on an extensive query and a thorough analysis of the functioning of the powerful Japanese Ministry of International Trade and Industry (MITI) (Van Wolferen, 1989), that author concluded that post-war Japan had established its own national development model duplicating neither mainstream capitalist economies (Keynesian economics) ${ }^{3}$ nor the coherent but inefficiently planned economies operating in real socialism (Kornai, 1993, p. 380).

Years later, Johnson (1999, p. 32) honestly admitted that he had intended "to go beyond the contrast between the American and Soviet economies" and found a solution in Japan. Concluding the book on MITI, apparently under the influence of an insightful publisher (Johnson, 1999, pp. 40-43), he summarised his considerations from his initial volume and specified the distinguishing features of the Japanese model. These included (Johnson, 1982, pp. 314-320) the following:

1 I suggest the term "East Asia" rather than the often used "Far East", as the latter is a Russian derived from Dalniy Vostok, meaning areas situated "behind the Ural" as Russians understand it.

2 Hong Kong was a British colony until July 1997 and has been a special region of China since then, while Taiwan, despite meeting the criteria of being a state, still has an unregulated international legal status, hence is not a UN member.

3 Lin writes about "structuralism", hence his "neostructuralism", i.e. a reference to Keynes. However, we would rather term it welfare state (Walicki, 2013, p. 321). 
- small, inexpensive but elitist state bureaucracy staffed by the best managerial talent available in the system;

- political system in which bureaucracy has a sufficient room for manoeuvre to take initiative and operate effectively;

- market-conforming methods of state intervention;

- a pilot organisation, namely the MITI ${ }^{4}$.

The response of the US and Western academic communities to that proposal was generally negative and very emotional at the same time. The author himself admits: "I came to realize (...) that my book was an ideological red flag" (Johnson, 1999 , p. 34). It challenged the applicable canon whereby the dominant role in the economic system was to be played by the market, not the state (Chang, 2003, p. 36). As commonly known, after less than a decade, this led to the emergence of "new faith" following the lines of the neoliberal Washington Consensus (in this case, Lin sticks to the accepted terminology5), even referred to as market fundamentalism or market authoritarianism (Halper, 2010, p. 32) supporting, or rather building, "phony capitalism". Among other things, this type of capitalism brought about huge income disparities (Stiglitz, 2015, p. 126), which in turn resulted in the concept being undermined and compromised after 2008.

No less controversy and even greater emotions than in the case of the role of the state were aroused by an issue - which is very vital for the developmental state - of the role performed by the state administration and its industrial and development policies. This was hastily compared to "social engineering" or even methods known from authoritarian and fascist states, including, notably, Italy under the rule of Mussolini (Woo-Cumings, 1999, pp. 52, 53). Johnson acknowledged that links between democracy and development were important. He also added that the developmental state could flourish under both autocratic and democratic conditions (as evidenced by his examination of the model in the long-time span of 1925-1975). However, he denied with much aplomb that the developmental state was only a "developmental dictatorship". Instead, he believed it had at least twofold legitimacy: firstly, it was based upon clear, transparent and modernisation-related goals beneficial for the state and society; secondly, it had proved to operate extremely effectively.

The key evidence supporting this thesis was Japan's enormous economic success at that time. Because of the gradually developed model that was fully implemented in the 1950s, the conquered state that had lost the war and was colonised for the first time in its history, rebounded impressively and grew up to become - as early

4 In Singapore, the Economic Development Board exists. In South Korea, there is the Economic Planning Board, and Taiwan has the Council on Economic Planning and Development (Bolesta, 2015, p. 39).

5 For an excellent comparative analysis of the developmental state and the neoliberal package identified as the "flying geese" paradigm see Kasahara, 2013. For an in-depth and thorough analysis of neoliberalism see Walicki, 2013. 
as the second half of the 1970s - the world's second-largest economy, next only to the US (Vogel, 19996). No wonder that other nations in the region quickly followed the example. There were four: Hong Kong, South Korea, Singapore and Taiwan, referred to as Newly Industrialized Countries (NICs), or commonly as "Asian tigers", in world literature. They did not replicate the model developed in Japan exactly. Hong Kong and Taiwan focused on small and medium-sized enterprises rather than on large public-private conglomerates, with the latter having combined a flexible market with a less flexible state (Castells, 2009, p. 239). All of them, however, shared such features as: methodical development planning to constantly move towards modernity and modernisation (from textiles to heavy industry, followed by high technologies, and from production to services); export-oriented and open economy, but also reservoirs of cheap labour force (at least at early stages of modernisation and reform); and often imposed social discipline (in some cases including repressions). The system was dynamic but also ruthless whenever necessary (which meant whenever the government deemed it appropriate) (Castells, 2009, pp. 253, 254).

Despite emerging controversies and contradictory assessments, NICs benefited greatly from the Japanese experience (the model implemented in South Korea proved to be closest to the original), adapted the model developed in Japan to their own local conditions, and then enjoyed as big economic success as Japan did. Their success generated considerable interest, which enticed many scientists to study them carefully. For example, Alice Amsden presented a key volume on South Korea (1989), Robert Wade published his observations on Taiwan (1990), and Manuel Castells, a famous sociologist, made perhaps the most thorough comparison of all four countries (2009, pp. 230-277).

Growing and increasingly extensive literature identified further important features of the developmental state model, such as:

- development based on either large public-private conglomerates (zaibatsul keiretsu in Japan, chaebole in South Korea) or small and medium-sized enterprises (Taiwan and Singapore);

- careful planning of state modernisation and a gradual but clear shift toward modern technologies and from production to services;

- the entire model based on export-oriented policy with reasonable reliefs (tax, special trade zones, etc.) to exporters;

- conscious inclusion of foreign capital (FDI) in development and modernisation policies of the state (Hong Kong and Singapore in particular);

- skilful but effective elimination of solutions alternative to those proposed by the state administration (especially in Singapore, initially also in the territory of the South Korean military regime, which controlled modernisation in 1962-1988).

6 It should be noted that the first version of this seminal book was published in 1979. In 2001, Vogel published another volume on this subject, entitled: Is Japan Still Number One? 
Japan is known to have broken down economically and financially in the early 1990s. Its system, quite elusive and full of paradoxes (such as the apparently strong centre and considerable flexibility, reliance on strong personal relationships rather than on law or institutions, etc.), best defined in the literature by K. van Wolferen, proved anachronous in the face of new globalisation challenges and under pressures from international markets (van Wolferen, 1990, p. 49).

From the early 1990s onwards, Japan ran into economic trouble, which naturally re-opened the debate on the developmental state, its advantages, and shortcomings; even more so that at that time global markets became dominated by the orthodoxy of the neoliberal Washington Consensus, so severly pushing for the principles of free market and private property at the expense of the state and public property (Walicki, 2013, pp. 12 and 121). Once again, the interest and debate focused on the state-market interfaces: how many of them should exist and in which proportions? (Wyżnikiewicz, 2016). Alex Kerr, one of the most distinguished experts on Japan, who was extremely critical of its modernisation pathway ${ }^{7}$, highlighted the main drawbacks of the model, such as unclear links between public-private companies and banks and the Ministry of Finance as well as bureaucracy much appreciated in literature for its professionalism and apoliticism. He accused bureaucracy of ossification and stated that it was Japan's only serious irresolvable problem, adding even more strongly that it was responsible for leading Japan to the brink of disaster in the 1990s (Kerr, 2008, p. 354). In turn, M. Castells, another insightful researcher studying the developmental state, sought the causes of Japan's collapse and the stock market crash elsewhere, albeit close. He writes that it is not excessive state intervention but lack of regulation and loose state oversight over the financial system that were essential decisive factors that made it possible for the financial crisis to ruin the economy (Castells, 2009, p. 268).

Kerr, van Wolferen, and others have argued that Japan was not adequately prepared for the challenges of globalisation, it was still a relatively closed country, and that the stock market crash was largely caused by the then famous Plaza Accord of September 1985 on the foreign exchange policy and the position of the Japanese yen, which first led to the loss of export benefits, then debt, and finally deflation, with which Japan has been struggling for more than two decades (excellent analysis: Pesek, 2014), unable to break out of the continuous loop.

\section{China as a developmental state}

Japan has been struggling with economic hardships for over two decades and Prime Minister Shinzo Abe's new national economic strategy, commonly called

7 He left Japan after decades spent there. 
abenomics, which has been strongly pushed forward since early 2013, has not been entirely helpful. In contrast, other regional economic tigers are generally performing very well today. One of them, Singapore, has become the main reference point and benchmark for the largest tiger that has emerged on this path, namely the People's Republic of China (Vogel, 2011, p. 287).

Since the beginning of the reforms launched in December 1978, China has been moving forward along its own unconventional path, pragmatically integrating market mechanisms in the centralised planned economy (Lin, 2009, Preface), thus creating a completely unique model. However, during the first decade of transformation, it still focused on reforms of real socialism, striving to consolidate it (Chao and Dickson, 2001, p. 9). Only after 1992, in response to the break-up of the USSR and the Eastern Bloc and the collapse of the inefficient model of the centralised planned economy, did Deng Xiaoping propose a totally different approach. Instead of reforming real socialism (as attempted from the very outset of the reforms), he suggested that his successors (indeed, it was his political testament) put the Chinese colossus on the globalisation path by further opening, expanding and liberalising China's huge market, and building on the experiences of the NIC "four little dragons" (si xiao long), in particular Singapore (Deng, 1993, p. 378).

Following new directives, hundreds or even thousands of senior Chinese officials travelled to Singapore to learn, and Deng himself, a convinced communist, had already established a close and cordial relationship with Lee Kuan-yew, "Singapore's father", its long-time Prime Minister and a visionary of its development. In fact, that new strategy implemented in China, communist by name, the model of the developmental state as already known in Japan and NICs but adapted to the Chinese needs and conditions. From approximately the 1990s onwards, the model developed the following characteristics (Góralczyk, 2016, pp. 49, 50):

- high economic growth as the priority of the state policy;

- export as the main driving force of the economy;

- opening of the huge domestic market to trade and world economy, almost fully capitalist now, and the use of foreign capital (FDI) for China's own modernisation needs;

- massive accumulation of largely infrastructural investment and boosting development in this way (first motorways, then bridges and viaducts, seaports and airports, and finally fast railways);

- the use of huge (in fact, of a unique size in the world, except perhaps India) resources of cheap rural and backcountry labour as slave workers ${ }^{8}$ without social benefits and with low wages;

8 This unique phenomenon can perhaps be most vividly understood when watching "China" (Chung-Kuo - Cina), a 1972 documentary directed by Michelangelo Antonioni and available on YouTube, where one of three episodes clearly shows Chinese peasants doing nothing because they have no work. This changed radically after 1978. The film by Antonioni - see: https://www.youtube.com/watch?v=Z9tAd_-2AoM (accessed on: 17.04.2017). 
- the state's responsibility for strategic decisions and areas (national defence and astronautics, but also banking, airports, seaports, telecommunications, energy, etc.) and state interventions undertaken in line with one specific principle: the invisible hand of the market - yes of course, but where legitimate interests of the state are at stake, it is the government's hand, very well visible, that comes into play (Halper, 2010, p. 8).

It should be observed that many Western experts openly doubt whether China possesses or has produced its own development model (Halper, 2010, p. 32), treating it primarily as an authoritarian system (which is, however, a political rather than economic category). Nonetheless, it appears that the PRC authorities would not have achieved such a spectacular success in the past four decades without their own model or a carefully thought-out and implementable vision of national modernisation and development. Furthermore, after 1992, unlike the Russian Federation under the leadership of Boris Yeltsin and the vast majority of post-communist countries, the PRC not only rejected the neoliberal market orthodoxy, treated as having no alternative according to the Washington Consensus after 1991 (Walicki, 2013, p. 65) but also skilfully integrated ${ }^{9}$ the rudiments of the developmental state model in its own system.

The recorded and statistically proven success (average annual economic growth of $9.8 \% 10$ in 1978-2012 in the world's most populous country!) is the best evidence that the applied solutions are working well. China has gone its own way, inspiring Joshua Cooper Ramo, a Western expert lecturing in the PRC, to coin the term of "Beijing Consensus" (for a good analysis, although full of Western prejudices against China, see Halper, 2010). Ramo did not fully explain and define its distinctive features but the main message was more than clear: the Washington Consensus prioritises the market and private economy, whereas the Beijing Consensus stipulates that the state maintains the controlling interest and the intervention right, although the economy is mainly a market economy.

China did not accept that concept: firstly, it was developed by a Western intellectual and, even more importantly, it went too far in opposing the Washington Consensus. This resulted in a post-2010 extensive national debate on the "Chinese developmental model" (Zhongguo moshi) that continues to date (Góralczyk, 2016; Zheng Yongnian, 2016). Justin Yifu Lin's concept of New Structural Economics should be definitely considered in this context. Before that, however, it is important to address the crucial adaptation of the development model derived from capitalist Japan and NICs to the PRC with its communist nature and political system.

9 This was done by the third generation of leadership in the 1990s, in particular by Prime Minister Zhu Rongji, a brisk and brave reformer.

10 Data from: http://www.tradingeconomics.com/china/gdp-growth-annual (accessed on: 17.04.2017). 
The model presented above and developed by Zhu Rongji and others proved to be effective, yet it also delivered some side effects (the terminology used in the PRC) of reforms after years of operation. These include excessive enfranchisement of the CPC nomenclature; wide social disparities (Gini coefficient of up to 0.6, higher than in the US); regional disparities; excessive support for not always efficient state-owned conglomerates; natural environment devastation in the course of rapid industrialisation and urbanisation ${ }^{11}$.

During the implementation of reforms and the wide-scale debate on the "Chinese developmental model", it also appeared that there were at least two structural barriers disrupting the harmonious functioning of the developmental state model under "socialism with Chinese characteristics". The first one was the legal system that worked so well in Singapore, where regulations are very strict. The PRC as a country of communist origin governed by the "four cardinal

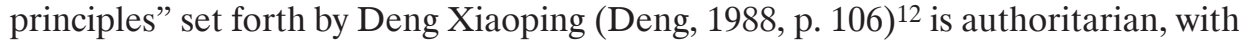
the fundamental and overriding principle involving the rule of the CPC, which is no longer as revolutionary as it used to be during Mao Zedong's reign (1949-1976) and is now a classic power party, rather than the rule of law. The second barrier was the fact that staff and administration officials continued to be largely selected from among the (more and more enfranchised) nomenclature and not exclusively based on merit and experience as recommended by the classical model of the developmental state.

These factors made Xi Jinping, the head (since the end of 2012) of the fifth generation of leadership, come up with an unprecedented national anti-corruption campaign that has resulted (at the moment of writing this text) in over 1.2 million convicts, including people holding highest-ranked offices in the country. More importantly, in the lively debate on Zhongguo moshi, the "Chinese dream" and the "great renaissance of the Chinese nation" slogans strongly advocated by Xi Jinping (2014, p. 37) were combined with the rudiments of the modified developmental state model consisting of the following (Góralczyk, 2016, p. 59):

- sustainable development instead of growth at all cost (hence a recent decline in the GDP growth from a double-digit growth to $6.5 \%$ );

11 At the end of 1978, at the outset of reforms, 84\% of PRC citizens lived in rural areas; in 2014, as many as $53 \%$ lived in cities and Prime Minister Li Keqiang announced that urbanisation might affect $70 \%$ of the population by 2030. See his key speech on this issue delivered on 25 May 2013. Li Keqiang expounds on urbanization, http://china.org.cn/china/2013-05/26/ content_28934485.htm (accessed on: 17.04.2017).

12 They include: 1. upholding the socialist path; 2. upholding (the people's) dictatorship; 3. upholding the leadership of the CPC, Marxism-Leninism, Mao Zedong's thought and the latest CPC concepts such as Jiang Zemin's "Three Represents" theory of 2001 allowing large capitalists to join the CPC and the recently pushed forward "scientific development concept" (kexue fazhan guan). More about the latter: http://baike.baidu.com/item/\%E7\%A7 $\% 91 \% \mathrm{E} 5 \% \mathrm{AD} \% \mathrm{~A} 6 \% \mathrm{E} 5 \% 8 \mathrm{~F} \% 91 \% \mathrm{E} 5 \% \mathrm{~B} 1 \% 95 \% \mathrm{E} 8 \% \mathrm{~A} 7 \% 82 / 317422 ? \mathrm{fr}=$ aladdin $($ accessed on: 15.04.2017). 
- developed internal market instead of increasingly expensive exports ("The End of Cheap China"; see Rein, 2012);

- "moderately prosperous society" (xiaokang shehui), meaning the middle class as the basis for the functioning of the country, which requires massive social expenditures among other things;

- urbanisation rather than infrastructure investment as the driving force of modernisation, since the infrastructure, has already been largely upgraded;

- the development of green areas or even "carbon footprint-free economy" - given that the environment was badly degraded in the previous extensive and offensive phase of development;

- creation of the innovative society, involving, for example, a continuous shift to state-of-the-art technologies, hence an inherently difficult shift from production quantity to production quality.

\section{Developmental State and New Structural Economics}

It is in this context that J.Y. Lin's new theory, referred to as New Structural Economics, should be understood and considered. It should be argued that it is essentially, first and foremost, an interesting proposal for "emerging markets" (the author is rather consistent in calling them "catching-up economies") and, above all, a developed concept of industrial policy implemented within a broader model of the developmental state.

Like other authors (Bolesta, 2007, p. 105; Johnson, 1999, p. 33), J.Y. Lin acknowledges he seeks a model different from those working so far in the Western world, yet he primarily invokes Western literature and his text discussed in this volume is addressed to Western rather than Chinese readers. Surprisingly, he makes no reference to "developmental state", although he obviously knows the term and cites it in his other works (Lin, 2009, pp. 40-42). Considering how astonishing and puzzling this evasion is, it probably should have been explained by that author somehow. Indeed, the mere statement that this is a "third proposal", a new wave of thinking about the economy after "structuralism" and neoliberalism (as mentioned above), which obviously had their shortcomings, is definitely too superficial and not really convincing.

Although Lin does make it clear that Japan initially, and the four named Asian tigers later, were "pursuing an entirely different development approach", he does not, unfortunately, elaborate on this anymore. Reading between the lines, J.Y. Lin also admits that the model developed earlier was taken over by China, but points out that China "adopted a dual-track transition, continuing to protect and subsidize nonviable state-owned firms in the old prioritized capital-intensive industries, while liberalizing the market entry for the previously repressed labor-intensive industries". 
In other words, he confines himself again to industrial strategy and economy rather than a broader development model.

Therefore, his new concept should be, above all, seen as a new, innovative theory of industrial policy linked with one of the basic goals of the new Chinese development model that is now, and painfully, implemented by the Beijing government, namely constant emphasis on innovation and technological progress. This is what should be regarded as the fundamental value of this theory, in particular for "catching-up economies" as the author calls them. It is the greatest value added of that study and it seems worthwhile to address this issue more broadly.

J.Y. Lin is definitely right when he writes that "improving infrastructure and institutions is beyond the capacities of individual firms". Against this background and beyond, he is therefore against neoliberalism, which "threw the baby out with the bath water, vehemently opposing any role for governments", on the one hand. On the other hand, what he does not mention or explain (since it is obvious to him) is that he follows the spirit of the developmental state model by advocating considerable development planning and a steering role for the state, hence state interventions also, and perhaps primarily, in the form of a rational and elaborated industrial policy.

It is in this context that the most innovative contents of that text appear, namely the division of industries into five basic types: catching-up industries, leadingedge industries, comparative-advantage-losing industries, short-innovation-cycle industries, comparative-advantage-defying strategic industries. It seems that this unique division can be effectively and without much controversy implemented in most "catching-up economies", if they continue to cling to market orthodoxy and agree to state interventions.

Long time ago experts concluded that the strength of China's solutions and model (still being vehemently disputed) lay and still lies in "rationalisation of the state" and of the state sector (Chao and Dickson, 2001, p. 26). In other words, the key to success is a rational state rather than not fully controlled, uncompelled market (although liberals and neoliberals believe otherwise). Here, however, comes the proverb of squaring the circle, that is the already mentioned dilemma: how much state and how much market?

J.Y. Lin does not dwell extensively on this, probably considering it - based on the previous Chinese experience - quite obvious: the primacy of the state must prevail, end of story. Nevertheless, others hold different views. Chalmers Johnson clearly demonstrates that this is the key, most critical dilemma within the developmental state model. Not only does he point out that there is one major argument against an industrial policy implemented by the state (or rather its broad-minded elites), namely a practically evidenced and real threat that diverse and extensive collective interests, including those of industrial policy makers, may prove more important than their development policies and strategies (Johnson, 1999, p. 48). Thereby, he seems to confirm the above-mentioned Alex Kerr's diatribe against the Japanese state administration. 
Japan's experience is a serious warning, yet it is not Japan but Singapore that provides a model for China. Singapore, as claimed by Lee Kuan-yew, tackled this issue in one way: by granting the state administration not only the highest possible authority but also such salaries as those in the private sector. Therefore Singapore, although Chinese by nature (about $80 \%$ of its population is of Chinese origin), is free of corruption and even leads the Transparency International's rankings as one of the least corrupt parts of the world ${ }^{13}$.

The question is how to develop such honest and transparent managerial classes in a one-party state primarily governed by the logic and will of the CPC, a party of power and nomenclature, but also in democratic countries, where the logic of particracy is prevalent, meaning that party divisions and interests dominate over the state interests. Lee Kuan Yew advises: "There are three basic essentials for the successful transformation of any society. First, a determined leadership [...] two, an administration which is efficient; and three, social discipline" (Alison, Blackwill, and Wyne, 2013, p. 157). He then adds that - as in Singapore - production of future leaders should start in early schooling, according to their "capability, proclivities, temperament", which are "genetic" (Alison, Blackwill, and Wyne, 2013, p. 163). Except that, from the point of view of liberal democracy, which is apparently in crisis now, such an approach is nothing different from the manifestations of authoritarianism or even social engineering, unacceptable in the liberal order. Thus, no wonder that the two allegations are made against both Singapore and the PRC.

Chalmers Johnson, however, goes even further and deeper in his exploration of the hitherto experience of introducing the developmental state model and finally stops at the state-market and government-business environment relations. He finds that these questions are even more profound than the apparently fundamental division into autocracy and democracy ${ }^{14}$. On that basis, he concludes that solely the issues of individual and social self-discipline as well as the system of values in place are concerned. Thereby, we reach the very heart of the matter: "dialectical progression toward public-private cooperation" (Johnson, 1999, p. 58). In this case, there seems to be only one conclusion: the East Asian value system based on duties is better suited to implement the developmental state model than the Western system relying on individual freedoms ${ }^{15}$.

13 In recent years, its rating has dropped slightly to only eighth position in the 2015 ranking, but its scores are still very high, placing it among top countries after Scandinavia, New Zealand and Switzerland. See https://www.transparency.org/cpi2015/ (accessed on: 17.04.2017).

14 Let us remind that he studied the MITI and the Japanese model from 1925 to 1975, when various political systems existed on the Japanese islands.

15 The idea of "Asian values" was developed in the 1990s by Lee Kuan-yew mentioned above and Mahathir bin Mohammad, long-time Malaysian Prime Minister. The latter found that Asia sticks to the overarching values of: social order and good organisation; harmony in society; responsibility of public officials; respect for authority and hierarchy; whereas the western system regards the overarching values as individual and connected with freedom of expression, individual freedoms, individual rights, open debates, and care of oneself. This and 
In his theory, J.Y. Lin does not dwell on these dilemmas and challenges since they might seem to him quite obvious from the Chinese perspective. However, from the point of view of other cultures and civilisations, in particular, the Western one, they are not obvious at all. They concern imponderables which no Western politician (including economic policy makers) can escape while attempting to implement the propounded model of New Structural Economics and new industrial policy proposed by that author.

This conclusion should be noted and its importance stressed, even more so nowadays, when - as predicted by Lee Kuan-yew ${ }^{16}$ - China neither has nor will or even "is going to become a liberal democracy; if it did, it would collapse. Of that, I am quite sure" (Alison, Blackwill, and Wyne, 2013, p. 41). Therefore, we have to coexist rather than to converge our systems and models of development. Appropriate conclusions should be drawn in this respect.

\section{Conclusion}

This study focused on the developmental state understood as a broader context of new ideas proposed by J.Y. Lin in this volume. Based on a review of the experiences of countries and regions that have applied this model with an overwhelming success, namely Japan, later NICs, and most recently the PRC, the model seems to be specific and characteristic of East Asia and its "Asian values" rather than a one-size-fits-all solution capable of being implemented in various parts of the globe. By contrast, the second, unique idea of that Chinese author, a new approach to the industrial policy of the state, may be more universal. Except that, to put it into practice, a "green light" is needed for a meaningful role of the state and state interventions undertaken by wise, experienced and non-corrupt elites. These, however, seem to be conditions that are difficult to fulfil even in China or Japan, not to mention the wider world.

J.Y. Lin's new theories are timely as the entire world and, above all, Western democracies are learning lessons from the previous neoliberal market orthodoxy and the resultant - as believed by the majority - extensive crisis in the global (western) markets in 2007-2008 and afterwards. The present time is also very good for China, where a great debate is ongoing on the new development model and conclusions are being drawn from the prior expansive and extensive development phase and on the threats that it has brought about (Chi, 2010). Paradoxically, the West is again considering an increased role of the state (hence the discussion on the developmental state model is even more valid and attractive). On the other

other analyses suggest that Asian values are more strongly linked to collectivity and duties, while the Western ones are based on individual freedoms. See Mahathir, 1999, pp. 157-168.

16 Who proved that he was right on numerous occasions. Lee Kuan Yew died in 2015. 
hand, if the insightful diagnosis made by Zheng Yongnian, a lecturer in Singapore who mainly publishes his works in the PRC, is to be believed, China is currently empowering its society. This process may take as long as the first phase of enhancing the power of the state, that is even 30 years, and only later will the third and last transition phase, namely political transition, take place (Zheng Yongnian, 2012).

In the second phase of transition and transformation, the dilemmas regarding the state-market interface will, however, still be crucial, except that this time society will be also at stake, with an emerging triple link: government-market-society (Chi, 2010, p. 9). This seems to be the most correct conclusion and path of exploration since it has already been shown that as modernisation progresses, the role of the state as a driving force behind development and industrial policy slightly diminishes while the role of (civil) society gradually increases in the entire process due to the nature of changes and the orientation towards knowledge-based society. As aptly stated by M. Castells, the legitimacy principle has shifted from developmental nationalism to civil nationalism. (Castells, 2009, p. 273).

As at the launch of the developmental state model, efficiency in the quadrilateral: the ruling elite, the state administration, society, and business community is again being commonly discussed (Bolesta, 2015, p. 13). The efficiency of this model depends, first and foremost, on them and their harmonious cooperation - on how to prevent any strong interdependencies within this quadrilateral. Nonetheless, what should be noted in this context is Grzegorz Kołodko's keen observation: "There are lobbies everywhere fighting for their particular interests by all available means, but there are no strong lobbies willing to fight for long-term growth and far-reaching policy goals with similar resolve and strength. This role must be performed by the state" (Kozłowski and Wojtysiak-Kotlarski, 2014, p. 333).

In other words, it is the state that must remain the prime guardian of farreaching development and modernisation goals. Therefore, it is most preferable that the state is transparent, fair and enlightened, making the full use of well prepared and educated elites suggesting the directions to be followed and further goals to be set by the public and business. On top of that, only such state seems to be able to break through the glass ceiling and avoid the middle-income trap, which is a further, although not overriding, goal in the implementation of J.Y. Lin's new theories presented in this volume and a matter of serious concern in all "catching-up economies" including Poland.

There is evidence that the developmental state model gradually leads to the empowerment of civil society, although this is also one of the most critical challenges in its practical application. This is because of the previously defined dilemma: how much state, how much market? is topped with a further problem, equally important for the model effectiveness, namely how much state and its arbitrary role, how much civil liberties?, as well as another well-defined dilemma: how much state and how much globalisation in the development process (Chang, 2003, p. 11), the question about the degree of openness to ideas, impulses and external markets. None of 
these issues is a foregone conclusion yet. However, these questions obviously lie at the very heart of ongoing academic and political debates and disputes.

Nowadays, the whole world is at a turning point, and any new concepts and ideas such as those put forward by J.Y. Lin are highly desirable in breakthroughs and critical times. We are heading towards what is new, albeit we have yet to see what "new" will mean. Therefore, our investigations are even more difficult and important.

\section{Bibliography}

Alison, G., Blackwill, R. and Wyne A. (eds). (2013). Chiny, Stany Zjednoczone $i$ świat w oczach wielkiego mistrza Lee Kuan Yewa (Lee Kuan Yew: The grand master's insights on China, the United States, and the World). Warsaw: Kurhaus.

Amsden, A.H. (1989). Asia's next giant: South Korea and late industrialization. New York, Oxford: Oxford University Press.

Bolesta, A. (2007). China as a developmental state. Montenegrin Journal of Economics, 5.

Bolesta, A. (2015). China and post-socialist development. Bristol, Chicago: Policy Press.

Castells, M. (2009). Koniec tysiaclecia (End of millenium). Warsaw: PWN.

Chang, H.J. (2003). Globalisation, economic development and the role of the state. New York: Zed Books.

Chao, Chen-min and Dicson B.J. (eds). (2001). Remaking the Chinese state. Strategies, society, and security. London and New York: Routledge.

Chi, Fulin (2010). Di er ci Gaige. Zhongguo weilai 30 nian de qiangguo zhi lu (The second reform. Thirty years of building a strong state in China). Beijing: Zhongguo Jingji Chubanshe.

Deng Xiaoping (1988). Chińska droga do socjalizmu (The Chinese Road to Socialism). Warsaw: Książka i Wiedza.

Deng Xiaoping (1993). Deng Xiaoping Wenxuan (Selected works...), vol. 3. Beijing: Renmin Chubanshe.

Góralczyk, B. (2016). W poszukiwaniu chińskiego modelu rozwojowego (In Search of Chinese Development Model). Sprawy Międzynarodowe, LXIX, 1, 40-61.

Halper, S. (2010). The Beijing Consensus. How China's authoritarian model will dominate the twenty-first century. New York: Basic Books.

Johnson, Ch. (1982). MITI and the Japanese miracle. The growth of industrial policy 1925-1975. Stanford: Stanford University Press.

Johnson, Ch. (1999). The developmental state: Odyssey of a concept. In: Woo-Cumings (ed.), The Developmental State (pp. 32-60). Ithaca and London: Cornell University Press.

Kasahara, S. (2013). The Asian developmental state and the flying geese paradigm. UNCTAD Discussion Papers, November. New York: United Nations.

Kerr, A. (2008). Psy i demony. Ciemne strony Japonii (Dogs and demons. Tales from the dark side of Japan). Kraków: Universitas.

Kornai, J. (1993). A Szocialista rendzyer. Kritikai polituikai gazdaságtan (Socialist system. Critical political economics). Budapest: HVG Kiadói Rt. 
Kozłowski, P. and Wojtysiak-Kotlarski, M. (eds). (2014). Grzegorz W. Kołodko i ćwierćwiecze transformacji (Grzegorz W. Kotodko and a Quarter-Century of Transformation). Warsaw: Wydawnictwo Naukowe Scholar.

Lin, J.Y. (2009). Economic development and transition. Thought, strategy, and viability. Cambridge: Cambridge University Press.

Mahathir, M. (1999). Rozważania o wartościach azjatyckich (Considering the Asian Values). Azja-Pacyfik, 2.

Pesek, W. (2014). Japanization: What the world can learn from Japan's lost decades. New York: Wiley.

Rein, S. (2012). The end of cheap china. Economic and cultural trends that will disrupt the world. New York: Wiley.

Stiglitz, J. (2015). The great divide. London, New York: Penguin.

van Wolferen, K. (1990). The enigma of Japanese power. New York: Alfred A. Knopf.

Vogel, E. (1999). Japan as no. 1. Lessons for America. New York: Universe.

Vogel, E. (2011). Deng Xiaoping and the transformation of China. Cambridge, Massachusetts and London: The Belknap Press of Harvard University Press.

Wade, A. (1990). Governing the market economic theory and the role of government in East Asian industrialization. Princeton: Princeton University Press.

Walicki, A. (2013). Od projektu komunistycznego do neoliberalnej utopii (From the Communist Project to Neoliberal Utopia). Kraków: PAN - Universitas.

Woo-Cummings, M. (ed.). (1999). The developmental state. Ithaca and London: Cornell University Press.

Wyżnikiewicz, B. (2016). Ile rynku ile państwa? (How Much Market, How Much State?) In: J. Kleer, P. Szukalski, K. Prandecki (eds), Dokad zmierza Europa? Państwo-GospodarkaSpoteczeństwo-Finanse (pp. 131-143). Warsaw: Komitet Prognoz Polska 2000 Plus przy Prezydium PAN.

Xi, Jinping (2014). The governance of China. Beijing: Foreign Languages Press.

Zheng, Yongnian (2012). Zhongguo Gaige san bu zou (Three phases of Chinese reforms). Beijing: Dongfang Chubanshe.

Zheng, Yongnian (2016). Zhongguo moshi. Jingyan yu tiaozhan (Chinese development model: Experiences and challenges). Beijing: Zhongxin Chuban Tuanji. 


\section{ALOJZY Z. NOWAK}

\section{New Structural Economics and dilemmas of the economic development}

This article addresses the processes unfolding in the context of globalisation and some challenges for efficient and healthy socio-economic development, in particular in Poland. It is believed that many problems that have emerged globally should lead to new solutions and a new economic order and arrangement. In countries such as Poland, the so-called New Structural Economics is attracting more and more interest. It applies a neoclassical approach to study the determinants of economic structure and its evolution. It postulates that the industrial structure in an economy is endogenous to its endowment structure. The author of this article shares the view that the assumptions of New Structural Economics are worth considering, also critically. New Structural Economics argues that the key to success in a country's development is to have an enabling state which applies the industrial policy to facilitate firms' entry to latent comparative advantage industries in a competitive market. This should be done by overcoming the first-mover's externality issue and coordinating the required improvements in hard and soft infrastructure, to turn the latent comparative advantage industries to the nation's competitive advantages.

The need for an analytical evaluation of the development philosophy based on New Structural Economics is even more justified as the policy and strategy of the current Polish government respond to the development policy trends in countries catching up with highly industrialised economies, as outlined by New Structural Economics. This article was undoubtedly inspired by the visit of one of the theoreticians and authors of New Structural Economics, Professor Justin Yifu Lin, an economic adviser to the Chinese government and Vice President of the World Bank in 2008-2012, to the Faculty of Management at the University of Warsaw.

Keywords: globalisation, developmental challenges, New Structural Economics, Strategy for Responsible Development.

\section{Introduction}

The world economy globalisation processes, in particular, the main mega-trends occurring in it, such as privatisation, deregulation, integration, liberalisation and financisation are contributing to accelerated structural transformations in the economies of individual countries and economic groups. Structural changes are primarily reflected in an increased growth rate of hi-tech industries where innovative 
firms and companies with high shares of knowledge in their production structures are playing an ever more important role.

Globalisation gives rise to numerous questions and dilemmas regarding the model and limits of modernisation, to say the least. It may be assumed, however, that modernisation offers an opportunity to:

- increase the welfare of individuals and nations,

- strengthen the prestige and position of the state, local communities, families, etc.

- enrich spiritual and intellectual values (Nowak, 2013).

Apparently, these opportunities are understood and interpreted differently given the fundamental economic and cultural diversity of nations and states. Therefore, expanding and sometimes imposing of the system of values and attitudes typical of the western world, such as consumerism, belief in the automatically triggered positive effect of the market, and human rights has been criticised and has often led to rejection of the modernisation model characteristic of the key actors in the global market, including the US or European countries. Today, it can be seen that the Islamic countries and the world of Chinese civilisation, where changes and reforms involve anti-liberal modernisation, have fallen out of the mainstream or, at least, found themselves in some opposition to the dominant development model.

An increasing number of economists, but also politicians, believe that many problems that have emerged globally should lead to new solutions and a new economic order and arrangement, relying not only on the US, the European Union, and Japan but also on the interests and strength of new economic powers, such as China, India, Brazil, Mexico, that is emerging economies.

Basic guidelines for economic policy are also being modified. Economic canons, such as those of maintaining financial discipline, balanced budget deficits, liberalisation of the world trade rules, removing obstacles to foreign direct investment so that foreign companies are ensured an equal and level playing field, deregulation and privatisation, are still vital preconditions for economic growth, yet they are not accepted everywhere or implemented uncritically.

In this regard, the 2007-2009 global financial crisis became a breakthrough, with its unexpected scale and magnitude. Its extensive effects have not been completely overcome yet. Certain theoretical assumptions of economic theories based on the belief in the automatic remedial mechanisms of the free market have been seriously questioned. Moreover, the free-market system dominant in the global economy, but lacking regulatory mechanisms, began to "produce" various kinds of deformities. This can be said, in particular, about financial markets. It is these markets that are a major source of excessive financisation of the global economy, with negative consequences for it. Today, there is a growing awareness that while Adam Smith was right in saying that the free market was the future and an essential regulator of the economy, not all decisions taken today in the global market must lead to expected and desired outcomes. 
One view expressed by Professor Kazimierz Ryć should also be endorsed - namely, that critical attitudes to globalisation have clearly strengthened since the recent crisis and the downturn in the world economy. As he put it: "Many economists and economic journalists - both leftist and rightist - pinpoint the negative side of the process. Globalisation is blamed for the loss of jobs in highly developed countries, notably in industry, because of production relocation to low-labour-cost countries and the competition from low-cost producers in poorly developed countries who are intensively developing industrial production. Besides its benefits, globalisation is thus contributing to unemployment in many parts of the world, worsening the negotiating power of employees in highly developed countries, which in turn results in the stagnation of real wages and incomes of workers and the middle class. The effects of economic growth are unevenly distributed: the output accrued mostly goes to a small group of capital holders, senior managers, in particular in the financial sector. Consumer demand restrained by low incomes earned by a large part of the population and high savings of the top earners give rise to the formation of a setup that slows down the growth rate. Limited consumer demand is not conducive to investment, and high savings that are not spent on production capacity enhancement increase financial market resources or are invested abroad. Globalisation may lead to a loss of jobs in industry, not only in the industry of the most developed countries but also in less developed economies or those with moderate development, wherever labour costs are higher" (Nowak and Ryć, 2017, p. 60).

Poland belongs to a group of countries that associate the internationalisation of their economies with the transformation of their political and economic systems after 1989, with the accession to the European Union in 2004, but also with all global processes leading to progressive interdependence and integration of countries. The openness of Polish economy and its integration with the European Union partners are particularly important conditions for Poland's modernisation and, on balance, for its success in the global economic environment. Nonetheless, a factor that remains decisive in its socio-economic development is a wise and reasoned development strategy that would provide a lasting and robust foundation for a long term sustainable economic growth.

\section{Towards competitive Poland. How can Poland climb the world economic league table? - a diagnosis for Poland}

The most interesting diagnoses concerning the condition of the Polish economy after 26 years of transition, but also critical assessments of Poland's current development model, together with conclusions on changes and reforms, are basically contained in three analytical papers.

An essential conclusion of the report on Towards Competitive Poland. How Can Poland Climb the World Economic League Table? (Hausner, 2013) is that the 
ongoing global crisis and the ensuing problems of Polish economy call for urgent and necessary structural and systemic measures that will not only revive the economy but also set it on a path to long-term high growth. According to its authors, making a better use of the development potential will consequently increase the much-desired competitiveness of Polish economy and ensure its enduring presence in the economic and political core of the European Union. Simultaneously, it is necessary to introduce measures that would protect Polish economy from slower productivity growth and the so-called middle-income trap. As claimed by the authors, to accomplish this, comprehensive and coordinated measures must be undertaken, which are defined in the literature as new industrial policy or as new structural policy. "This terminology refers to the overall effect of institutional changes that create a set of stimuli and, at the same time, an environment conducive to improving an economy's competitiveness" (Hausner, 2013). Yet, no response to the present global crisis in the form of global mechanisms for international joint management is likely to appear any soon. The way forward is through measures undertaken by individual countries in respect of their own economies and through simultaneous international cooperation, so that autarchic and protectionist solutions can be rejected and outcomes needed for an open, competitive and cooperative economy can be sought (Hausner, 2013).

The Hausner report rightly argues that structural characteristics of Polish economy have crucial importance, and that, accordingly, it is imperative to think strategically about development, to implement pro-competitive structural policy (including a new industrial policy), and to engender structural change. In short: to secure pro-innovative reorientation of the Polish economy. As the report postulates, more modern and compatible Polish infrastructure should become an important link supporting such reorientation. This requirement is yet to be fulfilled.

\section{Poland 2030. Third wave of modernity. Long-term National Development Strategy}

The analytical document Poland 2030. Third Wave of Modernity. Long-term National Development Strategy also diagnoses the condition of the Polish economy and provides a list of measures related to the implementation of individual strategic economic policy objectives in Poland (MAD, 2013).

As pointed out by its authors, its principal objective is to improve the quality of life of Polish people, measured by quality indicators as well as by the GDP value and growth rate in Poland. The Long-Term National Development Strategy drawn up to this end has a 2030 temporal horizon. What really distinguishes it, is an attempt to include main trends, challenges, and scenarios of the socio-economic development and land use, with the principle of sustainable development considered. 
Hence, the analysis highlights the third wave of modernity, namely the next stage of the worldwide technological revolution. Thus, the Long-Term National Development Strategy is intended to be an analytical document, yet containing recommendations and describing a future-oriented civilisational project by 2030. As far as three areas of Poland's strategic development are concerned, the document essentially confirms the recommendations of the majority of our economists and sociologists as well as the content of the previously mentioned in Hausner report. Poland should develop in three main directions simultaneously:

(1) competitiveness and innovation of its economy (modernisation),

(2) balancing the development potential of Polish regions (diffusion),

(3) efficiency and effectiveness of the state (efficiency).

In each of these three strategic areas, objectives to be achieved have been identified. The first area, namely competitiveness, and innovation, or modernisation of Poland, encompasses the following objectives and directions:

- to stimulate economic innovation, efficiency, and people's creativity. State intervention should primarily focus on education - from pre-school to higher education - but also on support for research and science to improve their quality and efficiency. It is also important to develop effective financial engineering instruments and strengthen business environment institutions, improve the efficiency of the central and local administrations, and remove barriers, both legislative and administrative, which hinder or slow down business development.

- to accelerate technological change. For the Digital Poland project not to be reduced to written words only, further, necessary infrastructure investments should be made in broadband Internet available to all. This will enhance the opportunities for the development of peripheral areas. Equally, the use of the Internet should be increased by developing e-services and e-economy. Digitisation of cultural resources will, in turn, allow for the extension of the traditional roles of cultural institutions. Integrated computerisation based on a logical and effective information flow as well as the introduction of the principles of process management and cost effectiveness should foster greater efficiency and flexibility of the state and business. All this can be attained provided that digital skills of the society are improved and the exclusion of the elderly people illiterate in terms of Internet is prevented.

- to put emphasis on human capital development, which should definitely be more strongly related to health system reforms and social cohesion: education and transfer of graduates to the labour market. Active pro-family and migration policies would significantly reduce the risks arising from the unfavourable demographic change. Strengthening the linguistic skills of Poles is also very important in this area.

- to consider the importance of Poland's security through greater commitment to energy security and protection of the environment. The need for greater and 
effective intervention for energy security has also been clearly emphasised in the Hausner report. Such measures should include the use of renewable energy sources.

In the second area, concerning balancing the development potential of regions (diffusion), the document modified the previous polarisation-diffusion model of balancing regional development and complemented it with the model of territorial balancing (diffusion). The concept of polarisation-diffusion regional development policy presumes that strong development centres, so-called engines of development, should be supported, whereas the surrounding areas will benefit from diffusion (spill-over) of economic and social effects. According to this concept, the activation of low-growth areas is a waste of limited public resources, and financial transfers to such areas should only provide access to basic public services. Diffusion is expected to occur automatically at later stages of development thanks to swinging labour migration and capital flows. However, the condition is ensuring spatial, including transportation, cohesion.

This model has not worked equally well everywhere in Poland. The reason was that development of peripheries seemed to depend not only on the efficient creation of development potential. Anyway, such a capacity was also restricted by the lack of cohesion policy and the failure to consistently develop basic infrastructure such as good transportation and supra-local transport systems (which is largely due to the specificity of the local government system, especially the weakness of Polish counties).

Given that, the document recommends complementing regional development with a sustainable development model encompassing the redistribution of income to lagging areas. It is also recommended that peripheral areas should be involved in greater foreign cooperation.

Besides the previously mentioned e-services development and integrated computerisation, the third strategic area - efficiency and effectiveness of the state - focuses on the role of social capital related to the organisation of society characterised by trust, norms, and relations that can improve the functioning of society, facilitating coordinated action. For example, a group composed of members who are trustworthy and trust others will be able to achieve much more than a comparable group lacking trust.

Polish sociologists agree that faster development of Poland will be impossible without improved social capital. This means that in our circumstances the growing mistrust in human relations and the lack of confidence in the state institutions need counteracting. This is largely due to increasing bureaucracy, unstable law, and corruption. The low social capital is also reflected by relatively small social and civic participation (for example, low turnout in elections) and still inadequate position of non-governmental organisations. 
The long-term national development strategy proposed in that document, together with the instruments and objectives contained therein, was an opportunity for Poland's civilisational development. It was largely compatible with the assessments and analysis in the report on "Competitive Poland. How Can Poland Climb the World Economic League Table?". What is characteristic of these two documents is that they express the conviction that there is room in the market economy for a meaningful role of the state in the development of economic and social policies. This particularly concerns the investment policy aimed at structural change and at stimulating entrepreneurship and competitiveness.

\section{Strategy for Responsible Development by Mateusz Morawiecki}

As far as diagnoses are concerned, many analyses, assessments, and conclusions contained in both discussed documents, namely "Competitive Poland. How Can Poland Climb the World Economic League Table?" and "Poland 2030. Third Wave of Modernity. Long-Term National Development Strategy", are included in the third, seemingly most ambitious, a document on Strategy for Responsible Development by Deputy Prime Minister Mateusz Morawiecki (2017). Today, this strategy is already being implemented by the Polish government and is distinguished by its lofty aspiration regarding development goals, the complexity of analysis and - in Polish conditions - an innovative approach, although it is not devoid of controversial assumptions.

Indeed, the strategy for responsible development implemented in practice presupposes that the potential of the economic and social development model adopted at the time of transition has reached its limits and that Poland needs a new impulse to break out of the middle-income trap. The new economic policy makers intend to make "a breakthrough in the approach to many strategic issues" that are important to Poland.

"The strategy does not duplicate the approach to national development policy programming that prevailed in the transition period and was essentially based on copying and imitating of solutions 'imported' from abroad and consistent with basic prescriptions of the Washington Consensus" (Raczkowski, 2016, p. 10-11).

The team of the National Development Council of the President of the Republic of Poland emphasises that "the Strategy builds on the earlier Responsible Development Plan, with the enhanced social component in the strategic planning of national socio-economic development. While in the previous Responsible Development Plan the elements of the state's social policy were only secondary (complementary) to those of the pure economic policy, which formed a clear cornerstone of the initial concept, the Strategy for Responsible Development contains a social component 
that is already a fully-fledged pillar of the strategy" (NDC, 2016, p. 12). The Strategy, currently implemented by the Polish government, assumes that Poland can and should develop simultaneously in three main directions:

(1) modernisation (enhanced competitiveness and innovation of the economy),

(2) diffusion (balancing the development potential of individual Polish regions),

(3) efficiency (substantial increase in efficiency and effectiveness of the state and its institutions).

The Strategy for Responsible Development specifies five focus areas ("pillars of development"):

- creating conditions for reindustrialisation,

- fostering the development of innovative companies (Polish champions),

- sustainable socio-economic development (including support for small and medium-sized enterprises),

- building capital for development, and

- foreign expansion.

These five pillars of development were identified following a critical analysis and diagnosis of the previous economic and social policies pursued by Polish governments. However, the Strategy for Responsible Development, which forms the basis for decisions taken by the current government, in which Mateusz Morawiecki serves as Deputy Prime Minister, Minister of Finance and Minister of Development, is distinguished by a new quality in its approach and in the implementation of priorities that are strategic for the state.

It is also significant that the present new philosophy of the Polish government assigns a far more prominent role to the state institutions regarding defining frameworks and implementing strategic objectives of economic and social policies. This is a consequence of the belief in the hitherto institutional weakness of the Polish state but probably also of lessons learned from the experiences of the global financial crisis.

According to the Strategy, the government plans to pursue an industrial policy implementing a so-called smart reindustrialisation. This is expected to provide an impetus to the development of new industries based on digital technologies that require the intense involvement of science and highly-skilled staff. The Strategy, therefore, refers to the postulates included in the current 2020 National Development Strategy for increasing the share of medium- and high-technology industries and services in the GDP.

In its opinion on the Strategy for Responsible Development, the team of the National Development Council of the President of the Republic of Poland states that "the intention to boost global competitiveness of the Polish industry is a legitimate aim of the Strategy, and the measures for smart reindustrialisation will 
result in industry saturation with high-value services (R\&D, design, information and communications technologies - ICTs). This is to increase the share of innovative products produced in the industry and provide a leverage for productivity growth. The level of employment in the industry and industry-related services is to be maintained" (NDC, 2016, p. 18).

As highlighted by Professor Witold Orłowski, "Poland (...) needs development based more strongly on domestic capital, primarily because it is the national expansive companies that may be interested in development based on innovation and in the use of intellectual potential". As he rightly adds, "triggering the processes that modernise the economy through innovation is not an easy task since it may be hindered not only by internal administrative, systemic, awarenessrelated barriers but also by external obstacles, such as the existing division of labour and the competitive advantage of global (foreign) companies" (Orłowski, 2016, p. 13).

The implementation of ambitious plans that are already being carried out by the current government would be difficult if it were hindered by a funding barrier. Hence, the Strategy puts such a strong emphasis on the need to build capital for development. Poland needs to make better use of the EU funds, in particular, the structural funds. The EU funds should represent endogenous pro-development capital. Yet, in the face of the need to increase the investment rate and, at the same time, to reduce foreign debt, raising funds from exports of Polish goods and services is, at the same time, another important element of the current government's programme. A rise in the investment rate up to $25 \%$ of the GDP (currently, it is the lowest in Central and Eastern Europe, only accounting for 20\%) should be accompanied, among other things, by a change in the functioning of institutions supporting and financing the expansion of Polish exporters.

In the Strategy by Deputy Prime Minister Mateusz Morawiecki, a link can be observed between breaking Poland out of dependent development and a radical reform of higher education. This is because education is the fundamental mechanism for investing in human capital - competences of individuals. In this field, Poland is expecting a genuine reform of higher education.

The objectives of the Strategy for Responsible Development largely respond to the needs existing at the current stage of Poland's development. Its main goal is to create conditions for increasing Poles' incomes while improving social, economic and territorial cohesion. The effects of the implementation of the new idea of Poland's socio-economic development will be possible to asses after several years of implementation. The central economic and social goals of Poland's development strategy in the 2020 and 2030 horizon seem to have been correctly identified. The opponents of the current government are particularly quick to question the prioritisation of public intervention to be undertaken by the government in the coming years. Concerns are also voiced about the financial capacity of the state to achieve the government's ambitious goals. 


\section{New Structural Economics and its assumptions}

However, it is not difficult to see that the new socio-economic philosophy of the current Polish government also responds to the development policy trends in countries catching up with highly industrialised economies. In countries such as Poland, the so-called New Structural Economics is attracting more and more interest. It applies a neoclassical approach to the study of the determinants of economic structure and its evolution. It postulates that the industrial structure in an economy is endogenous to its endowment structure. One of the theoreticians and authors of New Structural Economics, Professor Justin Yifu Lin, an economic adviser to the Chinese government and Vice President of the World Bank in 2008-2012, believes that - as confirmed by his article included herein - according to New Structural Economics, the key for development success is to have an enabling state using an appropriate industrial policy to facilitate firms' entry to latent comparative advantage industries in a competitive market by overcoming the first-mover's externality issue and coordinating the required improvements in hard and soft infrastructure so as to turn the latent comparative advantage industries to the nation's competitive advantages.

As claimed by Professor Justin Yifu Lin, a country's economic structure at any given time is endogenous to its factor endowments - the amounts of capital, labour, and natural resources at that time. Countries at different development stages vary in their relative abundance of factor endowments. In developing countries, capital is generally relatively scarce, while labour and often natural resources are comparatively abundant. In developed countries, capital is relatively abundant, while labour is comparatively scarce. Although an economy's factor endowments are given at any particular period, they can change over time. New structural economics posits an economy's factor endowments as the starting point for development analysis because they determine an economy's total budget and relative factor prices at that time, which are two of the most important parameters in economic analysis.

"Relative factor prices determine a country's comparative advantage. For example, countries with both relatively abundant labour and scarce capital would have a comparative advantage in labour-intensive industries because production costs will be lower than in countries with relatively scarce and more expensive labour. A prerequisite to achieving competitive advantage is for a country to develop its industries according to its comparative advantages determined by factor endowments" (Porter, 1990, p. 81).

In developed countries, income and labour productivity are high because the countries' relative capital abundance means that their industries and technologies are capital intensive. If a developing country wants to catch up with the income and industrial structure of developed countries, first it needs to increase the relative abundance of capital in its factor endowment structure to the level in advanced 
countries. The ultimate goal of economic development is to raise a country's income, the intermediate goal is to develop capital-intensive industries, and the immediate goal should be to accumulate capital quickly so that the country's comparative advantages change to more capital-intensive industries. In other words, boosting a country's income requires industrial upgrading, which in turn requires changing a country's endowment structure" (Ju, Lin, and Wang, 2015, p. 244-263).

\section{Conclusions}

It is easy to see that the views of Professor Justin Yifu Lin have inspired the "Strategy for Responsible Development" by Deputy Prime Minister Mateusz Morawiecki. Both see the point and legitimacy in the idea that countries such as Poland need to intensively look for an impetus to shift their economies to more innovative routes. Such opportunities are offered by the fourth industrial revolution. They both advocate the idea of industrial development adapted to the contemporary requirements. It consists in defining the industries where a country can build its competitive advantages over other countries in the foreseeable future. A further step is the establishment of a system that allows these opportunities to be seized. Yet, as mentioned by Professor Justin Yifu Lin, "even if the government is up to the challenge and will build an efficient system for the development of selected industries, this may not be enough. It is also necessary to reduce transaction costs, that is costs associated with business operations coordination, arising out of, for instance, the need for market monitoring or control. This is possible but requires cooperation between entrepreneurs and the government" (Lin, 2017, p. 23-40).

Contrary to what opponents of the Chinese economist and Deputy Prime Minister Morawiecki are signalling, both, in outlining the currently desired development model for those catching up with rich and highly industrialised countries, recognise the need for state decision-making centres to ensure that industrial policy programs, the so-called smart reindustrialisation or building an effective intellectual property protection system system, are successfully implemented. On the other hand, however, this unquestionable role of the state never obliterates the fact that the key factor to increase market competitiveness and advantages should mainly be sought among economic, financial and innovation actors.

Professor Justin Yifu Lin is not far from the truth when he states that "the fourth industrial revolution brings with it many opportunities for countries such as Poland" in his interview for "Polska The Times". He continues that "New areas of development are emerging that have not yet been filled by, for instance, Germany. It will only take time. It is impossible to immediately invent a new remedy that will be needed around the world or a new mobile phone that will become a global hit. What is needed is time and money to conduct research" (Koziński, 2016). 


\section{Bibliography}

Hausner, J., (ed.). (2013). Towards a Competitive Poland. How Can Poland Climb the World. A report prepared by an independent team of experts at the initiative of the President of the Republic of Poland., Kraków, 2013.

Ju, J., Lin, J.Y. and Wang, Y. (2015). Endowment Structures, Industrial Dynamics, and Economic Growth. Journal of Monetary Economics, 76, 244-263.

Koziński, A. (2016). Justin Yifu Lin: Polska powinna zainwestować w kilka kluczowych dziedzin przemysłu (Poland should invest in several crucial industry areas). WWW.POLSKATIMES. PL, 7 February. Taken from: http://www.polskatimes.pl/artykul/9368600,justin-yifu-linpolska-powinna-zainwestowac-w-kilka-kluczowych-dziedzin-przemyslu,3,id,t,sa.html.

Lin, J.Y. (2009). Economic Development and Transition: Thought, Strategy, and Viability. Cambridge, UK: Cambridge University Press.

Lin, J.Y. (2011). New Structural Economics: A Framework for Rethinking Economic Development. World Bank Research Observer, 26(2).

Lin, J.Y. (2017). New Structural Economics and Industrial Policies for Catching-up Economies (Nowa Ekonomia Strukturalna dla gospodarek doganiających). In: I.Y. Lin, A.Z. Nowak (eds.), New Structural Economics for less advanced countries (Nowa Ekonomia Strukturalna wobec krajów mniej zaawansowanych). Warsaw: University of Warsaw, Faculty of Management Press.

MAD. (2013). Polska 2030. Trzecia fala nowoczesności. Długookresowa Strategia Rozwoju Kraju (Third Wave of Modernity. Long-Term National Development Strategy). Warsaw: the Ministry of Administration and Digitalization, 11 January: Taken from: https://mac. gov.pl/files/wp-content/uploads/2013/02/Strategia-DSRK-PL2030-RM.pdf.

Morawiecki, M. (2017). Strategia na rzecz Odpowiedzialnego Rozwoju do roku 2020 (z perspektywa do 2030 r.) (Strategy for Responsible Development until 2020 (with perspective up to 2030) Warsaw: the Ministry of Development.

Nowak, A.Z. (2013). Współczesny świat w erze turbulencji (Contemporary world in the turbulence era). In: J. Bogdanienko, W. Piotrowski (eds.), Zarzadzanie: tradycja $i$ nowoczesność (Management: tradition and modernity). Warsaw: PWE.

Nowak, A.Z. and Ryć, K. (eds.). (2017). Globalizacja a reindustrializacja (Globalisation and industrialisation). In: A.Z. Nowak, K. Ryć (eds.), Polityka $w$ regionach $w$ warunkach globalizacji (Regional policies in conditions of globalisation). Warsaw: University of Warsaw, Faculty of Management Press.

NDC. (2016). Opinia o projekcie Strategii na rzecz Odpowiedzialnego RozwojuI (Opinion on the Strategy for Responsible Development). Warsaw: National Development Council, 27 September. Taken from: http://ieo.pl/dokumenty/aktualnosci/18102016/opinia_o_ projekcie_strategii_na_rzecz_odpowiedzialnego_rozwoju.pdf.

Orłowski, W. (2016). Opinia na temat dokumentu: „Strategia na rzecz odpowiedzialnego rozwoju” (projekt do konsultacji spotecznych) (Opinion on the document Strategy for Responsible Development (Draft for Social Consultancy). Analytical materials prepared for the National Development Council at the President of the Republic of Poland. Warsaw, 8 September 2016.

Porter, M.E. (1990). The Competitive Advantage of Nations. New York: Free Press.

Raczkowski, K. (2016). Opinia przygotowana na zlecenie Kancelarii Prezydenta Rzeczypospolitej Polskiej w sprawie zaopiniowania projektu „Strategia na rzecz 
odpowiedzialnego rozwoju". Materiał analityczny przygotowany dla Narodowej Rady Rozwoju przy Prezydencie RP (Opinion prepared at the order of the Chancellery of the President of the Republic of Poland concerning an assessment of the draft: Strategy for Responsible Development. Analytical materials prepared for the National Development Council at the President of the Republic of Poland). In: NRR, Opinia o projekcie Strategii na rzecz Odpowiedzialnego Rozwoju (Opinion on the draft Strategy for Responsible Development). Warsaw: National Development Council, 27 September. Taken from: http://ieo.pl/dokumenty/aktualnosci/18102016/opinia_o_projekcie_strategii_ na_rzecz_odpowiedzialnego_rozwoju.pdf.

\section{Internet sources:}

http://www.polskatimes.pl/artykul/9368600,justin-yifu-lin-polska-powinna-zainwestowac-wkilka-kluczowych-dziedzin-przemyslu,3,id,t,sa.html 


\title{
The expiring real convergence process under conditions of the common market - how to counteract
}

\begin{abstract}
Developing countries face a threat of a slowdown in their economic growth. To some extent, this also relates to Poland. The question arises: how to counteract that slowdown, often referred to as the middle-income trap? New Structural Economics suggests methods to successfully initiate and then maintain proper dynamics of economic growth. Also: is it possible to apply its recommendations to enliven the slowing rate of economic growth in developing countries as they seem to lose their ability to grow up quickly and catch-up with highly-developed countries?

The common market within the European Union, after all, consists of well-developed countries and of countries at the middle level of development. It is imperative, then, to achieve some compromise between the interests of the former and the latter. This article analyses the reasons for the economic slowdown which largely stem from the phenomenon of domestic manufacturers remaining, or perhaps locked in, in roles of subcontractors and co-operators of international corporations, and suppliers of cheap products - roles they perform basing on low labour costs. This, of course, determines the inferior status of the national economy with respect to technological leaders of the common market and becomes a real threat in the context of progress achieved through the industrial revolution 4.0. Hence the efforts to seek inspiration to raise the level of innovativeness in less developed countries and to apply recommendations given by New Structural Economics - which also relates to Polish economy.
\end{abstract}

Keywords: convergence, middle income trap, innovations, creation of product value, restructuring, reindustrialisation.

\section{Economic growth slowdown or the middle-income trap?}

The issue of economic growth slowdown seems the most topical problem in the pool of economic debate. Problems of stagnation and slow rate of growth following the recent crisis were experienced in most countries, both well developed and newly industrialised, in the process of catching-up with the former ones. All this relates to member states of the European Union - in particular, those of the "old fifteen", i.e. members before the great enlargement of 2004, although the same also relates, to some extent, to newer member states. 
The accession to the Community brought very measurable benefits to all member states. Admittedly, both groups of countries benefitted from the accession - well-developed ones, having higher Gross Domestic Product per capita and less wealthy ones which experienced an acceleration of growth and thereby could diminish the gap from their better developed and wealthier neighbours. Rich countries found newly-opened and large sales markets, while poorer countries enjoyed the key advantage of obtaining serious organisational and financial support for their economic growth. However, as time went by, the much-expected process of real convergence was slowing down and then, after the most recent crisis in the euro area, it stopped altogether. Worse still, it even turned around toward divergence. This is clearly seen in relations between the well-developed North and the lagging South.

The following question appears in this context: is this a failure of the common currency area or rather just a part of a global problem? The problem which is given various names in the macroeconomic debate: it is known as the middle-income trap, economic slowdown of countries relying upon technology imitation or drying up convergence, as they draw nearer to the borderline defined by the level of technology - to "global technology frontier" as J.Y. Lin calls it.

How to counteract the slowdown in newly-industrialised countries? Can New Structural Economics (NSE) prove useful in this context? The concept works in China and in other far Eastern countries. Can an active industrial policy deliver a remedy to the slowdown? Isn't it wrong to reckon - as is quite common - that the world today enters the post-industrial era? As a matter of fact, modern times are post-agricultural as well, however, both agriculture and industry - although its share in total employment and in the GDP decreases - hardly lose their significance. There is nothing that can replace either agriculture or industry, so we are now and we will remain an industrial civilisation.

In witness of failures suffered in the past by structural approach to a country industrialisation with its firm intention to build an industry-based economy, J.Y. Lin's concept of NSE, following the model of well-developed countries, postulates an organic method of initiating and generating the economic growth. According to it, the process starts with an assessment of resources which give comparative advantages, then follows the stage of production and sale of goods, leading to the generation of savings which will make further investments possible. New businesses are then expected to initiate the growth using their own modest capabilities at an early stage. Later on, they will achieve one technological level after another, from imitation of existing technologies through to their genuine achievements that render them closer and closer to the global technology frontier.

This sort of practice of generating economic growth is often referred to as farEastern protectionism. The endogenous nature of programmes and implementation methods of this policy has proven effective. Progress achieved by Japan at an early 
stage, and then by Singapore, Taiwan, South Korea, recently followed by China, are undeniable and convincing indeed.

During the same period, the economic theory in the West, as well as the practice of operation of international institutions and of most governments, opted for another approach: free market and exogenous nature of economic growth, based upon neoliberal economic doctrine. A significant source of dynamic growth was seen in the liberalisation of trade exchange. It was also believed that a method to accelerate the growth of underdeveloped countries and countries at a medium level of development could be found in their closer integration and cooperation with well-developed countries. This idea of growth remains quite vivid. In Poland, the authors of the report "Industrial policy and the 21 $1^{\text {st }}$ Century challenges" (Bukowski and Śniegocki, 2017) acknowledge the need to increase the cooperation with the "European factory" seen as one of three "factories of global economy". Germany, its leading country, is also closest to Poland in geographic terms and by now both countries have become bound with firm economic ties.

Let us now consider the potential of the three above-mentioned types of policies and paths for supporting the economic growth or for avoiding the middle-income trap. The first one is an endogenous path - that of active economic policy and the important role of the state in managing the process of development. The second one is the path of the free market with horizontal support for growth - which really comes down to carrying on the policy based on the neoliberal doctrine.

The choice of the path of endogenous growth and application of methods of economic policy proposed by NSE, in conditions of a small open economy operating within a community of states which associates countries at a medium level of development with well-developed ones, is confronted with quite a different set of circumstances than those faced in regions where it was implemented with much success. The experiences of Eastern Asian countries - especially those whose size is comparable to Poland, as South Korea, might not be applied directly. Differences in terms of the starting point of growth and external circumstances are just too great.

The success of any efforts which promote new or even innovative technologies largely depends on the nature of the market and the level of competition. It is critical whether a foreign competitor in possession of a superior technology is near or far enough in terms of distance - or perhaps it is discouraged by differing regulations, tariff restrictions or other types of barriers. In fact, relative separation is crucial for a new initiative to start up and develop some strength. These were the conditions present in South Korea. Then, another important factor is to have a large domestic internal market in which, never mind the presence of foreign entities equipped with high technologies, it is still possible to find enough room for local initiatives - risky as they may be, but promising nonetheless. In such conditions even making an impressive technological leap, at the level of the global technology frontier, may be practicable. In this case, however, the innovators could benefit from the enormous 
Chinese market. The NSE postulates active support with all pragmatism typical of this sort of initiatives, as well as efforts to reduce the risk inherent in new and innovative undertakings. Equally important is to provide adequate infrastructure, both soft and hard.

A pool of resources which may offer some comparative advantage also exists in Poland. It takes the forms of well-educated society, favourable geographical situation and - still true - relatively low wages.

As a matter of fact, the cutting-edge technology has already found its way to Poland as well as to other EU member states on a similar level of growth. It is represented there by international corporations for which these countries are not only sales markets but also quite a fitting place for placing a part of their activities in manufacturing and services. They open assembly plants for their products there and acquire subcontractors, taking advantage of low labour costs, the relative abundance of investment land, favourable geographical situation and improving infrastructure. At the same time, they are also suppliers for the final products markets. International corporations situate on either end of the curve of value added generation in the process of production - often called the smiling curve. Left and right ends of the curve represent breeding, designing, management, and marketing; segments closer to the middle include business services, while the portion situated in the far low central part stands for actual manufacturing in factories or assembly of final products. This way, a new technology theoretically exists in the country, but in fact, it "shines in the parlour" while the assembly and servicing activities remain "in the grange" of the national economy. It is difficult for manufacturers of products, contractors, and suppliers of auxiliary services to enter either high end of the smiling curve. Also, the owners of international corporations don't make it any easier. And where no path is found to climb the high ends of the curve, national economy ends up doomed for lower productivity and poorly paid repetitive execution jobs.

Recently, a dynamic employment growth can be observed in the sector of services for domestic, and in particular, foreign business. However, even in this case still, the same comparative advantages are in use, including well-educated and cheap labour force ${ }^{1}$. Employment in services, increasing or not, fails to become a well-paved way toward most productive portions of the value generation chain - those with high wages and high profits. In Polish conditions, the renouncement of an active industrial policy aiming at stimulation of growth and relying, instead, upon mechanisms of the free market, not only means the preservation of the development gap but also entails a threat stemming from technological changes occurring in the world. Perhaps, from a broader point of view, this means giving up participation in the fourth industrial revolution.

1 In the past they were called white collars, as distinguished from blue collars. 


\section{The exogenous development trap}

If no circumstances emerge to enable an acceleration of growth through an active industrial policy of the state, then it will most likely occur that the potential to maintain a higher rate of growth or to overcome the middle-income trap, will, unfortunately, look paltry. J.Y. Lin distinguishes five following types of industries from the point of view of economic growth:

(1) catching-up industries,

(2) leading-edge industries,

(3) comparative advantage-losing industries,

(4) short innovation cycle industries,

(5) comparative-advantage-defying strategic industries.

Let us first consider the problems experienced by two groups - comparative advantage-losing industries and catching-up industries. This order of consideration stems from the degree of Poland's economic development. The first of the two above-mentioned groups suffers from most serious growth-related problems. It extends onto a very substantial area of the economy and its slackening economic growth may act as the principal reason for a slowdown to happen or may even trigger the fall of Polish economy into the middle-income trap. In the case of catching up industries, instead, there are considerable opportunities to take advantage of the NSE's experience.

Focusing on comparative advantage-losing industries, we shall start with a particular case - that of manufacturers cooperating with large foreign companies. Whereas the latter ones achieve or have already achieved the global technology development line or the global technology frontier, their Polish co-operators situate in lower segments of their production chain curve. Those Polish manufacturers which are subsidiaries of international corporations are better situated. As mentioned before, they have a chance - small as it is but still a chance - to advance onto upper ends of the curve, thus achieving the highest level of value added. If they succeed, this means that co-operators and executors of assembly activities turn into new producers of final products. In such a case, it is not relevant anymore whether they remain subsidiaries of international corporations or go independent. However, it is very unlikely that their parent companies appreciate such a change. After all, their intention while transferring their production lines to Poland was to reduce manufacturing costs of their products - the goal they achieved, ensuring themselves the potential of participation in production that yielded higher value added.

Therefore, we increasingly have to deal with a situation where the substantial value of a product is generated not in the factory. In our days, it is no longer fantasy but a sheer reality to see producers who manufacture some goods without having factories. Furthermore - and here verging on fantasy - it's quite hard to foresee at which moment might a factory transform into a producer without a factory. In 
fact, it might just as well lose its place in the production chain, overtaken by other, cheaper competitors.

Uncomplicated manufacturing or assembly activities may also be transferred to countries with even lower wages combined with the sufficiently skilled labour force. The same holds true for business services. Skyscrapers in Warsaw, crowded with white collar employees of many international corporations, are just one proof that more complex and labour-intensive management-related activities are also transferred to Poland. This area situates higher than the low central segment of the smiling curve.

Figure 1. Production value generation chain

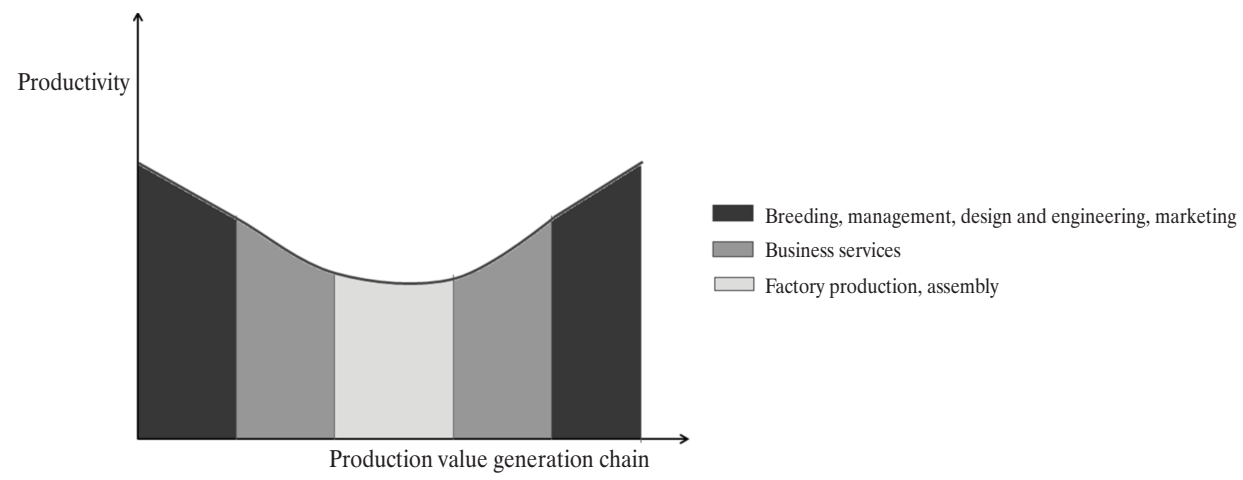

Source: Author's own.

Still, cheap assembly of semi-finished products, cheap business services, and closed promotion paths don't sum up to an excessive pessimism.

Domestic companies, whose technologies lag behind globally leading producers also generate their value added thanks to low labour costs. Low level of wages in Poland dates back to the period of systemic transformation and high unemployment. Their later gradual growth, in some periods lower than the growth of labour efficiency, was not favourable to production upgrading, acquisition of new technologies or investments in the reduction of labour-intensiveness. It can be reckoned, then, that low cost of labour was poor incentive to introduce costly and often risky innovation.

Low wages translate into a meagre domestic market populated by relatively poor consumers. This encourages firms to specialise in manufacturing a cheap range of goods. That's how a circular chain of reasons and effects emerges - something that may be called, with some overstatement, perhaps, the low wages trap. Demand for goods manufactured is limited in the domestic market, thus inducing export, which is additionally favoured by competitive prices. All this sums up to an adverse situation in international labour distribution. A country becomes specialised in low 
cost production with high demand flexibility. This way it achieves success on the common market thanks to low prices - as a competitor, it plays the card of the cheap offer. Its partners on the common market, instead, are likely to offer goods with low price flexibility. Accordingly, their products are more expensive because their manufacturing, involving more efficient technologies, enables them to accept costs of high wages and higher prices of goods never hinder the demand.

After all, the common European market can be seen as a neighbourhood of leading companies, situated close to the global technology frontier, and companies involved in imitation. The point is that leaders of new technologies mostly operate in well-developed countries, whereas imitating and catching-up companies operate in less developed countries. Whereas goods originating from the former and the latter countries have equal rights in the common market, the same cannot be said about their chances. Any less experienced partner, who endeavours to implement a new technology created in a less-developed country, is always confronted with some strong competitor. His outlooks for winning in this confrontation are slim unless he benefits from the support given by his own state. Indeed, in such circumstances, he should be able to count for such support and obtain it. This is an important argument to advocate an active role of the state in the field of industrial policy.

\section{Prospects for cooperation}

Whoever considers the problem, faces one difficult question: whether the gradually increasing share of national players in the final products' value generation chain is going to lead, in cooperation with new technologies leaders, to a more equal distribution of fruits. To be sure - and putting it very plainly, beside co-operation of factories, cooperation in office work will appear, as well as new duties in the area of management. This, however, requires other skills, a great deal of joint responsibility and promotion, some capital and creation of relations to achieve true participation in designing, engineering, management and marketing behind the production of finished goods. This would be a more optimistic scenario for the final stage in the evolution of cooperation and in levelling the productivity chain curve. It isn't unrealistic - there might be some hope things will evolve this way, considering further consolidation of relations with the "European factory" of the global economy. This would mean that the real convergence process would be retained, albeit slowed down. So far, the process of Poland's convergence with our better-developed partners still goes on, although it loses its momentum. This may be seen while comparing the rate of economic growth of Poland with that of its principal trade partner, Germany (see Figure 2). 
Figure 2. The growth of Poland's and Germany's GDP in the years 2005-2015

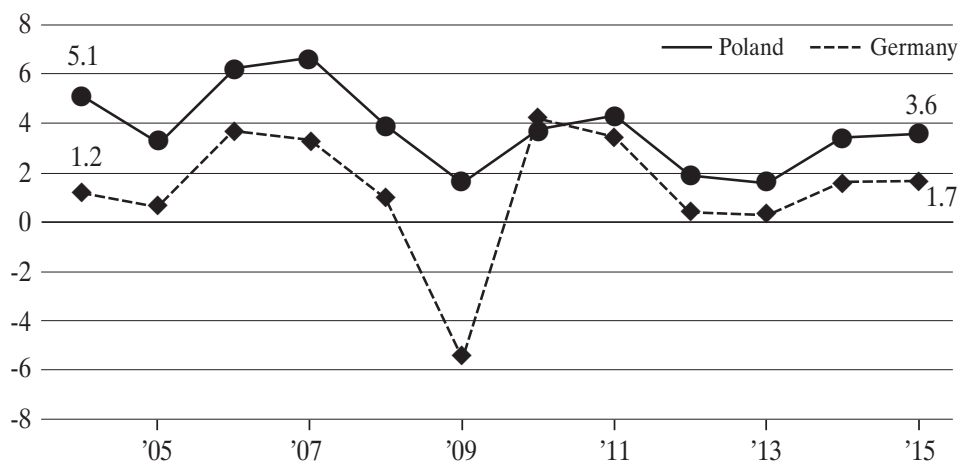

Source: GUS, Destatis, AHK (infographics OF/LR) after Ramotowski, 2016.

However, such expectations or hopes must not make us let our guards down nor tone down our motivation to actively support the growth. There are at least two reasons to keep alert in this respect; two reasons for constant concern. Firstly, our country seems to last in acceptance - forced, as a matter of fact - of the inferior status of its economy. There is some kind of consent for playing the role of an underdog partner whose offer mainly includes goods and services featuring high price flexibility and hence, low costs. Moreover, these goods and services are also highly sensitive to oscillating exchange rates so that they easily lose their sales markets each time the national currency appreciates. This is especially important in the case of the common currency (euro) and of belonging to the euro area.

Secondly, there is another ground for concern, even more serious. It is the threat occurring for a country manufacturing low-cost products and playing an inferior role in the global economy and potentially stemming from the process of reindustrialisation of well-developed countries, including the heralded 4.0 industrial revolution (Ryć, 2017). This process will involve technologies of industrial processing far superior to automation or robotics used in manufacturing - namely, smart factories. Smart factories, digital-and-physical systems will generate the situation which eliminates some human labour not only in actual manufacturing but also in the business services sector. As a result, new 4.0 industry will not only fail to reconstruct the previous level of employment in this sector but will make even further savings in the field of human work, thus reducing the employment. The announced industrial revolution is already underway. It is desirable in many respects, especially to technology leaders. In effect, it consolidates the advantage of countries which are most advanced and developed in industrial production. Domestic production will become profitable for them again, even with high labour costs. Moreover, this will yield high value added and - quite importantly - will improve and further consolidate their positive trade balance. 
Furthermore, industrial production is going to become attractive not only in terms of costs but also in terms of quality - thus bringing the producers closer to sales markets. It will be able to manufacture products that are just as reasonably priced, even if made in short series and near their final consumers, and therefore also better customised to suit their taste and personal requirements.

\section{What it implies for Poland and other mid-developed countries?}

These phenomena add up to quite a serious and very evident threat to countries at mid-level of development, including Poland. On the other hand, the same thing opens some opportunities, too. Competitiveness of economies based on low costs and labour and land still exists, but it is going to dry up because costs of labour will lose most of their relevance. What will remain valid and relevant are capitals: financial, human and social (relational) capitals which are all favourable to the progress of new technology. Accordingly, we can expect relocations of the industry from less to more developed countries. The process, already observable today, may soon gain much momentum².

Then, Poland may also face the problem of re-industrialisation. Polish economy underwent the previous stage of re-industrialisation and it was a hard experience. This happened at the turn of 1980s/90s as a part of the transformation from centrally planned to market economy. Poland paid dearly for that trauma - with huge unemployment, declining GDP, and the loss, for no price at all, of a great number of enterprises threatened with bankruptcy. If new re-industrialisation is indeed on its way, Poland should be carefully prepared this time.

What remains is some hope for a more effective vertical (sector-wise) policy which applies, among other things, recommendations given by J.Y. Lin's New Structural Economics. This relates to Lin's area one, i.e. catching-up industries and concerns the ability to use the experiences in the field of local entrepreneurial initiatives, support given to start-ups and their promotion by state authorities. I describe such a policy as microeconomic growth stimulation model (Ryć, 2017). Another important thing is to use the experience in the field of support for innovative technologies in industries with short innovation cycle and low-capital investments. In this field, Poland has significant achievements. In the catching-up industries, on the other hand, using the NSE indications is not enough - recommendations given by other modern concepts of supporting business activity should also be followed, including that proposed by Dani Rodrik (2011).

The point is to seek and find market innovators with their discoveries and inventions - market niches which enable them to undertake profitable activity;

2 Since 2010 as many as 400,000 jobs returned from China to USA (see: Ciesielski, 2017). 
the word profitable understood as having the potential for the income on the undertaking to cover and exceed the sum of investment outlays and running costs. In most cases, these are imitative innovations, based on technologies learnt through the process of distributing knowledge on technological advancements and copying the same. This may be called the spill-over effect. Sure enough, it is also possible that genuine inventions of new products or new manufacturing processes also appear on the way, however, it is rarely the case and thus should not be expected. According to the most desirable scenario, public authorities undertake the task of searching, provide incentives and really support the start-ups. Such efforts are accompanied by a screening of business failures at various stages. More specifically, there are several levels of incubation and support to be distinguished. Starting with the level of business incubators supported by Seed Found capital, start-ups and venture investments, through venture capital invested in more mature projects that promise some extent of market success. Then there are various forms of private involvement in new business projects, including so-called business angels. Other practices, such as symbiosis between start-ups and great industrial or trading corporations, are also observed. These and other forms of support as well as organisations of mutual assistance among innovators are known in Poland, but funds earmarked for support remain inadequate (Ryć, 2017).

All types of efforts in question are foreseen both in the Strategy for Responsible Development prepared by Polish Deputy Prime Minister Mateusz Morawiecki, and in the practice of the European Union applied under the 2014-2020 financial perspective. This includes methods of stimulating local initiative under Intelligent Regional Specialisation (IRS) and Intelligent National Specialisation (INS). Financial support of these efforts with Community funds provides an incentive and enables their actual implementation. At the same time, learning about the farEastern experience of stimulating local business initiatives, in particular in Chinese economy - the same source that inspired the NSE - may be very useful in fostering innovation on a national and regional scale.

\section{Bibliography}

Bukowski, M. and Śniegocki A. (2017). Made in Europe. Polityka przemystowa wobec wyzwań XXI wieku (Made in Europe. Industrial policy and the 21 st Century challenges). Warsaw: WiseEuropa, Fundacja Warszawski Instytut Studiów Ekonomicznych i Europejskich.

Ciesielski, M. (2017). To biznes, nie polityka, decyduje o powrocie przemysłu do USA (Business rather than politics determines industry return to USA). Obserwator Finansowy, 8 February. Taken from: https://www.obserwatorfinansowy.pl/forma/rotator/to-biznes-niepolityka-decyduje-o-powrocie-przemyslu-do-usa/ (14.05.2017).

Ramotowski, J. (2016). Niemcy pozostaną dla Polski partnerem pierwszego wyboru (Germany to remain Poland's first-choice partner). Obserwator Finansowy, 16 May. Taken from: 
https:/www.obserwatorfinansowy.pl/warto-wiedziec/badania/niemcy-pozostana-dla-polskipartnerem-pierwszego-wyboru/ (16.05.2017).

Rodrik, D. (2011). Jedna ekonomia, wiele recept (One economy, many receipts). Warsaw: Wydawnictwo Krytyki Politycznej.

Ryć, K. (2017). Globalizacja a reindustrializacja. In: A. Z. Nowak, K. Ryć (eds.), Polityka $w$ regionach $w$ warunkach globalizacji (Politics in regions under conditions of globalisation) (p. 60-68). Warsaw: University of Warsaw, Faculty of Management Press. 


\section{ANDRZEJ SOPOĆKO}

\section{Comparative advantage. A condition or a process?}

Historical experience reveals that the economy in our days does not evolve in line with any imposed projects. Instead, it is shaped by processes triggered by a variety of factors, both external and internal. Only a few of them are controlled by state governments. Contemporary economy rests within a very complex system of international links and ties. Areas of cooperation significant for the operation of enterprises have long ago crossed national borders. We are not witnessing sharply defined national manufacturing systems any longer. The process of integration evolves at pace, leaving less and less room for economic policy applied by the state. However, existing instruments - fiscal, legal and, albeit to a limited degree, monetary - still make it possible to support certain processes which are vital for the economic progress. Their identification and stimulation by the well-reasoned structure of state expenditure is essential because there are no economic systems capable of independently overcoming any deficits. Then, there are also some structural weaknesses, such as an inadequately short time perspective in business activities of enterprises which reduces necessary infrastructural and research \& development projects. States which proved unable to develop a rational policy for supporting their economies in those areas, inevitably struggle and end up left behind. Unfortunately, it becomes more and more difficult to create such a policy. There aren't any universal or unambiguous development models to be found in books of the theory of economics - even if some time ago we tended to believe there were. Such belief resulted, in certain periods, in very common prioritisation of some particular sectors (such as heavy industry back in the 1950s, electronics in the 1970s and 80s and so on). Any attempt to stick to such an approach today should be defined just a pursuit of illusive objectives at the cost of loss of actual prospects, developed in the long run. The economic policy must be more complex, fundamentally focused on the development of the system rather than its individual elements. It should give support, sure enough, but not to any individual attainments - if anything, it should support the creation of an economy profile which fits well within the global economic progress. This seems to be the right way to develop economic and social potential of any country.

Keywords: integration process, economic policy, role of the state, comparative advantages.

\section{Purpose of economic policy}

Regarding this issue, there is simply no consensus at all, even in the very general framework. The range of use and meanings given to that very notion is extremely broad. If we reject definitions unrelated to the economy (such as salvation or the harmony of all existence) or overtly nihilistic (to pretend to do something and in fact avoid any effort), one that seems most minimalistic is the approach applied by classic 
liberals. According to them, an economic policy is exclusively reduced to ensuring economic freedom under conditions of unrestricted competition market (Hayek, 1948, p. 110). Any state activity, according to that concept, should be limited to the provision of conditions for such market to smoothly operate (among other things, free of hegemony imposed by monopolies) and to ensuring the minimum dignified level for those who are frail and unable to make their living on their own. On the other end, we find an extensive variety of concepts for the state involvement in fundamental fields of economy, such as distribution of the final product, its manufacturing structure, production methods, relationships with the outside world, access to natural resources, both renewable (forests, for example) and non-renewable (raw materials), not mentioning the ideas of return to nature. To even attempt to review these theories would be to review economics in its entirety. Therefore, we assume here that the notion of "economic policy" includes efforts focused on the following:

- ensuring free and competitive market in the country,

- opening onto international markets,

- reducing the areas of poverty,

- restricting the exploitation of non-renewable natural resources.

This way, conditions may be provided and when met, - according to liberal approach - an automatic release of economic growth will follow. How shall we, then, define the notion of economic growth? Following one World Bank's report (2011, p. XI), we shall regard it as "a process in which welfare is created - a process of generation of capital: productive, natural and institutional. The key element here is the intangible welfare which includes human and organisational capital"1. Of course, it might be doubted whether the above-mentioned conditions would suffice, and therefore whether a certain set of efforts, exogenous to the system, is either essential or at least stimulating for a dynamic growth of this type of capital. Nonetheless, such activities may be defined as economic policy. This way, economic policy is an activity which co-creates, together with some immanent economic processes, a country's productive, natural, human and organisational potential.

Still, the adoption of such axioms yields a very extensive range of possible economic policies, whereas only one can be applied over any given period. Which one seems the most effective now? This question, quite naturally, arises in every macroeconomic analysis, unlike the answers which don't come naturally at all. After all, one also has to define places where the policy will be applied, and the stage of development of cooperation and exchange partners, both existing and potential. Moreover, individual countries face different situations in terms of their size and quality of their economies. They also differ in cultural and institutional heritage

1 Development is, at heart, a process of building wealth - the produced, natural, human, and institutional capital which is the source of income and wellbeing. A key finding is that it is intangible wealth, human and institutional capital, which dominates the wealth of all countries (World Bank, 2011, p. XI). 
and their histories, especially most recent. Some activities which prove effective in one region fail in another, even if seemingly quite close in cultural and geographic terms. One fitting example were attempts to recreate family-run farms - successful in Poland thanks to an uninterrupted history of individual farming, but struggling in other post-socialist countries, including East Germany. In the latter countries, a long-term (50 years) gap in ownership of land handed over from one generation to another acted as a barrier to restore the land as a family working place. Another failure, despite favourable climate, was when Italy attempted (back in the 1940s) to develop cultivation of rice on a large scale: the very peculiar culture of rice cultivation simply had no roots in Europe.

Modern economy sees many more examples like these. It is easy, then, to use them and justify how misleading it is to opt for one uniform model of economic policy. In evaluating its possible variants, one should relate them to specific conditions of a country - not only natural and geographic conditions but also the specific stage of development and the existing organisational and legal structure. This structure forms the pivotal element determining the present condition and development potential of the economy, one that enables (or not) the introduction of new, hopefully, positive solutions in this area. In fact, regulations and the way the society is organised, shape the economic potential of an economy (Acemoglu, Johnson and Robinson, 2002). However, the opposite is also true: for example, post-socialist countries were unsuccessful in their attempts to develop efficient horizontal structures of self-regulation (associations, unions, chambers), because, as it occurred, some essential models were missing that only evolve over several generations (like in the case of customary regulations of the financial environment in the United Kingdom). In Central European countries - except for trade unions - such organisations are still frail and more about image than about actual influence.

Some authors believe such influence of the economy upon institutions is much less significant than the opposite relation. For example, Daniel Rodrick (2000, p. 2) regards an institutional and legal system as exogenous to economic development - which in our opinion can hardly be agreed with. There are institutions which, quite simply, in some countries really operate, whereas in other countries they are passive: the social and economic system failed to assimilate them. As the economy evolves, good and bad experiences accumulate as regards implementation of particular solutions. In Poland, it is bureaucracy prevalent in cooperatives or farming unions - bureaucracy which spreads across them, rooted deep before the transformation began - that seriously discourages from regenerating these organisations. Nonetheless, they are undeniably important as bodies able to confront strong enterprises dealing in purchase and processing of agricultural crops. Who knows whether it is too late or perhaps too early to reform them, but still it is certain that:

- there may be no single economic policy replicated across various systems,

- even well-proven solutions have to fit into their window of opportunity in the process of economic development. 


\section{First and foremost - system-oriented activities}

Most of all, it should be remembered that a country's economic policy is strongly determined by external conditions. This is so because it consists of actions aimed at one element (a single economy) within the system in which many things happen, quite independent from that policy as well as hard to foresee. Even in the shortterm perspective of several years to come, we are uncertain what is going to happen in the area of technology or in economic relations. For Poland, for example, one significant area of uncertainty is that of relations with Russia. While Poland's trade exchange with that country isn't very significant at present (4.2\% of export) (GUS, 2015), that market has serious potential for growth. This mainly concerns agriculture and the sector of household articles, including furniture, which develops very well in Poland.

Sure enough, Poland is also subject to phenomena unfolding on the global scale, which are neither continuous nor foreseeable. For example, subsequent rounds of negotiations in WTO brought progress in shaping regulations which opened many countries of the world to international competition. It seemed at that time there wouldn't be any retreat toward autarchy - and yet recently the USA undertook measures aiming at renouncement of the free trade arrangement known as the Trans Pacific Partnership, introducing, at the same time, restrictions on the investment export. Also, a couple of years ago nobody would have imagined as serious emigration crisis as we are facing these days. It turns out we have to be prepared all the time for new things to happen, for which any previous preparations might prove inadequate. J.Y. Lin rightly points out that economic development is a process which unfolds with the continuous transformation of economic structure. Any country has to redefine its place in that process time after time. Considering that such country always operates under conditions of uncertainty, it has to reckon with making mistakes and being confronted with surprises.

The primary objective of any economic policy should not be about indicating what the economy should do, but defining to which system it should tend, or, in other words, which systemic features should be cultivated. It seems we might mention three such features we reckon fundamental:

- entrepreneurship,

- the flexibility of internal structure,

- absorption of innovation.

Entrepreneurship is the critical element in the competitive market economy. However, there is some diversity in this respect, even among Central European countries, as similar as they may seem. In the countries of our region, relatively lowest levels of entrepreneurship are observed in those places where the former centrally-planned socialist economy was replaced with family-controlled oligopolies. In Poland, this process never happened, partly because private enterprises and 
individual land ownership had already existed under the previous system. These areas became the seeds for spontaneous business activity - no longer limited or licensed. During the initial decade of transformation, problems with the emergence of economic oligarchy occurred in Hungary and Czechoslovakia - by the way, countries with per capita income higher, at that time, than Poland. This, among other things, might have explained their rate of economic growth, slower than in Poland. In Bulgaria, Romania and Ukraine enormous problems in overcoming corporations of oligarchs which freeze the system never ceased and last to this day, the same problem being most aggravated in Russia. Admittedly, Poland began to counteract monopolies at a very early stage. The Act on counteracting monopolistic practices entered into force in 1988 (two years before the political system was changed). The Antimonopoly Office and the Antimonopoly Court were established in 1991. The importance of undertaking such efforts was certainly overlooked in other countries. Only later on were they to understand that economic freedom is not enough to automatically create the market. What turned out to be essential was imposing rules of operation which would ensure efficient regulation in the market - and doing it early on. It should also be added that in Poland there was a favourable social attitude to do this. The independence of business activity, won by the Solidarity movement, could hardly go in pair with acceptance of any administrative entities over enterprises. Other countries neglected the task of dismantling hierarchical economic organisations and failed to properly empower regulations and institutions responsible for monopoly control. This phenomenon gives further evidence to the opinion that the deficit of organisational and legal infrastructure in any society leads to the emergence of influential social fractions. They soon become stronger than the market and stronger than democracy. In consequence, the system splits up rather than integrates, thus resulting in the growth slowdown (Tornel and Lane, 1999, p. 26).

Entrepreneurship also requires competitive market which is easy to enter. This, paradoxically enough, was favoured by underdeveloped commercial network - the deficit that was most serious in Poland. In this area costs of entry are relatively modest, thus enabling thousands of business beginners to test themselves and collect start-up capital to expand later to other areas, more demanding in this respect.

The flexible internal structure also seems to depend, primarily, on the share of small industry in the total national production. Small enterprises find it easier to change and adapt and, at the same time, they usually feature the climate propitious to seeking new opportunities. Enterprises with short histories are also free of such burdens as brand tradition or highly-specialised staff. The role of the small enterprises sector seems especially important in developing countries where it is not confronted with strong competition on the part of large companies sector'. This is quite important, considering that in countries of our region large enterprises were actually developing as oligopolies, facing no competition nationally, whereas internationally they hardly competed at all. This made quite a different situation than in well-developed countries where great corporations are in continuous 
confrontation with other greats in the global market. For them, any shortage in the flexibility of operation would result in being pushed out of the market by their global competitors so they learnt long ago to do their best to detect market trends and adapt thereto.

Innovations are the third problem. If fact, it ranks among the most discussed issues in the context of development. It suggests that the problem is both complicated indeed and inadequately solved. There is no single receipt for being innovative, but still, there are some characteristic phenomena that may be observed in this respect. Firstly, innovation rarely happens in poor countries. While one could argue that this is the reason why they are poor in the first place, but in reality, it is not so simple. Secondly, excessive support given to innovation easily leads to the researchers' circles losing touch with the needs of reality. Examples observed in Poland included research work on high-energy military lasers or electronic sub-components based on germanium, where some interesting discoveries were made - without, however, any prospect for their application.

One might say there is a sort of feedback between the economic growth and innovations. Accordingly, it can hardly be expected of a country at a middle level of development to rank among the most innovative economies.

High level of innovativeness favours a good rate of technological progress - however, it is much more important to have an opposite relationship in place. The level of technology achieved also determines the level and dynamics of innovation. Excessive innovation-promoting pressure gives little effect unless there is actual potential for the results to be absorbed by the economy which is not yet well-developed. Therefore, whilst the investments in space technologies and industry in Germany or France can drive major segments of their entire economies - due, among other things, to well-developed aviation industry - in Poland or Hungary space industry would probably remain an isolated niche. It isn't really justified to test cutting-edge materials used in the space industry if all they could serve thereafter is the manufacturing of passenger cars, buses, trains or white goods.

That's why it is critical for the state support to that area to be well measured. This isn't a simple task as it requires efforts undertaken in many aspects. Then, it is also difficult to resist the research lobby which has one crucial advantage - that of knowledge, although very selectively applied in this case - over those who control the funds.

To be innovative, a society needs to be flexible - be capable of prompt transformation of manufacturing, education or information exchange structures. A system best adapted to this task is one consisting of horizontal relationships (civil and legal contracts), where individual elements are tied together by common interests rather than orders coming from above (e.g. from corporations' headquarters). It is the role of the state to consolidate the faith in the effectiveness of this sort of relationships. In this network of links, relationships between enterprises and scientific/researching units are especially important. 
However, this problem is even more complex. The essence, really, is that scientific and research approach operated along a different horizon than business approach. The business environment is changing and that requires from entrepreneurs quick decision-making about what to produce and how, where changes should be made and so on. Time in which an investment is made - at least as regards machinery and equipment - was seriously shortened over the recent years, mainly due to globalisation (most things in demand are there somewhere already, waiting to be bought), but also to organisational infrastructure, understood as presence of professional organisers of the investment process. However, no parallel shortening of research cycles and processes occurs. This probably stems, partially at least, from the fact that it takes more time to improve technologies and products as they become more and more complex. Despite increasing efficiency of all sorts of scientific instruments, it is difficult to compress the amount of work - increasing as well - on any final product. To verify the usefulness of any component is labour- and time-consuming yet very important, and not only for commercial reasons. For example, textile industry uses around 7000 so-called auxiliary substances (mainly dyes). Some of them are potentially carcinogenic (Zentrum der Gesundheit, 2016). With this in mind, they should all be thoroughly tested (e.g. to check whether they are harmful in any or just in large doses, etc.). Whereas developed countries have the potential to cope with such challenges, other countries are usually devoid of it. The more complex the product, the more extensive its development base should become. Countries at lower levels of development often have to give up this area of complex manufacturing. Alternatively, they choose to operate at the border of serious legal and moral risk (for example, manufacturing toys that are potentially harmful to children).

The increasing complexity of products - the phenomenon peculiar to manufacturing in well-developed countries - requires scientific and research potential to evolve at a faster rate than the economy does. Accordingly, the expenditure needed is proportionally higher in places where - apart from examining the individual elements, it is also desirable to analyse relationships between them. As anybody knows, the number of such relationships increases in an exponential, rather than linear, manner. While not every relation is significant, the number of relations undeniably significant is still very high. Additionally, this sector has to act proactively with respect to the needs of the economy. In practice, it is not possible for scientific institutions to only react to the needs reported and satisfy them quickly. Should there be no serious research work already carried out in any given area, it would just take too long to answer the questions asked by the business players. To be able to perform tasks commissioned by the industry, research centres have to involve in basic research activities before they are asked questions. This costs money. For such activity to be profitable in purely commercial terms, the scope of collaboration with the industry would have to be very extensive. Large numbers of orders concerning the implementation of specific solutions could cover the costs of some programmes of basic and proactive research. 
For such model to really work, the economy would have to be extremely innovative, which is simply not the case in most countries. Then, to stay competitive, market players have to save on their outlays. In effect, financing of anything not essential at any given moment or uncertain to be useful in the future is cancelled. And this is precisely here that some support of the state is indispensable. Even where it exists, it is still difficult to balance the support the right way - so that scientific institutions are not encouraged to only focus on the governmental grants and seek ways to maximise the inflow of the state funds.

\section{Irreplaceable role of the state}

Innovations, along with material and social infrastructure (roads, railway, educational system) belong to areas where long-term strategies have to be applied. Private economy struggles in this respect and there are basically no solutions which could replace the state in performance (joint in some cases) of projects whose effects will occur only in the long run (Burghof and Müller, 2016). The same holds true for innovative undertakings, especially those which demand greater expenditure. Considerable outlays whose repayment is seriously delayed in time are - quite objectively - risky. This risk increases even more if we take its subjective aspect into account. In a lot of such projects (for example in pharmaceutics ${ }^{2}$ ), costs arise over a period extending onto two or more terms of office of an enterprise's board of management, while effects appear even much later. As we know, to work for somebody else's success is very laudable but happens seldom.

The state does not invent innovations so it should support those who do. That's where another question arises: how to stay objective in this area and give priority to those who are able - at any particular stage of progress - to really effectively improve technologies and products?

There isn't any receipt here: there are just specific solutions, more and less successful. In Poland as well as in other countries a point system is applied which leads to ranking the research institutions into categories. Of course, to be in the highest category, one has to collect most points and the principal criterion for awarding points is the number of publications. This practice can be observed everywhere. In consequence, the number of publications exceeds the number of their readers. According to Allen Institute for Artificial Intelligence, there are about 2 million scientific articles annually published worldwide. Half of them is only read by no more than 2-3 persons (including the authors, the editor, and peer reviewers) (Lattier, 2016).

2 European Patients' Academy as well as other similar institutions quote the period of 12-15 years. Taken from: https://www.eupati.eu/pl/opracowywanie-leku/tworzenie-lekow-etap1-okres-poprzedzajacy-odkrycie-leku/). See also: Edwards, Fox and Stonier, 2010. 
The practice applied so far fails to provide adequate solutions or to answer the question how to distribute the funds of the state support among various institutions. It seems, however, that this is not the crucial problem anyway. Funds earmarked for science and research are defined in budgets, mainly in the state budget. In practice, their levels increase in proportion to the growth of GDP. They are always considered insufficient, but usually, their level remains rather stable, due to pressures from other expenditure areas rivalling for funds. That's why it makes little sense to discuss how much money should be spent on science. The answer is rather obvious: just spend what you get. What is really worthwhile, instead, is to try and stimulate the channel of knowledge flow from science to production systems.

The most important task is to intensify the process in horizontal relations. This demands creation, in enterprises, of will to seek for new solutions for manufacturing processes. From this point of view, the outlays on R\&D should grow up, but this should be a gradual growth process, determined by the emergence of effective organisational solutions which enable proper supervision over and evaluation of the effects of direct state support. International comparisons are elusive when they reveal that one country spends a smaller percentage of its GDP to that purpose than another country. It isn't correct at all to judge on that basis that the former one behaves less reasonably than the latter. Quite irrespectively from any absolute values of that index, both countries may operate at equally rational level. Perhaps this is going to suffice to the first country, at its particular level of development. Perhaps in the second country greater funds might verge on the border of waste because of the missing area of efficient implementation adequate for them.

If innovation is generated at a rate that exceeds the potential of their application, there is a tendency to go along a quicker way of acquiring money - by multiplying the number of new solutions rather than their quality. Quantity, as a matter of fact, is much more visible as a criterion than quality, despite different indicators being used. Moreover, shifting an assessment of work usefulness onto various contests leads to the formation of a network of scientific establishments, the true aim of which is to exchange mutual benefits and lobbying for more funds. Pure research work becomes overshadowed, thus definitely undermining pro-innovative motivation.

It should be remembered that creative people have very developed needs of selffulfilment. For an architect, a bridge well-built and standing there is more important than a bridge awarded a prize for design but left on paper. Creative people desire to distinguish themselves with their talents and skills and to enjoy general appreciation. This makes them more satisfied with projects not necessarily pioneering, but those actually implemented. Innovative economy flourishes in places where a high GDP is accompanied by a relatively high level of industrialisation. The innovativeness of the economy correlates strictly with the industry development - the better developed the industry, the larger the area in which innovations may be implemented. There can be no better receipt for healthy innovation process in the economy than to 
cultivate it without any significant excess of funds or solutions over the actual possibilities of absorption of innovations by the economy.

Unfortunately, in developing countries, we usually observe insufficient demand for products of domestic innovation sector. This deficit becomes especially evident where a country's economy is dominated by foreign corporations. It is only natural for them to trust scientific centres situated nearest their own corporate headquarters. This results from the language, from long-standing personal ties and, perhaps most of all, from the image their brand commands in a given environment. Then there is the need of concentration and comprehensiveness of research. In effect, it is much easier to commission an entire research programme to one single scientific institution than to search for most efficient solutions throughout the region or worldwide. The countries which feature a strong feedback between the economy sector with purely manufacturing area tend to become centres which attract both businessmen and people of science (Korzeniewicz and Moran, 2005).

This phenomenon occurs on the global scale and makes an important factor determining the economic relationships which become more and more independent of national borders. Centres emerge which attract global demand in a given field - and thereby they also attract capital, both material, and human. Just like with gravitation, they pull in more and more capital base, tangible and not. This is especially visible from the perspective of individual sectors, as the principal research centres of leading sectors which determine the development are situated in well-developed countries, thus strengthening these countries even further.

In these conditions developing countries, in order not to lose contact with the leading group, have to undertake some actions to increase the strength with which their own innovations are absorbed by dynamically developing industries. As already mentioned, the point is, in fact, not in the creation of scientific establishments which will hover high above the reality of the manufacturing sphere. Instead, the point is that, firstly, such scientific centres exist at all and represent a level needed for ensuring good future for the industry. Secondly, what is most important but also most difficult in organisational terms, is that enterprises operating domestically really benefit from the output of these research centres, rather than fully relying upon innovation flowing from countries where corporate headquarters are situated.

This, therefore, is the field for the state to play. How? This might be defined the following way: if a country has a large enough segment of the well-doing industry, it should endeavour to ensure proper research backing for it. Here, it seems, the supply should precede the demand. Commissions from the industry (demand) are going to appear only if managers begin to believe that it is more advantageous to their company to apply domestic solutions than to order the same in their headquarter. This belief has to be anchored in specific facts (working technologies, reliable products, etc.). For this to come true, such facts have to become reality first. Sole intentions are little attraction. 
The state, therefore, should care for the creation of a scientific and research base for the existing industry - mainly for that part which seems capable of surviving in a highly competitive global market. The process is rather complicated, considering how easily institutions and support channels fall into bureaucracy and soon may come to demand further support from the state not based on what they do but on the very fact they exist.

As shown in Deloitte research on the enterprises in Poland, in half of them the expenditure never exceeds 5\% and in around 90\% they remain at levels below $10 \%$ (Deloitte, 2015, p. 6). However, which is significant, these enterprises still expect support for their R\&D activities from the state and indicate shortages in this support as the principal reason of inadequate level of development of these activities.

\section{Non-systemic activities}

Apart from positive indications (what to do), it is worth mentioning solutions which seem right and in practice usually occur counterproductive. Most of them seem to originate from the attempts to create some entirely new reality. On the one hand, they consist in stopping an autonomous process of structural changes and in striving to preserve specific industries in places they occupy today. On the other hand, they stem from visions of achieving some major civilisation leap through the development of industries which have no real anchorage in the system but act as symbols of some very advanced technology. In either case, it is industrial lobbies that play the leading role. In Poland, this phenomenon results in continuous subsidisation of black coal mining and relying the production of energy on it instead of developing nuclear and environment-friendly power industry. This practice is not at all necessary due to social reasons, because, as we see, wherever the coal mining disappeared, we witnessed a release of very disciplined and very creative labour resources. As an example, the town Nowe Tychy may be quoted with its exemplary economic and general progress. Once a town almost exclusively populated by miners' families, today it is one dynamic centre of small and medium industry.

Speaking about the implementation of subjective visions, this was quite common shortly before the socialist economy collapsed. For example, in the late 1970s came a trend in fashion for clothes made of crimplene (stretching synthetic fibre). With great political mobilisation, decisions were made to meet the demand for these clothes with domestic production. When appropriate factories were built, it occurred that the passing trend was already gone and nobody liked this fashion anymore. Another, more modern example is the production of motor cars - almost every country is eager to involve in it and then boast the numbers of cars manufactured. It isn't very clear where the point is since there are several other countries which 
never joined that race and never regretted that. In this extremely resource- and energy-consuming production, Switzerland ranks very far, near the end of the list, as do Australia, New Zealand, Ireland, Taiwan and more.

It is worth remembering that a high place given in assessments of any given country doesn't have to be - and usually isn't - defined in a single-faceted way. A country may not belong to leaders in any particular area and still rank very high on a list in terms of its economic development as a whole. In most cases, it is a number of factors rather than just one that determines specific comparative advantages and it is not always easy to distinguish the principal factors. However, all together they determine the success of some specific economy profile in the long run. For example, how shall we explain the fact that Italians have been unrivalled for decades in product styling and top-class clothes and fashion? After all, we don't seem to believe that the most successful designs require being drawn under the Italian sky by designers served with top quality Italian pasta. Instead, this ability to design objects undeniably originates from a very long, very rich and uninterrupted artistic tradition.

Well-developed countries achieve their advantage not in one dimension, but in a sort of packages. Such packages become more and more complex over time and they gradually transform. The World Bank's Report shows how, in countries with low and medium income in the periods 1995-2000 and 2000-2005, the value of natural capital remained at the same level, while produced capital and intangible capital increased by c. $80 \%$ and 30\%, respectively (World Bank, 2011, p. 8). Economic reality becomes more and more complex and more difficult to measure, which results from a growing share of intangible capital in it.

This fact alone generated some difficulties in the formulation of an adequate economic strategy. To act wisely, one needs knowledge in at least two aspects and it takes a lot of effort to master it. Firstly, one has to know very well about the specific nature of a given country to be able to identify its potential of growth. Then, it isn't enough to only know the object of the activities planned: it is just as essential to know the history of the policy applied and social reception of the measure it uses. Secondly, one also has to know actions and effects of the economic strategy implemented elsewhere. Global experiences in this area are invaluable and cannot be replaced with ideas of local experts, no matter how talented. However, ideas coming from the outside should be applied with much caution and never at any cost. A given country's scope of possibilities may allow for either less or more than somewhere else and even absorb activities that seemed unrealistic. This was the case in the early 1960s in South Korea where - contrary to what the World Bank recommended - universal secondary education was developed. In Poland, following the recommendations of the IMF in the field of monetary policy brought the threat of a crisis. It was believed that the remedy to high inflation at that time should be found in the maintenance of extremely high-interest rates of the Central Bank (around $10 \%$ in real terms for several years). In these conditions, it was not reasonable to involve funds in any production. In other Central and Eastern 
European countries, hasty privatisation became a negative experience, without the creation of a competitive market, which - as already mentioned - led to the emergence of oligarchies in their economies.

Economic policy should follow one unrelenting rule - its goal is to support the development and not economic visions. What seems significant and viable today, in a couple of years may turn out not useful or surprisingly difficult to implement (the programme of shale gas exploitation being a good example). Whenever objectives are defined as vectors or rankings, they inevitably seem to lead to the implementation of strategies out of touch with the reality. Any economy is verified by its international environment, and only to an incomparably lesser degree by an extent of implementation of programmes planned.

Development is rarely a continuous process. At some stages, particular effort is required which is not at all comparable to the one that sufficed before. This is a little like with phase transitions in physics. For example, as we heat water up to the boiling point, up until $99^{\circ} \mathrm{C}$ the process is linear, but then to achieve that one final degree we need much more energy than, for example, to go up from $98^{\circ}$ to $99^{\circ} \mathrm{C}$. At present, Polish retail trade struggles with difficulties similar to phase transitions. The growth was impressively strong until the point of saturation with local-range businesses (single shops or small networks of several outlets bound together). Now networked enterprise can no longer survive - this concerns, among others, such brands as Marcpol, Piotr i Pawel or Alma - they lose ground to foreign networks such as Biedronka or Carrefour.

Of course, not every business confronted with barriers to its growth at some stage should automatically obtain support. Globalisation enabled operation of economies with seriously incomplete production profiles. If, for example, Poland or other European countries face problems with construction of large sea-worthy ships because no covered production lines were installed with which it would be possible to build entire segments under one roof, then it is doubtful that any forms of admissible support could fund investments enabling the shipyards to compete with South Korea or Singapore.

Namely, financing should be focused in places where the potential of success is largest. Where does that happen? It is never quite certain, but it seems most reasonable to support industries (enterprises) which have already proven successful. Just like in sport - financing of participation in prestigious competitions or training under top coaches are offered to those who already distinguished themselves. But even then, the question always remains open whether the beneficiary fulfils expectations and the results achieved so far don't occur an isolated outburst of form.

It may seem illogical to support those who overcome barriers on their own in the first place. If they have proven capable of coping with hardships involved in starting up and initial stages of development, public support might only undermine the determination of businesses once they sense they have the strength of the 
state behind them. In fact, things may go this way, but on the other hand, entities successful at an early stage may experience a crisis in their development, not so much due to any objective barriers, but to fears about undertaking a risk and advancing to the next level.

For large and in particular for very large ("too big to fail") enterprises, support given retroactively is almost regarded a rule. Smaller entities have to actively seek support, often from local authorities. Significant help in this respect (perhaps less in tangible terms, more in psychological and organisational / procedural ones) comes from chambers of commerce. This segment is best developed in West Germany and in Austria where membership in them is obligatory, whereas in other countries usually, it's voluntary. In many cases, they actually resemble lobby organisations. Anyway, what they always do is a help to overcome an apprehension about entering a new stage of development.

One of J.Y. Lin's significant recommendations is to focus the state efforts in areas of comparative advantages. Undeniably, this is a logical consequence of criticism against state intervention which tends to be regarded a flopped experiment of economic policy - although it might be doubted whether this holds true for countries of Eastern Asia (e.g. the case of Singapore). It seems that at least some elements of such practice contributed to that country's economic success, while in socialist countries the same certainly contributed to the creation of a strong industrial base. At present, no reasons to return to state intervention as applied by Juan Domingo Perón in Argentina are evident (construction of metallurgic and machine industry) or, more recently, as the attempts to introduce developed agriculture based on underground water sources in desert-like petroleum exploiting countries. Today, as existing comparative advantages are more complex than they were several decades ago, activities need to be more refined and complex.

However, the first problem is whether comparative advantages should be exploited to the full. For example, one of them is cheap labour force. If we reckon it a factor that determines the structure, we are risking negative feedback in which cheap labour force shapes the economic structure (i.e. labour-intensive industries prevail). In this case, that very structure exerts pressures to keep wages low for domestic production to be competitive globally.

Another problem is to identify comparative advantages under conditions of international integration. Globalisation determines the fact that today any final product is assembled rather than produced. Every new Boeing 787 Dreamliner leaving Boeing factory in Seattle is assembled from circa 2000 parts supplied by external contractors dispersed around the world. Every one of them had to have a previous record of significant success to take part in this prestigious project, no doubt about that. However, does an enterprise's manufacturing success translate into its country's comparative advantage?

Recently, Poland has become a significant manufacturer of buses in Europe - something that twenty years ago seemed unthinkable. If anybody attempted to 
foresee the leader at that time, Hungary was the obvious favourite with its huge bus manufacturing industry developed years before. While its largest customer - the Soviet market - disappeared soon after the transformation, still it seemed that such a powerful potential should have coped successfully with quick adaptation to new requirements. That just never happened. On the other hand, things went the opposite way in the Czech Republic. Prior to the transformation, this country had a very extensive passenger car industry. The process of transformation not only did not devastate it but quite contrarily, Czech car industry soon began to enjoy an impressive success in demanding West European markets.

There is no doubt that in individual countries there are some comparative advantages. Nowadays, however, they seem to relatively poorly relate to natural characteristics of the economic environment. They are shaped by the system, as a joint result of a set of circumstances that are hard to analyse, including talents of entrepreneurs active in a certain field, informed state support, conscious opening onto the risk of foreign customers or the existence of local reserves of the highly-skilled labour force. Such comparative advantages are formed in long term processes, but it is not possible to foresee in which fields and for how long new ones will appear. Sometimes it may seem that success is achieved against objectively existing conditions. For example, how have trains and trams become an important export product for Poland, if in previous years they were produced in small numbers and in outdated range (mainly coal wagons)? Of course, one could explain this with orders coming from the public sector, however, there were also manufacturers from the European Union participating in tender procedures. Also, it wouldn't be easy to explain the success of farming and export of sturgeon in Poland - certainly not based on natural conditions advantage, considering that this noble and demanding fish normally lives in quite a different climate. Therefore, it seems there are two types of comparative advantages:

(1) the environment-related determinant, occurring only in certain countries. For instance, Iceland is naturally specialised in fishing and processing of fish, Australia and New Zealand in farming sheep, Argentina in cattle, etc. Natural conditions in these regions of the world are especially favourable to these types of activities;

(2) independently developed by social and economic system - like the advantage of German motor car industry, Korean and Japanese consumer electronics, French gourmet foods, and so on.

Skilful exploitation of both types of comparative advantages results in accelerated growth, however, the process has to be under control all the time. The advantages in question, in particular, the latter type, aren't always long-standing. One phenomenon that is especially emphasised these days is the big difference in labour intensity between countries of Northern and Southern Europe. In the South, there is simply less motivation to undertake real effort than in the North. Perhaps 
this could be explained, to a certain extent, with a climate which was shaping this sort of work ethics and attitudes for centuries. In modern days, however, with air conditioning everywhere, this factor should have lost its relevance - and still, the labour intensity in the South hardly seems to close the gap with levels achieved in the North. Then again, if we consider this phenomenon permanent, the logic of adaptation would suggest developing capital-intensive industries in the South and labour-intensive ones in the North. Quite obviously, this would be totally contrary to trends evolving for decades in European work distribution.

\section{Conclusions}

Economic policy should provide support to processes which strengthen a country's competitive position on the international market. The achievement of this objective should be favoured by regulatory and fiscal measures. Direct financial aid given to production, on the other hand, has to be very limited, mostly due to restrictions imposed by the WTO and EU treaties. This is also consistent with reckoning free economy the fundamental regulator of the world economy. There is no need to intervene where such regulatory function is performed well enough. This actually happens in the case of most short- and medium-term operations. However, with projects implemented in the long run, some support from the state is indispensable. This relates to most basic research and some development research, to the process of skill upgrading and to the creation of tangible and social infrastructure (including commercial unions and chambers, foundations, etc.). Such efforts should primarily tend to use a country's existing potential, including the opportunities that appear in each period. Nonetheless, one has to remember that as the economy evolves, conditions for such activities change as well. Priorities of the economic policy should follow these changes. If there is a sort of compass to help find direction, it's certainly in the success achieved in specific areas or product groups. This is a changing game. Paradoxically, comparative advantages change as they are used. Where products based upon cheap labour enjoy international success, two things happen: costs of that labour increase and capital begins to flow in. This encourages businesses to shift towards areas where the role of capital is bigger. Then, sheer technological progress also alters the structure of global demand for products. As the state efforts are focused on areas where enterprises achieve success in international markets, it must be remembered that this success is only temporary. Accordingly, some support should certainly go in the fields where the process only begins, i.e. opportunities to achieve success are beaconing. 


\section{Bibliography}

Acemoglu, D., Johnson, S. and Robinson, J.A. (2002). Reversal of fortune. Geography and Institutions in Making Modern Worlds Income Distributioon. The Quarterely Journal of Economics, 4.

Burghof, H.P. and Müller, C. (2016). The State as a Financial Intermediary to Foster LongTerm Investments. Applied Economics Quarterly, 3, 205-230.

Deloitte. (2015). Badania $i$ rozwój w przedsiębiorstwach. Raport 2015 (Research \& Developement in Enterprises. Report 2015). Taken from: https://www2.deloitte.com/ content/dam/Deloitte/pl/Documents/Reports/pl_Badania_i_rozwoj_w_Polsce_2015.pdf.

Edwards, L., Fox, A. and Stonier, P. (eds.). (2010). Principles and practice of pharmaceutical medicine (3rd ed.). Oxford: Wiley-Blackwell.

Gill, I.S. and Raiser, M. (2012). Golden Growth: Restoring the Lustre of the European Economic Model. Washington, DC: World Bank. Taken from:: https://openknowledge. worldbank.org/handle/10986/6016 License: CC BY 3.0 IGO.

GUS. (2015). Rocznik statystyczny handlu zagranicznego 2015 (2015: Statistical Yearbook of Foreign Trade). Warsaw: Central Statistical Office of Poland.

Hayek, F. (1948). Individualism and Economic Order. Chicago: University of Chicago Press.

https://www.eupati.eu/pl/opracowywanie-leku/tworzenie-lekow-etap-1-okres-poprzedzajacyodkrycie-leku/.

Korzeniewicz, R.P. and Moran, T.P. (2005). Theorizing the relationship between inequality and economic growth. Theory and Society, 34, 277-316.

Lattier, D. (2016). Academics Write Rubbish Nobody Reads. Foundation For Economic Education, October 27.

Lederman, D. and Maloney, F. (2012). Does What You Export Matter? In Search of Empirical Guidance for Industrial Policies. Washington, DC: World Bank.

Rodrick, D. (2000). Institution for High- Quality Growth. Center for Economic Policy Research, Discussion Paper, No. 2370.

Tornel, A. and Lane, Ph.R. (1999). The Voracity Effect. The American Economic Review, 89(1), March, 22-46.

World Bank. (2011). The Changing Wealth of Nations: Measuring Sustainable Development in the New Millennium. Environment and Development. Washington, DC: World Bank. a: https://openknowledge.worldbank.org/handle/10986/2252 License: CC BY 3.0 IGO.

Zentrum der Gesundheim. (2016). Kleidung und Textilien mit Giftstoffen, 3 August. Taken from: 3.08.2016. https://www.zentrum- der-gesundheit.de/textilien-giftstoffe-ia.html 


\section{GRZEGORZ JĘDRZEJCZAK \\ HENRYK STERNICZUK}

\section{New Structural Economics and Poland's development challenges}

This chapter looks at New Structural Economics (NSE) from the point of view of its usefulness for the modernization challenge Poland is currently facing - the convergence with the "old European Union" members in perspective of decades to come. The attractiveness of NSE approach stems from its undeniable modernization achievements in the countries of the Far East.

Three issues are considered as significant for the potential usefulness of NSE for solving Polish development problems: (a) the notion of endowment, exogenous resources, which determine the structure of modern postindustrial economy, (b) the global context of modernization policy; (c) the role of the state in the implementation of economic policy aimed at improvement of competitiveness on the global scale.

In conclusion, it is stated that, from the point of view of Poland's needs, NSE presents several useful recommendations but also the risk of a potential trap related to methods in which the state (the government) intends to implement the modernization policy. NSE implicitly assumes non-political nature of the state. According to it, the state enjoys solid and permanent mandate and administrative potential to implement its strategy without having to worry about voices contesting its ways and means. Such approach is very attractive from a pragmatic point of view of the speed of implementation, however, this approach is not compatible with the Polish (or, in a broader scope, Western) reality of the political state, i.e. being subject to the democratic control.

Keywords: modernisation, role of the state, cultural determinants of modernisation, global determinants of modernisation, Polish modernization challenge.

\section{Introduction}

The theory of New Structural Economics (NSE) which has its leading advocate in Justin Yifu Lin has been the subject of numerous analyses, including its practical usefulness for catching-up with highly-developed countries by low- and mediumincome countries (Lin, 2012).

The scope of this article is narrower - the goal here is to evaluate New Structural Economics from the point of view of its usefulness for the modernization challenge 
Poland is facing - convergence with the "old Union" member states in perspective of the coming decades.

The end of the first decade of the 21st century has witnessed significant revaluation in economics, including the economics of development. It became evident that the doctrine of neoliberalism, predominant in the last decades of the 20th century, not only proved incapable to address the structural effects of global financial breakdown, but had also been inept in either foreseeing its occurrence, or its far-reaching economic and social consequences. As put by Queen Elizabeth II as she visited the London School of Economics in 2008: "Why did nobody notice that?"1.

The predominant neo-classic doctrine was based upon inadequate assumptions regarding human behaviour, optimal "rules of the game" and their consequences. Myths such as that "the rising tide lifts all boats", "trickle-down theory" or the role of the state limited to eliminating market failures, might have looked correct in periods of economic growth, but revealed all their powerlessness at the time of breakdown.

The economics of development with its central practical issue of catching-up (convergence) by underdeveloped countries also had (and still has) its share of myths.

The most fundamental myth is the conviction that countries experiencing a deficit of growth should be assisted by developed countries "to become as we are". Such an attitude seems quite frequent, both then and now, among Western donors and international organisations. It results in the production of strategic programmes for governments, with a long and eclectic list of postulates stemming from the experience of high-income countries. Meeting these postulates is indispensable to achieve success in building a highly-developed economy and a wealthy society. In the great majority of cases, such programmes remain on paper without ever being implemented in practice. In reality, the addressees of the advice know much better than the experts that conditions and requirements needed to implement the fundamental structural changes reach far beyond such an a priori made list of "things to do". They are also well aware that to undertake the programme of structural reforms infringes the interests of various groups and is really more akin to waging a war (with all its unforeseen factors, its need of adaptation and constant correction of targets, shifting coalitions or, finally, being in luck or out of it) than to the routine of introducing new laws from behind the desk and establishing new institutions.

In this context, NSE brings a rather radical breakaway from the doctrine of neoliberalism. As its cornerstone, the NSE doctrine assumes that "in brief, a country's economic structure at any given time is endogenous to its factor endowments - the amounts of capital, labor, and natural resources at that time. Countries at different

1 Pierce A., 2008. The Queen asks why no one saw the credit crunch coming. The Telegraph. 05 Nov 2008. Symptomatic is an answer given by the Director of Studies in the Managing Department of LSE: "At every stage, someone was relying on somebody else and everyone thought they were doing the right thing". 
development stages vary in their relative abundance of factor endowments. In developing countries, capital is generally relatively scarce, while labor and often natural resources are comparatively abundant. In developed countries, capital is relatively abundant, while labor is comparatively scarce. Although an economy's factor endowments are given at any particular period, they can change over time." (Lin, 2012).

Basically, this assumption - as the author admits - largely goes along the lines of neoclassical thinking found at the fundament of the theory of growth based upon the production function in Cobb-Douglas tradition. The novelty lies in practical consequences: in postulated disaggregation of the economy and in the treatment of thus specified segments in line with recommended procedures of economic policy aimed at proper utilisation of resources to strengthen the economic competitiveness.

Without questioning the presented assumptions, some questions arise that, in our opinion, are consequential for the practical application of NSE to address Polish developmental challenges. These, in particular, are the following: (a) the notion of endowment, exogenous resources, which determine the structure of modern postindustrial economy, (b) the global context of modernization policy; (c) the role of the state in the implementation of economic policy aimed at the improvement of competitiveness on the global scale.

It is upon these questions that we are going to focus further on. In the final part, we will put forth some conclusions about the scope in which NSE may be useful to Polish modernization programme.

\section{Post-industrial economy endowment}

In the tradition of neoclassical economics, NSE considers three fundamental endowment factors: labour, capital, and natural resources. This implies two important consequences: (a) narrowing of the analysis to the industry; (b) the underrated role of knowledge and culture of the society in the process of catching up with high-income economies.

As a natural consequence of the endowment being specified in this way, the analysis, as well as following policy recommendations, become narrowed to the industry. For NSE, the core of an effective economic policy is to be able to cope with specific challenges faced by specific sectors of the economy.

Of course, this limitation to the industry has its justification, however, it should be remembered that in a high-income economy, the industry is responsible for the generation of no more than one fourth of the national income. Therefore, effects would only have limited importance for the economy as a whole.

During the transition, Poland underwent an abrupt decline of the share of industry in GDP, but still, this share remains at a level of highly developed countries 
with a significant role of the industry (Germany, Japan) and it exceeds the EU-15 average by 5 percentage points.

The competitiveness of Polish industry in the global division of labour depends on the structure of the industry and the place it holds in the value-added chain - whether it is manufacturing plain furniture based on foreign design or producing innovative medicines based upon original and proprietary technologies. This difference is well illustrated by the distance between Poland and Germany (Fig. 1).

Figure 1. Polish industrial production, considering the level of technological sophistication in Poland and Germany (2011)

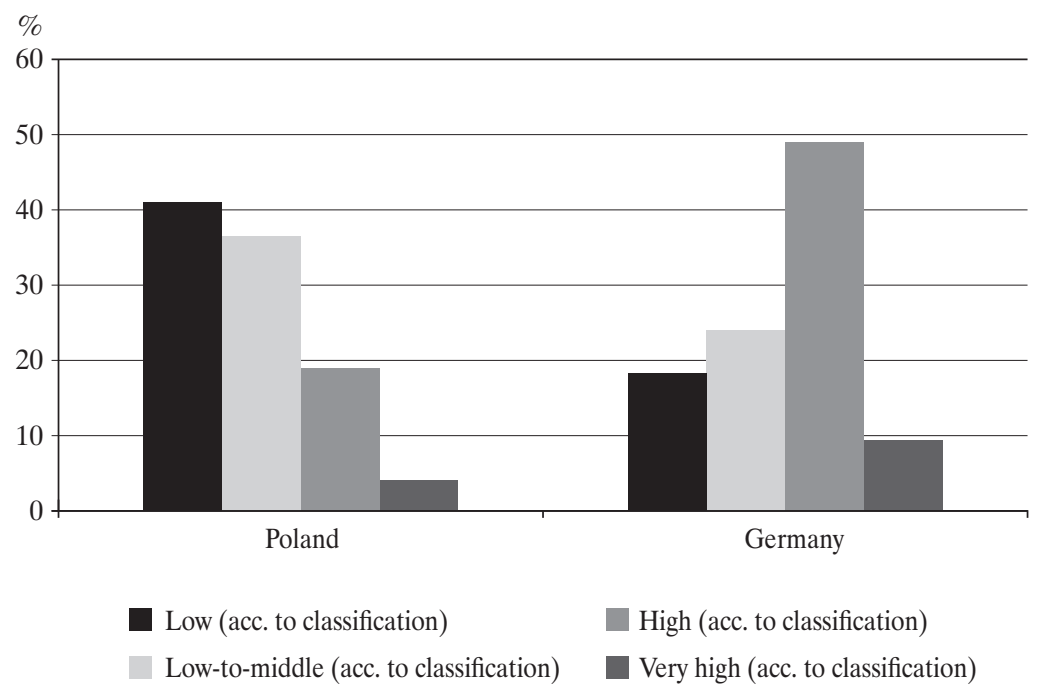

Source: Bukowski, 2014.

The competitiveness of national industry within the global economy depends on two factors: diversification and uniqueness of production. Countries with the high diversification of export and at the same time exporting highly specialised products are, quite naturally, in the best situation - they are winners in the global competition, due to the relatively high diversification of their export offer, generated by a relatively small number of foreign competitors. Such countries have the most competitive structure of the economy in terms of their static advantage over the competitors at any given time, as well as the structure that is most resilient to the fluctuation of global markets (Hausman et al., 2013).

It is no surprise that Germany and the USA have the highest export diversification, combined with the most unique offer. Similarly, it seems quite natural that the export offer of low-income, underdeveloped countries is poorly diversified and consists of simple products whose manufacturing technology is easily transferable. 
In these terms, Poland ranks quite well - export diversification is much better than in many countries which rank higher in competitiveness and development rankings - such as Japan or Canada. Moreover, Poland also ranks quite well, at the level of Sweden, in terms of uniqueness of products it exports (Hausman et al., 2013).

Here, however, the following question should be asked: why, despite good diversification and high uniqueness of export, Polish economy fails to take real advantage of innovativeness as the driving force to improve its global competitive advantage?

The answer to that question should be sought in two areas: (a) the development path taken by Polish economy until now and (b) the available endowment, i.e. availability of factors beyond the neoclassical menu of labour, capital, and natural resources.

Low innovativeness of Polish economy during the transition period should be seen as a particularly paradoxical case. On the one hand, Poland has rightly been admired for impressive dynamics of its economic growth and for profound structural changes carried out to upgrade its economy. Effects of these changes are quite evident, for example as we use banking services, car service stations, private dentists or doctors - they are all at levels comparable to that seen in high-income Western countries. At the same time, Poland performs poorly in rankings regarding expenditures on R\&D and general innovativeness. For example, in the reputable innovativeness ranking of the Global Economic Forum, Poland occupies 49th place - not only trailing all high-income countries but also behind Romania, Moldova, Montenegro, and Lithuania (GEF, 2016).

The growth achieved by producing more of the same, albeit with technological improvements leading to reduced costs, was the dominant development strategy of Polish industry during the transition. The recent 25 years saw significant modernisation in Polish economy in terms of technology and organisation, mostly implemented in companies (both privatised and greenfield) by their new, usually foreign owners. Technological and organisational innovativeness has not originated from Polish inventions or pressure exerted by Polish entrepreneurs to have them implemented. Instead, it occurred in the result of absorption of technologies and organisational solutions generated abroad and brought to Poland by parent companies. Under a typical model of privatisation, foreign owners of privatised enterprises retained highly skilled employees, the market for the product and its brand, and then upgraded the manufacturing process by installing new machinery; streamlined the product concept and improved its marketing and management. That was the process of pushing innovations into the economy. For example, in the market of dairy products old names and tastes of products are often accompanied by new production technologies, along with methods of collecting raw materials and of distribution which reduce costs, including costs of employment.

Foreign companies in Poland have played - and will continue so for the foreseeable future - a significant role in the introduction of innovations to Polish 
economy, both in the capital and non-capital form. Therefore, it is vital to maintain Poland's attractiveness for foreign investments as they provide a major channel of inflow of new products, technologies and organisation and management culture from abroad. This serves well the entire economy, considering that a half of Polish export is generated by companies dominated by foreign capital. The newer technologies are adopted by these companies from high-income countries, the sooner their diffusion onto the entire economy will occur through small and medium-sized enterprises cooperating with exporters. However, one should not only be aware that such a strategy implies further domination of imitative innovation, but also bear in mind that these innovations are not sovereign. In fact, they are installed in Polish production divisions which only execute manufacturing orders placed with them by globally operating parent companies.

Non-sovereign innovations entail two types of risks. Firstly, such innovations may be removed from Poland at any time as production is transferred to other locations, more profitable from a parent company's point of view. Secondly, nonsovereign innovations, usually in the form of imported machinery, do not develop local innovation potential.

In Poland, as in any peripheral country, a serious restriction on "the highest shelf innovation" may reflect the strategy of foreign investors who prefer to place in peripheral countries operations that are technologically less advanced. This attitude results from lower skill levels of labour and from lower costs of externalities than in countries from which the capital originates.

Labour force in Poland may well have (and often actually has) better formal education than in high-income countries, because the attractiveness of working for a foreign company attracts people who are better qualified than really required for a given job. For an investor, however, what really counts is the practical experience which - as the name suggests - is acquired through practice, by years of following the example given by occupation masters and years of participation in a specific occupational team. Such skills are hardly transferable from one country or society to another - and they are only developed in the long run. Then, the requirements of practical knowledge are more easily met in activities which rank lower in the production chain.

In high-income countries, exorbitant environmental standards and requirements of labour code act as a serious reason to transfer some segments of business activities - those which cannot easily meet the norms - to countries willing to accept them under less restrictive conditions. Therefore, localisation is determined by opportunities of externalisation of costs related to meeting the standards. This concerns, to a major extent, "dirty" elements of the manufacturing chain, usually those least penetrated by high technology and least innovative.

The growth achieved through an advancement to higher levels in the product chain is an effective development strategy for open economies participating in the international division of labour. Despite progress recorded in the recent years, it 
is very limited in the case of Poland. The newest and most innovative products and technologies, which determine the competitive advantage, remain under the strictest control of enterprises which produce them. That is why they look with much suspicion at modification proposals put forth by the cooperating partners - the risk of losing the monopoly in the area of product upgrading is often believed to be higher than benefits resulting from an opportunity to reduce costs.

Also, foreign owners are more likely to restrict production high in the value chain in a peripheral country than in the investor's country of origin, when they experience a decline in global demand for a given product. The matter of the so-called nationality of capital - or perhaps of the owners succumbing to political pressures from the countries they originate - has come back in the aftermath of the crisis of 2008. As a result, the structure of the economy becomes less innovative and the pool of well-paid jobs decreases, and in the long run, there are fewer and fewer places where the employees may acquire their practical knowledge and skills which, later, negatively affect the social capability to build the potential of innovativeness.

The broader question regards validity of limiting the modernization policy to industry only. In a developed economy, around three-fourth of GDP is generated beyond industry and agriculture. In the recent decades, one can observe an increasing importance of innovativeness in many fields of broadly understood services. The crucial and ever-present problem of economy - that of generating material objects through utilisation of "knowledge oriented on things" - abruptly loses its relevance. Instead, what becomes increasingly important is "knowledge oriented at another person". Human-oriented knowledge is, quite naturally, more algorithmically ambiguous than knowledge oriented at the generation of things. Moreover, it depends upon a number of immeasurable and contextual "soft" factors, such as local culture.

The economic growth is also accompanied by an increasing participation of the public sector as the area of generation of social wealth. Whereas in economies with per capita income in the range of USD 2,000-5,000 the public sector usually accounts for one fourth of GDP, in economies in which the respective income in the range of USD 5,000-10,000, the public sector is responsible, on the average, for one-third of GDP. This proportion increases even more, up to about a half of GDP, in economies with income exceeding USD 20,000. Boston Consulting Group lists 37 public services available online in various countries. These services relate to such areas as municipal facilities, health care, education, taxes, registration or social benefits (Carrasco and Goss, 2014).

Accordingly, under conditions of the post-industrial economy, to restrict innovation to just products and technologies created by science and implemented by enterprises seems to be an excessive limitation. This excludes significant and growing fields of innovative activities from the scope of policy research and implementation. Indeed, in modern world, an increasing role is played by innovations which are not built around products in the traditional meaning, i.e. those which first require 
a large capital expenditure for research and development, and then for equipment and for employment of the appropriate labour force.

The emergence of the Internet - in itself one of the most important innovations of last decades (and not at all created by the science/industry duo) - broadened the areas of innovativeness and revolutionarily changed the processes of creating innovations. A brand-new type of networked innovations emerged, including social media (e.g. Facebook, LinkedIn, Twitter) or specialised trade and exchange platforms (Allegro, Expedia, Alibaba). Here the entire logic of acquiring a competitive advantage is quite different than in case of traditional product-related innovations. Rather than competing with new functions and utilities, it is based on locking-in certain spheres of social activity. Moreover, network-related innovations do not have to compete with prices as they are available to their users free of charge.

We are witnessing an increasing importance of innovations contained in virtual products and services. As an example of how this type of innovation becomes more and more relevant, one could mention new financial products offered by capital markets over the recent decades. Interestingly, there is much evidence that despite (or perhaps because of) the markets' volumes shrinking, the rush of innovation in financial markets has not wavered at all. If anything, it undergoes some rather radical correction, shifting to social networks and traditional services, such as credit clubs, local currency (private money) or crowd financing.

In our opinion, in the light of the above it is justified to ask about the concept of the very notion of endowment when talking about societies which aspire to join the group of high-income countries and hence build the welfare of their citizens less and less based on growing consumptions of tangible goods, and to an increasing extent upon the availability and high-quality health care, education, social safety or unpolluted environment.

In this context, it seems unjustified to restrict the notion of an endowment to the neoclassical menu of labour, capital, and natural resources. Even natural resources, apparently the easiest to identify, actually are not quite that. For example, the resources of crude oil are not only about their geological identification: it is also about their accessibility following the extraction and their use to achieve social targets. Understood this way, a resource of crude oil depends upon technological factors, but it also does upon security in the region of extraction, corruption, political attitude toward foreign capital and so on. Norway and Venezuela are two countries endowed in abound resources of oil, but the former ranks among the wealthiest countries of the world, whilst people in the latter have to stand in queues for hours to secure some basic goods.

The current debate among economists concerning a country's endowment in resources providing its exogenous fundamentals for growth broadens the scope compared with the neoclassical triad of labour, land, and capital.

Acemoglu and Robinson (2012) associate differences in growth with the issue of institutions - the system of governing and other institutions, including the 
existence of central government, stability of the society, favourable class structure, opportunities for technical education (STEM), regulations protecting the right of ownership, facilitating economic system, advantageous macroeconomic conditions, supportive religion or even war, or rather preparations to wage a war.

Ferguson (2011) analysing historical reasons of Western civilisation success, identifies six principal pre-conditions: (1) market competitiveness; (2) development of sciences; (3) compliance with the right of ownership; (4) development of medicine and of common health care; (5) mass consumption; (6) work ethics.

Hausmann (2013) links the wealth of nations with two crucial factors: (a) migration from countryside and agriculture to cities, and (b) lower fertility which allows parents to ensure better education to their children, who can become more creative in their work over time. However, Hausmann also observes that such changes are not at all automatically translated into success. In fact, statistics reveal it quite clearly that despite some developing countries having already achieved changes in the field of urbanisation and fertility comparable to results recorded in developed countries in the 1960s, still their GDP (in fixed prices) remains lower than that achieved by the latter group at that time. Hausmann explains this by a slow rate of transfer and of assimilation of practical skills "hidden" in the heads of workers.

It is our belief that the endowment in resources which are necessary for sustained ability to innovate - and thereby for development of post-industrial societies - involves all the areas of the social potential: (1) technology - the potential to generate or adapt new solutions, as function of the expenditures on R\&D, education and skills; (2) economy - macroeconomic conditions, private and public capital investments, proper management of risk related to financing the innovation, availability of infrastructure; (3) institutions and regulations - effective and efficiently enforced legal system; (4) cultural capital - values and behavioural patterns, both positive and negative, e.g. the ability to collaborate, to ensure constructive competition, to control corruption, to stimulate social activism, openness, trust.

In post-industrial societies - with their cultural characteristics manifested in competences and institutions (both formal and informal) which regulate the effectiveness of collective collaboration - become a sort of endowments: an "algorithm" of decision-making regarding the use of traditional resources and identification of opportunities to achieve economic growth as they appear. This is so because, both in the industrial production and in services, we are witnessing an increasing share of worker activity which is really less determined by the machine rhythms than it is with "human interplay" (Bell, 1974).

The debate regarding cultural traditionalism, the modernization and growth has been an important axis in the developmental economics. The neo-Marxism regards development limitations experienced by less developed countries as a consequence of appropriation of the global economic space by dominant countries and describes the processes of contemporary development in categories of the centre and the peripheries. On the other hand, the success achieved by the so-called Asian tigers, 
nowadays emulated by the rapid growth of the communist Party of China, shows that in Asia at least, it is possible to have economic growth without previous social transformation along the Western pattern. One additional element which makes this debate even more complex is the processes of globalisation which, in effect of flowing and mixing of ideas, labour and capital, complicates these changes by creating all sorts of development niches, evolving according to various social logics. Globalisation brings unification in some areas, however in others it supports skipping some stages of growth and thus increases the level of divergence among different societies.

The most competent source for the evaluation of culture is provided by the World Value Survey (http://www.worldvaluessurvey.org/wvs.jsp). In constructing the map of cultures, each country participating in the WVS studies was considered in two dimensions: (1) values of attitudes between the traditional and the rational; (2) values between survival and expression of one's needs.

Figure 2 represents the most recent map of cultures available, based upon the WVS research.

Figure 2. Map of cultures

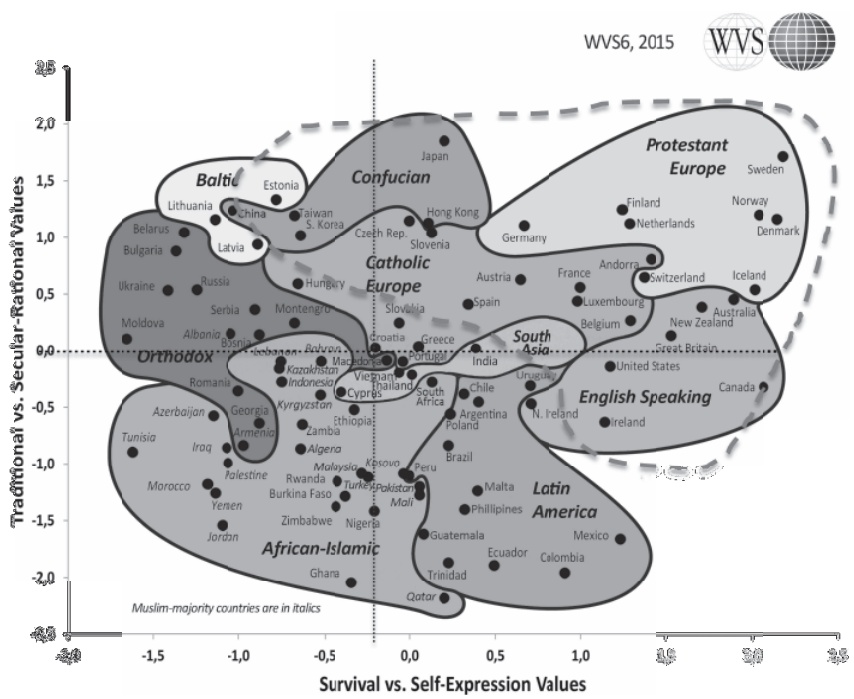

The dashed line delineates the area gathering the countries featuring high ability of innovation.

Source: World Value Survey. Taken from: http://www.worldvaluessurvey.org/WVSContents.jsp.

Precise localization of individual countries on the map should be treated with some reservation, as the names of cultural areas are rather meant to only identify them than provide strict scientific classification. High-income countries, "old" and "new" alike, may be found in various places across the map, depending on how far they went away from traditionalism and how capable they are of self-expression. 
However, there is an evident gravitation of most successful countries toward an upper right segment of the map, with the combination of rational values and selfexpression. In this context, Poland's location is evidently in the "wrong place" of the map given the country's historical experience. On the one hand, we find Poland removed quite far from other countries of Catholic Europe, such as Austria, France, Spain, Hungary or Slovakia. On the other hand, it is also far from other postcommunist countries with which we had shared the brutal attempts at changing our culture by force. In effect, Polish culture, as seen by WVS, is "torn-out" between modernity and traditionalism.

The individual cases of success, but of defeat as well, show that there are no cultural receipts for growth. What we find, however, are cultural limitations. A society whose citizens feel deeply rooted in traditionalist values, while at the same time being focused upon survival-oriented values, with little or no approval for self-expression, are not likely to be innovative. In deeper sense innovations are an expression of being different, and to be able to generate innovations people need to feel free in expressing their opinions and attitudes, even if they are in the minority of the society or in the workplace; even potentially being wrong should not threaten them with social rejection and ostracism.

\section{The global context of modernization policy}

Although the main objective of New Structural Economics is to build a competitive advantage of a country catching-up with leaders, NSE practically overlooks the feedback - the impact the world has on potential domestic choices regarding the economic policy - and its exogenous limitations. Such attitude might be justified in the case of the dominant economic position (sheer scale) of China, and in the case of countries which had managed to catch-up with the high-income countries before the era of globalisation. Nowadays, however, countries that undertake the effort of catching-up, are faced with new limitations which result from global megatrends that seem to dominate the first half of the 21st century: a greatly increased scale of migration, a new stage in the class conflict resulting from the emergence of mobile cognitive elites; and an increasing populism that stems from "new Luddites", related to robotics.

Migration is one great unknown of the development potential of specific countries. Until mid-21st century, the migration potential may increase to between 30 million, and as many as 100 million people ${ }^{2}$. The actual level and directions of immigration will depend upon such factors as long-term armed conflicts, the persistence of

2 It is assessed that by the mid-21st Century the group of population in the 15-39 age group in low income countries (i.e. potentially most open to emigration) will amount to circa 570 million (World Bank, 2009). 
income and wealth gaps between countries, and a deficit of labour in some countries. Without attempting to solve the current dispute to which extent migration is the factor that strengthens and to which it undermines the economic competitiveness of individual countries - it is certainly going to have an increasing importance not only in the area of economic policy but social policy as well (Borjas, 2016).

Among rather unexpected phenomena of the 21st century is the end of "the end of history" and the rebirth of class conflicts. Of course, these are no longer conflicts defined the Marxist way around the conflict between labour and capital about the distribution of the value added. Instead, these are conflicts about the distribution of wealth between the cognitive class and rank-and-file employees: the present ones (the employed), the former ones (the retired), the future (the youth) and the potential ones (social aid beneficiaries).

We witness labour market disintegration into two separate groups. One, much smaller, is formed by cognitive elites - those who generate new and innovative technologies, and - in addition - employees cooperating with new technologies. This group also includes content creators such as authors of games, bloggers, celebrities, professional athletes and so on. Another group, much greater in numbers, is involved in the execution of simple and repetitive work that cannot (as of yet) be replaced by technology. These are types of work in the areas of simple services performed personally by those employed, for example, as waiters, cleaners, hospital personnel or housekeepers or, finally, servicemen to the rich. Additionally, this group also includes a new phenomenon of the working poor - people who are unable to make the living out of their work and hence require assistance from the state. Beyond the labour market, are those who neither have talent or skills to join the first group nor motivation strong enough to find their place in the latter. These people also depend on social aid. The borders between the group of working poor and the group living off the state are fluent and depend on relations between wages earned from work and money obtained from social benefits. Social mobility between these two groups on the one hand, and the cognitive elite, on the other hand keeps decreasing.

We have also witnessed an intensifying debate about the consequences of technological transformations, including, in particular, the impact of robotics and artificial intelligence on the labour market. According to an increasing group of both scholars and business practitioners, new technologies are going to cause a structural decline of demand for labour, even leading to "the end of labour" (Rotman, 2013).

Unlike any previous technological revolutions, the employees ousted by technologies, do not really have "a place to go". Services, a traditional area of new employment, have already achieved the saturation point, and the demand for cognitive work is limited and requires special talents and education anyway.

These trends give rise to a serious threat of populism: either populism in which those who control the resources buy the peace of masses or populism of revolting masses against the elites. Both cases, despite very different sources, are detrimental 
to the economy. Liberal democracy is poorly prepared to solve these types of conflicts: the elites control the resources, but it is the rest of society that dominates the electorate ${ }^{3}$.

\section{The role of state in the implementation of economic policy oriented at increased competitiveness}

The role of the state in creating conditions and stimulating growth has been changing over time - from the period of intensified economic activism of welfare state in decades following the World War 2 (even including central planning and nationalisation of strategic sectors) through the withdrawing of state from the economy (beginning with the Thatcherism period of the 1980s, with its deregulation and privatisation), to returning to the state as an economically active entity beginning with the end of the first decade of the 21st century.

The acceptance of a more active economic policy of the state by the mainstream economics, but also by the IMF and the World Bank, has its direct source in the breakdown of 2008, followed by its market consequences. On a more fundamental level, increasing state activism is related to secular changes in post-industrial societies: growing income of narrow groups of creative workers, accompanied by stagnation or even decrease, in real terms, of the income earned by the middle class; structural unemployment, especially among young people; withdrawal of significant groups from the labour market; disappearing educational effects; worsening of demographic situation as a result of population aging.

Active state policy also originates from the fact that in the quickly changing architecture of the global economy, the ability to achieve and maintain a competitive advantage in international markets becomes increasingly dependent on the innovation potential of a society as a whole, rather than individual enterprises.

The vast majority of nations have an ambition of significantly increasing the role of innovations as the growth factor leading to a higher level of wealth of their citizens. Such ambitions are well reflected in institutions created and programmes adopted. Unfortunately, the number of successful attempts to build strong and sustained innovative potential remains frustratingly small. In many cases, the lack of success happens despite vast public funds involved, provision of financial incentives, and adoption of friendly regulations.

New Structural Economics goes, however, one step further, by assigning the state the role beyond being an important player in the stimulation of growth.

3 Kurt Vonnegut's dystopian novel Piano Player (see: Vonnegut, 1952) becomes not less likely to happen in reality than the optimistic Keynes's utopia of 15 hours long working week (see: Keynes, 1930). 
According to NSE, the state is attributed the role of a builder of a harmonious society (a Confucian hexie shehui); the role of filling the folk's stomach by the enlightened ruler, to revoke Laozi wisdom ${ }^{4}$.

This mandate, but also the state responsibility for "reasonable ruling" finds its symmetrical equivalent in the so-called "Asian values" being declared by the people. This includes putting the social order above individual freedom, recognition of the authority of state leadership, loyalty toward persons standing higher in a family or social hierarchy (Sławiński, 2013). It is hard to say to which extent such a congruence between the rulers and the ruled has reflection, if only approximate, in countries so different in both political and historical terms as Japan, Taiwan, Singapore, Korea or China. It would be even harder, and beyond the scope of this article, to express opinions about sources of such attitudes (see: Sławiński, 2013).

What can, instead, be observed without any profound analysis is that there must be a good reason for over-representation of Far East countries in a rather small group of countries which managed to catch-up with the high-income Western states. This is an indirect proof that an unprecedented development success of the so-called Asian Tigers, and that of China as well, have the same establishing roots (the proof of the pudding is in the eating). Therefore, it can be said that the countries of the Far East are endowed in the peculiar development resource of the state having a long-term acceptance and support of the ruled for the implementation of "the NSE type of receipt", no matter which specific form of government is in power.

Unlike far Eastern cultures, Western and Central Europe (and later its clones) took a different way regarding solving developmental conflicts. In the West, the physical conflict gradually transformed into a symbolical conflict where various stakeholders are involved, through those who politically represent them in combat - with no killing or wounding, but still combat - for the attainment of group interests. ${ }^{5}$

The political framework in which such symbolical conflict takes place is a democracy which, historically, extends its electoral base and therefore increases the number of group interests to be considered.

This shift from direct and physical to representational and symbolical solving the conflicts increases the role of elites understood as groups, either formal or not, which have an influence on decisions that have long-term consequences for the entire societies 6 .

4 "That is why, when a wise man rules, people's hearts and minds are empty and stomachs are full”. See: Laozi, 2015.

5 One of explanations comes from specific nature of rice cultivation which really requires collective efforts (to maintain the system of irrigation operational, which is only practicable with strong central authority, contrary to cereals cultivation for which such central discipline is not indispensable.

6 The notion of "elites" is applied here in purely functional way: elites include people who have significant influence upon life and functioning of the society. The borders of such a pool are rather vague, both in terms of a degree of such influence on the society and in 
The behaviour of elites, rather than the extent of their "enlightenment" or good will, depends on either occurrence or the lack of conditions described by Acemoglu and Robinson (2006) as the "effect of political replacement of elites". The strongest resistance to changes is seen in political systems in which the exchange of ruling elites occurs in a destructive way. How intensely changes are opposed depends on the rents enjoyed by those in power (the higher the rents, the more intensely changes are blocked) as well as on external threats (the more serious the threat, the less determined blocking).

The very mechanism of systematic replacement of elites increases the strategy's chances of success since the changing elites are not afraid to carry on the efforts of those before them, being aware that political cycles tend to go around and the exchange between the rulers and the opposition occurs in a regular way. The practical solution of such strategic stabilisation is the continuity of the bureaucracy capable of handing over the practical know-how to new political decision-makers. In mature democracies, such a mechanism is ensured through the existence of politically uninvolved civil service.

Although in many countries the political system has the outward appearance of democracy, from the point of view of deep mechanisms and structures conducive to growth, the social system has to possess characteristics that D.C. North, J.J. Wallis and B.R. Weingast (2009) describe as the open access order society. At its base, such a society features a "double democracy" understood as non-discriminatory access of all citizens to activities in the economy and in politics.

The advantage of societies with the open access order occurs through their capability of adaptive reaction to changes, both exogenous and endogenous, which occur quite naturally in the normal functioning of the societies. Such societies are not only more effective and dynamic in reacting with innovative actions to challenges they experience, but in many cases, they also show the ability to change threats into sources of their success. Such results are possible thanks to:

- experimenting with various solutions to problems encountered and being able to choose the best solutions for given situation and available resources;

- having diversified and independent feedbacks which allow to evaluate the results of efforts undertaken and to introduce necessary corrections;

- solving conflicts constructively, mainly through compromise and cooperation rather than destruction (actually or symbolically) of the opponent treated as an enemy.

those of specific occupational appurtenance. By the way, this is a dynamic group not only as regards profession or activities of individual persons or channels through which they exert their influence. The increasing complexity of societies and economies, increasing global interdependencies and increasing "virtualisation" of products result in the growth of the elites in sheer numbers as well as their extension to include new segments (for example, cognitive groups or celebrities). 
In political dimension, it means that the opposition can freely contest the government, but it also implies the historically-based experience of exchangeability between the government and the opposition - and hence the sustained division of the elite of a given society into several (often just two) "partial elites" which constructively compete through their programmes for the electoral votes and then alternately assume the roles of the government and the opposition. The economic democracy signifies equal freedom of entry to and exit from any type of business activities for all, irrespective of the political affinities.

Meeting the conditions for the open access order society is more than just declarations and legislation (putting them down on paper) but, first of all, their implementation in effective and achieved in an efficient manner.

During transition period Poland has achieved much progress in joining the elitist club of the open access order societies, however, the technocratic direction of steps undertaken during the last decade on the way towards this type of society ("hot water in the tap") turned to be insufficient, the more so that even such a limited program was implemented rather ineffectively. There is still much to do in the area of improving the social functioning, including, for instance, the system of jurisdiction or that of public procurement. The recent years have also revealed the existence of quite a significant segment of the society which feels excluded from the benefits of transformation, while, at the same time, only learning about democratic standards of public expression and formulation of its interests.

\section{Conclusions. The importance of New Structural Economics for the Strategy for Responsible Development}

New Structural Economics does indeed contain precious ideas worth applying for the implementation of the Strategy for Responsible Development (The Ministry of Development, 2017) but it includes some traps, too.

The NSE's fundamental guideline that is really worth following is to choose one particular model country as an aspirational reference point to Poland's proposed modernization activities. This is quite important, considering that - as we have mentioned and what Lin also emphasises - it is a common mistake to have excessive and misguided ambitions to achieve an inconsistent set of growth objectives (a Christmas tree syndrome). In the case of Poland, Germany fits well as such a natural developmental model. This is justified by economic factors: the gap in per capita GDP (Poland's per capita GDPPPP is 49\%, of Germany's per capita GDPPPP), but also the relations in productivity (46\% GDPPPP per working hour). In both cases, differences are significant enough, but not excessive if considered as target levels over the perspective of some dozen years. Equally important are strong economic relations: as much as $25 \%$ of Polish export goes to Germany; with 
a long-standing tradition of exchange of people and institutional solutions being another significant factor. On the other hand, some serious cultural differences must not be underestimated: indeed, overcoming problems this entails should be assumed as part of the catching-up process.

One NSE's recommendation we consider important is for the "government to identify industries with latent comparative advantages" (Lin, 2012, p. 17). This entails an investment in an entire constellation of analytical centres, both public and private, necessary to implement the programme, to perform its current modifications and to independently evaluate the results. As shown by practice, this is an investment with a high rate of return.

Another crucial element of NSE is to apply a classification of industries depending on their distance to the global technological frontier: (1) catching-up industries, which have less advanced technology and lower value-added than similar industries in higher-income countries; (2) leading-edge industries, which are global technological frontier industries; (3) comparative advantage losing industries, which the country is about to exit due to changes in endowment structure and comparative advantages; (4) industries which have short innovation cycles, allowing a middleincome country to compete directly with high-income countries; and (5) strategic industries, which have no competitive advantages but are developed due to the importance to the national security. This classification enables an efficient allocation of state funds, and using instruments considering specific nature of individual enterprises or industries.

The general strength of NSE comes from its pragmatic attitude. Theoretical fundamentals (which fit within the neo-classical mainstream) are not intended as an intellectual exercise, but actually, lead to practical recommendations regarding instruments of the economic policy, and allow to formulate practical guidelines for particular sectors or even individual enterprises.

From the point of view of Poland's needs, however, NSE also entails a risk of the potential trap as regards the manner in which the state (the government) intends to implement the modernization policy. As we have said before, NSE implicitly assumes non-political nature of the state - the state having a long-term mandate and administrative capacity to implement its strategy, without having to worry about voices contesting its ways and means. Such a scenario, albeit quite attractive from a purely pragmatic point of view of how swiftly changes may be made, hardly reflects the reality in Poland.

As a matter of fact, Poland had witnessed the phenomenon of non-political government at the beginning of the transition process when there was a popular consensus about the direction of desired modernization efforts of building the market economy modelled along Western European patterns. The modernization efforts were consistent, despite government changing over the entire spectrum of political orientations. This time, however, has passed, and will not return. 
In the political culture of democratic dispute, any attempts of shortcuts present a threat to the successful achievement of long-term modernization programmes. Any programme which has no broad acceptance, at least regarding its main objectives, is exposed to the risk of rejection at the moment of change of government. This stems from the fact that in many cases the modernization programme competes for the state funds with needs of other areas of the economy and/or social services. Expressing such preferences, often in a volatile way, is normal practice in democracy - which, however, hardly fits within the logic of NSE.

In Poland, the temptation to ignore the political nature of choices concerning the economic policy is so much stronger that, apart from the traditional area of regulation and legislation, the state also controls a significant pool of the stateowned companies. This sort of regulatory and proprietary combination gives the state the executive power that exceeds the typical scope of state intervention in developed economies. Moreover, this peculiar power may occur counter-productive in the long run as it becomes subject to political interests. Due to these reasons, the Strategy faces a crucial challenge: that of self-control; it is the natural tendency to use the power of the state in imposing particular solutions without gaining the acceptance (or at least comprehension) of the programme addressees, as well as of public opinion and its political representatives.

This problem isn't unknown to mature democracies in well-developed countries where adequate answers are sought for in two areas: the meritocracy and external control. The meritocracy is achieved by the establishment of stable civil service. In Polish conditions, this also includes a selection of managers of the state-owned companies based on merits (i.e. non-political). So far Polish state has proven unable to create satisfactory solutions. The external control means the existence of independent merit-based centres of supervising the Strategy implementation, which quite naturally, will undergo some adaptation resulting from successes and failures, as well as reflecting changing external circumstances.

\section{Bibliography}

Acemoglu, D. and Robinson, J. (2006). Economic Backwardness in Political Perspective. American Political Science Review, 100(1), February.

Acemoglu, D. and Robinson, J. (2012). Why Nations Fail: The Origins of Power, Prosperity, and Poverty. New York: Crown.

Bell, D. (1974). The Coming of Post-Industrial Society: A Venture in Social Forecasting. New York: Heinemann Educational Publishers.

Borjas, G. (2016). We wanted workers: Unraveling the Immigration Narrative. New York: Norton.

Bukowski, M. (2014). Przemyst na peryferiach (Industry in the Peripheries). IRB Presentation. Warsaw: WiseEuropa Institute. 
Carrasco, M. and Goss, P. (2014). Digital Government: Turning the Rhetoric into Reality. bcg. perspectives. Taken from: https://www.bcgperspectives.com/content/articles/public_sector center_consumer_customer_insight_digital_government_turning_rhetoric_into_reality/.

Ferguson, N. (2012). Civilization The West and the Rest. USA: Penguin Books.

GII. (2016). The Global Innovation Index 2016. Winning with Global Innovation. Taken from: https://www.globalinnovationindex.org/.

Hausmann, R. (2013). The Tacit-Knowledge Economy. Project Syndicate, 30 October. Taken from: https://www.project-syndicate.org/commentary/ricardo-hausmann-on-the-mentalsources-of-productivity-growth?barrier =accessreg.

Hausmann, R., Hidalgo, C.A., Bustos, S., Coscia, M., Simoes, A. i Yildirim, M.A. (2013). The Atlas of Economic Complexity: Mapping Paths to Prosperity. MA: Centre for International Development, Harvard University.

Keynes, J.M. (1930). Economic Possibilities for our Grandchildren II. The Nation and Athenaeum, 48(3), 18 October.

Laozi. (2015). Księga Dao I De (Tao Te Ching). Kraków: Jagiellonian University Press.

Lin, J.Y. (2012). New Structural Economics: A Framework for Rethinking Development and Policy. Washington, DC: World Bank Publications. Taken from: https://openknowledge. worldbank.org/handle/10986/19919 License: CC BY 3.0 IGO.

Pierce, A. (2008). The Queen asks why no one saw the credit crunch coming. The Telegraph. 05 Nov 2008,

The Ministry of Development. (2017). Strategia na Rzecz Odpowiedzialnego Rozwoju (The Strategy for Sustained Growth). Taken from: https://www.mr.gov.pl/. 


\section{Macroeconomic conditions for New Structural Economics - the case of Poland}

This article consists of two parts. In part one, the author attempts to place the concept of New Structural Economics (NSE) within the framework of traditional macroeconomic state policy, i.e. within fiscal and monetary policy. Here the crucial problem stems from limitations in the expansiveness of both fiscal and monetary policy from the perspective of their negative impact on inflation rates, as well as from the capacity of the state to fund development-fostering initiatives from other-than-budgetary resources.

Part two attempts, by describing how Polish economy developed over the years 1990-2016, to answer the following question: to what extent and in what scope, the process of such development exploited (either consciously or not) the concept of NSE? Indeed, the industrial policy resulting from that concept could be implemented using the EU's financial aid, the idea of special economic zones (SEZ) and thanks to public capital funds, such as venture capital (PCF).

Keywords: New Structural Economics (NSE), structural economic policy (SEP), monetary policy, fiscal policy, European Union (EU), special economic zones (SEZ), venture capital-based public capital funds (PCF).

Professor Justin Yifu Lin, the author of New Structural Economics (NSE), in his lecture entitled New Structural Economics and Industrial Policy for Catching up Country $^{1}$ emphasises that his concept consists of three following areas:

1) the crucial problem of coexistence of the state and markets in the process of national economies' development;

2) industry-wise directions of structural state intervention, with the original classification of industries (into 5 categories) considered, based upon their place in the process of catching up with higher-income countries' industries;

3) methods of state intervention in individual categories of industries and upon particular stages of the catching-up process.

The first area mainly emerges in the form of opposing NSE to "structuralism" - the trend prevailing over most of the post-war era (during the 1960s and 1970s in particular) and to the ideology of "neoliberalism" which used to be much in

1 The lecture was delivered on 30 January 2017 in Warsaw University Faculty of Management at $1 / 3$, Szturmowa street in Warsaw. 
favour over two most recent decades. However, the state influence upon economic development not only occurs through its impact on the growth of individual industries (for example, through import-restricting or export-stimulating instruments), but also - or perhaps mainly - upon general condition and balance of the economy under the state macroeconomic policy implemented on the level of the Central Bank's monetary policy and the government's fiscal policy.

Neither one of the two above-mentioned economic doctrines has survived. In fact, both were assessed negatively from a political perspective. Admittedly, it wasn't because they failed to bring expected effects in the area of economic development. Rather than that, it was because they also entailed serious crises of macroeconomic imbalance: first, the wave of inflation at the turn of the 1970s and 1980s, and then the global financial crisis of 2008-2009. At present, instead, it seems important that - in line with NSE and contrary to the neoliberal doctrine - the state: (1) on the one hand, involves in running an active economic policy, at the same time being prudent enough not to corrupt or override the markets, and, (2) on the other hand, operates so that the intervention on its part does not imply such consequences as excessive budgetary expenditure, similar to that dictated in the post-war period by expansive fiscal policy.

What is equally important is to keep in mind that economic objectives are not the only ones among state policy objectives - and that, in fact, they might even be subjugated to other social aims. This is especially evident in electoral campaigns in the recent years where political parties' programs tend to underestimate economic problems and to focus much more on such issues as nationalism versus universalism, attitude towards immigrants or emigrants, health care, attitude towards religion or evaluation of historical events. Such criteria, sometimes highly emotional, result in the unprecedented polarisation of opinions, both on the part of politicians and the voting public. Authorities elected in such a process inevitably become a hostage of their respective electorates which may well be quite in opposition to pursuing justified and desirable economic objectives. For example, it seems that, at present, the superior and really prevailing criterion for electing the parties in authority in Europe is their attitude to the European Union - either sceptical or enthusiastic.

According to the NSE concept, the state facilitating and fostering influence upon the economy should be exercised within its industrial policy. Personally, I prefer to use another term here: that of "structural economic policy" (SEP). This type of policy, I reckon, is better described by its attitudes and methods it applies than by its scope and its extent of the operation. The instruments it provides are equally directed to the industry in the narrow meaning, as they are to other areas of the economy, such as services, construction or agriculture ${ }^{2}$.

Both methods and directions of state intervention under NSE mostly result from this concept's neo-classic lineage. “...Economic structure (...) is endogenous to its

2 This, however, may well come down to just a linguistic issue in the Polish language. 
factor endowments - the amounts of capital, labour, and natural resources. (...) The structural economic policy has to facilitate firms' entry to latent comparativeadvantage industries in a competitive market" (Lin, 2017, p. 23-40). This suggests that in this case state intervention must not consist in manipulation with taxes, subsidies, pricing, tariffs or excise tax, as used to be quite common for state interventionism during the era of "structuralism". The argument against it points out that such actions distort signals coming from the market, so that, under such circumstances, it becomes impossible to properly evaluate the level of competitiveness of industries or their comparative advantages. However, state intervention should consist in controlled increasing of access to resources of real, financial and human capital for entrepreneurs operating in latent comparative advantages industries.

Elsewhere in his lecture J.Y. Lin gives an important guideline regarding actions to be undertaken as state intervention. "The latent comparative advantage refers to an industry with low factor costs of production relative to the rest of the world. This is determined by the economy's endowment structure and too high transaction costs (due to poor hard and soft infrastructure) to be competitive in domestic and international markets. Firms will be viable and the sectors competitive once the government helps the firms reduce transaction costs by overcoming coordination and externality issues to improve hard and soft infrastructure" (Lin, 2017, p. 23-40). This sort of declaration alters the priorities for budgetary expenditure and methods of transferring public financial resources to the economy.

In the traditional economy, state budget mainly performs the function of redistribution, redirecting resources acquired from the wealthier so that they reach the poorer (social spending). It also plays general social roles (providing expenditure for national defence, home security, health care, etc.). According to the NSE concept, instead, the development-fostering budget includes, most of all, state spending for development of hard and soft infrastructure which decreases the transaction costs for the economy. This favours preference for investment outlays from the budget to improve hard communication infrastructure which facilitates the accessibility of real capital (roads, sea ports, airports); IT infrastructure (e.g. optical fibre networks, access to quick Internet); energy infrastructure (power plants, transmission networks) as well as for soft infrastructure which improves the quality of human capital - in the form of expenditure for education, research and development. It seems that, from perspective of NSE, budgetary outlays for soft infrastructure might also include spending on health care - the area which undisputedly improves the quality of human capital, spending on national defence which may result in the transfer of modern technologies from that sector to the economy as the whole, as well as spending on home security - the area which consolidates the sense of security - an indispensable factor in business activity.

However, according to the NSE concept, investment outlays play quite a special role in the range of state expenditure. This is because they not only entail a multiplied (consistent with Keynes's multiplier) impact upon global demand but they usually 
also cause some external effects in the form of improvement in living standards of all citizens and decreased transaction costs for businesses.

Still, the scope and directions of financing the economy from budgetary resources have to conform to global - and in the case of European countries, the Community - macroeconomic standards of fiscal policy. At the level of global limitations, I mainly relate here to the environment and climate policy with the $\mathrm{CO}_{2}$ emission restrictions it imposes. While adapting thereto, a state should renounce supporting the industries which, despite having some comparative advantages in the short term, also involve high emissions. And the other way round, a state should support technologies which either reduce or even eliminate the emissions of $\mathrm{CO}_{2}$. Nonetheless, it happens that states undermine negative consequences of such emissions to the climate, thereby temporarily raising the competitiveness of polluting industries.

European fiscal policy standards at the level of national states are mostly related to the following:

- the standard of the maximum deficit to GDP ratio (at 3\% GDP) and the excessive deficit procedure it implies;

- the requirement to obtain the European Commission's approval for individual cases of granting financial aid from public resources to businesses, either state-owned or private;

- the principles of the European policy for strengthening competitiveness and counteracting economy monopolisation.

The budgetary transfer of financial capital to the economy fails to achieve the NSE objectives in a satisfactory and sufficient manner. It seems it would be much more preferable to take advantage of public capital funds such as venture capital, public-and- private partnership (PPP) and special economic zones (SEZ).

Public venture capital funds, unlike private ones, do not necessarily have to keep to the idea of maximising the profit. However, they still should be managed based on economic calculations oriented at the maintenance of the value of capitals. Compared to private funds, this makes them potentially more attractive as an offer to entrepreneurs. Along with providing the financial support, venture capital funds have another strength: they make the assessment of the risk of innovative undertakings more objective and professional on the social scale. No matter which form of financing - whether it is debt capital or equity capital - financing with venture capital funds only has temporary nature. As early as the moment of entry, the funds involved already have the exit strategy in place. In effect, once the public funds are earmarked for such purpose, they may be utilised several times.

On the other hand, the state capital support given to private enterprises entails a risk - or perhaps a temptation to some governments - to proceed with nationalisation or re-nationalisation of the economy. In this case, one principal question has to be answered: is public property inherently less efficient and as 
such, detrimental for the economy? In a situation where it is either the only or the prevailing form of ownership, the answer is yes - this is both quite obvious and historically verified. However, there is no evidence that this has to be the case where it only constitutes some enclaves in a dominant environment of private ownership operating under conditions of the competitive market. Anyway, in case any doubts remain about the efficacy of public ownership, it should be underlined that with the investment of public venture capital funds we have to deal with investing money in a provisional manner, that they are firmly based upon an economic calculation and that rather than resulting in full ownership, they bring co-ownership of public and private capital.

How useful it may be to implement the idea of special economic zones (SEZ) in putting the NSE concept into practice, was already mentioned in J.Y. Lin's article. SEZ manage to provide hard and soft infrastructure propitious for the development of business activity. Moreover, they may also offer tax reliefs, mainly in the area of real estate taxes and corporate income tax (CIT). From the fiscal policy point of view, this implies the necessity to bear investment costs, mostly at the level of regional authorities, and therefore some decrement in the income of both the state budget and local budgets. However, even in a short term, the same becomes compensated by a growth in the number of jobs, which reduces social expenditure borne on the unemployed. Furthermore, this also results in an increased production which in turn raises the level of income on the VAT. Besides, there are significant effects in infrastructure that remain in the long run ${ }^{3}$.

Proper and combined use made of public venture capital funds, public-andprivate partnership, and SEZ enables the state to raise the level of intervention in the economy in a manner consistent with the NSE concept, while at the same time avoiding any serious threat of exceeding the standards of budgetary deficit or those of public aid.

Of course, the government's development-fostering structural economic policy would be more effective under conditions of an expansive fiscal policy run by the same government and of an equally expansive monetary policy run by the central bank. However, facing the threats of inflation, no government and no central bank is able to ensure such a policy mix. Undeniably, an expansive monetary policy may be supportive to the acceleration of growth, but it is not a sufficient factor. For example, an extremely expansive policy, applied by FED and EBC in the years 2008-2016 in the form of quantitative easing, reveals it may provide a remedy and control recession but it does not ensure a sufficient impulse to accelerate economic growth ${ }^{4}$.

3 I am quite positive about this, having served for some time as an advisor to the Minister of Economy for the establishment of SEZ.

4 This is confirmed, among other things, by the statement, presented by the former President of the Managing Board of the National Bank of Poland, Professor Marek Belka, on a conference of the faculties of finance of Polish universities in September 2016: "The central banks' monetary policy is only effective to an extent to which it supports expansive fiscal policy". 
It should also be explained that monetary policy consists of more than just quantitative instruments such as the level of interest rates and the scale of regulation of money supply. Along with that, it has qualitative instruments as well, mainly related with crediting procedures. For example, the supply of money may be regulated by the accessibility of credits through the evaluation of creditworthiness, including the system of credit repayment guarantees. The government's structural economic policy may be supported with the following:

- special procedures for evaluation of the creditworthiness of businesses across the supported industries;

- a system of credit repayment guarantees, applied by public institutions (central government, local governments, the central bank, public guarantee funds and venture capital funds) to businesses in the supported industries.

I would like to end this part of the article with some comparison. As Joan Robinson (1937) presented the dilemma of the role of both fiscal and monetary policies in economic development, she used the following anecdote. She compared the economy to a horse-drawn cart. The cart was meant to be driven by two men, representing fiscal policy and monetary policy, i.e. the Minister of Finance and the President of the Central Bank, respectively. To run their policies, they could use two instruments: a cord and a pole. More specifically, she equipped the Minister of Finance with a cord and seated him at the front of the cart so that he could draw the economy forward, at the same time steering it and thus giving the proper direction to its development. The President of the Central Bank, instead, equipped with the pole, was seated in the back of the vehicle so that he could support the economy whenever the cart found its way upwards, but also to brake it when it gained too much momentum going downwards.

Nowadays and considering the NSE concept, we should change the vehicle in the anecdote and apply more advanced instruments of state intervention. Also, the tandem of the Minister of Finance and the President of the Central Bank should be extended to include the third partner, namely the Minister of Economy. The economy, then, is a car which consists of the body, engine, steering wheel and brakes. The dominant private ownership is the car body. The economy is the engine. The Minister of Finance and the President of the Central Bank are there to control the accelerator and the brake pedal as they apply either expansive or restrictive variants of fiscal and monetary policy. Moreover, the car moves at a speed regulated by provisions of the Highway Code, including, in particular, speed limits - as excessive speed would cause a threat of macroeconomic imbalance crises. Then, there is the Minister of Economy sitting at the wheel and steering the car along the desired direction. The aim of the journey is to accelerate the growth of GDP to match the level achieved in a reference developed high-income country that the vehicle tends to catch up with. Unlike the horse-drawn cart, the car can only drive along proper roads - in this model represented by markets. Any swerve beyond the road 
brings the risk of a crash or, at best, bogging down in the mud. Luckily, the driver is equipped with navigation system - resulting from the NSE principles - which enables him to choose the optimum route leading to the destination and to avoid traffic jams and other obstacles along the way.

Anyway, as described, the model lacks one vital element for the car to start and be able to move on its way: it needs fuel. The fuel, of course, is represented by capital, labour and natural resources. These factors, however, aren't entirely exogenous. The state has a significant influence on their availability and quality. Domestically available capital originates from the propensity to save, revealed by domestic businesses, and from the accessibility of credit which, in turn, depends on the central bank's monetary policy and may also come from abroad. Nonetheless, capital costs money. The price to pay for capital is expressed as its interest rate and in the case of foreign capital, also the transfer of profits abroad. Then, the inflow of foreign capital determines relatively higher interest rates in the absorbing country, which is necessary to increase the attractiveness of foreign investments. Both the availability and the quality of labour resources may be regulated by appropriate types of state policy: concerning demography (e.g. in the form of family benefits); migration (possibility of emigration and immigration); education (at all levels of education: elementary, high and especially academic); and housing (which improves labour resources mobility). Among those factors, the availability of natural resources has most exogenous nature. However, as witnessed in many cases, too easy access to raw materials may have a corruptive influence upon the two former factors of growth.

\section{The growth of Polish economy in perspective of New Structural Economics}

Back in 1990 Polish economy inherited the ownership and industry structure from the former era, 45 years long, of the centrally planned economy and its unrelenting rules. The ownership structure was dominated by state property. One exception was agriculture, the area in which - due to tradition and to the resistance of peasantry - private ownership was retained. This, however, consisted of very fragmented and minor semi-subsistence farms which in fact were a pool of hidden unemployment. The structure of industries by no means reflected the level of competitiveness of domestic industries in international trade. If anything, it rather resulted from the model of complementary cooperation among the Eastern Bloc countries under the Council for Mutual Economic Assistance (COMECON). The principal natural resource was (and still is) black coal which at present presents serious problems in the adaptation of Polish economy to the standards of global climate policy. Alternative energy sources - natural gas and crude oil - were exclusively of Soviet 
origin (nowadays from Russia). To render the country finally independent of those supplies has remained the crucial task for the state energy policy in Poland.

In the early stage of the transformation process, the fundamental issue was to establish and stimulate market-based structures and instruments for the economy and to start the process of ownership changes toward privatisation. In these conditions, industrial policy was overshadowed. The atmosphere of those years is aptly if radically represented by an opinion expressed by one of the first ministers of the industry after the transformation began, Andrzej M. Zawiślak. He said: "The best industry policy is to have no industry policy at all”. Such an ultra-liberalist declaration was quite an obvious abreaction to prevalent state control and manual steering of the centrally-planned economy over the previous socialist period, but it also stemmed from rather naïve faith in markets as omnipotent prime movers. General attitude at that time toward methods of implementation of the state economic policy soon resulted in significant institutional changes. The Ministry of Industry was liquidated and incorporated in the structure of the newly-created Ministry of Economy. In 2015 the Ministry of Economy was renamed as the Ministry of Development and the person performing the function of the Minister of Economy not only combined it with the function of the Minister of Finance but was also appointed the Deputy Prime Minister. Such changes undeniably illustrate the retreat of political authorities from the neoliberal current. It seems now we might expect development-stimulating state intervention within its structural economic policy (SEP).

The above thesis is also confirmed by changes made in the ministry responsible for the transformation of ownership structure within the economy. The initial name of this body - the Ministry of Ownership Transformation - was changed in 1997 to the Ministry of Treasury. This was done at the time when the process of privatisation visibly lost its momentum. The Ministry of Treasury played the role of representative of the state acting as the owner in enterprises of which the State Treasury was a shareholder. However, in 2016 the Ministry was put in liquidation and the ownership-related functions were handed over to other ministries, as appropriate regarding respective scopes of competence - namely, to ministries of development, energy, construction, etc. In my opinion, this has been yet another institutional change which fosters the government's ability to apply the structural economic policy.

The early manifestations of implementation of the structural economic policy were related to opening of the economy which enabled our country to evaluate the level of competitiveness of our industries against the global economy and to attract the inflow of foreign capital.

Polish economy meets the conditions of a small open economy model as formulated by Robert Mundell and Marcus Fleming. As concluded from the impossible triangle hypothesis, in a small open economy it is possible to run the economic policy which achieves two out of three political objectives: liberalisation 
of foreign capital flows and the stability of foreign currencies exchange rates or the independence of the central bank's monetary policy which gives the central bank some influence upon formulation of monetary policy. Out of three potential combinations in pursuing those objectives, in Poland in the years 1990-1997 the variant of control of foreign capital flow, independent monetary policy, and the stable exchange rates were applied, and then, since 1997 and still going, the variant of liberalisation of liberalisation of foreign capital flows, independent monetary policy, and the floating exchange rates.

Restrictions in the flow of foreign capital were related with limited domestic currency convertibility. While domestic entities were given the right to exchange currencies, foreign ones were each time obliged to apply for individual approvals from the National Bank of Poland (NBP). The Bank granted such approvals for direct investments, quite often related to participation of foreign investors in the privatisation of enterprises. This way the state could control the inflow of foreign capital to individual industries. It should be assumed that as they were undertaking investments in Poland, foreign investors properly assessed comparative advantages of industries in which they became involved. Foreign capital was flowing in through foreign investors' participation in the privatisation of state-owned enterprises and in the establishment of subsidiary companies in Poland. The following industries attracted the particular interest of foreign investors: motor car industry (Fiat, Volkswagen, General Motors); household appliances (Miele, Whirlpool, Bosch, Siemens, Electrolux); telecommunications; banking; insurances; financial and accounting centres. Without a doubt, one of the principal reasons for many investors was that of relatively cheap labour, however it could be expected that, at least in some cases, we will have to deal with the effect described by J.Y. Lin (Lin, 2017, p. 23-40) - that of benefits stemming from "latecomer advantage in technological innovation and industrial upgrading".

In my opinion, such an effect has already occurred in banking. The presence of foreign investors in Polish banking sector became visible in 1993. It took the forms of participation of European banks, acting in privatisation of banking sector in the role of strategic investors (in Poland, the ceiling level of such investor's shareholding in stock exchange quoted companies is at $75 \%$ ); establishing their own banking companies in Poland; opening operational branches in Poland - which became possible in 2004 with our country's accession to the EU, according to the European principle of a single banking licence in the EU area. Earlier on, banking was seriously underdeveloped in Poland. It was only since 1990 that two-stage banking sector was created, with commercial banks which simply weren't there in the first place. The level of banking penetration in Polish society was very low, with less than $50 \%$ of the adult population running current accounts in banks. Banking technologies were also obsolete, entirely traditional, i.e. using only paper documents and offering just two types of services: deposits and credits. Foreign investors supplied their companies with new accounting technologies and product 
innovations, such as credit cards, leasing, factoring, private banking and - sometime later and in the area of electronic banking - Internet-based and mobile banking as well. Actually, the entire domestic banking sector was undergoing modernisation under pressure of competition. Quite obviously, crucial elements of banking technologies include skilful and proper risk management regarding all types of risks involved in banking, i.e. credit, liquidity, interest rates, exchange rates and operational risks. In terms of technologies applied and of risks borne, at present, the banking sector in Poland ranks above the average European level. This may be evidenced, among other things, by the fact that it managed to steer clear of the reefs of the international financial crisis of the years 2008-2009 and the European post-2010 financial crisis. One could even go as far as argue that it was some sort of residual technological immaturity that prevented our banks from investing in "toxic securities" that soon became the very source of the crisis.

As a result, no Polish bank was under a serious threat. The same cannot be said about European parent companies of certain banks operating in Poland. Irish AIB was bailed out thanks to public aid and profound restructuring. As part of that, it was obliged to sell its healthy assets, i.e. shares it had in Bank Zachodni WBK SA. These were acquired by Spanish Santander Bank. Belgian KBC was in a similar situation as it had to sell its shares in Polish Kredyt Bank. They were also purchased by Santander Bank which incorporated Polish Kredyt Bank into the structure of Bank Zachodni WBK. The most recent case of the same type happened in 2015 when Italian Unicredit was forced to sell the controlling interest in Poland's second-largest bank - PeKaO SA. In this case, this was bought by Polish insurance company PZU in common with Polish Development Fund (PDF). The transaction was carried out under the state program for returning the ownership in the banking sector into Polish hands. PZU is a company quoted on the Warsaw Stock Exchange with strategic shareholding kept by the state treasury, while PDF is a public fund. Nonetheless, liberals argue that the government hides behind the slogan of "return into Polish hands" to run the policy of re-nationalisation.

The growth of foreign capital inflow was significantly fostered by a change that took place in principles of foreign exchange rates in 1997. Since that time Polish Zloty became a fully convertible currency according to the IMF standards. This way, any entity, either domestic or foreign, may place a selling or buying order for Polish currency in Forex. In Poland, unlike some other countries, such as Baltic states or those that emerged from the disintegration of former Yugoslavia, the policy of floating exchange rates was adopted. It was in that period that foreign portfolio investments started in Poland. Within this category, foreign investors invest in: Polish treasury bonds denominated in PLN (domestically) and denominated in foreign currencies - in global markets, as well as in shares on the Warsaw Stock Exchange (WSE). As a price to pay for floating exchange rates and for liberalisation of foreign capital flows, the rates occurred highly volatile and mainly dependent upon decisions made by foreign investors. The inflow of foreign capital in the period 
between 2005 until August 2008 resulted in Polish Zloty appreciation at 25\% versus EUR and USD, while the capital outflow between September 2008 and March 2009 brought depreciation of Polish national currency at almost $60 \%$.

As mentioned earlier, the structural economic policy (SEP) requires a shift of priorities in state expenditure performed under fiscal policy. The current structure of this spending results to a higher extent from the state social policy and an intention to extend the electoral base than from any real development-fostering aspirations. In 2016, the outlays of the public funds sector amounted to EUR 182 billion which accounted for $41.3 \%$ GDP, while the state budget expenditure achieved a level of EUR 86 billion, thus accounting for $20 \%$ GDP. In the state budget, $40 \%$ of outlays consisted in redistribution operations (over 30\% - benefits and pensions, almost $10 \%$ - social aid); over $11 \%$ for education and about the same for health care. To investments made out of public funds the amount of EUR 15 billion was earmarked, accounting for $8 \%$ of the total public expenditure and 3.3\% GDP. Budgetary outlays on research and development accounted for $0.9 \%$ GDP, with the average in the EU being more than twice that level (Chądzyński and Osiecki, 2017). The state budget deficit was at $2.4 \%$ GDP thus leaving a modest margin before the European ceiling level standard would be achieved at 3\% GDP5. Public debt, at the end of 2016, reached the level of $54.1 \%$ GDP and this is already quite close to that specified in the prudential standards under the Constitution of the Republic of Poland. According to those standards, a government which allows for the public debt to exceed 55\% GDP, should prepare the budget for the subsequent year entirely free of deficit. If instead, public debt exceeds $60 \%$ GDP, such a government should resign and new elections should take place. Therefore, political risk related with exceeding those standards is very serious ${ }^{6}$. Budgetary expenditure is often stiff and results from the need to carry on the government's programs. In these conditions, one should look for other-than-budgetary sources of financing for SEP. As I will

5 Actually, Poland exceeded that standard in 2013, which resulted in the country being subject to the European excessive deficit procedure.

6 In 2014 Poland found itself on the threshold of exceeding the first prudential standard (55\% GDP). This triggered the renouncement of the capital pension system that had been implemented since 1998 in the form of open pension funds (OFE). As a part of obligatory superannuation was supplying that system, this resulted in a serious gap in the repartition system which concerned all the current pensioners. This way the State had to subsidise the system while the open pension funds also invested in the government bonds. In February 2014 the government bonds portfolio amounting to EUR 38 billion was transferred to the State pension fund (PFE) - the move which enabled the government to compensate the value of the public debt by the same amount. As a result, the level of public debt decreased to $50.2 \%$ GDP. Since that time OFE could no longer invest in the government bonds and the contributions made on behalf of the insured were recorded upon their individual accounts in the PFE. Then, since 2017, OFE are going to be transformed into private pension funds (PFE) and for the insured the superannuation's are going to become voluntary. 
attempt to prove, these may include resources obtained from the European Union, in the form of SEZ mentioned earlier and public capital funds.

One milestone in the process of internationalisation of Polish economy and in the implementation of the structural economic policy was put when Poland became a European Union (EU) member state in 2004. Directly following the accession (2004-2006) Polish economy absorbed circa EUR 10 billion. Then the stream of European funds increased significantly over the subsequent years. In the years 2007-2013 businesses in Polish economy obtained, under both domestic and regional operational programmes and under subsidies provided by the Common Agricultural Policy (CAP) as much as EUR 90 billion. At the same time, the sum of Poland's contributions to the EU budget over that period amounted to EUR 22 billion. Therefore, at that time Polish economy was supplied with the net amount of around EUR 68 billion (Cieślak-Wróblewska, 2017). This accounts for $50 \%$ of the total state expenditure in 2015 and about $1.9 \%$ of the average annual GDP over that entire period. This money was invested mainly in elementary infrastructure (especially transport-related) - 60\%; support for the enterprise sector $-23 \%$ and in human resources development $-10 \%$.

The scale of European aid and directions to which it went have significantly supplemented modest spending from the state budget on development-related objectives - according to the NSE concept. So far, this source, very precious for economic upgrading, doesn't seem to vanish. In perspective of the years 2014-2020, under the European cohesion policy, Poland has the amount of EUR 82.5 billion to absorb. It should be hoped that these resources will be utilised in a manner which is even more effective for the acceleration of the economic growth under the Strategy for Responsible Development. Nonetheless, the opportunity to benefit from these exogenous and non-refundable sources of financing should not discourage from creating and involving domestic sources for financing the process of economic upgrading.

Further presence of Poland in the European Union depends upon the crucial decision concerning our country's accession to the euro area. Until 2008 there was a major obstacle in the form of incomplete fulfilment of the Maastricht criteria. At present, the criteria have already been met; however, there is some resistance, mainly of political nature, related with debt crisis suffered by some states belonging to the euro area as well as with the Community crisis concerning the problem of immigration. From the point of view of prospects for future implementation of the structural economic policy, the accession to the euro area seems rather advantageous. The euro area not only means the common currency which eliminates the exchange rate-related risks in trade between member countries - it also means a common monetary policy which, so far at least, was more expansive. It should be assumed the same will hold true in the future, because Poland is going to cease to be a small open economy which attracts foreign investors mainly with relatively higher interest rates, and will become a portion of large European economy which has an influence 
on the exchange rate of its own currency. Moreover, it will also become possible to take advantage of the common budget of the monetary union which will most certainly be formed.

The first special economic zone (SEZ) in Poland was established in 1995 in Mielec. Its creation was supported by advisors who previously used to manage the world's very first SEZ, created in Shannon ${ }^{7}$ (Ireland). By the end of the 1990s, as many as 14 SEZ emerged in Poland and they have remained operational. The total area of land sorted out for the SEZ activities amounted, at the end of 2015, to nearly 20,000 hectares. The original objective in the establishment of SEZ was the economic activation of regions which had been especially seriously affected by bankruptcies or liquidations of former large state-owned enterprises, while the first expected effect of their operation was to reduce unemployment in such regions. The principal privilege given to investors in the zones created is relieving them from some taxes, namely from CIT and from the real estate tax. Besides, SEZ also offer the following: fully prepared investment land available at competitive prices; an opportunity to purchase or to rent the premises existing in the area; know-how and free support from the SEZ manager in the performance of formalities, and so on. Unfortunately, data on macroeconomic effects of SEZ operation are not easily available and fragmented. According to the data presented by Colliers International consulting company, at the end of 2015, the employment in SEZ amounted to almost 300,000 jobs, which accounted for nearly $2 \%$ of Poland's total employment. The accumulated investment outlays in SEZ verged on the level of EUR 28 billion - the sum which, per annum, accounted for between $2 \%$ and $6 \%$ of the total value of investments made and as much as $20-30 \%$ of direct foreign investments. There were mainly foreign investors to invest in SEZ (80\%, including Germany 19\%; the USA $12 \%$; Netherlands $12 \%$ ) with the domestic ones accounting for the remaining $20 \%$. Among foreign investors, the following three were prevalent: GM Manufacturing Poland (USA), Volkswagen Poznań (Germany) and Toyota Manufacturing Poland (Japan) (Colliers International, 2016). Therefore, we may safely argue that SEZ have been and remain an additional magnet to attract foreign investors and act as an accelerator of domestic investments.

Polish Development Fund (PDF) was established in 2016 as a company of the state treasury and of Bank Gospodarstwa Krajowego (BGK). BGK has been the only state-owned commercial bank through which the government has implemented its social programmes in the banking sector (such as scholarships for students or subsidies to the interest on housing credits). The establishment of PDF manifests, among other things, that this bank has been involved in the implementation of the government's programmes in the area of its SEP. Besides, the state treasury has also been a strategic owner in the largest Polish bank, i.e. PKO BP SA and, albeit indirectly, in the second largest one, PeKaO SA.

7 The Author of this article used to cooperate with the advisor as a partner of Polish professional services company. 
PDF carries on and consolidates the activities of such bodies created earlier on as: the Industrial Development Agency (IDA), Export Credit Insurance Corporation Joint Stock Company (KUKE), the Polish Investment and Trade Agency (PITA) and the Polish Agency for Enterprise Development (PAED). These are public funds of the private equity type (IDA) which support innovativeness, entrepreneurship and Polish business entities' export.

PDF's scope of responsibilities includes financing upon commercial principles, collaboration in preparation and distribution of programmes in need of completion; implementation of development programmes adapted to the needs of business environment (enterprises and investors operating in the territory of Poland), of consumers and of the state (bodies of regional governments). However, considering relatively modest equity capital of both PDF and other development-oriented state agencies (PDF's share capital amounts to EUR 0.3 billion) macroeconomic effects of their activities can hardly be expected to be really impressive. PDF's largest investments include participation in the repurchase of PeKaO SA. bank from the Unicredit; investments (announced in 2017) in the financing of start-ups (EUR 0.25 billion) as well as investments in the modernisation of Polish energy industry (EUR 1.2 billion). The activities of PDF and other development-oriented state agencies significantly supplements development-stimulating expenditure from the state budget, but this mainly occurs in the area of small and medium-sized enterprises. Also, the government counts on the joint participation of Chinese capital in the financing of a major project to build a central hub airport near Warsaw, under China's intention to reconstruct the historical Silk Road.

In conclusion to the final part of this article, I would like to quote some facts that manifest the growth experienced by Polish economy over the period of its transformation (Górski, 2015, p. 37). In the years 1993-2015 the average annual rate of economic growth in Poland was at $4.1 \%$. It should be observed that not a single year over that time ended with a negative development rate (recession) being recorded. More specifically, the rates of economic growth oscillated within the range between 7.0 in 1995 and $1 \%$ in 2001. Such rate of economic growth would have enabled Polish economy to double its GDP level over the period of 18 years, and indeed, Polish GDP increased in the entire period under analysis by $153 \%$. The effect of catching up is evident as well. While in 2008 Poland's per capita GDP accounted for $55 \%$ of the average per capita GDP in the European Union, in 2015 this was already at $69 \%$, with 8.9 percentage points out of that being attributed by experts from the NBP to good use made of the Community funds. These estimations do not consider long-term infrastructural effects which will contribute in the future to the reduction of transaction costs. In the ranking of economies featuring the highest GDP Poland ranked 23rd, the effect of it being evident in July 2016 when the Prime Minister of the Polish Government was invited, for the first time ever, to the meeting of the G-20 summit in Hamburg. 


\section{Bibliography}

Chądzyński, M., Osiecki, G. (2017). Nasze bardzo socjalne państwo (Our Very Social State). Dziennik Gazeta Prawna, 25 April.

Cieślak-Wróblewska, A. (2017). Szybszy rozwój dzięki unijnemu wsparciu (Accelerated Growth Thanks to the Community Support). Rzeczpospolita, 25 April.

Colliers International. (2016). Potencjat inwestycyjny. Specjalne Strefy Ekonomiczne w Polsce (Investment Potential. Special Economic Zones in Poland). Taken from: http://www.colliers. com/pl-pl/-/media/files/emea/poland/reports/2016/Colliers_Raport_Specjalne_Strefy_ Ekonomiczne_PL.pdf.

Cukiernik, T. (2007). Prawda i fatsz o dotacjach $z$ EU (What Is True and What Is False About the EU Subsidies). Taken from: http/tomaszcukiernik.pl.

Górski, M. (2015). Makroekonomiczne skutki polityki fiskalnej i monetarnej w Polsce w latach 1992-2015 (Macroeconomic Effects of Fiscal and Monetary Policy in Poland in the Years 1992-2015). In: A.Z. Nowak (ed.), Gospodarka na rozdrożu XXI wiek. Księga jubileuszowa z okazji osiemdziesiatych urodzin Profesora Kazimierza Rycia. Warsaw: Warsaw University, Faculty of Management Press.

Lin, J.Y. (2017). New Structural Economics and Industrial Policies for Catching-up Economies (Nowa Ekonomia Strukturalna dla gospodarek doganiających). In: I.Y. Lin, A.Z. Nowak (eds.), New Structural Economics for less advanced countries (Nowa Ekonomia Strukturalna wobec krajów mniej zaawansowanych). Warsaw: University of Warsaw, Faculty of Management Press.

Robinson, J.V. (1937). Introduction to the Theory of Employment. London: Macmillan.

Wikipedia. (2017). Polski Fundusz Rozwoju. Taken from: https://pl.wikipedia.org/wiki/Polski_ Fundusz_Rozwoju. 


\author{
MICHAŁ KURTYKA
}

\title{
Development of electromobility in Poland in the context of New Structural Economics
}

Until today the economic policy in Poland focused on horizontal elimination of barriers stemming from the inherited burden of an overgrown and ineffective state. It was dominated by processes of deregulation, liberalisation and privatisation. It managed to stimulate the potential of entrepreneurship in Polish society. This achievement, combined with high quality of human capital, brought significant effects: first, under conditions of the process of the country's preparation for membership in the European Union, and then, following the accession, it translated into an impressive economic growth and success achieved by many enterprises. Nowadays, however, the attainment of a higher level of economic growth, and in particular the transition from an effective economy of imitation to the equally effective economy of innovation, requires more advanced instruments to be applied. As learnt from examples of the most competitive economies and industries worldwide, their development in many cases happened in synergy. An active role of the public sector supplemented efforts undertaken in private sector in anticipating trends to emerge and created innovative technologies for it, opened new markets and extended the pioneering market niches.

New Structural Economics provides a conceptual framework needed to supplement the range of instruments of the economic policy in Poland, by adding a sector-specific industrial policy. This policy has to be applied in line with the rules of fair competition and it should support the involvement of market forces. The state on its part should provide favourable conditions to those forces and eliminate barriers - not through subsidising but through support given to private creativity and entrepreneurship.

Popularisation of electric cars provides perspectives for the global revolution in a relatively stable market for manufacturers of motor vehicles. There is much evidence to suggest that in that sector the success enjoyed by Tesla may be evaluated by history as the event comparable in terms of its consequences to the introduction of iPhone for manufacturers of cell phones. In effect, a whole new market will appear, in which previously existing advantages, related with the know-how of the combustion engine, will cease to act as an entry barrier for new players. Poland has quite an extensive industry of subcontractors to motor industry, and it has a considerable pool of competence in areas crucial for the electromobility, including electrical engineering, electronics, and IT. Thanks to pioneering work performed by enterprises manufacturing electric buses, our country also has got skills that favour its involvement in the electromobility revolution. However, for such revolution to really mean success for Polish enterprises and for the entire country, it is essential to have a carefully considered economic policy in place. New Structural Economics provides a relevant reference framework for the re-orientation of Polish economic policy toward new areas and ideas.

Keywords: New Structural Economics, industrial policy, policy of development, electromobility, electric car, Polish industrial policy. 


\section{The outline of Polish economy development until today}

Twenty-five years after regaining its sovereignty, Poland is an open and dynamic economy whose success is anchored in market-fostering institutions and high-quality human capital: considerable entrepreneurship of Polish people and their high level of education.

In early 2017 the unemployment decreased and achieved another record low level of 5.3\% (Eurostat, 2017). Forecasts for 2017 announcing the economic growth at the level of $3.4 \%$ rank Poland in a group of global leaders in terms of growth (World Bank, 2017) and the trade exchange with foreign countries breaks one record after another. The dynamics of export prevails over that of import and in effect, since 2015 , our country records a positive trade balance with foreign countries ${ }^{1}$. The economic indexes keep improving. Since 1990 the GDP per capita increased from USD 1700 to 12,500, thus overshadowing, in terms of growth, not only other European countries but actually all the OECD countries (Cipiur, 2017). During 10 years of membership in the European Union, Poland's GDP doubled, while GDP per capita measured by purchasing power parity accounted for almost $70 \%$ of the EU average level (GUS, 2014).

The level of education is very high and Poland's position in PISA international students skills survey keeps improving (OECD, 2017). Poles also rank among the hardest working nations worldwide. In 2015 a statistical Pole worked for 1963 hours, which ranks our country in 7th place among 38 countries surveyed by OECD (2017). Moreover, they also belong to the most active in Europe in terms of entrepreneurship - as revealed by Gallup's research, almost half of population have taken advantage of self-employment - and they are more eager than other European nations to rely upon this form of work (OECD, 2012). The structure of entrepreneurship is relatively flexible, considering that out of 1.5 million businesses $96 \%$ are micro-firms, compared to the European average of $92 \%$.

A dominant role in Poland's economic policy after 1989 was played by a horizontal type of activities, avoiding prioritisation of any specific industries as catalysers of growth. Liberalisation, privatisation and deregulation were key words. Efforts to counteract the formation of monopolies were undertaken relatively early. Another success was the avoidance of emergence of oligarchy in the economy - something that has been very seriously experienced in Ukraine or Russia but also felt in the Czech Republic (Sopoćko, 2017).

In general, the state was withdrawing from the economy, replaced by a individual initiative and creativity, supported with the adoption of the acquis communautaire -

1 According to preliminary data by GUS (Central Statistical Office), the year 2016 saw an increase of Polish export by $2.3 \%$ (up to EUR 183.6 billion), of import by $0.9 \%$ (up to EUR 178.9 billion) accompanied by further significant increase of a surplus in the trade balance (which more than doubled, growing up to nearly EUR 4.8 billion). See: the Ministry of Development, 2017. 
the process encouraged by the prospects of the accession to the European Union, which actually happened in mid-2004. The state was not attempting to play an active role in promoting any specific industries. Wherever an economic growth occurred, it took place "beside the state" or, in some cases, perhaps even "despite the state" rather than "hand in hand with it". Such an attitude largely stemmed from an enormous overgrowth of the state, developed in the period between 1945-1989, but also from the philosophy adopted, which reckoned the state as one of the principal barriers to the economic growth to blossom.

Transformation and intensive processes of privatisation in the early 1990s led to a quick and often painful transfer of productive potential from less to more productive industries, or even a complete disappearance of entire unviable sectors. After the collapse of the early 1990s, near the end of that decade, the proportions of GDP generation turned around: from the domination of the public sector to domination of ownership and production in the private sector.

As shown by Orłowski (2010), the TFP (Total Factor Productivity) should be regarded the key to understanding the economic success of Poland and the entire Central and Eastern European region. "The fundamental fact about the economic growth of Central and Eastern European countries during the period of the New Growth [i.e. 1990-2007] was its relying on a growth of productivity and efficiency in utilisation of production factors. A supplementary factor was given in the form of increased - largely through the inflow of foreign investments - capital outlays, while the increase of work inputs only played a marginal role in the growth of production" (Orłowski, 2010, p. 171). Neither capital nor labour increased significantly, but the existing resources were used better, which was favoured by systemic changes. In other words, the potential of previously passive simple reserves was skilfully applied and accompanied by the provision of a market-enhancing legal framework. Possibilities were created to run various forms of business activity; better communication reduced costs of logistics; liberalisation and deregulation of many sectors helped to open new markets, etc. Then there were some stand-alone events - such as the accession to the European Union and the access - fully achieved since 2004 - to the single market and the three other freedoms.

\section{Challenges for Poland's economic policy and New Structural Economics}

In thus described context, we are at present confronted in Poland with the following questions:

- can the success of the initial twenty-five years of transformation serve as a convincing argument that the subsequent period is going to be equally successful? 
- is the same set of measures as those that enabled the achievement of the economic growth of the country after 1989 going to work in the future?

- is further economic growth "beside the state" going to suffice in the long run to catch up with the developed countries?

- can/should the state be an instrument of the economic policy that adds value?

Any country seriously thinking about achieving a top economic position on the global scale, has to take the ability of its economy to generate innovation into account. In Poland, however, the fundamental problem in the present situation is that we've witnessed virtually no change at all in terms of key parameters regarding innovativeness of Polish economy. Despite the amount of money ${ }^{2}-$ significant in proportion to the country's budget - allocated to the areas of innovation and scientific research over the last 10 years, not a single Polish specialty was successfully promoted and no breakthrough was achieved in any industry having global range. Then, the funds spent on research and development activity remain modest, both in relative and absolute terms and do not exceed 1\% of GDP. In the innovativeness rankings prepared by Eurostat in 2012, Poland was 24th out of 27 countries. Three years later this inferior place remained the same, this time among 28 countries. The situation concerning Polish universities is hardly better, considering that none has achieved any significant progress in the global rankings. The number of patents has not changed significantly, either.

As pointed out by P. Koryś (2015), Poland has achieved considerable success in terms of growth of industrialisation, both when compared to neighbouring countries and against the background of historical examples of other European and Asian countries. The period since 1989 saw an impressive increase of industrialisation in Poland, far superior to other Central European economies comparable in terms of their starting points. The market value-added in the industry increased almost 5 times, compared to 4 times in the Czech Republic, with both countries ranking far above the rest, such as Slovakia, Hungary or Romania. The difference is even greater if the reference point is set in the year 1970, which is more representative of the historical situation of Poland: in this case, we have recorded the growth verging on 8 times, compared to 3.3 times in the Czech Republic. All this was accompanied by an improvement of human capital in the industry.

However, despite all this success, the levels of productiveness still resemble some peripheral countries more than the innovative core of Europe.

Polish enterprises do not allocate sufficient funds to research and development activities. Then, even the funds actually dedicated to that purpose are largely used to achieve an improvement in sectors with no potential to yield any technological breakthrough in the world's most advanced industries anyway. Most money is spent on business services and only $40 \%$ of the outlays on innovation goes to

2 Over PLN 30 billion only by the National Centre for Research and Development, not including budgets of universities, research institutes and other science-supporting institutions. 
enterprises having high or medium-high levels of technology - compared to nearly $80 \%$ in Germany and $70 \%$ in Finland. This way, not only the level of expenditure remains insufficient in absolute terms, but also the structure of outlays hardly encourages optimism about their prospects to really contribute to economic transformation.

It seems that in many industries Polish enterprises have indeed achieved the global level. However, these individual cases aren't enough to make us conclude that we've witnessed any systemic breakthrough. As Orłowski (2015) puts it: "While sometimes it happens otherwise, generally, Polish enterprises situate in the middle of the value generation chain: they are focused on manufacturing, making products at a medium level of technological advancement and either deliver the same to those who sell them under their own brand or sell them on their own, but as generic products" (Orłowski, 2015, p. 161). This results in a risk that the "situation described may become routine, thus preventing the firms from any further expansion and discouraging them from efforts to raise their innovativeness. This way, it becomes impossible for a country to build its brands, to increase wages and to catch up with its wealthier neighbours" (Orłowski, 2015, p. 162). This sums up to such a country falling in a middle-income trap.

The development of most advanced industries in Poland happened along with the above-mentioned logic "beside the state". The state never supported them and the industries involved never seemed to expect anything good therefrom. Perceived as little effective at best, or as harmful and overwhelming with its sluggishness in the worst case, the state really had no instruments to attract the entrepreneurs and make them change their minds.

Today there is no distinguished economic brand "Poland" to help the exportoriented efforts of Polish firms. As shown by examples of Switzerland, Germany or the United States, the image of the state may also act as quite a significant lever to support its businesses. Moreover, some states are readily associated with particular industries and their products, even if, in some cases, such associations are little more than stereotypes. For example, Swiss quality - watches; German reliability - cars; American dream - show business and the digital revolution. Polish firms rarely proved capable of developing really recognisable brands in the world, mostly being content with the role of subcontractors or manufacturers of generic goods. Should they, however, be supported with the recognisable and positive brand of the state, they probably could occur significantly more effective in developing their own identity in the global markets.

Therefore, on the path toward the economic success, at least three following challenges are going to become crucial at the subsequent stage of economic transformation to avoid falling in the middle-income trap:

- to increase not only the scale but most of all the productivity of the outlays allocated to research and development; 
- to enable proper commercialisation of innovations created, doing it under proprietary brands, thus advancing to a higher level in the global value-added generation chain;

- to support individual efforts of businesses with consistent communication of the state as the whole.

Before we answer these challenges, it should be emphasised that a good economic policy needs not to impose any alternatives: instead, it should enable conjunction. Transparent institutions, simple regulations, consolidation of systemic fundaments of the economy are essential conditions of economic success. As rightly pointed out by D. Acemoglu and J.A. Robinson (2013) in their splendid book, that long-standing economic success originates from the combination of mechanisms which support the involvement, on equal rights, of all citizens in the economic life - referred to as inclusive institutions - with an individual historical path of any given country. The success which fosters the entrepreneurship stimulates innovation, leaves room for creative destruction, avoids preservation of the past and enables replacement of old industries with new ones. The success which avoids privileging of any specific social group by giving it some advantages, the defence of which might then involve a pursuit after political rent. As also shown by Olson (1987), any small and wellorganised group is ever going to be more effective in lobbying for its interests, and in consequence, it may dominate the model of growth by locking the country for long periods - in its own interest - within a trap of unused potential.

Certainly, there is room in Polish economy for further reduction of transaction costs, both in hard infrastructure and in the field of quality of institutions. To achieve this, it is essential to reform the courts, to cure the problem of bureaucratic stiffness and to increase legal certainty in running any business activity. Further improvement of transport infrastructure, including inland waters and intermodal transport, and modernisation of the railway network, are challenges already identified and supported with the funds from the European Union. Any excessive stratification may occur as counter-productive; therefore, it is necessary to constantly smooth out any social or territorial inequalities which might act as barriers to the achievement of the optimum level of economic growth.

However, the scope of further systemic and horizontal changes, as significant as it is, still cannot answer the fundamental challenges related with the decisive leap from a country being an effective manufacturer to a country of innovative success. Also, it would be unreasonable to expect another breakthrough to happen, whose positive effects to the economy would be comparable to the effect of the accession to the European Union.

Furthermore, an extension of the market, whatever it is, leads to the redefinition of what is the centre and what are peripheries. Any integration brings with itself the challenge of retaining the consistence of the entire space. For a country like Poland, not to undertake efforts now, aiming at closing the gap in development between 
Poland and wealthier Western European countries, may translate, in the long run, into a negative spiral of a fixed peripheral model. The lack of growth prospects and the middle-income trap will discourage even the most talented and businesslike from investing their future in the country which fails to give them fair opportunity to express their talents. In consequence, such people will emigrate to countries situated in the centre. The outflow of over 1 million young people makes one of the most painful side effects of Poland's accession to the European Union. If this is going to continue, peripheral status is going to become a self-fulfilling prophecy.

It seems that New Structural Economics, defined by Justin Yifu Lin (2017), provides the good theoretical basis for reflection about the evolution of Polish economic policy. It may supplement the above-mentioned horizontal and institutional measures, but it may just as well stimulate to a new and fresh perspective about the role the state plays in the economy. Through focusing efforts on promotion of industries with latent competitive advantages, it is possible to raise a country onto another level of economic growth.

In my opinion, therefore, an answer to the three above-mentioned challenges is in the supplementation of the economic policy applied by the state with sector-specific component and focusing on those industries which may combine the existence of latent competitive advantages with significant advantages related to their own development. It is essential to indicate specific objectives, since, as put by Chorowski (2016), "Historical experiences and the experiences of the contemporary countries-leaders of innovativeness suggest that the modern edge is achieved through an appropriate definition of the strategic objectives for the state, requiring new technologies, and then provision of conditions for their achievement. Strategic objectives should consider geopolitical conditions, technological potential, natural resources and the needs of neighbouring countries". These objectives could be pursued by some specific industries, aiming at the achievement of some pre-defined advantage or result.

Relating once more to the challenges listed at the beginning of this fragment, prioritising some specific industry in the economic policy makes it possible to:

- focus research and development outlays upon some specific objective, and in perspective to increase their productivity;

- stimulate the advancement of domestic enterprises within the global value-added generation chain, where the most effective pioneers are going to create a globally recognised image (brand), supporting, over time, also emancipation and development of their subcontractors;

- and, as a further result, through the snowball effect and thanks to an active promotional policy applied by the state, it may become possible to achieve synergy between the country image and competitiveness of that chosen industry.

In my opinion, one of the most interesting, most future-oriented and promising options for Poland is the development of an electric car and the creation of the electromobility industry as a new sector having serious global prospects. 


\section{Electric cars and the electromobility industry in Poland - why?}

Arguments for undertaking the project of an electric car may be divided into three groups. Firstly, there are arguments indicating that this is the industry which has latent competitive advantages. Secondly, that it may become a quickly developing sector of the future, so it might be worth focusing the efforts and means to stimulate it. Thirdly, that its development is going to positively influence the country's entire economic and political situation. It is a fortunate and perhaps exceptional coincidence that an electric car combines all three above-mentioned groups of arguments - the fact described in more detail for the first time in the book entitled New Electricity and New Cars, co-written by the Author together with Leszek Jesień (Jesień and Kurtyka, 2016).

The vast majority of components needed for the production of electric cars in Poland is already in place. There are over 1000 domestic subcontractors and co-operators of the traditional motor car industry. Over 100 thousand employees generate export at a level of almost EUR 20 billion. The annual production of passenger cars amounts to 522 thousand, of delivery vans and special purpose cars 122 thousand, of buses 5.5 thousand. The latter segment is especially interesting from the point of view of the creation of electromobility industry. In fact, Poland has become one of Europe's leading centres of bus production. Volvo and Man relocated their production here and then there is also a group of Polish manufacturers, such as Solaris, Ursus, Autosan or Solbus. Polish manufacturers of buses relatively early chose the path of electrification and public transport perfectly meets the conditions of an early shift from diesel engines to electric machines. First Polish enterprises operating on the global scale are already there, manufacturing electrified means of transport, such as the above-mentioned Solaris in Greater Poland, having 10\% share in the German market for some years already, or Bydgoszcz-based Pesa. It was, in particular, the pioneering involvement of Solaris in the early 2000s in the development of electromobility that contributed to the title of the European bus of 2017 being awarded to its Urbino electric model. These companies were soon followed by an entire manufacturing chain specialised in the production and supply of components and infrastructure for electric buses (see: http://www.me.gov.pl/ node/26719).

It should be added that Poland also has traditionally well-developed electric machinery industry and high level of electric engineering skills, essential for the emergence of the electromobility industry in the future. As we learn from the example given by Tesla, the electric car also managed to focus the attention of manufacturers of software and hardware ("computers on four wheels") - and Poland, as a country having very well-developed IT competences, may provide solid backing for its growth.

At the same time, however, there is not a single significant domestic car manufacturer operating in Poland. This argument, paradoxically perhaps, may 
advocate the creation of a new industry of electric cars, because there are no burdens from the past and no sunk costs which would relate domestic enterprises with the know-how of traditional combustion engine. Indeed, the vast pool of knowledge and engineering skills, accumulated in the latter technology for well over the past 100 years, act as a serious challenge for German manufacturers in the motor industry. For them, the too hasty shift from existing to new technologies would involve considerable costs. For Polish businesses, instead, to involve in the electromobility means opening of the entire "blue ocean": a new perspective with fewer natural competitors than in the case of the "red ocean", i.e. traditional motor industry.

Then, there is much evidence to suggest that the electromobility is going to become a quickly growing industry of the future. As foreseen by Bloomberg, among others, by 2040 every fourth car in the world will be battery-driven, which opens perspectives for a market of 500 million vehicles. According to a more conservative forecast by the International Energy Agency, in 2030 there will be at least 150 million such vehicles on the roads.

Out of ten most innovative enterprises worldwide, three others also involved in projects related to the development of electric cars (Apple, Google, Tesla), which seems a good sign about future popularisation and development of this type of cars and technologies.

The electric car is much simpler in production and maintenance than conventional vehicle driven by a combustion engine. It is produced out of around 1000 parts, compared to around 3500 in the case of a conventional car. Due to its less complex construction, it is also less prone - by c. $20 \%$ - to defects, which should translate into its attractiveness to users.

Finally, the popularisation of electric cars also means a considerable and multifaceted opportunity for Polish society and economy.

Electric car and the development of infrastructure related therewith constitute both an opportunity and an impulse for the upgrading of Polish electricity and power systems and the possibility of productive use of the so-called night valley. Thanks to its potential of storing the energy, an electric car may contribute significantly to the stabilisation of the energy systems in the future, when European systems will be dominated by instable sources, such as the wind and solar farms. Then, it also increases the opportunities for raising the profitability of conventional sources of energy, considering the potential of unused power generation in night hours (night valley). The achievement of the level of 1 million electric cars ${ }^{3}$ with the timeline of 2025 - the level that would now account for $5 \%$ of the total number of cars in Poland - enables to store around $10 \%$ of national daily energy consumption and to increase the production of electric power by 4-5 TWh.

3 For the sake of comparison, in Poland there are around 2.5 million cars fuelled by LPG, which makes it one of the largest fleets in Europe and in the world - and stems exclusively from stable fiscal regulations which favour this type of fuel compared to traditional petrol and diesel. 
Electrification of transport gradually leads to reduced dependency upon the import of mineral oil - and potentially eliminates this dependency altogether. In the years 2000-2015 Poland was spending, on a yearly average, 2.15\% of its GDP to import mineral oil. This sum burdens the foreign trade balance of Polish economy, whereas electrification of transport will allow retaining some of these funds in the country.

Very importantly, electric vehicles reduce the environmental impact of transport and contribute to improved quality of life in cities. In Polish conditions, an enormous significance of electric cars stems from their potential of radical improvement of the quality of air in agglomerations, in which cars are the source of up to $60 \%$ of pollution (Warsaw). Cities suffering from highest level of air pollution (such as Kraków, Warsaw, and Silesian agglomeration) have already shown their interest in the popularisation of this category of vehicles. Moreover, electric car as supplementation of public transport (as shown, for example, by Autolib in Paris) may also be regarded as a method to alleviate the problem of parking, thus matching the new trend of more occasional use of private passenger cars.

From the point of view of consistence of economic policy, focusing efforts upon popularisation of electric vehicles gives a clear signal for business players, which:

- gives an impulse for the development of an entire sector in motor industry and favours an intensive growth of subcontractors, also becoming an opportunity for them to build their own brands and create new cooperation networks;

- enables focusing the R\&D efforts on future-oriented technologies, including energy storing, controlling transport networks (including self-driving cars) and automation of manufacturing processes;

- enables channelling of public investments undertaken by local and central authorities: construction of power distribution networks and electric cars charging stations; purchase of cars and buses for municipal transport and for own use of public authorities - as a step to be followed, thus starting the movement of a flywheel of the project development; support for auxiliary projects around the central one, including creation of a network of co-operators and industrial clusters, centres of innovation and start-up incubators; propagation of the idea of electric transport.

Summing up, electric car and the development of the electromobility industry is a project which may enable Poland to make a crucial leap onto a new level of technological development, advance the existing subcontractors of motor industry onto a higher level in the value-added generation chain, and perhaps even enter the market of mass produced cars without the intermediate stage of manufacturing traditional combustion engine-driven cars. All this opens the opportunities to skip an entire stage in the development of technologies and to overtake traditional producers and manufacturing centres specialised in the previous generation engines - considering how costly it is for them to give it up and that for them to develop and 
promote the new standard sums up to a sort of cannibalisation of their own pools of competence and markets.

Considering how an electric car becomes an icon of modernity in many countries, a combination of technological innovation and true care for the environment, it may become really representative for a new stage of transformation and reindustrialisation of Poland in the spirit of innovativeness. Then, proprietary passenger car brands are also an element of national pride and the country's image, thus translating into its effective promotion abroad.

\section{The electromobility development programme as sector-specific policy}

In effect of a diagnosis carried out, the government adopted the Electromobility Development Plan (www.me.gov.pl) for implementation. The plan assumes comprehensive coordination of efforts aimed at the development of the electromobility industry and popularisation of electric vehicles in Poland, under an overall programme. Its objectives include: (1) popularisation of electric vehicles and the achievement of the level of 1 million of them by 2025; (2) extension of Polish electromobility industry, and (3) preparation of electric power supply network to meet the demand for power which will result from the need to charge electric vehicles, in particular in city centres.

The involvement of all the government's agencies in the coordination of work has been planned, along with the establishment of the Electromobility Programme Steering Committee. The programme implementation focuses around five areas of action: industry, market, acceptance, infrastructure, regulation.

As already mentioned, the programme's key assumptions include the stimulation of production of electric vehicles and their components with a high percentage of value added generated in Poland, accompanied by the promotion of Polish manufacturers as a positive side effect. Accordingly, it is planned to prepare and implement a comprehensive electromobility ecosystem: from research and implementing activities, through the development of cooperation networks, to creation and popularisation of innovative transport models and construction of factories to manufacture the vehicles and their principal components.

Another very important element of the programme is the need to gradually stimulate the demand for electric vehicles in Poland. In this context, it is crucial to properly dispense and coordinate the financial support. This effort should be accompanied by the provision of benefits for electric cars users - in fact, both aspects are of pivotal importance. Specific instruments to achieve this may include the release from the excise tax, earmarking funds for subsidies through the establishment of dedicated Low-Emission Transport Fund, introduction of increased depreciation allowances, introduction of low-emission zones in cities, introduction 
of the minimum quota for electric buses in municipal transport systems and for electric vehicles in municipal and administration fleets.

To build social acceptance for electric vehicles and to promote electromobility is certainly essential for the whole project to have chances of success. In this context, the key role is played by the population of big agglomerations - people for whom a small electric city car fits well into the profile of their needs (an average user covers the distance of just over 14 miles per day). Such a car should also provide the answer to problems of noise and emissions in cities and perfectly suit the role of the second car in a family. Still, it is necessary to develop dedicated pilot programmes - educational and promotional at the same time - for the electromobility. The achievement of social acceptance for electric vehicles is also an opportunity to promote cooperation between science, business, administration and local authorities.

To build infrastructure and to create the market for electric vehicles recharging are essential conditions for the programme to succeed. In its initial stage is it necessary to have the state involvement in the construction of the charging infrastructure as this will ensure the credibility of the electric vehicle as a viable alternative to conventional combustion engine cars which still retain the advantage of bigger autonomy and shorter time needed to refuel. Following that first stage, it is assumed that further priorities will include the attraction of demand for electric vehicles which is going to drive the development of infrastructure to avoid misplaced charging stations and misallocated public funds. It will also be necessary to disseminate the practice of providing charging facilities for electric vehicles in the existing and newlyconstructed buildings, including the enactment of new building standards.

Development of transport based on electric vehicles requires comprehensive legislative adaptations. It is necessary to adapt the energy, building and environmental law. Legal framework will be provided for the creation of the market of charging the cars and other potential accompanying activities, with gradual narrowing of the state role to the limitation of redundant overlapping in market operators' activities. Another necessary condition is to stimulate initiatives in the area of financing, both systemic and in terms of pilot programmes.

The implementation of the Electromobility Development Plan is scheduled to happen over three stages, distinguished by the level of market development and the resulting intensity and scope of the state involvement in its stimulation.

The first, preparatory stage started in 2017 and will last until 2018. It will include the implementation of, among other things, pilot programmes which will direct social interest onto electromobility and provide conditions for the development of electromobility on the regulatory side. Incentives for local authorities will be strengthened to encourage them to prepare concepts for the development of public transport, including gradual electrification of mass road transport, both public and individual.

In stage two (2019-2020), the infrastructure for charging electric vehicles will be constructed in main agglomerations and incentives will be intensified to 
purchase electric vehicles, the latter properly correlated with a level of development of the electromobility industry. It is also expected to commercialise the findings collected in the research of electromobility started during stage one and to start the implementation of new business models for popularisation of electric vehicles.

It is assumed that by stage three (2020-2025) the growing popularity of electric vehicles in households and in public transport will lead to the creation of the lifestyle trend making the environmental transport much in a fashion which, quite naturally, will stimulate the demand even further. The charging infrastructure, installed by that time, will act as an additional demand-fostering factor. It is planned that the network will be completely ready for supplying energy for 1 million electric vehicles and adapted to use these vehicles as means of stabilisation of the electric power systems. Bodies of public administration will use electric vehicles in their fleets. Polish industry will produce high-quality components for the need of the electromobility sector and electric vehicles registered in Poland will feature a high percentage of components manufactured domestically.

Of course, to choose and prioritise some specific industries rather than other ones always involves some risk. Firstly, the very choice may miss the point. A country - contrary to the initial diagnosis - may occur not to possess the sufficient potential in a given industry. Or, alternatively, its development may happen at a quicker rate than in other countries, thus resulting in the level of competitive advantage achieved being relatively lower than others - or may even fail to justify the efforts invested.

Secondly, any concentration of public involvement upon some specific objective and narrow group entails some political risk. Privileging some products - and therefore their producers - may encourage them to cater for political rent to permanently take over the fruits of the developmental policy, securing them to narrow groups of interest. Also, any potential failure of the project may bring negative consequences to its political promoters, including sanctions expressed by the electorate through their votes.

Thirdly and finally - but perhaps most importantly as well - any diagnosis, no matter how right it is, is never enough to fully determine the efficacy of an economic policy. As indicated by A.Z. Nowak (2017), Poland already saw at least three attempts to define a comprehensive concept of economic development. In two cases out of three, despite the relative consistency of the postulates put forth, the attempt to set them in practice in specific implementation instruments failed. Indeed, steering the processes of growth demands, very tight and consistent coordination of efforts of many government agencies over a sufficiently long-time perspective.

Nonetheless, in the area as capacious as popularisation of electric transport, it seems there are more than enough arguments in favour of public involvement. Benefits are multi-faceted, the horizon of their emergence highly diversified and even if they fail to achieve their full potential in every area or quick enough, they are still going to be very significant. 


\section{Summary - electromobility as prospective industry and the opportunity for releasing the country from the middle-income trap}

Twenty-five years after the outset of political and economic transformation in Poland it is time to analyse the sources of success achieved and failures suffered so far. There is much evidence to suggest that the model of the economic development occurring until now was based on gradual withdrawal of the state from the economy. This was justified by two parallel phenomena - of weakness and of overgrowth of centrally-planned economy prevailing until 1989. This was also an effect of the philosophy adopted, rather reluctant to look up to the state while seeking potential for increasing the value, as well as of global trends favouring liberalisation and deregulation, at that time prevalent also in the European Union.

Raising the quality of market institutions and extending their inclusive character should certainly be seen as fundaments for Poland's further economic success. However, examples of the world's most advanced economies suggest that a broadlyunderstood state may bring a considerable contribution to the success of those industries which generate relatively highest value added. After all, we would not have witnessed man's landing on the Moon, the launch of the Internet, the phenomenon of the Silicon Valley, or that of cellular telephony and the iPhone, unless there was an active role played by the state in the economy (Mazzucato, 2016). Poland's further economic growth, and in particular the challenge of breaking through the "glass roof" of the imitative economy (no matter how impressively productive) and of transforming into the economy capable of creating new ideas and then their global commercialisation, demands the state's involvement in the development of specific, prospective industries.

Development of electromobility industry may occur for Poland one of such prospective and promising industries, which will help the country to deliver itself from the middle-income trap. Through concentration of forces that the state has under its control, including the funds for research, development, innovativeness, and their allocation to some specific purpose, even resources that are relatively modest on the global scale, may bring the desired effect of creating an innovative and competitive industry. Thanks to mutual dependencies between electric transport and electric supply industry, an electric car may become the lever for development of many new business models and technologies, such as energy storage or autonomous transport.

Popularisation of electric vehicles in the country, as one of the conditions for the development of the electromobility industry, is not going to be possible without the active involvement of the state. In the regulatory area, it is necessary to define the new market and to provide conditions favouring the pioneers so that they can test new solutions. It is also essential to create an adequate infrastructure for charging 
electric vehicles to show the electromobility as a viable and legitimate alternative, ready for general use. Through its involvement, the state should make it possible to overcome the "egg or hen" dilemma, because there must be a sufficient level of infrastructure in place for electric vehicles to become really commonplace, but unless they do, the underused infrastructure brings a threat of failure of the whole undertaking. Considering how great this challenge is, there aren't many entities powerful enough (such as Tesla is in the United States or, on a smaller scale, Autolib in Paris) that are capable of meeting both challenges at the same time - i.e. to produce the cars and to build the infrastructure for charging their batteries. Admittedly, even in these two cases, it wouldn't be possible to achieve success without the active participation of the public sphere.

In effect, electromobility is a good example of the potential of synergy occurring between private and public sectors. It may also play a pioneering role and serve as testing ground for the re-formulation of methods of running the economic policy - from oriented onto horizontal and systemic support towards one focused upon some specific effect and selected industry. Finally, with the promotion of the country in mind, and to achieve its identification with particular industries, the development of electromobility may be attractive for a country like Poland and to many already existing Polish enterprises.

\section{Bibliography}

Acemoglu, D. and Robinson, J.A. (2013). Why Nations Fail. The Origins Of Power, Prosperity and Poverty. CPI Group, Croydon.

Bank Światowy (World Bank). (2017). Bank Światowy: polska gospodarka przyspiesza (World Bank: Polish Economy Accelerates). Press release, 20 April. Taken from: http://www. worldbank.org/pl/news/press-release/2017/04/20/poland-economic-growth-acceleratessays-world-bank.

Chorowski, M. (2016). Modernizacje. Polski projekt (Modernisations. Polish Project). Teologia Polityczna Co Tydzień, 23. Taken from: http://www.teologiapolityczna.pl/maciej-chorowskiczy-plan-na-rzecz-odpowiedzialnego-rozwoju-moze-stac-sie-zaczynem-innowacyjnejgospodarki-w-polsce-tpct-23-.

Cipiur, J. (2017). Polska z największym w OECD i Europie wzrostem PKB na mieszkańca (Poland: OECD's and Europe's Largest Growth of per capita Income). Obserwator Finansowy, 22 March. Taken from: https:/www.obserwatorfinansowy.pl/tematyka/ makroekonomia/polska-z-najwiekszym-w-oecd-i-europie-wzrostem-pkb-na-glowemieszkanca/.

Eurostat. (2017). Taken from: http://ec.europa.eu/eurostat/web/main.

GUS (Central Statistical Office of Poland. (2014). Polska w Unii Europejskiej 2004-2014 (Poland in the European Union 2004-2014). Warsaw: GUS.

Jesień, L. and Kurtyka, M. (2016). New Electricity And New Cars. Warsaw: CeDeWu Press. 
Koryś, P. (2015). Zatrudnienie w Polsce 2014. Praca czasu innowacji. Polska uprzemystowiona na nowo (Employment in Poland 2014. Working at the Time of Innovation. Poland reindustrialised). Presentation delivered in the Faculty of Economic Sciences, University of Warsaw, 16 November. Warsaw: The Institute for Economic Studies at Warsaw. Taken from: http://wise-europa.eu/wp-content/uploads/2016/04/ZWP-2014-cz-II.pdf.

Lin, J.Y. (2017). New Structural Economics and Industrial Policies for Catching-up Economies (Nowa Ekonomia Strukturalna dla gospodarek doganiających). In: I.Y. Lin, A.Z. Nowak (eds.), New Structural Economics for less advanced countries (Nowa Ekonomia Strukturalna wobec krajów mniej zaawansowanych). Warsaw: University of Warsaw, Faculty of Management Press.

Mazzucato, M. (2016). Przedsiębiorcze państwo (Entrepreneurial State). Warsaw: Wydawnictwo Ekonomiczne Hetorodox.

The Ministry of Development. (2017). Handel zagraniczny Polski w 2016 r. (Poland's Foreign Trade in 2016). Warsaw: The Ministry of Development. Taken from: https://www.mr.gov. $\mathrm{pl} /$ strony/aktualnosci/handel-zagraniczny-polski-w-2016-r/.

Nowak, A.Z. (2017). New Structural Economics and dilemmas of the economic development (Nowa Ekonomia Strukturalna a dylematy rozwoju gospodarki). In: I.Y. Lin, A.Z. Nowak (eds.), New Structural Economics for less advanced countries (Nowa Ekonomia Strukturalna wobec krajów mniej zaawansowanych). Warsaw: University of Warsaw, Faculty of Management Press.

OECD. (2012). Mate i średnie przedsiębiorstwa oraz polityka przedsiębiorczości w Polsce. Przeglad OECD (Small and Medium-sized Enterprises and the Policy of Entrepreneurship in Poland). Warsaw: OECD and the Ministry of Economy. OECD. (2017). Taken from: https://data.oecd.org/poland.htm.

Olson, M. (1987). Logique de l'action collective. Paris: PUF.

Orłowski, W. (2010). W pogoni za straconym czasem. Wzrost gospodarczy w Europie Środkowo-Wschodniej w latach 1950-2030 (In Pursuit of Lost Time. Economic Growth in Central and Eastern Europe in the years 1950-2030). Warsaw: PWE.

Orłowski, W. (2015). Czy Polska dogoni Niemcy (Will Poland Catch-up with Germany?). Warsaw: PWN.

Sopoćko, A. (2017). Comparative Advantage. A Condition or a Process? (Przewaga komparatywna. Stan czy proces). In: I.Y. Lin, A.Z. Nowak (eds.), New Structural Economics for less advanced countries (Nowa Ekonomia Strukturalna wobec krajów mniej zaawansowanych). Warsaw: University of Warsaw, Faculty of Management Press. 
GRZEGORZ TCHOREK

\title{
Selected development concepts and New Structural Economics. Conclusions for electromobility in Poland ${ }^{1}$
}

\begin{abstract}
The vast pool of economic thought gathers together a great variety of theories, concepts and empirical research findings applied to answer the question about factors that determine the growth and success achieved by economies. New Structural Economics (NSE) refers to the output of growth and convergence theories and institutional economics, and integrates macro- and microeconomic approaches present in many other inquiries, to offer promising recommendations for an economy at any stage of development.

It is not the intention of this article to engage in a direct discussion with the assumptions of New Structural Economics. Instead, its aim is to indicate it as a proposal which is complementary to several other concepts, including those of the middle-income trap, of the investment development path and of the diversification curve. Conclusions from these currents of thought were then used to evaluate prospects for development of the electromobility market in Poland in the context of public efforts undertaken, which made it one of the priorities of the economic policy.
\end{abstract}

Keywords: New Structural Economics, middle-income trap, diversification, FDI, electromobility.

\section{Introduction}

The problem with using the output of economic thought to solve practical dilemmas faced by economic policy often comes down to the fact that, in their inquiries, economists come to a point where they restrict themselves to only give some recommendations about "what to do". Only in very rare cases do they go a step further and consider the problem "how to actually implement" the solutions proposed and which difficulties this might involve. Such an approach results from a sort of concentration - functional, institutional and scientific - within narrow specialisations, as evidenced by relatively limited knowledge exchange between

1 This article was written under the research project implemented in the Faculty of Management, University of Warsaw, entitled Export competitiveness of automotive industry and the development of electromobility in Poland. 
disciplines, even as closely related to each other as international business and international trade ${ }^{2}$.

According to the approach which recommends "what to do", it is assumed that the last stage of implementation of recommendations regarding growth stimulation is under the responsibility of the economic policy which should be run by the government and institutions cooperating with it. NSE, drawing inspiration from the earlier output of economic thought, emphasises the crucial - and very refined at the same time - role played by the government in formulating the macroeconomic policy and in fostering the country's evolution in the process of growth. NSE is rather precise in pointing out the instruments which may be used to effectively implement the economic policy (including the provision of information about market trends, searching for market leaders and market niches, acceleration of businesses as well as concentration and cooperation in clusters, economic zones and industrial parks, etc.).

The purpose of this article, in its first part, is to concisely present three relatively new approaches to factors of growth and to the evolution that occurs within economic structures such as GDP per capita increases and to compare them with the assumptions behind NSE. The three approaches include the middle-income trap, the investment development path, and the export diversification curve. Whereas it may be argued that these concepts lack any solid theoretic fundament and that their very choice may seem arbitrary, still there is one important thing they have in common. Namely, they all discuss the conditions for the evolution of an economy over time and in comparison to other countries.

Part two of this article attempts to consider the development potential of the electromobility market in Poland, in the context of the three concepts in question. The automotive industry has long traditions in Poland. At present, although highly concentrated in the hands of foreign investors in terms of the production and export volume, it still should be seen as a vast pool of accumulated knowledge, competence, and diversification of a number of domestic entities with their

2 Considering the assumptions of international business, it was already since the 1970s that the role of transaction costs, productivity and size of companies as well as internal resources in overcoming barriers to internationalisation was emphasised. The so-called "new" new trade theory led economists dealing with international trade to similar conclusions only after the early 2000s. Until that time the trade theory had assumed that it was countries that were involved in trade and competition among themselves, while the new approach shifted toward the assumption - as natural and obvious in international business - that it is enterprises that do it. At the same time, enterprises are very diversified in many aspects and in terms of resources. In effect, only few of them achieve the position which enables them to internationalise. However, such a perspective could become common in the studies on trade only at the time when it became possible to do the research basing on the data relating to individual companies. Even then, by the way, general conclusions formulated on the basis of the "new" trade theory are not substantially different from those put forth in the managerial approach two or three decades earlier. 
respective localisation-related advantages. At the same time, efforts undertaken on the part of the government administration for development of electromobility encourage a reflection and assessment of the perspectives this market has in Poland.

\section{Evolutionary concepts of the approach to economy and NSE}

\subsection{The middle-income trap}

The notion of the middle-income trap, also existing under other similar names, raises some controversies among economists. According to some of them, this is little more than a catchy name given to problems and dilemmas experienced by the economics of growth and development since, really, quite long ago (more in Wojtyna, 2016, p. 5-22).

In the economic debate, the notion of middle-income trap was popularised by I.S. Gill and H. Kharas (2007). They suggest that the middle-income economies may find themselves trapped between low-income economies which compete with cheap labour and high-income economies whose competitive advantages come from innovative industries. The scope of this notion also encompasses such proposals as the "imitation trap" (Agénor et al., 2012) or the "non-convergence trap" (Aghion and Howitt, 2009).

As pointed out by A. Wojtyna (2016), Gill and Kharas (2015) presented a summary of the discussion concerning the notion of the trap, and distinguished its three following broad meanings:

- a misdiagnosis in defining the strategy for a country's development which reflects the structural features of its economy; persistence with a development strategy based on export of labour-intensive industrial goods despite the loss of competitive advantage as a result of growing wages; and an attempt to make a premature leap towards the knowledge-based economy despite the lack of essential institutional infrastructure;

- a long period during which a country remains locked within one particular range of GDP per capita;

- a loss of momentum of the convergence process in relation to a specific high-income country.

The debate concerning the notion of trap revolves around factors which bring a threat for a country to fall in the trap and around the level of GDP per capita at which this may happen. Usually, this level is expressed as intervals and proposals presented in this context in literature confirm that the trap is defined rather broadly. It seems more adequate to compare the GDP per capita of a country to that of another high-income country. Agénor et al. (2012) define the trap interval 
in relation to the USA, assuming that this is between 5 and $45 \%$ of the USA's GDP per capita ${ }^{3}$.

The following may act as factors conducive to being caught in a trap: poor human and physical capital endowment (inadequate infrastructure), unfavourable institutional and regulatory environment, domination of sectors with weak links to other sectors and high share of low-processed goods, low export openness and poor economic diversification, population aging, excessively high rate of investments, undervalued currency exchange rate, decreasing rates of return on capital and depletion of imitation and low labour costs advantages, lack of mechanisms for proper allocation of talents and skills, lack of access to financing (Eichengreen, 2011; Felipe et al., 2012; Agénor, 2016).

NSE proposes several types of actions which may either prevent or reduce the risk of falling into the middle-income trap (Lin, 2012):

1) through identifying and supporting of the latent comparative advantage industries - as they may give more dynamics to the country's economic growth. The government and its bodies should actively assist in this effort of detection;

2) through an active role played by the government as animator, coordinator and, where appropriate, organiser of the market - to reduce transaction costs involved in business activity. Accordingly, the government should take proper care about the quality of soft infrastructure (including human capital, with knowledge, experience and skills known as tacit knowledge) as well as hard infrastructure (e.g. transport network in the form of roads, telecommunications network etc.);

3) through pragmatic government intervention in market-based mechanisms. This should take place in line with the laws of the free market, but at the same time, provide conditions for healthy competition and cooperation. This way, the government becomes the player that shapes the market not only on the side of regulatory impulses (mainly on the supply side) but on the demand side, too.

In the context of market animation (but also stimulation of knowledge transfer from the incoming FDI), NSE postulates instruments that were also recommended at an earlier time, such as supporting intelligent specialisations and regional innovation systems, reducing transaction costs, ensuring the proximity of business entities to agglomerations, building relations between various sectors and actors, including between enterprises and science (Girma et al., 2015, p. 157-169). The instruments it recommends include economic zones, industrial parks, industrial clusters, and more.

While one might reckon that, in terms of GDP per capita, the Polish economy has entered the area of risk of falling into the trap, it should be remembered that countries may experience a long-lasting slowdown of their growth also at a much

3 For example, Eichengreen (2011) suggests the range between 10,000 and 11,000 and later on Eichengreen et al. (2013) propose another range of GDP per capita between 15,000 and 16,000 (1990 according to PPP). 
higher GDP per capita (Japan, Italy) ${ }^{4}$ (see Figure 1 ). This means that in the process of identification of the risk of the trap, the set of factors conducive to it may be more important than the sheer level of income at which the trap actually snaps shut. Indeed, economies at any level of development may be at the threat of colliding with the "glass ceiling". The Polish economy might have made a significant civilisation leap over more than a quarter century of transformation and in the recent years its economic growth might have distinguished itself positively compared to other EU member states, but still a threat of some kind of slowdown in the convergence process remains real. To overcome it, a country should reveal an ability to generate its own specialties and to internationalise them with an increasing share of domestic added value.

Figure 1. GDP per capita in selected countries (USD, fixed prices)

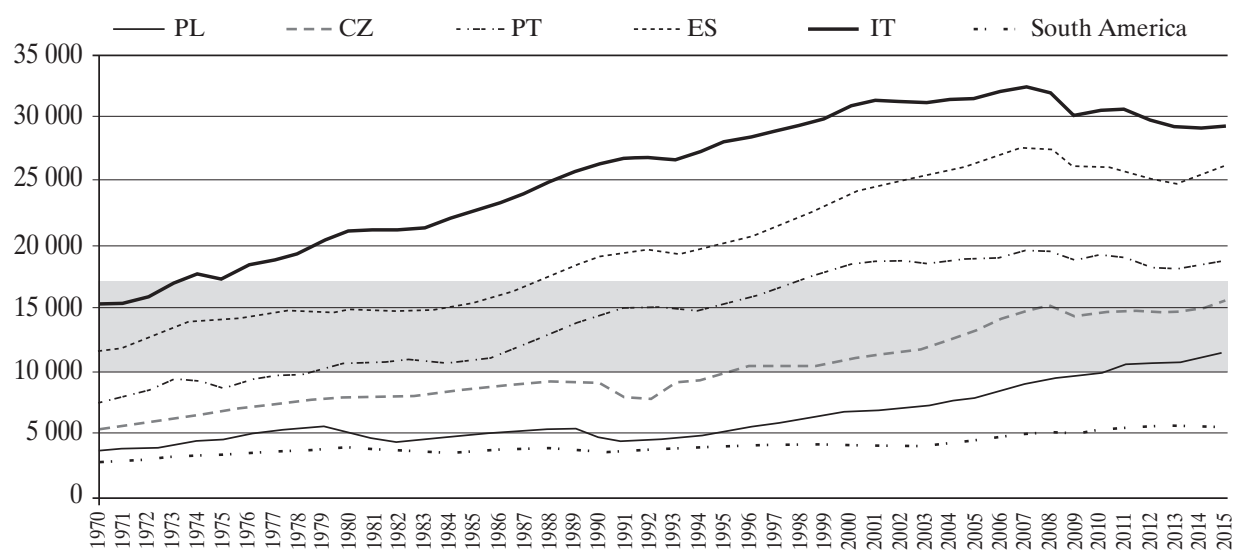

A potential trap was defined, for the illustrative purposes, in the interval between USD 10,000 and 17,000

Source: Authors' own elaboration based on data from the World Bank (15.05.2017).

4 One frequently quoted comparison of economies which managed to avoid the trap is included in Agenor, Canuto and Jelenic (2012, p. 1-7). It points out that, out of 101 countries with middle income economies (per capita income in 1960), only 13 managed to advance to the group of high income countries in 2008. Then, while this could suggest that only countries that were extremely efficient in their macroeconomic policy actually achieved success, a closer analysis of individual countries leads to a little different conclusions from the comparison. The successful thirteen in question include Equatorial Guinea, Greece, Hong Kong, Ireland, Japan, Mauritius, Portugal, Puerto Rico, South Korea, Singapore, Spain, Taiwan and China. However, at least a couple of them are tax havens: Mauritius and Singapore, although Ireland could also be ranked in that category (actually, Hong Kong, too). Then, Greece and Puerto Rico were countries which reached the verge of bankruptcy during the financial crisis. Finally, among the EU members Portugal is another country which can hardly be regarded as a good quality model of its macroeconomic policy over the recent decades. All this confirms that even where a country managed to achieve some economic growth in the past, this is hardly any guarantee for the same to happen in the future. 


\subsection{The investment development path}

The Investment Development Path (IDP) assumes direct relations between development measured by the GDP per capita and the net result in terms of net FDI position (Gammeltoft and Kokko, 2013, p. 1-20). The evolution of a country's position, together with an increasing GDP per capita, results from the ability of companies to gather assets, both tangible and intangible, and to get involved in foreign expansion in its most advanced form - that of FDI.

According to the assumptions behind the IDP concept, countries move through several stages in their development. At stage one, mainly relevant to the most underdeveloped countries, the inflow of FDI - and its outflow in particular - is marginal, due to the lack of competitive advantages in such countries and to their institutional shortages. At stage two, the inflow of FDI increases in effect of the country's improving attractiveness to investors. Because of FDI inflow, the net position usually deteriorates. On the other hand, this stage tends to bring favourable spill-over effects in the form of transfer of knowledge from the incoming FDI, which in turn improves the competitiveness of local companies and stimulates subsequent outflow of foreign investments. This, however, happens on condition that relevant absorptive capacities are created, as well as the dynamic capabilities to enable absorption based on high (improving) quality of production factors (more in Meliciani and Tchorek, 2017; Tchorek, 2016, p. 201-212). Stage three usually brings the turning point: while the net position in terms of accumulated FDI is negative, the outflows of FDI may actually exceed the inflows, thanks to increasing competitiveness of domestic firms. This stage indicates higher specialisation in the area of high value-added products. In effect, domestic firms begin to develop their own advantages. In stage four, the net position is already positive, because the outflow of FDI is greater than their inflow. By the way, the level of their technological sophistication also increases. Finally, in stage five, which occurs only in the most developed countries, the net position oscillates but is already close to zero.

According to the Investment Development Path, it is necessary to have an ability to move upwards the value chain in the sector as the country's income increases. One of the key factors in the GDP growth is the accumulation of foreign investments, while the national potential of expansion and export of capital is developed at the same thanks to them.

M. Gorynia, J. Nowak and R. Wolniak (2010, p. 5-26), who analysed IDP for six countries of Central and Eastern Europe (countries of the Visegrad Group known as V4 plus Bulgaria and Romania), classified the V4 countries as undergoing stage two. These authors indicate that the Polish economy may be nearest to the point of entry into stage three, despite the fact of Poland being the least developed among V4. J. Klich (2014, p. 19-31) observed, basing on data relating to the period until the end of 2012, that Poland, the Czech Republic, and Slovakia had already entered stage three and that Hungary had achieved the same even earlier. 
In the context of internationalisation, on which the investment development path focuses, NSE postulates substitution of imports with domestic production and attributes an important role to trade openness as a channel of competitiveness and convergence. Then, it also suggests attraction of FDI in industries in which latent comparative advantages were identified and building of the capacity of domestic capital expansion onto foreign markets (Lin, 2012).

\subsection{Economy diversification curve}

As one considers the process of a country's evolution in terms of GDP growth over time, an important role is played by the diversification curve of the economy and exports. Literature suggests that as the GDP per capita level increases so does the economy's product diversification. Later, the process slows down and after exceeding a certain level of development, the decreasing dynamics of diversification is replaced by product re-specialisation. The process may be illustrated by an inverted U curve, which presents the relationship between the level of GDP per capita and product diversification, measured, in most cases, with a number of exported products (see Figure 2).

Figure 2. GDP per capita and the number of export products (left) compared to GDP per capita and Theil index (right)
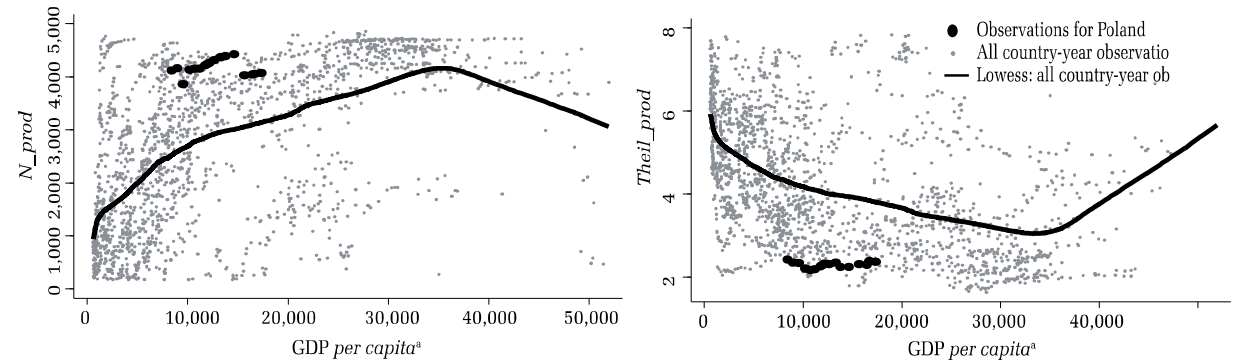

Source: Parteka, 2013.

This relationship, while contrary to what intuition suggests, was actually confirmed by many empirical studies on samples including countries very different in terms of development levels, and using different research methods. The precursors of this approach, J. Imbs and R. Wacziarg (2003, p. 63-86), indicate, on a sample of 99 countries, a U-shaped relationship between the GDP per capita and a level of concentration (which is the opposite of diversification). In a similar way, B. Klinger and D. Lederman (2006) confirm the same relationship on a sample of 130 countries. Furthermore, the research reveals an important role of such factors as the size of the economy and the raw materials endowment in the process of diversification 
- both potentially influencing it. Nonetheless, all this confirms a general tendency defined by the diversification curve - first, levels of diversification increase together with the GDP growth, and then the process of re-specialisation takes over ${ }^{5}$.

Changes in the number of exported products in the selected group of countries, illustrated in Figure 3, also suggest that such a relationship exists. Within a group of developed countries, reduced numbers of product lines are usually observed over the period of recent twenty years, whilst in a group of developing countries, the respective numbers grow.

Figure 3. The number of exported products in selected countries (all products)

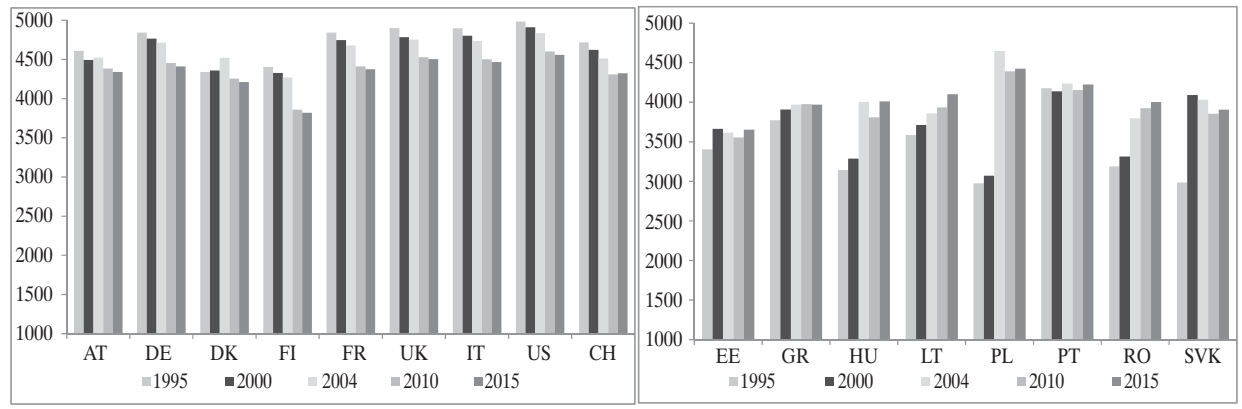

Source: Authors' own elaboration based on WITS data (15.05.2017).

While an increasing product specialisation may be regarded as a market-based process stimulated by the focus upon the most profitable products and segments of the value chain, still this process gives rise to some doubt among economists. They quite often call for a greater deal of intervention in that process, due to risks stemming from increasing specialisation. They also encourage efforts to increase diversification in the economy. Even the private sector may be an area of improper investment decisions and from the systemic point of view, misallocation of resources affects resilience of the economy negatively, especially during shocks. Therefore, one of the crucial postulates put forth by NSE is to raise the care taken in the state policy for diversification in the economy through the skilful use of the industrial policy. Product diversification should be accompanied by a growing level of national value added in export and favourable positioning of enterprises in value chains (through incoming and outgoing FDI).

5 Empirical studies for Central and Eastern Europe based upon an analysis of diversification levels in countries of the region in the years 1993-2000 revealed that the turning point may occur at the value of GDP per capita of USD 25,000 (Funke and Ruhwedel, 2005 p. 25-50). In Parteka's study (2013), the inflection point of the curve was marked, for a group of 163 countries, at the GDP per capita value verging on USD 35,000. 
As one observes changes occurring in the Polish export, it becomes clear that it does follow the path of product diversification. Poland is a country which has experienced an increase in the number of products exported, especially after the accession to the EU, which was, among other things, related to the appearance of new agricultural and food products in international trade. In terms of the number of products offered, Poland is at a level comparable to well-developed countries (see Figure 4). On the other hand, however, the level of technological advancement of the Polish production and export is, in many cases, inferior to the competition from the Czech Republic and Hungary.

Figure 4. Diversification of markets and products

(products whose annual export value exceeds USD 10,000)

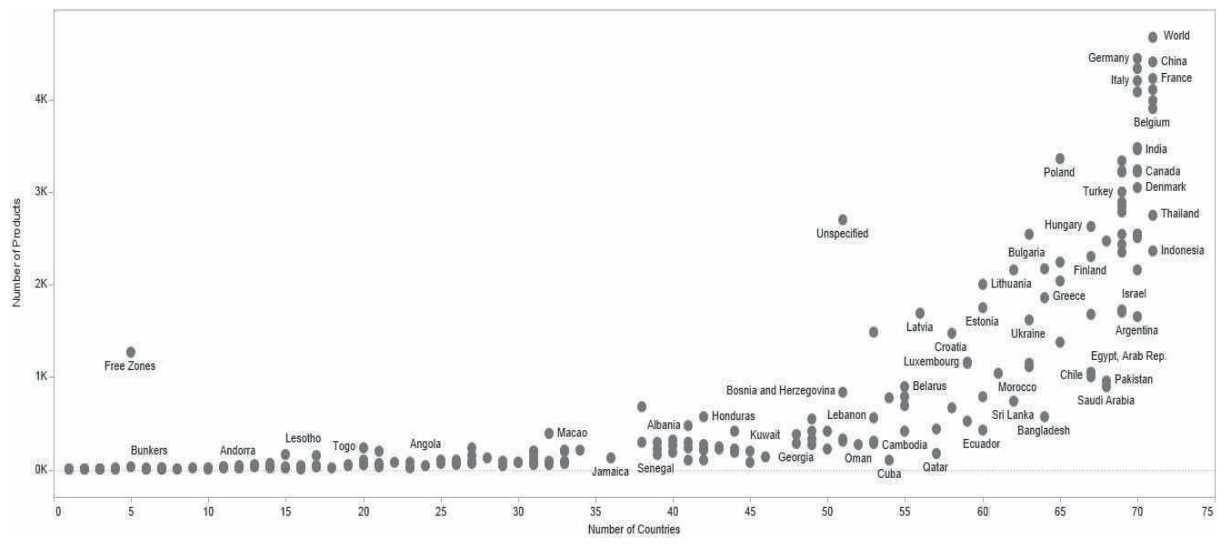

Source: Authors' own elaboration based on WITS data (15.05.2017).

In confronting the measures applied to achieve the economic goals according to the NSE concept with the three above-mentioned concepts of evolutionary development of the economy, one has to observe that their pragmatic use enables us to reduce the risk of falling in the middle-income trap, as well as the risk of excessive specialisation of the economy. Moreover, this also favours efforts to build the country's capacity to attract foreign investors to raise its own competitiveness (see Table 1).

It is equally noteworthy that NSE attributes quite a significant role in the process of formulating the industrial policy to the government. A similar perspective on the role of the state is also proposed by Mazzucato (2016), who postulates to change the role of the government as one of the main actors in the economic system. Specifically, she reckons it necessary to supplement the existing role - that of fixing market failures - by adding an additional function of shaping and creating the market. According to that concept, in its efforts, the state should also be more creative and entrepreneurial (hence the title: the Entrepreneurial State). Finally, the state should 
bear the risk of the activities undertaken during an early stage of development of the market and of business concepts. This should favour the accumulation of new and acceleration of the already acquired knowledge, generation of new ideas and their commercialisation by the private sector. Professor Mazzucato illustrates this thesis with the example showing that the iPhone was basically assembled by Apple based on technological solutions generated with serious input of public efforts.

Table 1. New Structural Economics and selected concepts of development

\begin{tabular}{|c|c|c|c|}
\hline \multicolumn{2}{|c|}{ Concept } & Key assumptions & $\begin{array}{l}\text { NSE recommendations } \\
\text { for economic policy }\end{array}$ \\
\hline & 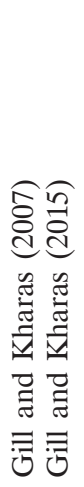 & $\begin{array}{l}\text { The focus is on factors which } \\
\text { potentially might stop the process of } \\
\text { economic growth (catching-up); the } \\
\text { trap may result from: } \\
\text { - misdiagnosis made within } \\
\text { the strategy of the country } \\
\text { development, based on export of } \\
\text { labour-intensive industrial goods } \\
\text { despite the loss of price vs. cost } \\
\text { advantage, } \\
\text { too hasty a leap toward } \\
\text { a knowledge-based economy despite } \\
\text { the lack of necessary resources and } \\
\text { institutions. }\end{array}$ & $\begin{array}{l}\text { The task of the economic policy is } \\
\text { to identify the latent comparative } \\
\text { advantage industries capable } \\
\text { of giving more dynamics to the } \\
\text { country's economic growth and to } \\
\text { favour convergence. } \\
\text { - The role of the government really } \\
\text { consists in performing an important } \\
\text { task of coordinating the efforts. It } \\
\text { has to be far-sighted and capable } \\
\text { of taking the risk and ensuring } \\
\text { the infrastructure, both hard and } \\
\text { soft, to reduce transaction costs in } \\
\text { selected industries/sectors. }\end{array}$ \\
\hline 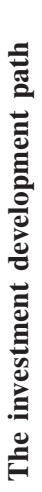 & 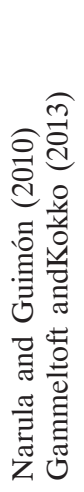 & $\begin{array}{l}\text { Changes in the GDP per capita are } \\
\text { related to the evolution of the FDI } \\
\text { net position: } \\
\text { - as the quality of resources is raised, } \\
\text { countries attract more and more } \\
\text { FDI } \\
\text { care for the proper FDI structure } \\
\text { may be crucial, } \\
\text { - as companies reach the critical mass } \\
\text { of domestic capital accumulation, } \\
\text { they expand into foreign markets } \\
\text { and are able to generate their own } \\
\text { global supply chains and achieve } \\
\text { superior positions therein. }\end{array}$ & $\begin{array}{l}\text { FDI is the most desirable form } \\
\text { of capital as it usually follows } \\
\text { comparative advantages of sectors } \\
\text { in which it is made. } \\
\text { - It is the most preferable to attract } \\
\text { investments in the tradable goods } \\
\text { sector (industry). } \\
\text { - The inflow of FDI should be } \\
\text { encouraged in the identified } \\
\text { industries that the industrial policy } \\
\text { is to support. }\end{array}$ \\
\hline
\end{tabular}


continued Table 1

\begin{tabular}{|c|c|c|c|}
\hline \multicolumn{2}{|c|}{ Concept } & Key assumptions & $\begin{array}{l}\text { NSE recommendations } \\
\text { for economic policy }\end{array}$ \\
\hline 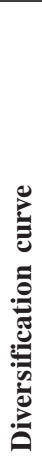 & 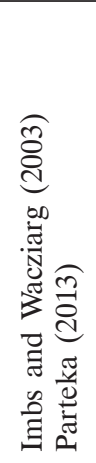 & $\begin{array}{l}\text { Together with a rising level of } \\
\text { economic development, the level } \\
\text { of diversification increases as well, } \\
\text { measured by the extent of (export- } \\
\text { oriented) production variety. } \\
\text { - After a critical level is exceeded, } \\
\text { the process of the economy } \\
\text { re-specialisation follows. } \\
\text { - Increasing specialisation may expose } \\
\text { the economy to the threat of } \\
\text { external shocks. }\end{array}$ & $\begin{array}{l}\text { - One challenge to structural policy is } \\
\text { to stimulate diversified production } \\
\text { and more technologically advance } \\
\text { the industry. } \\
\text { - The role the state plays in these } \\
\text { efforts is reduced to ensuring } \\
\text { the essential information about } \\
\text { the industries stimulated, to } \\
\text { coordination of investments } \\
\text { between individual companies } \\
\text { within the industry and to } \\
\text { incubation of new industries and } \\
\text { business entities. }\end{array}$ \\
\hline
\end{tabular}

Source: Authors' own elaboration.

\section{Prospects for growth of the electromobility market in Poland}

Until very recently, both the debate and actual activities in the area of electromobility in Poland were in serious delay compared to other European countries $^{6}$. However, the efforts undertaken in the years 2016-2107 by the Ministry of Energy and the Ministry of Development go a long way to catch up. It seems that this is the last moment to spur the growth of the national electromobility market, considering that the motor industry across the world has already matured to mass production of electric cars, and this process is going to gain significant momentum in the years to come. According to Bloomberg New Energy Finance (quoted after Randal, 2017), by 2020 we will see around 120 various models of electric cars on offer (see Figure 5).

The lack of diversified and advanced domestic production of components (or, according to a more optimistic scenario, of Polish electric car and other mobile vehicles) will result in the need to import them. This is easily concluded from the assumption that the demand for vehicles driven by electric machines will grow in proportion to an ever-increasing pressure upon the environment protection and restrictions on the access of combustion engine vehicles to cities. The problem of air pollution will be alleviated by more common use of electric vehicles in public transport. However, clean and "smart" cities are going to impose limits upon the free traffic of traditional vehicles anyway, restricting them to some zones and

6 For example, in Norway the debate about electromobility started in the 1990s. In Germany a plan for electromobility development was adopted in 2009 and in Estonia in 2011. 
expanding the areas for pedestrian and bicycle traffic. This means that the share of vehicles driven by electric energy will increase. At the same time, from the point of view of market diversification, one should remember how important it is to test and stimulate various types of products related to the sector of personal mobility based on electric power (bicycles, mopeds, wheelchairs), as the demand for them will certainly rise as well.

Figure 5. Models of electric cars foreseen in the market until 2020

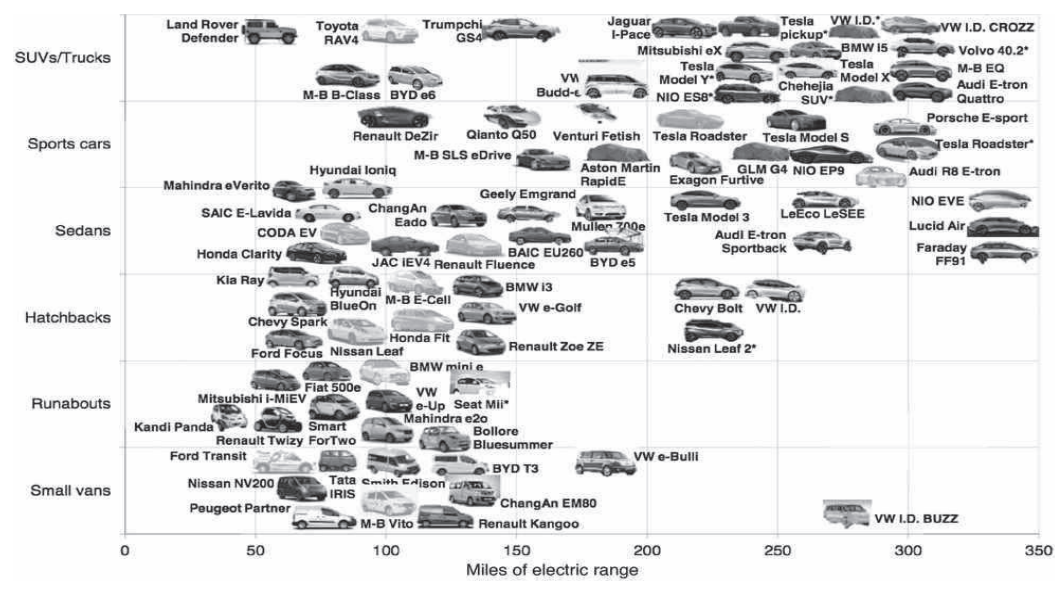

Source: Randal, 2017.

The process of replacing traditional combustion engine-driven vehicles with electric ones is going to gain momentum in the years to come, due to three groups of reasons: technological, economic and environmental. Firstly, an electric motor features less complex construction compared to the combustion engine. This makes it less prone to defects and that is why it is going to gradually replace traditional engines. Secondly, the cost of electric power is lower than that of fuel, and emissions involved can be more easily controlled (due to localised power generation) than in the case of millions of dispersed vehicles driven by combustion engines.

There are several important factors which should encourage the development of the electric vehicles market in Poland. In fact, what seems most important is their mix which should produce synergy effects and release endogenous forces for market growth (Kurtyka, 2017). Whereas the development of electromobility certainly depends on a number of additional conditions and reservations and involves some risk, there are some equally undeniable reasons to look at Poland as a potential place of concentration of this industry and related industries.

Firstly, the development of electromobility is going to rely upon the relatively well-developed and competitive automotive industry (operated by foreign and national manufacturers alike) concentrated in Poland. 
Secondly, electromobility may give an impulse for systemic utilisation of industrial and innovative potential of the Polish economy.

Thirdly, electromobility will favour the implementation of sustained development postulates and the environment protection through solutions to at least some problems concerning transport in cities.

Fourthly, the prospects for success of such an undertaking seem to improve considering that the state has assumed the role of animator of the innovativeness ecosystem and is currently striving to provide hard and soft market infrastructure. Efforts in this respect take the form of new regulations, support given to R\&D, construction of battery-charging facilities, creation of financial incentives to stimulate demand, etc.

Fifthly, electromobility may well be a factor which reduces the country's dependence upon purchase of imported resources (fuels), reduces the scale of purchase of this type of vehicles, thus stabilising the trade balance, and may also become a factor favouring stabilisation of the energy system.

\subsection{Motor car industry matured to mass production of electric cars}

In a KPMG survey (2017), Global Automotive Executive Survey 2017, respondents from 42 countries agreed that the key challenge in the context of transformations in the car market is in the development of electric vehicles (while in the years 2014-2015 the same issue ranked around 10th in importance). This means that the market has generated a critical mass of resources and processes which are going to necessitate the accelerated development of electric vehicles. The same is favoured by an increasing involvement of the largest market players (including VW, GM, BMW and some companies from other sectors, like Apple, Google or Uber) and by technological progress which will lead, within several years, to comparable prices of electric and traditional cars. Also, electric vehicles should become more popular in effect of the trend to introduce autonomous cars as a safer transport solution. While the issue of the use of autonomous cars is, technically, neutral in terms of their drive system, still they seem likely to be electric-driven in a substantial part.

The automotive industry is starting a global race in electromobility; a race in which the achievements of the most recent electronics, telecommunications and big data management are going to be used. At the same time, the motor car industry will undergo serious changes in terms of business model, based on optimal utilisation of the existing resources. According to KPMG, it will lead to a reduced demand for passenger cars. This also results from changing customer attitudes. The research done by KPMG suggests that, by the year 2025, as many as $50 \%$ of car owners will no longer feel any need to have a car of their own, also due to an ever-extending offer of various forms of car-sharing schemes, long-term rental and lease. 


\subsection{Acceleration of the Polish industry and innovativeness potential}

The total share of the motor industry in the Polish economy (officially included in the Polish Classification of Economic Activities as Production of motor vehicles, trailers and semi-trailers, and Production of other transport machinery and equipment) accounted for circa $10 \%$ of the total industrial production. In 2015, it employed around 220 thousand people 7 . At the same time, both above-mentioned categories accounted for circa $20 \%$ of total export and had around $20 \%$ share in the entire industry's spending on R\&D. In the years 2000-2008, the contribution of these categories (together with the machine industry, which is closely related therewith) to the export growth accounted for circa $40 \%$ (a level which decreased to circa $30 \%$ after the global crisis, which is often explained by structural deceleration of trade within global value chains) (see Figure 6).

Figure 6. Contribution to the export growth

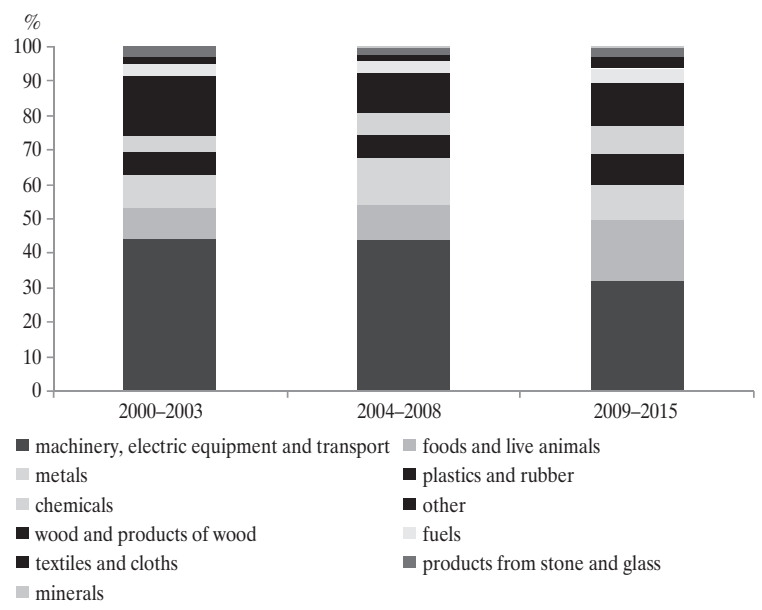

Source: Authors' own elaboration based on WITS data (15.05.2017).

The motor industry tends to simultaneous defragmentation of production and geographic concentration because the final product (a car) is made by assembling around 3500 parts which are not manufactured by its ultimate producer. Therefore, a network of suppliers and contractors concentrated around the manufacturing process of a car has vital importance for that process.

Localisation of the motor car industry in the countries of Central and Eastern Europe, including Poland, mainly results from the inclusion of motor car industries in individual countries into supply chains formed by foreign investors from Germany,

7 Taking into account the employment in the categories Production of motor vehicles, trailers and semi-trailers and Production of other transport machinery and equipment. 
France, and Italy. This means that Poland provides a strong manufacturing base for final products, which stems from traditions of that sector, high level of technological skills, infrastructure, and supply networks (Füzi, Gombos and Tóth, 2012). Around $2 / 3$ out of 30 world's largest car manufacturers have their factories in Poland. As illustrated in Figure 7, locally concentrated networks of suppliers are able - thanks to the variety and multi-national mix of enterprises - to meet, to a major extent, the needs of that sector.

Figure 7. An exemplary network of suppliers localised in "Invest-Park" Special Economic Zone in Poland

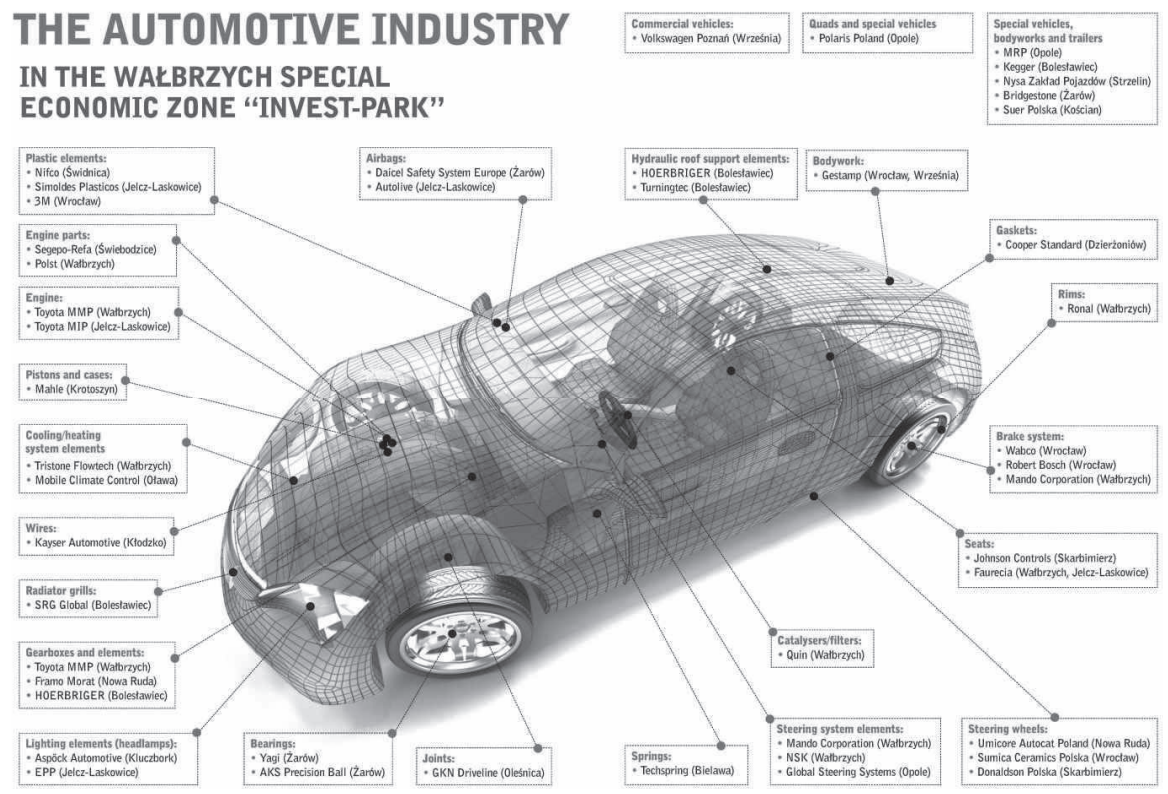

Source: https://invest-park.com.pl/en/blog/2015/06/30/zone-of-automotiv/ (20.05.2017).

Even if manufacturers and exporters of finished goods from Poland are mostly business entities with a foreign capital share, still it remains true that this industry has already accumulated the critical mass of local knowledge, technology and relationships, thus making the region more attractive to new investors and seriously increasing its pool of competence. The Policy Insight analysis indicates that, compared to the Czech Republic, Hungary, and Slovakia, Poland ranks highest in terms of proximity to the customer in GVC. Other factors that illustrate the competitiveness and maturity of the sector include a number of established Polish companies which successfully build their own value chains and become European leaders in their fields, e.g. Boryszew, Solaris, Wielton, Pesa. 
These observations are confirmed by the RCA index ${ }^{8}$ for selected product groups related to the motor car industry, which even indicates certain advantages of Polish over German exporters (see Figure 8).

Figure 8. Comparative advantages in Polish and German industries

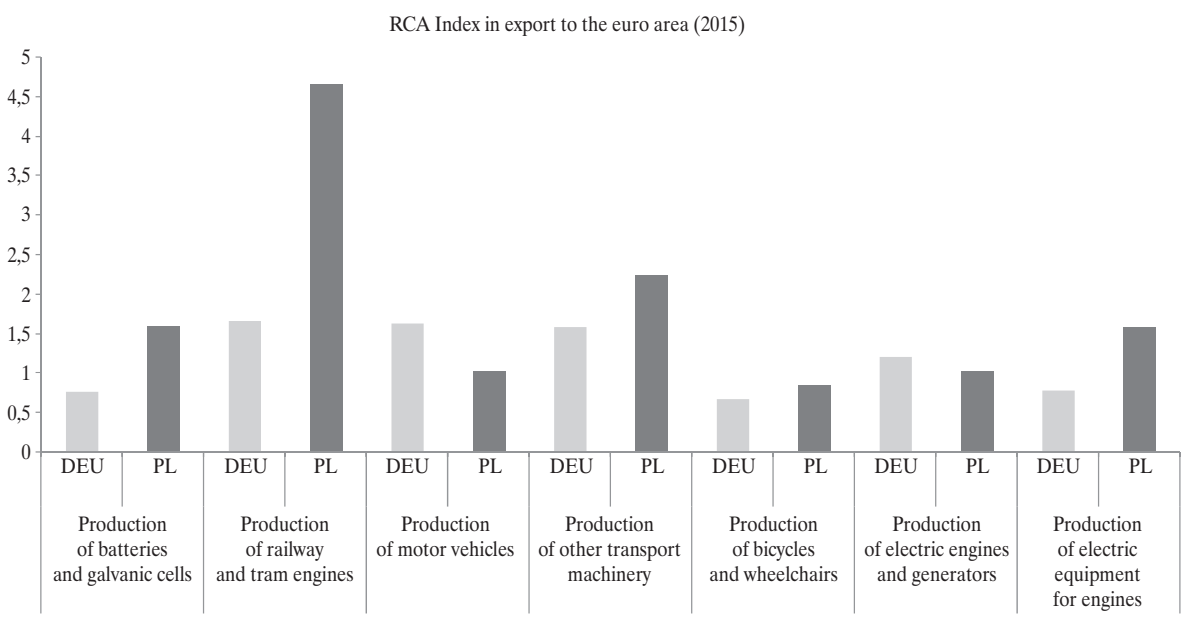

Source: Barteczko and Tchorek, 2016.

Indisputably, the electromobility industry has the potential to stimulate other sectors, such as IT, energy, aviation, as well as the production of components for broadly understood electric machines-driven mobility. For example, in Denmark, there were many crucial innovations stemming from the sector as traditional as agriculture (penicillin contributed to the development of the pharmaceutical industry; the agriculture and food processing industry stimulated the development of the food storage equipment sector) while wind farms favoured the development of the ITC sector.

\subsection{An enterprising and innovative state}

Experiences in the area of shaping the policy of innovativeness in Scandinavian countries indicate that innovation, creativity, and enthusiasm in action may be associated both with private and with the public sector. In that group of countries,

8 The RCA (Revealed Comparative Advantage) index measures revealed comparative advantages through the assessment of export concentration on individual products or groups of products. The index measures the intensity of specialisation of a given country in international trade in a given product compared to the rest of the world, another country or another region. The RCA value above one indicates that a country in question has comparative advantage (specialisation) in export of a given group of products compared to its reference group. 
the public sector is responsible for fixing market failures as well as for market stimulation - efforts in which the state acts as a pioneer, leader and guide skilfully distributing impulses for activities of enterprises and other actors of the entire ecosystem. It may be concluded from experiences of countries which achieved success in innovativeness that important elements in the innovativeness ecosystem included clusters, often driven by demand from the public sector, and publicprivate partnerships. Then, a significant role was also played by innovativeness networks oriented at the creation of relationships and exchange between research and development institutions and the business sector, in particular as regards small enterprises for which transaction costs may be really serious (NBP, 2016).

Efforts undertaken by the Ministry of Energy and the Ministry of Development (with cooperation from the Ministry of Environment, Polish Development Fund, National Fund for Environmental Protection and Water Management, National Centre for Research and Development) make a significant step in stimulating the entities involved in manufacturing cars and their components, concentration of potential demand and supply, reduction of transaction costs and transfer of knowledge.

In the years 2016-2017, amid important events, conferences, seminars and public debate, the considerable intellectual potential was mobilised, the essential consensus was achieved for a common vision of development. Moreover, specific activities were initiated to seek and find directions to follow and the set of solutions to apply. Pilot projects were defined in the key segment of institutional customers, where it will be vital to follow these efforts with a further, more profound assessment of possibilities to launch electricity-powered transport. This is very important, considering that this segment of buyers, including corporate fleets, is probably going to be the first one to develop ${ }^{9}$. Of course, further studies and consultation are also necessary for such fields as possibilities to use electric buses in city transport, depending on the profile of daily power consumption, distances between stops in cities and so on. However, the initial stage of stimulation of demand and supply, accompanied by defined market frames, notably increased the interest in electromobility among local governments: 41 of them decided to join the pilot programme and have already planned to purchase around 800 electric buses. A company, ElectroMobility Poland, was established and a competition was announced for the concept of a Polish electric car. The government intends to earmark the amount of circa PLN 20 billion for the entire project. Four power companies were entrusted with the task of the construction of national battery-charging infrastructure all over the country, thus providing the critically important element for the market growth.

9 For example, the battery range available today would suffice for many courier companies which are likely to invest in their own charging stations and might very well charge the batteries at night, thus contributing to stabilisation of power network - which is not certain at all in the case of individual users concentrated in agglomerations of Polish cities. 


\section{Conclusions for electromobility in Poland}

\section{To have a vision, look into the future and create it (to lead rather than catch up)}

Among many repeated attempts to formulate the diagnosis of the present condition of the Polish economy and its prospects for the future, published in a variety of documents ${ }^{10}$, valuable and useful as they were, no effort was made to try to define the key industries in which development potential should be expected. This role should be played by the government economic policy- and it seems that in the case of the Responsible Development Plan, which includes the Electromobility Development Plan as one of its parts, we indeed deal with a well-reasoned attempt at such an activity.

It is for the first time since the transformation process began that we have managed to make a significant step ahead in our strategic planning and economic vision, instead of acting only reactively. Rather than responding to what has already happened, we attempt to shape what may happen in the future. However, this factor will not suffice unless based upon soft (education of personnel, gaining social acceptance for new solutions), hard (charging systems and increasing the range of batteries) and regulatory (a system of financial and non-financial incentives for the purchase of electric cars) infrastructures.

Summing up the same in the NSE nomenclature, public activities have succeeded in identification of a sector with latent competitive advantages. While in fact it will be built upon the basis of the traditional car industry, at the same time it is going to rely to a greater extent upon Polish technological and intellectual contribution. Most importantly, Poland seems to have resources needed for this enterprise - the point is to allocate them properly and define a healthy regulatory framework for them to operate.

\section{To promote variety and diversification}

Development of the electromobility market in Poland concerns many areas of economy and extends onto social relations. The essential element for jump-starting this growth is to install a national battery-charging system covering all the country's territory and compatible on both domestic and international scale. The process should also be accompanied by the emergence of new business models based on digital strategies, related to changes in the ways cars are used (including on carsharing principles). Then, it is also necessary to ensure viable solutions for recycling of used batteries, in line with the concepts of sustainable development and circular

10 Such as the reports: Competitive Poland. How to Advance in Global Economic League? prepared under editorial supervision of Professor J. Hausner (2013) and The Economy's Potential for Innovation: Conditions, Determinants, Perspectives, edited by Professors A. Sławiński and J. Growiec (2016). 
economy. Efficient data management will be equally important, in particular, in such contexts as the need to measure electric power consumption, use of intelligent measurement units and an increasing presence and importance of autonomous cars. The national IT sector seems ready to meet these challenges, considering that more and more Polish companies are ranked among European leaders.

At the same time, it is necessary to try to define the process of evolution from traditional industry. According to M. Kurtyka (2017), electric cars have an advantage of being easier to manufacture as they are assembled of around 1000 parts, compared to as many as circa 3500 in the case of traditional combustion-engine cars. While this favours the potential to reduce the rate of vehicle defects by around $20 \%$, the same aspect will also significantly influence changes in patterns of the industry operation - which also calls for careful analyses. The question that remains open is to which extent manufacturers of those 2500 parts, made redundant in the new reality of electric cars, will prove capable of quickly adapting and entering the process of electric cars production anyway. Perhaps there might be some opportunities for new specialisations and new, prospective market segments for them to settle in. However, this also warrants a thorough discussion and, quite possibly, more detailed research, especially in the context of promoting diversification.

Finally, diversification also relates to the range of drive systems developed. Analysts expect that within several years a hybrid drive system (rather than solely electric) will emerge as the most common solution ${ }^{11}$. In addition, the variety of drive systems is reflected in the diversification of energy carriers. In this context, it is important to remember about - and to develop - gas-based mobility.

\section{To stimulate internationalisation}

In the context of internationalisation of NSE, the concepts discussed here postulate to replace imports with domestic production and attribute an important role to openness as a channel of competitiveness and convergence. This means that we also need to look at the development of electromobility from perspectives of internationalisation of research, export of national production and capital expansion. Unless we achieve a really international scale of our activities, including in the field of FDI, we are unlikely to become the global leader. A strong presence in foreign markets is an essential condition for being able to acquire knowledge and to monitor market trends as they occur. From the point of view of decisions made by enterprises, any entry into a new export market and/or launch of a new product involves significant costs and requires relevant resources, both tangible and intangible. Accordingly, the support offered in other areas of the Responsible Development Plan will be of utmost importance in this respect. Some dilemmas

11 According to BCG, in global sales of cars in 2025, vehicles with alternative drive systems will account for $25 \%$. Within that pool, around $65 \%$ will go to hybrid drives, with purely electric cars only achieving a level of circa 1/4 (see: Kędzierski, 2017). 
remain to be solved on the part of economic policy - including answers to be found to the question of how to deal with attracting "better quality" FDI in the automotive industry (investments that implement R\&D activities in partnership and with strong involvement of national entities); with the transfer of knowledge from investors and its spillover among national entities; with the quality of production factors which favour absorption of knowledge and technology; and with creation of advantages based on intangible resources. In this context, it also seems worth discussing the possibility of entering into a strategic technological partnership with some foreign player from the same sector, which could prove helpful in accelerating market development. Just imagining - it would not seem unthinkable for Tesla to be interested in cooperating in the development of a small and low-budget city car to be sold on the relatively large Polish market.

Creation of a national brand of passenger cars will be relatively difficult, considering that it takes around 4 years for such a process to fully unfold and that Poland lacks domestic experience in this field. Nonetheless, development of the electromobility market in Poland could be regarded beneficial for the economy if it achieves a level of $20-40 \%$ of the final added value generated in the country. What is important is that such added value was increasingly based upon intangible advantages.

\section{Conclusion}

To synthetically sum up the concepts discussed here - the middle-income trap, the investment development path, the diversification curve, and NSE, in the context of the development of the electromobility market in Poland - the following conclusions may be proposed:

Firstly, it is desirable to strengthen the potential of the state as the entity which ensures scarce and precious resources and takes the risk in shaping market rules and creating markets. If there is a clear and reliable signal sent to the market about a comprehensive effort to stimulate industries with identified significant potential, this favours stable planning and facilitates investment decisions in at least mid-term perspective.

Secondly, it is strongly recommended to foster market variety and diversification. At present, the electromobility market is only at the start of its evolution and it is yet quite hard to foresee how it will develop, even in the immediate future of several years. This relates to technologies applied, to products and to additional services alike. The advice to search for variety and diversification is explained by the need to stimulate the market through looking for all sorts of new possibilities, including technological, organisational and business-related. Increasing diversification should also make the economy more immune to shocks and favour development of different industries. 
Thirdly, internationalisation of the Polish electromobility sector should be promoted. This is one of the key conditions of its competitiveness and therefore increases chances for success of the project, which should be seen as a difficult social and economic challenge. Reaching for international experiences, including those gathered in Asian countries, well advanced in the field of electromobility, attraction, and absorption of FDI, export of capital and support given to national champions are all very important tasks for the economic policy.

It should be admitted that in a relatively short time the vision of the Polish electromobility market was created. Directions of future development over the years to come were defined, resources and capital conducive to the achievement of the objective were programmed. The role of the state is evolving towards synergy of knowledge and creativity on the one hand and, on the other hand, toward acting as an animator which defines boundary conditions for demand and supply on the market and for taking the risk and testing solutions. Furthermore, initiatives were undertaken aiming at the concentration of $\mathrm{R} \& \mathrm{D}$ activities around related industries and at the creation of an ecosystem which favours commercialisation of research which until recently was one of the greatest weaknesses of the innovativeness system in Poland. Apart from the fact that social capital was mobilised relatively quickly and that the vision of growth was created, one should still remember that, in terms of building the electromobility market in Poland, we are only at the start of a long road. Unfortunately, even New Structural Economics is unable to provide easy recipes for how to act promptly and at the same time reasonably under conditions of strong market pressures and the global race which the Polish industry intends to join.

Innovation - and the development of electromobility market in both technological and social aspects should certainly be regarded as innovation - often tends to unfold in a series of leaps along the path heavily burdened with risk. Accordingly, any attempt to explain the phenomenon of the rapidly blossoming debate, but also that of specific actions in the field of electromobility in Poland and further growth of that market, requires more than the just linear perception of reality. Most economists, however, despite being one of the social and professional groups largely aware that many processes in the economy deviate from linear development, still tend to apply projections based on linear relations in dealing with economic problems.

\section{Bibliography}

Agénor, P.R., Canuto, O. and Jelenic, M. (2012). Avoiding middle-income growth traps. World Bank-Economic Premise, (98), 1-7.

Agénor, P.R. (2016). Caught in the middle? The economics of middle income traps. Journal of Economic Surveys, 22 August, http://dx.doi.org/10.1111/joes.12175. 
Aghion, P. and Howitt, P. (2009). The Economics of Growth. Cambridge, MA: MIT Press.

Barteczko, K. and Tchorek, G. (2016). Wprowadzenie euro a konkurencyjność polskich przedsiębiorstw na rynkach zagranicznych (The introduction of the euro and competitiveness of Polish enterprises in foreign markets). Database gathered for the needs of the NCN project. Grant No. DEC-2011/03/D/HS4/01954. Taken from: http://www.eurocompetitiveness.eu/.

Hausner, J. (ed.). (2013). Competitive Poland. How to Advance in Global Economic League? Kraków: GAP Foundation.

Eichengreen, B. (2011). Escaping the middle-income trap. Berkeley: Barry Eichengreen University of California. Taken from: http://www.kc.frb.org/publicat/sympos/2011/2011.

Eichengreen, B., Park, D. and Shin, K. (2013). Growth slowdowns redux: New evidence on the middle-income trap. NBER Working Papers from National Bureau of Economic Research, Inc., No. 18673.

Felipe, J. (2012). Tracking the Middle-Income Trap: What is It, Who is in It, and Why. ADB Economics Working Paper Series, No. 306, March.

Funke, M. and Ruhwedel, R. (2005).Export Variety and Economic Growth in East European Transition Economies. The Economics of Transition, 13(1), 25-50.

Füzi, A., Gombos, Sz. and Tóth, T. (2012). Location factors of automotive industry in Central and Eastern Europe. In: J. Rechnitzer, M.Smahó (eds), Vehicle Industry and Competitiveness of Regions in Central and Eastern Europe. Győr: Universitas-Győr Nonprofit Limited.

Gammeltoft, P. and Kokko, A. (2013). Introduction: Outward foreign direct investment from emerging economies and national development strategies: three regimes. International Journal of Technological Learning, Innovation and Development, 6(1/2), 1-20.

Gill, I.S. and Kharas, H. (2007). An East Asian Renaissance: Ideas for Economic Growth. Washington: World Bank.

Gill, I.S. and Kharas, H. (2015). The Middle-Income Trap Turns Ten. Policy Research Working Paper, No. 7403. World Bank Group, August.

Girma, S., Gong, Y., Görg, H. and Lancheros, S. (2015). Estimating direct and indirect effects of foreign direct investment on firm productivity in the presence of interactions between firms. Journal of International Economics, 95(1), 157-169.

Gorynia, M., Nowak, J. and Wolniak, R. (2010). Foreign Direct Investment in Central and Eastern Europe: The IDP trajectories of selected countries. Poznań University of Economics Review, 10(1), 5-26.

Imbs, J. and Wacziarg, R. (2003). Stages of Diversification. American Economic Review, 93(1), 63-86.

Kędzierski, T. (2017). Elektromobilność a energetyka (Electomobility and Power Industry). BCG presentation at the Economic Congress in Katowice, May.

Klich, J. (2014). Foreign Direct Investment in the the Visegrad Countries after 2004: Have the Visegrad Countries' Membership in the European Union Changed Something? Entrepreneurial Business and Economic Review, 2(3), 19-31.

Klinger, B. and Lederman, D. (2006). Diversification, Innovation, and Imitation Inside the Global Technology Frontier. World Bank Policy Research Paper, No. 3872. Washington: The World Bank.

KPMG. (2017). KPMG's Global Automotive Executive Survey 2017. Taken from: https://assets. kpmg.com/content/dam/kpmg/xx/pdf/2017/01/global-automotive-executive-survey-2017. pdf. 
Kurtyka, M. (2017). Development of electromobility in Poland in the context of New Structural Economics (Rozwój elektromobilności w Polsce w kontekście Nowej Ekonomii Strukturalnej). In: I.Y. Lin, A.Z. Nowak (eds.), New Structural Economics for less advanced countries (Nowa Ekonomia Strukturalna wobec krajów mniej zaawansowanych). Warsaw: University of Warsaw, Faculty of Management Press.

Lin, J.Y. (2012). New Structural Economics: A Framework for Rethinking Development and Policy. Washington, DC: World Bank Publications.

Mazzucato, M. (2016). Przedsiębiorcze państwo (Entrepreneurial State). Warsaw: Hetorodox Economic Press.

Meliciani, V. and Tchorek, G. (2017). Global value chains, innovation and firms' performance during the crisis. NBP Working Paper, No. 259.

Narula, R. and Guimón, J. (2010). The investment development path in a globalized world: implications for Eastern Europe. Eastern Journal of European Studies, 1(2), 5-19.

Sławiński, A. and Growiec, J. (eds). (2016). Potencjat innowacyjny gospodarki: uwarunkowania, determinanty, perspektywy (Economy's Potential for Innovation: Conditions, Determinants, Perspectives). Warsaw: National Bank of Poland. Taken from: https://www.nbp.pl/ aktualnosci/wiadomosci_2016/20160530_Raport_innowacyjnosc.pdf.

Parteka, A. (2013). The evolving structure of Polish exports (1994-2010) - diversification of products and trade partners. Bank $i$ Kredyt, 44(5).

Randal, T. (2017), The Electric-Car Boom Is So Real Even Oil Companies Say It's Coming https://www.bloomberg.com/news/articles/2017-04-25/electric-car-boom-seen-triggeringpeak-oil-demand-in-2030s (20.05.2017).

Tchorek, G. (2016). Foreign Direct Investment and Investment Development Path. The Case of Visegrad Countries. Studia i Materiaty WZ UW, 22(2/2), 201-212.

Wojtyna, A. (2016). Kontrowersje teoretyczne wokół koncepcji pułapki średniego poziomu rozwoju (Theoretic Controversies About the Middle Incone Trap). Gospodarka Narodowa, (6), 5-22.

World Integrated Trade Solution (WITS). Taken from: http://wits.worldbank.org/ (15.05.2017). 
BEATA KOZŁOWSKA-CHYŁA

\title{
Juridical aspects of the economic position of state in the sphere of dominium
}

\begin{abstract}
The state influence upon the economy occurs in particular through its ruling efforts undertaken in the sphere of empire. In the area of public law, the state has a range of legal instruments through which it provides and regulates conditions for economic growth and the form of economic and social relations. Significant influence is also exerted upon the economy through activities undertaken in the area of ownership relations with the participation of state as it is involved through the State Treasury. In the sphere of dominium, the state (the State Treasury) is the subject of rights and obligations having private and legal nature. This way, together with other state legal persons, it acts as the owner of the state property, and its actions in this field have a serious impact upon the way the economy operates. This study analyses legal conditions of the state position in the area of dominium. The issue seems very topical in the context of far-reaching changes, made recently, as regards legal status in the field of ownership relations in which the state is involved. The shape of normative solutions proposed, as well as their ratio legis, contribute to the debate about the economic position of the state de lege lata.
\end{abstract}

Keywords: state, the State Treasury, state legal persons, state property, the sphere of empire, the sphere of dominium.

\section{Introduction}

The issue of the role of the state as a provider of conditions for the economic growth and an actor involved in economic relations, including the question of the borders of the state influence upon the broadly-understood national economy, has long been an object of an economic and legal debate. Its discussion has seen differing opinions confronted about the extent of admissible state intervention in market-based mechanisms. The state, a highly complex organism as it is, obliged to perform tasks reaching beyond the scope of the public law, out of its very nature constitutes an indivisible entirety. As a person of public law, it also has - in the form of the State Treasury - legal personality in private (or perhaps civil and legal) relations. This way, it performs the owner's functions with respect to the property owned. In private and legal relations, the State Treasury, acting as a legal person, 
performs its owner's competences in the sphere of dominium and it does that in a manner which, in principle, has no character of public and legal action (- empire). The reason is that the state, acting in powers of the State Treasury is, in civil and legal relations, the subject of rights and obligations which concern the state property (see: Całus, 1995, p. 13). In the area of public law, the state is endowed in the empire - it acts from the position of power, performs its functions using means of coercion (orders and prohibitions) and under conditions of subordination. Both in the sphere of empire and that of dominium, the state plays important roles - on the one hand as a regulator of economic relations, and on the other hand as a player in economic activities. The implementation of the assumptions set for the state economic policy occurs, in particular, through the shaping of a normative system in the area of public and private law in a manner which sets forth a legal framework for the economic and social relations together with their actors. The state, as it performs functions attributed thereto, consisting in allocation, redistribution, and stabilisation operates in the sphere of empire through appropriate bodies of authority which formulate legal norms in order to regulate the broadly understood area of the economy. In a legislative aspect, these legal regulations concern, in particular, the right of ownership and its protection, the scope of freedom of business activity, the protection of competition, the labour and social welfare legislation, the environment protection legislation, legislation concerning state budget, taxes, state administration and even criminal law. The shape of those regulations stems from some specific "philosophy" adopted by the legislator in the process of normative definition of the role of the state in the economy. The nature of both juridical assumptions and solutions in this respect determines, de lege lata, an answer to the question about the present scope of the state intervention in economic relations. De lege ferenda, instead, the debate remains open.

Recently, thanks to provisions of the Act on the rules of the state property management ${ }^{1}$ and of the Act - Provisions implementing the Act on the rules of the state property management ${ }^{2}$, significant normative changes were made in the field relating to the state activity in the sphere of private and legal economic relations. New legal regulations redefine the hitherto-existing status of the state operating in the sphere of dominium. Admittedly, their importance for economic activities is crucial, because the state, as pointed out above, not only plays a regulative role in the economy but also, as the State Treasury acts as a player in economic relations by actively participating in civil and legal dealings on par with other enterprises. Moreover, it also is the subject of rights and obligations which relate to the state property not belonging to other state legal persons (Article 34 of the Civil Code). The scope of state ownership, defined by legal regulations, as well as conditions

1 Act of 16 December 2016 on the rules of the state property management (Journal of Law 2016, item 2259), entry into force on 1 January 2017.

2 Act of 16 December 2016 - Provisions implementing the Act on the rules of the state property management (Journal of Law 2016, item 2260). 
on which this may be "executed", consequently influence the market structure and economic processes occurring within it, thereby forming an important element of the state economic policy.

At the same time, it should be emphasised that both the analysis of legal regulations in this respect, currently in force, and an inquiry into the direction in which normative changes are made and their ratio legis, constitute a significant contribution to the debate about the present and future role of the state in the economy.

It has become an intention of the legislator to implement a multi-faceted reform of the sphere of the performance of the owners' competences of the State Treasury (dominium), understood as an area in which the state operates as the property owner. It was reckoned that legal regulations in force until that time had been created to meet the needs of the process of transformation of the economic sphere and ownership structure. In consequence - it was believed - they mostly lost their relevance to the present economic reality and thus required profound systemic changes. The purpose of normative changes introduced is for the state, as it operates in the sphere of dominium, to put the crucial emphasis upon the efficient management of the property it possesses, in order to build its lasting value, as well as upon securing the same against any potential abuse. Moreover, the hithertoexisting model was regarded to have serious structural defects which consisted in the actual execution of rights with respect to state property by a large number of bodies and persons without proper coordination of the state policy in the area of state property management at the level of the Council of Ministers. The result was that economically strong persons were operating on their own, failing to really take advantage of the potential stemming from acting in a manner capital groups do, in the implementation of joint undertakings. This, in turn, generates costs related to lost development opportunities that could have been taken advantage of through the more efficient use of resources at hand ${ }^{3}$.

Among normative areas which - according to the Author - crucially redefine the hitherto-existing model of ownership relations with the participation of state and state bodies, special attention should be paid to new legal solutions discussed below.

\section{The notion of state legal person}

The structure of the state property ownership relies upon the principle that the property and other property rights that constitute the state property, remain within the competence of the State Treasury or other state legal persons (Article $44^{1}$ of the Civil Code). Therefore, there are a number of other legal persons, apart

3 See: Justification to the draft act on the rules of the state property management. Taken from: www.orka.sejm.gov.pl. 
from the State Treasury, involved in the dealings, whose property is entirely the state property, but usually - and due to various reasons, mostly to management efficiency - such persons act in civil and legal relations as legal persons separate from the State Treasury (Frąckowiak, 2012, p. 1175 ff.). The definition of a state legal person, in force until 1 January 2017, was included in Article 1a of the Act of 8 August 1996 on the rules regulating execution of competences awarded to the State Treasury ${ }^{4}$, pursuant to which state legal person is an organisational unit, other than the State Treasury, which has legal personality and whose property is entirely owned by the state.

The present, very extensive definition of state legal person has been based upon a listing of organisational units classed in the category of state legal persons, supplemented by some additional criteria which also qualify some persons not included in the enumerative list, thus including them in that category anyway. At the same time, the new definition eliminates the logical error (idem per idem) inherent in the regulation previously in force. What was wrong was that state legal person was defined using the notion of the state property whereas the notion of the state property was defined using the notion of the state legal person. Now, instead, pursuant to Article 3(1) of the Act on the principles of state property management, the following entities are state legal persons:

1) an organisational unit which has legal personality and has either been established by an Act or based on execution on an Act by a body of the government administration with the purpose of implementation of public tasks, in which:

- the right of enacting and amending the articles, provided for under provisions of an Act which regulates the status of such legal person, is bestowed upon a body of the government administration or where the same provisions stipulate that the right of participation in such legal person's regulative body, including the body competent to amend its articles, is entirely bestowed upon the State Treasury, and

- the right to the surplus occurring between the gross receipts earned and costs borne by such legal person (where such receipts or costs are subject to disposal), provided for under provisions of an Act which regulates the status of such legal person, is entirely attributable to the State Treasury, unless such provisions provide for another use to be made of such surplus than the right thereto, and

- in case such legal person is dissolved or loses its legal personality due to whatever reason, the rights to its property, including the right to dispose of such property, are exclusively attributable to the State Treasury;

2) the executive agency mentioned in the Act of 27 August 2009 on public finance (Journal of Law 2016, items 1870, 1948 and 1984), in particular:

4 Act of 8 August 1996 on the rules regulating execution of competences awarded to the State Treasury (as in Journal of Law 2016, item 154 with later amendments) overruled on 1 January 2017. 
- The Agricultural Property Agency,

- The Agricultural Market Agency,

- The Military Property Agency,

- The Material Reserves Agency,

- Polish Agency for Enterprise Development,

- The National Science Centre,

- The National Centre for Research and Development,

- Centre for Cultivar Testing,

- Agency for Restructuring and Modernisation of Agriculture,

- Polish Space Agency;

3) the budget economy institution mentioned in the Act of 27 August 2009 on public finance;

4) a state target fund having legal personality;

5) a state cultural institution;

6) Polish Film Institute;

7) The Fryderyk Chopin Institute;

8) The Ossolineum;

9) Polish Academy of Science and its scholar units having legal personality;

10) a public university established by the state represented by a relevant body of authority or of public administration;

11) a research institute in the understanding of provisions of the Act of 30 April 2010 on research institutions (Journal of Law2016, items 371, 1079 and 1311);

12) International Institute of Molecular and Cell Biology in Warsaw;

13) an independent public health care institution for which the establishing body is the State Treasury represented by a minister, a central body of the government administration, a provincial governor or a public university as mentioned in (10) above;

14) a national park;

15) a state-owned enterprise;

16) a state bank;

17) The Agency for Health Technology Assessment and Tariff System;

18) National Fund for Environmental Protection and Water Management;

19) Polish Organisation for Tourism;

20) The Office of Technical Inspection;

21) Transport Technical Supervision;

22) Polish Centre for Accreditation;

23) Polish Air Navigation Services Agency;

24) Social Insurance Company;

25) National Health Fund;

26) Financial Ombudsman;

27) The Polish Jockey Club;

28) The Centre For Polish-Russian Dialogue and Understanding; 
29) The Centre For Agricultural Counselling and provincial agricultural counselling centres;

30) The Polish Institute of International Affairs.

Pursuant to Article 3(2) of the Act in question, an organisational unit mentioned in paragraph 1(1), does not cease to be state legal person on the reason that an Act which regulates the status of such legal person provides that the right of participation in a decision-making body of such legal person, including the body competent to amend its articles, will be endowed, in the whole or in part, to another body or bodies, where a body of the government administration, even if another than that establishing the legal person in question, exercises supervision over such legal person, resulting from the provisions of that Act.

Then, pursuant to Article 3(3), state legal persons also include the following: (1) an organisational unit which does not meet the criteria mentioned in paragraph 1(1), where an Act provides so; (2) a company whose shareholders only include the State Treasury or other state legal persons.

The property belonging to the State Treasury and to other state legal persons (i.e. the state property) is a measure of the "quantity" of state property in the economy. Defining the proportions between the state property and private property that are favourable to the market, has been one of the axes of the dispute about the problem of the state property privatisation. This area has also undergone significant changes of legal status quo, important from the point of view of evaluation of the role and position of state in the sphere of dominium.

\section{The issue of privatisation of the state property}

Serious normative changes have occurred in the Act on commercialisation and privatisation ${ }^{5}$. From the point of view of the issues in question here, what has crucial importance is an abrogation of provisions concerning indirect and direct privatisation as well as the change of the Act name into the Act on commercialisation and selected competences of the employees ${ }^{6}$. This way, the legislator entirely abandons the notion of privatisation. Accordingly, the procedure of direct privatisation disappears from the legal system altogether. This procedure consisted in the disposal of all the elements of a state enterprise property, tangible and intangible alike, achieved through the sale of such enterprise, the contribution of such enterprise to another company or releasing the same for use against

5 Act of 30 August 1996 on commercialisation and privatisation (as in Journal of Law 2016, item 981 with later amendments).

6 Article 14 of the Act - Regulations implementing the Act on the principles of state property management. 
payment. The sale of stocks or shares belonging to the State Treasury is no longer going to be made under the hitherto-existing procedure of indirect privatisation, but instead on general principles defined in the Act on the principles of state property management (Article 11-12). One of the principal assumptions of that Act is to change the very philosophy in the scope of sale of stocks and shares of the State Treasury. In effect, such sale becomes just one of several elements of management of such state property, rather than the key process in this respect. The mechanism in force until now was based on the assumption that the Minister of the State Treasury was the principal body competent to sell stocks and shares on behalf of the State Treasury. Such sale occurred according to rules and along procedures defined in the Act on commercialisation and privatisation. Now, the rejection of that model consists in the adoption of the principle that stocks and shares are sold, on behalf of the State Treasury and upon approval from the Council of Ministers, by a body or person competent to execute the rights attached to such stocks or shares. Another abandoned element is the enumerative list of admissible types of privatisation. This was replaced with a solution in which a body or person seeking approval for the sale of stocks or shares proposes some specific method of such sale to the Council of Ministers. Eventually, the method of sale is going to be defined by the Council of Ministers at the time it approves the transaction to take place. According to the legislator's intention, the above solution is an expression of marketization of the sphere of execution of competences endowed to the State Treasury. At the same time, however, such sale, according to the new conditions, has to take the protection of the State Treasury's interests into account ${ }^{7}$.

Importantly, new regulations enact a total prohibition of selling stocks of companies which are regarded to have significant importance for the state economy. Such companies are enumeratively listed in Article 13 of the Act on the principles of state property management ${ }^{8}$. Legal sanction foreseen for any infringement of the

7 See: Justification to the draft act on the principles of state property management, op. cit.

8 The stocks of the following companies are included in the prohibition of sale: (1) Industrial Development Agency JSC based in Warsaw; 2) Enea JSC based in Poznan; 3) Energa JSC based in Gdańsk; 4) Warsaw Stock Exchange JSC based in Warsaw; 5) Azoty Group JSC based in Tarnów (chemical industry); 6) Azoty Group Chemical Plant JSC based in Police; 7) Azoty Group "Puławy" JSC based in Puławy (chemical industry); 8) LOTOS Group JSC based in Gdańsk (oil industry); 9) Jastrzębska Spółka Węglowa JSC based in Jastrzębie-Zdrój (coal mining); 10) KGHM Polska Miedź JSC based in Lubin (copper industry); 11) PGE (Polish Energy Group JSC based in Warsaw; 12) Polska Grupa Zbrojeniowa JSC based in Radom (defence industry); 13) Polish Development Fund JSC based in Warsaw; 14) Polish Oil and Gas Company PGNiG JSC based in Warsaw; 15) Polski Holding Nieruchomości JSC based in Warsaw (real estate); 16) Polski Holding Obronny limited liability company based in Warsaw (defence industry); 17) Polski Koncern Naftowy Orlen JSC based in Płock (oil industry); 18) PKP Polskie Linie Kolejowe JSC based in Warsaw (railways); 19) PKP Cargo JSC based in Warsaw (railways); 20) Powszechna Kasa Oszczędności Bank Polski JSC based in Warsaw (banking); 21) Powszechny Zakład Ubezpieczeń JSC based in Warsaw (insurances); 22) Polish Security Printing Works JSC based in Warsaw; 23) Totalizator Sportowy limited 
Act requirements (Article 11-15) concerning the sale of stocks and shares belonging to the State Treasury is that any legal action consisting such sale of stocks and shares would be declared null and void - according to Article 16 of the Act.

\section{Execution of rights attached to stocks and shares belonging to the State Treasury}

Under the legal status in force until recently, the function of the body responsible, in particular, for protection of the State Treasury interests, commercialisation, privatisation, and execution of rights attached to stocks and shares in companies with the State Treasury shareholding, was performed by the Minister the State Treasury. The new solution currently in force consists in the dissolution of a department of the State Treasury and of a ministry competent for the State Treasury ${ }^{9}$ affairs, and in the transfer of a substantial part of the Minister's of the State Treasury competences onto the Prime Minister. Pursuant to Article 7(1) of the Act on the principles of state property management, the Prime Minister coordinates the execution of competences endowed to the State Treasury in companies and strives to ensure a consistent manner of execution of rights attached to shares belonging to the State Treasury; executes the rights attached to shares belonging to the State Treasury, together with personal rights stemming therefrom, unless separate provisions provide for otherwise; executes the rights attached to shares belonging to the State Treasury on the general meeting of shareholders in issues mentioned in Article $201 \S 4$ and Article $368 \S 4$ of the Code of Commercial Companies ${ }^{10}$; and files, on behalf of the State Treasury, declarations of will about the establishment of the company, on the accession to the company or on acquisition of shares. Most of these competences may be passed down by the Prime Minister to another member of the Council of Ministers, to a proxy of the government or to a state legal person. In such case, the Council of Ministers is obliged to define, through a regulation, a list of companies in which such competences are executed by such other members of the Council of Ministers, proxies of the government or state legal persons. As this happens, the Prime Minister retains (along with the body/person authorised according to the above-mentioned procedure) the right to convoke or to demand to convoke the general meeting of shareholders and to include particular issues in its agenda - Article 8 of the Act.

liability society based in Warsaw (lotto games); 24) Tauron Polska Energia JSC based in Katowice (energy).

9 Article 23 of the Act - Provisions implementing the act on the principles of state property management, op. cit.

10 Act of 15 September 2000 - The Code of Commercial Companies (as in Journal of Law 2016, item 1578, 1579, 2255). 
The Council of Ministers, under the above-mentioned procedure, defined the list of companies in which the rights attached to shares belonging to the State Treasury are executed by members of the Council of Ministers other than the Prime Minister, heading departments relevant for the appropriate scope of activities ${ }^{11}$.

The change made in the model of execution of the ownership competences in the area of execution of rights attached to stocks and shares in companies belonging to the State Treasury should be assessed in several aspects. Most of all, the official transferring of those competences to the Prime Minister should be seen as a strengthening of the state supervision over companies with the State Treasury shareholding. Actually, the Prime Minister conveyed the right of execution of most competences with respect to such companies to members of the Council of Ministers. However, he retained the statutory obligation to coordinate the execution of competences endowed to the State Treasury in companies as well as the obligation to strive to ensure the uniform manner of execution of rights attached to shares belonging to the State Treasury (Article 7(1.1) together with Article 8(1) of the Act). It is assumed that to that purpose, the Prime Minister will apply measures to standardise the above-mentioned process, for example in the form of issuing orders binding to the bodies and persons under his authority in which the principles of the ownership supervision will be defined or précised ${ }^{12}$.

Additionally, another peculiar element in the present model of execution of rights attached to stocks and shares in the State Treasury companies is that actual supervision over individual companies of the State Treasury is transferred upon the ministers who head those departments of the government administration to which specific types of individual companies' activities are related. Supervision of particular ministries over companies of the State Treasury implies strengthening of the performance of the role the state plays in the economy through the performance of some tasks by the companies involved. This solution becomes especially significant in the case of companies which have a particular importance for the national economy ${ }^{13}$. In principle, the state performs its public functions that are strategic from the point of view of undisturbed development of the country (for example in such areas as defence, public security, provision of infrastructure, protection of citizens or another function in the area of public utility) through its actions undertaken in the sphere of empire. Such actions are supplemented by the state activity in the sphere of dominium, implemented by the State Treasury in

11 Regulation of 3 January 2017 of the Council of Ministers concerning the list of companies in which the rights attached to shares of the State Treasury are executed by persons other than the Prime Minister, members of the Council of Ministers, proxies of the government or state legal persons (Journal of Law 2017, item 10).

12 See: Justification to the draft act on the rules of the state property management, op. cit.

13 See: Regulation of 13 January 2017 of the Prime Minister concerning specification of the list of companies having a significant importance for the state economy (Journal of Law 2017, item 95). See also: Article 32 and 33 of the act on the principles of state property management, enacting more exacting rigours of execution of rights attached to shares in such companies. 
companies having strategic importance for the national economy. Therefore, from the point of view of economic instruments the state has in its arsenal, companies of the State Treasury having strategic importance for national economy constitute the crucial element of the performance of the vital public functions by the state. To entrust supervision over these companies to ministers who head those departments of the government administration to which specific types of individual companies' activities relate, undeniably strengthens the performance of economically and publicly important functions of the state.

\section{Management of the State Treasury's property}

The state property is used to perform public tasks. It is managed in line with rules of healthy economy, with all the due diligence required (Article 4 of the Act on the principles of state property management). In its Chapter 6, the Act puts forth detailed rules of managing state property other than shares, while Chapter 7 is dedicated to supervision over legal actions carried out by state legal persons (pursuant to Article 3(4), provisions of the Act concerning state legal persons do not apply to companies). What is especially noteworthy is the obligation, stemming from Article 38 of the Act, to obtain the approval of a relevant body for any action consisting in disposal of elements of fixed assets in the understanding of the Act on accountancy, classed as intangible and legal assets, of tangible fixed assets or long-term investments, including contributing them as contribution to a company or a cooperative, where the market value of such elements exceeds PLN 200,000. Another action that requires approval of a relevant body is where a state legal person involves in a legal action consisting in the release of such elements for disposal to another body, for a period longer than 180 days during a calendar year, if the value of the object of such legal action exceeds the amount of PLN 200,000. The Act specifies the detailed procedure for execution of such actions, the body whose approval is essential, as well as exceptions, both with respect to objects and to persons involved. Any legal action undertaken without the approval of such a relevant body, required under the Act, is deemed null and void. One should also point out the provisions of the Act on General Counsel to the Treasury of the Republic of Poland ${ }^{14}$ that will enter into force on the 1st of July 2017, in particular, its Articles 18-20. The bodies which represent the State Treasury will be obliged to seek the Counsel's legal opinion on draft acts, settlements and unilateral legal actions undertaken by the State Treasury, if the value of the object of such legal action exceeds the amount of PLN 100,000 (Article 18 of the Act). Pursuant to Article 20 of the Act, the bodies which represent the State Treasury, as well as

14 Act of 15 December 2016 on General Counsel to the Treasury of the Republic of Poland (Journal of Law 2016, item 2261). 
bodies represented which are state legal persons, are obliged to obtain the Counsel's legal opinion about the draft of the following: (1) a contract for provision of legal services if the sum of total remuneration earmarked for payment for the services provided will exceed the net amount of PLN 500,000 per annum; (2) an amendment to a contract for legal counselling which increases the level of such remuneration above the amount mentioned in (1) above; (3) a contract for legal counselling in which the ceiling level of remuneration is indefinite.

With respect to companies with a shareholding of the State Treasury or of other state legal persons, the legislator has not imposed, directly through an Act, an obligation of obtaining corporate approvals for some specific actions undertaken by the company. However, the legislator still obliges the bodies competent to execute the rights attached to shares belonging to the State Treasury or a state legal person, within the scope of execution of rights attached to that company's shares, to undertake actions aiming at the introduction, to the articles (partnership agreements) of such companies or through a resolution passed by the general meeting of shareholders, of appropriate provisions which will imply the obligation to obtain the approval of the general meeting (or, in some cases, of the supervisory body) of legal actions defined in the Act. The catalogue of such legal actions is extensive (Article 17 of the Act $^{15}$ ) and it relates to disposal of property, to releasing

15 Pursuant to Article 17 of the Act on the principles of state property management:

Any person competent to execute the rights attached to shares belonging to the State Treasury or state legal person, within the scope of execution of such rights attached to shares in the company, shall be obliged to undertake actions aimed to enact, through resolution of the general meeting of shareholders or in the company articles of association, that the following requires the approval of the general meeting: (1) disposing of elements of the fixed assets in the understanding of the Act of 29 September 1994 on the accountancy (Journal of Law 2016, items 1047 and 2255), classed as intangible and legal values, as tangible fixed assets or as long-term investments, including their contributing as contribution to a company or a cooperative, provided that the market value of such elements exceeds $5 \%$ of the sum of assets in the understanding of the Act of 29 September 1994 on the accountancy, defined on the basis of the most recent approved financial report, as well as releasing of these elements for disposal to another person for a period longer than 180 days during a calendar year, on the basis of a legal action, if the market value of such object of legal action exceeds $5 \%$ of the sum of assets, where such releasing for disposal in the case of: (a) rental contracts, lease contracts or other contracts on releasing an element of assets for disposal against payment to other persons - the market value of an object of legal action shall be understood as the value of benefits for: - one year - if the release of such a property element occurred on the basis of contracts made for an indefinite period, - the entire period of the contract validity - in the case of contracts made for a definite period, (b) contracts of and other non-chargeable contracts on releasing a property element for disposal to other persons the market value of an object of legal action shall be understood as an equivalent of benefits which would accrue should the rental or lease contract have been made, for: - one year - if the release of such a property element occurs on the basis of contracts made for an indefinite period, - the entire period of the contract validity - in the case of contracts made for a definite period; (2) the acquisition of elements of fixed assets in the understanding of the Act of 29 September 1994 
some specified elements of the property to another person to benefit therefrom, to acquisition of some elements of property, including acquisition of shares in another company, to disposal of shares in another company, to conclusion of a contract for provision of services including legal, marketing PR, social communication or management-related counselling services - which meet the terms and conditions defined in detail in the Act.

The above-described legal solutions give clear evidence of the legislator's obvious intention to significantly strengthen the supervision over operation of companies with a shareholding of the State Treasury or of other state legal persons. Quite importantly, a similar obligation was imposed with respect to companies subsidiary to companies with shareholding of the State Treasury or of other state legal persons (to be more precise: this relates to companies, towards which a company with shareholding of the State Treasury or a state legal person acts as the dominant entrepreneur in the understanding of the Act on the competition

on the accountancy, whose value exceeds: (a) the amount of PLN 100,000,000 or (b) the value of $5 \%$ of the sum of assets in the understanding of the Act of 29 September 1994 on the accountancy, defined on the basis of the most recent approved financial report; (3) the acquisition of shares or acquisition of shares of another company, for the value exceeding: (a) the amount of PLN $100,000,000$ or (b) the value of $10 \%$ of the sum of assets in the understanding of the Act of 29 September 1994 on the accountancy, defined on the basis of the most recent approved financial report; (4) sale of shares of another company, for the value exceeding: (a) the amount of PLN 100,000,000 or (b) the value of $10 \%$ of the sum of assets in the understanding of the Act of 29 September 1994 on the accountancy, defined on the basis of the most recent approved financial report. 2. A person entitled to execute the rights attached to shares belonging to the State Treasury or a state legal person, within the scope of execution of the rights attached to shares in a company, shall be obliged to undertake actions aimed to enact, through resolution of the general meeting of shareholders or in the company articles of association, that conclusion of the following requires the approval of the supervisory body: (1) a contract for legal services, marketing services, public relations and social communication services as well as counselling services in the scope related with management, if the total value of remuneration earmarked for performance of such services exceeds the net amount of PLN 500,000 per annum; (2) any amendments made to contracts for legal services, marketing services, public relations and social communication services as well as counselling services in the scope related with management, if such amendments raise the level of remuneration above the amount mentioned in (1) above; 3) contracts for legal services, marketing services, public relations and social communication services as well as counselling services in the scope related with management, in which no ceiling levels are defined for remuneration. 3. Any person competent to execute the rights attached to shares belonging to the State Treasury or state legal person, within the scope of execution of such rights attached to shares in the company, shall be obliged to undertake actions aimed to enact, through resolution of the general meeting of shareholders or in the company articles of association, that conclusion, by the company, of the following types of contracts requires the approval of the company' supervisory body: (1) donation or another agreement resulting in a similar effect for the value exceeding the amount of PLN 20,000 or $0.1 \%$ of the sum of the assets in the understanding of the Act of 29 September 1994 on the accountancy, defined on the basis of the most recent approved financial report; (2) release from debt or 
and consumers protection ${ }^{16}$ - Article 17(7) of the Act on the principles of state property management). The strengthening of supervision is also achieved through provisions of the Act concerning the appointment of members of the managing and supervisory boards or requirements regarding the eligibility of such persons (Article 18 and subs. of the Act) (see: more in: Kozłowska-Chyła, 2017, p. 13 ff.).

Finally, a similar effect is achieved by the appointment of the Council for companies with a shareholding of the State Treasury and of state legal persons. The scope of competences of the Council includes most of all, issuing opinions concerning the candidates for members of supervisory boards, indicated by the State Treasury or a state legal person. The Council also gives its opinions about candidates for members of supervisory bodies in companies in relation to which a company with the State Treasury shareholding or a state legal person is the dominant entrepreneur in the understanding of provisions of the Act on competition and customers protection (Article 24(1) of the Act on the principles of state property management). In this context, it should be emphasised that the Council's opinions about the above-mentioned candidates are obligatory. Apart from that and in a nonobligatory manner, the Council may also deliver its opinions about candidates for

another agreement resulting in a similar effect for the value exceeding the amount of PLN 50,000 or $0.1 \%$ of the sum of the assets in the understanding of the Act of 29 September 1994 on the accountancy, defined on the basis of the most recent approved financial report. 4. Any person competent to execute the rights attached to shares belonging to the State Treasury or state legal person, within the scope of execution of such rights attached to shares in the company, shall be obliged to undertake actions aimed to enact, through resolution of the general meeting of shareholders or in the company articles of association, the rules concerning disposal of fixed assets in the understanding of the Act of 29 September 1994 on the accountancy. Such rules have to consider the application of the tender procedure and exceptions from its obligatory application, where the company disposes the elements of its fixed assets for the value exceeding $0.1 \%$ of the sum of the assets in the understanding of the Act of 29 September 1994 on the accountancy, defined on the basis of the most recent approved financial report, unless that value exceeds not the amount of PLN 20,000. 5. Any person competent to execute the rights attached to shares belonging to the State Treasury or state legal person, within the scope of execution of such rights attached to shares in the company, shall have the right to undertake actions aimed to enact, through resolution of the general meeting of shareholders or in the company articles of association, the requirements that are more strict than those defined in paragraphs 1-4 above. 6. Any person competent to execute the rights attached to shares belonging to the State Treasury or state legal person, within the scope of execution of such rights attached to shares in the company, shall be obliged to undertake actions aimed to enact, through resolution of the general meeting of shareholders or in the company articles of association, the obligation to present to the general meeting of shareholders, by the managing body, of a report, complete with the opinion given by the supervisory body, on expenses borne on representation as well as expenses on legal services, marketing services, public relations and social communication services as well as counselling services in the scope related with management.

16 Article 4(3) of the Act of 16 February 2007 on the protection of competition and customers (as in Journal of Law 2015, item 184 with later amendments). 
managing bodies of companies with a shareholding of the State Treasury or a state legal person and their subsidiary companies (Article 26 of the Act) ${ }^{17}$. Furthermore, the Council also has competences in the area of issuing opinions concerning the documents of the state policy in the field of the state property management, drafts of normative acts in the field of the state property management and - upon the Prime Minister's motion - about issues concerning the management of the state property (Article 24(2), 24(3) and 24(5) of the Act).

\section{Conclusion}

The above-presented review of normative solutions in selected areas indicates the legislator's evident intention to strengthen the role of the state operating in the sphere of dominium. What we see in the field of ownership relations with the state participation is, most of all, consolidation of the hitherto-existing scope of the state ownership through the normative abandonment of the procedures of direct and indirect privatisation of the state property. The new juridical model currently in force relies upon the assumption that sale of stocks or shares belonging to the State Treasury or to another state legal person requires an approval given as high as at the level of the Council of Ministers. At the same time, any possibility of selling shares of a group of precisely listed twenty-four companies reckoned to have strategic importance for national economy has been excluded altogether. These companies include, among others, Azoty Group JSC, Lotos Group JSC, Jastrzębska Spółka Węglowa JSC, KGHM Polska Miedź JSC, PKN Orlen JSC, PZU JSC or PKO BP JSC. All companies having significance for the state economy (at present thirty of them) have been subordinated to the particular supervision of the Prime Minister. The legislator's efforts also tend to improve the efficacy of the state operation within the area of ownership relations, i.e. in the sphere of dominium, through increased scopes and efficiency of supervision over the state property. This is especially evident in the area of operation of companies with a shareholding of the State Treasury or of other state legal persons. In effect, the legal instruments applied to increase the state's scope of involvement in private and legal relations in which it participates.

\section{Bibliography}

Całus, A. (1995). Problematyka prawna Skarbu Państwa (The State Treasury - Legal Issues). Biuletyn Rady Legislacyjnej, 6.

17 More about the structure and the manner of operation of the Council for companies with the State Treasury shareholding and state legal persons - see Kozłowska-Chyła, 2017, p. 13 ff. 
Frąckowiak, J. (2012). W: M. Safjan (ed.), System Prawa Prywatnego. Prawo cywilne - część ogólna (The Private Law System. Civil Law - general part) (vol. I, p. 1175 ff). Warsaw: C.H. Beck.

Kozłowska-Chyła, B. (2017). Nowe regulacje zasad zarządzania mieniem państwowym w zakresie powoływania i odwoływania członków organów nadzorczego i zarządzającego w spółkach z udziałem Skarbu Państwa (New regulation of principles of state property management in the scope of the appointment and revoking of members of supervisory and managing bodies in companies with the State Treasury shareholding). Przeglad Ustawodawstwa Gospodarczego, 2.

Regulation of 13 January 2017 of the Prime Minister concerning specification of the list of companies having significant importance for the state economy. Journal of Law 2017, item 95.

Regulation of 3 January 2017 of the Council of Ministers concerning the list of companies in which the rights resulting from the State Treasury shareholding are executed by persons other than the Prime Minister, members of the Council of Ministers, proxies of the government or state legal persons. Journal of Law 2017, item 10.

Act of 15 December 2016 on General Counsel to the Treasury of the Republic of Poland. Journal of Law 2016, item 2261.

Act of 15 September 2000 - The Code of Commercial Companies. Journal of Law 2016, item 1578, 1579, 2255.

Act of 16 December 2016 - Provisions implementing the Act on the rules of the state property management. Journal of Law 2016, item 2260.

Act of 16 December 2016 on the rules of the state property management. Journal of Law 2016, item 2259.

Act of 16 February 2007 on the protection of competition and customers. Journal of Law 2015, item 184 with later amendments.

Act of 30 August 1996 on commercialisation and privatisation. Journal of Law 2016, item 981 with later amendments.

Act of 8 August 1996 on the rules regulating execution of competences awarded to the State Treasury. Journal of Law 2016, item 154 with later amendments.

Justification to the draft act on the rules of the state property management.

www.orka.sejm.gov.pl. 


\title{
NOWA EKONOMIA STRUKTURALNA WOBEC KRAJÓW MNIEJ ZAAWANSOWANYCH
}

\author{
Redakcja naukowa: \\ Justin Yifu Lin i Alojzy Z. Nowak
}

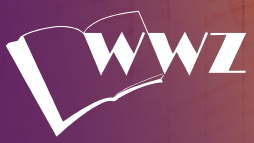

Wydawnictwo Naukowe

Wydziału Zarzadzania

Uniwersytetu Warszawskiego

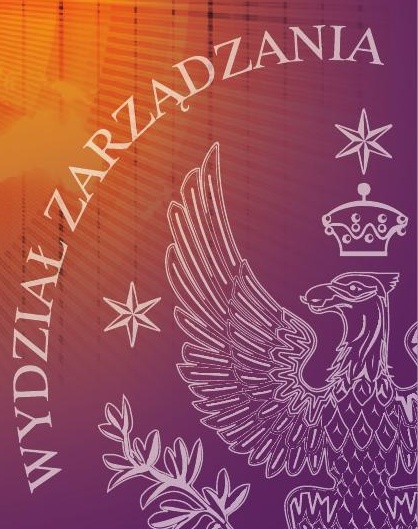





\section{Noty o Autorach}

Bogdan Góralczyk - profesor w Centrum Europejskim Uniwersytetu Warszawskiego; politolog i sinolog. Były szef Gabinetu Politycznego Ministra Spraw Zagranicznych (2001-2003) i długoletni dyplomata, m.in. w latach 2003-2008 ambasador RP w Tajlandii, na Filipinach i w Związku Mjanma (d. Birma). Od 1 września 2016 r. dyrektor Centrum Europejskiego UW. Stały komentator kanału TVN24 Biznes $i$ Swiat oraz w Instytucie Obywatelskim; częsty gość radia TOK FM. Publikuje m.in. na łamach portalu NBP „Obserwator Finansowy” i wp.pl. Autor wielu książek i publikacji na temat Chin i Azji, problemów globalnych oraz Węgier, m.in.: Zmierzch i brzask. Notes z Bangkoku, Toruń 2009/2010; Chiński Feniks. Paradoksy wschodzacego mocarstwa, Warszawa 2010; Ztota Ziemia roni tzy. Esej birmański, Warszawa 2011; Przebudzenie smoka. Powrót Chin na scenę globalna, Warszawa 2012; Sun Yat-sen. Misjonarz rewolucji, Warszawa 2013. Redaktor i współautor tomów: Polska-Chiny. Wczoraj, dziś, jutro, Toruń 2010 (wersja anglojęzyczna 2014); Unia Europejska jako aktor na scenie globalnej. Razem czy osobno?, Warszawa 2014 (rozszerzona wersja anglojęzyczna w przygotowaniu) oraz European Union in the Global Scene: United or Irrelevant?, Warszawa 2015.

Wykłada w kraju i za granicą. Specjalizuje się w tematyce globalnej i azjatyckiej (Chiny, Birma-Mjanma, Tajlandia, Filipiny), ale w polu jego zainteresowań znajdują się także kwestie z zakresu Protokołu Dyplomatycznego oraz różnic kulturowych (z racji wieloletniego doświadczenia dyplomatycznego i długoletnich pobytów za granicą).

Marian Górski - profesor ekonomii; kierownik Katedry Systemów Finansowych i Zakładu Bankowości i Rynków Pieniężnych na Wydziale Zarządzania Uniwersytetu Warszawskiego. Specjalizuje się w finansach, bankowości, makroekonomii, polityce pieniężnej. Autor i współautor wielu monografii i artykułów naukowych. Jego podręcznik akademicki pt. System finansowy gospodarki był trzykrotnie wydawany (2007; 2009; 2013). W latach 1990-1996 dziekan Wydziału Zarządzania UW. Obecnie członek Senatu Uniwersytetu Warszawskiego, przewodniczący senackiej komisji ds. budżetu i finansów.

Był i jest związany z praktyką gospodarczą. W latach 1991-2005 członek i przewodniczący rady nadzorczej jednego z większych banków w Polsce - BZWBK S.A. Jako partner firmy consultingowej Premium-econ w latach 1991-2003 doradzał m.in. Ministrowi Skarbu Państwa i Ministrowi Gospodarki. Aktualnie członek Rady ds. stawek referencyjnych WIBID i WIBOR, która nadzoruje rynek depozytów międzybankowych w Polsce. 
Grzegorz Jędrzejczak - doktor habilitowany, profesor UW. W latach 1989-1991 podsekretarz stanu w Ministerstwie Przekształceń Własnościowych odpowiedzialny za stworzenie polskiego rynku kapitałowego. W latach 1993-2013 pracownik Banku Światowego w Waszyngtonie w Departamencie Rozwoju Prywatnego Sektora i Systemu Finansowego Europy i Azji Centralnej oraz przedstawiciel Banku Światowego w Ukrainie i Azerbejdżanie. Członek Rady Nadzorczej Polskiej Fundacji Badań nad Zarządzaniem oraz IBD Business School.

Od lat 80 . XX w. z powodzeniem łączy zainteresowania naukowe z działalnością praktyczną. Obszary jego zainteresowań obejmują: prywatyzację, tworzenie regulowanych rynków kapitałowych, powstawanie ładu korporacyjnego w Polsce i innych krajach przechodzących transformację od gospodarki planowej do gospodarki rynkowej. Ważnym obszarem jego działalności praktycznej i analitycznej były programy rozwojowe w krajach rozwijających się oraz możliwości pomocy ze strony organizacji międzynarodowych, ze szczególnym uwzględnieniem Banku Światowego. Obecnie specjalizuje się $\mathrm{w}$ tematyce $\mathrm{z}$ zakresu uwarunkowań polityki gospodarczej promującej innowacyjność w krajach o średnich dochodach oraz analizy długookresowych szans i zagrożeń gospodarki polskiej.

Beata Kozłowska-Chyła - doktor habilitowany nauk prawnych; pracownik naukowy na Wydziale Prawa i Administracji Uniwersytetu Warszawskiego w Katedrze Prawa Handlowego Instytutu Prawa Cywilnego; wykładowca na Wydziale Nauk Ekonomicznych Uniwersytetu Warszawskiego. Radca prawny specjalizujący się w sprawach gospodarczych. Członek zarządów i rad nadzorczych dużych spółek akcyjnych, w tym spółek z udziałem Skarbu Państwa. Arbiter rekomendowany w Sądzie Arbitrażowym przy Krajowej Izbie Gospodarczej w Warszawie.

Autorka licznych publikacji naukowych z zakresu prawa spółek, prawa papierów wartościowych, problematyki przekształceń własnościowych i prywatyzacji przedsiębiorstw oraz prawa ubezpieczeniowego, m.in.: Reprezentacja spótki kapitatowej w organizacji, Warszawa 2015; Komentarz do Ustawy o dziatalności ubezpieczeniowej $i$ reasekuracyjnej (współaut.), Warszawa 2017; Nowe regulacje zasad zarzadzania mieniem państwowym $w$ zakresie powolywania i odwolywania cztonków organów nadzorczego i zarzadzającego w spótkach z udziatem Skarbu Państwa, PUG 2/2017; Wyzwania globalizacji dla rynku ubezpieczeń (współaut.), Warszawa 2016; Postępowanie administracyjne $w$ sprawie zezwolenia na wykonywanie dziatalności ubezpieczeniowej $i$ reasekuracyjnej - wybrane aspekty (współaut.), Wiadomości Ubezpieczeniowe 2/2016; Jurydyczna koncepcja podmiotowości spótki partnerskiej a status prawny jej zarzadu, Forum Prawnicze 2/2015; Zdolność prawna handlowych spótek osobowych na przyktadzie spótki partnerskiej, Forum Prawnicze 3/2015; Nieformalny zarzad spótki partnerskiej, PUG 5/2015; Tryb wytaniania zarządu w spótkach zależnych od spótek Skarbu Państwa, Wrocław 2015; Petnomocnik w obrocie wekslowym - uwagi na tle art. 8 Prawa wekslowego, PUG 9/2015; Status prawny zawieszonego cztonka zarzadu spótki akcyjnej oraz wplyw zawieszenia na strukturę organizacyjna zarzqdu, PPH 5/2015. 
Michał Kurtyka - absolwent prestiżowej paryskiej uczelni Ecole Polytechnique, gdzie uzyskał w 1996 r. tytuł inżyniera. Stypendysta w zakresie optyki kwantowej, znajdującego się pod Waszyngtonem (DC), National Institute of Standards and Technologies, gdzie pracował pod przewodnictwem, laureata Nagrody Nobla z fizyki, Williama D. Phillipsa, będącego jednocześnie promotorem jego pracy dyplomowej dotyczącej warunków powstania kondensatu Bosego-Einsteiena. W trakcie studiów specjalizował się również w ekonomii, ze szczególnym uwzględnieniem organizacji rynku pod przewodnictwem prof. Jean Tirole, laureata Nagrody Nobla z ekonomii w 2014 r. W obszarze ekonomii międzynarodowej studiował na uniwersytecie w Louvain La Neuve oraz uzyskał tytuł magistra w Szkole Głównej Handlowej w Warszawie.

Pracownik Urzędu Komitetu Integracji Europejskiej, gdzie prowadził zespół analityczny wspierający negocjacje akcesyjne z Unią Europejską w zespole Głównego Negocjatora, Jana Kułakowskiego, oraz bezpośrednio zajmował się obszarem transportu i energii. Jako doradca współprowadził projekty modernizacji największych polskich firm i wspierał ich dostosowanie do wyzwań rynku europejskiego. Promotor europejskiej współpracy w zakresie zmian przemysłowych i dostosowania przemysłu w Europie do wyzwań globalizacji, m.in. w ramach Europejskiego Uniwersytetu Pracy oraz Fundacji Dublińskiej.

Obronił pracę doktorską na Uniwersytecie Warszawskim. Wykładowca zarządzania zmianą, ekonomii, organizacji rynku i strategii przemysłowej na Uniwersytecie Warszawskim, Collegium Civitas, Oxford Programme On Modern Poland. Współautor koncepcji prowadzenia skutecznych zmian w przedsiębiorstwie opisanej w książce pt. Zarzqdzanie zmiana. Od strategii do działania, jak również autor książki pt. Od restrukturyzacji do modernizacji. Opóźniona transformacja polskiego sektora elektroenergetycznego w latach 1990-2009.

Autor rządowego programu rozwoju elektromobilności w Polsce, opisanego po raz pierwszy jako koncepcja w książce we współautorstwie z prof. Leszkiem Jesieniem, New Electricity and New Cars (2013/2015), a następnie w postaci dokumentu, przyjętego przez Radę Ministrów w marcu 2017 roku jako Plan Rozwoju Elektromobilności.

Justin Yifu Lin - profesor i honorowy dziekan Krajowej Szkoły Rozwoju Uniwersytetu Pekińskiego. W 1986 r. uzyskał stopień doktora ekonomii na Uniwersytecie w Chicago, a w 1987 r. powrócił do Chin. Przez piętnaście lat pełnił funkcję dyrektora-założyciela Chińskiego Centrum Ekonomii Uniwersytetu Pekińskiego, którego był również profesorem. W latach 2008-2012 piastował stanowiska głównego ekonomisty i wiceprezesa Banku Światowego jako pierwszy ekonomista z kraju rozwijającego się.

Zagraniczny członek Akademii Brytyjskiej, członek Academy of Sciences for the Developing World; doktor honoris causa Uniwersytetu w Owernii.

Autor dwudziestu pięciu książek, w tym Economic Development and Transition: Thought, Strategy and Viability (2009); Demystifying the Chinese Economy (2011); 
New Structural Economics: A Framework for Rethinking Development and Policy (2012); The Quest for Prosperity: How Developing Countries Can Take Off (2012); Against the Consensus. Reflections on the Great Recession (2013).

Jego skłaniające do refleksji prace inspirują pracowników naukowych, studentów, decydentów oraz wszystkie osoby interesujące się gospodarką światową.

Mateusz Morawiecki - powołany na stanowisko Wiceprezesa Rady Ministrów oraz Ministra Rozwoju 16 listopada 2015 r., na stanowisko Wiceprezesa Rady Ministrów i Ministra Rozwoju i Finansów - 28 września 2016 r.

W 1998 r. zastępca dyrektora Departamentu Negocjacji Akcesyjnych w Komitecie Integracji Europejskiej. Członek zespołu, który negocjował warunki przystąpienia Polski do Unii Europejskiej, m.in. w obszarze finansów. Następnie związał się z Grupą Banku Zachodniego WBK (wcześniej z Bankiem Zachodnim). Od maja 2007 r. prezes zarządu tej instytucji.

Ukończył historię na Uniwersytecie Wrocławskim, studia Business Administration na Politechnice Wrocławskiej i Central Connecticut State University. Uzyskał dyplom MBA Akademii Ekonomicznej we Wrocławiu. Absolwent Uniwersytetu w Hamburgu, Uniwersytetu w Bazylei oraz Kellog School of Management Uniwersytetu Northwestern, Evanston w Stanach Zjednoczonych.

Współautor podręcznika z zakresu prawa unijnego i ekonomiki integracji gospodarczej. W latach 1998-2001 członek rad nadzorczych Agencji Rozwoju Przemysłu i Zakładu Energetycznego Wałbrzych. Zasiadał też w sejmiku dolnośląskim I kadencji. Od 2008 r. do objęcia stanowiska wicepremiera i Ministra Rozwoju konsul honorowy Republiki Irlandii w Polsce. W 2013 r. odznaczony Krzyżem Wolności i Solidarności; w 2015 r. - Krzyżem Kawalerskim Orderu Odrodzenia Polski.

Alojzy Zbigniew Nowak - profesor nauk ekonomicznych; absolwent: SGPiS (obecnie Szkoła Główna Handlowa w Warszawie); w zakresie ekonomii - University of Illinois at Urbana-Champaign w Stanach Zjednoczonych i Free University of Berlin oraz International Economics at RUCA w Antwerpii; w zakresie bankowości, finansów i rynków kapitałowych - Uniwersytetu w Exeter w Wielkiej Brytanii. W roku 1991 otrzymał nagrodę Rektora za pracę doktorską; dwukrotnie został wyróżniony Nagrodą Ministra Edukacji Narodowej - w 1996 r. za książkę Banki a gospodarstwa domowe - dynamika rozwoju, a w 2002 r. za monografię Integracja europejska. Szansa dla Polski.

Od roku 1985 zatrudniony na Wydziale Zarządzania Uniwersytetu Warszawskiego, gdzie pełnił funkcję prodziekana do spraw współpracy z zagranicą oraz przez dwie kadencje dziekana Wydziału. W latach 2012-2016 prorektor ds. Badań Naukowych i Współpracy Uniwersytetu Warszawskiego. Obecnie dziekan Wydziału Zarządzania Uniwersytetu Warszawskiego. 
Autor licznych publikacji naukowych w języku polskim, angielskim, niemieckim i rosyjskim; laureat wielu nagród, wyróżnień, uczestnik organizacji naukowych i członek rad programowych wielu czasopism.

Visiting Professor w: University of Cambridge; Postgraduate Business School, Grenoble, Francja; University of North Florida USA; Rostov University; University of North Colorado; The Catholic University of America; Freie Universitat Berlin; University of Illinois at Urbana-Champaign.

Kazimierz Ryć - profesor nauk ekonomicznych; zatrudniony na Wydziale Zarządzania Uniwersytetu Warszawskiego. Karierę naukową rozpoczął jako asystent w Katedrze Ekonomii Politycznej, kierowanej przez wybitnego polskiego ekonomistę prof. Oskara Langego, promotorem jego pracy doktorskiej był zaś prof. Włodzimierz Brus. W latach 70. XX w. odbył trzy staże naukowe we Francji na Sorbonie. Współautor zrealizowanej koncepcji popularnej motoryzacji w Polsce. Współtwórca Wydziału Zarządzania Uniwersytetu Warszawskiego - najstarszego wydziału biznesu w Polsce, pierwszego w Europie Środkowo-Wschodniej. Ekspert w Komisji ds. Reformy Gospodarczej; kierownik Zakładu Gospodarki Rynkowej.

Wielokrotny prodziekan i dziekan Wydziału Zarządzania Uniwersytetu Warszawskiego. Obecnie wykłada makroekonomię, politykę makroekonomiczną i sektorową oraz politykę społeczną. Opiekuje się przewodami doktorskimi, prowadzi badania naukowe w dwóch obszarach: makroekonomii i sektora ochrony zdrowia. Autor wielu publikacji z zakresu zmian dynamiki struktury konsumpcji, polityki przemysłowej oraz problemów polityki makroekonomicznej w warunkach integracji ponadnarodowej i globalizacji.

Andrzej Sopoćko - profesor od 1994 r. (tytuł nadany przez Prezydenta RP); zatrudniony na Wydziale Zarządzania Uniwersytetu Warszawskiego oraz w Polskiej Akademii Nauk. Jeden z twórców polskiej transformacji ustrojowej początku lat 90. Wiodąca postać w procesie tworzenia ustawy antymonopolowej i Urzędu Ochrony Konkurencji i Konsumenta. Prezes UOKiK w latach 1995-1997. Odegrał znaczącą rolę przy powstawaniu Giełdy Papierów Wartościowych (na początku jako Member of Board, a następnie, w latach 2003-2006, jako wiceprezes). Główny doradca ekonomiczny premiera, wiceminister finansów (w latach 2001-2003).

Autor licznych (ok. 150, w tym 8 książek) publikacji. Odbywał staże zagraniczne - trzykrotnie w RFN, trzykrotnie w USA, w Szwajcarii, w Rosji. Laureat nagród i wyróżnień: trzykrotnie nagrodzony przez Polską Akademię Nauk za najlepszą książkę roku w zakresie nauk społecznych oraz czterokrotnie - przez Ministra Nauki.

Wychował dwoje dzieci i trzy psy. 
Henryk Sterniczuk - profesor zarządzania i biznesu międzynarodowego w University of New Brunswick w Kanadzie. Wieloletni dyrektor MBA w University of New Brunswick i profesor Wydziału Biznesu w The Pensylwania State University w USA. W latach 90. XX w. doradca Ministra Przekształceń Własnościowych i założyciel Centrum Prywatyzacji w Polsce, Instytutu Prywatyzacji i Zarządzania w Rosji oraz Międzynarodowego Instytutu Biznesu na Ukrainie, Białorusi i Kazachstanie. Przewodniczący Rady Nadzorczej Polskiej Fundacji Badań nad Zarządzaniem oraz Przewodniczący Rady Naukowej IBD Business School.

Jego zainteresowania naukowe to m.in. uwarunkowania społeczne i kulturowe procesu generowania innowacji w post-industrialnych społeczeństwach innowacyjnych. Autor i redaktor naukowy obszernej monografii pt.: Nadzór korporacyjny, która kompleksowo przedstawia najważniejsze zagadnienia dotyczące kształtowania w Polsce zasad ładu korporacyjnego i dobrych praktyk w spółkach.

Grzegorz Tchorek - doktor; adiunkt na Wydziale Zarządzania Uniwersytetu Warszawskiego; doradca w Narodowym Banku Polskim.

Pracę doktorską obronił na Wydziale Zarządzania Uniwersytetu Warszawskiego w 2007 r. Dysertacja, pt. Teoria optymalnego obszaru walutowego a praktyka akcesyjna, została nagrodzona przez Prezesa Rady Ministrów w 2008 r.

Główny wykonawca i współwykonawca kilku grantów realizowanych w Narodowym Centrum Nauki oraz Narodowym Banku Polskim. Autor publikacji z zakresu integracji walutowej, handlu zagranicznego, kursu walutowego i innowacyjności przedsiębiorstw.

Współautor i redaktor zespołowych projektów badawczych, m.in. raportu dotyczącego bilansu korzyści i kosztów przyjęcia euro w Polsce przygotowanego w NBP w 2009 r. pt. Report on full membership of the Republic of Poland in the third stage of the Economic and Monetary Union; raportu dotyczącego oceny konkurencyjności polskiej gospodarki przygotowanego w 2014 r. pod redakcją prof. Jerzego Hausnera, pt. Competitive Poland. How to Advance in Global Economic League? Recommendations oraz raportu podejmującego problematykę innowacyjności w Polsce pod redakcją prof. Andrzeja Sławińskiego oraz prof. Jakuba Growca z 2016 r., pt. The innovative potential of the economy: condition prospects. Realizowanego w latach 2012-2016 projektu pn. The Euro introduction and competitiveness of Polish enterprises.

W polu jego zainteresowań znajdują się: problematyka integracji europejskiej i walutowej, międzynarodowy system walutowy, międzynarodowe stosunki gospodarcze, polityka regionalna oraz aktualnie: problematyka mikroekonomiczna i sektorowa w zakresie umiędzynarodowienia przedsiębiorstw, eksport i bezpośrednie inwestycje zagraniczne, konkurencyjność gospodarek i przedsiębiorstw oraz ich innowacyjność. 


\section{Przedmowa}

Polska po dwudziestu ośmiu latach od dokonania transformacji ustrojowej i gospodarczej oraz po ponad dziesięciu latach swojego członkostwa w Unii Europejskiej stanęła przed niełatwym wyzwaniem opracowania spójnej polityki gospodarczej. Takiej, która z jednej strony zapewni kontynuację oraz szerokie zdyskontowanie dotychczasowych osiągnięć, z drugiej zaś - dostosuje polski rozwój do wyzwań zewnętrznych i oczekiwań polskiego społeczeństwa.

Ostatnie wskaźniki gospodarcze wskazują na niespotykany dotąd w polskiej historii rozkwit gospodarczy. Na koniec maja 2017 roku stopa bezrobocia wyniosła 7,4\%, co jest najniższym wynikiem po 1989 roku. Z kolei ostatnie badanie CBOS wskazuje, że $42 \%$ Polaków ocenia bieżącą sytuację ekonomiczną jako dobrą, co daje najlepszy wynik w historii. Tylko w samym 2017 roku odsetek ten wzrósł o 11\%. I co równie ważne - wreszcie znacząco spadł wskaźnik nierówności finansowych między Polakami. Od września 2015 roku różnica między 25\% najlepiej a 25\% najgorzej sytuowanymi Polakami spadła w kwietniu 2017 roku z poziomu 5,9 do 4,4!

Przez pierwsze ćwierćwiecze wolności Polska była pozbawiona spójnej polityki gospodarczej. Głównym wektorem podejmowanych działań przed unijną akcesją było dostosowanie legislacji i polityki budżetowej do wymogów określonych przez Unię Europejską. Z kolei po 2004 roku nasz rozwój został oparty na wykorzystywaniu funduszy unijnych. Niestety, mimo dużej efektywności pozyskiwania przyznanych nam środków (z danych udostępnionych przez Komisję Europejską wynika, że Polska wykorzystała budżet UE z lat 2007-2013 w 95\%), fundusze te nie złożyły się na jeden a priori ustalony cel, mający stać się wehikułem polskiej gospodarki.

Wreszcie zero-jedynkowe podejście do teorii ekonomicznych, które zantagonizowało gospodarkę centralnie planowaną do gospodarki neoliberalnej spowodowało, że Polska weszła w model rozwojowy opracowany przez państwa zachodnie, nieuwzględniający specyfiki historycznej i społecznej Europy Środkowo-Wschodniej. Fundament, na którym budowaliśmy dotychczas polski kapitalizm i dobrobyt stanowił zbiór reguł tzw. konsensusu waszyngtońskiego, niedoceniający brzemienia charakterystyki postkomunistycznej rzeczywistości. Klasyczna teoria neoliberalna nie sprawdziła się w pełni w krajach naszego regionu. Jednak przez wiele lat była ona postrzegana jako nienaruszalny aksjomat, co uniemożliwiało dostosowanie rzeczywistych potrzeb rozwojowych do prowadzonej polityki. 
Kryzys gospodarczy 2009 roku pozwolił na dokonanie rewizji powszechnie uznawanych teorii ekonomicznych. $Z$ coraz większą uwagą śledzono poglądy takich autorów, jak Justin Yifu Lin. Dzięki tej zmianie z mniejszą podejrzliwością, z większym zaś zainteresowaniem zaczęto spoglądać na teorie łagodzące neoliberalizm, zaopatrujące go w pierwiastki solidarystyczne oraz dostrzegające potencjał i przestrzeń dla aktywnej roli państwa. Nowa Ekonomia Strukturalna to nie tylko czysta teoria. Yifu Lin, propagując ją, opiera się na doświadczeniach empirycznych, badających różnice i doświadczenia krajów, które osiągnęły sukces gospodarczy, nie podążając klasyczną drogą neoliberalizmu.

Nową Ekonomię Strukturalną można określić jako nową doktrynę pokazującą pułapki, przed jakimi stają kraje rozwijające się, zbliżające się już do statusu krajów rozwiniętych. Co jednak ważniejsze, pokazuje ona rozwiązania i recepty, pozwalające na przebicie się przez średni wzrost i realne dogonienie najbogatszych państw. Polską odpowiedzią na tę doktrynę jest Strategia na rzecz Odpowiedzialnego Rozwoju (SOR). To pierwszy dokument uwzględniający zarówno oczekiwania społeczne, jak i potrzebę nadania nowego, prorozwojowego impulsu. Uważam, że Polska XXI wieku powinna opierać się na trwałym wzroście gospodarczym zbudowanym dzięki reindustrializacji gospodarki i rozwoju małych i średnich oraz innowacyjnych firm, rozwoju społecznie wrażliwym i terytorialnie zrównoważonym, a także skutecznym państwie i jego instytucjach. Wszystkie te działania przewidują aktywną rolę administracji, daleką od koncepcji leseferystycznych. Nie można uciec od refleksji, przedstawionej przez Prof. Góralczyka, że funkcjonujący na Zachodzie dogmat o braku trzeciej drogi, o braku alternatywy dla klasycznego kapitalizmu i realnego socjalizmu powinien zostać jak najszybciej obalony. Trzecia droga istnieje, stała się udziałem sukcesu tygrysów azjatyckich, a obecnie coraz więcej państw Zachodu stara się z niej czerpać. Polska chce być pionierem tych rozwiązań w tej części świata. Co jednak równie istotne - nie mamy zamiaru bezmyślnie kopiować cudzych rozwiązań. Nasza Strategia w pełni uwzględnia polską specyfikę i jest dostosowana do naszych potrzeb i oczekiwań.

Jedną z największych wad prowadzonej, po transformacji, polityki gospodarczej był brak synchronizacji pomiędzy wzrostem PKB a wzrostem zamożności wszystkich grup społecznych w Polsce. Wysoki wzrost gospodarczy często nie był wystarczająco odczuwany przez rodziny i gospodarstwa domowe, co skutkowało rozczarowaniem i zniechęceniem do elit politycznych. Niesłusznie uznano, za tezami konsensusu waszyngtońskiego, że neoliberalna gospodarka doprowadzi do zatarcia różnic rozwojowych. W związku z tym za słuszne należy uznać podawane przez Yifu Lina tezy, w których wiąże on dochody per capita ze stabilnym i równomiernym wzrostem. Według tej teorii, niemożliwe jest odniesienie sukcesu przez kraje doganiające bez bogacenia się całego społeczeństwa. Dlatego po 25 latach, w trakcie których jedynie część społeczeństwa odczuwała skutki wzrostu PKB, rząd Prawa i Sprawiedliwości zdecydował się na dokonanie niespotykanych do tej pory transferów społecznych. Co szczególnie dla nas istotne, to fakt, iż są to świadczenia niezagrażające stabil- 
ności finansów publicznych. Stawiamy na budżet bardziej redystrybucyjny, ale też w pełni odpowiedzialny. Dzięki temu polski sukces gospodarczy stanie się udziałem całego społeczeństwa.

Głównym celem SOR-u jest jednak zacieranie różnic rozwojowych poprzez działania inwestycyjne, a nie redystrybucyjne. To w małych i średnich firmach tkwi największy potencjał rozwojowy. Rolą państwa jest stworzenie im jak najlepszych warunków do funkcjonowania. Taką postawę można określić jako uzupełniające rynek metody państwowego interwencjonizmu. W ślad za Profesorem Góralczykiem musimy postawić sobie pytanie dotyczące styku państwo-rynek: ile ich ma być, w jakich proporcjach? Z pewnością państwo powinno być odpowiedzialne za staranne planowanie własnej modernizacji i wspomaganie stopniowego, ale też i wyraźnego przechodzenia na nowoczesne technologie. Ponadto państwo winno stanowić i nadzorować wykonywanie przepisów regulujących system finansowy. Justin Yifu Lin ma rację, gdy pisze, że wielkie projekty infrastrukturalne leżą poza zasięgiem możliwości indywidualnych firm. Należy tutaj liczyć na współpracę państwa i biznesu, przy zachowaniu wzajemnej autonomii. Nie wolno natomiast zgodzić się na neoliberalną wizję państwa konkurującego z drugim sektorem. W stosunkach publiczno-prywatnych widzę pole do współpracy, w którym obie strony się uzupełniają. Chciałbym podkreślić, że uznając aktywną rolę państwa w gospodarce, nie przyznaję temu pierwszemu prymatu czy dominującej roli. To związek konieczny, a jednocześnie przynoszący korzyści obu partnerom. Dlatego SOR proponuje odejście od stereotypu dwubiegunowości, a proponuje współpracę opartą na zaufaniu i wsparciu.

Zaczynając pogoń za krajami rozwiniętymi, należało zwrócić uwagę na poziom nierówności społecznych. Nie można zbudować silnego oraz sprawiedliwego ekonomicznie państwa (brak któregoś z tych czynników powoduje, że drugi automatycznie traci na znaczeniu i w pespektywie czasowej doznaje znacznego osłabienia) bez stworzenia klasy średniej, będącej podstawą funkcjonowania kraju, rozbudowania rynku wewnętrznego zamiast coraz kosztowniejszego eksportu czy dążenia do zrównoważonego (zarówno regionalnie, jak i społecznie) rozwoju. Program 500+ to program nie tylko prodemograficzny, lecz także likwidujący rozwarstwienie społeczne, likwidujący ubóstwo polskich rodzin. Nie moglibyśmy liczyć na sukces SOR-u, nie likwidując uprzednio pauperyzacji dużych grup społecznych. Co szczególnie dla mnie istotne, jest to program sfinansowany dzięki dobrej sytuacji gospodarczej, na którą złożyła się praca wszystkich Polaków. Tym ważniejsze było wdrożenie transferów społecznych, które sprawiają, że po raz pierwszy od czasów transformacji sukces gospodarczy staje się udziałem zdecydowanej większości Polaków, a nie jedynie najbogatszych. Wszystkich nas cieszy sukces tego pomysłu, ale jego powodzenie wymusza jeszcze pilniejszą potrzebę realizacji SOR-u i skierowania działań w kierunku tego, co stanowi clou każdego sukcesu gospodarczego - zwiększenia inwestycji i rozwoju małej oraz średniej przedsiębiorczości. Obecnie należy uznać, że program $500+$ zapewnia dostateczny poziom transferów socjalnych. Gospodarka 
oczekuje jeszcze większej przedsiębiorczości, a państwo jest zobligowane do stworzenia odpowiednich ku temu warunków.

Mimo ostatniego kryzysu gospodarczego i dopuszczenia stosowania odstępstw wobec konsensusu waszyngtońskiego, nasz program ciągle budzi obawy wśród neoliberałów. Jednym z często przedstawianych zagrożeń jest rzekomo prezentowany w SOR-ze zamiar bezmyślnego powielenia wzorców Nowej Ekonomii Strukturalnej, stosowanych w krajach Dalekiego Wschodu. Warto więc wyjaśnić, że Strategia Odpowiedzialnego Rozwoju jest autorskim projektem Rządu RP, wykorzystującym porady i wskazówki Justina Yifu Lina, jednakże dostosowującym jego koncepcje do warunków panujących w Europie Środkowo-Wschodniej. To, co jest najcenniejsze w koncepcji Nowej Ekonomii Strukturalnej, to nowatorskie ujęcie podejścia do polityki przemysłowej państwa. Twórcze ujęcie tzw. efektywnego czworokąta, złożonego z elity rządzącej, państwowej administracji, społeczeństwa oraz biznesu stanowi cenny fundament SOR-u. Jednak jego szczegółowe treści i proponowane rozwiązania to rzetelna analiza polskich trudności i polskich dróg do ich rozwiązania. Nie odchodząc od podstawowego założenia Nowej Ekonomii Strukturalnej o konieczności dużej roli sektora państwowego i państwowego interwencjonizmu, prowadzonego przez doświadczone i wykształcone kadry, stworzyliśmy projekt skrojony na polskie możliwości i oczekiwania. Wielką zaletą pracy Justina Yifu Lina jest przełamanie tzw. prawd niepodważalnych, wskazanie nowych możliwości i rozwiązań. Przełożenie jej jednak na założenia praktyczne to już obowiązek poszczególnych krajów. Dlatego, mimo wspólnego korzenia, trudno porównywać politykę gospodarczą państw azjatyckich i europejskich - różnice wynikają jednak nie z powodu sporów teoretycznych, a różnic geopolitycznych, które są traktowane jako naturalne.

Szczególnie istotne jest płynne przejście z procesu tworzenia sprawiedliwej partycypacji całego społeczeństwa w dochodzie narodowym do etapu tworzenia zachęt i wsparcia dla proinwestycyjnych postaw. Nie ma możliwości osiągnięcia trwałego sukcesu gospodarczego bez zrównoważonego, pod względem zasobności w środki pieniężne społeczeństwa. Wzrost, nawet bardzo silny, oparty jedynie na prostych procesach inwestycyjnych, nieprowadzący do powstania klasy średniej, ulega szybkiemu hamowaniu i nie pozwala przejść do elity krajów rozwiniętych. Samo państwo nie jest jednak w stanie doprowadzić do wyklarowania się silnej i licznej klasy średniej. Może jedynie stworzyć ku temu odpowiednie warunki. Pierwszym, już zrealizowanym, jest zasypanie największych materialnych różnic społecznych. Program $500+$ pozwolił na to, by zlikwidować najbardziej rażące przypadki pauperyzacji i ubóstwa. Dzisiaj musimy skoncentrować się na najtrudniejszym, ale i najważniejszym projekcie, czyli pełnym wykorzystaniu potencjału inwestycyjnego Polski i Polaków. To małe i średnie przedsiębiorstwa są w stanie zapewnić budowę silnego i stabilnego społecznego dobrobytu. To także prorozwojowe inwestycje zagraniczne, nietraktujące Polski tylko jako montowni. To wreszcie powiększające się oszczędności Polaków, lokowane w programach zbiorowego inwestowania, mające stać się 
wehikułem finansowym rozwoju kraju. Rolą państwa w realizowaniu tych pomysłów jest usunięcie dotychczasowych barier inwestycyjnych w obszarze prawa. Ministerstwo Rozwoju przygotowało gruntowną reformę prawa gospodarczego. Projekty ustaw są zgrupowane w dwóch pakietach: „Konstytucji Biznesu” oraz „100 zmianach dla firm”. Pakiet „100 zmian dla firm” przewiduje wprowadzenie takich rozwiązań, jak skrócenie okresu przechowywania akt pracowniczych oraz ich elektronizacja, sukcesja przedsiębiorstwa osoby fizycznej, wprowadzenie do prawa Prostej Spółki Akcyjnej czy reforma działania Głównego Urzędu Miar, który stanie się istotnym partnerem dla firm przemysłowych w wypracowywaniu innowacyjnych rozwiązań. Zmiany wspierają przede wszystkim polskie mikro-, małe i średnie przedsiębiorstwa - swoim zasięgiem obejmą ponad 90\% wszystkich aktywnie działających firm w kraju. Szczególne znaczenie nadajemy „Konstytucji Biznesu” przewidującej wprowadzenie katalogu podstawowych zasad prowadzenia działalności gospodarczej oraz reguł rządzących relacjami przedsiębiorca - organy państwa. Kolejny krok to wprowadzenie skutecznego, ale jednocześnie prostego i przejrzystego systemu podatkowego. Dotychczasowy nieszczelny system podatkowy prowadził do strat budżetu państwa szacowanych na dziesiątki miliardów złotych rocznie. Działania podejmowane przez Ministerstwo Finansów prowadzą zarówno do uszczelniania systemu podatkowego, jak i do przywracania uczciwej konkurencji bez mafii VAT-owskich i szarej strefy. Obok tych działań wprowadziliśmy także zmiany od lat postulowane przez przedsiębiorców: obniżenie stawki CIT do $15 \%$ dla małych firm, wprowadzenie ulgi inwestycyjnej i innowacyjnej oraz reformę administracji skarbowej. Chcemy, aby fiskus był postrzegany jako sprawny i przyjazny urząd, ale też silny i skuteczny wobec przedsiębiorców unikających płacenia podatków, a tym samym zaburzających uczciwą konkurencję.

Szczególna rola w realizacji SOR-u przypadła Polskiemu Funduszowi Rozwoju integrującemu Agencję Rozwoju Przemysłu (ARP), Bank Gospodarstwa Krajowego (BGK), Korporację Ubezpieczeń Kredytów Eksportowych (KUKE), Polską Agencję Inwestycji i Handlu (PAIH) oraz Polską Agencję Rozwoju Przedsiębiorczości (PARP). Priorytety Grupy PFR to inwestycje infrastrukturalne, innowacje, rozwój przedsiębiorczości, eksport i ekspansja zagraniczna polskich przedsiębiorstw oraz obsługa inwestycji zagranicznych. Istotnym zadaniem PFR jest także aktywny udział w procesach repolonizacji strategicznych sektorów polskiej gospodarki. PFR już zdążył zainwestować w polską gospodarkę blisko 10 mld złotych - bez powiększania deficytu i długu publicznego. Szczególną rolę państwo ma do odegrania przy wsparciu polskiego eksportu. Ekspansję zagraniczną polskich firm charakteryzuje obecnie wysoka dynamika - realizowana jest polityka dywersyfikacji kierunków eksportu, a wartość eksportu na koniec 2017 roku - według prognoz rynkowych - może wzrosnąć nawet dwukrotnie. 60 mld zł to sumaryczna wartość nowoczesnych i elastycznych instrumentów finansowania polskiego eksportu, jakie udostępnia rodzimym przedsiębiorcom Grupa Polskiego Funduszu Rozwoju (PFR). Składają się na to m.in. gwarancje finansowe, ubezpieczenia, kredyty eksportowe oraz fundusz eks- 
pansji zagranicznej. Jedną z fundamentalnych zmian w polityce eksportowej Polski wprowadzonej przez rząd jest stworzenie nowego systemu zachęt dla polskich firm, które chcą być aktywnymi podmiotami na międzynarodowym rynku fuzji i przejęć. Wreszcie Ministerstwo Rozwoju uruchomiło program wsparcia dla małych i średnich miast. Wartość programu przekracza 2,5 mld złotych. Również wspierane przez rząd inwestycje lokowane są na terenach poza aglomeracyjnych - 23 spośród 27 (85\%) inwestycji o charakterze strategicznym trafiło do małych i średnich polskich miastach. W ramach Funduszu możliwe jest uzyskanie wsparcia na inwestycje finansowane w całości ze środków krajowych lub zdobycie kapitału na wkład własny do projektów finansowanych ze środków unijnych.

Ostatnim ważkim elementem SOR-u, wartym zaznaczenia na łamach niniejszej publikacji, są jego sztandarowe programy, takie jak: Elektromobilność, Polska Platforma Przemysłu 4.0 czy Program Budowy Kapitału. Warto poświęcić parę osobnych zdań słynnej już Elektromobilności. Przede wszystkim nie można tego projektu sprowadzać wyłącznie do określonej ilości samochodów czy autobusów elektrycznych. To program przyszłości, przygotowujący Polskę na nadejście nieuchronnej rewolucji $\mathrm{w}$ transporcie. To stosowne zmiany w polskim prawie, uruchomienie programów grantowych, ale przede wszystkim - zmiana mentalności i nastawienia Polaków do innowacji w tym obszarze. To projekt przyszłości, projekt rodzący wiele wyzwań i trudności, od którego nie ma już możliwości odejścia. Polska do tej pory przyglądała się biernie takim inicjatywom, oczekując na gotowe rozwiązania innych krajów. Powodowało to zapóźnienie technologiczne Polski wobec krajów rozwiniętych, które zawsze wyprzedzały nas o krok. Dziś to my chcemy być pionierem, pierwsi stawić czoło wyzwaniom i korzystać z najnowocześniejszych rozwiązań.

Polska staje w obliczu nowych wyzwań. Nowa Ekonomia Strukturalna i Strategia na rzecz Odpowiedzialnego Rozwoju są na nie odpowiedzią. Wierzę, że jej realizacja przyczyni się do uzyskania trwałego, społecznie i terytorialnie zrównoważonego rozwoju gospodarczego, który doprowadzi do wzrostu dobrobytu polskich rodzin. Wyrwanie Polski z dryfu rozwojowego wymaga mądrego i skutecznego działania administracji publicznej, lecz przede wszystkim dalszego rozwoju przedsiębiorczości i kreatywności polskich obywateli. Z pewnością, w światowej gospodarce idzie „Nowe”. Mniej istotne, jak to „Nowe” zostanie ostatecznie nazwane. Zdecydowanie ważniejsze, żebyśmy to „Nowe” potrafili przekuć na sukcesy i zwycięstwa polskiej gospodarki. Jestem przekonany, że tak właśnie się stanie. 


\title{
Nowa Ekonomia Strukturalna dla gospodarek doganiających ${ }^{1}$
}

\begin{abstract}
Rozwój gospodarczy jest procesem przemian strukturalnych, który cechują nieustanna innowacja technologiczna i postęp przemysłowy. Zjawiska te podnoszą produktywność pracy i towarzyszą udoskonaleniom w dziedzinach infrastruktury i instytucji, co z kolei wpływa na obniżenie kosztów transakcji. Polityka przemysłowa stanowi dla rządów niezbędne narzędzie pozwalające wytyczać priorytety w zakresie wykorzystania ograniczonych zasobów. Pozwala to na pobudzenie obu tych zjawisk: innowacji technologicznej i postępu przemysłowego, poprzez rozwiązywanie nieodłącznych problemów uzewnętrzniania $i$ koordynacji w ramach przemian strukturalnych. Gałęzie gospodarki w kraju osiągającym średni poziom dochodów można zaliczyć do pięciu typów, w zależności od odległości, jaka dzieli je od globalnej granicy technologicznej, czyli: branże doganiające, przodujące, tracące przewagę komparatywną, działające w krótkim cyklu innowacji oraz strategiczne, które z racji niezdolności do konkurencji nie posiadają przewagi komparatywnej. Polityka przemysłowa winna być projektowana stosownie do tych typów.
\end{abstract}

Słowa kluczowe: Nowa Ekonomia Strukturalna, rozwój gospodarczy, polityka przemysłowa.

\section{Wprowadzenie}

Tezy akademickie:

- rozwój gospodarczy jest ze swej natury procesem nieustannej przemiany strukturalnej, w ramach której innowacje technologiczne i postęp przemysłowy podnoszą produktywność pracy, a udoskonalenia infrastruktury twardej i miękkiej obniżają koszty transakcji;

- Nowa Ekonomia Strukturalna, stosująca podejście neoklasyczne do badania czynników determinujących strukturę ekonomiczną i jej rozwój, postuluje, że struktura przemysłowa w ramach gospodarki ma charakter endogeniczny względem struktury jej wyposażenia w zasoby;

- Nowa Ekonomia Strukturalna stoi na stanowisku, że czynnikiem o znaczeniu decydującym dla sukcesu rozwojowego jest państwo, które umożliwia ten rozwój, prowadząc odpowiednią politykę przemysłową. Polityka taka musi ułatwiać

1 Pragnę podziękować Panu Slavo Radosevicowi za pomocne uwagi. 
przedsiębiorstwom wchodzenie do branż cechujących się ukrytą przewagą komparatywną na konkurencyjnym rynku poprzez pokonanie problemu uzewnętrzniania wartości przez pierwszego inicjatora oraz koordynowanie wymaganych udoskonaleń twardej i miękkiej infrastruktury. Polityka taka winna mieć na celu przekształcanie branż cechujących się ukrytą przewagą komparatywną w narodowe przewagi konkurencyjne.

\section{Tezy polityczne:}

- politykę przemysłową kraju osiągającego średnie dochody w procesie doganiania podzielić można na pięć kategorii - w zależności od tego, jaka odległość dzieli daną gałąź gospodarki od globalnej granicy technologicznej. Państwo może ułatwiać działalność przedsiębiorstwom, dobierając właściwe w danych sytuacjach kategorie wśród polityki przemysłowej:

- dla branż w krajach doganiających o wyższym dochodzie;

- utrzymywania w skali globalnej czołowej pozycji technologicznej przez branżę, która pozycję taką zdobyła;

- dla krajów o wysokich dochodach, dokonujących przeskoku technologicznego w branżach krótkiego cyklu innowacji;

- pomagania przedsiębiorstwom w wychodzeniu $\mathrm{z}$ branż tracących przewagę komparatywną;

- rozwijania branż nieposiadających przewagi komparatywnej, związanych $\mathrm{z}$ dziedziną obrony narodowej.

Szybki i zrównoważony rozwój gospodarczy jest zjawiskiem właściwym epoce nowoczesnej, zachodzącym dopiero od XVIII wieku. Wcześniej przeciętny wzrost produktu krajowego brutto (PKB) na głowę w krajach Europy Zachodniej wynosił tylko $0,05 \%$. W takim tempie podwojenie PKB per capita zajęłoby gospodarce aż 1400 lat (Maddison, 2006). W okresie od XVIII do połowy XIX wieku średni wzrost PKB per capita w Europie Zachodniej przyśpieszył do 1\%, co umożliwiało podwojenie go w ciągu zaledwie 70 lat. Od połowy XIX wieku do czasów obecnych tempo wzrostu PKB per capita przyśpieszyło do $2 \%$ rocznie, czyli okres podwojenia dochodu uległ skróceniu do 35 lat. Impulsu do zwiększenia tempa wzrostu dostarczyła rewolucja przemysłowa połowy XVIII wieku. Proces ciągłej innowacji technologicznej i rozwój przemysłu przyniosły w efekcie szybszy wzrost produktywności pracy oraz wzrost dochodów, który zdecydowanie zwiększał PKB per capita².

Inaczej mówiąc, nowoczesny wzrost gospodarczy jest procesem ciągłej innowacji technologicznej, który podnosi produktywność pracy w istniejących gałęziach gospodarki, oraz procesem rozwoju przemysłowego, który przekształca gospodarkę od

2 W okresie, w którym Adam Smith pisał swoje dzieło Badania nad natura i przyczynami bogactwa narodów, Rewolucja Przemysłowa znajdowała się w fazie początkowej. Dlatego Smith nie zwracał szczególnej uwagi na innowacje technologiczne i rozwój przemysłu, skupiając się raczej na handlu i specjalizacji w ramach określonych technologii i branż. 
branż o niskiej wartości dodanej do branż o wyższej wartości dodanej i w ten sposób również wpływa na wzrost produktywności pracy. Jednakże wykorzystanie potencjału technologii i nowych branż wymaga sprawnie funkcjonującej twardej infrastruktury, która umożliwia dostarczanie towarów na duże rynki krajowe i zagraniczne. W miarę zwiększania się skali handlu wymiana na rynku w coraz większym stopniu zachodzi na zasadach pełnej konkurencji, co wymaga zawierania umów i działania systemów prawnych zdolnych do ich egzekwowania. Ponadto, gdy wraz z doskonaleniem technologii i rozwojem branż gospodarki rosną skala i ryzyko inwestycji, do przemian tych musi się także dostosowywać struktura finansowa. Podnoszenie poziomu twardej i miękkiej infrastruktury obniża koszty transakcji w inwestycjach i handlu (Kuznets, 1966; Lin i Nugent, 1995; Harrison i Rodríguez-Clare, 2010). Chociaż nowoczesny wzrost gospodarczy wydaje się procesem rosnącej produktywności pracy, w istocie jest on procesem nieustannych przemian strukturalnych w zakresie technologii, gałęzi gospodarki oraz twardej i miękkiej infrastruktury.

Wysoki dochód i produktywność pracy w kraju rozwiniętym wskazują na to, że poziom jego technologii i przemysłu plasuje się na globalnej granicy. Jako taki wymaga on miejscowej wynalazczości - tworzenia nowych technologii i rozwijania przemysłu - dla zapewnienia innowacji technologicznej i doskonalenia przemysłu. Tworzenie nowych technologii i branż jest procesem kosztownym i ryzykownym. Innowacje technologiczne i doskonalenie przemysłu w krajach rozwijających się zachodzą przeważnie nieco z tyłu, za globalną granicą technologiczną i przemysłową. Większość innowacji i udoskonaleń w takim kraju opiera się na przejmowaniu technologii i branż, które w tym kraju są nowością, ale w innych miejscach na świecie osiągnęły już dojrzałość. Dlatego też cechują je niższe koszty i niższe ryzyko niż w kraju rozwiniętym. Innymi słowy, kraj rozwijający się korzysta z pozycji późnego przejęcia innowacji technologicznej i udoskonaleń przemysłu. Potencjalnie zatem jest w stanie rozwijać się szybciej od kraju rozwiniętego i dzięki temu doganiać go w rozwoju.

Po drugiej wojnie światowej większość państw świata rozwijającego się zerwała pęta kolonializmu lub systemu półkolonialnego i w warunkach nowej niepodległości przystąpiła do samodzielnej pogoni za nowoczesnym wzrostem gospodarczym. Do roku 2008 tylko dwa kraje zdołały przejść najpierw z poziomu dochodu niskiego do średniego, a następnie do wysokiego, a tylko $13 \mathrm{z}$ nich przeszło sam drugi etap - od dochodu średniego do wysokiego (Agenor i in., 2012). Oznacza to, że w okresie od końca wojny większość, z grupy około 200 państw rozwijających się, utkwiła w pułapce niskiego lub średniego dochodu, pomimo korzystania z przewagi późnego przejęcia. Cytując Keynesa, „to idee, a nie włożony kapitał są groźne dla dobra lub zła". Słabe wyniki rozwojowe tych krajów odzwierciedlały ich niezdolność do tworzenia idei. W niniejszym rozdziale analizuję idee obecne w dwóch poprzednich falach myśli rozwojowej, wprowadzam Nową Ekonomię Strukturalną jako trzecią falę i proponuję praktyczny przewodnik formatowania polityki przemysłowej w krajach rozwijających się w celu przyśpieszania procesów ich innowacji technologicznej i doskonalenia przemysłu. 


\section{Dlaczego winniśmy zrewidować ekonomię rozwoju?}

Teorie ekonomiczne pomagają nam zrozumieć ukryte determinanty obserwowanych zjawisk ekonomicznych. Są one czymś więcej niż tylko ćwiczeniami z logiki, mają bowiem znaczenie i rolę praktyczną. Czynniki ekonomiczne - rządy państw, przedsiębiorstwa, gospodarstwa domowe i osoby fizyczne - wykorzystują je w swoich działaniach, dążąc do osiągnięcia pożądanych celów. Jeżeli istniejące teorie nie pomagają nam w zrozumieniu przyczyn leżących u podstaw obserwowanych zjawisk lub jeżeli decyzje, jakie podejmujemy opierając się na tych teoriach, nie prowadzą nas do osiągnięcia zamierzonych celów, winniśmy teorie te rewidować. Ekonomia rozwoju takiej rewizji wymaga.

Ekonomia rozwoju jest młodą dziedziną nowoczesnej ekonomii. Pojawiła się po drugiej wojnie światowej. Przyświecała odbudowie krajów zrujnowanych wojną oraz kształtowaniu się państwowości w dawnych koloniach, które zyskały niepodległość.

Pierwszą falę myśli rozwojowej stanowił strukturalizm. Zakładał on, że jeżeli kraj rozwijający się dążył do doganiania, pod względem dochodu, krajów rozwiniętych, to powinien osiągnąć produktywność pracy taką samą, jak w owych krajach. To z kolei wymagało, aby kraj rozwijający się budował nowoczesne, kapitałowo i technologicznie intensywne gałęzie gospodarki, podobne jak w krajach rozwiniętych. Tymczasem w krajach rozwijających się takie branże nie zdołały się wykształcić. Dlaczego? Za niepowodzenie w spontanicznym powstawaniu i rozwoju takich branż ekonomiści winą obarczali niedostatki rynkowe wynikające ze sztywności strukturalnej (Arndt, 1985). Strukturalizm zalecał, ażeby rządy przyjmowały strategie zastępowania importu w celu pokonania niedowładu rynku poprzez mobilizację i alokację zasobów i sugerował bezpośrednie budowanie takich branż od podstaw (Rosenstein-Rodan, 1943; Prebisch, 1950).

Zarówno państwa kapitalistyczne, jak i socjalistyczne realizowały w okresie powojennym strategie proponowane przez strukturalizm (Chenery, 1961). Jednakże w krajach, które przyjęły strategie zastępowania importu, przeważnie dało się zaobserwować wzorzec gwałtownego rozwoju napędzanego przez inwestycje na dużą skalę, a następnie - kryzysów gospodarczych i długich okresów stagnacji (Krueger i Tuncer, 1982; Lal, 1994; Pack i Saggi, 2006).

Nieadekwatność strukturalizmu w roli przewodnika na temat procesu doganiania dla krajów rozwijających się doprowadziła, po roku 1980, do powstania drugiej fali ideowej w postaci neoliberalizmu. W tym okresie w krajach rozwijających się wszechobecnym zjawiskiem był interwencjonizm państwowy. Powodował on pogoń za rentą, korupcję, malwersacje i defraudacje oraz rozmaite inne wypaczenia gospodarcze i nieefektywne zagospodarowanie zasobów. W celu poprawienia wyników gospodarczych i zmniejszania dystansu wobec krajów rozwiniętych krajom rozwijającym się zalecano teraz budowę sprawnie funkcjonującej gospodarki ryn- 
kowej poprzez wdrażanie reform i działań łącznie określanych mianem konsensusu waszyngtońskiego. Obejmował on prywatyzację, urynkowienie gospodarki i liberalizację (Williamson, 1990). Rządom państw radzono, aby nie wybierały branż-faworytów, które miałyby otrzymywać wsparcie w imię innowacji technologicznych i rozwoju przemysłowego.

Także tym razem logika wydawała się słuszna. A jednak kraje, które zastosowały tę terapię szokową w wielu wypadkach doznały zapaści gospodarczej, stagnacji i przeżywały częste kryzysy, a dystans dzielący kraje rozwijające się od krajów rozwiniętych wzrósł jeszcze bardziej (Cardoso i Helwege, 1995). Za czasów wdrażania konsensusu waszyngtońskiego w latach 80. i 90. XX wieku tempo wzrostu okazywało się niższe, a kryzysy ekonomiczne częstsze niż w dobie realizacji polityki strukturalizmu, czyli w latach 60. i 70. Niektórzy ekonomiści nazwali nawet dwa ostatnie dziesięciolecia ubiegłego stulecia „straconymi dekadami” - straconymi dla krajów rozwijających się (Easterly i in., 1997; Easterly, 2001).

W okresie tym niektóre gospodarki azjatyckie przyjęły zupełnie inne podejście wobec kwestii rozwoju. Od lat 50. do 70. XX wieku Japonia oraz cztery tygrysy azjatyckie - Korea, Tajwan, Singapur i Hongkong - notowały dynamiczny wzrost dzięki przyjęciu strategii rozwoju ukierunkowanej na eksport, kształtowaniu branż o małej skali i wysokiej pracochłonności początkowej oraz poprzez stopniowe wspinanie się na szczeble drabiny przemysłowej ku coraz większym i bardziej kapitałochłonnym branżom. Ponadto, czyniły to w warunkach znacznego i proaktywnego wsparcia ze strony rządu (Amsden, 1989; Chang, 2003; Wade, 1990).

W latach 80. i 90., pod wpływem konsensusu waszyngtońskiego, ekonomiści piętnowali gospodarkę planową jako mniej wydajną od gospodarki wolnorynkowej i apelowali o przekształcanie tego pierwszego modelu w drugi metodami terapii szokowej. Oznaczało to pozbycie się wszystkich zniekształceń i wypaczeń ekonomicznych poprzez zaprzestanie interwencji państwowej i jednoetapowy przeskok od gospodarki planowanej do wolnorynkowej. Natomiast Chiny przyjęły inne podejście - transformacji dwutorowej. Polegała ona na kontynuowaniu protekcjonizmu państwowego i dotowaniu niewydolnych przedsiębiorstw państwowych w tradycyjnych, dawniej uprzywilejowanych branżach kapitałochłonnych, przy jednoczesnym liberalizowaniu dróg wejścia na rynek dla dawniej tłumionych branż pracochłonnych. Wielu ekonomistów prognozowało, że podejście takie będzie prowadziło do gwałtownej pogoni za rentą i psucia alokacji zasobów. Jednak w rzeczywistości okazało się, że te gospodarki, które podążały drogą transformacji dwutorowej - takie, jak: Kambodża, Chiny i Wietnam - doświadczyły stabilizacji i szybkiego rozwoju.

Polityka oparta na doktrynach strukturalizmu i neoliberalizmu nie osiągnęła swoich celów. Co więcej, ani strukturalizm, ani neoliberalizm nie były w stanie wyjaśnić tego wyjątkowego rozwoju gospodarczego i sukcesów transformacji, których byliśmy świadkami. Do tego bowiem potrzebujemy trzeciej fali myślenia rozwojowego. 


\section{Czym jest Nowa Ekonomia Strukturalna?}

Nowa Ekonomia Strukturalna jako trzecia fala myśli rozwojowej zakłada podejście neoklasyczne do badania czynników determinujących strukturę ekonomiczną i jej ewolucję w ramach rozwoju ekonomicznego danego kraju, co stanowi istotę nowoczesnego wzrostu gospodarczego (Lin, 2011) .

Jak brzmi zasadnicza teza Nowej Ekonomii Strukturalnej?

W krótkim ujęciu, struktura ekonomiczna kraju w danym okresie ma charakter endogeniczny względem jego wyposażenia w aktualnie dostępne zasoby kapitału, pracy i surowców naturalnych. Kraje znajdujące się na różnych etapach rozwoju różnią się pod względem relatywnego wyposażenia w zasoby. W kraju rozwijającym się przeważnie mamy do czynienia ze względnym deficytem kapitału, podczas gdy dostępność siły roboczej, a często także zasobów naturalnych jest relatywnie obfita. W krajach rozwiniętych stosunkowo łatwo o kapitał, przy jednoczesnej relatywnie trudnej dostępności siły roboczej. Co do wyposażenia gospodarki w zasoby, w dowolnym konkretnym okresie ich wielkość jest określona, ale z upływem czasu może się zmieniać. Nowa Ekonomia Strukturalna traktuje poziom wyposażenia gospodarki w zasoby jako punkt wyjścia dla analizy rozwoju, ponieważ determinują one łączny budżet gospodarki oraz relatywne ceny czynników produkcji w danym okresie, czyli wielkości będące dwoma najważniejszymi parametrami dla analizy ekonomicznej.

Relatywne ceny czynników produkcji stanowią o przewadze komparatywnej danej gospodarki. Na przykład, kraje posiadające stosunkowo bogate zasoby siły roboczej przy jednoczesnym deficycie kapitału miałyby przewagę komparatywną w branżach pracochłonnych, ponieważ ich koszty produkcji będą niższe niż w krajach o relatywnie ubogich zasobach siły roboczej i jej wysokich kosztach. Warunkiem wstępnym osiągnięcia przez dany kraj przewagi komparatywnej jest rozwinięcie w nim takich gałęzi gospodarki, które będą zgodne z jego przewagami komparatywnymi determinowanymi przez aktualny poziom wyposażenia w zasoby (Porter, 1990).

W krajach rozwiniętych dochód i produktywność pracy są wysokie, ponieważ ich względnie duża zasobność kapitałowa sprawia, że ich branże i technologie mają charakter kapitałochłonny. Jeżeli kraj rozwijający się pragnie dogonić kraje rozwinięte pod względem ich dochodu i struktury przemysłowej, najpierw musi zwiększyć swoje relatywne zasoby kapitału w ramach swojej struktury wyposażenia w zasoby do poziomu krajów rozwiniętych. Celem ostatecznym rozwoju gospodarczego jest zwiększenie dochodów kraju, natomiast celem pośrednim jest rozwijanie branż kapitałochłonnych. Z kolei celem w bliskiej perspektywie powinno być szybkie zgro-

3 Zasadniczo, badania takie należałoby określać mianem „ekonomii strukturalnej”. Przymiotnik „nowa” dodaje się do tej nazwy po to, aby odróżnić ten kierunek od strukturalizmu. Praktyka taka ma precedensy w nowoczesnej ekonomii. Na przykład, Douglass North, który posługiwał się podejściem neoklasyczny do badania instytucji w latach 60. XX w., nazywał swoje podejście „nową ekonomią instytucji”, aby odróżnić je od „szkoły instytucjonalnej”, która rozwijała się w Stanach Zjednoczonych na początku XX w. 
madzenie kapitału, aby móc przekształcić przewagi komparatywne tego kraju w kierunku branż bardziej kapitałochłonnych. Inaczej mówiąc, podniesienie poziomu dochodów danego kraju wymaga podniesienia jego poziomu przemysłowego, do czego z kolei konieczna jest zmiana struktury wyposażenia w zasoby w takim kraju (Ju i in., 2015).

W jaki sposób kraj może szybko zgromadzić kapitał? Kapitał pochodzi z odkładania nadwyżek ekonomicznych. Jeżeli branże przemysłu w danym kraju są w pełni dostosowane do jego przewag komparatywnych, determinowanych przez jego strukturę wyposażenia w zasoby, kraj taki będzie konkurencyjny na rynkach zarówno krajowych, jak i zagranicznych i jako taki generować będzie największe możliwe nadwyżki. Gdyby wszystkie inwestycje dokonywane były w branże, które są zgodne z przewagami komparatywnymi determinowanymi przez strukturę wyposażenia tego kraju w zasoby, zwroty z inwestycji będą zwiększone do maksimum możliwości, jak również najwyższa możliwa będzie zdolność i skłonność do oszczędzania. W warunkach najwyższej możliwej nadwyżki i najsilniejszych pobudek do oszczędzania, proces gromadzenia kapitału postępować będzie najszybciej. Przemiany w zakresie struktury wyposażenia w zasoby i przewag komparatywnych torują drogę dla przemian w zakresie struktury przemysłowej oraz rozwoju twardej i miękkiej infrastruktury.

Należy jednak pamiętać, że przewaga komparatywna jest pojęciem ekonomicznym. Jak przekłada się ono na wybory dokonywane przez przedsiębiorców w zakresie technologii i całych gałęzi gospodarki? Przedsiębiorcy zainteresowani są zyskiem. Skłonni więc będą zainwestować w takie branże, w jakich dany kraj posiada przewagę komparatywną, jeżeli względne ceny czynników produkcji odzwierciedlają relatywne deficyty czynników w ramach wyposażenia tego kraju w zasoby (Lin, 2009; Lin i Chang, 2009). Jeżeli kapitału jest stosunkowo mało, jego cena będzie relatywnie wysoka; jeżeli brakuje siły roboczej, względnie wysokie będą koszty pracy (wynagrodzenia). Jeżeli system cenowy adekwatnie odzwierciedla relatywny deficyt czynników, przedsiębiorcy dążący do maksymalizacji zysków w procesie wyboru technologii produkcji wykorzystają czynnik relatywnie niedrogi, by zastąpić nim czynnik relatywnie drogi. Oznacza to, że inwestować oni będą w branże, w których potrzeba więcej czynnika relatywnie niedrogiego, a mniej czynnika relatywnie drogiego. Jednak system cenowy o takich cechach charakterystycznych zaistnieć może tylko na rynku konkurencyjnym. Dlatego właśnie sprawnie funkcjonujący rynek jest niezbędny dla powodzenia rozwoju gospodarczego.

Rozwój gospodarczy jest procesem przemian strukturalnych, który cechują nieustanne innowacje technologiczne, doskonalenie przemysłu oraz poprawa stanu infrastruktury i instytucji. Kiedy struktura wyposażenia w zasoby zmienia się, proces ten w pierwszej kolejności wymaga inicjatorów, którzy jako pierwsi wchodzą do nowych branż, zgodnych ze zmieniającymi się przewagami komparatywnymi. Inicjatorzy narażają się na wysokie ryzyko. Jeżeli nie odniosą sukcesu, sami poniosą wszystkie straty. Jeśli zaś im się powiedzie, do tych samych branż przystąpią w ślad 
za nimi inne firmy. Konkurencja, jaka w związku z tym powstanie, wykluczy wszelkie zyski monopolowe (Aghion, 2009; Romer, 1990). Występuje tu zatem asymetria pomiędzy wielkością strat w wypadku porażki i zysków w razie powodzenia tych pierwszych inicjatorów (Hausmann i Rodrik, 2003).

Bez względu na to czy inicjatorzy osiągną sukces, czy poniosą porażkę dostarczają społeczeństwu użytecznych informacji. Rząd powinien zachęcać inicjatorów i wynagradzać ich za uzewnętrznianie informacji, które generują. W przeciwnym razie brakować będzie bodźców zachęcających firmy do podejmowania roli inicjatorów innowacji technologicznych i podnoszenia poziomu przemysłu (Rodrik, 2004; Lin, 2009; Lin i Monga, 2011; Harrison i Rodriguez-Clare, 2010). Ponadto, sukces lub porażka inicjatorów zależą również od tego czy udoskonalona twarda i miękka infrastruktura odpowiada potrzebom nowych branż. Poprawianie stanu infrastruktury i instytucji leży poza zasięgiem możliwości indywidualnych firm. Rząd winien albo koordynować wysiłki przedsiębiorstw na rzecz poprawiania infrastruktury i instytucji, albo zapewniać takie działania samodzielnie. Zatem kolejnym niezbędnym warunkiem dla dynamicznego rozwoju gospodarczego jest państwo, które ułatwia jego procesy rozwojowe. Nowa Ekonomia Strukturalna pomaga zrozumieć, dlaczego strukturalizm zawiódł. Zalecana przez strukturalizm strategia zastępowania importu sugerowała rządom, aby przyznawały priorytet branżom intensywnym pod względami kapitału i technologii w krajach rozwijających się, w których kapitału brakowało. W ten sposób doktryna ta ignorowała przewagi komparatywne krajów rozwijających się. Firmy w tych branżach nie miały siły przebicia na otwartych, konkurencyjnych rynkach. Bez protekcji i dotacji ze strony rządu przedsiębiorcy nie byli skłonni z własnej woli inwestować w te branże. Firmy powstawały, ale gdy ich niekonkurencyjność wychodziła na jaw, ostatecznie i tak musiały polegać na dotacjach i protekcji rządowej, aby przetrwać.

Nowa Ekonomia Strukturalna pomaga również zrozumieć, dlaczego zawiódł neoliberalizm. W krajach rozwijających się zakłócenia rynku przybierały taką skalę, że w ich warunkach konieczne stawały się protekcjonizm rządowy i dotowanie niekonkurencyjnych przedsiębiorstw, które uprzednio promowane były przez rządowe strategie zastępowania importu. Wyeliminowanie protekcjonizmu i dotacji państwowych skazywało niewydolne firmy na upadek, co skutkowało wysoką stopą bezrobocia oraz niezadowoleniem społecznym i niepokojami politycznymi. Chcąc uniknąć tych konsekwencji i utrzymywać przy życiu niewydolne branże kapitałochłonne, wciąż uznawane za stożek wzrostu w procesie modernizacji, rządy nie miały wyboru - musiały kontynuować politykę protekcjonizmu i subsydiów. Nawet jeżeli firmy prywatyzowano, utrzymywał się problem miękkich ograniczeń budżetowych. W niektórych wypadkach dotacje dla niewydajnych firm musiały jeszcze bardziej wzrosnąć, ponieważ ich prywatni właściciele mieli większe zachęty do lobbowania na rzecz polityki subsydiów i protekcji (Lin i Li, 2008). Co gorsza, taki nowy protekcjonizm i subsydia przeważnie okazywały się mniej wydajne niż poprzednio, zwłaszcza w przechodzących transformację gospodarkach krajach byłego Związku Radziec- 
kiego i krajach Europy Środkowej i Wschodniej (World Bank, 2002). Ponadto, neoliberalizm „wylewał dziecko z kąpielą”, zdecydowanie odrzucając jakąkolwiek rolę rządów w ułatwianiu przemian strukturalnych. Typowym tego przykładem było Chile. Kraj ten, modelowy adept doktryny konsensusu waszyngtońskiego, w latach osiemdziesiątych pilnie wdrażał zalecane reformy, a następnie wyeliminował wszelki protekcjonizm rządowy i dotacje. Według wskaźnika łatwości prowadzenia działalności gospodarczej Banku Światowego, opartego na kryteriach ułatwień i braku barier dla prowadzenia biznesu i inwestowania, Chile zajmuje wysoką pozycję wśród krajów rozwijających się. Jednakże Chile już od ponad 30 lat nie może pochwalić się dynamicznymi przemianami strukturalnymi i w rezultacie doświadcza wysokiego bezrobocia i poszerzania rozwarstwienia dochodów i nierówności społecznych. Inaczej mówiąc, kraj ten uwiązł w „pułapce średniego dochodu”.

Nowa Ekonomia Strukturalna również uzasadnia stopniowe i dwutorowe podejście do reform, które konwencjonalna myśl ekonomiczna krytykowała jako niewłaściwe strategie transformacji. Reforma dwutorowa utrzymuje stabilność, zapewniając przejściową ochronę niewydajnym firmom w sektorach dawniej uprzywilejowanych, a jednocześnie osiąga dynamiczny wzrost dzięki usuwaniu barier wejścia na rynek i ułatwianiu rozwoju branż uprzednio tłumionych, a obecnie zgodnych z przewagami komparatywnymi kraju. Dynamiczny rozwój sektorów dobrze dostosowanych do przewag komparatywnych pomaga gospodarce w szybkim gromadzeniu kapitału i zmienia strukturę wyposażenia w zasoby. W ten sposób niektóre dawniej niewydolne przedsiębiorstwa w branżach kapitałochłonnych stają się sprawne i konkurencyjne. Kiedy firmy działające w nowych sektorach osiągają konkurencyjność, przejściową protekcję, można znieść subsydia, gładko doprowadzając proces transformacji ku gospodarce wolnorynkowej do pomyślnego zakończenia (Naughton, 1995; Lau i in., 2000; Subramanian i Roy, 2003; Lin, 2009; 2012; 2013).

\section{Nowa Ekonomia Strukturalna i zdrowa polityka przemysłowa dla krajów rozwijających się}

Teorie ekonomiczne mają na celu pomóc ludziom nie tylko zrozumieć świat, lecz także go zmieniać. W jaki sposób rząd kraju rozwijającego się może zastosować Nową Ekonomię Strukturalną dla osiągnięcia dynamicznych przemian strukturalnych i dogonienia krajów o wysokim dochodzie? Aby efektywnie wykorzystać ograniczone zasoby, jakimi dysponuje i wywrzeć jak najsilniejszy wpływ na procesy przemian strukturalnych i wzrostu gospodarczego, rząd musi wiedzieć, które z nowych branż są zgodne z ukrytymi przewagami komparatywnymi kraju. Innymi słowy, rząd powinien orientować się, które gałęzie gospodarki cechują się niskimi kosztami środków produkcji w oparciu o strukturę wyposażenia kraju w zasoby, ale ze względu na wysokie koszty transakcji nie osiągają konkurencyjności globalnej. 
Ponadto, rząd powinien wiedzieć, które elementy infrastruktury i instytucje wymagają poprawy w celu obniżenia kosztów transakcji, to bowiem może pozwolić tym nowym branżom odnieść sukces.

Inaczej mówiąc, Nowa Ekonomia Strukturalna stoi na stanowisku, że rząd powinien najpierw wykryć branże cechujące się ukrytymi przewagami komparatywnymi, a następnie dostarczyć pierwszym inicjatorom bodźców zachęcających do pokonania niedostatków koordynacji w zakresie poprawiania infrastruktury i instytucji - po to, by przekształcić te branże w narodowe przewagi konkurencyjne. Teoretycznie, polityka przemysłowa winna stanowić dla rządów użyteczne narzędzie ułatwiające. W praktyce, w krajach rozwijających się polityka przemysłowa zazwyczaj zawodziła, psując im przy okazji opinię w ekonomii mainstreamu. Jeżeli jednak rząd nie ułatwia rozwoju branż zgodnie z przewagami komparatywnymi swojego kraju, to stare branże mogą upaść z powodu utraty swoich przewag komparatywnych, nowe zaś nie mają szans rozwinąć się samodzielnie i spontanicznie ze względu na brak inicjatorów oraz niedostatki twardej i miękkiej infrastruktury. Jedną z konsekwencji takiego stanu będzie dezindustrializacja. Bez nowych branż w gospodarce kraje nie są w stanie osiągnąć zdrowego wzrostu gospodarczego, stawić czoła wyzwaniu tworzenia miejsc pracy ani uniknąć wpadnięcia w pułapkę niskiego albo średniego dochodu.

Odrzucać wszelkie formy polityki przemysłowej dlatego, że jej wcześniejsze postacie zawiodły, oznaczałoby rezygnację ze sposobności do zrozumienia, dlaczego polityka przemysłowa przeważnie nie spełniała oczekiwań i do jej poprawiania w przyszłości. Polityka taka zawodziła, bo w wielu wypadkach rząd kraju rozwijającego się, działając w najlepszej wierze, lecz w nieświadomości endogenicznego charakteru struktury przemysłowej, usiłował zbyt ambitnie wspierać wysoko zaawansowane branże, zanim gospodarka osiągnęła właściwą strukturę wyposażenia w zasoby, umożliwiającą przekształcenie tych branż w przewagi komparatywne kraju. Firmy działające we wspieranych w ten sposób branżach nie były zdolne do rywalizacji na otwartych, konkurencyjnych rynkach, zatem rządy musiały je chronić i dotować, przyznając prawa monopolowe, udostępniając tani kapitał, surowce i ziemię albo przyznając przywileje podatkowe. Taka zniekształcająca rynek interwencja generowała ekonomiczne renty, które pobudzały pogoń za rentą, malwersacje i korupcję (Krueger, 1974; Krugman, 1993).

Pożądana polityka przemysłowa powinna mieć na celu ułatwianie rozwoju branż posiadających ukryte przewagi komparatywne i umożliwianie im szybkiego obejmowania na rynku roli narodowych przewag konkurencyjnych. Przez ukrytą przewagę komparatywną rozumiem tu branżę cechującą się niskimi kosztami środków produkcji w stosunku do reszty świata. Kwestię tę determinują struktura wyposażenia danej gospodarki w zasoby oraz koszty transakcji, które - z powodu niedowładu twardej i miękkiej infrastruktury - są zbyt wysokie, by być konkurencyjne na rynkach krajowych i międzynarodowych. Firmy staną się wydajne, a całe sektory - konkurencyjne, gdy rząd pomoże firmom obniżyć koszty transakcji poprzez pokonanie 
problemów koordynacji i zewnętrzności w zakresie poprawy stanu twardej i miękkiej infrastruktury.

Oprócz ułatwiania rozwoju branż cechujących się ukrytą przewagą komparatywną, polityka przemysłowa może również pomagać firmom w wychodzeniu z tych branż, w których dany kraj traci przewagi komparatywne lub w przenoszeniu działalności do innych krajów, w których występują niższe dochody i płace.

Branże gospodarki w kraju o średnich dochodach można pogrupować, w zależności od dystansu, jaki dzieli je od globalnej granicy technologicznej, w pięć następujących typów: 1) branże doganiające, które cechują się niższym poziomem technologii i wartości dodanej niż podobne branże w krajach o wyższych dochodach; 2) branże przodujące, które konkurują na globalnej granicy technologicznej; 3) branże tracące przewagę komparatywną, z których kraj wkrótce zrezygnuje z powodu przemian w zakresie struktury wyposażenia w zasoby i przewag komparatywnych; 4) branże „na zakręcie”, które charakteryzują się krótkimi cyklami innowacji i umożliwiają krajowi o średnich dochodach bezpośrednie konkurowanie z krajami o wyższych dochodach oraz 5) branże strategiczne, które działają pod prąd przewag komparatywnych swego kraju, ale rozwijane są ze względu na swoje znaczenie dla bezpieczeństwa narodowego. Poniżej omówię, w jaki sposób rząd może ułatwić funkcjonowanie tych pięciu typów branż poprzez prowadzenie odpowiedniej polityki przemysłowej.

\subsection{Typ I: branże doganiające}

W jaki sposób rząd może rozpoznać branże posiadające ukryte przewagi komparatywne w procesie doganiania przedsiębiorstw $\mathrm{z}$ analogicznych branż w krajach o wyższych dochodach? Historia dostarcza tutaj wielu wniosków odnośnie do tego, co czynić, a czego unikać.

Już od przełomu XVI i XVII w. gospodarki rozwijające się z powodzeniem wykazują pewną wspólną cechę: prowadzona w nich polityka przemysłowa miała na celu pomaganie przedsiębiorstwom we wchodzeniu do branż, które odnosiły największe sukcesy w krajach bardziej rozwiniętych i doświadczających dynamicznego wzrostu. Firmy takie mogły korzystać z przewagi późnego przejęcia i dołączenia. Na przykład, w wiekach XVI i XVII najbardziej rozwiniętym krajem świata były Niderlandy, posiadające bardzo zaawansowany przemysł włókienniczy. W porównaniu z nim, przemysł tkanin wełnianych w Wielkiej Brytanii był zapóźniony i niedojrzały. Rząd brytyjski zaczął jednak realizować politykę zachęcania do importu maszyn i wykwalifikowanych pracowników z Niderlandów. Polityka ta okazała się skuteczna. W okresie tym dochód per capita w Wielkiej Brytanii kształtował się na poziomie $70 \%$ dochodu niderlandzkiego. Oznaczało to, że potencjały i przewagi komparatywne tych krajów były bardzo zbliżone.

Po rewolucji przemysłowej Wielka Brytania stała się najbardziej zaawansowaną gospodarką świata. Pod koniec XIX wieku podobną politykę doganiania Wielkiej Brytanii zaczęły wdrażać inne kraje: Francja, Niemcy i Stany Zjednoczone. 
Ich dochody per capita dochodziły już wówczas do poziomu ok. 60-75\% względem Wlk. Brytanii (Gerschenkron, 1962). Z kolei w latach 50. i 60. XX wieku Japonia imitowała wzorce przemysłowe Stanów Zjednoczonych, notując w tym okresie dochód per capita na poziomie nieco powyżej $40 \%$ dochodu amerykańskiego. Później sukces odniosły cztery tygrysy azjatyckie (Korea, Tajwan, Singapur i Hongkong), wzorując się na gospodarce Japonii - w okresie, w którym ich dochody per capita wynosiły tylko około 30-40\% dochodu japońskiego (Akamatsu, 1962; Chang, 2003; Ito, 1980; Kim, 1988).

W latach po II wojnie światowej również inne kraje usiłowały imitować strukturę przemysłu Stanów Zjednoczonych, ale nie odniosły sukcesu. Jedną z przyczyn był fakt, że ich ówczesne poziomy dochodu nie sięgały nawet $20 \%$ dochodu USA. Przykładowo, w latach 50. Chiny zaczęły wzorować się na branżach przemysłu amerykańskiego, pomimo że ich dochód per capita wynosił zaledwie 5\% poziomu USA. W ramach starań rządu o budowę nowoczesnego przemysłu Chiny zdołały wypróbować w latach 50. i 60. bomby atomowe i wodorowe, a w latach 70. wysyłały satelity na orbitę Ziemi. Osiągnięcia te miały jednak bardzo wysoką cenę dla gospodarki kraju. W roku 1979, kiedy Chiny rozpoczęły transformację ku gospodarce wolnorynkowej, ich dochód per capita wynosił mniej niż jedną trzecią przeciętnego dochodu krajów Czarnej Afryki.

Opierając się na doświadczeniach gospodarek odnoszących sukcesy oraz na teorii przewagi komparatywnej, proponuję przyjęcie nowych ram wykrywania wzrostu i ułatwiania rozwoju dla celów polityki przemysłowej w krajach doganiających. Ramy te obejmują dwa tory i sześć etapów (Lin and Monga, 2011).

\section{Etap 1. Wykrywanie branż dysponujących towarami zbywalnymi}

Kiedy rząd kraju rozwijającego się zabiega o ułatwienie rozwoju przemysłowego w dziedzinie produkcji niesurowcowej, powinien rozpoznać branże towarów zbywalnych w krajach, które wykazują dynamiczny wzrost w okresie ostatnich 20-30 lat i których dochód per capita jest wyższy w zakresie 100-200\% niż dochód własnego kraju. Chociaż z wcześniejszych doświadczeń wynika, że najlepszym punktem odniesienia jest tutaj różnica $100 \%$, próba większego skoku też może być uzasadniona, ponieważ w naszych czasach podnoszenie poziomu technologii i przemysłu zachodzi znacznie szybciej.

Istnieje prawdopodobieństwo, że zbywalne towary i usługi produkowane w krajach branych za wzór są towarami i usługami, w jakich kraj doganiający posiada ukrytą przewagę komparatywną. Jeżeli dany kraj rozwijał się szybko przez ostatnich 20-30 lat, to jego branże w sektorach dóbr zbywalnych muszą być zgodne z jego przewagami komparatywnymi. Jednakże ze względu na szybką akumulację kapitału i wzrost płac w takim kraju, branże, które były zgodne z przewagami komparatywnymi cechującymi jego dawniejszą strukturę wyposażenia w zasoby, wkrótce utracą swoją przewagę komparatywną. Branże schyłkowe, stojące w obliczu rychłej 
utraty swojej przewagi komparatywnej w kraju branym za wzór, staną się branżami wschodzącymi w kraju doganiającym, a to z uwagi na jego ukrytą przewagę komparatywną. Kraj taki ma bowiem podobną strukturę wyposażenia w zasoby, a jednocześnie niższy PKB per capita.

\section{Etap 2. Rozpoznanie przeszkód}

Spośród branż rozpoznanych na etapie 1, rząd może przyznać priorytet tym, do których pewna liczba krajowych przedsiębiorstw już spontanicznie przystąpiła. Rząd winien wykryć i ustalić jakie przeszkody utrudniają tym firmom podnoszenie jakości swoich produktów oraz bariery utrudniające innym prywatnym firmom wejście do tych branż. Bariery takie wiążą się przeważnie z kwestią wysokich kosztów transakcji. Należy zadać sobie pytanie, co jest pierwszorzędną przeszkodą: niedostatki infrastruktury, słabość logistyki, niewystarczające wsparcie finansowe, czy może ograniczone zasoby wykwalifikowanej siły roboczej? Przeszkody można identyfikować metodami analizy łańcucha wartości albo przy użyciu schematu diagnostyki wzrostu, jaki proponują Hausmann, Rodrik i Velasco (2008). Następnie, rząd może podjąć środki zmierzające do pokonania tych przeszkód. W tym celu najpierw przeprowadza pilotaż, czyli losowe, kontrolowane eksperymenty testujące efektywność podjętych działań, a dopiero na podstawie ich wyników wdraża odpowiednią politykę w pełnej skali krajowej (Duflo, 2004).

\section{Etap 3. Zachęcanie firm działających $w$ innych, bardziej zaawansowanych systemach gospodarczych, do przenoszenia się do kraju doganiającego}

Niektóre spośród branż określonych na etapie 1 mogą być jeszcze nieznane w danym kraju. Rząd może podjąć działania na rzecz zachęcenia firm z krajów o wyższych dochodach, obranych za cel pogoni, do przeniesienia się do kraju doganiającego, gdzie będą one mogły korzystać z przewagi niższych płac. Ponadto, rząd może wdrożyć programy inkubacji, aby pobudzać proces wchodzenia prywatnych firm krajowych do tych branż.

\section{Etap 4. Dostrzeganie i uwzględnianie firm odnoszących sukcesy w nowych branżach}

Technologia ewoluuje szybko. Oznacza to, że obecnie istnieje wiele branż, które 20 lat temu nie istniały. Niektórzy krajowi przedsiębiorcy mogą odkryć nowe, zyskowne sposobności biznesowe, które nie zostały wykryte na etapie 1. Jako przykład weźmy sektor usług informatycznych w Indiach w latach 80. Z początku firmy indyjskie, korzystające z usług zewnętrznych firm amerykańskich, posługiwały się łącznością satelitarną, co było bardzo kosztowne. W reakcji na to rząd indyjski zbudował systemy oparte na światłowodach, które zdecydowanie ograniczyły koszty 
łączności i w ten sposób pomogły firmom indyjskim zyskać przewagę konkurencyjną nad innymi podobnymi przedsiębiorstwami z reszty świata. Kiedy nowa technologia otwiera nowe możliwości i prywatne firmy krajowe już je dostrzegły, rządy winny pilnie obserwować ich sukcesy i zapewniać im wsparcie, aby ich skala rosła. Ponadto, każdy kraj może mieć pewne specyficzne i unikalne potencjały. Jeżeli przedsiębiorcy w danym kraju odkrywają możliwości zyskownego wykorzystania takich możliwości, rząd również może udzielić im wsparcia, by poszerzać pole ich możliwości i pomóc im urosnąć do poziomu dojrzałych, konkurencyjnych sektorów.

\section{Etap 5. Wykorzystanie specjalnych stref ekonomicznych do przyciągania firm krajowych i zagranicznych}

W krajach rozwijających się, o słabej infrastrukturze i środowisku nieprzyjaznym dla biznesu, bariery budżetu i zdolności nie pozwalają rządom dokonywać w rozsądnych ramach czasowych niezbędnych udoskonaleń, z których korzystałyby wszystkie sektory na terenie całego kraju. W takiej sytuacji rząd może wprowadzać środki lokalne: otwierać parki przemysłowe, strefy przetwórstwa na eksport lub specjalne strefy ekonomiczne, by przyciągać firmy krajowe i zagraniczne i zachęcać je do inwestowania w wybranych branżach. Udoskonalenia w zakresie infrastruktury i środowiska biznesowego na takich specjalnych obszarach mogą prowadzić do obniżenia kosztów transakcyjnych i ułatwiać rozwój branż posiadających ukrytą przewagę komparatywną. Atutem specjalnych stref ekonomicznych jest także fakt, że sprzyjają one tworzeniu klastrów przemysłowych, zdolnych obniżać koszty logistyczne.

\section{Etap 6. Wynagradzanie firm pionierskich za uzewnętrznianie wartości}

Rząd może dostarczać ograniczonych zachęt dla pionierskich firm krajowych lub zagranicznych, które inwestują w branże określone na etapach 1 i 4, aby w ten sposób wynagrodzić je za zasób wiedzy, jaki w efekcie ich inwestycji trafił do domeny publicznej. Zachęty takie powinny być ograniczone w czasie i skali alokacji budżetowych. Ograniczenie takie jest istotne, ponieważ branże, do których kierowane są zachęty, winny zachować swoją ukrytą przewagę komparatywną, pozwalającą im osiągnąć konkurencyjność na rynkach krajowych i zagranicznych, gdy tylko obniżą się koszty transakcyjne. Zachęty mogą przybierać postać wakacji podatkowych na okres kilku lat, uprzywilejowanego dostępu do kredytu (w krajach represji finansowej o ujemnych stopach procentowych) lub do rezerw walutowych na import najważniejszego wyposażenia (w krajach z kontrolą kapitału). Aby ograniczyć do minimum ryzyko sprowokowania pogoni za rentą i niezdrowych nacisków politycznych, zachęty nie powinny przybierać formy renty monopolistycznej, wysokich taryf celnych ani innych zakłóceń wolnej konkurencji. Rząd może wynagradzać firmy, które samodzielnie odkryły nowe, drożne branże (zob. etap 4) metodą nagród lub innych specjalnych wyróżnień za wkład w rozwój gospodarczy. 
Ten rodzaj wynagradzania za udostępnianie wartości na zewnątrz jest zasadniczo różny od protekcjonizmu i subsydiowania - środków właściwych dla dawnej strategii zastępowania importu, które miały na celu podtrzymywanie działalności niewydolnych firm z sektorów uprzywilejowanych. W ramach nowego systemu firmy są zachęcane, podtrzymywane przy życiu i są to przedsiębiorstwa o niskich kosztach środków produkcji, wydolne i wydajne na rynku, a udzielana im pomoc ma na celu udoskonalenie ich zarządzania i zapewnienie im zyskowności, gdy tylko poprawi się stan twardej i miękkiej infrastruktury, a koszty transakcyjne zostaną obniżone.

\subsection{Typ II: branże przodujące}

Kiedy kraj osiąga etap średnich dochodów, niektóre branże jego gospodarki mogą wkroczyć na obszary opuszczone przez kraje o wyższych dochodach z powodu uzyskiwanej na nich ograniczonej wartości dodanej (ograniczonej z punktu widzenia krajów o wyższych dochodach). W takich wypadkach kraj wchodzący na taki obszar staje się na tymże obszarze krajem o najwyższych na świecie dochodach w ramach danej branży i posiadaczem przodującej technologii. Dobrym przykładem jest tutaj sektor urządzeń gospodarstwa domowego - takich, jak telewizory, lodówki, kuchenki mikrofalowe i inne sprzęty AGD - w Chinach. Warunkiem utrzymania przez dany kraj przodującej pozycji i konkurencyjności w takich branżach jest angażowanie się jego firm z tych branż w samodzielną działalność badawczo-rozwojową w zakresie nowych technologii i produktów.

Taką samodzielną działalność badawczo-rozwojową można podzielić na dwie dziedziny: rozwijanie nowych produktów i nowych technologii oraz dokonywanie przełomów w naukach stanowiących podstawę dla rozwijania nowych technologii i produktów. Jeżeli starania firmy o opracowanie nowego produktu lub technologii uwieńczone są powodzeniem, może ona zostać nagrodzona przyznaniem patentu. Dlatego rozwijanie nowych produktów i technologii winno pozostawać w gestii firm. Natomiast badania w zakresie nauk leżących u podstaw działalności badawczorozwojowej wymagają poważnych wkładów kapitałowych i narażone są na wysokie ryzyko. Co więcej, otrzymywane wyniki mają zazwyczaj formę artykułów akademickich, które stają się dobrem publicznym. Indywidualne firmy mogą zatem niechętnie pochodzić do angażowania się w badania u podstaw.

W krajach zaawansowanych, takich jak Stany Zjednoczone, większość branż zajmuje pozycję przodującą w skali globalnej. Badania podstawowe związane z ich działalnością prowadzone są głównie przez uniwersytety i wyspecjalizowane instytuty badawcze, na których działalność łożą takie organizacje, jak Narodowa Fundacja Nauki, Narodowy Instytut Zdrowia, Departament Obrony i inne źródła rządowe (Mazzucato, 2013). Podobnie jest w innych gospodarkach zaawansowanych, takich jak Japonia i niektóre kraje Europy: badania podstawowe również tam są realizowane lub fundowane przez instytucje rządowe. $Z$ faktów tych wynika, że aby utrzymać globalną konkurencyjność i czołową pozycję swoich przodujących branż, 
kraj o średnich dochodach powinien przyjąć analogiczne podejście do wspierania podstawowych badań, niezbędnych dla pobudzania innowacji i rozwijania nowych technologii i produktów. Ponadto, rząd takiego kraju winien wzmocnić ochronę praw własności intelektualnej.

Mówiąc konkretniej, rządy krajów o średnich dochodach mogą promować rozwój nowych produktów i technologii metodami alokacji fiskalnych, by za ich pomocą tworzyć fundusze badawcze wspierające instytucje badacze w odpowiednich dziedzinach. Mogą one także zachęcać do współpracy pomiędzy instytutami badawczymi a firmami z odpowiednich branż. Rządy mogą wreszcie wspierać właściwe firmy finansowo poprzez zakładanie wspólnych platform badawczych, które można wykorzystywać do pokonywania najważniejszych barier technicznych. Z kolei firmy mogą rozwijać nowe produkty lub technologie niezależnie, jednak w oparciu o przełomy dokonane na ogólnym froncie technologicznym. I sprawa ostatnia: rządy mogą posłużyć się zamówieniami publicznymi, by w ten sposób pomóc firmom w szybkim zwiększaniu skali produkcji, co przekłada się na obniżenie kosztów jednostkowych i zwiększenie konkurencyjności międzynarodowej.

Aby poszerzyć rynek w skali globalnej, firmy w odpowiednich branżach muszą stworzyć światowe sieci sprzedaży, przetwórstwa produktów i obsługi posprzedażowej. Rząd może pomagać firmom z tego typu branż we wchodzeniu na rynki zagraniczne poprzez zapewnienia szkoleń personelu, dostępu do usług prawnych i ochrony konsularnej.

\subsection{Typ III: branże tracące przewagę komparatywną}

Dla branż pracochłonnych jednym z najważniejszych komponentów łącznego kosztu produkcji są płace. W kraju rozwijającym się, przechodzącym fazę gwałtownego wzrostu, jak obecnie Chiny, płace rosną bardzo szybko. $Z$ tego powodu branże pracochłonne przekształcać się będą z przewagi komparatywnej kraju w jego branże schyłkowe. W obliczu takiej przemiany niektóre firmy z sektora pracochłonnego, działające w zakresie przetwórstwa na eksport, mogą awansować na obydwa końce „krzywej uśmiechu”, cechujące się wyższą wartością dodaną - to znaczy angażować się w branding, działalność badawczo-rozwojową, kontrolę jakości, marketing, sprzedaż itd. Jednak dla większość firm wyjściem z sytuacji będzie przeniesienie produkcji do krajów o niższych płacach - jak czynili to japońscy producenci z branż włókienniczej, odzieżowej i elektronicznej w latach 60., a firmy z podobnych branż z czterech tygrysów azjatyckich w latach 80 . Przeniesienie produkcji pozwala firmom robić ciąły użytek z posiadanej i strzeżonej wiedzy w zakresach technologii, zarządzania i marketingu, a ponadto ich produkcja z czynnika współtworzącego PKB kraju staje się czynnikiem współtworzącym jego PNB - produkt narodowy brutto. Co więcej, sukces, jaki firmy te odnoszą za granicą, może przyśpieszać rozwój przemysłowy ich rodzimego kraju poprzez zwolnienie zasobów dla nowych branż i generowanie popytu na części lub maszyny pośrednie, stosowane w bran- 
żach pracochłonnych, zazwyczaj bardziej chłonnych w zakresie kapitału i technologii i przynoszących wyższą wartość dodaną.

Większość firm z sektora pracochłonnego, działających w zakresie przetwórstwa na eksport, zgrupowana jest w klastrach. Aby wspomagać takie firmy, rząd może posłużyć się dwoma rodzajami polityki. Pierwszym rodzajem jest udostępnienie szkoleń w zakresie wzornictwa, prac badawczo-rozwojowych i marketingu, co może pomóc niektórym firmom awansować na dwa krańce „krzywej uśmiechu”. Drugim - ułatwianie takim firmom przetwórczym wyjścia na rynki zagraniczne. Konkretne środki w tym zakresie obejmują oferowanie informacji o krajach docelowych i szkolenia personelu potrzebnego do prowadzenia działalności zagranicznej lub tworzenie stref przetwórstwa na eksport wspólnie z rządami krajów docelowych, z myślą o zapewnieniu odpowiedniej infrastruktury i środowiska biznesowego dla firm. Przykładem strefy przetwórstwa na eksport jest singapurski Park Przemysłowy w Suzhou w Chinach.

\subsection{Typ IV: branże „na zakręcie”}

Nadejście epoki informacji stwarza krajom rozwijającym się sposobność do bezpośredniego konkurowania w ramach niektórych branż z krajami rozwiniętymi. Do branż takich należą oprogramowanie komputerowe i urządzenia przenośne - dziedziny, w których innowacje zależą przede wszystkim od kapitału ludzkiego, a cykl innowacji jest względnie krótki (Lee, 2013). Wynalezienie nowego leku może zająć kilka dziesięcioleci i pochłonąć miliardy dolarów, podczas gdy stworzenie nowego programu komputerowego lub telefonu komórkowego może trwać zaledwie kilka miesięcy i to przy zaangażowaniu jedynie małego zespołu inżynierów. Ponieważ wymagany wkład kapitałowy, potrzebny na wspieranie innowacji, jest stosunkowo niewielki, upośledzenie kraju relatywnie ubogiego w zasoby kapitałowe w porównaniu z krajem w nie zasobnym jest, w kontekście innowacji tego typu produktów, możliwe do przezwyciężenia. Przed krajem rozwijającym się branże takie otwierają sposobność wyprzedzenia krajów rozwiniętych - wyprzedzenia ich na zakręcie. Rząd kraju rozwijającego się może ułatwiać rozwój takich branż metodą inwestowania w edukację odpowiedniego kapitału ludzkiego poprzez zakładanie inkubatorów, wzmacnianie ochrony praw własności intelektualnej, przyciąganie kapitału wysokiego ryzyka, oferowanie preferencji podatkowych, ułatwianie start-upów prowadzonych przez uzdolnione, twórcze jednostki w kraju i za granicą oraz wykorzystanie zamówień rządowych do wspierania produkcji nowych produktów.

\subsection{Typ V: branże strategiczne}

Każdy kraj potrzebuje obrony narodowej. Branże działające w sektorze obrony narodowej cechuje przeważnie wysoka kapitałochłonność oraz długie cykle badawczo-rozwojowe i duża skala ekonomiczna. Ogólnie, branże takie nie są zgodne 
z przewagami komparatywnymi danego kraju i zależność ta sprawdza się szczególnie w wypadku krajów rozwijających się. Niemniej, niektóre z takich branż mogą być niezbędne dla obrony narodowej, toteż kraj potrzebuje posiadać je i kontrolować wewnętrznie. Firmy działające w tych branżach nie byłyby wydolne na otwartym, konkurencyjnym rynku - rządowy protekcjonizm i dotacje są bowiem dla nich niezbędne. Stanowisko strukturalistyczne, omówione w pierwszej części niniejszego rozdziału, proponowało wykorzystanie zniekształceń w zakresie cen środków produkcji oraz monopoli rynkowych w charakterze środków subsydiowania i chronienia branż, które z racji niezdolności do skutecznej konkurencji nie posiadają przewagi komparatywnej. Lepszym podejściem jest subsydiowanie tych firm bezpośrednio, poprzez granty na działalność badawczo-rozwojową lub pośrednio, poprzez zamówienia publiczne na produkty. Są to praktyki podobne do stosowanych w Stanach Zjednoczonych i innych krajach wysoko rozwiniętych. W kraju rozwijającym się zdolność fiskalna rządu do subsydiowania branż strategicznych jest ograniczona. Dlatego dobór takich branż strategicznych powinien być bardzo selektywny, natomiast ich liczba winna pozostawać mała. Chodzi o to, ażeby wybierać tylko te branże, które są naprawdę nieodzowne z punktu widzenia interesów obrony narodowej i które cechuje duża skala uzewnętrznienia wartości do domeny branż cywilnych.

\section{Uwagi końcowe}

Niniejszy rozdział analizował ewolucję doktryn ekonomii rozwoju od czasu ich powstania w latach powojennych i proponował Nową Ekonomię Strukturalną jako podejście alternatywne. Każdy kraj rozwijający ma potencjał dynamicznego wzrostu i zdolność uniknięcia pułapki średniego dochodu. To jednak może się udać tylko wtedy, gdy jego rząd odgrywa właściwą, ułatwiającą rolę w realiach gospodarki rynkowej poprzez wspieranie rozwoju branż powiązanych z ukrytymi przewagami komparatywnymi tego kraju.

Osiągnięcie takiego wyniku wymaga zmiany nastawienia i nawyków. W dwóch pierwszych falach myśli rozwojowej ekonomiści jako punkty odniesienia przyjmowali kraje o wysokich dochodach. Badali, jakimi atutami kraje takie dysponowały (branże kapitałochłonne) i w czym wykazywały sprawność (dobrze funkcjonujący rynek), a krajom rozwijającym się zalecali wzorowanie się na nich. Nowa Ekonomia Strukturalna odwraca ten model. Zaleca, ażeby kraje rozwijające się starannie przeanalizowały, jakimi atutami same dysponują w danym czasie (poziom wyposażenia w zasoby) i w jakich obszarach są zdolne do skutecznego działania, opierając się na tym, co posiadają (przewagi komparatywne). Rządy winny wynagradzać przedsiębiorstwa za wnoszenie do domeny publicznej wartości wypracowanych przez pierwszych inicjatorów w nowych branżach - tych, w których dany kraj posiada ukryte przewagi komparatywne - oraz koordynować lub zapewniać we własnym zakresie 
udoskonalenia twardej i miękkiej infrastruktury, aby obniżać koszty transakcyjne. Dzięki temu branże, o których mowa, osiągną status narodowych przewag konkurencyjnych i jako takie staną się podmiotami dochodowymi. Konkurencyjność dostarczy podłoża dla trwałego i zrównoważonego rozwoju, tworzenia dochodu, eliminowania ubóstwa oraz szybkiego doskonalenia struktury wyposażenia w zasoby/ struktury przemysłu, co w efekcie prowadzić będzie do doganiania krajów wysokiego dochodu. Mam nadzieję, że rodzaje polityki przemysłowej stosownej dla pięciu typów branż omówionych w niniejszym rozdziale pomogą rządom w europejskich krajach doganiających uwolnić i wykorzystać ich potencjały wzrostu oraz osiągnąć sukces rozwojowy.

\section{Bibliografia}

Agenor, P.R., Canuto O. i Jelenic, M. (2012). Avoiding Middle-income Growth Traps. Economic Premise, 98, 1-7.

Aghion, P. (2009). Some Thoughts on Industrial Policy and Growth. Document de Travail 2009-09. Observatoire Français des conjonctures économiques, Sciences Po, Paris. Pozyskano z: http://www.ofce.sciences-po.fr/pdf/dtravail/WP2009-09.pdf (14 kwietnia 2016).

Akamatsu, K. (1962). A Historical Pattern of Economic Growth In Developing Countries. Journal of Developing Economies, 1(1), 3-25.

Amsden, A.H. (1989). Asia's Next Giant. New York and Oxford: Oxford University Press.

Arndt, H.W. (1985). The Origins of Structuralism. World Development, 13(2), 151-159.

Cardoso, E. i Helwege, A. (1995). Latin America's Economy. Cambridge, MA: MIT Press.

Chang, H.-J. (2003). Kicking Away the Ladder: Development Strategy in Historical Perspective. London: Anthem Press.

Chenery, H.B. (1961). Comparative Advantage and Development Policy. American Economic Review, 51(1), 18-51.

Duflo, E. (2004). Scaling Up and Evaluation. W: F. Bourguignon, B. Pleskovic (red.), Annual World Bank Conference on Development Economics 2004. Washington, DC: World Bank.

Easterly, W. (2001). The Elusive Quest for Growth: Economists' Adventures and Misadventures in the Tropics. Cambridge, MA: MIT Press.

Easterly, W., Loayza, N. i Montiel, P.J. (1997). Has Latin America's Post-Reform Growth Been Disappointing? World Bank Policy Research Paper 1708. Washington, DC: World Bank.

Gerschenkron, A. (1962). Economic Backwardness in Historical Perspective: A Book of Essays. Cambridge, MA: Belknap Press of Harvard University Press.

Harrison, A. i Rodríguez-Clare, A. (2010). Trade, Foreign Investment, and Industrial Policy for Developing Countries. W: D. Rodrik (red.), Handbook of Economic Growth, 5. Amsterdam: North-Holland.

Hausmann, R. i Rodrik, D. (2003). Economic Development as Self-Discovery. Journal of Development Economics, 72(2), 603-633.

Hausmann, R., Rodrik, D. i Velasco, A. (2008). Growth Diagnostics. W: N. Serra, J. Stiglitz (red.), The Washington Consensus Reconsidered: Towards a New Global Governance. Oxford, UK: Oxford University Press. 
Ito, T. (1980). Disequilibrium Growth Theory. Journal of Economic Theory, 23(3), 380-409.

Ju, J., Lin, J.Y. i Wang, Y. (2015). Endowment Structures, Industrial Dynamics, and Economic Growth. Journal of Monetary Economics, 76, 244-263.

Kim, Y.H. (1988). Higashi Ajia Kogyoka to Sekai Shihonshugi (Industrialisation of East Asia and the World Capitalism). Tokyo: Toyo Keizai Shimpo-sha.

Krueger, A. (1974). „The Political Economy of Rent-Seeking Society.” American Economic Review, 64(3), ss. 291-303.

Krueger, A. i B. Tuncer. (1982). An Empirical Test of the Infant Industry Argument. American Economic Review, 72(5), 1142-52.

Krugman, P. (1993). Protection in Developing Countries. W: R. Dornbusch (red.), Policy making in the Open Economy: Concepts and Case Studies in Economic Performance. New York: Oxford University Press.

Kuznets, S. (1966). Modern Economic Growth: Rate, Structure and Spread. New Haven, CT: Yale University Press.

Lal, D. (1994). Against Dirigisme: The Case for Unshackling Economic Markets. San Francisco: International Center for Economic Growth, ICS Press.

Lau, L., J.Y. Qian i Roland, G. (2000). Reform without Losers: An Interpretation of China's Dual-track Approach to Transition. Journal of Political Economy, 108(1), 120-43.

Lee, K. (2013). Schumpeterian Analysis of Economic Catch-up: Knowledge, Path Creation, and the Middle-income. Trap. Cambridge, UK: Cambridge University Press.

Lin, J.Y. (2009). Economic Development and Transition: Thought, Strategy, and Viability. Cambridge, UK: Cambridge University Press.

Lin, J.Y. (2011). New Structural Economics: A Framework for Rethinking Economic Development. World Bank Research Observer, 26(2), 193-221.

Lin, J.Y. (2012). Demystifying the Chinese Economy. Cambridge, UK: Cambridge University Press.

Lin, J.Y. (2013). Against the Consensus: Reflections on the Great Recession. Cambridge, UK: Cambridge University Press.

Lin, J.Y. i Chang, H. (2009). DPR Debate: Should Industrial Policy in Developing Countries Conform to Comparative Advantage or Defy It? Development Policy Review, 27(5), 483-502.

Lin, J.Y. i Li Z.Y. (2008). Policy Burden, Privatisation and Soft Budget Constraint. Journal of Comparative Economics, 36, 90-102.

Lin, J.Y. i Monga. C. (2011). DPR Debate: Growth Identification and Facilitation: The Role of the State in the Dynamics of Structural Change. Development Policy Review, 29(3), 259-310.

Lin, J.Y. i Nugent, J. (1995). Institutions and Economic Development. W: T.N. Srinivasan, J. Behrman (red.), Handbook of Development Economics (vol. 3). Amsterdam: North Holland.

Maddison, A. (2006). The World Economy. Paris: OECD.

Mazzucato, M. (2013). The Entrepreneurial State: Debunking Public vs. Private Sector Myths. New York: Anthem Press.

Naughton, B. (1995). Growing Out of Plan: Chinese Economic Reform 1978-1993. Cambridge, UK: Cambridge University Press.

Pack, H. i Saggi. K. (2006). Is There a Case for Industrial Policy? A Critical Survey. World Bank Research Observer, 21(2), 267-97.

Porter, M.E. (1990). The Competitive Advantage of Nations. New York: Free Press. 
Prebisch, R. (1950). The Economic Development of Latin America and its Principal Problems. New York: United Nations. Reprinted in: Economic Bulletin for Latin America, 7(1) (luty 1962), 1-22.

Rodrik, D. (2004). Industrial Policy for the Twenty-First Century. Cambridge, MA: Harvard University Press.

Romer, P.M. (1990). Endogenous Technological Change. Journal of Political Economy, 98(5), S71-S102.

Rosenstein-Rodan, P. (1943). Problems of Industrialization of Eastern and Southeastern Europe. Economic Journal, 111, 202-11.

Subramanian, A. i Roy. D. (2003). Who Can Explain the Mauritian Miracle? Mede, Romer, Sachs, or Rodrik? W: D. Rodrik (red.), In Search of Prosperity: Analytic Narratives on Economic Growth. Princeton, NJ: Princeton University Press.

Wade, R. (1990). Governing the Market. Princeton, NJ: Princeton University Press.

Williamson, J. (1990). What Washington Means by Policy Reform. W: J. Williamson (red.), Latin American Adjustment: How Much Has Happened?. Washington, DC: Institute for International Economics.

World Bank. (2002). Transition, the First Ten Years: Analysis and Lessons for Eastern Europe and Former Soviet Union. Washington, DC: World Bank. 


\section{BOGDAN GÓRALCZYK}

\section{Wschodnioazjatycki model rozwojowy - państwo rozwojowe}

Na Zachodzie przez dekady panowało przekonanie, iz nie ma alternatywy dla klasycznego kapitalizmu i realnego socjalizmu, nie ma trzeciej drogi. Tę bezalternatywność próbowano powielić po upadku ładu zimnowojennego dyktatem rynków spod znaku neoliberalnego konsensusu z Waszyngtonu. Tymczasem w Azji Wschodniej wynaleziono model będący połączeniem rynku i państwowego interwencjonizmu, nazwany "państwem rozwojowym". Autor tego artykułu dowodzi i wyjaśnia, że nie można dobrze zrozumieć nowej teorii Justina Yifu Lina, zwanej Nową Ekonomią Strukturalną, bez tego szerszego kontekstu, a ponadto przekonuje, iż jest to nie tyle nowa teoria gospodarcza, ile innowacyjna koncepcja polityki przemysłowej, która - w przeciwieństwie do modelu państwa przemysłowego, a ściślej państwa rozwojowego, powiązanego z "wartościami azjatyckimi" - może być zastosowana w innych państwach i obszarach "doganiających", o ile tylko zdecydują się one na połączenie rynku i silnego państwa.

Słowa kluczowe: modele rozwoju, polityka przemysłowa, Azja Wschodnia, Chiny, wschodzące rynki - państwa doganiające.

\section{Wprowadzenie}

Przez kilka dekad, w ramach porządku zimnowojennego, świat był skazany na swoisty duopol, również w wymiarze gospodarczym: klasyczny kapitalizm, głównie w wersji Johna M. Keynesa, w USA i na Zachodzie ścierał się z bardziej ujednoliconym systemem socjalistycznym, czyli socjalizmem państwowym, zwanym też realnym socjalizmem w ZSRR i bloku wschodnim. Jak wiemy, chociażby z klasycznych już studiów Jánosa Kornaia (1993), ten drugi model, polegający na dominacji ideologii i polityki w gospodarce, a także centralizacji, planowaniu oraz miękkich ograniczeniach budżetu, najpierw doprowadził do powszechnych niedoborów, a potem okazał się gospodarczo niewydolny i w końcu się załamał.

Zanim jednak do tego doszło, przez kilka dekad nawet w kręgach akademickich, nie mówiąc o politycznych, uważano, że sytuacja jest zero-jedynkowa, mamy wybór albo między liberalną gospodarką otwartą, albo modelem scentralizowano-planowym (Bolesta, 2007, s. 105). Tymczasem już na przełomie lat 50. i 60. ubiegłego 
stulecia, na jednym obszarze - Azji Wschodniej ${ }^{1}$ - pojawiła się ideowa i gospodarcza alternatywa. Najpierw w Japonii (Bolesta, 2015, s. 24), potem na kilku obszarach regionu $^{2}$, a w końcu na terenie Chin zadomowił się zupełnie nowy model, który jest przedmiotem niniejszego studium, będącego zarazem odniesieniem do nowej propozycji ideowo-programowej czy nowej teorii Justina Yifu Lina, prezentowanej w tym tomie.

Podstawowe założenie i hipoteza tego studium mówią o tym, że nowa teoria J.Y. Lina może być w pełni i głębiej rozumiana jedynie w szerszym kontekście już wcześniej wykorzystywanych rozwiązań modelowych, zastosowanych w Azji Wschodniej i że w żadnym stopniu nie dziwi, iż taka teoria - głównie dotycząca polityki przemysłowej, w mniejszym stopniu całej gospodarki - narodziła się w Chińskiej Republice Ludowej (ChRL). Wiele wskazuje, że może być ona bardzo pożyteczna dla - zapóźnionych gospodarczo - wschodzących rynków. Chociaż - to druga hipoteza tego artykułu - jest wątpliwe i dyskusyjne czy uda się tę propozycję równie skutecznie wprowadzić w życie na innych obszarach niż Azja Wschodnia czy Południowo-Wschodnia (tu chodzi głównie o państwa Stowarzyszenia Narodów Azji Południowo-Wschodniej - ASEAN), przede wszystkim ze względów kulturowych.

\section{Geneza i rozwój państwa rozwojowego}

W 1982 roku znany amerykański ekspert zajmujący się Azją Wschodnią, a szczególnie współczesną Japonią, Chalmers Johnson, opublikował tom, który najpierw wywołał środowiskową burzę, a potem zaś - jak się okazało - stał się klasyczną pracą przedstawiającą zupełnie nowy fenomen, nazwany państwem rozwojowym (developmental state) (Johnson, 1982). Na podstawie bogatej kwerendy i wnikliwej analizy funkcjonowania potężnego w japońskim systemie ministerstwa handlu międzynarodowego i przemysłu (Ministry of International Trade and Industry - MITI) (Van Wolferen, 1989) autor doszedł do wniosku, że powojenna Japonia ukształtowała własny model rozwojowy państwa, niepowielający ani głównego nurtu gospodarek kapitalistycznych (keynesizmu)3 ${ }^{3}$, ani koherentnej, lecz mało wydajnej gospodarki planowej w ramach realnego socjalizmu (Kornai, 1993, s. 380).

1 Proponuję stosowanie terminu „Azja Wschodnia” zamiast często używanego „Daleki Wschód” (Far East), będącego rusycyzmem wywodzącym się z terminu Dal'nij Wostok, czyli w rosyjskim pojmowaniu, obszarów leżących „poza Uralem”.

2 Hongkong był do lipca 1997 r. brytyjską kolonią, a od tamtej pory jest specjalnym regionem Chin, natomiast Tajwan, chociaż spełnia kryteria państwowe, ciągle ma nieuregulowany status prawno-międzynarodowy, z tego powodu m.in. nie jest członkiem ONZ.

3 Lin pisze o „strukturalizmie”; stąd jego „neostrukturalizm”, a więc nawiązanie do Keynesa, ale my w tym przypadku powiedzielibyśmy raczej: welfare state (Walicki, 2013, s. 321). 
Po latach Johnson (1999, s. 32) uczciwe przyznał, że szukał czegoś „poza rozwiązaniami w amerykańskiej i sowieckiej ekonomii” i znalazł, właśnie w Japonii. Na zakończenie tomu o MITI, jak się okazuje pod wypływem przenikliwego wydawcy (Johnson, 1999, s. 40-43), skondensował on wywody ze swojego pionierskiego tomu i zwięźle wyspecyfikował cechy wyróżniające japoński model. Zaliczył do nich (Johnson, 1982, s. 314-320):

- funkcjonowanie małej, niezbyt kosztownej, ale elitarnej państwowej biurokracji, korzystającej z najlepszych menedżerskich talentów dostępnych w systemie;

- system polityczny, w ramach którego biurokracja ma wystarczające pole manewru, by przejąć inicjatywę i funkcjonować efektywnie;

- uzupełniające rynek metody państwowego interwencjonizmu;

- organizację model pilotującą, czyli MITI4.

Reakcje środowiska naukowego na tę propozycję w USA i na Zachodzie były na ogół zdecydowanie negatywne, a zarazem wielce emocjonalne. Autor sam przyznaje, że „szybko uzmysłowiłem sobie, iż moja książka okazała się ideologiczną czerwoną flagą" (Johnson, 1999, s. 34). Podważała bowiem obowiązujący kanon, zgodnie z którym dominującą rolę w systemie gospodarczym ma odgrywać rynek, a nie państwo (Chang, 2003, s. 36), co - jak wiadomo - po niespełna dekadzie przeobraziło się w „nową wiarę”, czyli neoliberalny pakiet spod znaku konsensusu z Waszyngtonu (tutaj już Lin nie wyłamuje się z przyjętej terminologii5), zwany nawet fundamentalizmem rynkowym czy rynkowym autorytaryzmem (Halper, 2010, s. 32) wspierającym, a raczej budującym „fałszywy kapitalizm” (phony capitalism) prowadzący m.in. do ogromnych nierówności dochodowych (Stiglitz, 2015, s. 126), co z kolei po 2008 roku doprowadziło do jego podważenia i podminowania.

Przedmiotem nie mniejszych kontrowersji niż rola państwa, a jeszcze większych emocji, była - skąd inąd newralgiczna dla państwa rozwojowego - kwestia funkcjonowania państwowej administracji oraz prowadzonej przez nią polityki przemysłowej i rozwojowej, której funkcjonowanie porywczo porównywano do „społecznej inżynierii”, a nawet metod znanych z państw autorytarnych i faszystowskich, w tym przede wszystkim Włoch Mussoliniego (Woo-Cumings, 1999, s. 52, 53). Johnson przyznawał, iż kwestia powiązań demokracji i rozwoju jest ważna, dodawał też, iż państwo rozwojowe może rozwijać się zarówno w warunkach autokratycznych, jak w demokracji (czego dowodem jest badanie wynalezionego przez niego modelu na długiej przestrzeni lat 1925-1975). Zdecydowanie jednak zaprzeczał, jakoby pań-

$4 \quad$ W Singapurze jest to Rada Rozwoju Gospodarczego (Economic Development Board), w Korei Płd. Rada Planowania Gospodarczego (Economic Planinng Board), a na Tajwanie Rada Planowania Gospodarczego i Rozwoju (Council on Economic Planning and Development) (Bolesta, 2015, s. 39).

5 Świetna analiza porównawcza modelu państwa rozwojowego oraz pakietu neoliberalnego, utożsamianego z modelem „lecących gęsi” (zob. Kasahara, 2013). Głęboka i wnikliwa analiza neoliberalizmu zob. Walicki, 2013. 
stwo rozwojowe było jedynie „dyktaturą rozwoju”, gdyż posiada ono, jego zdaniem, co najmniej podwójną legitymację: po pierwsze, jest oparte na jasnych, przejrzystych i korzystnych dla państwa i społeczeństwa celach modernizacyjnych, a po drugie, okazało się być niezwykle skuteczne w działaniu.

Koronnym dowodem na obronę tej tezy był ogromny sukces gospodarczy Japonii w tamtym okresie. Albowiem w wyniku wypracowanego stopniowo, ale w pełni zastosowanego w latach 50. ubiegłego wieku, modelu państwo (przegrane, podbite i po raz pierwszy w swych dziejach skolonizowane po II wojnie światowej) już w drugiej połowie lat 70. wyrosło na drugą gospodarkę świata po USA (Vogel, 19996). Nic dziwnego, że szybko znalazło naśladowców w regionie (m.in. Hongkong, Koreę Płd., Singapur i Tajwan), którzy weszli do światowej literatury jako państwa nowo uprzemysłowione (New Industrialized Countries, NIC), zwane potocznie azjatyckimi tygrysami. Nie do końca powieliły one wypracowany w Japonii model. Hongkong i Tajwan postawiły na małe i średnie przedsiębiorstwa, a nie wielkie konglomeraty państwowo-prywatne, przy czym ten ostatni połączył elastyczny rynek z mniej elastycznym państwem (Castells, 2009, s. 239). Wszystkie z wymienionych państw łączyły jednak wspólne cechy, takie jak: metodyczne planowanie rozwoju, by stale zmierzać ku nowoczesności i modernizacji (od tekstyliów po przemysł ciężki, a potem wysokie technologie i od produkcji ku usługom); proeksportowa i otwarta na świat gospodarka, ale też rezerwuary taniej siły roboczej (przynajmniej w początkowej fazie modernizacji i reform) oraz często przymusowo narzucana dyscyplina społeczna (w niektórych przypadkach sięgano nawet po represje). System był dynamiczny, ale gdy zaistniała taka potrzeba (czytaj: państwo tak uznało), również bezwzględny (Castells, 2009, s. 253, 254).

Mimo budzących się kontrowersji i sprzecznych ocen państwa oraz terytoria NIC mocno skorzystały z japońskich doświadczeń (najbliższy pierwowzoru okazał się model zastosowany w Korei Płd.), dopasowały wypracowany tam model do własnych lokalnych uwarunkowań, a potem święciły równie duże, jak Japonia, sukcesy gospodarcze. Ich sukces wywołał spore zainteresowanie, w ślad za którym wielu naukowców poddało je wnikliwej naukowej analizie, m.in. Alice Amsden przedstawiła kluczowy tom nt. Korei Płd. (1989), Robert Wade opublikował swoje obserwacje dot. Tajwanu (1990), a znany socjolog Manuel Castells dokonał bodaj najbardziej wnikliwego porównania całej czwórki (2009, s. 230-277).

Z coraz szerszej i bogatszej literatury zaczęły wyłaniać się kolejne ważne cechy modelu państwa rozwojowego, takie jak:

- oparcie rozwoju albo na wielkich konglomeratach państwowo-prywatnych (zaibatsu/keiretsu w Japonii, chaebole w Korei Płd.), albo na małych i średnich przedsiębiorstwach (jak na Tajwanie i Singapurze);

- staranne planowanie modernizacji państwa i stopniowe, ale wyraźne przechodzenie na nowoczesne technologie, jak też od produkcji do usług;

6 Pierwsza wersja tego znaczącego tomu, co ważne, ukazała się w 1979 roku. W 2001 roku Vogel dodał kolejny tom na ten temat zatytułowany: Is Japan Still Number One? 
- oparcie całego modelu na polityce proeksportowej, z należytymi ustępstwami (podatkowymi, w postaci specjalnych stref handlowych itp.) na rzecz eksporterów;

- świadome włączenie do polityki rozwojowej i modernizacyjnej państwa obcych kapitałów (BIZ) (szczególnie na terenie Hongkongu i Singapuru);

- umiejętne, ale skuteczne eliminowanie alternatywnych wobec proponowanych przez państwową administrację rozwiązań (szczególnie w Singapurze, początkowo także na terenie reżimu wojskowego w Korei Płd., który sterował modernizacją w okresie 1962-1988).

Japonia, jak wiadomo, w początkach ostatniej dekady XX stulecia załamała się gospodarczo i finansowo. Tamtejszy dość trudno uchwytny i pełen paradoksów (np. pozory silnego centrum i duża elastyczność, oparcie go na silnych osobistych relacjach, a nie prawie czy instytucjach itp.) system, najlepiej zdefiniowany w literaturze przez K. van Wolferena, w obliczu nowych globalizacyjnych wyzwań i pod presją międzynarodowych rynków okazał się być anachronizmem (van Wolferen, 1990, s. 49).

Od początków lat 90 . XX stulecia Japonia popadła w gospodarcze tarapaty, co naturalnie wznowiło debatę nad państwem rozwojowym, jego zaletami czy mankamentami; tym bardziej że akurat wtedy niemal całkowicie zapanowała na światowych rynkach ortodoksja spod znaku neoliberalnego konsensusu z Waszyngtonu, tak mocno forsującego zasady wolnego rynku i prywatnej własności, kosztem państwa i własności publicznej (Walicki, 2013, s. 12 i 121). Po raz kolejny w centrum zainteresowania i debaty znalazły się wtedy kwestie dotyczące styku państwo - rynek: ile ich ma być, w jakich proporcjach? (Wyżnikiewicz 2016). Jeden z najwybitniejszych znawców Japonii, Alex Kerr, niezwykle krytyczny wobec przyjętej przez nią ścieżki modernizacyjnej ${ }^{7}$ jako główne mankamenty modelu wymienił nieprzejrzyste powiązania między państwowo-prywatnymi firmami oraz bankami i ministerstwem finansów, a także, tak cenioną w literaturze za jej fachowość i apolityczność, biurokrację, której autor zarzucił skostnienie i stwierdził, że ,jest jedynym poważnym, nierozwiązywalnym problemem kraju”; a nawet mocniej, że „jest ona odpowiedzialna za doprowadzenie Japonii w latach 90. na skraj katastrofy" (Kerr, 2008, s. 354). Z kolei inny przenikliwy badacz państwa rozwojowego, M. Castells, przyczyn japońskiego załamania i giełdowego krachu szukał gdzie indziej, chociaż jakby nieco w pobliżu. Pisze on: „To nie nadmierny interwencjonizm państwowy, lecz brak przepisów i luźny nadzór państwowy nad systemem finansowym były w gruncie rzeczy decydującymi czynnikami, które przesądziły o tym, że finansowy kryzys zrujnował gospodarkę" (2009, s. 268).

Kerr, van Wolferen i inni specyfikowali, że Japonia nie była należycie przygotowana na wyzwania płynące z globalizacji, była ciaggle państwem relatywnie zamknię-

$7 \quad$ Po dekadach pobytu opuścił ten kraj. 
tym, a do tamtejszego krachu giełdowego w dużym stopniu przyczyniło się głośne swego czasu porozumienie z Plaza z września 1985 r., dotyczące polityki kursowej i pozycji japońskiego yena, które najpierw doprowadziło do utraty korzyści eksportowych, potem zadłużenia i wreszcie deflacji, z którą kraj ten boryka się już ponad dwie dekady (świetna analiza: Pesek, 2014), nie mogąc wyjść z głębokiego zapętlenia.

\section{Chiny jako państwo rozwojowe}

Japonia już ponad dwie dekady boryka się z trudnościami gospodarczymi i nie do końca pomogła, ostro forsowana od początków 2013 roku, nowa strategia gospodarcza państwa premiera Shinzo Abe, zwana nawet popularnie abenomiką ${ }^{8}$. Natomiast inne tygrysy gospodarcze w regionie radzą sobie do dziś na ogół bardzo dobrze, a jeden z nich, Singapur, stał się głównym punktem odniesienia i wzorcem dla największego, jaki wyłonił się na tej ścieżce, czyli Chińskiej Republiki Ludowej (Vogel, 2011, s. 287).

Chiny od początku reform, zainicjowanych w grudniu 1978 roku, szły nieortodoksyjnie i własną ścieżką, pragmatycznie włączyły mechanizmy rynkowe do scentralizowanej gospodarki planowej (Lin, 2009, Preface), tworząc w ten sposób swój własny model sui generis. W pierwszej dekadzie reform koncentrowały się jeszcze jednak na reformach realnego socjalizmu, próbując go umocnić (Chao i Dickson, 2001, s. 9) i dopiero po 1992 roku, w odpowiedzi na rozpad ZSRR i bloku wschodniego oraz upadek niewydajnego modelu scentralizowanej gospodarki planowej, wizjoner chińskich reform, Deng Xiaoping, zaproponował zupełnie inne niż dotychczas podejście. Zamiast reformowania realnego socjalizmu (jak było od zarania tych reform), zaproponował swoim następcom (w istocie był to jego polityczny testament) włączenie chińskiego kolosa do globalizacji, dalsze otwarcie własnego ogromnego rynku, jego rozszerzenie i liberalizację, a także opieranie się na doświadczeniach „czterech małych smoków” (si xiao long) z NIC, a szczególnie Singapuru (Deng, 1993, s. 378).

Wypełniając nowe dyrektywy, setki, a nawet tysiące chińskich urzędników wysokiego szczebla jeździło po nauki do Singapuru, a sam Deng, przekonany komunista, już wcześniej nawiązał bliski i serdeczny kontakt z „ojcem Singapuru”, długoletnim premierem i wizjonerem jego rozwoju Lee Kuan Yewem (Vogel, 2011, s. 290). Ta nowa strategia państwa w istocie wprowadziła w komunistycznych z nazwy Chinach ${ }^{9}$

8 Temat jest niezwykle istotny, ale wychodzi poza obszar badawczy niniejszego studium. Zob. oficjalną stronę internetowa japońskiego rządu na jej temat: http://www.japan.go.jp/abenomics/ (wejście: 15.04.2017).

9 Od XIII zjazdu Komunistycznej Partii Chin - KPCh we wrześniu 1987 r. aż do dziś formalna nazwa chińskiego ustroju brzmi: „socjalizm o chińskiej specyfice”. 
model państwa rozwojowego, znany już nam z Japonii czy z NIC, ale dostosowany do chińskich potrzeb i uwarunkowań. Model ten z kolei nabrał, mniej więcej od połowy lat 90. XX wieku, następujących cech (Góralczyk, 2016, s. 49, 50):

- wysoki wzrost gospodarczy jako cel nadrzędny w polityce państwa;

- eksport jako główna siła napędowa gospodarki;

- otwarcie ogromnego własnego rynku na handel i gospodarkę światową, teraz już niemal w pełni kapitalistyczną oraz wykorzystanie obcego kapitału (BIZ) na własne potrzeby modernizacyjne;

- bardzo wysoki stopień akumulacji i nakręcanie rozwoju przez inwestycje, w tym w dużej mierze infrastrukturalne (najpierw autostrady, potem mosty i wiadukty, porty morskie i lotnicze, wreszcie szybkie koleje);

- wykorzystanie ogromnych, w istocie jedynych takich na globie, może poza Indiami, zasobów taniej siły roboczej na wsi i prowincji do niewolniczej wręcz pracy ${ }^{10}$, bez świadczeń socjalnych i z niskim uposażeniem;

- zachowanie strategicznych decyzji i sfer (oprócz obrony narodowej i kosmonautyki, także bankowości, portów lotniczych i morskich, telekomunikacji, energetyki itp.) w rękach państwa oraz stosowanie interwencjonizmu państwowego na specyficznej zasadzie: „niewidzialna ręka rynku - jak najbardziej, ale tam, gdzie chodzi o istotne interesy państwa, to jego/rządu całkowicie widzialna ręka wkracza do gry" (Halper, 2010, s. 8).

Należy zauważyć, że wielu ekspertów zachodnich otwarcie powątpiewa czy Chiny mają lub wypracowały własny model rozwojowy (Halper, 2010, s. 32), traktując je przede wszystkim jako system autorytarny (co jest jednak kategorią polityczną, nie zaś ekonomiczną). Wydaje się jednak, że władze ChRL nie odniosłyby w minionych czterech dekadach aż tak spektakularnych sukcesów bez własnego modelu oraz starannie przemyślanej i skutecznej w implementacji wizji modernizacji i rozwoju państwa. Co więcej, po 1992 roku, w przeciwieństwie do Federacji Rosyjskiej pod wodzą Borysa Jelcyna oraz zdecydowanej większości państw pokomunistycznych, ChRL nie tylko odrzuciła neoliberalną ortodoksję rynkową, na mocy konsensusu z Waszyngtonu traktowaną po 1991 r. jako wręcz bezalternatywną (Walicki, 2013, s. 65), lecz także umiejętnie wkomponowała ${ }^{11}$ rudymenty modelu państwa rozwojowego do własnego systemu.

10 Ten swoisty fenomen bodaj najbardziej plastycznie można zrozumieć, oglądając, dostępny na YouTube, film dokumentalny Michelangelo Antonioniego „Chiny” (Chung-Kuo - Cina) z 1972 r., gdzie w jednym z trzech odcinków doskonale widać, jak chińscy chłopi stoją z założonymi rękami, bo nie mają co robić. Sytuacja po 1978 r. diametralnie się zmieniła. Film Antonioniego zob.: https://www.youtube.com/watch?v=Z9tAd_-2AoM (dostęp: 17.04.2017).

11 Zrobiła to tzw. trzecia generacja przywódców w latach 90., a szczególnie rzutki i odważny reformator, premier Zhu Rongji. 
Notowane i udowodnione statystycznie sukcesy (przeciętny roczny wzrost gospodarczy w okresie 1978-2012 wynosił 9,8\%12, i to w najludniejszym państwie świata!) najlepiej dowodziły, że zastosowane rozwiązania się sprawdzają. Chiny poszły własną drogą, z czego wiosną 2004 roku jeden z zachodnich ekspertów wykładających w ChRL, Joshua Cooper Ramo, ukuł pojęcie „konsensusu pekińskiego” (dobra analiza, choć pełna zachodnich uprzedzeń wobec Chin; Halper, 2010). Ramo nie do końca wyjaśnił i zdefiniował jego cechy wyróżniające, ale główne przesłanie było więcej niż jasne: w konsensusie z Waszyngtonu najważniejszy jest rynek i gospodarka prywatna, natomiast w konsensusie z Pekinu - państwo zachowuje pakiet kontrolny i prawo do interwencji, chociaż gospodarka jest w głównej mierze rynkowa.

Strona chińska tej koncepcji nie zaakceptowała, ponieważ była ona - po pierwsze - wypracowana przez intelektualistę z Zachodu, po drugie zaś i ważniejsze - zbyt ostro stawiała na opozycję wobec Waszyngtonu. W konsekwencji po 2010 roku narodziła się wielka, trwająca do dziś, wewnątrznarodowa debata nad „chińskim modelem rozwojowym” (Zhongguo moshi) (Góralczyk, 2016; Zheng Yongnian, 2016). Koncepcję Nowej Ekonomii Strukturalnej Justina Yifu Lina należałoby jak najbardziej w nią wkomponować. Zanim to jednak zrobimy, należy jeszcze podjąć niezwykle istotną kwestię harmonizacji wywodzącego się z kapitalistycznej Japonii i także NIC modelu rozwojowego do komunistycznej z charakteru i ustroju państwowego ChRL.

Przedstawiony powyżej, a wypracowany przez Zhu Rongji i innych, model okazał się skuteczny, ale po latach funkcjonowania przyniósł też ze sobą tzw. skutki uboczne (to obowiązująca w ChRL terminologia) reform, wśród których wymienia się takie m.in., jak: nadmierne uwłaszczenie nomenklatury spod znaku KPCh; wysokie rozwarstwienie społeczne (współczynnik Gini sięgający nawet 0,6 - a więc wyższy niż w USA); stratyfikacja regionalna; nadmierne forsowanie, nie zawsze efektywnych, konglomeratów państwowych; zdewastowanie środowiska naturalnego w trakcie szybkiej industrializacji i urbanizacji ${ }^{13}$.

Podczas implementacji reform oraz toczącej się z dużym rozmachem debaty nad „chińskim modelem rozwojowym” okazało się też, że istnieją co najmniej dwie strukturalne bariery zakłócające harmonijne funkcjonowanie modelu państwa rozwojowego w ramach „socjalizmu o chińskiej specyfice”. Pierwsza, to kwestia systemu prawnego, który tak dobrze funkcjonuje w - surowym z przepisów - Singapurze. ChRL, jako państwo z rodowodem komunistycznym i pod dyktatem „czterech

12 Dane z: http://www.tradingeconomics.com/china/gdp-growth-annual (dostęp: 17.04.2017).

13 W końcu 1978 r., u progu reform, 84\% obywateli ChRL żyło na wsi, w 2014 r. już 53\% z nich żyło w miastach, a premier Li Keqiang zapowiedział, że do 2030 r. proces urbanizacji może dosięgnąć 70\% społeczeństwa. Zob. jego kluczowe wystąpienie na ten temat z 25 maja 2013 r. Li Keqiang expounds on urbanization, http://china.org.cn/china/2013-05/26/content_28934485. htm (dostęp: 17.04.2017). 
podstawowych zasad" Deng Xiaopinga (Deng, 1988, s. 106) ${ }^{14}$ jest autorytarne, a naczelną i nadrzędną zasadą są tam nie tyle rządy prawa, ile rządy KPCh, dzisiaj już nie rewolucyjnej, jak w „epoce Mao Zedonga” (1949-1976), lecz klasycznej partii władzy. Druga zaś - dobór kadr i administracji nadal w wysokim stopniu odbywa się na zasadzie obsady stanowisk poprzez nomenklaturę (coraz bardziej uwłaszczoną), a nie tylko na zasadach kompetencji i doświadczenia, jak zaleca klasyczny model państwa rozwojowego.

Czynniki te sprawiły, że kierujący (od końca 2012 r.) tzw. piątą generacją przywódców Xi Jinping wystąpił z bezprecedensową kampanią zwalczania korupcji w państwie, w ramach której do chwili pisania tych słów skazano ponad 1,2 mln osób, w tym zasiadających dotychczas na najwyższych stanowiskach w państwie. A co ważniejsze, w ramach ożywionej debaty nad Zhongguo moshi połączono, forsowane przez Xi Jinpinga, hasła „chińskiego marzenia” oraz „wielkiego renesansu narodu chińskiego" (Xi, 2014, s. 37) z rudymentami zmodyfikowanego modelu państwa rozwojowego, na który składają się (Góralczyk, 2016, s. 59):

- zrównoważony rozwój, zamiast wzrostu za wszelką cenę (stąd m.in. spadek wzrostu PKB z dwucyfrowego na 6,5\% ostatnio);

- rozbudowany rynek wewnętrzny zamiast coraz kosztowniejszego eksportu („Tanie Chiny się skończyły”; zob. Rein, 2012);

- „społeczeństwo umiarkowanego dobrobytu” (xiaokang shehui), czyli klasa średnia jako podstawa funkcjonowania państwa, co m.in. wymaga wielkich nakładów na cele socjalne;

- urbanizacja jako koło zamachowe modernizacji, zamiast dotychczasowych inwestycji infrastrukturalnych, ponieważ infrastrukturę już w wielkim stopniu zmodernizowano;

- rozwój „zielonek”, a nawet „bezwęglowej gospodarki”, z racji zdewastowanego w poprzedniej, ekstensywnej i ofensywnej fazie rozwoju środowiska naturalnego;

- budowa innowacyjnego społeczeństwa, czyli inter alia stałe przechodzenie na najnowocześniejsze technologie, a wraz z tym - niełatwe z natury - przechodzenie z ilości na jakość produkcji.

14 Nakazują one trzymać się: 1) socjalistycznej drogi; 2) dyktatury (proletariatu); 3) kierowniczej roli KPCh oraz zasad marksizmu-leninizmu, idei Mao, Denga i najnowszych koncepcji KPCh, takich jak „teoria trzech reprezentacji” Jiang Zemina z 2001 r., pozwalająca wkraczać w szeregi KPCh wielkim kapitalistom oraz forsowana ostatnio koncepcja „naukowej ścieżki rozwoju” (kexue fazhan guan). Szerzej nt. tej ostatniej: http://baike.baidu.com/item/\%E7\%A$7 \% 91 \% \mathrm{E} 5 \% \mathrm{AD} \% \mathrm{~A} 6 \% \mathrm{E} 5 \% 8 \mathrm{~F} \% 91 \% \mathrm{E} 5 \% \mathrm{~B} 1 \% 95 \% \mathrm{E} 8 \% \mathrm{~A} 7 \% 82 / 317422$ ?r =aladdin (wejście: 15.04.2017). 


\section{Państwo rozwojowe a Nowa Ekonomia Strukturalna}

To w takim kontekście należy ujmować i rozpatrywać nową teorię J.Y. Lina, nazwaną przez niego Nową Ekonomią Strukturalną, a w istocie będącą - jak należałoby dowodzić - po pierwsze, interesującą propozycją dla „wschodzących rynków” (emerging markets) konsekwentnie zwanych przez niego „gospodarkami doganiającymi" (catching-up economies), a po drugie, rozwiniętą koncepcją polityki przemysłowej, funkcjonującej w ramach szerszego modelu państwa rozwojowego.

Podobnie jak inni autorzy (Bolesta, 2007, s. 105; Johnson, 1999, s. 33), J.Y. Lin nie ukrywa, że szuka innego modelu niż obowiązujące dotychczas w świecie zachodnim, choć na zachodnią literaturę się przecież przede wszystkim powołuje i do zachodniego, a nie chińskiego, czytelnika omawiany w tym tomie jego tekst jest adresowany. Dziwne, że ani razu nie odwołuje się on do pojęcia „państwa rozwojowego", chociaż oczywiście doskonale je zna i w innych swoich pracach się na nie powoływał (Lin, 2009, s. 40-42). Ten unik jest zaskakujący i zastanawiający, toteż chyba powinien być przez tego autora jakoś wyjaśniony. Samo bowiem stwierdzenie, że jest to „trzecia propozycja”, nowa fala w myśleniu o ekonomii po „strukturalizmie" oraz neoliberalizmie (o czym wspominano już wyżej), które oczywiście nie były pozbawione mankamentów, jest stanowczo zbyt powierzchowne i stosunkowo mało przekonujące.

Owszem, autor jak najbardziej wspomina, że najpierw Japonia, a następnie cztery, wymienione z nazwy, azjatyckie tygrysy „przyjęły zupełnie inne podejście wobec kwestii rozwoju”, ale nigdzie - a szkoda - się nad tym za bardzo nie rozwodzi. J.Y. Lin przyznaje też między wierszami, że model wypracowany wcześniej przejęły Chiny, ale podkreśla, że „zastosowały u siebie inne podejście - transformacji dwutorowej”. Polegała ona, jak wyjaśnia dalej, na „kontynuowaniu protekcjonizmu państwowego i dotowaniu niewydolnych przedsiębiorstw państwowych w tradycyjnych, dawniej uprzywilejowanych branżach kapitałochłonnych, przy jednoczesnym liberalizowaniu dróg wejścia na rynek dla dawniej tłumionych branż pracochłonnych". Innymi słowy, raz jeszcze ogranicza się bardziej do strategii i gospodarki przemysłowej, a nie szerszego modelu rozwojowego.

Toteż jego nową koncepcję należy przede wszystkim uznać za nową, innowacyjną teorię polityki przemysłowej, powiązanej z jednym z podstawowych azymutów nowego chińskiego modelu rozwojowego, właśnie - nie bez bólu - wdrażanego przez władze w Pekinie, jakim jest stały nacisk na innowacyjność i postęp technologiczny. To właśnie należy uznać za podstawową wartość tej teorii, szczególnie dla „państw doganiających”, jak je autor nazywa. To jest największa wartość dodana tego studium i warto się tym zagadnieniem zająć nieco szerzej.

J.Y. Lin ma zdecydowanie rację, gdy pisze, iż „poprawianie stanu infrastruktury i instytucji leży poza zasięgiem możliwości indywidualnych firm”. Na tej podstawie, i nie tylko, opowiada się więc z jednej strony przeciwko neoliberalizmowi, który „wylewał dziecko z kąpielą, zdecydowanie odrzucając jakąkolwiek rolę rządów”, 
z drugiej zaś, czego już nie dodaje i nie wyjaśnia, ponieważ jest to dla niego rzecz wręcz oczywista, postępuje zgodnie z duchem modelu państwa rozwojowego, opowiadając się za istotną rolą państwa w planowaniu i sterowaniu rozwoju, a więc za interwencjonizmem państwowym, także, a może przede wszystkim, w postaci rozsądnej i rozbudowanej polityki przemysłowej.

To w tym kontekście pojawia się najbardziej innowacyjna warstwa tego tekstu, jaką jest podział gałęzi gospodarki na pięć podstawowych branż: doganiające, przodujące, tracące przewagę komparatywną, działające w krótkim cyklu innowacji oraz strategiczne, które z racji niezdolności do konkurencji nie posiadają przewagi komparatywnej. Wydaje się, że ten właśnie oryginalny podział można skutecznie i bez większych kontrowersji wprowadzić w życie w większości „państw doganiających”, o ile tylko nie będą one nadal trzymały się ortodoksji rynkowej i zgodzą się na państwowy interwencjonizm.

Już dość dawno temu eksperci doszli do wniosku, że siła chińskich rozwiązań i tamtejszego modelu (wokół którego nadal toczą się zażarte spory) była i pozostaje „racjonalizacją państwa” i sektora państwowego (Chao and Dickson, 2001, s. 26). Innymi słowy, kluczem do sukcesu jest racjonalne państwo, a nie do końca kontrolowany, żywiołowy rynek (chociaż liberałowie i neoliberałowie uważają inaczej). Tu jednak pojawia się przysłowiowa kwadratura koła, czyli już wspominany dylemat: ile państwa, ile rynku?

J.Y. Lin za bardzo się nad tą kwestią nie rozwodzi, uważając ją pewnie - na podstawie dotychczasowych chińskich doświadczeń - za oczywistą: ma być prymat państwa. Inni jednak tak nie uważają, a Chalmers Johnson jednoznacznie dowodzi, iż jest to kluczowy, najbardziej newralgiczny dylemat w ramach modelu państwa rozwojowego. Nie tylko wskazuje on, że istnieje jeden koronny argument przeciwko prowadzonej przez państwo (a raczej jego światłe elity) polityce przemysłowej, jakim jest realna, jak wykazuje praktyka, groźba, iż różnorodne i rozległe interesy grupowe, w tym osób prowadzących politykę przemysłową, mogą okazać się ważniejsze od prowadzonej przez nich polityki i strategii rozwojowej (Johnson, 1999, s. 48). Tym samym zdaje się on potwierdzać cytowaną wcześniej diatrybę Alexa Kerra, wymierzoną w japońską państwową administrację.

Doświadczenie Japonii jest poważnym ostrzeżeniem, ale modelem dla Chin jest Singapur, a tam, jak dowodzi Lee Kuan Yew, poradzono sobie z tą kwestią w jeden sposób: nadając administracji państwowej nie tylko najwyższy możliwy autorytet, lecz także uposażenia niczym w sektorze prywatnym. To dlatego Singapur, chociaż chiński z natury (ok. 80\% społeczeństwa pochodzenia chińskiego) nie jest skorumpowany, a wręcz przewodzi w rankingach Transparency International jako jedno z najmniej skorumpowanych miejsc na globie ${ }^{15}$.

15 W ostatnich latach jego miejsce nieco spadło, był dopiero ósmy w rankingu z 2015 r., ale nadal tamtejsze wskaźniki są bardzo wysokie i zajmuje pozycję w samej czołówce, za państwami skandynawskimi, Nową Zelandią i Szwajcarią. Zob. https://www.transparency.org/cpi2015/ (wejście: 17.04.2017). 
Jak jednak dochować się takiej uczciwej i transparentnej klasy menedżerskiej w państwie partyjnym, gdzie przede wszystkim obowiązuje logika i wola KPCh, partii władzy i nomenklatury, ale również w państwach demokratycznych, gdzie coraz częściej obowiązuje logika partokracji, a więc partyjnych podziałów i interesów dominujących nad państwowymi? Lee Kuan Yew radzi: „Są trzy zasadnicze warunki udanego przekształcenia społeczeństwa: po pierwsze - zdecydowane kierownictwo..., po drugie - skuteczna administracja, i po trzecie - dyscyplina społeczna” (Alison, Blackwill i Wyne, 2013, s. 157). Później zaś dodaje, by - podobnie jak w Singapurze - już wcześnie w szkołach zacząć kształtować przyszłych liderów, „stosownie do ich osobistych uzdolnień, skłonności i temperamentu”, bo to „kwestia genów” (Alison, Blackwill i Wyne, 2013, s. 163). Tyle tylko, że z punktu widzenia demokracji liberalnej, teraz najwyraźniej w kryzysie, takie podejście to nic innego, jak przejawy autorytaryzmu czy nawet społecznej inżynierii, nie do przyjęcia w porządku liberalnym. Nic więc dziwnego, że oba te zarzuty są stawiane zarówno Singapurowi, jak i ChRL.

Chalmers Johnson idzie jednak jeszcze dalej i głębiej w peregrynacji dotychczasowych doświadczeń wprowadzania modelu państwa rozwojowego i zatrzymuje się na koniec właśnie nad relacjami państwo - rynek oraz rząd - środowisko biznesu. Wychodzi mu, że są to kwestie nawet głębsze niż fundamentalny, wydawałoby się, podział na autokrację i demokrację ${ }^{16}$. Na tej podstawie dochodzi on do wniosku, że w grę wchodzi nic innego, jak kwestie indywidualnej oraz społecznej samodyscypliny, a także obowiązującego systemu wartości. Sięgamy więc tym samym samego sedna, czyli „dialektyki postępu w dziedzinie współpracy sektora publicznego i prywatnego" (Johnson, 1999, s. 58). A tu wniosek wydaje się być jeden: lepiej przystosowany do implementacji modelu państwa rozwojowego jest wschodnioazjatycki system wartości, oparty na powinnościach, a nie zachodni, oparty na indywidualnych wolnościach ${ }^{17}$.

J.Y. Lin nie zajmuje się w swej teorii tymi dylematami i wyzwaniami, być może, z chińskiej perspektywy wydają mu się one wręcz oczywiste. Jednakże patrząc z punktu widzenia innej kultury i cywilizacji, przede wszystkim zachodniej, wcale takimi nie są, dotyczą imponderabiliów, od których nie może uciec żaden zachodni polityk, także ten gospodarczy, próbujący wprowadzać w życie zaproponowany

16 Przypomnijmy, że badał MITI i japoński model na przestrzeni lat 1925-1975, gdy były na wyspach japońskich różne systemy polityczne.

17 Koncepcję „wartości azjatyckich” wypracowali w latach 90. XX wieku, wspominany tutaj, Lee Kuan Yew oraz długoletni premier Malezji, Mahathir bin Mohammad. Ten ostatni stwierdził, że w Azji nadrzędnymi wartościami są: porządek społeczny i dobra organizacja; harmonia w społeczeństwie; odpowiedzialność funkcjonariuszy publicznych; poszanowanie władzy i hierarchia; natomiast w systemie zachodnim nadrzędne wartości są indywidualne i wiązane z wolnością wypowiedzi, wolnościami osobistymi, prawami jednostki, otwartymi debatami i dbałością o samego siebie. Z tej i innych analiz wynika, że wartości azjatyckie są bardziej związane ze zbiorowością i powinnościami, podczas gdy zachodnie są oparte na indywidualnych wolnościach. Zob. Mahathir, 1999, s. 157-168. 
model Nowej Ekonomii Strukturalnej, a także nowej polityki przemysłowej, zaproponowanej przez tego autora.

Tę konstatację warto odnotować i podkreślić jej znaczenie tym bardziej teraz, gdy zgodnie z przewidywaniami Lee Kuan Yewa ${ }^{18}$, Chiny nie stały się i nie staną, a nawet „nie zmierzają być liberalną demokracją. Gdyby się nią stały to upadną. Mam co do tego całkowitą pewność" (Alison, Blackwill i Wyne, 2013, s. 41). Skazani więc jesteśmy na współistnienie, bo raczej nie na konwergencję systemów i modeli rozwojowych, z czego też należy wyciągać odpowiednie wnioski.

\section{Zakończenie}

Przedmiotem niniejszego studium było państwo rozwojowe rozumiane jako szerszy kontekst nowych idei zaproponowanych przez J.Y. Lina w tym tomie. Na podstawie przeglądu doświadczeń państw i regionów, które ten model nadzwyczaj skutecznie u siebie zastosowały, a więc Japonii, potem zaś NIC, a ostatnio ChRL, wygląda, że to jednak model specyficzny, charakterystyczny dla Azji Wschodniej i tamtejszego zestawu „wartości azjatyckich”, a nie uniwersalny do zastosowania w różnych punktach globu. Bardziej uniwersalne znaczenie może mieć natomiast druga, oryginalna koncepcja tego chińskiego autora, jaką jest nowe podejście do polityki przemysłowej państwa. Tyle tylko, że chcąc ją wprowadzić w życie, potrzebne jest „zielone światło” dla dużej roli sektora państwowego i państwowego interwencjonizmu, prowadzonego na dodatek przez mądre, doświadczone i nieskorumpowane elity, a to już zdają się być warunki trudne do spełnienia, nawet w samych Chinach czy w Japonii, nie mówiąc już o szerszym świecie.

Nowe teorie J.Y. Lina pojawiają się w dobrym momencie, gdyż w całym świecie, a przede wszystkim w demokracjach zachodnich wyciagane są wnioski z poprzedniej neoliberalnej rynkowej ortodoksji oraz - w opinii większości - będącego jej efektem wielkiego kryzysu na rynkach światowych (zachodnich) z lat 2007-2008 i późniejszych. Ten moment jest również bardzo dobry dla Chin, gdzie również trwa wielka debata nad nowym modelem rozwojowym oraz wyciąganie wniosków z poprzedniej ekspansywnej i ekstensywnej fazy rozwoju i nad zagrożeniami, które ze sobą przyniosła (Chi, 2010). Paradoksalnie, jak na Zachodzie mówi się ponownie o zwiększonej roli państwa (stąd rozważania nad modelem państwa rozwojowego są tym bardziej aktualne i atrakcyjne), tak w Chinach - jeśli wierzyć przenikliwej diagnozie wykładającego w Singapurze, ale publikującego przede wszystkim na terenie ChRL Zheng Yongniana - trwa właśnie nadawanie większej podmiotowości tamtejszemu społeczeństwu, co może potrwać równie długo, jak pierwsza faza polegająca na nadawaniu większej mocy państwu, czyli nawet ze 30 lat, a dopiero

18 Który za życia wielokrotnie udowodnił, że ma rację. Lee Kuan Yew zmarł w 2015 r. 
potem przyjdzie faza trzecia i ostatnia transformacji - politycznych zmian (Zheng Yongnian, 2012).

Nadal jednak, również w tej drugiej fazie transformacji i przemian, kluczowe będą dylematy na styku państwo - rynek; tyle że tym razem dojdzie do tego jeszcze społeczeństwo i ujawni się tym samym potrójne powiązanie: rząd - rynek - społeczeństwo (Chi, 2010, s. 9). To są, jak się wydaje, jak najbardziej słuszny wniosek i kierunek poszukiwań, już wcześniej bowiem wykazano, iż w miarę postępu modernizacji nieco maleje rola czynnika państwowego jako siły sprawczej rozwoju i polityki przemysłowej, rośnie natomiast stale w całym procesie - ze względu na charakter dokonujących się zmian i przechodzenia na społeczeństwo oparte na wiedzy - rola społeczeństwa (obywatelskiego). Jak to celnie ujął M. Castells, „zasada legitymizacji przesunęła się od nacjonalizmu rozwojowego do nacjonalizmu obywatelskiego" (Castells, 2009, s. 273).

Raz jeszcze, jak na początku wprowadzania modelu państwa rozwojowego, na porządku dziennym staje kwestia efektywności w czworokącie: elita rządząca, państwowa administracja, społeczeństwo oraz kręgi biznesu (Bolesta, 2015, s. 13). To przede wszystkim od nich i ich harmonijnej współpracy zależy efektywność tego modelu - od tego, jak zapobiec, by ktokolwiek w tym czworokącie zbudował swoją klientelę złożoną z pozostałych współgraczy. Jednakże w tym akurat kontekście warto zwrócić uwagę na przenikliwą uwagę Grzegorza W. Kołodko, który stwierdził: „Wszędzie istnieją lobbies walczące wszelkimi dostępnymi środkami o swoje partykularne interesy, ale nigdzie nie ma silnych lobbies skłonnych z podobną determinacją i siłą walczyć o długookresowy wzrost i odległe cele polityki gospodarczej. Tę rolę musi odgrywać państwo" (Kozłowski i Wojtysiak-Kotlarski, 2014, s. 333).

Innymi słowy, to państwo musi pozostać nadrzędnym strażnikiem wytyczonych dalekosiężnych celów rozwoju i modernizacji. Dlatego też jak najbardziej byłoby wskazane, żeby było to państwo transparentne, uczciwe i światłe, pełnymi garściami korzystające z dobrze przygotowanych i wykształconych elit, podpowiadających społeczeństwu i biznesowi, w którym kierunku iść i jakie kolejne cele przed sobą stawiać. Ponadto, tylko takie państwo, jak się wydaje, ma szansę przebić szklany sufit i uniknąć pułapki średniego dochodu, co jest jednym z kolejnych, choć nie nadrzędnych celów przy wprowadzaniu w życie nowych teorii J.Y. Lina, zaprezentowanych w tym tomie, a będących przedmiotem poważnej troski we wszystkich „państwach doganiających", z Polską włącznie.

Jest udowodnione, że model państwa rozwojowego stopniowo prowadzi do upodmiotowienia społeczeństwa obywatelskiego, chociaż jest to zarazem jedno z najbardziej newralgicznych wyzwań w trakcie jego implementacji. Albowiem na wcześniej zdefiniowany dylemat: ile państwa, ile rynku? nakłada się drugi problem, nie mniej ważny z punktu widzenia skuteczności modelu - ile państwa i jego arbitralnej roli, a ile obywatelskich wolności?, a także inny dobrze zdefiniowany dylemat: ile państwa, a ile globalizacji w procesie rozwojowym (Chang, 2003, s. 11), czyli - jak bardzo być otwartym na idee, impulsy i rynki z zewnątrz? Żadna z tych kwestii 
nie jest, jak dotąd, nigdzie przesądzona, leży natomiast - co oczywiste - w samym sercu prowadzonych debat i sporów akademickich oraz politycznych.

Obecnie cały świat znajduje się na zakręcie, a w takich przełomowych czy kluczowych momentach wszelkie nowe idee i pomysły, takie jak te ze strony J.Y. Lina, są ze wszech miar wskazane. Idziemy ku nowemu, chociaż jakie będzie to „nowe” jeszcze dokładnie nie wiemy, co nie tylko podnosi poprzeczkę, lecz także rangę naszych dociekań.

\section{Bibliografia}

Alison, G., Blackwill, R. i Wyne A. (oprac.). (2013). Chiny, Stany Zjednoczone i świat w oczach wielkiego mistrza Lee Kuan Yewa [Lee Kuan Yew: The Grand Master's Insights on China, the United State and then World]. Warszawa: Kurhaus.

Amsden, A.H. (1989). Asia's Next Giant: South Korea and Late Industrialization. New York, Oxford: Oxford University Press.

Bolesta, A. (2007). China as Developmental State. Montenegrin Journal of Economics, 5.

Bolesta, A. (2015). China and Post-Socialist Development. Bristol, Chicago: Policy Press.

Castells, M. (2009). Koniec tysiaclecia [End of Millenium]. Warszawa: PWN.

Chang, H.J. (2003). Globalisation, Economic Development and the Role of the State. New York: Zed Books.

Chao, Chen-min and Dicson B.J. (red.). (2001). Remaking the Chinese State. Strategies, Society, and Security. London and New York: Routledge.

Chi, Fulin (2010). Di er ci Gaige. Zhongguo weilai 30 nian de qiangguo zhi lu [Druga reforma. 30 lat budowania silnego państwa w Chinach]. Beijing: Zhongguo Jingji Chubanshe.

Deng Xiaoping. (1988). Chińska droga do socjalizmu. Warszawa: Książka i Wiedza.

Deng Xiaoping. (1993). Deng Xiaoping Wenxuan [Dzieła wybrane...], vol. 3. Beijing: Renmin Chubanshe.

Góralczyk, B. (2016). W poszukiwaniu chińskiego modelu rozwojowego. Sprawy Międzynarodowe, LXIX, 1, 40-61.

Halper, S. (2010). The Beijing Consensus. How China's Authoritarian Model Will Dominate The Twenty-First Century. New York: Basic Books.

Johnson, Ch. (1982). MITI and the Japanese Miracle. The Growth of Industrial Policy 1925-1975. Stanford: Stanford University Press.

Johnson, Ch. (1999). The Developmental State: Odyssey of a Concept. W: Woo-Cumings (red.), The Developmental State (s. 32-60). Ithaca and London: Cornell University Press.

Kasahara, S. (2013). The Asian Developmental State and the Flying Geese Paradigm. UNCTAD Discussion Papers, November. New York: United Nations.

Kerr, A. (2008). Psy i demony. Ciemne strony Japonii [Dogs and demons. Tales from the Dark Side of Japan]. Kraków: Universitas.

Kornai, J. (1993). A Szocialista rendzyer. Kritikai polituikai gazdaságtan [System socjalistyczny. Krytyczna ekonomia polityczna]. Budapest: HVG Kiadói Rt.

Kozłowski, P. i Wojtysiak-Kotlarski, M. (red.). (2014). Grzegorz W. Kołodko i ćwierćwiecze transformacji. Warszawa: Wydawnictwo Naukowe Scholar. 
Lin. J.Y. (2009). Economic Development and Transition. Thought, Strategy, and Viability. Cambridge: Cambridge University Press.

Mahathir, M. (1999). Rozważania o wartościach azjatyckich. Azja-Pacyfik, 2.

Pesek, W. (2014). Japanization: What the World Can Learn from Japan's Lost Decades. New York: Wiley.

Rein, S. (2012). The End of Cheap China. Economic and Cultural Trends That Will Disrupt The World. New York: Wiley.

Stiglitz, J. (2015). The Great Divide. London, New York: Penguin.

van Wolferen, K. (1990). The Enigma of Japanese Power. New York: Alfred A. Knopf.

Vogel, E. (1999). Japan As No. 1. Lessons for America. New York: iUniverse.

Vogel, E. (2011). Deng Xiaoping and the Transformation of China. Cambridge, Massachussets and London: The Belknap Press of Harvard University Press.

Wade, A. (1990). Governing the Market Economic Theory and the Role of Government in East Asian Industrialization. Princeton: Princeton University Press.

Walicki, A. (2013). Od projektu komunistycznego do neoliberalnej utopii. Kraków: PAN Universitas.

Woo-Cummings, M. (red.). (1999). The Developmental State. Ithaca and London: Cornell University Press.

Wyżnikiewicz, B. (2016). Ile rynku ile państwa?. W: J. Kleer, P. Szukalski, K. Prandecki (red.), Dokad zmierza Europa? Państwo-Gospodarka-Spoteczeństwo-Finanse (s. 131-143). Warszawa: Komitet Prognoz Polska 2000 Plus przy Prezydium PAN.

Xi, Jinping (2014). The Governance of China. Beijing: Foreign Languages Press.

Zheng, Yongnian (2012). Zhongguo Gaige san bu zou [Trzy fazy chińskich reform]. Beijing: Dongfang Chubanshe.

Zheng, Yongnian (2016). Zhongguo moshi. Jingyan yu tiaozhan [Chiński model rozwojowy: doświadczenia i wyzwania]. Bejing: Zhongxin Chuban Tuanji. 


\section{ALOJZY Z. NOWAK}

\section{Nowa Ekonomia Strukturalna a dylematy rozwoju gospodarki}

Artykuł podejmuje kwestie związane z procesami zachodzącymi w warunkach globalizacji i niektórymi wyzwaniami wynikającymi z efektywnego i dojrzałego rozwoju społeczno-ekonomicznego, przede wszystkim w odniesieniu do Polski. Uważa się, że do rozwikłania wielu problemów pojawiających się w skali globalnej należy poszukiwać nowych rozwiązań oraz nowego ładu i porządku ekonomicznego. Dlatego w takich krajach, jak Polska coraz większe zainteresowanie wzbudza koncepcja Nowej Ekonomii Strukturalnej, stosująca podejście neoklasyczne do badania czynników determinujących strukturę ekonomiczną i jej rozwój. Postuluje ona, że struktura przemysłowa w ramach gospodarki ma charakter endogeniczny względem struktury jej wyposażenia w zasoby. Autor tego artykułu podziela opinię, iż warto przeanalizować, także krytycznie, założenia Nowej Ekonomii Strukturalnej, która zakłada m.in., że czynnikiem o znaczeniu decydującym dla sukcesu rozwojowego jest państwo, które umożliwia ten rozwój, prowadząc odpowiednią politykę przemysłową. Polityka taka musi ułatwiać przedsiębiorstwom wchodzenie do branż cechujących się ukrytą przewagą komparatywną na konkurencyjnym rynku poprzez pokonanie problemu uzewnętrzniania wartości przez pierwszego inicjatora oraz koordynowanie wymaganych udoskonaleń twardej i miękkiej infrastruktury. Polityka ta winna mieć też na celu przekształcanie branż cechujących się ukrytą przewagą komparatywną w narodowe przewagi konkurencyjne. Potrzeba analitycznej oceny filozofii rozwoju, opartej o założeniach Nowej Ekonomii Strukturalnej, jest tym bardziej uzasadniona, gdyż polityka i strategia obecnego rządu polskiego wychodzi naprzeciw tendencjom w zakresie polityki rozwojowej krajów doganiających kraje wysoko uprzemysłowione, zawartym we wskazaniach Nowej Ekonomii Strukturalnej. Obecność w Polsce i na Wydziale Zarządzania Uniwersytetu Warszawskiego jednego z teoretyków i twórców Nowej Ekonomii Strukturalnej, Prof. Justina Yifu Lina, doradcy rządu chińskiego w zakresie gospodarki oraz wiceprezydenta Banku Światowego w latach 2008-2012, była niewątpliwie inspiracją do powstania tego artykułu.

Słowa kluczowe: globalizacja, wyzwania rozwojowe, Nowa Ekonomia Strukturalna, Strategia na rzecz Odpowiedzialnego Rozwoju.

\section{Wprowadzenie}

Procesy globalizacji gospodarki światowej, główne megatrendy w niej występujące, takie jak: prywatyzacja, deregulacja, integracja, liberalizacja czy finansyzacja przyczyniają się do przyspieszenia przemian strukturalnych w gospodarkach 
poszczególnych krajów oraz ugrupowań gospodarczych. Przemiany strukturalne wyrażają się przede wszystkim w przyspieszeniu tempa wzrostu gałęzi o wysokiej technologii, w których coraz ważniejszą rolę odgrywają firmy innowacyjne o wysokim udziale wiedzy w strukturze produkcji.

W procesie globalizacji pojawia się wiele pytań i dylematów dotyczących choćby modelu i granic modernizacji. Można przyjąć, że modernizacja stwarza jednak szansę na:

- wzrost dobrobytu jednostek i narodów,

- wzmocnienie prestiżu i pozycji państwa, społeczności lokalnych, rodziny,

- wzbogacanie wartości duchowych i intelektualnych (Nowak, 2013).

Te szanse najwyraźniej są inaczej rozumiane i interpretowane ze względu na zasadnicze zróżnicowanie ekonomiczne oraz kulturowe narodów i państw. Dlatego poszerzanie, a niekiedy narzucanie systemu wartości i postaw typowych dla świata Zachodu, takich jak: konsumpcjonizm, wiara w samoczynny, pozytywny skutek rynku czy prawa człowieka, spotkały się z krytyką, a nierzadko odrzuceniem modelu modernizacji typowego dla głównych aktorów globalnego rynku (USA czy państw europejskich). Dziś można zauważyć, że poza głównym nurtem, a przynajmniej w pewnej opozycji do dominującego modelu rozwojowego, znalazły się kraje islamu i świat cywilizacji chińskiej, gdzie zmiany i reformy mają charakter modernizacji antyliberalnej.

Coraz większe grono ekonomistów, ale również i polityków uważa, że do rozwikłania wielu problemów pojawiających się w skali globalnej należy poszukiwać nowych rozwiązań oraz nowego ładu i porządku ekonomicznego, opartych już nie tylko na USA czy Unii Europejskiej lub Japonii, lecz także na interesach i sile nowych potęg gospodarczych takich m.in., jak: Chiny, Indie, Brazylia, Meksyk, a więc na tzw. gospodarkach wschodzących.

Podstawowe wytyczne dla polityki gospodarczej również ulegają pewnym modyfikacjom. Choć nadal takie kanony ekonomiczne, jak: utrzymanie dyscypliny finansowej; zrównoważony deficyt budżetowy; liberalizacja zasad handlu światowego; zniesienie przeszkód dla bezpośrednich inwestycji zagranicznych, tak aby firmy zagraniczne konkurowały z krajowymi na równych zasadach; deregulacja i prywatyzacja, są ważnymi przesłankami wzrostu gospodarczego, nie są przyjmowane wszędzie i realizowane bezkrytycznie.

Momentem przełomowym w tym względzie stał się niespodziewany, co do skali i rozmiarów, światowy kryzys finansowy w latach 2007-2009. Jego rozległe skutki nie zostały całkowicie przezwyciężone. Pewne założenia teorii ekonomicznych, opartych na wierze w samoczynne mechanizmy naprawcze wolnego rynku, zostały poważnie zakwestionowane. Co więcej, dominujący w globalnej gospodarce system wolnorynkowy, pozbawiony mechanizmów regulacji, zaczął „produkować” różnego rodzaju wynaturzenia. Szczególnie zaś, gdy idzie o rynki finansowe. To właśnie te rynki są jednym z ważnych źródeł nadmiernej finansyzacji gospodarki światowej, z ujemnymi 
dla niej skutkami. Dziś istnieje coraz większa świadomość, iż choć Adam Smith miał rację, stwierdzając, że wolny rynek jest przyszłością gospodarki i jest jej niezwykle ważnym regulatorem, to niekoniecznie wszystkie decyzje podejmowane obecnie na globalnym rynku prowadzą do oczekiwanych i pożądanych rezultatów.

Należy również zgodzić się z opinią wyrażoną przez prof. Kazimierza Rycia, iż po ostatnim kryzysie i trwającej dekoniunkturze w gospodarce światowej nasilił się wyraźnie krytyczny stosunek do globalizacji. „Wielu ekonomistów i publicystów ekonomicznych - stwierdza prof. Ryć - zarówno lewicowych, jak i prawicowych - eksponuje ujemne strony tego procesu. Globalizację obciąża się winą za utratę miejsc pracy w krajach wysoko rozwiniętych, przede wszystkim w przemyśle, w wyniku przenoszenia produkcji do krajów o niskich kosztach pracy oraz konkurencję tanich producentów z krajów słabo rozwiniętych, intensywnie rozwijających produkcję przemysłową. Tym sposobem - konstatuje prof. Kazimierz Ryć - globalizacja, poza korzyściami, w wielu miejscach na świecie przyczynia się do bezrobocia, pogarsza pozycję negocjacyjną pracowników najemnych w krajach wysoko rozwiniętych, co skutkuje stagnacją zarobków i dochodów realnych pracowników i klasy średniej. Efekty wzrostu gospodarczego rozkładają się nierównomiernie - przyrastający produkt trafia w większości do wąskiej warstwy właścicieli kapitału, wysokiej rangi menedżerów, zwłaszcza sektora finansowego. Ograniczony niskimi dochodami popyt konsumpcyjny znacznej części społeczeństwa oraz wysokie oszczędności warstw najwyżej sytuowanych w hierarchii dochodów stwarzają układ spowalniający tempo wzrostu. Ograniczony popyt konsumpcyjny nie sprzyja inwestycjom, a wysokie oszczędności, niewykorzystane na powiększenie zdolności wytwórczych, powiększają zasoby rynków finansowych bądź są inwestowane w innych krajach. W wyniku globalizacji może następować ubytek miejsc pracy w przemyśle. Dotyczy to nie tylko przemysłu krajów najwyżej rozwiniętych, może również wystąpić w krajach mniej czy średnio zaawansowanych w rozwoju, wszędzie tam, gdzie koszty pracy są wyższe" (Nowak i Ryć, 2017, s. 60).

Polska należy do tej grupy państw, które proces internacjonalizacji, czyli umiędzynarodowienia swoich gospodarek wiążą z transformacją systemu politycznego i ekonomicznego po 1989 roku, z wstąpieniem do Unii Europejskiej w 2004 roku, ale także z ogółem procesów o charakterze globalnym prowadzących do postępującej współzależności i integracji państw. Otwartość polskiej gospodarki i jej integracja z partnerami w Unii Europejskiej to szczególnie ważne przesłanki modernizacji Polski, a w ogólnym bilansie, jej sukcesu w globalnym otoczeniu ekonomicznym. Wciąż jednak decydującym czynnikiem rozwoju społeczno-gospodarczego kraju pozostaje mądra i przemyślana strategia rozwojowa, która zapewniałaby trwałe i solidne podstawy do długofalowego, zrównoważonego wzrostu gospodarczego.

Najbardziej interesujące diagnozy, dotyczące stanu polskiej gospodarki po 26 latach transformacji, ale także krytyczne oceny dotychczasowego modelu rozwojowego Polski wraz z wnioskami zmian i reform, pojawiły się głównie w trzech opracowaniach analitycznych. 


\section{Konkurencyjna Polska. Jak awansować do światowej ligi gospodarczej - diagnoza dla Polski}

Jedna z zasadniczych konkluzji raportu Konkurencyjna Polska. Jak awansować do światowej ligi gospodarczej (Geodecki i Hausner, 2013) stwierdza, że trwający kryzys światowy i wynikające z niego problemy polskiej gospodarki zmuszają do pilnego i koniecznego podjęcia takich strukturalnych i systemowych działań, które pozwolą nie tylko ożywić gospodarkę, lecz także wprowadzić ją na ścieżkę długookresowego wysokiego wzrostu. Według autorów raportu pełniejsze wykorzystanie potencjału rozwojowego pozwoli w konsekwencji zwiększyć tak pożądaną konkurencyjność polskiej gospodarki oraz zapewnić jej trwałą obecność w gospodarczym i politycznym trzonie Unii Europejskiej. Jednocześnie konieczne jest podjęcie działań, które uchroniłyby polską gospodarkę przed spowolnieniem tempa wzrostu wydajności i utknięciem w tzw. pułapce średniego poziomu rozwoju (middle income trap). Osiągnięcie takiego celu, zdaniem autorów raportu, wymaga prowadzenia całościowych i skoordynowanych działań, określanych w literaturze jako „nowa polityka przemysłowa” lub „nowa polityka strukturalna”. „Chodzi tu o całokształt zmian instytucjonalnych, które tworzą zespół bodźców i jednocześnie środowisko sprzyjające poprawie konkurencyjności gospodarki” (Geodecki i Hausner, 2013, s. 10). Odpowiedzią na światowy kryzys nie będzie zaś szybkie pojawienie się globalnych mechanizmów międzynarodowego współzarządzania. „Droga wiedzie przez działania każdego państwa w obszarze własnej gospodarki i równoczesnej międzynarodowej współpracy, by odrzucić rozwiązania autarkiczne i protekcjonistyczne oraz poszukiwać rozstrzygnięć potrzebnych dla gospodarki otwartej, zdolnej do konkurencji i kooperacji” (Geodecki i Hausner, 2013, s. 13).

Tzw. raport Hausnera trafnie dowodzi, że istnieje kwestia strukturalnych cech polskiej gospodarki i właśnie dlatego trzeba zdecydowanie zdobyć się na strategiczną refleksję rozwojową, wdrożyć program prokonkurencyjnej polityki strukturalnej, w tym nowej polityki przemysłowej oraz doprowadzić do strukturalnej zmiany, czyli proinnowacyjnej reorientacji polskiej gospodarki. Jak stwierdza dokument, coraz bardziej nowoczesna i kompatybilna polska infrastruktura powinna stać się ważnym ogniwem wspomagającym tę reorientację polskiej gospodarki. Jak na razie, jest to jeszcze w dużej mierze postulat niepodjęty do realizacji.

\section{Polska 2030. Trzecia fala nowoczesności. Długookresowa Strategia Rozwoju Kraju}

Diagnozę stanu polskiej gospodarki, ale także prezentację listy działań związanych z realizacją poszczególnych strategicznych zadań polityki gospodarczej w Pol- 
sce zawiera także dokument analityczny pt.: Polska 2030. Trzecia fala nowoczesności. Dtugookresowa Strategia Rozwoju Kraju (MAiC, 2013).

Głównym celem tego dokumentu jest - jak wskazują jego autorzy - poprawa jakości życia Polaków mierzona zarówno wskaźnikami jakościowymi, jak i wartością oraz tempem wzrostu PKB w Polsce. Długookresowa strategia rozwoju kraju, która ma ten cel zrealizować, została ujęta w perspektywie do 2030 roku, co więcej, dokument ten wyróżnia się próbą uwzględnienia głównych trendów, wyzwań i scenariuszy rozwoju społeczno-gospodarczego kraju, kierunków przestrzennego zagospodarowania kraju z uwzględnieniem zasady zrównoważonego rozwoju.

Stąd też w analizie wydobyty został element trzeciej fali nowoczesności, czyli kolejnego etapu rewolucji technologicznej dokonującej się na świecie. Tym samym Długookresowa Strategia Rozwoju Kraju jest w zamierzeniu dokumentem analitycznym, ale jednocześnie rekomendacyjnym, stanowiącym opis pewnego projektu cywilizacyjnego, zorientowanego na przyszłość, w perspektywie do $2030 \mathrm{r}$. W sprawie trzech obszarów rozwoju strategicznego dla Polski dokument w zasadzie potwierdza zalecenia większości naszych ekonomistów oraz socjologów, także zawartość wspomnianego wcześniej tzw. raportu Hausnera. Rozwój Polski powinien odbywać się równocześnie w trzech głównych kierunkach:

1) konkurencyjności i innowacyjności gospodarki (modernizacji),

2) równoważenia potencjału rozwojowego regionów Polski (dyfuzji),

3) efektywności i sprawności państwa (efektywności).

W każdym z tych trzech obszarów strategicznych zostały określone cele do realizacji. Tak więc w obszarze pierwszym, który dotyczy konkurencyjności i innowacyjności, a więc modernizacji Polski, cele i kierunki obejmują:

- pobudzanie innowacyjności, efektywności gospodarki i kreatywności ludzi - interwencja państwa powinna dotyczyć przede wszystkim edukacji: od opieki przedszkolnej po szkolnictwo wyższe, ale również wspierania badań i nauki, tak aby podnieść ich dotychczasową jakość i efektywność. Ważne jest też tworzenie skutecznych instrumentów inżynierii finansowej i wzmacnianie instytucji otoczenia biznesu, poprawa sprawności funkcjonowania administracji państwowej i samorządowej oraz znoszenie barier legislacyjnych i administracyjnych, blokujących lub spowalniających rozwój firm;

- przyspieszenie przemian technologicznych - aby projekt Polska Cyfrowa nie był zapisany tylko na papierze, należy podjać dalsze niezbędne inwestycje infrastrukturalne w szerokopasmowy Internet, dostępny dla wszystkich. Zwiększy to szanse rozwoju obszarów peryferyjnych. Zadaniem równie ważnym jest zwiększenie używania Internetu poprzez rozwój e-usług oraz e-gospodarki. Z kolei cyfryzacja zasobów kultury pozwoli na rozszerzenie tradycyjnych ról instytucji kultury. Zintegrowana informatyzacja, która jest oparta na logicznym i skutecznym obiegu informacji, wprowadzenie zasad zarządzania procesowego, efektywności kosztowej powinny sprzyjać większej sprawności i elastyczności państwa oraz firm. To 
wszystko da się przeprowadzić pod warunkiem zwiększenia kompetencji cyfrowych społeczeństwa i zapobieżeniu zjawisku wykluczenia osób starszych, nie używających Internetu;

- położenie nacisku na rozwój kapitału ludzkiego, który zdecydowanie mocniej powinien być powiązany z reformami sytemu zdrowia oraz zapewnieniem spójności społecznej - edukacją i transferem absolwentów na rynek pracy - aktywna polityka prorodzinna oraz polityka migracyjna w zdecydowanie większym stopniu ograniczyłyby zagrożenia związane z niekorzystnymi przemianami demograficznymi. Wzmacnianie kompetencji językowych Polaków, to także ważne zdanie w tym obszarze;

- uwzględnienie wagi bezpieczeństwa Polski poprzez większe zaangażowanie na rzecz bezpieczeństwa energetycznego oraz ochrony środowiska - potrzebę większej i skutecznej interwencji na rzecz bezpieczeństwa energetycznego podkreślał bardzo mocno także tzw. raport Hausnera. Działania takie powinny uwzględniać wykorzystywanie odnawialnych źródeł energii.

W obszarze drugim, dotyczącym równoważenia potencjału rozwojowego regionów (dyfuzji), dokument modyfikował dotychczasowy model polaryzacyjno-dyfuzyjny równoważenia rozwoju regionalnego i uzupełnił go modelem terytorialnego równoważenia (dyfuzji). Koncepcja polaryzacyjno-dyfuzyjnej polityki rozwoju regionalnego opiera się na założeniach, iż należy wspierać silne centra rozwoju, tzw. lokomotywy rozwoju, natomiast obszary otaczające je będą korzystały z dyfuzji (tzw. spill-over) efektów ekonomicznych i społecznych. Według tej koncepcji aktywizowanie obszarów o niskim poziomie rozwoju jest marnotrawstwem ograniczonych środków publicznych, a transfery finansowe dla tego typu obszarów powinny jedynie zapewniać dostęp do podstawowych usług publicznych. Dyfuzja ma nastąpić automatycznie na późniejszych etapach rozwoju przez wahadłowe migracje siły roboczej oraz przepływy kapitału. Jednak warunkiem jest tu zapewnienie spójności przestrzennej, w tym komunikacyjnej.

Model ten nie wszędzie sprawdził się w polskich warunkach, także dlatego, że okazało się, iż rozwój peryferii nie zależy tylko od skuteczności w budowaniu własnego potencjału rozwojowego, który jest jednak ograniczony, również poprzez brak polityki spójności i konsekwentnego rozwoju infrastruktury podstawowej, jakim jest np. dobry system komunikacji i ponadlokalnego transportu (co w dużej mierze wynika ze specyfiki systemu samorządowego, w szczególności słabości powiatów).

W tej sytuacji dokument zaleca raczej uzupełnienie rozwoju regionalnego o model zrównoważonego rozwoju, gdzie wprowadza się m.in kategorię redystrybucji dochodów na rzecz obszarów zapóźnionych w rozwoju. Zaleca się także włączanie obszarów peryferyjnych do większej współpracy zagranicznej.

Trzeci obszar strategiczny - efektywności i sprawności państwa - poza wymienionymi wcześniej programami rozwoju e-usług i tworzenia zintegrowanej informatyzacji, zwraca uwagę na rolę kapitału społecznego, który odnosi się do takich cech 
organizacji społeczeństwa, jak: zaufanie, normy i powiązania, które mogą zwiększyć sprawność społeczeństwa, ułatwiając skoordynowane działania. Przykładowo, grupa, której członkowie wykazują, że są godni zaufania i ufają innym będzie w stanie osiągnąć znacznie więcej niż porównywalna grupa, w której brakuje zaufania.

Polscy socjolodzy są zgodni, że szybszy rozwój Polski będzie niemożliwy bez wzrostu kapitału społecznego, co w naszym warunkach oznacza przeciwdziałanie rosnącemu brakowi zaufania w relacjach międzyludzkich, ale również brakowi zaufania do instytucji państwa. W dużej mierze dzieje się tak z powodu rosnącej biurokracji, niestabilnego prawa i korupcji. Niski poziom kapitału społecznego manifestuje się także stosunkowo małą aktywnością społeczną i obywatelską (np. słabe uczestnictwo w wyborach), niedostateczną jeszcze pozycją organizacji pozarządowych.

Długookresowa strategia rozwoju kraju, zaproponowana w omawianym dokumencie wraz z instrumentami i celami w nim zawartymi, stanowiła szansę cywilizacyjnego rozwoju Polski. W dużej mierze współgrała z ocenami i analizą raportu Konkurencyjna Polska. Jak awansować do światowej ligi gospodarczej. Cechą charakterystyczną obu tych dokumentów jest wyrażane przekonane, że w warunkach gospodarki rynkowej jest miejsce na istotną rolę państwa w kształtowaniu polityki gospodarczej i społecznej. W szczególności w dziedzinie polityki inwestycyjnej, prowadzonej na rzecz zmian strukturalnych oraz w celu pobudzania przedsiębiorczości i konkurencyjności.

\section{Strategia na rzecz odpowiedzialnego rozwoju Mateusza Morawieckiego}

W warstwie diagnostycznej wiele analiz i ocen, a także wniosków zawartych w obu zaprezentowanych opracowaniach, tj. w raporcie Konkurencyjna Polska. Jak awansować do światowej ligi gospodarczej oraz w dokumencie Polska 2030. Trzecia fala nowoczesności. Dtugookresowa Strategia Rozwoju Kraju pojawia się w trzecim - jak się wydaje - najbardziej ambitnym dokumencie pt. Strategia na rzecz odpowiedzialnego rozwoju, autorstwa wicepremiera Mateusza Morawieckiego (2017). Dziś ta strategia jest już realizowana przez polski rząd i wyróżnia się śmiałością w stawianiu celów rozwojowych, kompleksowością analizy i nowatorskim - jak na polskie warunki - podejściem, choć nie jest pozbawiona także dyskusyjnych założeń.

Strategia na rzecz odpowiedzialnego rozwoju (SOR), realizowana w praktyce, wychodzi bowiem z założenia, że potencjał przyjętego wraz z transformacją modelu rozwoju gospodarczo-społecznego wyczerpał się i Polska potrzebuje nowego impulsu, by wyrwać się z pułapki średniego rozwoju, a intencją twórców nowej polityki gospodarczej jest dokonanie „przełomu w podejściu do wielu strategicznych kwestii, ważnych dla kraju". 
„Strategia nie powiela dominującego w okresie transformacyjnym podejścia do programowania polityki rozwojowej państwa, opartego w istotnym stopniu na kopiowaniu i naśladownictwie rozwiązań ‘importowanych’ z zagranicy, a zgodnych z podstawowymi założeniami Konsensusu Waszyngtońskiego" (Raczkowski, 2016, s. 10-11).

Zespół Narodowej Rady Rozwoju przy Prezydencie RP w Opinii o projekcie Strategii na rzecz Odpowiedzialnego Rozwoju podkreśla, że „Strategia jest rozwinięciem wcześniejszego 'Planu na rzecz Odpowiedzialnego Rozwoju', przy dowartościowaniu komponentu społecznego w planowaniu strategicznym rozwoju społecznogospodarczego kraju. O ile we wcześniejszym Planie na rzecz odpowiedzialnego rozwoju elementy ze sfery polityki społecznej państwa pełniły funkcję drugoplanową (uzupełniającą) względem elementów polityki stricte gospodarczej, stanowiących wyraźny zręb wyjściowej koncepcji, o tyle w przypadku Strategii Odpowiedzialnego Rozwoju komponent społeczny jest już pełnowartościowym filarem strategii” (NRR, 2016, s. 12).

Strategia, obecnie realizowana przez rząd polski, również zakłada, że rozwój Polski może i powinien odbywać się równocześnie w trzech głównych kierunkach:

1) modernizacyjnym (podniesienie konkurencyjności i innowacyjności gospodarki),

2) dyfuzyjnym (równoważenie potencjału rozwojowego poszczególnych regionów Polski),

3) efektywnościowym (zasadniczego wzrostu efektywności i sprawności funkcjonowania państwa i jego instytucji).

SOR wyznacza pięć obszarów koncentracji działań („filarów rozwoju”):

- tworzenie warunków na rzecz reindustrializacji,

- sprzyjanie rozwojowi innowacyjnych firm (polskie czempiony),

- zrównoważony rozwój społeczno-gospodarczy (z uwzględnieniem wspierania małych i średnich przedsiębiorstw),

- budowanie kapitału dla rozwoju oraz

- ekspansja zagraniczna.

Wyodrębnienie tych pięciu filarów rozwojowych jest konsekwencją krytycznej analizy i diagnozy dotychczasowych założeń polityki gospodarczej i społecznej polskich rządów. Jednak Strategia na rzecz Odpowiedzialnego Rozwoju, która jest podstawą decyzji obecnego rządu, w którym Mateusz Morawiecki pełni funkcję wicepremiera, ministra finansów i ministra rozwoju, wyróżnia się nową jakością w podejściu oraz $\mathrm{w}$ realizacji strategicznych priorytetów dla państwa.

Rzeczą znamienną jest również, że obecna, nowa filozofia rządu polskiego zdecydowanie większą wagę w wytyczaniu koncepcji i realizacji strategicznych zadań polityki gospodarczej i społecznej nadaje instytucjom państwa. Jest to konsekwencją przekonania o dotychczasowej słabości instytucjonalnej polskiego państwa, a także zapewne i refleksji wynikających z doświadczeń światowego kryzysu finansowego. 
Zgodnie z SOR rząd planuje prowadzić politykę przemysłową wdrażającą tzw. inteligentną reindustrializację. Ma to dać impuls do rozwoju nowych gałęzi przemysłu opartych na technologiach cyfrowych, wymagających dużego zaangażowania nauki i wysoko wykwalifikowanej kadry pracowników. Strategia nawiązuje zatem do postulatów zawartych w obowiązującej Strategii Rozwoju Kraju 2020, dotyczących wzrostu udziału w PKB przemysłów oraz usług średnio i wysoko zaawansowanych technologicznie.

Zespół Narodowej Rady Rozwoju przy Prezydencie RP w Opinii o projekcie Strategii na rzecz Odpowiedzialnego Rozwoju stwierdza, że „stawianie na wzrost globalnej konkurencyjności polskiego przemysłu to prawidłowy cel obrany w Strategii, a efektem podejmowanych działań na rzecz inteligentnej reindustrializacji będzie nasycenie przemysłu wysokowartościowymi usługami $(\mathrm{B}+\mathrm{R}$, design, information and communications technologies - ICT). Ma to zwiększyć udział innowacyjnych produktów wytwarzanych w przemyśle oraz będzie dźwignią wzrostu produktywności. Poziom zatrudnienia w przemyśle i usługach około-przemysłowych ma zostać utrzymany" (NRR, 2016, s. 18).

Jak zaznacza prof. Witold Orłowski, „Polska (...) potrzebuje rozwoju opartego silniej na rodzimym kapitale, przede wszystkim dlatego, że to właśnie własne, ekspansywne firmy mogą być zainteresowane rozwojem opartym na innowacjach i wykorzystaniu potencjału intelektualnego" i jak słusznie dodaje: „wyzwolenie procesów modernizujących gospodarkę przez innowacje to zadanie niełatwe, bo na przeszkodzie stoją nie tylko wewnątrzkrajowe bariery administracyjne, systemowe, świadomościowe, ale także bariery zewnętrzne: dotychczasowy podział pracy, przewagi konkurencyjne firm globalnych (zagranicznych)" (Orłowski, 2016, s. 13).

Realizacja ambitnych planów zawartych i już wdrażanych przez obecny rząd byłaby trudna do zrealizowania, gdyby napotkała barierę dotyczącą sfinansowania tych planów. Stąd tak mocno zaznaczona w SOR konieczność budowania kapitału dla rozwoju. Polska potrzebuje lepszego wykorzystania funduszy unijnych, w szczególności funduszy strukturalnych. Fundusze unijne powinny stanowić endogenny kapitał prorozwojowy. Ale jednocześnie, wobec potrzeby wzrostu stopy inwestycji, a zarazem ograniczenia zadłużenia zagranicznego, pozyskiwanie kapitału z eksportu polskich towarów i usług jest ważnym elementem programu obecnego rządu. Wzrostowi stopy inwestycji do 25\% PKB (obecnie jest ona najniższa w regionie Europy Środkowo-Wschodniej i wynosi 20\%) powinna m.in. towarzyszyć zmiana funkcjonowania instytucji wspierających i finansujących ekspansję polskich eksporterów.

W Strategii na rzecz Odpowiedzialnego Rozwoju wicepremiera Mateusza Morawieckiego dostrzega się też związek pomiędzy wyrwaniem Polski z rozwoju zależnego i radykalną reformą szkolnictwa wyższego. Edukacja to bowiem podstawowy mechanizm inwestowania w kapitał ludzki - kompetencje poszczególnych jednostek. W tej dziedzinie Polska oczekuje na prawdziwą reformę szkolnictwa wyższego.

Cele, jakie zakłada SOR, odpowiadają w dużym stopniu na potrzeby obecnego etapu rozwoju Polski. Głównym jej zadaniem jest tworzenie warunków do wzrostu 
dochodów Polaków, a zarazem poprawa spójności w wymiarze społecznym, ekonomicznym i terytorialnym. Ocena efektów realizacji nowej koncepcji rozwoju społeczno-gospodarczego Polski będzie możliwa po kilku latach jej realizacji. Wydaje się, że trafnie zostały wyznaczone główne założenia gospodarcze i społeczne strategii rozwoju Polski w horyzoncie 2020 i 2030. Przeciwnicy obecnego rządu gotowi są stawiać znaki zapytania, w szczególności dotyczy to bardzo wysokiej rangi przewidzianych dla zakresu interwencji publicznej, podejmowanej przez rząd w najbliższych latach. Wyrażane są też zastrzeżenia co do finansowych możliwości państwa zrealizowania ambitnych zamierzeń rządu.

\section{Nowa Ekonomia Strukturalna i jej założenia}

Nie trudno jednak zauważyć, że nowa filozofia społeczno-gospodarcza obecnego rządu polskiego wychodzi również naprzeciw tendencjom w zakresie polityki rozwojowej krajów doganiających kraje wysoko uprzemysłowione. Dlatego w takich krajach, jak Polska coraz większe zainteresowanie wzbudza koncepcja Nowej Ekonomii Strukturalnej, stosująca podejście neoklasyczne do badania czynników determinujących strukturę ekonomiczną i jej rozwój. Postuluje ona, że struktura przemysłowa w ramach gospodarki ma charakter endogeniczny względem struktury jej wyposażenia w zasoby. Jeden z teoretyków i twórców Nowej Ekonomii Strukturalnej, Prof. Justin Yifu Lin, doradca rządu chińskiego w zakresie gospodarki oraz wiceprezydent Banku Światowego w latach 2008-2012, uważa, co zresztą znajduje potwierdzenie także w jego artykule zamieszczonym w niniejszej publikacji, iż Nowa Ekonomia Strukturalna stoi na stanowisku, że czynnikiem o znaczeniu decydującym dla sukcesu rozwojowego jest państwo, które umożliwia ten rozwój, prowadząc odpowiednią politykę przemysłową. Polityka taka musi ułatwiać przedsiębiorstwom wchodzenie do branż cechujących się ukrytą przewagą komparatywną na konkurencyjnym rynku poprzez pokonanie problemu uzewnętrzniania wartości przez pierwszego inicjatora oraz koordynowanie wymaganych udoskonaleń twardej i miękkiej infrastruktury. Polityka taka winna mieć na celu przekształcanie branż cechujących się ukrytą przewagą komparatywną w narodowe przewagi konkurencyjne.

Struktura ekonomiczna kraju, uważa prof. Justin Yifu Lin, w danym okresie ma charakter endogeniczny względem jego wyposażenia w aktualnie dostępne zasoby kapitału, pracy i surowców naturalnych. Kraje znajdujące się na różnych etapach rozwoju różnią się pod względem relatywnego wyposażenia w zasoby. W kraju rozwijającym się przeważnie mamy do czynienia ze względnym deficytem kapitału, podczas gdy dostępność siły roboczej, a często także zasobów naturalnych, jest relatywnie obfita. W krajach rozwiniętych stosunkowo łatwo o kapitał, przy jednoczesnej relatywnie trudnej dostępności siły roboczej. Co do wyposażenia gospodarki w zasoby, w dowolnym konkretnym okresie ich wielkość jest określona, ale 
z upływem czasu może się zmieniać. Nowa Ekonomia Strukturalna traktuje poziom wyposażenia gospodarki w zasoby jako punkt wyjścia dla analizy rozwoju, ponieważ determinują one łączny budżet gospodarki oraz relatywne ceny czynników produkcji w danym okresie, czyli wielkości będące dwoma najważniejszymi parametrami dla analizy ekonomicznej.

„Relatywne ceny czynników produkcji stanowią o przewadze komparatywnej danej gospodarki. Na przykład, kraje posiadające stosunkowo bogate zasoby siły roboczej przy jednoczesnym deficycie kapitału miałyby przewagę komparatywną w branżach pracochłonnych, ponieważ ich koszty produkcji będą niższe niż w krajach o relatywnie ubogich zasobach siły roboczej i jej wysokich kosztach. Warunkiem wstępnym osiągnięcia przez dany kraj przewagi komparatywnej jest rozwinięcie w nim takich gałęzi gospodarki, które będą zgodne z jego przewagami komparatywnymi determinowanymi przez aktualny poziom wyposażenia w zasoby" (Porter, 1990, s. 81).

W krajach rozwiniętych dochód i produktywność pracy są wysokie, ponieważ ich względnie duża zasobność kapitałowa sprawia, że ich branże i technologie mają charakter kapitałochłonny. Jeżeli kraj rozwijający się pragnie dogonić kraje rozwinięte pod względem ich dochodu i struktury przemysłowej, najpierw musi zwiększyć swoje relatywne zasoby kapitału w ramach swojej struktury wyposażenia w zasoby do poziomu krajów rozwiniętych. „Celem ostatecznym rozwoju gospodarczego jest zwiększenie dochodów kraju, natomiast celem pośrednim jest rozwijanie branż kapitałochłonnych. Z kolei celem w bliskiej perspektywie powinno być szybkie zgromadzenie kapitału, aby móc przekształcić przewagi komparatywne tego kraju w kierunku branż bardziej kapitałochłonnych. Inaczej mówiąc, podniesienie poziomu dochodów danego kraju wymaga podniesienia jego poziomu przemysłowego, do czego z kolei konieczna jest zmiana struktury wyposażenia w zasoby w takim kraju" (Ju, Lin i Wang, 2015, s. 244-263).

\section{Konkluzje}

Trudno nie doszukiwać się pewnej inspiracji poglądami Prof. Justina Yifu Lina w Strategii na rzecz Odpowiedzialnego Rozwoju autorstwa wicepremiera Mateusza Morawieckiego. Obaj dostrzegają sens i zasadność w twierdzeniu, że takie kraje, jak Polska muszą intensywnie szukać impulsu, który pozwoliłby przestawić ich gospodarkę na bardziej innowacyjne tory. Szanse na to stwarza czwarta rewolucja przemysłowa. Obaj Autorzy opowiadają się za koncepcją rozwoju przemysłowego dostosowanego do wymagań współczesności, która polega na zdefiniowaniu dziedzin, w jakich dane państwo może w przewidywalnej przyszłości zbudować swoje przewagi konkurencyjne nad innymi krajami. Kolejnym krokiem jest stworzenie systemu pozwalającego te możliwości wykorzystać. Jednak - jak wspomina Prof. Justin 
Yifu Lin - „nawet jeśli rząd stanie na wysokości zadania i zbuduje efektywny system rozwoju wybranych gałęzi przemysłu, może to nie wystarczyć. Trzeba także - jak podkreśla - obniżyć koszty transakcyjne, a więc koszty związane z koordynacją działania przedsiębiorstw, m.in. związane z potrzebą monitoringu rynku czy przeprowadzania kontroli. To jest możliwe, ale wymaga współpracy przedsiębiorców i rządu" (Lin, 2017, s. 208-209).

Wbrew temu co sygnalizują przeciwnicy prof. Y.F. Lina oraz wicepremiera Morawieckiego, obaj ekonomiści, kreśląc pożądany obecnie model rozwojowy dla krajów doganiających kraje bogate i wysoko uprzemysłowione, z jednej strony dostrzegają potrzebę istnienia państwowych centrów decyzyjnych na rzecz polityki przemysłowej programującej tzw. inteligentną reindustrializację czy tworzącej skuteczny system ochrony własności intelektualnej. Z drugiej zaś - uważają, że ta niepodważalna rola państwa nie zmienia faktu, iż klucza do wzrostu konkurencyjności i przewagi na rynkach należy szukać głównie w podmiotach gospodarczych, finansowych i w samych innowatorach.

Prof. Justin Yifu Lin nie jest daleki od prawdy, kiedy w wywiadzie dla „Polska The Times” stwierdza: „czwarta rewolucja przemysłowa niesie ze sobą sporo szans dla takich państw, jak Polska. Pojawiają się nowe obszary do rozwoju, których na przykład Niemcy jeszcze nie zdołali zapełnić. Tylko potrzeba czasu. Nie da się od razu wynaleźć nowego lekarstwa, które będzie potrzebne na całym świecie, czy nowego telefonu komórkowego, który stanie się globalnym hitem. Trzeba do tego czasu i pieniędzy na prowadzenie badań" (Koziński, 2016).

\section{Bibliografia}

Geodecki, T. i Hausner, J., (red.). (2013). Konkurencyjna Polska. Jak awansować do światowej ligi gospodarczej. Raport zespołu niezależnych ekspertów z inspiracji Prezydenta RP. Kraków: Krajowa Izba Gospodarcza, Fundacja Gospodarki i Administracji Publicznej.

Ju, J., Lin, J.Y. i Wang, Y. (2015). Endowment Structures, Industrial Dynamics, and Economic Growth. Journal of Monetary Economics, 76, 244-263.

Koziński, A. (2016). Justin Yifu Lin: Polska powinna zainwestować w kilka kluczowych dziedzin przemysłu. WWW.POLSKATIMES.PL, 7 lutego. Pozyskano z: http://www.polskatimes.pl/artykul/9368600,justin-yifu-lin-polska-powinna-zainwestowac-w-kilka-kluczowychdziedzin-przemyslu,3,id,t,sa.html.

Lin, J.Y. (2009). Economic Development and Transition: Thought, Strategy, and Viability. Cambridge, UK: Cambridge University Press.

Lin, J.Y. (2011). New Structural Economics: A Framework for Rethinking Economic Development. World Bank Research Observer, 26(2).

Lin, J.Y. (2017). Nowa Ekonomia Strukturalna dla gospodarek doganiających. W: J.Y. Lin, A.Z. Nowak (red.), Nowa Ekonomia Strukturalna wobec krajów mniej zaawansowanych (s. 199-219). Warszawa: Wydawnictwa Naukowe Wydziału Zarządzania UW. 
MAiC. (2013). Polska 2030. Trzecia fala nowoczesności. Długookresowa Strategia Rozwoju Kraju. Warszawa: Ministerstwo Administracji i Cyfryzacji, 11 stycznia. Pozyskano z: https://mac.gov.pl/files/wp-content/uploads/2013/02/Strategia-DSRK-PL2030-RM.pdf.

Morawiecki, M. (2017). Strategia na rzecz Odpowiedzialnego Rozwoju do roku 2020 (z perspektywa do 2030 r.). Warszawa: Ministerstwo Rozwoju.

Nowak, A.Z. (2013). Współczesny świat w erze turbulencji. W: J. Bogdanienko, W. Piotrowski (red.), Zarzadzanie: tradycja i nowoczesność. Warszawa: PWE.

Nowak, A.Z. i Ryć, K. (red.). (2017). Globalizacja a reindustrializacja. W: A.Z. Nowak, K. Ryć (red.), Polityka w regionach $w$ warunkach globalizacji. Warszawa: Wydawnictwo Naukowe Wydziału Zarządzania UW.

NRR. (2016). Opinia o projekcie Strategii na rzecz Odpowiedzialnego Rozwoju. Warszawa: Narodowa Rada Rozwoju, 27 września. Pozyskano z: http://ieo.pl/dokumenty/aktualnosci/18102016/opinia_o_projekcie_strategii_na_rzecz_odpowiedzialnego_rozwoju.pdf.

Orłowski, W. (2016). Opinia na temat dokumentu: „Strategia na rzecz odpowiedzialnego rozwoju” (projekt do konsultacji spotecznych). Materiał analityczny przygotowany dla Narodowej Rady Rozwoju przy Prezydencie RP. Warszawa, 8 września 2016 roku.

Porter, M.E. (1990). The Competitive Advantage of Nations. New York: Free Press.

Raczkowski, K. (2016). Opinia przygotowana na zlecenie Kancelarii Prezydenta Rzeczypospolitej Polskiej w sprawie zaopiniowania projektu „Strategia na rzecz odpowiedzialnego rozwoju”. Materiał analityczny przygotowany dla Narodowej Rady Rozwoju przy Prezydencie RP. W: NRR, Opinia o projekcie Strategii na rzecz Odpowiedzialnego Rozwoju. Warszawa: Narodowa Rada Rozwoju, 27 września. Pozyskano z: http://ieo.pl/dokumenty/aktualnosci/18102016/opinia_o_projekcie_strategii_na_rzecz_odpowiedzialnego_rozwoju.pdf. 


\title{
Wygasanie procesu konwergencji realnej w warunkach wspólnego rynku. Problemy przeciwdziałania
}

\begin{abstract}
Krajom rozwijającym się grozi spowolnienie wzrostu gospodarczego. W pewnym zakresie dotyczy to również Polski. Powstaje więc pytanie, jak przeciwdziałać temu spowolnieniu lub, jak się często nazywa, pułapce średniego dochodu. Nowa Ekonomia Strukturalna proponuje sposoby skutecznego startu i utrzymania dynamiki wzrostu gospodarczego. Czy można jej wskazania wykorzystać dla ożywienia słabnącego tempa wzrostu gospodarczego krajów rozwijających się, tracących zdolność do szybkiego rozwoju i skrócenia dystansu do krajów wysoko rozwiniętych?

Wspólny rynek w ramach Unii Europejskiej obejmuje przecież kraje zarówno wysoko rozwinięte, jak i średnio zaawansowane w rozwoju. Trzeba więc godzić interesy jednych i drugich. W artykule przeanalizowano przyczyny tego spowolnienia, które $w$ znacznym stopniu są wynikiem pozostawania krajowych wytwórców w roli podwykonawców i kooperantów międzynarodowych korporacji, jak też producentów tanich wyrobów, dzięki niskim kosztom pracy. Skazuje to gospodarkę narodową na podrzędność w stosunku do liderów technologicznych wspólnego rynku i staje się niebezpieczne w przypadku postępów rewolucji przemysłowej 4.0. Stąd bierze się poszukiwanie inspiracji do podniesienia innowacyjności w krajach mniej zaawansowanych i wykorzystania wskazań Nowej Ekonomii Strukturalnej, co dotyczy także gospodarki polskiej.
\end{abstract}

Słowa kluczowe: konwergencja, pułapka średniego dochodu, innowacje, tworzenie wartości produktu, restrukturyzacja, reindustrializacja.

\section{Spowolnienie wzrostu gospodarczego czy pułapka średniego dochodu}

Temat spowolnienia wzrostu gospodarczego jest chyba najbardziej aktualny w dyskusjach ekonomicznych. Problemy stagnacji i wolnego tempa wzrostu po ostatnim kryzysie dotknęły większość krajów, zarówno tych zaawansowanych w rozwoju, jak i nowo uprzemysłowionych, doganiających kraje wysoko rozwinięte. Dotyczy to również państw wchodzących w skład Unii Europejskiej, zwłaszcza „starej” jej części sprzed wielkiego rozszerzenia z 2004 roku, ale nie omija też nowych państw członkowskich. 
Akcesja do wspólnoty przyniosła wszystkim państwom wymierne korzyści i to zarówno tym bardziej rozwiniętych o wyższym produkcie krajowym brutto na jednego mieszkańca, jak i tym uboższym, przyspieszając ich wzrost i tym samym zbliżenie do wysoko rozwiniętych, bogatszych sąsiadów. Dla krajów zamożnych pojawił się większy rynek zbytu, dla uboższych zaś - ważne, merytoryczne i finansowe wsparcie rozwoju gospodarczego. Lecz wraz z upływem czasu ten oczekiwany proces realnej konwergencji zwalniał, aby po ostatnim kryzysie w obszarze strefy euro zatrzymać się, a następnie nawet odwrócić w kierunku dywergencji. Widać to wyraźnie w relacji między wysoko rozwiniętą Północą strefy, a pozostającym w tyle Południem.

Rodzi się pytanie: czy jest to przypadłość strefy wspólnej waluty, czy też cześć ogólnoświatowego problemu, w dyskusjach makroekonomicznych nazywanego różnie: pułapką średniego dochodu, spowolnieniem gospodarczym krajów bazujących na imitacjach technologii bądź też wygaszaniem konwergencji wraz ze zbliżaniem się do granicy wyznaczanej przez poziom technologii, tj. globalnej granicy technologicznej, jak określa ją J.Y. Lin.

Jak zapobiegać temu spowolnieniu w krajach nowo uprzemysłowionych? Czy w tym przypadku przydatna może okazać się koncepcja Nowej Ekonomii Strukturalnej (NES)? Koncepcja ta sprawdza się w Chinach i innych krajach Dalekiego Wschodu. Czy sposobem zaradczym na spowolnienie może być aktywna polityka przemysłowa? Wątpliwość budzi, że zwykło się uważać, iż świat wchodzi obecnie w erę postindustrialną. W istocie współczesność jest również postrolnicza, ale zarówno rolnictwo, jak i przemysł, którego udział w zatrudnieniu i PKB maleje, nie tracą na znaczeniu. Rolnictwa i przemysłu nie można niczym zastąpić, jesteśmy i jednak nadal będziemy cywilizacją przemysłową.

Wobec niepowodzenia, jakie odniosło w przeszłości podejście strukturalne do uprzemysłowienia kraju, charakteryzującego się zamiarem budowy gospodarki przemysłowej, koncepcja NES J.Y. Lina postuluje, na wzór krajów wysokorozwiniętych, organiczny sposób rozpoczęcia i generowania wzrostu gospodarczego, począwszy od oceny zasobów dających przewagę komparatywną, wytwarzanie i zbyt towarów, aż po tworzenie oszczędności, które umożliwiają dalsze inwestycje. Nowe podmioty gospodarcze zapoczątkowują rozwój, wykorzystując własne skromne możliwości, aby następnie pokonywać kolejne progi technologiczne, od imitacji istniejących technologii, aż po własne osiągnięcia, przybliżające do owej globalnej granicy technologicznej.

Tego typu praktyka generowania wzrostu gospodarczego nazywana jest często protekcjonizmem dalekowschodnim. Endogeniczny charakter programów i metod realizacji tej polityki okazał się skuteczny. Osiągnięcia początkowo Japonii, a następnie Singapuru, Tajwanu, Korei Południowej i ostatnio Chin są rzeczywiście przekonujące.

W tym czasie teoria ekonomiczna na Zachodzie i praktyka działania instytucji międzynarodowych oraz większości rządów wybrała inne podejście: wolny rynek i egzogeniczny charakter rozwoju gospodarczego oparty na neoliberalnej doktrynie ekonomicznej. Istotnego źródła dynamicznego rozwoju upatrywano w liberalizacji 
wymiany handlowej. Sposobem na przyspieszenie wzrostu krajów słabo rozwiniętych i na średnim poziomie rozwoju miała być ściślejsza integracja i kooperacja z krajami wysoko rozwiniętymi. Taka idea rozwoju jest ciągle żywa. W Polsce autorzy raportu Polityka przemystowa wobec wyzwań XXI wieku (Bukowski i Śniegocki, 2017) widzą potrzebę pogłębienia kooperacji z „fabryką europejską” jako jedną z trzech „fabryk gospodarki światowej”. Krajem wiodącym tej „fabryki” są Niemcy - geograficznie Polsce najbliższe i już teraz silnie powiązane gospodarczo.

Rozpatrzmy możliwości wspomnianych typów polityki i dróg wspierania wzrostu gospodarczego czy też uniknięcia pułapki średniego dochodu. Pierwsza to droga endogeniczna, aktywnej polityki gospodarczej, dużej roli państwa sterującego rozwojem. Druga to droga wolnego rynku, horyzontalnego wspierania rozwoju, a więc kontynuacja dotychczasowej polityki opartej na doktrynie neoliberalnej.

Wybór drogi endogenicznego rozwoju i wykorzystanie metod polityki gospodarczej proponowanej przez NES w warunkach małej gospodarki otwartej, działającej w ramach wspólnoty państw, która łączy kraje średnio- i najbardziej zaawansowane w rozwoju, natrafia na całkiem inne okoliczności niż w krajach, gdzie była wykorzystywana z powodzeniem. Doświadczenia krajów wschodniej Azji, a zwłaszcza kraju o zbliżonych rozmiarach do Polski, np. Korei Południowej, nie można wykorzystać bezpośrednio. Zbyt duże są różnice w punkcie startu do rozwoju i odmienne okoliczności zewnętrzne.

Powodzenie działań promujących nowe czy też nowatorskie technologie zależy w dużym stopniu od charakteru rynku i poziomu konkurencji. Ważne jest czy zagraniczny konkurent dysponujący wyższą technologią jest bliski, czy też wystarczająco oddalony przestrzennie lub zniechęcony przez odmienne regulacje, ograniczenia taryfowe i pozataryfowe. Potrzeba bowiem względnej separacji, aby nowa inicjatywa nabrała żywotności. Takie warunki były w Korei Południowej. Ważny jest także rozległy, własny rynek wewnętrzny, na którym, mimo obecności podmiotów zagranicznych dysponujących wysoką technologią, można jednak znaleźć miejsce na ryzykowne, lecz rokujące powodzenie lokalne inicjatywy, nawet wykonanie skoku technologicznego na poziomie globalnej granicy. W tym przypadku sprzyjał jednak innowatorom ogromny rynek chiński. NES postuluje aktywne wspieranie nacechowane pragmatyzmem tego typu inicjatyw oraz działanie na rzecz zmniejszenia ryzyka nowych innowacyjnych przedsięwzięć. Ważne jest też tworzenie odpowiedniej i to tak twardej, jak i miękkiej infrastruktury.

Pula zasobów umożliwiających przewagę komparatywną istnieje również w Polsce. Jest to dobrze wykształcone społeczeństwo, korzystne położenie geograficzne i przy tym nadal stosunkowo niskie płace.

Najnowsza technologia w istocie już gości zarówno w Polsce, jak i w innych krajach UE o zbliżonym poziomie rozwoju. Reprezentują ją międzynarodowe korporacje, dla których jest to nie tylko rynek zbytu, lecz także dobre miejsce lokowania części produkcji i usług. Umieszczają one montownie wyrobów i pozyskują podwykonawców, wykorzystując niskie koszty pracy, względną obfitość terenów inwesty- 
cyjnych, korzystne położenie oraz poprawiającą się infrastrukturę. Równocześnie są one też dostawcami na rynki produktów finalnych. Korporacje międzynarodowe zajmują pozycje na obu krańcach krzywej łańcucha tworzenia wartości dodanej w procesie produkcji, nazywanej krzywą uśmiechu. Krańce lewy i prawy tej krzywej to breeding, projektowanie, zarządzanie i marketing. Bliżej środka natomiast znajdują się usługi dla biznesu, a w samej dolnej części - produkcja fabryczna czy też montaż wyrobów gotowych. Istnieje więc w kraju nowa technologia, lecz „gości na salonach”, a montaż i serwis znajduje się w „obejściu” gospodarki narodowej. Wejście wykonawców wyrobów i kooperantów oraz usługodawców na krańcowe części krzywej uśmiechu jest trudne do osiągnięcia. Nie ułatwiają tego bynajmniej właściciele międzynarodowych korporacji. Jeśli nie znajdzie się drogi prowadzącej na te wysokie krańce, to gospodarka narodowa będzie skazana na niższą produktywność i nisko opłacane prace wykonawcze.

Ostatnio dynamicznie rośnie zatrudnienie w usługach dla krajowego, a przede wszystkim zagranicznego biznesu. Nadal jednak w tym wypadku wykorzystuje się te same przewagi komparatywne, w tym dobrze wykształconą i tanią siłę roboczą ${ }^{1}$. Zatrudnienie w usługach nie staje się bynajmniej prostą drogą do najbardziej produktywnych części łańcucha tworzenia wartości, przynoszących wysokie wynagrodzenia i zyski. W polskich warunkach rezygnacja $\mathrm{z}$ aktywnej polityki przemysłowej pobudzania wzrostu i stawianie na mechanizmy wolnego rynku oznacza nie tylko utrzymywanie dystansu rozwojowego, lecz także niebezpieczeństwo wypływające ze zmian technologicznych na świecie, czy szerzej, z czwartej rewolucji przemysłowej.

\section{Pułapka rozwoju egzogenicznego}

Jeśli okoliczności nie pozwolą na przyspieszenie rozwoju drogą aktywnej polityki przemysłowej państwa, to zapewne okaże się, że szanse utrzymania wyższego tempa wzrostu czy też wychodzenia z pułapki średniego dochodu nie są niestety zbyt duże. J.Y. Lin wyodrębnia pięć typów branż z punktu widzenia wzrostu gospodarczego, tj.: 1) doganiające,

2) przodujące,

3) tracące przewagę komparatywną,

4) innowacyjne niskokapitałowe,

5) strategiczne.

Rozpatrzmy więc przede wszystkim problemy branż tracącej przewagę komparatywną oraz doganiającej. Taka kolejność jest uzasadniona stopniem zaawansowania gospodarczego Polski. Ta pierwsza stwarza największe problemy wzrostu. Jest zasadniczym obszarem gospodarki, a jej słabnący wzrost gospodarczy może

1 Dawniej nazywaną „białymi kołnierzykami” w przeciwieństwie do „niebieskich koszul”. 
być główną przyczyną spowolnienia lub wpadnięcia polskiej gospodarki w pułapkę średniego dochodu. Natomiast w przypadku branży doganiającej występują duże możliwości wykorzystania doświadczeń NES.

W branży tracącej przewagę komparatywną zaczniemy rozważania od przypadku producentów kooperujących z firmami, które osiągnęły lub osiągają globalną linię rozwoju technologii albo granicę technologiczną. Natomiast rodzimi, polscy kooperanci plasują się u nich w dolnych partiach krzywej łańcucha produkcji. Jeśli ich firmy są częścią zagranicznych korporacji to - jak wskazano wcześniej - istnieje niewielka szansa, że mogą awansować na krańce tej krzywej, osiągając najwyższy poziom wartości dodanej. Tym samym bowiem montażyści i kooperanci zamieniliby się w nowych producentów wyrobów finalnych. Nie jest w tym przypadku ważne czy pozostaną częścią międzynarodowych korporacji, czy się uniezależnią. Jest mało prawdopodobne - jak wspomniano - że może się to spotkać się z aprobatą „matczynych" korporacji. Przenosiły one przecież produkcję do Polski, by obniżyć koszty swoich wyrobów i cel ten osiągnęły, pozostawiając sobie możliwość udziału w produkcji przynoszącej większą wartość dodaną.

Tak więc mamy coraz częściej do czynienia z sytuacją, w której podstawowa wartość wyrobu tworzona jest poza fabryką. Obecnie nie wymysłem, lecz rzeczywistością są już producenci wyrobów bez fabryk. Trudno przewidzieć, w którym momencie fabryka, w sposób graniczący z fantazją, przekształci się w wytwórcę bez fabryki. Prędzej bowiem straci swoje miejsce w łańcuchu wytwórców na rzecz innych tańszych konkurentów.

Proste prace produkcyjne czy montażowe mogą być również przenoszone do krajów o jeszcze niższych płacach i dostatecznie kwalifikowanej sile roboczej. To samo odnosi się do usług dla biznesu. Warszawskie wieżowce, zapełnione pracownikami licznych międzynarodowych korporacji, świadczą o przenoszeniu również pracochłonnych czynności służących zarządzaniu. Jest to ta część umiejscowiona nieco wyżej na krzywej uśmiechu.

\section{Rysunek 1. Lańcuch tworzenia wartości produkcji}

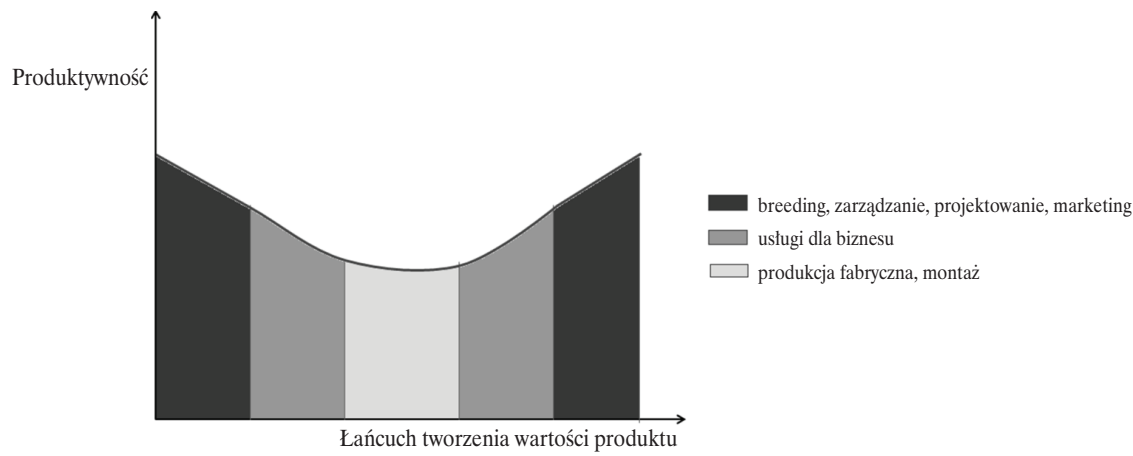

Źródło: opracowanie własne. 
Tani montaż półproduktów, tanie usługi biznesowe i zamknięty awans to nie jest przesadne czarnowidztwo.

Krajowe firmy, w których technologia pozostaje w tyle za przodującymi na świecie producentami, uzyskują wartość dodaną również dzięki niskim kosztom pracy. Niski poziom płac w Polsce datuje się od czasów transformacji systemowej i wysokiego bezrobocia. Ich późniejszy, stopniowy powolny wzrost, niższy nawet okresowo od wzrostu wydajności pracy, nie sprzyjał modernizacji produkcji, pozyskiwaniu nowych technologii i inwestowaniu dla zmniejszenia pracochłonności. Można więc uważać, że niska cena pracy nie zachęcała do kosztownych, często ryzykownych innowacji.

Niskie płace to szczupły rynek wewnętrzny stosunkowo ubogich konsumentów. Skłania to do specjalizacji w wytwarzaniu taniego asortymentu wyrobów. Powstaje więc układ przyczynowości okrężnej, który - z pewną przesadą - możemy nazwać pułapką niskich płac. Popyt na produkowane wyroby jest na rynku krajowym ograniczony, a więc wymusza eksport, który jest możliwy również w wyniku konkurencyjności cenowej. W międzynarodowym podziale pracy powstaje niekorzystny układ. Kraj specjalizuje się w produkcji niskokosztowej o wysokiej elastyczności popytu. Na wspólnym rynku osiąga więc powodzenie dzięki niskim cenom jako tani konkurent. Jego partnerzy na wspólnym rynku mogą natomiast oferować wyroby o niskiej elastyczności cenowej, a więc droższe, przy których produkcja wykorzystująca wydajniejszą technologię pozwala na ponoszenie kosztów wysokich płac, a wysoka cena nie jest zaporą dla popytu.

Wspólny rynek europejski to przecież sąsiedztwo firm technologicznie przodujących blisko granicy technologicznej i firm imitujących. Jednak liderzy nowych technologii działają w większości w krajach zaawansowanych, a firmy imitujące i doganiające - w krajach mniej rozwiniętych. Na wspólnym rynku wyroby pochodzące z jednych i drugich krajów mają równe prawa, lecz nierówne szanse. Mniej doświadczony partner, usiłujący wykorzystać nową technologię z kraju słabo rozwiniętego, napotyka bowiem silnego konkurenta. Konfrontacja nie może być dla niego korzystna, jeśli nie uzyska on wsparcia od własnego państwa. I w tych okolicznościach powinien on na to wsparcie liczyć i je uzyskać. Jest to ważny argument za aktywną rolą państwa w zakresie polityki przemysłowej.

\section{Szanse kooperacji}

Przed analitykami pojawia się trudne pytanie, czy stopniowe poszerzanie udziału krajowych uczestników w łańcuchu tworzenia wartości wyrobów finalnych, kooperacji z liderami nowych technologii pozwoli doprowadzić do bardziej równomiernego podziału korzyści. Znaczy to, że do kooperacji - mówiąc kolokwialnie - fabrycznej dojdą: kooperacja w pracy biurowej i obowiązki w zakresie zarządzania. To jednak wymaga innych kwalifikacji i współodpowiedzialności oraz awansu, z wykorzysta- 
niem kapitału, relacji dla współuczestnictwa w projektowaniu, zarządzaniu i marketingu produkcji wyrobów finalnych. Będzie to bardziej optymistyczny finał ewolucji współpracy i wygładzenie łańcucha krzywej produktywności. Nadzieje na taki bieg zdarzeń można wiązać z dalszym pogłębianiem związku ze wspomnianą „europejską fabryką" gospodarki światowej. Oznaczałoby to utrzymanie stopniowego, choć spowolnionego procesu konwergencji realnej. Jak dotąd, proces konwergencji Polski względem naszych partnerów wyżej rozwiniętych nadal trwa, choć niestety słabnie. Świadczy o tym porównanie tempa wzrostu gospodarczego Polski i głównego jej partnera handlowego - Niemiec (zob. rys. 2).

Rysunek 2. Wzrost PKB Polski i Niemiec w latach 2005-2015

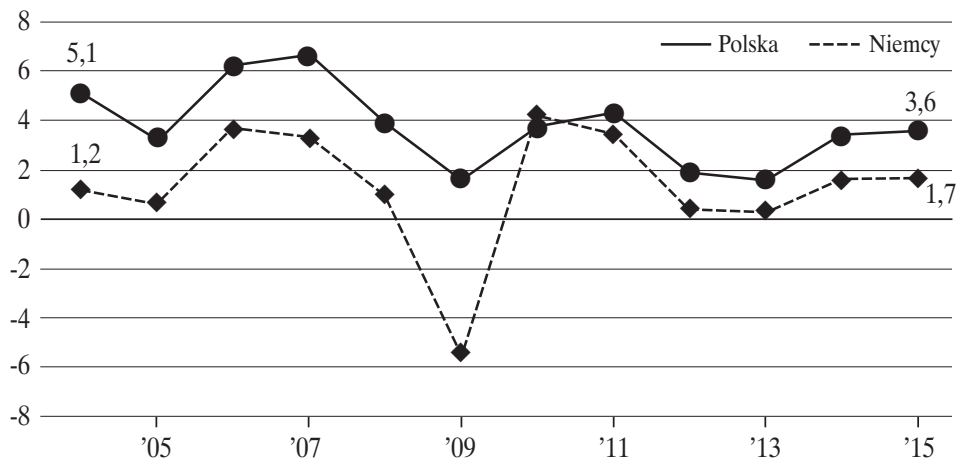

Źródło: GUS, Destatis, AHK (infografika OF/ŁR) za: Ramotowski, 2016.

Tego typu oczekiwania czy nadzieje nie mogą uśpić naszej czujności, zmniejszyć motywacji do aktywnego wspomagania rozwoju i są ku temu przynajmniej dwa ważne powody. Pierwszy, to w istocie wymuszona zgoda na podrzędność gospodarki, przyzwolenie na pozostawanie w pozycji słabszego partnera, oferującego większość dóbr i usług mających wysoką elastyczność cenową, a więc niskokosztowych. Są to również dobra i usługi bardzo wrażliwe na zmiany kursu walut, łatwo tracące rynek zbytu przy jej aprecjacji, co jest szczególnie ważne w przypadku wspólnego pieniądza euro i przynależności do strefy euro.

Drugi powód niepokoju, bardziej poważny, to niebezpieczeństwo dla kraju wytwarzającego produkty niskokosztowe, o podrzędnej roli w globalnej gospodarce światowej, jakie może przynieść proces reindustrializacji krajów wysoko rozwiniętych i zapowiadana rewolucja przemysłowa 4.0 (Ryć, 2017). Przyniesie on bowiem technologię przetwórstwa przemysłowego wyniesioną ponad automatyzację, czy też dotychczasową robotyzację produkcji, czyli inteligentne fabryki (smart factory). Inteligentne fabryki, systemy cyfrowo-fizyczne tworzyć będą sytuację eliminującą cześć pracy ludzkiej nie tylko w produkcji, lecz także w usługach biznesowych. Skutkiem tego nowy przemysł 4.0 nie dość, że nie odbuduje poziomu zatrudnienia w tym 
sektorze, to jeszcze bardziej niż obecny oszczędzi pracę ludzką i ograniczy zatrudnienie. Zapowiadana rewolucja przemysłowa jest już realizowana i z różnych powodów pożądana, zwłaszcza przez liderów w zakresie technologii. W konsekwencji umacnia ona przewagę w produkcji przemysłowej krajów najbardziej zaawansowanych w rozwoju. Ich produkcja krajowa staje się ponownie opłacalna, nawet przy wysokich kosztach pracy. Przynosić ona będzie wysoką wartość dodaną i - co jest nie bez znaczenia - poprawi lub też jeszcze bardziej umocni dodatnie saldo obrotów handlowych.

Ponadto produkcja przemysłowa stanie się atrakcyjna pod względem nie tylko kosztów, lecz także jakości - przybliży producentów do rynku zbytu. Produkty moga być równie tanie, nawet wytwarzane w małych seriach i w pobliżu ostatecznych odbiorców, oraz lepiej dostosowane do gustów i upodobań konsumentów.

\section{Co to oznacza dla Polski i krajów średnio rozwiniętych?}

Dla krajów średniego rozwoju, do których należy Polska, stanowi to dość duże i bardzo widoczne zagrożenie, choć stwarza także pewne szanse. Konkurencyjność gospodarek oparta na niskich kosztach pracy i ziemi jeszcze istnieje, będzie jednak zanikać, ponieważ koszt robocizny stanie się mało istotny. Ważne natomiast pozostaną nadal kapitały finansowy, ludzki i społeczny (relacyjny), a więc sprzyjające postępom nowej technologii. Zanosi się więc na przemieszczania przemysłu z krajów mniej zaawansowanych w rozwoju do krajów wysoko rozwiniętych. Proces ten już dziś widoczny może wyraźnie przyspieszyć².

Przed Polską może znów stanąć problem reindustrializacji. Gospodarka polska boleśnie przeżyła poprzednią reindustrializację z przełomu lat 80. i 90. ubiegłego wieku, związaną z przejściem od gospodarki nakazowo rozdzielczej do gospodarki rynkowej. Zapłaciła za nią wysokim bezrobociem, spadkiem PKB i wyzbyciem się za bezcen wielu zagrożonych upadkiem przedsiębiorstw państwowych. Do tej nowej reindustrializacji powinna się dobrze przygotować.

Pozostaje więc nadzieja na bardziej skuteczną politykę wertykalną (sektorową), wykorzystującą również wskazania NES J.Y. Lina. Odnosi się to do obszaru pierwszego, czyli branży doganiających, a więc wykorzystania doświadczeń w zakresie lokalnych inicjatyw przedsiębiorczych, wspierania wytwórców początkujących i ich promowania przez władze państwowe. Tego typu politykę nazywam mikroekonomicznym modelem pobudzania rozwoju (Ryć, 2017). Ważne jest także wykorzystanie doświadczeń w zakresie wspierania innowacyjnych technologii w branżach krótkiego cyklu inwestycyjnego i inwestycji niskokapitałowych. W tym obszarze Polska ma znaczne osiagnięcia. W branżach doganiających z kolei trzeba wykorzystać nie

2 Od 2010 roku wróciło już z Chin do USA 400 tys. miejsc pracy (zob. Ciesielski, 2017). 
tylko wskazania NES, lecz także inne współczesne koncepcje wspierania aktywności gospodarczej m.in. Daniego Rodrika (2011).

Idzie więc o znajdywanie innowatorów rynkowych i ich odkryć - nisz rynkowych umożliwiających podjęcie opłacalnej działalności, czyli jest takich, które dają szansę, że przychody z przedsięwzięcia będą pokrywały z nawiązką nakłady inwestycyjne i koszty bieżące. Są to z reguły innowacje naśladowcze z wykorzystaniem technologii poznanej w wyniku rozpowszechnienia się wiedzy o zmianach technologicznych i jej kopiowania. Można to nazwać efektem rozlewania (spillover effect). Oczywiście mogą się też zdarzyć autentyczne wynalazki nowych produktów czy też nowych sposobów wytwarzania, lecz trudno ich oczekiwać, są to bowiem sytuacje raczej rzadkie. W wariancie najbardziej pożądanym władze publiczne podejmują się wyszukiwania, stosują zachęty i wspierają startujących przedsiębiorców. Działanie to jest połączone również z selekcją nieudanych prób biznesowych w różnych fazach zaawansowania. Wyróżnia się bowiem kilka szczebli inkubacji i wsparcia. Począwszy od poziomu inkubatorów przedsiębiorczości wspieranych przez kapitał zalążkowy (Seed Found), start-upy i inwestycje podwyższonego ryzyka, aż po venture capital, tj. fundusze angażujące się w projekty bardziej dojrzałe i rokujące sukces rynkowy. Powstają też różne formy prywatnego angażowania w nowe inicjatywy biznesu, np. tzw. aniołów biznesu. Występują też praktyki symbiozy start-upów z wielkimi korporacjami przemysłowymi czy handlowymi. Te i inne formy wsparcia oraz organizacje wzajemnej współpracy innowatorów są w Polsce znane, lecz fundusze przeznaczone na cele wsparcia zbyt skromne (Ryć, 2017).

Wspomniane działania znajdują się zarówno w Strategii Odpowiedzialnego Rozwoju, wicepremiera polskiego rządu, Mateusza Morawieckiego, jak i w praktyce Unii Europejskiej z perspektywy finansowej 2014-2020. Chodzi tu zarówno o metody pobudzania inicjatywy lokalnej w ramach Regionalnej Inteligentnej Specjalizacji (RIS), jak również Krajowej Inteligentnej Specjalizacji (KIS). Wsparcie finansowe tych przedsięwzięć środkami funduszy unijnych stwarza zachętę oraz daje możliwość ich realizacji. Poznanie doświadczeń aktywizowania lokalnych inicjatyw przedsiębiorczych z Dalekiego Wschodu, zwłaszcza gospodarki chińskiej, z których to doświadczeń czerpie inspirację NES, może być owocne w pobudzeniu aktywności innowacyjnej tak w skali państwa, jak i regionu.

\section{Bibliografia}

Bukowski, M. i Śniegocki, A. (2017). Made in Europe. Polityka przemystowa wobec wyzwań XXI wieku. Warszawa: WiseEuropa, Fundacja Warszawski Instytut Studiów Ekonomicznych i Europejskich.

Ciesielski, M. (2017). To biznes, nie polityka, decyduje o powrocie przemysłu do USA. Obserwator Finansowy, 8 lutego. Pozyskano z: https://www.obserwatorfinansowy.pl/forma/ rotator/to-biznes-nie-polityka-decyduje-o-powrocie-przemyslu-do-usa/ (14.05.2017). 
Ramotowski, J. (2016). Niemcy pozostaną dla Polski partnerem pierwszego wyboru. Obserwator Finansowy, 16 maja. Pozyskano z: https://www.obserwatorfinansowy.pl/warto-wiedziec/badania/niemcy-pozostana-dla-polski-partnerem-pierwszego-wyboru/ (16. 05.2017).

Rodrik, D. (2011). Jedna ekonomia, wiele recept. Warszawa: Wydawnictwo Krytyki Politycznej.

Ryć, K. (2017). Globalizacja a reindustrializacja. W: A. Z. Nowak, K. Ryć (red.), Polityka $w$ regionach $w$ warunkach globalizacji (s. 60-68). Warszawa: Wydawnictwo Naukowe Wydziału Zarządzania UW. 


\section{ANDRZEJ SOPOĆKO}

\section{Przewaga komparatywna. Stan czy proces}

Doświadczenia historyczne pokazują, że gospodarka obecnie nie kształtuje się według narzuconych projektów. Tworzą ją procesy uruchamiane przez czynniki zewnętrzne i wewnętrzne. Zaledwie niewielka część tych ostatnich kontrolowana jest przez rządy. Współczesna gospodarka osadzona jest w bardzo złożonym systemie powiązań międzynarodowych. Istotne dla funkcjonowania przedsiębiorstw obszary kooperacji dawno przekroczyły granice narodowe. Nie ma więc ostrego wyodrębnienia się systemów krajowych wytwarzania. Proces integracji postępuje szybko, pozostawiając coraz mniej miejsca dla realizowanej przez państwo polityki gospodarczej. Istniejące jednak narzędzia fiskalne, prawne, jak również, w ograniczonym zakresie, monetarne pozwalają wspomagać pewne procesy, które są wiodące dla postępu ekonomicznego. Ich identyfikacja i stymulacja przez racjonalną strukturę wydatków państwa jest konieczna, ponieważ nie ma systemów gospodarczych samodzielnie przezwyciężających wszelkie niedostatki. Istnieją także strukturalne słabości, jak np. zbyt krótki horyzont działań przedsiębiorstw, redukujący niezbędne przedsięwzięcia infrastrukturalne i naukowo-badawcze. Państwa, które nie zdołały wypracować racjonalnej polityki wsparcia gospodarki $w$ tych obszarach pozostają $w$ tyle. Niestety tworzenie takiej polityki jest coraz trudniejsze. Na gruncie teorii ekonomii nie ma ani uniwersalnych, ani jednoznacznych wzorców rozwoju, choć kiedyśs wydawało się, że takie istnieją. Skutkowało to m.in. powszechnym, w swoim czasie, udzielaniu priorytetu określonym dziedzinom (przemysł ciężki w latach 50., elektronika w 70. i 80.). Obecnie kontynuację takiego podejścia można określić jako próbę realizacji iluzorycznych celów, kosztem utraty rzeczywistych szans, uksztaltowanych w wieloletnich procesach. Polityka gospodarcza musi być bardziej złożona, nakierowana przede wszystkim na rozwój systemu, a nie na jego poszczególne elementy, pomagać nie tyle w realizacji jednostkowych dokonań, ile ukształtowaniu profilu gospodarki współgrającego z globalnym postępem ekonomicznym i tą droga rozwijać potencjał ekonomiczno-społeczny kraju.

Słowa kluczowe: proces integracji, polityka gospodarcza, rola państwa, przewagi komparatywne.

\section{Cel polityki gospodarczej}

W tej kwestii nie ma konsensusu nawet w najbardziej ogólnym ujęciu. Spektrum operacjonalizacji tego terminu jest bardzo szerokie. Jeżeli odrzucimy definicje niezwiązane z ekonomią (np. zbawienie, harmonia wszystkich istnień) lub całkiem nihilistyczne (tak zrobić, żeby się nie narobić itp.), najbardziej minimalistyczne wydaje się podejście klasycznych liberałów, gdzie polityka gospodarcza sprowadza się wyłącznie do zapewnienia wolności gospodarczej w ramach rynku pełnej konku- 
rencji (Hayek, 1948, s. 110). Aktywność państwa w tej koncepcji powinna ograniczyć się do stworzenia warunków takiego rynku (m.in. bez władczych działań monopoli) oraz zapewnienia godziwego poziomu egzystencji dla osób, które nie są w stanie poradzić sobie same. Po drugiej stronie jest szeroka gama koncepcji zaangażowania państwa w podstawowe obszary ekonomii, jak podział produktu końcowego, struktura wytwarzania, metody produkcji, relacje ze światem zewnętrznym, dostęp do zasobów przyrody odnawialnej (np. lasy) i nieodnawialnej (surowce), nie mówiąc o ideach powrotu do natury. Przegląd tych teorii byłby przeglądem całej ekonomii. Przyjmijmy więc, że pojęcie „polityki gospodarczej” charakteryzować się będzie działaniami zmierzającymi do:

- zapewnienia wolnego, konkurencyjnego rynku w kraju,

- otwarcia na rynek międzynarodowy,

- zmniejszania strefy ubóstwa,

- ograniczeń wykorzystywania zasobów naturalnych.

W ten sposób tworzy się warunki, których spełnienie w liberalnym podejściu wyzwala samo przez się rozwój gospodarczy. Ten zaś można uznać, idąc za jednym z raportów World Banku (2011, s. XI) za „proces budowania dobrobytu - wytwarzania produkcyjnego, naturalnego i instytucjonalnego kapitału. Kluczowym elementem jest niematerialny dobrobyt, czyli kapitał ludzki i organizacyjny" 1 . Budzą się oczywiście wątpliwości czy wspomniane warunki wystarczą, a więc czy pewne działania egzogeniczne wobec systemu są albo niezbędne, albo przynajmniej przyspieszające namnażanie tego rodzaju kapitału. Takie działania można określić jako politykę gospodarczą. A więc polityka gospodarcza jest działaniem współtworzącym, wraz z immanentnymi procesami gospodarczymi, potencjał produkcyjny, naturalny ludzki i organizacyjny kraju.

Przyjęcie wspomnianych aksjomatów daje bardzo szeroki wachlarz możliwych polityk gospodarczych. Jednakże w danym okresie stosowana może być tylko jedna. Która obecnie wydaje się najskuteczniejsza? Pytanie to w naturalny sposób narzuca się każdej makroekonomicznej analizie, odpowiedzi jednak bynajmniej same się nie narzucają. Trzeba przecież określić miejsce stosowania tej polityki, etap rozwoju obecnych i potencjalnych partnerów w kooperacji i wymianie. Poszczególne kraje znajdują się ponadto w różnej sytuacji, jeśli chodzi o wielkość i jakość gospodarki. Różnią się też swoim dziedzictwem kulturowym i instytucjonalnym, biegiem swojej historii, szczególnie najnowszej. Niektóre działania, przynoszące skutek w jednym rejonie, ponoszą porażkę w drugim, wydawałoby się całkiem nieodległym kulturowo i geograficznie. Przykładem są (były) próby odtwarzania rodzinnych gospodarek farmerskich, skuteczne w Polsce ze względu na ciagłość rolnictwa indywidualnego,

1 Development is, at heart, a process of building wealth-the produced, natural, human, and institutional capital which is the source of income and wellbeing. A key finding is that it is intangible wealth, human and institutional capital, which dominates the wealth of all countries (World Bank, 2011, s. XI). 
nieudane zaś w pozostałych krajach postsocjalistycznych, z Niemcami Wschodnimi włącznie. Długotrwałe zerwanie (50 lat) z własnością ziemi przechodzącej z pokolenia na pokolenie nie pozwoliło uczynić z niej na powrót rodzinnego warsztatu pracy. Nie udało się także, mimo właściwych warunków klimatycznych, rozwinąć produkcji ryżu we Włoszech (lata 40. XX w.), ponieważ specyficzna kultura tej uprawy nie miała zakorzenienia w Europie.

Tego rodzaju przykładów jest we współczesnej gospodarce wiele. Łatwo nimi uzasadnić iluzję jednolitego wzorca polityki ekonomicznej. Oceniając jej możliwe warianty, trzeba je odnieść do konkretnych warunków kraju, nie tylko naturalnogeograficznych, lecz także do etapu rozwoju, ale również do istniejącej struktury organizacyjnoprawnej. Jest ona ważnym elementem określającym stan i potencjał rozwojowy gospodarki, który pozwala (lub nie) na wnoszenie nowych, wydawałoby się, pożytecznych rozwiązań w tym zakresie. Co prawda regulacje i sposób organizacji społeczeństwa kształtują jego potencjał ekonomiczny (Acemoglu, Johnson i Robinson, 2002), ale także i odwrotnie, np. nie udało się w krajach postsocjalistycznych rozwinąć efektywnych poziomych struktur samoregulacji (stowarzyszenia, związki, izby), ponieważ, jak się okazało, pożądane wzorce muszą być kształtowane przez pokolenia (jak np. zwyczajowe regulacje środowiska finansowego w Wielkiej Brytanii). W krajach środkowej Europy, z wyjątkiem związków zawodowych, organizacje te mają głównie fasadowy charakter.

Niektórzy autorzy uznają ten wpływ gospodarki na instytucje za znacznie mniej istotny od relacji odwrotnej. Przykładowo, Daniel Rodrick (2000, s. 2) uznaje system instytucjonalno-prawny za egzogeniczny w stosunku do rozwoju gospodarczego, z tym jednak byłoby się trudno zgodzić. Są instytucje, które w jednych krajach działają, w innych tylko są. System społeczno-gospodarczy ich nie zasymilował. Gospodarka się zmienia, gromadzą się dobre i złe doświadczenia związane z wprowadzaniem niektórych rozwiązań. W Polsce zbiurokratyzowanie spółdzielni i związków rolniczych, które nastąpiło przed transformacją, jest powodem niechęci do ich odtwarzania. Jest ono jednak niewątpliwie ważne dla przeciwstawiania się silnym przedsiębiorstwom skupu i przetwórstwa rolnego. Jest na to albo za późno, albo jeszcze za wcześnie, a więc:

- nie może być jednej polityki gospodarczej, powtarzanej w różnych systemach,

- nawet sprawdzone rozwiązania muszą trafić na swój czas w procesie rozwoju gospodarki.

\section{Na pierwszym miejscu - działania skierowane na system}

Przede wszystkim trzeba pamiętać, że polityka gospodarcza kraju jest silnie uzależniona od warunków zewnętrznych. Dotyczy bowiem działania wobec jednego elementu (jednej gospodarki) w systemie, gdzie dzieją się rzeczy niezależne od tej 
polityki, a w dodatku mało przewidywalne. Nawet w pespektywie najbliższych kilku lat nie jesteśmy pewni, co się wydarzy w sferze technologii, w relacjach gospodarczych. Dla Polski znaczącym obszarem niepewności są np. relacje z Rosją, z którą co prawda wymiana gospodarcza jest stonkowo niewielka (4,2\% eksportu) (GUS, 2015), ale rynek ten ma znaczny potencjał wzrostu. Dotyczy to przede wszystkim rolnictwa i dobrze rozwijającej się w Polsce branży produkcji wyrobów użytku domowego i mebli.

Polski dotyczą też, co jest oczywiste, zjawiska o charakterze globalnym, które okazują się nie być ani ciągłe, ani przewidywalne. Tak np. kolejne rundy negocjacji WTO przynosiły postęp w kształtowaniu regulacji otwierających kraje świata na międzynarodową konkurencję. Wydawało się więc, że niemożliwe będzie cofnięcie się w kierunku autarkii, a jednak USA podejmują kroki zmierzające do wycofania się z układu o wolnym handlu z krajami Azji i Pacyfiku (TTP), wprowadzając jednocześnie ograniczenia w eksporcie inwestycji. Jeszcze kilka lat temu nikt nie wyobrażałby sobie również tak wielkiego, jak to mamy obecnie, kryzysu emigracyjnego. Musimy więc być, jak się okazuje, przez cały czas przygotowani na to, do czego dotychczasowe przygotowania na niewiele się zdadzą. J.Y. Lin słusznie wskazuje, że rozwój gospodarczy znajduje się w procesie stałej przemiany struktury gospodarczej, każdy kraj musi zaś nieustannie odszukiwać swoje miejsce w tym procesie, a że stale działa w warunkach niepewności, musi się liczyć zarówno z błędami, jak i z zaskoczeniami.

Pierwszym celem polityki gospodarczej powinno być nie tyle wskazanie co gospodarka ma robić, ile określenie, jaki ma to być system, a w istocie - jakie cechy systemowe rozwijać. Wydaje się, że można wymieć trzy podstawowe:

- przedsiębiorczość,

- elastyczność struktury wewnętrznej,

- absorpcję innowacji.

Przedsiębiorczość w konkurencyjnej gospodarce rynkowej jest elementem pierwszoplanowym. Istnieje tu zróżnicowanie, nawet w tak pozornie jednorodnych krajach centralnej Europy. W krajach naszego regionu relatywnie najniższą przedsiębiorczość odnotowuje się tam, gdzie centralistyczną gospodarkę socjalistyczną zastąpiły rodzime oligopole. Polskę ominął ten proces w ogóle, co w jakiejś części wiązało się z istnieniem, także w poprzednim systemie, prywatnych przedsiębiorstw i indywidualnej własności ziemi. Istniał więc obszar, który stał się zalążkiem nielimitowanej, nielicencjonowanej i samorzutnej aktywności gospodarczej. W pierwszym dziesięcioleciu transformacji problemy z oligarchią gospodarczą miały natomiast, skądinąd dysponujące wyższym wówczas dochodem narodowym per capita, Węgry i Czechosłowacja, co może m.in. tłumaczyć słabsze tempo ich rozwoju gospodarczego w stosunku do Polski. Dalej ogromne trudności w przezwyciężeniu konserwującej system korporacji oligarchów ma Bułgaria, Rumunia i Ukraina, najbardziej zaś Rosja. Trzeba też dodać, że w Polsce bardzo wcześnie podjęto walkę z mono- 
polami. Ustawa o przeciwdziałaniu praktykom monopolistycznym weszła w życie w 1988 roku (dwa lata przed zmianą ustroju politycznego), w 1991 roku utworzono Urząd Antymonopolowy i Sąd Antymonopolowy. W innych krajach postsocjalistycznych niewątpliwie przeoczono znaczenie tego działania. Późno przekonały się one, że wolność gospodarcza nie tworzy automatycznie rynku. Potrzebne okazało się wczesne narzucenie zasad działania, które z rynku utworzą efektywny regulator. Warto też dodać, że istniał ku temu w Polsce odpowiedni klimat społeczny. Wymuszona przez ruch Solidarności samodzielność przedsiębiorstwa była nie do pogodzenia $z$ akceptacją administracyjnych nad nim nadbudówek. W innych krajach nie przeprowadzono rozbiórki zhierarchizowanych organizacji gospodarczych ani nie nadano odpowiedniej siły regulacjom i instytucjom odpowiedzialnym za demonopolizacje. Zjawisko to potwierdza opinię, że niedostatek organizacyjno-prawnej (legal) infrastruktury w społeczeństwie prowadzi do uksztaltowania się wpływowych grup społecznych. Stają się one silniejsze od rynku i demokracji. W rezultacie system nie tyle się integruje, ile dzieli, prowadząc do zwolnienia wzrostu (Tornel i Lane, 1999, s. 26).

Przedsiębiorczość wymaga także konkurencyjnego i łatwego do wejścia rynku. Paradoksalnie sprzyjał temu niedorozwój sieci handlowej, najdotkliwszy zresztą w Polsce. W tej dziedzinie istnieją dość niskie koszty wejścia, dlatego tysiące adeptów biznesu miało szansę spróbować swoich sił i zgromadzić kapitał początkowy do bardziej wymagających pod tym względem dziedzin.

Elastyczna struktura wewnętrzna gospodarki też w pierwszym rzędzie wydaje się zależeć od wielkości udziału drobnego przemysłu w całej produkcji krajowej. Takim przedsiębiorstwom łatwiej się przestawić, jednocześnie w grupie tej jest odpowiedni klimat do poszukiwania nowych szans. Krótko działające przedsiębiorstwa nie mają natomiast takich obciążeń, jak np. tradycja marki czy wyspecjalizowani pracownicy. Rola sektora małych przedsiębiorstw wydaje się szczególnie ważna w krajach rozwijających się, gdzie nie ma on w istocie konkurenta w sektorze dużych firm. Rzecz bowiem w tym, że duże przedsiębiorstwa w krajach naszego regionu rozwijały się w istocie jako oligopole, nie napotykając konkurencji wewnętrznej, a z zewnętrzną prawie się nie mierzyły. Jest to jakościowo całkiem inna sytuacja niż w krajach rozwiniętych, gdzie wielkie korporacje stale konfrontują swoje działania z innymi wielkimi na globalnym rynku. Brak elastyczności działania z ich strony oznaczałby wyparcie z rynku przez globalnych konkurentów, od wielu lat starają się więc wyczuwać i dopasowywać do trendów rynkowych.

Innowacje to trzeci z wymienionych problemów. Należy do najbardziej eksploatowanych problemów związanych z rozwojem. Fakt ten przy okazji wskazuje, że jest zarówno bardzo trudny, jak i niezadowalająco rozwiązywany. Recepty na innowacyjność nie ma, jednak w tym zakresie daje się dostrzec pewne charakterystyczne zjawiska. Po pierwsze, nie ma innowacji w ubogich krajach. Można, co prawda, powiedzieć, że właśnie dlatego są biedne, ale jest to znacznym uproszczeniem sprawy. Po drugie, zbytnie wspieranie innowacji łatwo prowadzi do oderwania 
się środowiska badaczy od potrzeb rzeczywistości. Przykładem były Polsce prace nad wysokoenergetycznymi laserami wojskowymi czy podzespołami elektronicznymi opartymi na germanie, gdzie dokonano ciekawych odkryć, tyle że nie było dla nich zastosowania.

Można powiedzieć, że między wzrostem gospodarczym a innowacjami istnieje dodatnie sprzężenie zwrotne. Stąd nie można wymagać, by średnio rozwinięty kraj był w czołówce gospodarek najbardziej innowacyjnych.

Wysoka innowacyjność sprzyja wysokiemu postępowi technicznemu, jednak znacznie ważniejsza jest zależność odwrotna. Poziom techniki określa również poziom i dynamikę innowacji. Niewiele daje zbyt duży nacisk proinnowacyjny, o ile nie ma szans, by efekty były wchłonięte przez gospodarkę na niewysokim poziomie rozwoju. Tak więc o ile inwestycje w technologie i przemysł kosmiczny w Niemczech i Francji są w stanie pociągnąć znaczną cześć pozostałej gospodarki, m.in. ze względu na rozwinięty sektor lotniczy, o tyle w Polsce czy na Węgrzech przemysł kosmiczny pozostałby raczej wyizolowaną enklawą. Do produkcji samochodów, autobusów, kolei i sprzętu domowego testowanie używanych tu materiałów w kosmosie nie jest uzasadnione.

Dlatego też wsparcie państwa dla tej sfery musi być dobrze miarkowane. A jest to zadanie trudne, ponieważ wymaga działań w wielu wymiarach. Trudno też oprzeć się lobby badaczy, którzy nad dysponentami środków mają przewagę wiedzy - w tym przypadku używanej wybiórczo.

Społeczeństwo, aby być innowacyjne, musi być elastyczne, tzn. zdolne do szybkiego przekształcania struktur wytwarzania, kształcenia, wymiany informacji. Najlepiej nadaje się do tego system tworzony przez związki poziome (umowy cywilnoprawne), gdzie poszczególne elementy łączą wspólne interesy, a nie idące z góry (np. kwatery głównej korporacji) dyspozycje. Rolą państwa jest umacnianie przekonania o skuteczności tego rodzaju więzi. Szczególne miejsce w tej sieci połączeń zajmują związki między przedsiębiorstwami a placówkami naukowo-badawczymi.

Otóż problem ten jest bardziej złożony. Jego główną częścią jest odmienny, od naukowo-badawczego, horyzont działania biznesowego. Zmienność otoczenia wymaga od przedsiębiorców szybkiego podejmowania decyzji: co i jak produkować, gdzie dokonać zmian itp. Czas realizacji inwestycji, przynajmniej jeśli chodzi o maszyny i urządzenia, uległ w ostatnich latach istotnemu skróceniu ze względu na globalizację (większość potrzebnych rzeczy jest już gdzieś gotowa do użycia), jak też infrastrukturę organizacyjną, czyli istnienie zawodowych organizatorów procesu inwestycyjnego. Jednak równoległego skrócenia tego czasu w procesach badawczych nie ma. Częściowo prawdopodobnie dlatego, że doskonalenie techniki i wyrobów, które stają się coraz bardziej złożone, wymaga więcej czasu. Mimo rosnącej wydajności rozmaitego rodzaju instrumentów naukowych, trudno nadrobić rosnącą ilość pracy nad produktem finalnym. Sprawdzenie użyteczności każdego składnika jest pracochłonne, czasem jednak bardzo ważne nie tylko ze względów komercyjnych. W przemyśle tekstylnym stosuje się np. ok. 7000 tzw. substancji pomocni- 
czych (głównie barwników). Część z nich jest potencjalnie rakotwórcza (Zentrum der Gesundheit, 2016). Należałoby je wszystkie przetestować (m.in. czy szkodzą w ogóle, czy tylko w dużych dawkach itp.). O ile kraje rozwinięte mają potencjał, by sprostać takiemu wyzwaniu, pozostałym - na ogół go brakuje. Im bardziej złożony produkt, tym bardziej rozbudowana powinna być towarzysząca mu baza rozwojowa. Gorzej rozwinięte kraje muszą więc z tej bardziej złożonej wytwórczości zrezygnować albo działać na granicy poważnego ryzyka prawnego i moralnego (np. produkować zabawki potencjalnie szkodliwe dla dzieci).

Wzrost złożoności wyrobów, właściwych produkcji krajów rozwiniętych, wymaga by potencjał naukowo-badawczy rozwijał się szybciej niż gospodarka. Dlatego proporcjonalnie więcej potrzeba nakładów tam, gdzie, poza badaniem elementów, należy analizować związki między nimi. Jak wiadomo, liczba tych relacji rośnie bynajmniej nie liniowo, ale wykładniczo. Nie wszystkie relacje są istotne, ale istotnych jest bardzo dużo. Dodatkowo sektor ten musi wyprzedzać potrzeby gospodarki. Proste działanie placówek naukowych, polegające na szybkiej realizacji zgłoszonych potrzeb, praktycznie nie jest możliwe. Odpowiedzi na pytania zadane przez przedsiębiorców, jeśli nie byłyby prowadzone przedtem prace $\mathrm{z}$ danego zakresu, zabrałyby dużo czasu. Placówki naukowe muszą więc prowadzić podstawowe badania, by być zdolnymi, w rozsądnym czasie, do realizacji zadań zleconych przez przemysł. To jednak kosztuje. Żeby się opłacało w kategoriach czysto komercyjnych, zakres współdzielenia z przemysłem musiałby być bardzo znaczny. Duża ilość zleceń o charakterze wdrożeniowym finansowałaby pewną liczbę programów o charakterze podstawowym.

Aby tak było, gospodarka musiałaby być niezwykle innowacyjna, a w większości krajów tak nie jest, konkurencja na rynku wymaga zaś oszczędności wydatków. Tnie się więc finansowanie tego, co nie jest potrzebne na bieżąco, a w przyszłości nie zawsze może się przydać. W tym miejscu niezastąpione jest wsparcie państwa. Trudności za to sprawia takie wyważenie tej pomocy, by placówki naukowe nie koncentrowały się tylko na państwowych grantach i sposobach maksymalizowania dopływu państwowych środków.

\section{Niezastąpiona rola państwa}

Innowacje obok infrastruktury materialnej i społecznej (drogi, koleje, system edukacji) należą do obszarów, gdzie realizowane muszą być strategie długookresowe. Gospodarka prywatna ma z tym kłopoty i w zasadzie nie ma rozwiązania, które zastąpiłoby państwo w realizacji (współrealizacji) przedsięwzięć o długim horyzoncie celu (Burghof i Müller, 2016). Dotyczy to także przedsięwzięć innowacyjnych, a szczególnie wymagających większych nakładów. Duże wydatki, których pokrycie odsunięte jest daleko w przyszłość, są obiektywnie ryzykowne. Ryzyko 
to jeszcze bardziej rośnie, jeśli uwzględnimy jego wymiar subiektywny. W wielu bowiem tego rodzaju przedsięwzięciach koszty powstają w czasie jednej lub nawet dwu kadencji zarządu przedsiębiorstwa (np. farmacja²), efekty zaś jeszcze później. Praca zaś dla sukcesów innych jest wielce chwalebna, jednak rzadko praktykowana.

Państwo nie wymyśla innowacji, powinno więc wspierać tych, którzy je wynajdują. Powstaje wobec tego pytanie, jak to zrobić, by być obiektywnym i dać pierwszeństwo tym, którzy na istniejącym etapie rozwoju mogą rzeczywiście skutecznie poprawić technikę i wyroby?

Tu nie ma recepty, są za to bardziej lub mniej udane pomysły. W Polsce, jak również w innych krajach stosuje się system punktacyjny, prowadzący do kategoryzacji placówek naukowych. Najwyższa kategoria wymaga, co oczywiste, największej liczby punktów, a najważniejszym kryterium ich przyznawania jest liczba publikacji. Tak zresztą robi się na całym świecie. W rezultacie liczba publikacji przewyższa liczbę czytających. Według Allen Institute for Artificial Intelligence na świecie rocznie publikuje się ok. 2 mln artykułów naukowych, z czego połowę czytają najwyżej 2-3 osoby (w tym autor, wydawca i recenzenci) (Lattier, 2016).

Dotychczasowa praktyka nie daje dobrych rozwiązań i odpowiedzi na pytanie, w jaki sposób dzielić środki państwowego wsparcia między różne placówki. Nie jest to jednak, jak się wydaje, najważniejszy problem. Środki na naukę określane są w budżecie, głównie centralnym. Praktycznie ich rozmiary rosną zgodnie z PKB, choć zawsze uważa się, że są za małe, to jednak konkurencja pozostałych pozycji wydatkowych powoduje, że zazwyczaj ich udział jest dość stabilny. Dlatego dyskusja na temat tego ile pieniędzy należy przeznaczyć na naukę jest raczej bezproduktywna. Wydaje się tyle, ile jest. Natomiast warto próbować udrożniać kanał przepływu wiedzy do systemu wytwarzania.

Najważniejszym zadaniem jest intensyfikacja tego procesu w relacjach horyzontalnych, co wymaga ukształtowania w przedsiębiorstwach woli poszukiwania nowych rozwiązań procesu wytwarzania. Stąd wydatki budżetu na badania i rozwój powinny rosnąć, musi to jednak być proces stopniowego wzrostu, uzależniony od kształtowania się skutecznych rozwiązań organizacyjnych, pozwalających na kontrolę i ocenę efektów bezpośredniej pomocy państwa. Złudne są porównania międzynarodowe, pokazujące, że jeden kraj przeznacza na ten cel mniejszą część PKB a inny większą. Bynajmniej nie da się na tej podstawie określić, że pierwszy działa mniej, a drugi bardziej rozsądnie. Wbrew relacjom bezwzględnej wartości tego wskaźnika, oba mogą działać na tym samym stopniu racjonalności. Być może na danym poziomie rozwoju gospodarki pierwszemu z nich to wystarczy, a większe środki zahaczać będą o sferę marnotrawstwa, ponieważ nie będzie stosownego dla nich obszaru efektywnych wdrożeń.

2 Europejska Akademia Pacjentów, jak i inne tego rodzaju instytucje, podaje okres 12-15 lat. Pozyskano z: https://www.eupati.eu/pl/opracowywanie-leku/tworzenie-lekow-etap-1-okrespoprzedzajacy-odkrycie-leku/). Por też Edwards, Fox i Stonier, 2010. 
Jeśli tworzenie innowacji przerasta możliwości ich zastosowania, to szybszą drogą pozyskiwania pieniędzy jest mnożenie ilości nowych rozwiązań, a nie ich jakości. Ilość jest bowiem znacznie bardziej czytelnym kryterium niż jakość, bez względu na zastosowane inne wskaźniki. Ponadto przesuniecie oceny użyteczności pracy na różnego rodzaju konkursy prowadzi do ukształtowania się sieci instytucji naukowych, której celem jest świadczenie wzajemnych korzyści oraz lobbowanie na rzecz nowych funduszy. Sama działalność badawcza staje się drugoplanowa, co nie jest bez znaczenia dla proinnowacyjnej motywacji.

Trzeba pamiętać, że u twórców bardzo silnie rozwinięta jest potrzeba samorealizacji. Dla architekta dobrze zbudowany most jest ważniejszy niż nagrodzony, ale nie zrealizowany projekt. Twórcy chcą wykazać się swoimi talentami i umiejętnościami, w miarę możliwości, jak najbardziej jednoznacznie. Największą satysfakcję przynoszą więc projekty nie tyle przełomowe, ile zrealizowane w praktyce. Innowacyjna gospodarka kwitnie tam, gdzie przy wysokim PKB poziom industrializacji jest relatywnie wysoki. Innowacyjność gospodarki koreluje ściśle z rozwojem przemysłu - im bardziej rozwinięty, tym większy jest obszar, gdzie innowacje mogą być wdrażane. Na zdrowy proces innowacji w gospodarce nie ma nic lepszego niż nierozwijanie go $\mathrm{z}$ istotnym nadmiarem w stosunku do możliwości absorpcji innowacji przez gospodarkę.

Niestety, w krajach rozwijających się można zaobserwować niedostatek zapotrzebowania na produkty krajowego sektora innowacji. Szczególnie silnie zaznacza się to, gdy gospodarka kraju zdominowana jest przez korporacje zagraniczne. Naturalną koleją rzeczy największym zaufaniem obdarzają one ośrodki naukowe najbliższe headquorter korporacji. Jest to bowiem sprawa języka, długoletnich powiazań personalnych, a przede wszystkim marki, jaką sobie wypracowały w danym środowisku. Do tego dochodzi potrzeba koncentracji i kompleksowości badań. Znacznie wygodniej jest więc powierzyć program badawczy znanej instytucji naukowej w całości, niż szukać najbardziej efektywnych rozwiązań w tym zakresie po całym regionie czy też świecie. Kraje zaś, w których występuje silne sprzężenie sektora gospodarki ze sferą stricte wytwórczą stają się ośrodkami przyciągającymi zarówno biznesmenów, jak i naukowców (Korzeniewicz i Moran, 2005).

Zjawisko to ma wymiar globalny i stanowi ważny czynnik kształtowania się zależności ekonomicznych, coraz bardziej niezależnych od granic państwowych. Tworzą się ośrodki, które ściągają do siebie popyt globalny, a co za tym idzie - także kapitał materialny i ludzki. Jak w procesie grawitacji, ściągają one do siebie coraz więcej budulca kapitałowego zarówno w fizycznym, jak i niefizycznym wymiarze. Uwidacznia się to przede wszystkim w wymiarze branżowym, ponieważ główne ośrodki wiodących dla rozwoju branż znajdują w krajach rozwiniętych, przez co następuje wzmocnienie tych krajów.

W tych warunkach kraje rozwijające się, aby nie oddalać się od czołówki, muszą podjąć działania zwiększające siłę zasysania własnych innowacji ze strony dobrze rozwijających się branż. Jak zostało to wcześniej wspomniane, rzecz nie w tworzeniu 
ośrodków naukowych, które daleko wybijają się ponad rzeczywistość sfery wytwarzania. Chodzi o to, po pierwsze, żeby te ośrodki były i reprezentowały poziom potrzebny dla zapewnienia przeszłości branży. Najważniejsze jednak, choć trudne od strony organizacyjnej, by działające w kraju przedsiębiorstwa korzystały z ich dorobku, a nie bazowały wyłącznie na innowacjach z krajów, gdzie znajdują się centrale branżowe.

To jest więc pole do działania dla państwa, które można zdefiniować w następujący sposób: jeśli dany kraj dysponuje dostatecznie dużym fragmentem dobrze funkcjonującego przemysłu, powinno się zadbać o jego zaplecze naukowe. Tutaj, jak się wydaje, podaż powinna wyprzedzić popyt. Zamówienia z przemysłu (popyt) popłyną bowiem tylko wtedy, gdy menedżerowie uzyskają przekonanie, że zastosowanie rodzimych rozwiązań jest korzystniejsze dla firmy niż składanie zamówień w centrali. To przekonanie musi być zaś umocowane w materialnych faktach (działające technologie, niezawodne wyroby itp.). Fakty te muszą jednak najpierw zaistnieć. Same zamiary są bardzo mało przyciągające.

Państwo powinno więc dbać o tworzenie bazy naukowo-badawczej dla istniejącego przemysłu, głównie dla tej jego części, która wykazuje zdolności utrzymania się na konkurencyjnym rynku światowym. Nie jest to proces łatwy, ponieważ nietrudno tu o zbiurokratyzowanie instytucji i kanałów wsparcia, które z biegiem czasu mogą żądać podtrzymywania przez państwo nie tyle ze względu na to co robią, ile z samego faktu, że istnieją.

$\mathrm{Z}$ badań Deloitte nad przedsiębiorstwami w Polsce wynika, że w połowie z nich wydatki nie przekraczają $5 \%$, a w ok. $90 \%$ kształtują się na poziomie poniżej $10 \%$ (Deloitte, 2015, s. 6). Co jednak ważne, przedsiębiorstwa te oczekują wsparcia działalności B+R ze strony państwa, a jego niedostatek uważają za główną przyczynę niedostatecznego rozwoju tej działalności.

\section{Działania niesystemowe}

Oprócz wskazań pozytywnych (co robić), warto wspomnieć o rozwiązaniach, które wydają się słuszne, a najczęściej stają się kontrproduktywnymi. Większość z nich, jak się wydaje, wywodzi się z prób kreowania całkiem nowej rzeczywistości. Polegają one, z jednej strony, na zatrzymywaniu autonomicznego procesu zmian strukturalnych, starając się konserwować dotychczasowe miejsce określonych branż. Z drugiej zaś - wynikają z wizji dokonania skoku cywilizacyjnego, przez rozwijanie branż, które nie mają znaczącego zakorzenienia w systemie, będących zaś symbolami zaawansowanej techniki. W jednym i w drugim przypadku wiodącą rolę odgrywają lobby przemysłowe. W Polsce jego skutkiem jest m.in. ciągłe dofinansowywanie górnictwa węglowego i oparcie na nim produkcji energii, zamiast rozwijania energetyki atomowej i ekologicznej. Bynajmniej nie jest to konieczne ze względów społecznych. 
Jak się bowiem okazuje, tam gdzie zniknęło górnictwo, nastąpiło uwolnienie bardzo zdyscyplinowanej i kreatywnej siły roboczej. Przykładem jest tu ekonomiczny i cywilizacyjny awans miasta Nowe Tychy, kiedyś zamieszkałego wyłącznie przez górników, teraz dynamicznego ośrodka małego i średniego przemysłu.

Jeśli chodzi o realizację subiektywnych wizji, to nasilenie takiej działalności miało miejsce pod koniec istnienia gospodarki socjalistycznej. Przykładowo, w latach 70. XX wieku modne były ubrania z tzw. krempliny (elastyczne tworzywo sztuczne). Przy wielkiej mobilizacji politycznej, postanowiono zaspokoić popyt na nie produkcją krajową. Kiedy zbudowano odpowiednie fabryki, nikt już takich ubrań nie chciał nosić. Bardziej współczesnym przykładem jest produkcja samochodów, które chcą wytwarzać prawie wszyscy, chlubiąc się liczbą wyprodukowanych sztuk. Nie wiadomo po co, jest bowiem kilka krajów, które w tym nie uczestniczą i tego nie żałują. W tej niezwykle materiało- i energochłonnej produkcji Szwajcaria jest na jednym z ostatnich miejsc, podobnie jak Australia, Nowa Zelandia, Irlandia, Taiwan itp.

Trzeba wziąć pod uwagę fakt, że wysokie miejsce w ocenach danego kraju nie musi i zwykle nie jest określone jednowymiarowo. W istocie nie trzeba być najlepszym w żadnej szczególnej dziedzinie, by znaleźć się na wysokiej pozycji na liście, jeśli chodzi o całość rozwoju gospodarczego. Zwykle bowiem nie jeden, ale wiele czynników decyduje o specyfice przewagi komparatywnej i nie zawsze da się wyodrębnić te wiodące. Wszystkie one jednak decydują w sumie o trwałym sukcesie określonego profilu gospodarki. Jak bowiem wytłumaczyć, że Włosi od wielu lat są niepokonani w najwyższej klasy konfekcji i stylizacji produktów? Nie jest przecież tak, że najbardziej udane projekty wymagają nieba włoskiego i odżywiania się wysokiej klasy makaronem. Ta umiejętność projektowania wynika niewątpliwie z bardzo długiej i niezwykle bogatej tradycji artystycznej.

Kraje wysoko rozwinięte zdobywają przewagę nie jednowymiarowo, ale niejako w pakietach. Stają się one coraz bardziej złożone i ulegają stopniowemu przekształceniu. Raport World Banku pokazuje, że w krajach o niskim i średnim dochodzie w okresach 1995-2000 i 2000-2005 wartość kapitału naturalnego utrzymała się na tym samym poziomie, a produced capital i intangible capital wzrosły odpowiednio o ok. 80 i 30\% (World Bank, 2011, s. 8). Rzeczywistość gospodarcza staje się więc coraz bardziej skomplikowana i trudniejsza do zmierzenia, co jest cechą wzrastającego udziału kapitału niematerialnego.

Fakt ten sam w sobie generuje trudności w budowaniu odpowiedniej strategii gospodarczej. Żeby działać mądrze, trzeba mieć bowiem dwojakiego rodzaju wiedzę, której zdobycie wymaga wiele pracy i wysiłków. Po pierwsze, trzeba dobrze znać specyfikę danego kraju, by umieć zidentyfikować jego potencjał wzrostu. Nie wystarczy jednak znajomość samego obiektu operacji, trzeba znać także historię stosowanej polityki i społeczny odbiór jej narzędzi. Po drugie, trzeba znać działania i skutki strategii gospodarczej stosowanej gdzie indziej. Światowe doświadczenia w tej dziedzinie są nieocenione, nie da się ich zastąpić pomysłami nawet najwybitniejszych ekspertów lokalnych. Pomysły z zewnątrz wdrażać należy jednak ostroż- 
nie, nie za wszelką cenę. Możliwości kraju mogą pozwalać zarówno na mniej, jak i na więcej oraz absorbować te działania, które wydawały się nierealistyczne. Tak było na początku lat 60 . XX wieku w Korei Płd., gdzie wbrew rekomendacjom Banku Światowego rozwinięto powszechne szkolnictwo średnie. W Polsce poddanie się rekomendacjom IMF w zakresie polityki pieniężnej zagroziło kryzysem. Jako remedium na wysoką wówczas inflację uznano utrzymywanie niezwykle wysokich stóp referencyjnych Banku Centralnego (przez kilka lat ok. 10\% realnie). W tych warunkach nieracjonalnym było angażowanie środków w jakąkolwiek produkcję. W pozostałych krajach Europy Centralnej i Wschodniej negatywnym doświadczeniem była pośpieszna prywatyzacja, bez tworzenia konkurencyjnego rynku, co jak wspomniano, doprowadziło do oligarchizacji tamtejszych gospodarek.

Polityka gospodarcza powinna kierować się twardą zasadą - ma ona wspierać rozwój, a nie wizje ekonomiczne. To co dzisiaj wydaje się mieć znaczenie i być możliwe do zrealizowania, za parę lat może być nieużyteczne lub zaskakująco trudne do wykonania (np. realizacja programu wykorzystania gazu łupkowego). Wektorowe lub rankingowe określanie celów zawsze wiąże się z realizacją oderwanych od rzeczywistości strategii. Gospodarkę weryfikuje jej otoczenie międzynarodowe, a w nieporównywalnie mniejszym stopniu - stopień realizacji zadanych programów.

Rozwój rzadko kiedy jest procesem ciagłym, w niektórych momentach potrzebny jest szczególny wysiłek, nieporównywalny z dotychczasowym. Dobrym przykładem wydają się tu fizyczne przemiany fazowe. Taką przemianą jest np. podgrzanie wody do stanu wrzenia. Do $99^{\circ} \mathrm{C}$ proces przebiega linearnie, dalsze jednak podgrzanie o jeden stopień wymaga znacznie więcej energii niż np. przejście z 98 do $99^{\circ} \mathrm{C}$. $\mathrm{Z}$ trudnościami odpowiadającymi przemianom fazowym spotyka się obecnie polski handel detaliczny. Niezwykle silny rozwój miał miejsce do etapu nasycenia przedsiębiorstwami o zasięgu lokalnym (pojedyncze sklepy bądź kilka działających razem placówek). Przedsiębiorstwa sieciowe nie mogą się utrzymać, co m.in. dotyczy takich firm, jak Marcpol, Piotr i Paweł czy Alma, ustępują oni zagranicznym sieciom, jak Biedronka, Carrefour.

Oczywiście nie wszystkim należy udzielać wsparcia, jeśli w swoim rozwoju napotkali bariery wzrostu. Globalizacja umożliwiła funkcjonowanie gospodarek o wysoce niepełnym profilu produkcji. Jeśli np. w Polsce, jak i w innych krajach Europy, występują trudności w budowie dużych statków pełnomorskich, ponieważ nie zbudowano krytych ciągów produkcyjnych pozwalających na budowanie pod dachem całych segmentów, to jest rzeczą wątpliwą, że jakiekolwiek formy dopuszczalnego wsparcia pozwolą na sfinansowanie inwestycji umożliwiających konkurowanie np. Koreą Płd. czy Singapurem.

Trzeba koncentrować finansowanie tam, gdzie istnieje największa szansa na sukces. A gdzie jest ta szansa? Nigdy nie ma pewności, ale najrozsądniej wspierać te branże (przedsiębiorstwa), które już weszły na ścieżkę sukcesu. Jak w sporcie - finasowanie prestiżowych zawodów, zajęcia u najlepszych trenerów przeznaczone są dla tych, którzy już wybijają się spośród innych. Czy jednak przedmiot wyboru nie 
zawiedzie oczekiwań, a jego dotychczasowe wyniki nie będą przejściowym efektem życiowej formy - zawsze pozostanie sprawą otwartą.

Wspieranie tych, którzy już sobie dają radę wydaje się z pozoru nielogiczne. Potrafili sami poradzić sobie z trudnymi warunkami startu i początkowego rozwoju, wsparcie publiczne może przecież osłabić determinację przedsiębiorstw czujących za sobą siłę państwa. Tak oczywiście może być, jednak na pewnym etapie może mieć miejsce zahamowanie rozwoju, związane nie tyle z obiektywnymi przeszkodami, ile z obawą o podjęcie ryzyka przejścia do następnego etapu.

Pomoc ex post jest dla dużych, a szczególnie bardzo dużych przedsiębiorstw raczej regułą (,za duże, żeby upaść”), mniejsze muszą starać się o wsparcie ze strony władz lokalnych. Istotną pomocą (mniej w kategoriach materialnych, bardziej psychologicznych i organizacyjno-proceduralnych) stanowią tu izby gospodarcze. Najsilniejsze pod tym względem są izby w RFN i w Austrii, gdzie przynależność do nich jest obowiązkowa, w innych krajach natomiast na ogół nie. Często zbliżają się one do organizacji o charakterze lobbystycznym. Zawsze jednak pomagają przemóc lęk przed ryzykiem wejścia w nowy etap rozwoju.

Jedną z ważnych rekomendacji J.Y. Lina jest koncentracja wysiłków państwa w obszarach przewag komparatywnych. Jest to niewątpliwie logiczna konsekwencja krytyki interwencjonizmu państwowego, który uznaje się powszechnie za nieudany eksperyment polityki ekonomicznej. Choć można mieć wątpliwości czy np. w krajach Wschodniej Azji jest to prawda (np. casus Singapuru). Jak się wydaje, przynajmniej pewne jego elementy nie przyczyniły się do sukcesu ekonomicznego tej części świata, a w krajach socjalistycznych - utworzenia bazy przemysłowej. W tej chwili nie widać przesłanek do powrotu interwencjonizmu w wersji Juana Domingo Perona (budowa przemysłu metalurgicznego i maszynowego w Argentynie) czy, ostatnio, próby zaprowadzenia w pustynnych krajach naftowych rozwiniętego rolnictwa, wykorzystującego podziemne źródła wody. Istniejące przewagi komparatywne są bardziej złożone niż kilkadziesiąt lat temu, potrzebne jest obecnie działanie bardziej subtelne i złożone.

Pierwszym jednak problemem jest to czy przewagi komparatywne powinno się wykorzystywać w pełnym zakresie. Jedną z nich jest np. tania siła robocza. Jeśli uznać ją za czynnik decydujący o strukturze, to może dojść do negatywnego sprzężenia zwrotnego, w którym tania siła robocza kształtuje strukturę gospodarczą (dominują branże pracochłonne), a z kolei ta właśnie struktura naciska na niskie płace, aby produkcja krajowa była konkurencyjna w świecie.

Drugim problemem jest identyfikacja przewag komparatywnych w warunkach międzynarodowej integracji. Globalizacja powoduje, że produkt końcowy bardziej składa się niż produkuje. Każdy nowy Dreamliner, opuszczający fabrykę Boeinga w Seattle, jest zmontowany z ok. 2000 części dostarczonych przez zewnętrznych kooperantów rozrzuconych po całym świecie. Niewątpliwie każdy z tych kooperantów musiał odnieść znaczące sukcesy, by wziąć udział w prestiżowej produkcji. Czy jednak sukces produkcyjny przedsiębiorstwa oznacza przewagę komparatywną kraju? 
Polska stała się ostatnio znaczącym producentem autobusów w Europie. Jeszcze 20 lat temu nikt by o tym nie pomyślał. Jeśli zaś można byłoby typować lidera w tej dziedzinie, to wówczas byłyby nim Węgry, które w swoim czasie rozbudowały potężny przemysł produkcji autobusów. Co prawda, po transformacji odpadł najważniejszy odbiorca - rynek radziecki, ale wydawało się, że tak duży potencjał powinien pozwolić na szybkie adaptowanie się do nowych wymogów. Nic z tego jednak nie wyszło. Inaczej natomiast zdarzyło się Czechom. Przed transformacją mieli oni bardzo rozbudowany przemysł wytwarzający samochody osobowe. Transformacja mu nie zaszkodziła, wręcz przeciwnie, zaczął on odnosić coraz większe sukcesy na wymagających rynkach zachodniej Europy.

Niewątpliwym jest, że istnieją w poszczególnych krajach przewagi komparatywne. Chyba jednak obecnie relatywnie słabo wiążą się one naturalnymi cechami środowiska ekonomicznego. Kształtuje je sam system, wskutek trudnej do zanalizowania koniunkcji talentów przedsiębiorców w jakiejś dziedzinie, rozumnego wsparcia państwa, otwarcia na ryzyko zagranicznych odbiorców, istnienia lokalnych rezerw wykwalifikowanej siły roboczej. Przewagi te ukształtowane są w procesie wieloletnim, ale nie da się określić na jak długo i w jakim obszarze powstaną nowe. Czasem sukces osiaggany jest, wydawałoby się, wbrew istniejącym obiektywnie warunkom. Dlaczego bowiem ważnym produktem eksportowym Polski stały się pociaggi i tramwaje, skoro przedtem produkowano je zarówno w niewielkich ilościach, jak i w bardzo przestarzałym asortymencie (głównie węglarki). Można to oczywiście wytłumaczyć zamówieniami sektora publicznego, jednak w przetargach na równych prawach brali udział także producenci z Unii Europejskiej. Bardzo trudno byłoby też wytłumaczyć przewagą warunków naturalnych sukces eksportu hodowanego w Polsce jesiotra, skoro ta, wymagająca i szlachetna ryba na wolności żyje w zupełnie innych warunkach klimatycznych. W związku z tym wydaje się, że istnieją dwa rodzaje korzyści komparatywnych:

1) właściwa tylko niektórym krajom determinanta środowiskowa; tak więc Islandia na pewno będzie się specjalizowała w połowach i przetwórstwie ryb; Australia i Nowa Zelandia - w hodowli owiec; Argentyna - w hodowli bydła itd.; w tych rejonach istnieją warunki przyrodnicze, które w szczególny sposób sprzyjają tej działalności;

2) wypracowane przez sam system społeczno-gospodarczy, jak przewaga niemieckiej branży samochodowej, koreańska i japońska elektronika użytkowa, delikatesowa żywność francuska itp.

Wykorzystanie obu przewag komparatywnych daje przyspieszenie rozwoju. Cały czas trzeba jednak ten proces kontrolować. Przewagi te, szczególnie drugiego rodzaju, nie są i nie muszą być długotrwałe. Mocno podkreślanym obecnie zjawiskiem jest różnica miedzy intensywności pracy między krajami północy naszego kontynentu a krajami południa. W tych ostatnich istnieje mniejsza motywacja do podejmowania ciężkiej pracy niż na północy. Prawdopodobnie dałoby się to uza- 
sadnić klimatem, który ukształtował tego rodzaju podejście do pracy. Obecnie jednak, przy powszechnie użytkowanej klimatyzacji, nie powinno to mieć znaczenia, a jednak intensywność pracy nie zbliża się do zakresów osiąganych na północy. Jeśli jednak uznać ten stan rzeczy za trwały, należałoby, zgodnie z logiką dostosowania, rozwijać na południu branże kapitałochłonne, a na północy - pracochłonne. A to przecież byłoby całkowicie wbrew tendencjom kształtującym się od lat w europejskim podziale pracy.

\section{Konkluzje}

Polityka gospodarcza powinna być wsparciem dla tych procesów, które wzmacniają pozycję konkurencyjną kraju na rynku międzynarodowym. Służyć temu powinny działania regulacyjne i fiskalne. Natomiast bezpośrednie wsparcie finansowe produkcji musi być bardzo ograniczone, przede wszystkim ze względu na ograniczenia traktatów WTO i UE. Jest to także zgodne z uznaniem wolnej gospodarki rynkowej za podstawowy regulator gospodarki światowej. Nie ma potrzeby ingerowania tam, gdzie funkcje regulatora wykonuje on zadowalająco. Tak się dzieje w większości operacji o krótkim i średnim horyzoncie działania. W przypadku jednak długiego horyzontu - wsparcie państwa jest niezastąpione. Dotyczy to większości badań podstawowych i części rozwojowych, procesu podnoszenia kwalifikacji oraz budowy infrastruktury materialnej i społecznej (związki i izby gospodarcze, fundacje itp.). Działania te powinny w pierwszym rzędzie wykorzystywać istniejące możliwości kraju, w tym takie, jakie pojawiły się danym okresie. Trzeba jednak pamiętać, że wraz z rozwojem gospodarki zmieniają się warunki działania. W ślad za nimi powinny zmieniać się preferencje polityki gospodarczej. Kompasem jest tu niewątpliwie sukces odnoszony w określonych dziedzinach czy grupach produktowych. To się jednak zmienia. Paradoksalnie komparatywne korzyści zmniejszają się wraz z ich wykorzystywaniem. Produkty oparte na taniej pracy, odnoszące sukcesy międzynarodowe, powodują, z jednej strony, wzrost jej kosztów, z drugiej zaś - napływ kapitału. To natomiast skłania do przestawienia się na dziedziny o większym udziale tego ostatniego. Postęp techniczny także zmienia strukturę światowego zapotrzebowania na produkty. Koncentrując więc wysiłki państwa na dziedzinach, gdzie przedsiębiorstwa legitymują się sukcesem na rynkach międzynarodowych, należy brać pod uwagę także czasowy charakter tego sukcesu. Oznacza to konieczność pewnego wsparcia działań rozwojowych tam, gdzie rysuje się jedynie szansa na sukces. 


\section{Bibliografia}

Acemoglu, D., Johnson, S. i Robinson, J.A. (2002). Reversal of furtune Geography and Institutions in Making Modern Worlds Incoeme Distributioon. The Quarterely Journal of Economics, 4.

Burghof, H.P. i Müller, C. (2016). The State as a Financial Intermediary to Foster LongTerm Investments. Applied Economics Quarterly, 3, 205-230.

Deloitte. (2015). Badania i rozwój w przedsiębiorstwach. Raport 2015. Pozyskano z: https:// www2.deloitte.com/content/dam/Deloitte/pl/Documents/Reports/pl_Badania_i_rozwoj_w_Polsce_2015.pdf.

Edwards, L., Fox, A. i Stonier, P. (red.). (2010). Principles and practice of pharmaceutical medicine (3rd ed.). Oxford: Wiley-Blackwell.

Gill, I.S. i Raiser, M. (2012). Golden Growth: Restoring the Lustre of the European Economic Model. Washington, DC: World Bank. Pozyskano z: https://openknowledge.worldbank. org/handle/10986/6016 License: CC BY 3.0 IGO.

GUS. (2015). Rocznik statystyczny handlu zagranicznego 2015. Warszawa: GUS.

Hayek, F. (1948). Individualism and Economic Order. Chicago: University of Chicago Press. https:/www.eupati.eu/pl/opracowywanie-leku/tworzenie-lekow-etap-1-okres-poprzedzajacyodkrycie-leku/.

Zentrum der Gesundheim. (2016). Kleidung und Textilien mit Giftstoffen, 3 sierpnia. Pozyskano z: 3.08.2016. https://www.zentrum- der-gesundheit.de/textilien-giftstoffe-ia.html

Korzeniewicz, R.P. i Moran, T.P. (2005). Theorizing the relationship between inequality and economic growth. Theory and Society, 34, 277-316.

Lattier, D. (2016). Acadamic Write Rubish Nobody Redads. Fundation of Economic Education, October 27.

Lederman, D. i Maloney, F. (2012). Does What You Export Matter? In Search of Empirical Guidance for Industrial Policies. Washington, DC: World Bank.

Rodrick, D. (2000). Institution for High- Quality Growth. Center for for Economic Policy Research, Discussion Paper, No. 2370.

Tornel, A. i Lane, Ph.R. (1999). The Voracity Effect. The American Economic Review, 89(1), March, 22-46.

World Bank. (2011). The Changing Wealth of Nations: Measuring Sustainable Development in the New Millennium. Environment and Development. Washington, DC: World Bank. Pozyskano z: https://openknowledge.worldbank.org/handle/10986/2252 License: CC BY 3.0 IGO. 


\section{GRZEGORZ JĘDRZEJCZAK \\ HENRYK STERNICZUK}

\section{Nowa Ekonomia Strukturalna \\ a polskie wyzwania rozwojowe}

Przedmiotem rozdziału jest ocena Nowej Ekonomii Strukturalnej (NES) z punktu widzenia jej przydatności dla obecnego polskiego wyzwania modernizacyjnego - konwergencji z krajami "starej Unii” w perspektywie nadchodzących kilkunastu lat. Atrakcyjność NES wynika z autentycznych sukcesów modernizacyjnych krajów Dalekiego Wschodu.

Rozpatrywane są trzy pytania o istotnym znaczeniu dla możliwości zastosowania NES do rozwiązania polskich problemów rozwojowych: (a) wyposażenia (endowment) w zasoby egzogenicznie determinujące strukturę nowoczesnej gospodarki postindustrialnej, (b) kontekstu globalnego gospodarki; (c) roli państwa w realizacji polityki gospodarczej mającej na celu wzrost konkurencyjności globalnej.

W konkluzji stwierdzono, że z punktu widzenia potrzeb Polski, NES jest obarczona ryzykiem potencjalnej pułapki, jeśli chodzi o sposób, w jaki państwo (rząd) zamierza realizować politykę modernizacji. NES zakłada implicite niepolityczny charakter państwa - państwo ma trwały mandat i administracyjną możliwość realizacji swojej strategii, bez potrzeby uwzględniania głosów kontestujących jego cele i metody. Taka opcja jest atrakcyjna z czysto pragmatycznego punktu widzenia szybkości wprowadzania zmian, ale nie odpowiada polskim realiom (czy szerzej zachodnim) państwa politycznego, a więc poddawanego okresowej ocenie wyborów demokratycznych.

Słowa kluczowe: modernizacja, rola państwa, kulturowe uwarunkowania modernizacji, globalne uwarunkowania modernizacji, polskie wyzwanie modernizacyjne.

\section{Wprowadzenie}

Teoria Nowej Ekonomii Strukturalnej (NES), której czołowym orędownikiem jest Justin Yifu Lin jest przedmiotem licznych analiz, również z punktu widzenia jej praktycznej przydatności w doganianiu (catching-up) krajów wysoko rozwiniętych przez kraje niskiego i średniego dochodu (Lin, 2012).

Zakres tego artykułu jest węższy - jego przedmiotem jest ocena Nowej Ekonomii Strukturalnej z punktu widzenia jej przydatności dla obecnego polskiego wyzwania modernizacyjnego, czyli konwergencji z krajami „starej Unii” w perspektywie nadchodzących kilkunastu lat. 
Koniec pierwszej dekady XXI wieku to czas istotnych przewartościowań w ekonomii, w tym ekonomii rozwoju. Okazało się bowiem, że doktryna neoliberalizmu dominująca w końcu XX wieku nie umiała nie tylko poradzić sobie ze strukturalnymi efektami globalnego załamania finansowego, lecz także nawet przewidzieć jego wystąpienia oraz daleko idących skutków ekonomicznych i społecznych. Jak ujęła to królowa Elżbieta, wizytując London School of Economics w 2008 roku: Why did nobody notice that? ${ }^{1}$.

Jak się okazało, obowiązująca doktryna ekonomiczna opierała się na nieadekwatnych założeniach odnośnie do zachowań ludzkich, optymalnych „reguł gry” oraz ich konsekwencji. Mity, takie jak a rising tide lifts all boats, trickle-down theory czy roli państwa ograniczonej do usuwania market failures, wyglądały wiarygodnie w czasach wzrostu gospodarczego, lecz pokazały swoją bezradność w czasie załamania.

Ekonomia rozwoju z jej praktycznym centralnym zagadnieniem doganiania (konwergencji) krajów rozwiniętych przez kraje słabo rozwinięte miała (i ciągle ma) swoje mity.

Podstawowym mitem jest przekonanie, że krajom z niedostatkiem rozwoju trzeba pomóc „być jak my”. Podejście takie było/jest szczególnie częste wśród zachodnich donorów i międzynarodowych organizacji, a jego efektem jest produkowanie strategicznych programów dla rządów z długą, eklektyczną listą postulatów, wynikających z doświadczeń krajów wysoko rozwiniętych; postulatów koniecznych do spełnienia, aby odnieść sukces w budowie rozwiniętej gospodarki i zamożnego społeczeństwa. W znakomitej ilości przypadków programy takie zostają na papierze i nie są nigdy realizowane. $\mathrm{W}$ rzeczywistości bowiem adresaci tychże porad wiedzą znacznie więcej niż eksperci, że uwarunkowania i wymogi przeprowadzenia fundamentalnych strukturalnych zmian daleko wykraczają poza sporządzoną a priori listę „co zrobić”. Wiedzą też, że podjęcie programu strukturalnych reform narusza interesy różnych grup i bardziej przypomina prowadzenie wojny (z jej nieprzewidywalnością, potrzebą adaptacji i korekty celów, zmieniającymi się koalicjami, czy wreszcie szczęściem lub jego brakiem) niż wprowadzanie z za biurka kolejnych legislacji i powoływania kolejnych instytucji.

W tym kontekście NES jest dosyć radykalnym odejściem od doktryny neoliberalizmu. Kamieniem węgielnym doktryny NES jest bowiem założenie, iż „w krótkim ujęciu, struktura ekonomiczna kraju w danym okresie ma charakter endogeniczny względem jego wyposażenia w zasoby - aktualnie dostępnego kapitału, pracy i surowców naturalnych. Kraje znajdujące się na różnych etapach rozwoju różnią się pod względem relatywnej dostępności puli zasobów (wyposażenia - endowment). W kraju rozwijającym się przeważnie mamy do czynienia ze względnym deficytem kapitału, podczas gdy dostępność siły roboczej, a często także zasobów natural-

1 Symptomatyczna była też odpowiedź Dyrektora do spraw badań Departamentu Zarządzania LSE: At every stage, someone was relying on somebody else and everyone thought they were doing the right thing. Zob. Pierce, 2008. 
nych, jest relatywnie obfita. W krajach rozwiniętych stosunkowo łatwo o kapitał, przy jednoczesnej relatywnie trudnej dostępności siły roboczej. Co do puli zasobów w gospodarce, w dowolnym konkretnym okresie jest ona określona, ale z upływem czasu może się zmieniać" (Lin, 2012)

Założenie to w sumie nie odbiega od rozumowania neoklasycznego (co autor przyznaje), leżącego u podstaw teorii wzrostu opartej na funkcji produkcji w tradycji Cobba-Douglasa. Nowość polega na praktycznych konsekwencjach: proponowanej dezagregacji gospodarki i potraktowanie poszczególnych tak określonych segmentów według zalecanych procedur polityki gospodarczej, mającej na celu właściwe wykorzystanie zasobów dla wzmocnienia konkurencyjności gospodarki.

Powstają w tym miejscu pytania o istotnym w naszym przekonaniu znaczeniu dla praktycznego zastosowania NES do rozwiązania polskich problemów rozwojowych, które nie kwestionują jednak wspomnianego wyżej założenia. Dotyczą one w szczególności: (a) pojęcia wyposażenia (endowment) w zasoby egzogenicznie determinujące strukturę nowoczesnej gospodarki postindustrialnej, (b) kontekstu globalnego polityki modernizacyjnej; (c) roli państwa w realizacji polityki gospodarczej mającej na celu wzrost konkurencyjności w skali globalnej.

Na pytaniach tych skupimy nasze dalsze rozważania. W zakończeniu sformułujemy kilka konkluzji, w jakim zakresie NES może być przydatne polskiemu programowi rozwojowemu.

\section{Wyposażenie w zasoby gospodarki postindustrialnej}

W tradycji ekonomii neoklasycznej NSE rozważa trzy podstawowe składniki wyposażenia gospodarki: pracę, kapitał i surowce naturalne. Ma to dwie ważne konsekwencje: a) ograniczenie analizy do przemysłu; b) niedocenienie roli wiedzy oraz kultury społeczeństwa w doganianiu wyżej rozwiniętych gospodarek.

Naturalną konsekwencją takiego określenia zasobów jest zawężenie analizy i zaleceń dla polityki gospodarczej do przemysłu. Dla NES istota efektywnej polityki gospodarczej to umiejętność poradzenia sobie ze specyficznymi wyzwaniami poszczególnych branż gospodarki.

Ograniczenie się do przemysłu ma oczywiście swoje uzasadnienie, należy jednak pamiętać, że w gospodarkach wysokiego poziomu dochodów (rozwoju) przemysł wytwarza nie więcej niż $1 / 4$ dochodu narodowego, stąd uzyskiwane efekty będą miały odpowiednio ograniczone rezultaty dla całej gospodarki.

Polska przeszła okres gwałtownego spadku udziału przemysłu w PKB w czasie transformacji, ale ten udział jest ciągle na poziomie krajów wysoko rozwiniętych o dużym znaczeniu przemysłu (Niemcy, Japonia), a o 5pp wyższym niż w EU-15.

Dla konkurencyjności polskiego przemysłu w globalnym podziale pracy znaczenie ma struktura przemysłu i miejsce w łańcuchu tworzenia wartości dodanej - czy 
jest to produkcja prostych mebli według cudzych projektów, czy nowych lekarstw w oparciu o własne technologie. Różnice te obrazuje dystans między Polską a Niemcami (rys. 1).

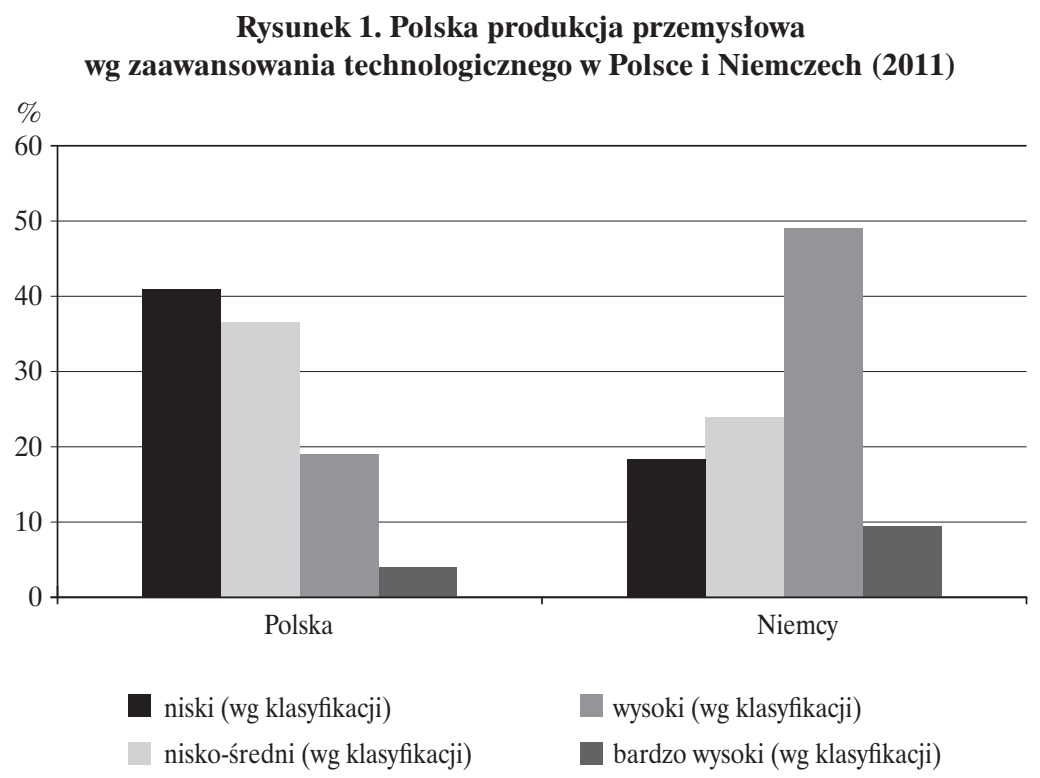

Źródło: Bukowski, 2014.

Konkurencyjność krajowego przemysłu w gospodarce globalnej jest wypadkową dwóch cech: dywersyfikacji i unikalności produkcji. Kraje o znacznej dywersyfikacji eksportu jednocześnie eksportujące wyspecjalizowane produkty są w sytuacji najlepszej - zwycięzców w konkurencji globalnej ze względu na relatywnie wysoką dywersyfikację oferty eksportowej produktów produkowanych przez relatywnie małą liczbę zagranicznych konkurentów. Kraje te mają zarówno najbardziej konkurencyjną strukturę gospodarki w sensie statycznej przewagi nad konkurentami na dany moment, jak i strukturę najbardziej odporną na fluktuacje globalnych rynków (Hausman i in., 2013).

Nie jest więc zaskoczeniem, że Niemcy i USA mają największą dywersyfikację eksportu przy najbardziej unikatowej ofercie. Nie jest też zaskoczeniem, że kraje biedne, słabo rozwinięte mają mało zróżnicowaną ofertę eksportową prostych produktów o łatwo przenaszalnej technologii wytwarzania. Polska wypada pod tym względem całkiem dobrze - ma zróżnicowanie eksportu większe niż wiele wysoko rozwiniętych krajów daleko lepiej notowanych w rankingach konkurencyjności i rozwoju, takich jak Japonia czy Kanada, oraz zupełnie przyzwoitą pozycję w unikatowości eksportowanych produktów na poziomie Szwecji (Hausman i in., 2013). 
Powstaje w tym miejscu pytanie: dlaczego polska gospodarka, mimo dobrej dywersyfikacji i unikalności eksportu, nie wykorzystuje innowacyjności jako motoru poprawy swojej globalnej konkurencyjności (competetive advantage)?

Odpowiedzi na to pytanie należy poszukać w dwóch obszarach: (a) dotychczasowej ścieżce rozwojowej gospodarki polskiej oraz (b) wyposażeniu (endowment) w czynniki wychodzące poza neoklasycystyczne menu: pracy, kapitału i zasobów naturalnych.

Niska innowacyjność polskiej gospodarki okresu transformacji jest przypadkiem szczególnego paradoksu. Z jednej bowiem strony, Polska jest słusznie podziwiana za dynamikę wzrostu gospodarczego i przeprowadzone głębokie zmiany strukturalne modernizujące gospodarkę. Efekty tych zmian widać gołym okiem, na przykład przy korzystaniu z usług banków, warsztatów samochodowych, prywatnego dentysty czy lekarza - usług oferowanych na poziomie nieodbiegającym od standardów rozwiniętych krajów Zachodu. Jednocześnie Polska zajmuje niskie pozycje w rankingach wydatków na badania i rozwój oraz w rankingach innowacyjności. Przykładowo, w renomowanym rankingu innowacyjności Global Economic Forum Polska znajduje się na 49 miejscu, nie tylko za wszystkimi krajami rozwiniętymi, lecz także za Rumunią, Mołdową, Czarnogórą i Litwą (GEF, 2016).

Rozwój przez produkowanie więcej tego samego ze zmianami technologii prowadzącymi do obniżania kosztów było dominującą strategią rozwojową polskiego przemysłu w latach transformacji. Przez ostatnie 25 lat nastąpiły w polskiej gospodarce poważne zmiany technologiczne i organizacyjne wdrażane do firm przez nowych, na ogół zagranicznych właścicieli przedsiębiorstw (prywatyzowanych i greenfield). Innowacyjność technologiczna i organizacyjna nie wynikała z oryginalnych polskich wynalazków czy też presji polskich przedsiębiorców na ich wdrożenie. Dokonywała się w wyniku absorpcji technologii i rozwiązań organizacyjnych wynalezionych poza Polską, przywiezionych z firm matek. W typowym modelu prywatyzacji zagraniczni właściciele prywatyzowanych przedsiębiorstw zatrzymywali dobrze przygotowanych pracowników, rynek produktu, jak również markę produktu, a następnie modernizowali proces produkcji przez wprowadzenie nowych maszyn, doskonalili koncepcję produktu oraz marketing i zarządzanie. Był to proces wtłaczania innowacji w gospodarkę. Przykładem może być rynek produktów mlecznych, gdzie pod starymi nazwami i smakami produktów kryje się często nowa technologia ich produkcji, pozyskanie surowców i dystrybucji - ograniczająca koszty, w tym zatrudnienia.

Zagraniczne firmy w Polsce odgrywają i będą odgrywać w dającej się przewidzieć przyszłości znaczącą rolę we wprowadzaniu innowacji do polskiej gospodarki, zarówno kapitałowej, jak i bezkapitałowej. Należy więc utrzymywać atrakcyjność Polski dla inwestycji zagranicznych, ponieważ są one poważnym kanałem dopływu z zewnątrz nowych produktów, technologii i metod organizacji i zarządzania. Służy to całej gospodarce, gdyż połowa polskiego eksportu wytwarzana jest przez firmy zdominowane przez kapitał zagraniczny. Im więcej wobec tego nowych technologii napłynie do tych firm z krajów najwyżej rozwiniętych, tym szybsza będzie ich 
dyfuzja na całą gospodarkę, poprzez małe i średnie przedsiębiorstwa kooperujące z eksporterami. Trzeba sobie jednak nie tylko zdać sprawę, że strategia taka oznacza dominację innowacji imitacyjnych, lecz także pamiętać, że są to innowacje niesuwerenne - instalowane u polskich wykonawców zleconych zadań produkcyjnych z firm matek, działających globalnie.

Innowacje niesuwerenne powodują dwa rodzaje ryzyka. Po pierwsze, innowacje takie mogą być wycofane z Polski w przypadku przeniesienia produkcji do lokalizacji bardziej opłacalnych z punktu widzenia firmy matki. Po drugie, innowacje niesuwerenne, na ogół ucieleśnione w importowanych maszynach, nie rozwijają miejscowego potencjału innowacyjnego.

W Polsce, jak w każdym kraju peryferyjnym, ograniczeniem innowacji z najwyższej półki może być strategia zagranicznych inwestorów lokujących w krajach peryferyjnych działalność technologicznie mniej zaawansowaną. Wynika to ze słabiej przygotowanej siły roboczej oraz niższych kosztów internalizacji kosztów zewnętrznych (externalities) niż w krajach pochodzenia kapitału.

Siła robocza w Polsce może mieć (i często ma) wyższe formalne wykształcenie niż siła robocza w krajach rozwiniętych, ponieważ atrakcyjność pracy w firmie zagranicznej przyciąga ludzi z wyższymi kwalifikacjami niż są potrzebne na danym stanowisku. Dla inwestora jednakże decydujące znaczenie ma wiedza praktyczna, a tę - jak nazwa wskazuje - zdobywa się w praktyce, naśladując mistrzów zawodu przez wiele lat oraz uczestnicząc w grupie pracowniczej. Są to zdolności trudne do przeniesienia między krajami i społecznościami, a nabywane latami. Wymagania wiedzy praktycznej są tym łatwiejsze do zdobycia, im niżej technologicznie w łańcuchu produkcji ulokowana jest działalność.

Wyśrubowane normy ekologiczne i wymogi prawa pracy w krajach rozwiniętych są istotną przyczyną przenoszenia elementów działalności gospodarczej niespełniających tych wytycznych do krajów gotowych do ich akceptacji w mniej ostrych formach. Motywem lokalizacji jest więc możliwość eksternalizacji kosztów związanych z przestrzeganiem norm. Dotyczy to w znaczącym stopniu „brudnych” elementów łańcucha produkcji, z reguły o najmniejszym nasyceniu wysoką technologią i najmniej innowacyjnych.

Rozwój przez wchodzenie na wyższe poziomy w łańcuchu tworzenia produktu jest skuteczną strategią wzrostową dla gospodarek otwartych uczestniczących w międzynarodowym podziale pracy. Jest to, mimo postępu odnotowanego w ostatnich latach, wciąż w niezbyt znacznym zakresie przypadek Polski. Najnowsze, najbardziej innowacyjne produkty i technologie decydujące o przewadze konkurencyjnej są pod najściślejszą ochroną przedsiębiorstw, które je wytwarzają. Dlatego patrzą one z dużą podejrzliwością na propozycję ulepszeń proponowane przez kooperantów - ryzyko utraty monopolu w zakresie ulepszania produktu jest nieraz oceniane jako większe niż korzyści wynikające z możliwości obniżki kosztów.

Zagraniczni właściciele są też bardziej skłonni do ograniczenia produkcji umiejscowionej wysoko w łańcuchu tworzenia wartości w kraju peryferyjnym niż w kraju 
pochodzenia inwestora $\mathrm{w}$ razie ograniczeń globalnego popytu na dany produkt. Kwestia tak zwanej narodowości kapitału, czy raczej ulegania właścicieli politycznym naciskom krajów ich pochodzenia, powróciła ze wzmożoną siłą w następstwie kryzysu 2008 roku. Efektem jest niekorzystna zmiana struktury gospodarki na mniej innowacyjną i zmniejszenie puli dobrze płatnych miejsc pracy oraz - w dłuższej perspektywie - likwidacja miejsca zdobywania przez pracowników wiedzy praktycznej, co odbija się niekorzystnie na społecznej zdolności budowy potencjału innowacyjnego.

Pytaniem o szerszym znaczeniu jest zasadność ograniczenia polityki modernizacyjnej do przemysłu. W rozwiniętej gospodarce około $3 / 4$ PKB wytwarzane jest poza przemysłem i rolnictwem. Zjawiskiem ostatnich dekad jest rosnące znaczenie innowacyjności w wielu dziedzinach szeroko pojętych usług. Istniejący od zarania historii główny problem gospodarczy - wytwarzanie rzeczy, a więc wykorzystanie „wiedzy nastawionej na rzecz” - gwałtownie traci na znaczeniu; do głosu dochodzi wykorzystanie „wiedzy nastawionej na drugiego człowieka”. Wiedza nastawiona na człowieka jest siłą rzeczy bardziej algorytmicznie niejednoznaczna niż wiedza nastawiona na (wytwarzanie) rzeczy i zależy od wielu niemierzalnych i kontekstualnych uwarunkowań „miękkich”, takich jak lokalna kultura.

W miarę wzrostu gospodarki wzrasta udział sektora publicznego jako obszaru budowania zamożności społecznej. Podczas gdy w gospodarkach z dochodem na głowę mieszkańca w przedziale \$2000-5000 sektor publiczny zagospodarowuje średnio jedną czwartą PKB, w gospodarkach z dochodem w przedziale \$5000-10000 - średnio jedną trzecią PKB, to w gospodarkach z dochodem ponad \$20000 - średnio połowę PKB. Boston Consulting Group wylicza 37 usług publicznych dostępnych online w różnych krajach. Usługi te dotyczą takich obszarów, jak: usługi komunalne, ochrona zdrowia, edukacja, podatki, rejestracja, świadczenia społeczne (Carrasco i Goss, 2014).

Stąd też w warunkach gospodarki postindustrialnej ograniczenie innowacji do innowacji ,produktowo-technologicznych” wymyślanych przez naukę i wprowadzanych przez przedsiębiorstwa jest nadmiernym zawężeniem pozostawiającym poza polem zainteresowania badawczego i polityki gospodarczej duże i stale rosnące obszary działań innowacyjnych. We współczesnym świecie rośnie rola innowacji niezbudowanych wokół produktu w tradycyjnym tego słowa znaczeniu i wymagających znacznych nakładów kapitałowych na badania, a następnie oprzyrządowanie i zatrudnienie niezbędnej siły roboczej.

Pojawienie się Internetu - samo w sobie będące jedną z najważniejszych innowacji ostatnich dziesięcioleci (i to nie stworzoną przez tandem naukowo-przemysłowy) - rozszerzyło obszary innowacyjności oraz zmieniło w sposób rewolucyjny zasady generowania innowacji. Pojawił się i szybko nabiera znaczenia nowy typ innowacji sieciowych, takich jak portale społecznościowe (np. Facebook, Linkedin, Twitter) czy specjalizowane platformy handlu i wymiany (Allegro, Expedia, Alibaba). Logika 
uzyskania przewagi konkurencyjnej jest tu inna niż w przypadku tradycyjnych innowacji produktowych. Polega ona nie na dostarczeniu nowych funkcji użytkowych, ale zawłaszczeniu (lock-in) pewnej sfery aktywności społecznej. Innowacje sieciowe nie konkurują też cenami, gdyż są dostępne dla użytkownika za darmo.

Rosnącego znaczenia nabierają innowacje ucieleśnione w produktach i usługach wirtualnych. Przykładem rosnącego znaczenia tego typu innowacji są nowe produkty finansowe wprowadzone na rynki kapitałowe w ostatnich dziesięcioleciach. Co ciekawe, wiele wskazuje, że mimo załamania rynku (a może właśnie dlatego), pęd innowacyjny na rynkach finansowych wcale nie osłabł, choć przechodzi dosyć radykalną korektę w stronę zagospodarowania za pomocą sieci społecznościowych tradycyjnych inicjatyw grupowych, takich jak kluby kredytowe, lokalne środki płatnicze (prywatnego pieniądza) czy rozdrobnione finansowania projektów (crowd financing).

Powyższe obserwacje uzasadniają, naszym zdaniem, pytanie o sens pojęcia „wyposażenia w zasoby” (endowment) w przypadku społeczeństwa aspirującego do dołączenia do grona krajów wysoko rozwiniętych, a więc budujących dobrobyt swoich obywateli w coraz mniejszym stopniu na większej konsumpcji dóbr, a w coraz większym stopniu na dostępności do wysokiej jakości ochrony zdrowia i edukacji, bezpieczeństwa socjalnego, dobrego środowiska naturalnego.

W tym kontekście wątpliwość budzi ograniczenie pojęcia „wyposażenia w zasoby” do neoklasycznego menu: praca, kapitał, zasoby naturalne. Nawet zasoby naturalne, pozornie najłatwiejsze do zidentyfikowania, w istocie takimi nie są. Przykładowo, zasób ropy naftowej to nie tyle sprawa ich geologicznej identyfikacji, ile ich dostępności po wydobyciu i użycia dla realizacji społecznej korzyści. Tak rozumiany zasób ropy naftowej zależy od czynników technologicznych, ale również od bezpieczeństwa regionu wydobycia, korupcji, polityki wobec obcego kapitału etc. Norwegia i Wenezuela to dwa kraje wyposażone w duże zasoby ropy, ale pierwszy jest jednym z najbogatszym krajów, podczas gdy w drugim trzeba stać godzinami w kolejkach po podstawowe produkty.

Dyskusja ekonomistów na temat wyposażenia kraju w zasoby stanowiące egzogeniczną podstawę rozwoju ma charakter rozszerzający w porównaniu z neoklasyczną triadą pracy, ziemi i kapitału.

I tak, Acemoglu i Robinson (2012) zróżnicowanie rozwoju łączą z instytucjami - systemem rządzenia i innych instytucji, takich jak istnienie centralnego rządu, stabilność społeczeństwa, korzystna struktura klasowa, możliwości edukacji technicznej (STEM), przepisy chroniące prawo własności, wspomagający system ekonomiczny, sprzyjające warunki makroekonomiczne, wspomagająca religia, wojna, a bardziej przygotowania do wojny.

Ferguson (2011), analizując historyczne przyczyny sukcesu cywilizacji zachodniej, identyfikuje sześć uwarunkowań sukcesu: (1) konkurencyjność rynków; (2) rozwój nauki ścisłych; (3) przestrzeganie prawa własności; (4) rozwój medycyny i powszechna opieka zdrowotna; (5) masowa konsumpcja; (6) etyka pracy. 
Hausmann (2013) wiąże natomiast bogactwo narodów z dwoma czynnikami: (a) migracją ludności z rolnictwa do miast oraz (b) mniejszą dzietnością rodzin, dzięki czemu rodzice mogą zapewnić lepsze wykształcenie swoim dzieciom, które z czasem stają się bardziej kreatywnymi pracownikami. Zwraca on jednak uwagę, że zmiany te nie przekładają się mechanicznie na sukces. Statystyki pokazują bowiem, że mimo iż niektóre kraje rozwijające się osiągnęły obecnie statystyki w zakresie urbanizacji i dzietności podobne do tych, które kraje rozwinięte miały w latach 60 ., to jednak ich PKB (w cenach stałych) nadal jest niższy od osiągniętego przez kraje rozwinięte $w$ tamtych latach. Hausmann tłumaczy to powolnym transferem i przyswajaniem wiedzy praktycznej, „ukrytej” w głowach pracowników.

Stoimy na stanowisku, że wyposażenie w zasoby niezbędne dla trwałej zdolności do innowacji, a przez to rozwoju społeczeństw postindustrialnych angażuje wszystkie obszary potencjału społecznego: (1) technologii - potencjału tworzenia lub adaptacji nowych rozwiązań jako funkcji nakładów na R\&D oraz edukację i umiejętności; (2) gospodarki - warunków makroekonomicznych, prywatnych i publicznych nakładów kapitałowych, zarządzania ryzykiem finansowania innowacji, dostępności materialnej infrastruktury; (3) instytucji i regulacji - skutecznego i sprawnie egzekwowanego systemu prawa; (4) kapitału kulturowego - wartości i wzorców zachowań zarówno pozytywnych, jak i negatywnych, np. zdolność współpracy, konstruktywnej konkurencja, korupcji, społecznego aktywizmu, otwartości, zaufania.

Właściwości kulturowe społeczeństwa, obrazujące się w kompetencjach oraz formalnych i nieformalnych instytucjach regulujących efektywność współdziałania zbiorowego stają się w postprzemysłowych społeczeństwach zasobem - „algorytmem” podejmowania decyzji o użyciu zasobów tradycyjnych i identyfikacji nadarzających się możliwości rozwoju gospodarczego. Staje się tak dlatego, że zarówno w produkcji przemysłowej, jak i w usługach rośnie udział działalności pracowników, która jest zdeterminowana nie rytmem maszyny, ale „grą między ludźmi” (Bell, 1974).

Debata pomiędzy kulturowym tradycjonalizmem a modernizacją rozwojową jest ważną osią ekonomii rozwoju. Neomarksizm traktuje trudności modernizacji w niżej rozwiniętych krajach, jak efekt zawłaszczenia przestrzeni gospodarczej świata przez dominujące kraje i opisuje współczesne procesy rozwojowe w kategoriach centrum i peryferii. Natomiast sukcesy tzw. azjatyckich tygrysów, obecnie naśladowane przez rozwój komunistycznych Chin, pokazują, że przynajmniej w Azji możliwy jest rozwój gospodarczy bez zmiany społecznej typu zachodniego. Dodatkowym elementem komplikującym tę dyskusję są procesy globalizacji, które w efekcie przepływów i mieszania idei, pracy i pieniędzy komplikują te zmiany, tworząc przeróżne enklawy rozwojowe rządzące się różnymi społecznymi logikami. Globalizacja przysparza unifikacji w pewnych obszarach, natomiast w innych wspomaga „przeskakiwanie” różnych form rozwojowych oraz podwyższa poziom niespójności w różnych społeczeństwach.

Najbardziej kompetentnym źródłem oceny kultury są badania World Value Survey (http://www.worldvaluessurvey.org/wvs.jsp). Przy konstruowaniu mapy kul- 
tur każdy kraj uczestniczący w badaniach WVS odniesiono do dwóch wymiarów: 1) wartości rozpiętych między tradycjonalność i racjonalność; 2) wartości rozpiętych między przetrwanie i ekspresję własnych potrzeb.

Na rysunku 2 przedstawiamy ostatnią dostępną mapę kultur sporządzoną przez na podstawie badań WVS.

\section{Rysunek 2. Mapa kultur}

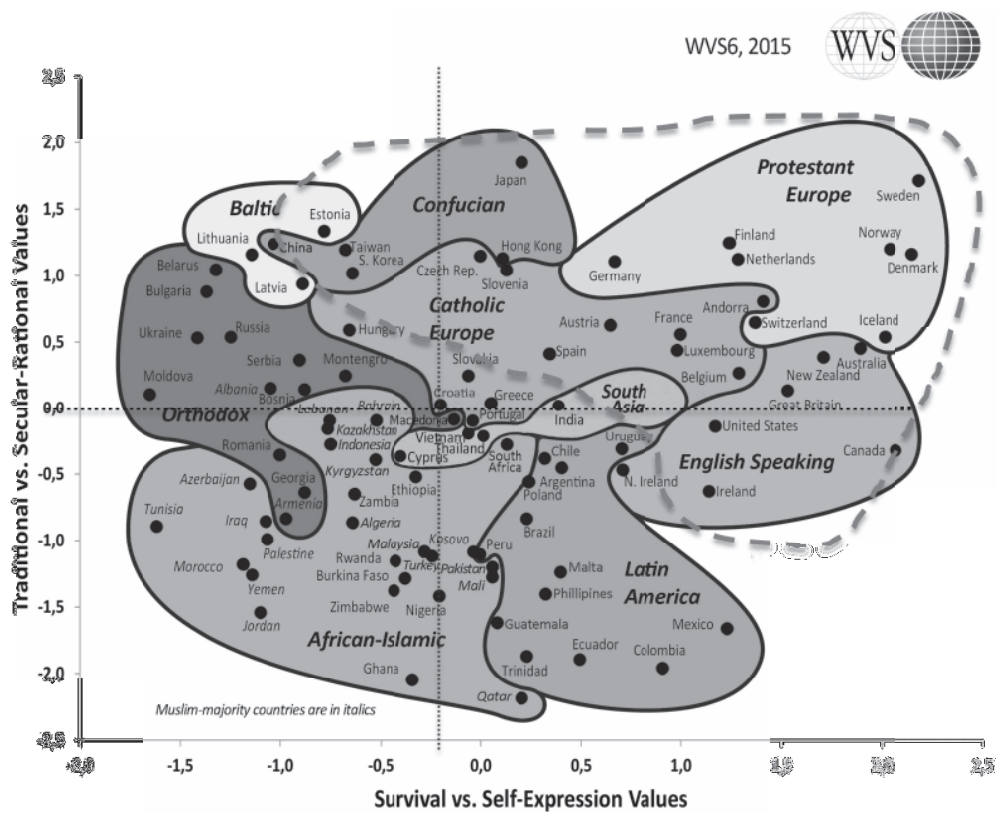

Linią przerywaną zaznaczono obszar skupiający kraje o wysokiej innowacyjności

Źródło: World Value Survey. Pozyskano z: http://www.worldvaluessurvey.org/WVSContents.jsp.

Dokładną lokację poszczególnych krajów na mapie należy traktować z ostrożnością, nazwy obszarów kulturowych to bowiem raczej identyfikatory niż naukowa klasyfikacja. Zarówno „stare”, jak i „nowe” kraje wysoko rozwinięte znajdują się w różnych miejscach mapy, jeśli chodzi o odejście od tradycjonalizmu, a także zdolności samoekspresji, mamy jednak wyraźne „ciążenie” krajów sukcesu w kierunku prawego górnego kwadrantu: kombinacji wartości racjonalnych i samoekspresji. Widoczne jest również „niedopasowanie” lokalizacji Polski do jej historycznego doświadczenia. $\mathrm{Z}$ jednej strony, mamy znaczną odległość od krajów katolickiej Europy, takich jak: Austria, Francja, Hiszpania, Węgry i Słowacja. Z drugiej zaś - mamy znaczną odległość od krajów pokomunistycznych, z którymi dzieliliśmy losy brutalnej próby zmian kultury. W efekcie, Polska kultura w wymiarach WVS jest „rozdarta” między nowoczesnością a tradycjonalizmem. 
Doświadczenie poszczególnych przypadków sukcesu, ale i porażki, pokazuje, że nie ma recepty kulturowej rozwoju, jest jednak ograniczenie kulturowe. Społeczeństwo, w którym jednostki czują się związane tradycjonalistycznymi wartościami, a jednocześnie skupione są na wartościach przetrwaniowych, przy braku lub bardzo małej legitymizacji dla samoekspresji, są też mało innowacyjne. Innowacja jest bowiem ekspresją inności i aby ją generować ludzie potrzebują czuć się swobodnie w uzewnętrznianiu swoich poglądów, nawet jeśli są one w mniejszości w społeczeństwie, czy konkretnej grupie w miejscu pracy, oraz gdy nawet ich błędność nie naraża autora na społeczną kpinę i ostracyzm.

\section{Kontekst globalny polityki modernizacyjnej}

Chociaż centralnym uzasadnieniem Nowej Ekonomii Strukturalnej jest zbudowanie przewagi konkurencyjnej kraju próbującego dogonić liderów, NES praktycznie nie uwzględnia sprzężenia zwrotnego - wpływu świata na możliwe krajowe wybory polityki gospodarczej - jej egzogeniczne ograniczenia. Stanowisko takie jest być może uzasadnione w przypadku dominującej pozycji (skali) gospodarczej Chin czy w przypadku krajów, którym udało się dogonić kraje najwyżej rozwinięte przed czasem globalizacji. Jednakże kraje podejmujące wysiłek dogonienia obecnie mają do czynienia z nowymi ograniczeniami wynikającymi z megatrendów globalnych, które wydają się dominować pierwszą połowę XXI wieku: zwiększonej skali migracji, nowej fazy konfliktu klasowego w wyniku powstania mobilnych elit kognitywnych, rosnącego populizmu w wyniku „nowego ludyzmu”, związanego z robotyzacją.

Migracja to wielka niewiadoma możliwości rozwojowych poszczególnych krajów. Do połowy XXI wieku, potencjał migracyjny może mieścić się w przedziale od 30 do nawet 100 milionów ludzi². Faktyczny poziom i kierunki imigracji będą zależały od czynników, takich jak: długotrwałe konflikty zbrojne, utrzymywanie się różnic materialnych między krajami, deficyt siły roboczej w określonych krajach. Nie rozstrzygając toczącego się sporu - na ile migracja jest czynnikiem budującym, a na ile osłabiającym konkurencyjność gospodarczą poszczególnych krajów - bez wątpienia będzie ona miała rosnące znaczenie dla polityki nie tylko gospodarczej, lecz także społecznej (Borjas, 2016).

Jednym z nieoczekiwanych zjawisk XXI wieku jest koniec „końca historii” i odrodzenie się konfliktów klasowych. Nie są to oczywiście konflikty zdefiniowane po marksistowsku wokół osi konfliktu pracy i kapitału o podział wytworzonej wartości, a konflikty o podział wartości pomiędzy klasą kognitywną a pracownikami

2 Ocenia się, że do połowy stulecia grupa osób w wieku 15-39 lat w krajach rozwijających się (a więc potencjalnie najbardziej podatnych na emigrację) wyniesie około $570 \mathrm{mln}$ osób (World Bank, 2009). 
odtwórczymi: obecnymi (pracjącymi), przeszłymi (emerytami), przyszłymi (młodzieżą), potencjalnymi (beneficjentami pomocy społecznej).

$\mathrm{Na}$ naszych oczach rynek pracy rozpada się na dwie grupy. Jedna, znacznie mniejsza, to elity kognitywne, ludzie tworzący innowacyjne technologie oraz pracownicy współpracujący z nowymi technologiami. Do grupy tej należy również zaliczyć twórców content, a więc twórców gier, autorów blogów, celebrytów, sportowców itp. Druga - to grupa znacznie liczniejsza, wykonująca proste prace niedające się zastąpić (jeszcze) technologią. W swej masie są to prace w zakresie prostych usług osobistych wykonywanych przez ludzi zatrudnionych przykładowo jako: kelnerzy, sprzątacze, obsługa szpitalna czy wreszcie służba domowa ludzi bogatych. Grupa ta to również pojawiający się fenomen biednych pracujących (working poor), czyli ludzi niezdolnych utrzymać się z zarobków z pracy i wymagających pomocy społecznej ze strony państwa. Poza rynkiem pracy znajdą się osoby niemające talentu i kwalifikacji, aby znaleźć się w pierwszej grupie oraz niemające motywacji, aby znaleźć sobie miejsce w drugiej grupie. Osoby te będą wymagały wsparcia państwowego. Granice między grupą biednych pracujących a grupą osób na utrzymaniu państwowym są płynne, w zależności od relacji między zarobkami z pracy i zasiłków. Ruchliwość społeczna między tymi dwoma grupami z jednej strony a kognitywną elitą z drugiej - staje się coraz mniejsza.

Coraz szerszej skali nabiera dyskusja o konsekwencjach zmian technologicznych, szczególnie wpływu robotyzacji i sztucznej inteligencji na rynek pracy. Według rosnącej grupy badaczy, ale i praktyków biznesu, nowe technologie mają spowodować strukturalny spadek popytu na pracę, w wyniku czego ma nastąpić „koniec pracy" (Rotman, 2013).

Inaczej niż przy poprzednich rewolucjach technologicznych, pracownicy wypierani przez technologie „nie mają dokąd iść”. Usługi, tradycyjny obszar nowego zatrudnienia, osiągnęły poziom nasycenia, a popyt na prace kognitywne jest ograniczony i wymaga specjalnych uzdolnień i wykształcenia.

Trendy te rodzą poważne zagrożenie populizmem: albo populizmem „kupującym" spokój mas przez dysponentów zasobów, albo populizmem buntu mas przeciwko elitom. Oba przypadki, mimo przeciwstawnej genezy, są szkodliwe dla gospodarki. Liberalna demokracja jest słabo przygotowana do rozwiązywania tego typu konfliktów - elity kontrolują zasoby, jednakże reszta społeczeństwa ma głosy wyborcze ${ }^{3}$.

3 Dystopijna powieść Kurta Vonneguta pt. Pianola (zob. Vonnengut, 1952) staje się nie mniej prawdopodobna niż optymistyczna keynesowska utopia 15-godzinnego tygodnia pracy (zob. Keynes, 1930). 


\section{Rola państwa w realizacji polityki gospodarczej, mającej na celu wzrost konkurencyjności}

Rola państwa w tworzeniu warunków i stymulowaniu rozwoju była zmienna - od okresu wzmożonego aktywizmu gospodarczego państwa dobrobytu w dekadach po II wojnie światowej (z państwowym planowaniem i nacjonalizacją strategicznych sektorów włącznie), przez wycofanie państwa z gospodarki, poczynając od okresu thatcheryzmu lat 80 . XX wieku z jego deregulacją i prywatyzacją, do ponownego zwrócenia się w stronę państwa jako podmiotu aktywnego, poczynając od końca pierwszej dekady XXI wieku.

Akceptacja bardziej aktywnej polityki gospodarczej przez główny nurt ekonomii, ale również MWF i Bank Światowy, ma swoje bezpośrednie przyczyny w załamaniu 2008 roku i jego następstwach na rynkach. Jednak na bardziej fundamentalnym poziomie zwiększenie aktywizmu państwa związane jest z sekularnymi zmianami w społeczeństwach postindustrialnych: wzrostem dochodów wąskich grup pracowników kreatywnych przy stagnacji, a nawet realnym spadku dochodów klasy średniej; strukturalnym bezrobociem, szczególnie wśród ludzi młodych; wycofywaniem się znaczących grup z rynku pracy; wyczerpaniem się efektu edukacyjnego; pogarszaniem się sytuacji demograficznej w wyniku starzenia społeczeństw.

Aktywna polityka państwa wynika też z faktu, że w szybko zmieniającej się architekturze gospodarki globalnej, zdolność budowania i utrzymywania przewagi konkurencyjnej na rynkach międzynarodowych w coraz większym stopniu jest określana przez potencjał innowacyjny danego społeczeństwa jako całości, a nie poszczególnych przedsiębiorstw.

Przytłaczająca większość krajów ma ambicje istotnego zwiększenia roli innowacji jako czynnika wzrostu konkurencyjności swojej gospodarki i w efekcie poprawy dobrobytu swoich obywateli. Ambicje te znajdują swój wyraz w przyjętych programach i instytucjach. Niestety, frustrująco mała ilość podejmowanych prób zbudowania silnego i trwałego społecznego potencjału innowacyjnego kończy się sukcesem. Dzieje się tak niejednokrotnie mimo zaangażowania znacznych środków publicznych, motywacji finansowych i przyjęcia przyjaznych regulacji.

Nowa Ekonomia Strukturalna idzie jednak dalej niż uznanie, że państwo ma do odegrania istotną rolę w stymulowaniu rozwoju. NES przypisuje państwu rolę „budowniczego” harmonijnego społeczeństwa (konfucjańskie hexie shehui); zapełnienia żołądków ludu przez mądrego władcę, odwołując się do mądrości Laozi ${ }^{4}$.

Ten mandat, ale i odpowiedzialność państwa za „rozumne rządzenie” ma swój symetryczny odpowiednik w wyznawaniu tzw. wartości azjatyckich ze strony poddanych: stawianie ładu społecznego przed wolnością indywidualną, uznanie autorytetu państwowego kierownictwa, lojalność wobec osób wyżej postawionych w hierarchii

4 „Dlatego, gdy rządzi mądry człowiek, serca i umysły są puste, a żołądki pełne”. Zob. Laozi, 2015. 
rodzinnej i społecznej (Sławiński, 2013). Trudno jest powiedzieć na ile taka zgodność między rządzącymi a rządzonymi ma nawet przybliżone odbicie w rzeczywistości w krajach tak politycznie i historycznie różnych, jak: Japonia, Taiwan, Singapur, Korea czy Chiny. Jeszcze trudniejsze i wychodzące poza ramy naszego artykułu byłoby wyrażenie opinii na temat źródeł takich postaw (por. Sławiński, 2013).

Bez pogłębionej analizy można jednak stwierdzić, że nie bez powodu w wąskiej grupie krajów, którym udało się doścignąć kraje wysoko rozwinięte mamy znaczną nadreprezentację krajów Dalekiego Wschodu. Jest to pośredni dowód, że niezwykły sukces rozwojowy tzw. tygrysów azjatyckich, a i w dużym stopniu Chin, wynika właśnie z takiej podstawy ustrojowej (the proof of the pudding is in the eating). Można więc powiedzieć, że państwa Dalekiego Wschodu są wyposażone w zasób rozwojowy, jakim jest państwo mające długoterminowe przyzwolenie i wsparcie rządzonych dla realizacji „recepty typu NES”, niezależnie od systemu politycznego sprawowania władzy.

W odróżnieniu od kultury Dalekiego Wschodu, Europa Zachodnia i Centralna (a później jej klony) poszła inną drogą w rozwiązywaniu konfliktu rozwojowego. Na Zachodzie konflikt fizyczny został z czasem zastąpiony konfliktem symbolicznym, gdzie przedstawiciele różnorodnych interesów przez swoich reprezentantów politycznych toczą walkę, na ogół bezkrwawą, ale jednak walkę o realizację interesów grupowych ${ }^{5}$.

Polityczną ramifikacją symbolicznego konfliktu była i jest demokracja, historycznie poszerzająca swoją podstawę wyborczą, a więc zwiększająca ilość interesów grupowych koniecznych do uwzględnienia.

Przejście od bezpośredniego fizycznego do reprezentacyjnego symbolicznego mechanizmu rozstrzygania konfliktów zwiększa rolę elit, rozumianych jako formalne i nieformalne grupy mające wpływ na kształt podejmowanych decyzji o ogólnospołecznych długofalowych konsekwencjach ${ }^{6}$.

Zachowanie elit zależy nie od stopnia ich „oświecenia” i dobrej woli, lecz od istnienia lub nie warunków określonych przez Acemoglu i Robinsona (2006) jako „efekt politycznego zastąpienia elit”. Najsilniejsze blokowanie zmian ma miejsce w systemach politycznych, gdzie wymiana elit u władzy ma charakter niszczący. Natężenie blokowania zmian zależy również od korzyści (rent) sprawowania władzy

5 Jednym z wytłumaczeń jest specyfika uprawy ryżu wymagająca działania zbiorowego (utrzymanie systemu irygacji), co jest możliwe jedynie przy silnej władzy centralnej, w odróżnieniu od uprawy zboża niewymagającej centralnej dyscypliny.

6 Pojęcie „elit” traktujemy czysto funkcjonalnie: do elit przynależą osoby mające istotny wpływ na funkcjonowanie społeczeństwa. Jest to zbiór o granicach rozmytych zarówno odnośnie do klasyfikującej do elit, stopnia wpływu na społeczeństwo, jak i przynależności zawodowej. Jest to grupa dynamiczna, nie tylko jeśli chodzi o przynależność poszczególnych osób oraz kanałów wpływu. Rosnąca złożoność społeczeństw i gospodarek, rosnąca współzależność globalna oraz rosnąca „wirtualizacja” produktu powodują zwiększenie liczebności elit oraz ich rozszerzenie o nowe segmenty (na przykład grupy kognitywne czy celebryci). 
(wyższe renty większe blokowanie) oraz zagrożenia zewnętrznego (wyższe zagrożenie mniejsze blokowanie).

Działanie mechanizmu uporządkowanego zastępowania elit zwiększa szanse powodzenia strategii, ponieważ wymieniające się elity nie obawiają się kontynuować wysiłków poprzednich elit, mając świadomość powtarzalności cyklu politycznego i regularnej wymiany rządzących i opozycji. Praktycznym elementem takiej strategicznej stabilizacji jest ciągłość kadry urzędniczej zdolnej przekazać praktyczny know-how nowym decydentom politycznym. W dojrzałych demokracjach mechanizmem takim jest istnienie politycznie niezaangażowanej służby cywilnej.

Jakkolwiek system polityczny wielu krajów ma „twarz” demokracji, z punktu widzenia „głębokich” mechanizmów i struktur sprzyjających rozwojowi, system społeczny musi posiadać cechy, które D.C. North, J.J. Wallis i B.R. Weingast (2009) określają jako społeczeństwo „otwartego porządku dostępu” (open access order society). U swych podstaw społeczeństwo takie cechuje „podwójna demokracja” niedyskryminacyjny dostęp wszystkich obywateli do działania w sferze gospodarczej i aktywności w sferze politycznej.

Przewaga społeczeństw z porządkiem otwartego dostępu realizuje się przez umiejętność reagowania dostosowawczego na pojawiające się naturalną koleją rzeczy zmiany zewnętrzne i wewnętrzne w warunkach funkcjonowania społeczeństw. Społeczeństwa te są sprawniejsze i bardziej efektywne nie tylko w reagowaniu na wyzwania za pomocą działań innowacyjnych, lecz także niejednokrotnie potrafią zmienić zagrożenia w źródła sukcesu. Rezultaty te są możliwe dzięki:

- eksperymentowaniu z różnorodnymi rozwiązaniami zaistniałych problemów i wybór rozwiązań najlepszych dla danej sytuacji i dostępności zasobów;

- zróżnicowanym i niezależnym sprzężeniom zwrotnym pozwalającym ocenić rezultaty podejmowanych działań i wprowadzić niezbędne korekty;

- konstruktywnym rozwiązywaniem konfliktów, często na zasadzie kompromisu i współpracy, a nie niszczeniu (realnie lub symbolicznie) oponenta traktowanego jako przeciwnik.

W wymiarze politycznym oznacza to możliwość kontestowania rządzącej ekipy przez opozycję, ale również historyczne doświadczenie przemienności pomiędzy rządem i opozycją - a więc trwały podział elity danego społeczeństwa na kilka (często dwie) „elity częściowe” konstruktywnie konkurujące, za pomocą programów, o głosy wyborców i naprzemiennie sprawujące funkcje rządu i opozycji. Demokracja ekonomiczna to równoprawna swoboda wejścia i wyjścia do poszczególnych typów aktywności gospodarczej dla wszystkich podmiotów niezależnie od ich sympatii politycznych.

Spełnianie warunków społeczeństwa otwartego dostępu to nie tyle sprawa deklaracji i legislacji (zapisania na papierze), ile praktyki wdrażania ich w życie w sposób sprawny i efektywny.

Polska w okresie transformacji uczyniła istotne postępy w dołączeniu do elitarnego klubu społeczeństw otwartego porządku jednakże technokratyczny kierunek 
dalszego postępu w stronę społeczeństwa otwartego porządku („,iepła woda w kranie”) okazał się niewystarczający, szczególnie, że i ta ograniczona agenda była realizowana niesprawnie. Zostaje wiele do zrobienia w zakresie usprawnienia systemu funkcjonowania społeczeństwa, np. systemu sądowniczego czy zamówień publicznych. Ostatnie lata pokazały ponadto, że istnieje znaczący segment społeczeństwa, który czuje się wykluczony z korzyści transformacji, a jednocześnie dopiero uczący się demokratycznych standardów publicznego „zabierania głosu” w artykułowaniu swoich interesów.

\section{Konkluzje. Znaczenie Nowej Ekonomii Strukturalnej dla Strategii na Rzecz Odpowiedzialnego Rozwoju}

Nowa Ekonomia Strukturalna zawiera istotnie cenne pomysły warte wykorzystania dla realizacji Strategii na Rzecz Odpowiedzialnego Rozwoju (Ministerstwo Rozwoju, 2017); zawiera jednak również pułapki.

Podstawowa wskazówka NES warta zastosowania to wybór kraju-wzorca, aspiracyjnego punktu odniesienia proponowanych działań modernizacyjnych Polski. Jest to o tyle ważne, że jak pisaliśmy i co podkreśla Y.F. Lin, częstym błędem jest nadmiar źle ukierunkowanej ambicji realizacji niespójnego zestawu celów rozwojowych (Christmas tree). W przypadku Polski takim naturalnym wzorcem rozwojowym mogą być Niemcy. Przemawiają za tym czynniki ekonomiczne: odległość w PKB per capita (PKBPPP per capita Polski to 49\% PKBPPP per capita Niemiec), ale także relacje produktywności (46\% PKBPPP na godzinę pracy). W obu przypadkach różnice są dostatecznie istotne, ale nie przesadnie duże, jeśli patrzeć na nie jako stan docelowy w perspektywie kilkunastu lat. Istotne są też znaczące powiązania gospodarcze, polski eksport w 25\% skierowany jest do Niemiec. Znaczenie ma również długa tradycji wymiany ludzi i rozwiązań instytucjonalnych, choć nie można lekceważyć istotnych różnic kulturowych, których pokonanie powinno być założone jako część procesu doganiania.

Rekomendacją NES o istotnym znaczeniu jest, że „rząd musi wiedzieć, które z nowych branż są zgodne z ukrytymi przewagami komparatywnymi kraju” (Lin, 2012, s. 17). Oznacza to inwestycję w całą konstelację ośrodków analitycznych, tak publicznych, jak i prywatnych, niezbędnych do implementacji programu, jego bieżącej modyfikacji oraz niezależnej oceny rezultatów. Jak pokazuje praktyka, jest to inwestycja o wysokiej stopie zwrotu.

Ważnym elementem NES jest wprowadzenie klasyfikacji branż gospodarki w zależności od dystansu, jaki dzieli je od globalnej rubieży technologicznej (technological frontier): 1) branże doganiające, które cechują się niższym poziomem technologii i wartości dodanej niż podobne branże w krajach o wyższych dochodach; 2) branże przodujące, które konkurują globalnie z przodującą technologią; 
3) branże tracące przewagę komparatywną, z których kraj wkrótce zrezygnuje z powodu przemian w zakresie struktury puli zasobów i przewag komparatywnych; 4) branże, które cechują się krótkimi cyklami innowacji i umożliwiają bezpośrednie konkurowanie z krajami o wyższych dochodach; oraz 5) branże strategiczne, które nie dają przewagi komparatywnej, ale rozwijane są ze względu na znaczenie dla bezpieczeństwa narodowego. Klasyfikacja taka pozwala na efektywną alokację środków państwowych za pomocą instrumentów uwzględniających specyfikę poszczególnych przedsiębiorstw czy branż.

Generalną zaletą NES jest pragmatyzm podejścia. Podbudowa teoretyczna (mieszcząca się w głównym nurcie neoklasycznym) nie jest ćwiczeniem intelektualnym, ale prowadzi w efekcie do bardzo praktycznych zaleceń, co do instrumentarium państwowej polityki gospodarczej i pozwala na sformułowanie praktycznych zaleceń dotyczących konkretnych sektorów czy nawet przedsiębiorstw.

$\mathrm{Z}$ punktu widzenia potrzeb Polski NES jest jednak obarczona ryzykiem potencjalnej pułapki, jeśli chodzi o sposób, w jaki państwo (rząd) zamierza realizować politykę modernizacji. Jak pisaliśmy, NES zakłada implicite niepolityczny charakter państwa - państwo ma trwały mandat i administracyjną możliwość realizacji swojej strategii, bez potrzeby uwzględniania głosów kontestujących jego cele i metody. Taka opcja jest atrakcyjna z czysto pragmatycznego punktu widzenia szybkości wprowadzania zmian, ale nie odpowiada polskim realiom.

Ze zjawiskiem niepolityczności rządu mieliśmy w Polsce do czynienia na początku procesu transformacji, gdy istniała powszechna zgoda co do kierunku pożądanych działań modernizacyjnych - stworzenia gospodarki rynkowej jak na Zachodzie. Modernizacja transformacyjna była spójna mimo zmian rządów w całym spektrum politycznym. Czas ten minął bezpowrotnie.

W politycznej kulturze demokratycznego sporu próby pójścia „na skróty” są jednak zagrożeniem dla realizacji długofalowych programów modernizacyjnych. Program, który nie jest szeroko akceptowany, chociażby w głównych zamiarach, jest narażony na ryzyko odrzucenia w momencie zmiany władzy politycznej. Wynika to z faktu, iż program modernizacji niejednokrotnie konkuruje o środki państwowe z potrzebami innych obszarów gospodarki i świadczeń społecznych. Wyrażanie tych preferencji, często w sposób gwałtowny, to normalna praktyka demokracji, która jednak nie mieści się w logice NES.

W Polsce pokusa lekceważenia polityczności wyborów polityki gospodarczej jest o tyle większa, że oprócz tradycyjnej domeny regulacji i ustawodawstwa, państwo dysponuje istotnym zasobem własności gospodarczej w postaci spółek Skarbu Państwa. Kombinacja regulacyjno-własnościowa wyposaża państwo w siłę sprawczą, wychodząca poza typowy zakres instrumentarium państwowej ingerencji w rozwiniętych gospodarkach. Ta siła sprawcza może okazać się jednak kontrproduktywna w długim okresie przez jej podporządkowanie interesom politycznym. Z tych powodów wyzwaniem dla strategii jest samoograniczanie naturalnej tendencji do wykorzystania siły państwa w narzucaniu rozwiązań, bez uzyskania akceptacji (a przynaj- 
mniej zrozumienia) adresatów programu, ale też opinii publicznej i jej politycznych reprezentantów.

Problem ten nie jest obcy dojrzałym demokracjom społeczeństw rozwiniętych, gdzie odpowiedzi szuka się w dwóch obszarach: merytoryczności i zewnętrznej kontroli. Merytoryczność to przede wszystkim stworzenie stabilnej służby publicznej. W polskiej sytuacji merytoryczność to również merytoryczny dobór zarządzających spółkami Skarbu Państwa. W obu obszarach państwo polskie nie potrafiło, jak dotychczas, stworzyć satysfakcjonujących rozwiązań. Zewnętrzna niezależna kontrola zaś - to istnienie niezależnych ośrodków merytorycznej kontroli realizacji strategii, która siłą rzeczy będzie ulegała dostosowaniom wynikającym ze zdobywania doświadczenia sukcesów i porażek, ale również zmieniających się uwarunkowań zewnętrznych.

\section{Bibliografia}

Acemoglu, D. i Robinson, J. (2012). Why Nations Fail: The Origins of Power, Prosperity, and Poverty. New York: Crown.

Acemoglu, D. i Robinson, J. (2006). Economic Backwardness in Political Perspective. American Political Science Review, 100(1), February.

Bell, D. (1974). The Coming of Post-Industrial Society: A Venture in Social Forecasting. New York: Heinemann Educational Publishers.

Borjas, G. (2016). We wanted workers: Unraveling the Immigration Narrative. New York: Norton.

Carrasco, M. i Goss, P. (2014). Digital Government: Turning the Rhetoric into Reality. bcg. perspectives. Pozyskano z: https://www.bcgperspectives.com/content/articles/public_sector_ center_consumer_customer_insight_digital_government_turning_rhetoric_into_reality/.

Ferguson, N. (2011). Civilization The West and the Rest. USA: Penguin Books.

Hausmann, R., Hidalgo, C.A., Bustos, S., Coscia, M., Simoes, A. i Yildirim, M.A. (2013). The Atlas of Economic Complexity: Mapping Paths to Prosperity. MA: Centre for International Development, Harvard University.

Hausmann, R. (2013). The Tacit-Knowledge Economy. Project Syndicate, 30 October. Pozyskano z: https://www.project-syndicate.org/commentary/ricardo-hausmann-on-the-mentalsources-of-productivity-growth?barrier=accessreg.

Keynes, J.M. (1930). Economic Possibilities for our Grandchildren II. The Nation and Athenaeum, 48(3), 18 October.

Laozi. (2015). Księga Dao I De (tłum. A.I. Wójcik). Kraków: Wydawnictwo Uniwersytetu Jagiellońskiego.

Lin J.Y. (2012). New Structural Economics: A Framework for Rethinking Development and Policy. Washington, DC: World Bank Publications. Pozyskano z: https://openknowledge. worldbank.org/handle/10986/19919 License: CC BY 3.0 IGO.

Ministerstwo Rozwoju. (2017). Strategia na Rzecz Odpowiedzialnego Rozwoju. Pozyskano z: https://www.mr.gov.pl/. 
North, D.C., Wallis J.J. i Weingast, B.R. (2009). Violence and Social Orders: A Conceptual Framework for Interpreting Recorded Human History. New York: Cambridge University Press.

Pierce, A. (2008). The Queen asks why no one saw the credit crunch coming. The Telegraph, 5 November. Pozyskano z: http://www.telegraph.co.uk/news/uknews/theroyalfamily/3386353/ The-Queen-asks-why-no-one-saw-the-credit-crunch-coming.html05 Nov

Rotman, D. (2013). How Technology Is Destroying Jobs. MIT Technology Review, June 12.

Sławiński, R. (2013). Społeczna funkcja „współczesnego nowego konfucjanizmu”. W: R. Sławiński (red.), Konfucjanizm i jego wspótczesne interpretacje. Warszawa: Wydawnictwo Naukowe Askon.

GII. (2016). The Global Innovation Index 2016. Winning with Global Innovation. Pozyskano z: https://www.globalinnovationindex.org/.

Vonnegut, K. (1952). Piano Player [Pianola]. USA: Charles Scribner's Sons.

World Bank. (2009). Shaping the future: a long-term perspective of people and job mobility in the Middle East and North Africa. Washington, DC: World Bank. Pozyskano z: http://documents.worldbank.org/curated/en/921151468276857302/Shaping-the-future-along-term-perspective-of-people-and-job-mobility-in-the-Middle-East-and-North-Africa

World Value Survey. Pozyskano z: http://www.worldvaluessurvey.org/wvs.jsp. 


\title{
Makroekonomiczne uwarunkowania Nowej Ekonomii Strukturalnej - przypadek Polski
}

\begin{abstract}
Prezentowany artykuł składa się z dwóch części. W pierwszej - podjęto próbę usytuowania koncepcji Nowej Ekonomii Strukturalnej (NES) w ramach tradycyjnej polityki makroekonomicznej państwa, czyli polityki fiskalnej i monetarnej. Głównym problemem w tym przypadku okazują się ograniczenia w ekspansywności polityki fiskalnej i monetarnej z punktu widzenia ich negatywnych skutków inflacyjnych oraz możliwość finansowania przez państwo ze środków pozabudżetowych prorozwojowych inicjatyw.

W części drugiej, za pomocą opisu rozwoju gospodarki polskiej w latach 1990-2016, starano się odpowiedzieć na pytanie: w jakim stopniu i zakresie w owym rozwoju była wykorzystana (świadomie bądź nieświadomie) koncepcja NES? Wynikająca z tej koncepcji polityka przemysłowa mogła być bowiem realizowana dzięki wsparciu finansowemu Unii Europejskiej (UE), wykorzystaniu idei specjalnych stref ekonomicznych (SSE) oraz kapitałowych funduszy publicznych typu venture capital (KFP).
\end{abstract}

Słowa kluczowe: Nowa Ekonomia Strukturalna (NES), strukturalna polityka gospodarcza (SPG), polityka monetarna, polityka fiskalna, Unia Europejska (UE), specjalne strefy ekonomiczne (SSE), kapitałowe fundusze publiczne venture capital (KFP).

Profesor Justin Yifu Lin, twórca teorii Nowej Ekonomii Strukturalnej (NES), w swoim wykładzie pt. New Structural Economics and Industrial Policy for Catching up Country ${ }^{1}$ nadmienia, że składa się ona z trzech wątków:

1) kardynalnego problemu koegzystencji państwa i rynków w rozwoju gospodarek krajowych;

2) branżowych kierunków strukturalnych interwencji państwa z uwzględnieniem oryginalnej klasyfikacji branż (5 grup) opartej na ich roli w procesie doganiania krajów rozwiniętych;

3) metod interwencji państwa w poszczególnych grupach branż na poszczególnych etapach procesu doganiania.

Pierwszy z nich pojawia się przede wszystkim jako przeciwstawienie NES dominującemu w okresie powojennym (szczególnie w latach 60. i 70. XX wieku) ,struk-

$1 \quad$ Wykład został wygłoszony 30 stycznia 2017 r. na Wydziale Zarządzania Uniwersytetu Warszawskiego przy ul. Szturmowej 1/3 w Warszawie. 
turalizmowi” oraz, hołubionej w dwóch ostatnich dekadach, ideologii „neoliberalizmu". Wpływ państwa na rozwój gospodarczy realizuje się jednak przez jego oddziaływanie nie tylko na rozwój poszczególnych branż gospodarczych (np. antyimportowych i proeksportowych), lecz także, a może przede wszystkim, na ogólną koniunkturę i równowagę gospodarki w ramach makroekonomicznej polityki państwa realizowanej na poziomie polityki monetarnej banku centralnego i polityki fiskalnej rządu.

Obie wspomniane doktryny ekonomiczne nie przetrwały i zostały negatywnie politycznie ocenione nie dlatego, że zabrakło odpowiednich efektów w rozwoju gospodarki, ale ze względu na wywołane kryzysy nierównowagi makroekonomicznej: fali inflacji na przełomie lat 70. i 80. XX wieku oraz globalny kryzys finansowy w okresie 2008-2009. Obecnie ważne jest natomiast, by w ramach NES, wbrew doktrynie neoliberalnej, z jednej strony państwo prowadziło aktywną politykę gospodarczą, a jednocześnie by nie psuło i nie zastępowało rynków, z drugiej zaś - żeby jego interwencje nie spowodowały podobnych efektów, jak nadmierne wydatki budżetowe w ramach ekspansywnej polityki fiskalnej w okresie powojennym.

Ważne jest również to, że cele gospodarcze nie są jedynymi celami polityki państwa, a mogą być wręcz podporządkowane innym celom społecznym. Widać to szczególnie w przebiegu kampanii wyborczych ostatnich lat, gdzie problemy gospodarcze w programach partii politycznych schodzą na dalszy plan, na czoło wysuwają się zaś: nacjonalizm versus uniwersalizm, stosunek do imigrantów i emigrantów, ochrona zdrowia, stosunek do religii i ocena wydarzeń historycznych. Kryteria te, niekiedy bardzo emocjonalne, powodują niespotykaną dotychczas polaryzację poglądów polityków i ich wyborców. Wybrane w wyniku wyborów władze stają się zakładnikami swoich elektoratów, co może pozostawać w sprzeczności z realizacją słusznych i pożądanych celów gospodarczych Wydaje się np., że aktualnie nadrzędnym, a nawet dominującym kryterium wyboru partii rządzących w Europie jest ich stosunek do Unii Europejskiej: sceptyczny bądź entuzjastyczny.

Zgodnie z koncepcją NES, prorozwojowy wpływ państwa na gospodarkę ma być realizowany w ramach jego polityki przemysłowej. Wolę jednak stosować termin „strukturalna polityka gospodarcza” (SPG). Politykę tę bowiem określa nie tyle jej zakres i obszar oddziaływania, ile sposób podejścia. Przewidziane w niej instrumenty są skierowane zarówno do wąsko rozumianego przemysłu, jak i do innych dziedzin gospodarczych, takich jak: usługi, budownictwo i rolnictwo ${ }^{2}$.

Kierunki i metody interwencji państwa w ramach NES wynikają przede wszystkim z neoklasycznego rodowodu tej koncepcji. „....struktura przemysłowa ma charakter endogeniczny względem struktury jej wyposażenia w zasoby kapitału, pracy i zasoby naturalne. Strukturalna polityka gospodarcza musi ułatwiać przedsiębiorstwom wchodzenie do branż cechujących się ukrytą przewagą komparatywną na konkurencyjnym rynku” (Lin, 2017, s. 199-200). Wynika z tego, że interwencje pań-

2 Być może jest jednak tylko problem lingwistyczny w języku polskim. 
stwa w tym przypadku nie mogą polegać na manipulowaniu podatkami, dotacjami, cenami, cłami i akcyzami, co było typowe dla interwencjonizmu państwa w dobie „strukturalizmu”. Działania takie wypaczają bowiem sygnały rynku i w tych warunkach nie można w sposób właściwy ocenić konkurencyjności branż i ich przewag komparatywnych. Interwencje państwa powinny polegać jednak na sterowanym zwiększaniu dostępności: zasobów kapitału rzeczowego, finansowego i ludzkiego dla przedsiębiorców w branżach z ukrytymi przewagami komparatywnymi.

W innym miejscu wykładu J.Y. Lin daje istotną wskazówkę dla działań interwencyjnych państwa. „Przez ukrytą przewagę komparatywną rozumiem tu branżę cechującą się niskimi kosztami środków produkcji w stosunku do reszty świata. Kwestię tę determinują wyposażenia danej gospodarki w zasoby oraz koszty transakcji, które - z powodu niedowładu twardej i miękkiej infrastruktury - są zbyt wysokie, by być konkurencyjne na rynkach krajowych i międzynarodowych. Firmy staną się wydajne, a całe sektory konkurencyjne, gdy rząd pomoże firmom obniżyć koszty transakcji poprzez pokonanie problemów koordynacji i zewnętrzności w zakresie poprawy stanu twardej i miękkiej infrastruktury" (Lin, 2017, s. 208-209). Taka deklaracja zmienia priorytety wydatków budżetowych oraz sposoby transferu publicznych środków finansowych do gospodarki.

Budżet państwa w tradycyjnej ekonomii spełnia przede wszystkim funkcje redystrybucyjne, przekazując środki od bogatszych do biedniejszych (wydatki socjalne) oraz ogólnospołeczne (wydatki na obronę, bezpieczeństwo wewnętrzne, ochronę zdrowia itp.). Prorozwojowy budżet w koncepcji NES to przede wszystkim wydatki państwa na rozwój twardej i miękkiej infrastruktury, zmniejszającej koszty transakcyjne gospodarki. Podnosi to wzrost preferencji dla wydatków inwestycyjnych budżetu na ułatwiającą dostępność kapitału rzeczowego twardą infrastrukturę komunikacyjną (drogi, porty, lotniska); informatyczną (np. sieć światłowodowa, dostęp do szybkiego Internetu); energetyczną (elektrownie, sieci przesyłowe) oraz na, poprawiającą jakość kapitału ludzkiego, infrastrukturę miękką w postaci wydatków na naukę, szkolnictwo, badania i rozwój. Wydaje się, że z perspektywy NES do wydatków budżetu na infrastrukturę miękką zaliczyć można również wydatki na ochronę zdrowia, które niewątpliwie powiększają jakość kapitału ludzkiego oraz wydatki na obronę narodową, które mogą skutkować transferem nowoczesnych technologii z tego sektora do całej gospodarki oraz wydatki na bezpieczeństwo wewnętrzne, które wzmacniają niezbędne w działalności gospodarczej poczucie bezpieczeństwa.

W palecie wydatków państwa szczególną jednak rolę, zgodnie z koncepcją NES, odgrywają wydatki inwestycyjne. Wywołują one bowiem nie tylko, zgodny z mnożnikiem Keynesa, zwielokrotniony wpływ na popyt globalny, lecz także powodują efekty zewnętrzne w postaci poprawy jakości życia wszystkich obywateli i zmniejszenie kosztów transakcyjnych przedsiębiorstw.

Zakres i kierunki finansowania gospodarki ze środków budżetowych muszą być jednak dostosowane do globalnych, a w przypadku krajów europejskich - unijnych, norm makroekonomicznej polityki fiskalnej. Na poziomie ograniczeń globalnych 
mam tu na myśli głównie politykę klimatyczną i związane z nią ograniczenia emisji $\mathrm{CO}_{2}$. Dostosowując się do niej, państwo nie powinno wspierać tych branż, które, mając nawet krótkookresowe przewagi komparatywne, emitują tę substancję. Powinno ono natomiast wspierać technologie zmniejszające i eliminujące emisję $\mathrm{CO}_{2}$. Zdarzają się jednak przypadki, że państwa podważają negatywne klimatyczne skutki tej emisji, przez co krótkotrwale podnoszą konkurencyjność wspomnianych branż.

Europejskie normy polityki fiskalnej na poziomie państw narodowych związane są przede wszystkim z:

- normą maksymalnego deficytu budżetu państwa (3\% PKB) i związaną z nią procedurą nadmiernego deficytu;

- koniecznością uzyskiwania zgody Komisji Europejskiej na indywidualne udzielenie pomocy finansowej ze środków publicznych przedsiębiorstwom państwowym i prywatnym;

- zasadami europejskiej polityki wzmacniania konkurencyjności i przeciwdziałania monopolizacji gospodarki.

Budżetowy transfer kapitału finansowego do gospodarki nie realizuje celów NES w sposób dostateczny i optymalny. Wydaje się, że znacznie lepszym rozwiązaniem jest wykorzystanie: kapitałowych funduszy publicznych typu venture capital, partnerstwa publiczno-prywatnego (PPP) oraz specjalnych stref ekonomicznych (SSE).

Publiczne fundusze venture capital, w przeciwieństwie do prywatnych, nie muszą kierować się ideą maksymalizacji zysków. Powinny być jednak zarządzane w oparciu o rachunek ekonomiczny nastawiony np. na utrzymanie wartości kapitałów. Przez to ich oferta dla przedsiębiorców może być bardziej atrakcyjna niż funduszy prywatnych. Poza wsparciem finansowym fundusze venture capital obiektywizują i profesjonalizują ocenę ryzyka innowacyjnych przedsięwzięć w skali społecznej. Niezależnie od formy finansowania - kapitał dłużny czy kapitał właścicielski - finansowanie funduszy venture capital ma charakter przejściowy. W momencie wejścia fundusze posiadają strategię wyjścia. Pozwala to na wielokrotne wykorzystanie raz wydzielonych na nie środków publicznych.

Wsparcie kapitałowe państwa dla przedsiębiorstw prywatnych stwarza jednak możliwość, a dla niektórych rządów być może pokusę, nacjonalizacji bądź renacjonalizacji gospodarki. W tym przypadku należy odpowiedzieć na zasadnicze pytanie: czy własność publiczna jest z natury mniej wydajna i przez to zła dla gospodarki? W sytuacji, gdy jest ona jedyną bądź dominującą formą własności, odpowiedź jest, w sposób oczywisty i historycznie potwierdzony, twierdząca. Nie ma jednak dowodów, że tak być musi w przypadku, gdy stanowi ona pewne enklawy w dominującym środowisku własności prywatnej, działającej w warunkach konkurencyjnego rynku. Gdyby jednak pozostawały wątpliwości w sprawie efektywności własności publicznej, należy podkreślić, że w przypadku inwestycji publicznych funduszy venture capital mamy do czynienia z inwestycjami przejściowymi, opartymi na rachunku 
ekonomicznym, które skutkują niepełną własnością, a współwłasnością kapitału publicznego i prywatnego.

Przydatność wykorzystania idei specjalnych stref ekonomicznych (SSE) w stosowaniu koncepcji NES została już opisana w artykule J.Y. Lina. SSE tworzą odpowiednią dla rozwoju działalności gospodarczej twardą i miękką infrastrukturę oraz związane być mogą z ulgami podatkowymi, głównie w zakresie podatku od nieruchomości i podatku dochodowego (CIT). Oznacza to z punktu widzenia polityki fiskalnej konieczność poniesienia kosztów inwestycyjnych, głównie na poziomie samorządów terytorialnych i pewne ubytki w dochodach budżetu państwa i samorządów. Jednak już w krótkim okresie rekompensowane są one przez wzrost liczby miejsc pracy, co obniża wydatki socjalne na bezrobotnych i powoduje przyrost produkcji, co z kolei daje wzrost dochodów z tytułu wzrostu podatku VAT. Poza tym pozostają długoterminowe efekty infrastrukturalne 3 .

Wykorzystanie publicznych funduszy venture capital, partnerstwa publiczno-prywatnego oraz SSE pozwala na wzrost interwencji państwa w gospodarkę zgodnych z koncepcją NES oraz nienarażanie go w sposób istotny na przekraczanie norm nadmiernych deficytu budżetowego i pomocy publicznej.

Niewątpliwie prorozwojowa strukturalna polityka gospodarcza rządu byłaby bardziej efektywna w warunkach ekspansywnej polityki fiskalnej rządu i ekspansywnej polityki monetarnej banku centralnego. Żaden rząd i bank centralny w warunkach zagrożeń inflacyjnych nie może jednak takiej policy mix zagwarantować. Niewątpliwie ekspansywna polityka monetarna może być wsparciem dla przyśpieszenia rozwoju, lecz nie jest czynnikiem wystarczającym. Ekstremalnie ekspansywna polityka w wersji ilościowego luzowania w wydaniu FED i EBC stosowana w latach 2008-2016 pokazuje, że może być remedium na powstrzymanie recesji, lecz nie musi być wystarczającym bodźcem do przyśpieszenia wzrostu gospodarczego ${ }^{4}$.

Należy również stwierdzić, że polityka monetarna to nie tylko narzędzia ilościowe: poziom stóp procentowych i skala zmian podaży pieniądza. Posiada ona również narzędzia jakościowe, związane głównie z procedurami kredytowymi. Podażą pieniądza sterować można przykładowo przez dostępność kredytów w ramach oceny zdolności kredytowej, w tym systemu gwarantowania spłaty kredytu. Strukturalna polityka gospodarcza rządu może być wspierana przez:

- specjalne procedury oceny zdolności kredytowej przedsiębiorstw w wspieranych branżach gospodarczych;

- systemem gwarantowania spłaty kredytów przez instytucje publiczne (rząd, samorządy, bank centralny, publiczne fundusze gwarancyjne i fundusze venture capital) dla przedsiębiorstw w wspieranych branżach.

3 Twierdzę to z całym przekonaniem, będąc w swoim czasie doradcą Ministra Gospodarki do zakładania SSE.

4 Potwierdza to m.in. teza wygłoszona przez byłego Prezesa Zarządu NBP, Marka Belkę, na konferencji katedr finansowych uczelni polskich we wrześniu 2016 r.: „Polityka monetarna baku centralnego jest o tyle skuteczna, o ile wspiera ekspansywną politykę fiskalną”. 
Tę część artykułu chciałbym zakończyć pewnym porównaniem. Joan Robinson (1937) przedstawiła dylemat roli polityki fiskalnej i monetarnej w rozwoju gospodarczym za pomocą następującej anegdoty. Porównała ona gospodarkę do wozu konnego, który napędzać mieli reprezentujący politykę fiskalną - minister finansów i politykę monetarną - prezes banku centralnego. Wykorzystać oni mogli następujące instrumenty ich polityki: sznurek i drąg. W sznurek wyposażyła ministra finansów i usytuowała go z przodu wozu, by mógł gospodarkę ciągnąć do przodu, nadając jej jednocześnie właściwy kierunek rozwoju. Prezes banku został zaś wyposażony w drąg i posadzony z tyłu, by mógł wspierać gospodarkę, kiedy jechała pod górę, ale również hamować, jeżeli zanadto się rozpędzała, jadąc w dół.

W świetle koncepcji NES, dzisiaj należy w tej anegdocie zmienić pojazd, wykorzystać bardziej nowoczesne instrumenty działania państwa oraz poszerzyć tandem ministra finansów i prezesa banku centralnego o trzeciego partnera - ministra gospodarki. Gospodarka to samochód, który posiada karoserię, silnik, kierownicę i hamulec. Karoserią jest dominująca własność prywatna; silnikiem - gospodarka; za gaz i hamulec odpowiadają minister finansów i prezes banku centralnego, mając w swej dyspozycji ekspansywne i restrykcyjne warianty polityki fiskalnej i pieniężnej. Samochód porusza się jednak w tempie wynikającym z norm przepisów prawa drogowego, szczególnie bacząc na nieprzekraczanie szybkości, co w przypadku gospodarki mogłoby zagrażać kryzysami nierównowagi makroekonomicznej. Za kierownicą zaś siedzi minister gospodarki, który nadaje właściwy kierunek jazdy. Celem natomiast jest przyśpieszenie wzrostu PKB do poziomu osiagnniętego we wzorcowym doganianym kraju rozwiniętym. Samochód, w przeciwieństwie do wozu, poruszać się może po drogach, którymi w tym przypadku są rynki. Zboczenie na bezdroża grozi katastrofą i ugrzęźnięciem w bagnie. Kierowca jest ponadto wyposażony w system nawigacji, wynikający z zasad NES, który pozwala dotrzeć do celu optymalną trasą i uniknąć zatorów oraz innych przeszkód drogowych.

W tym modelu brakuje jeszcze jednego elementu, by samochód mógł ruszyć i jechać niezbędne jest paliwo, są nim oczywiście: kapitał, praca i zasoby naturalne. Nie są to jednak czynniki w pełni egzogeniczne. Państwo ma istotny wpływ na ich dostępność i jakość. Dostępny w kraju kapitał jest efektem skłonności do oszczędzania podmiotów krajowych i dostępności kredytów, która z kolei jest pochodną polityki monetarnej banku centralnego oraz może pochodzić z zagranicy. Kapitał jednak kosztuje. Ceną kapitału jest stopa procentowa, a zagranicznego - dodatkowo transfer zysków za granicę. Napływ kapitału zagranicznego wymusza ponadto relatywnie wyższe stopy procentowe w kraju goszczącym, by podnieść atrakcyjność inwestycji zagranicznych. Dostępność zasobów pracy i ich jakość może być regulowana przez odpowiednie rodzaje polityki państwa: demograficzną (np. w formie zasiłków rodzinnych); migracyjną (możliwość emigracji i imigracji); edukacyjną (na wszystkich poziomach kształcenia: podstawowym, średnim i szczególnie wyższym); mieszkaniową (co podnosi mobilność zasobów pracy). Najbardziej egzogenna jest dostępność surowców. Jak jednak pokazują liczne przypadki, łatwy dostęp do 
surowców może mieć demoralizujący wpływ na rozwój dwóch pierwszych czynników wzrostu.

\section{Rozwój polskiej gospodarki w perspektywie Nowej Ekonomii Strukturalnej}

Polska gospodarka odziedziczyła, w 1990 roku, strukturę własnościową i branżową po czterdziestopięcioletnim obowiązywaniu zasad gospodarki centralnie planowanej. W strukturze własnościowej dominowała wówczas własność państwowa, z wyłączeniem rolnictwa, gdzie ze względu na tradycję oraz opór chłopstwa utrzymano własność prywatną. Jednak gospodarstwa rolne były rozdrobnione, niskotowarowe i stanowiły rezerwuar ukrytego bezrobocia. Struktura branżowa w żadnym stopniu nie wynikała z konkurencyjności krajowych branż w wymianie międzynarodowej, a raczej - z modelu komplementarnej współpracy krajów bloku sowieckiego w ramach Rady Wzajemnej Współpracy Gospodarczej (RWPG). Głównym surowcem naturalnym był, i nadal jest, węgiel, co stanowi aktualnie poważny problem w dostosowaniu się naszej gospodarki do norm globalnej polityki klimatycznej. Konkurencyjne źródła energii - gaz i ropa naftowa - pochodziły wyłącznie ze Związku Radzieckiego, obecnie zaś z Rosji. Uniezależnienie się Polski od tych dostaw to główne, realizowane dzisiaj zadanie polityki energetycznej państwa.

Fundamentalną kwestią początku procesu transformacji stało się uruchamianie rynkowych struktur i narzędzi gospodarki oraz przekształcenia własnościowe w kierunku jej prywatyzacji. Polityka przemysłowa w tych warunkach zeszła na dalszy plan. Jaskrawym wyrazem atmosfery tamtych lat była wypowiedź jednego z pierwszych ministrów przemysłu w okresie transformacji, Andrzeja M. Zawiślaka: „Najlepsza polityka przemysłowa to brak polityki przemysłowej”. Ta ultraliberalistyczna wypowiedź była oczywiście odreagowaniem na etatystyczne i ręczne sterownie gospodarką centralne planowaną, ale również efektem dość naiwnej wiary w sprawczą moc rynków. Panująca wówczas atmosfera wokół sposobów realizacji polityki gospodarczej państwa była źródłem zmian instytucjonalnych. Ministerstwo Przemysłu zostało zlikwidowane i włączone w struktury nowego Ministerstwa Gospodarki. W roku 2015 Ministerstwo Gospodarki zostało przemianowane na Ministerstwo Rozwoju, a pełniący funkcję Ministra Gospodarki, łącząc ją z funkcją Ministra Finansów, uzyskał rangę wicepremiera Rządu. Zmiany te niewątpliwie świadczą o odwrocie władzy politycznej od nurtu neoliberalnego i pozwalają oczekiwać prorozwojowych interwencji państwa w ramach jego strukturalnej polityki gospodarczej (SPG).

Tezę tę wzmacniają również zmiany w ministerstwie odpowiedzialnym za zmianę struktury własnościowej gospodarki. Pierwotna nazwa tego resortu - Ministerstwo Przekształceń Własnościowych - została zmieniona w roku 1997 na Ministerstwo 
Skarbu Państwa. Zmiana ta zbiegła się w czasie z wyhamowaniem procesu prywatyzacji. Ministerstwo Skarbu odgrywało rolę reprezentanta państwa jako właściciel w spółkach, w których Skarb Państwa posiadał swoje udziały. W roku 2016 zostało ono zlikwidowane, a funkcje właścicielskie państwa zostały przekazane do właściwych pod względem zakresu działalności ministerstw resortowych: rozwoju, energetyki, budownictwa itp. Sądzę, że jest kolejna zmiana instytucjonalna, która wspiera możliwość realizacji przez rząd SPG.

Pierwsze przejawy realizacji strukturalnej polityki gospodarczej związane są z otwarciem gospodarki, co dawało możliwość oceny konkurencyjności naszych branż gospodarczych na tle gospodarki światowej oraz związany z tym napływ kapitału zagranicznego.

Polska gospodarka spełnia warunki modelu małej gospodarki otwartej sformułowane przez Roberta Mundella i Marcusa Fleminga. Jak wynika z hipotezy unpossiible triangle, w małej gospodarce otwartej możliwa jest polityka gospodarcza, która realizuje dwa spośród trzech celów polityki: liberalizację zagranicznych obrotów kapitałowych, stabilność kursów walutowych lub niezależność polityki pieniężnej banku centralnego, w ramach której bank centralny ma wpływ na kształtowanie polityki pieniężnej. Spośród trzech możliwych kombinacji w realizacji tych celów w Polsce, w latach 1990-1997, stosowano wariant: kontroli przepływu kapitału zagranicznego, niezależnej polityki pieniężnej oraz stabilnych kursów walutowych; a od 1997 do 2017 - wariant: liberalizacji zagranicznych obrotów kapitałowych, niezależnej polityki pieniężnej i płynnych kursów walutowych.

Ograniczenia przepływu kapitału zagranicznego związane były z ograniczoną wewnętrzną wymienialnością waluty. Prawo do wymiany walut miały podmioty krajowe, podmioty zagraniczne zobowiązane zaś były do uzyskiwania indywidualnych zgód Narodowego Banku Polskiego (NBP). Bank udzielał takich zgód dla inwestycji bezpośrednich, związanych bardzo często z udziałem inwestorów zagranicznych w prywatyzacji przedsiębiorstw. W ten sposób państwo sterowało napływem kapitału zagranicznego do poszczególnych branż. Należy sądzić, że inwestorzy zagraniczni, podejmując inwestycje w Polsce, w sposób właściwy oceniali przewagi komparatywne branż, w które inwestowali. Kapitał zagraniczny napływał poprzez uczestnictwo inwestorów zagranicznych w prywatyzacji przedsiębiorstw państwowych oraz zakładanie spółek córek w Polsce. Szczególnym zainteresowaniem inwestorów zagranicznych cieszyły się następujące branże: motoryzacyjna (Fiat, Volkswagen, General Motors); artykuły gospodarstwa domowego (Miele, Whirpool, Bosh, Siemens, Elektrolux); telekomunikacja; bankowość; ubezpieczenia; centra finansoworozliczeniowe. Niewątpliwie jednym z głównych motywów, jakim kierowało się wielu inwestorów, była relatywnie tania siła robocza, jednak należy się liczyć, że przynajmniej w niektórych przypadkach wystąpi, opisany przez J.Y. Lina (2017), efekt korzyści z późnego przejęcia innowacji technologicznej i udoskonaleń przemysłu.

Efekt taki wystąpił już, moim zdaniem, w bankowości. Udział inwestorów zagranicznych w polskim sektorze bankowym rozpoczął się w 1993 roku i przybie- 
rał formy partycypacji europejskich banków w prywatyzacji sektora w roli inwestorów strategicznych (maksymalny udział takiego inwestora w spółkach giełdowych wynosi w Polsce 75\%); zakładania własnych spółek bankowych w Polsce; otwierania oddziałów operacyjnych w Polsce, co stało się możliwe w 2004 roku po przystąpieniu Polski do UE, na podstawie europejskiej zasady jednej licencji bankowej w ramach UE. Bankowość w Polsce nie była rozwinięta. Od roku 1990 tworzono dopiero dwuszczeblowy sektor bankowy z bankami komercyjnymi, których wcześniej nie było. Stopień ubankowienia społeczeństwa był bardzo niski, rachunki bankowe posiadało niecałe 50\% dojrzałej części społeczeństwa. Technologie bankowe były tradycyjne, wykorzystujące jedynie dokumenty papierowe i oferujące dwojakiego rodzaju usługi: depozyty i kredyty. Inwestorzy zagraniczni dostarczali swoim spółkom nowych technologii rozliczeniowych i innowacji produktowych, takich jak: karty kredytowe, leasing, factoring, private banking, a nieco później w ramach bankowości elektronicznej - bankowość internetową i mobilną. Pod presją konkurencji unowocześniał się cały krajowy sektor bankowy. Ważnym elementem technologii bankowych jest umiejętne, właściwe zarządzanie wszystkimi rodzajami ryzyka, jakie występują w działalności bankowej: kredytowego, płynności, stóp procentowych, walutowego i operacyjnego. Sektor bankowy w Polsce pod względem technologicznym i ryzyka jest obecnie rozwinięty na ponad przeciętnym poziomie europejskim. Świadczyć o tym może m.in. fakt, że ominęły go rafy globalnego kryzysu finansowego z lat 2008-2009 oraz europejskiego kryzysu finansowego po roku 2010. Można nawet stwierdzić, że pewna niedojrzałość technologiczna pozwoliła naszym bankom uniknąć inwestycji w, będące źródłem kryzysu, „toksyczne papiery wartościowe”.

Żaden bank nie był istotnie zagrożony, czego nie da się powiedzieć o europejskich spółkach matkach niektórych banków działających w Polsce. Irlandzki AIB został uratowany przed upadłością dzięki pomocy publicznej i głębokiej restrukturyzacji, w ramach której został zmuszony do sprzedaży dobrych aktywów, czyli akcji posiadanych w Banku Zachodnim WBK SA. Akcje te nabył hiszpański Santander Bank. Podobnie stało się z belgijskim KBC, który zmuszony był sprzedać akcje polskiego Kredyt Banku. Akcje te również nabył Santander Bank i włączył ten Bank w strukturę Banku Zachodniego WBK. Ostatni taki przypadek miał miejsce w roku 2015, kiedy włoski Unicredit był zmuszony sprzedać pakiet kontrolny - drugiego co do wielkości banku w Polsce - PeKaO SA. W tym przypadku nabywca była polska spółka ubezpieczeniowa PZU wspólnie z Polskim Funduszem Rozwoju (PFR). Transakcję tę zrealizowano w ramach rządowego programu repolonizacji własności w sektorze bankowym. PZU jest spółką notowaną na GPW w Warszawie ze strategicznym udziałem Skarbu Państwa, PFR jest zaś funduszem publicznym. Liberałowie argumentują zaś, że rząd pod hasłem repolonizacji realizuje politykę renacjonalizacji.

Istotne znaczenie dla wzrostu napływu kapitału zagranicznego miała zmiana zasad polityki kursowej w 1997 roku. Od tego roku złoty stał się walutą w pełni wymienialną według standardów IMF i każdy podmiot krajowy i zagraniczny może 
złożyć zlecenie sprzedaży i zakupu tej waluty na Forexie. W Polsce, w przeciwieństwie do niektórych państw np. nadbałtyckich i powstałych z rozpadu byłej Jugosławii, przyjęto politykę płynnych kursów walutowych. W tym okresie rozpoczęły się w Polsce zagraniczne inwestycje portfelowe. W grupie tej inwestorzy zagraniczni inwestują: w polskie obligacje skarbowe denominowane w złotych (w kraju) i denominowane w walutach zagranicznych na rynkach światowych oraz w akcje na Giełdzie Papierów Wartościowych w Warszawie (GPW). Ceną polityki płynnych kursów walutowych i liberalizacji zagranicznych obrotów kapitałowych była wysoka niestabilność kursów, uzależniona głównie od decyzji inwestorów zagranicznych. Napływ kapitału zagranicznego od 2005 do sierpnia 2008 roku spowodował ponad $25 \%$ aprecjację złotego względem EUR i USD, a odpływ kapitałów w okresie od września 2008 do marca 2009 roku - blisko 60\% deprecjację waluty krajowej.

Jak już o tym wcześniej wspomniałem, strukturalna polityka gospodarcza (SPG) wymaga zmiany priorytetów w wydatkach rządowych realizowanych w ramach polityki fiskalnej. Aktualna struktura tych wydatków jest w większym stopniu wynikiem polityki społecznej państwa oraz chęci poszerzania elektoratów i nie ma charakteru prorozwojowego. Wydatki sektora funduszy publicznych wyniosły w 2016 roku 182 mld EUR, co stanowiło 41,3\% PKB, natomiast wydatki budżetu państwa 86 mld EUR, co stanowiło $20 \%$ PKB. W budżecie państwa $40 \%$ wydatków miało charakter redystrybucyjny (ponad $30 \%$ - renty i emerytury, prawie $10 \%$ - pomoc społeczna); ponad $11 \%$ - edukacja i tyle samo ochrona zdrowia. Na inwestycje z funduszy publicznych przeznaczono 15 mld EUR, co stanowiło 8\% ogółu wydatków publicznych i 3,3\% PKB. Wydatki budżetu na badania i rozwój stanowiły $0,9 \%$ PKB i jest to udział ponad dwukrotnie niższy od przeciętnego w UE (Chądzyński i Osiecki, 2017). Deficyt budżetu państwa wyniósł 2,4\% PKB, co pozostawia niewielki margines do maksymalnej normy europejskiej 3\% $\mathrm{PKB}^{5}$. Dług publiczny osiągnął na koniec 2016 roku poziom 54,1\% PKB, co z kolei zbliża go do norm ostrożnościowych, zapisanych w Konstytucji Rzeczpospolitej Polski, które mówią, że rząd, który dopuści do przekroczenia długu ponad 55\% PKB powinien przygotować budżet na następny rok kalendarzowy bez deficytu. Gdyby zaś dług publiczny przekroczył $60 \%$ PKB, rząd powinien podać się do dymisji i powinny zostać rozpisane wybory. Ryzyko polityczne przekroczenia tych konstytucyjnych norm jest zatem bardzo wysokie ${ }^{6}$. Wydatki budżetowe są często sztywne i wynikają z koniecz-

5 Normę tę Polska przekroczyła w 2013 roku w wyniku czego została objęta europejską procedurą nadmiernego deficytu.

6 Polska znalazła się na progu przekroczenia pierwszej normy ostrożnościowej (55\% PKB) w roku 2014. Spowodowało to odejście od kapitałowego systemu emerytalnego wprowadzanego od 1998 roku w formie otwartych funduszy emerytalnych (OFE). Do systemu tego kierowana była część obligatoryjnych składek emerytalnych, co powodowało wysoką lukę w obowiązującym aktualnych emerytów systemie repartycyjnym. Państwo musiało dopłacać do tego systemu, a OFE inwestowały również w obligacje skarbowe. W lutym 2014 roku portfel obligacji skarbowych o wartości 38 mld EUR został przesunięty do państwowego funduszu emerytalnego (PFE), co pozwoliło jednocześnie skompensować o tę samą kwotę 
ności kontynuacji programów rządowych. W tych warunkach należy szukać pozabudżetowych źródeł finansowania SPG. Jak postaram się wykazać, mogą to być środki Unii Europejskiej, wspomniane wcześniej SSE oraz kapitałowe fundusze publiczne.

Krokiem milowym w umiędzynarodowieniu gospodarki i w realizacji strukturalnej polityki gospodarczej było przystąpienie Polski w roku 2004 do Unii Europejskiej (UE). Po akcesji (2004-2006) polska gospodarka wykorzystała około $10 \mathrm{mld}$ EUR. Strumień środków europejskich znacznie poszerzył się w latach następnych. W latach 2007-2013 podmioty polskiej gospodarki w ramach krajowych i regionalnych programów operacyjnych i dotacji w ramach Wspólnej Polityki Rolnej uzyskały 90 mld EUR. Jednocześnie suma wniesionych składek do budżetu UE wyniosła w tym okresie 22 mld EUR. W tym okresie polska gospodarka została zatem zasilona kwotą około 68 mld EUR netto (Cieślak-Wróblewska, 2017). Stanowi to 50\% wydatków budżetu państwa w roku 2015 i około 1,9\% średniorocznego PKB w całym tym okresie. Pieniądze te zostały zainwestowane przede wszystkim w: infrastrukturę podstawową (głównie transportową) - 60\%; wsparcie sektora przedsiębiorstw - $23 \%$ oraz w rozwój zasobów ludzkich - $10 \%$.

Skala pomocy europejskiej i kierunki jej wykorzystania w istotny sposób uzupełniają skromne wydatki budżetu państwa na cele rozwojowe, zgodne z koncepcją NES. To cenne dla rozwoju gospodarki źródło na razie nie wysycha. W perspektywie lat 2014-2020 w ramach europejskiej polityki spójności Polska ma do dyspozycji 82,5 mld EUR. Należy mieć nadzieję, że środki te zostaną wykorzystane w sposób jeszcze bardziej efektywny dla przyśpieszenia rozwoju gospodarczego w ramach Strategii na rzecz Odpowiedzialnego Rozwoju. Możliwość wykorzystania tych zewnętrznych i bezzwrotnych źródeł finansowania nie powinna jednak osłabiać kreowania i zaangażowania wewnętrznych źródeł w finansowanie rozwoju.

Dalsza obecność Polski w Unii Europejskiej zależy od kluczowej decyzji związanej z przystąpieniem naszego kraju do strefy euro. Do 2008 roku przeszkodą było niespełnianie wszystkich kryteriów z Maastricht. Aktualnie kryteria te są spełniane, jednak istnieją opory, głównie natury politycznej, związane z kryzysem zadłużeniowym niektórych państw tej strefy i z unijnym kryzysem imigracyjnym. Z punktu widzenia możliwości realizacji w przyszłości strukturalnej polityki gospodarczej przystąpienie do strefy euro wydaje się korzystne. Strefa euro to nie tylko wspólna waluta, eliminująca ryzyko walutowe w handlu między krajami strefy, lecz także wspólna polityka pieniężna, która jak dotychczas była bardziej ekspansywna. Należy sądzić, że tak będzie w przyszłości, gdyż Polska przestanie być małą gospodarką otwartą, która zachęca inwestorów zagranicznych względnie wyższymi stopami procentowymi, a stanie się częścią dużej gospodarki europejskiej, która ma wpływ na

wartość długu publicznego, która obniżyła się do 50,2\% PKB. OFE nie mogły inwestować później w obligacje skarbowe, składki ubezpieczonych zostały zapisane na ich indywidualnych rachunkach w PFE, natomiast od 2017 roku OFE zostaną przekształcone w prywatne fundusze emerytalne (PFE), wpłaty składek staną się zaś dla pracowników dobrowolne. 
kurs własnej waluty. Powstanie również możliwość korzystania z wspólnego budżetu unii walutowej, który niewątpliwie powstanie.

Pierwsza specjalna strefa ekonomiczna (SSE) powstała w Polsce w 1995 roku w Mielcu. Doradcami przy jej tworzeniu byli zarządzający pierwszą SSE na świecie, powstałą w Shannon ${ }^{7}$ (Irlandia). Do końca lat 90. wykształciło się w Polsce 14 SSE, które działają do dzisiaj. Łączna powierzchnia terenów wydzielonych na działalność SSE wyniosła na koniec 2015 roku blisko 20 tys. ha. Pierwotnym celem zakładania SSE była aktywizacja gospodarcza regionów w sposób szczególny dotkniętych upadłością lub likwidacją dużych przedsiębiorstw państwowych, a pierwszym spodziewanym efektem - spadek bezrobocia w regionie. Głównym przywilejem inwestorów w utworzonych strefach jest zwolnienie od podatków CIT i od nieruchomości. Poza tym strefy oferują: w pełni przygotowane tereny inwestycyjne po konkurencyjnych cenach; możliwość zakupu lub dzierżawy istniejących na terenie strefy nieruchomości; know-how oraz darmową pomoc ze strony zarządcy SSE formalnościach itp. Dane o makroekonomicznych skutkach działania SSE są niestety trudno dostępne i wyrywkowe. Według danych firmy consultingowej Colliers International, na koniec 2015 roku zatrudnienie w SSE wynosiło blisko 300 tys. osób, co stanowiło blisko $2 \%$ zatrudnionych w Polsce. Skumulowane nakłady inwestycyjne wyniosły tam blisko 28 mld EUR, co stanowiło w skali roku od 2 do $6 \%$ wartości inwestycji ogółem i 20-30\% bezpośrednich inwestycji zagranicznych. W SSE inwestowali przede wszystkim inwestorzy zagraniczni - 80\% (w tym: Niemcy 19\%; USA 12\%; Holandia $12 \%$ ) oraz krajowi - 20\%. Wśród inwestorów zagranicznych dominowali: GM Manufacturing Poland (USA), Volkswagen Poznań (Niemcy), Toyota Manufacturing Poland (Japonia) (Colliers International, 2016). Możemy zatem stwierdzić, że SSE były i są dodatkowym magnesem przyciągającym inwestorów zagranicznych i akceleratorem inwestycji krajowych.

Polski Fundusz Rozwoju (PFR) został utworzony w 2016 roku jako spółka Skarbu Państwa i Banku Gospodarstwa Krajowego (BGK). BGK jest jedynym państwowym bankiem komercyjnym, za pomocą którego rząd realizował swoje programy socjalne w sektorze bankowym (np. stypendia studenckie, dopłaty do oprocentowania kredytów mieszkaniowych). Utworzenie PFR świadczy m.in. o włączeniu tego banku do realizacji programów rządu w ramach jego SPG. Skarb Państwa jest również strategicznym właścicielem w największym polskim banku PKO BP SA i pośrednio w, drugim co do wielkości banku, PeKaO SA.

PFR kontynuuje i wzmacnia działanie powstałych wcześniej: Agencji Rozwoju Przemysłu (ARP), Korporacji Ubezpieczeń Kredytów Eksportowych (KUKE), Polskiej Agencji Inwestycji i Handlu (PAIiH) oraz Polskiej Agencji Rozwoju Przedsiębiorczości (PARP). Są to fundusze publiczne typu private equity (ARP) wspierające innowacyjność, przedsiębiorczość i eksport polskich przedsiębiorstw.

7 Piszący te słowa współpracował z doradcą jako partner polskiej firmy consultingowej. 
Wśród zadań PFR znajdują się: finansowanie na zasadach komercyjnych oraz współpracy przy przygotowaniu i dystrybucji programów, w których występują luki; prowadzenie programów rozwojowych dostosowanych do potrzeb biznesu (przedsiębiorstw i inwestorów na terytorium Polski), konsumentów oraz państwa (jednostek samorządu terytorialnego). Ze względu na relatywnie niskie kapitały własne PFR i innych prorozwojowych agencji państwowych (kapitał akcyjny PFR wynosi 0,3 mld EUR) efekty makroekonomiczne ich działalności nie mogą być jednak zbyt wysokie. Największe inwestycje PFR to: udział w odkupieniu od Unicredit banku PeKaO SA.; zapowiedziane w 2017 roku inwestycje w finansowanie start-upów (0,25 mld EUR) oraz inwestycje w unowocześnianie polskiej energetyki $(1,2 \mathrm{mld}$ EUR). Działalność PFR i innych prorozwojowych agencji państwowych w istotny sposób uzupełnia prorozwojowe wydatki budżetu państwa, jednak głównie w obszarze małych i średnich przedsiębiorstw. Rząd liczy również na współudział kapitału chińskiego w sfinansowaniu dużego projektu budowy centralnego lotniska przesiadkowego w okolicach Warszawy w ramach odbudowy przez ten kraj dawnego jedwabnego szlaku.

Konkludując drugą część artykułu, pragnę przytoczyć fakty świadczące o wzroście gospodarki polskiej w okresie jej transformacji (Górski, 2015, s. 37). W okresie 1993-2015 średnioroczne tempo wzrostu gospodarczego w Polsce wynosiło 4,1\%. Co warto podkreślić, w żadnym roku nie odnotowano ujemnej stopy wzrostu (recesji). Stopy wzrostu gospodarczego wahały się w przedziale: od 7,0 w 1995 roku do $1 \%$ w 2001 roku. Takie tempo wzrostu gospodarczego umożliwiłoby gospodarce polskiej podwojenie jej PKB w okresie 18 lat, a w analizowanym okresie polskie PKB wzrosło o $153 \%$. Efekt doganiania jest również widoczny. Polskie PKB per capita wynosiło w 2008 roku 55\% średniego PKB per capita w Unii Europejskiej, natomiast w 2015 roku - 69\%, z czego 8,9 pkt. proc. eksperci NBP przypisują wykorzystanym środkom unijnym. Szacunki te nie uwzględniają długotrwałych efektów infrastrukturalnych obniżających koszty transakcyjne w przyszłości. Polska znalazła się na 23 miejscu w rankingu gospodarek o najwyższym poziomie PKB, co znalazło wyraz w zaproszeniu premiera polskiego rządu, po raz pierwszy w historii, na spotkanie szczytu G-20 w Hamburgu, w lipcu 2016 roku.

\section{Bibliografia}

Chądzyński, M., Osiecki, G. (2017). Nasze bardzo socjalne państwo. Dziennik Gazeta Prawna, 25 kwietnia.

Cieślak-Wróblewska, A. (2017). Szybszy rozwój dzięki unijnemu wsparciu. Rzeczpospolita, 25 kwietnia.

Colliers International. (2016). Potencjat inwestycyjny. Specjalne Strefy Ekonomiczne w Polsce. Pozyskano z: http://www.colliers.com/pl-pl/-/media/files/emea/poland/reports/2016/ Colliers_Raport_Specjalne_Strefy_Ekonomiczne_PL.pdf. 
Cukiernik, T. (2007). Prawda i fatsz o dotacjach z UE. Pozyskano z: http/tomaszcukiernik.pl. Górski, M. (2015). Makroekonomiczne skutki polityki fiskalnej i monetarnej w Polsce w latach 1992-2015. W: A.Z. Nowak (red.), Gospodarka na rozdrożu XXI wiek. Ksiega jubileuszowa z okazji osiemdziesiatych urodzin Profesora Kazimierza Rycia. Warszawa: Wydawnictwo Naukowe Wydziału Zarządzania UW.

Lin, J.Y. (2017). Nowa Ekonomia Strukturalna dla gospodarek doganiających. W: J.Y. Lin, A.Z. Nowak (red.), Nowa Ekonomia Strukturalna wobec krajów mniej zaawansowanych. Warszawa: Wydawnictwa Naukowe Wydziału Zarządzania UW.

Robinson, J.V. (1937). Introduction to the Theory of Employment. London: Macmillan.

Wikipedia. (2017). Polski Fundusz Rozwoju. Pozyskano z: https://pl.wikipedia.org/wiki/Polski_Fundusz_Rozwoju. 


\author{
MICHAŁ KURTYKA
}

\title{
Rozwój elektromobilności w Polsce w kontekście Nowej Ekonomii Strukturalnej
}

\begin{abstract}
Dotychczasowa polityka gospodarcza w Polsce koncentrowała się na horyzontalnym eliminowaniu barier związanych z odziedziczonym, przerośniętym i nieefektywnym państwem. Dominowały procesy deregulacji, liberalizacji i prywatyzacji. Udało się uruchomić potencjał przedsiębiorczości Polaków, co w połączeniu z wysoką jakością kapitału ludzkiego zaowocowało w warunkach najpierw procesu przygotowania do członkostwa, a następnie, po przystąpieniu do Unii Europejskiej, znaczącym wzrostem gospodarczym i sukcesem wielu przedsiębiorstw. Jednakże osiągnięcie wyższego poziomu rozwoju gospodarczego, a szczególnie przejście z efektywnej gospodarki imitacji do skutecznej gospodarki innowacji, wymaga sięgnięcia po bardziej zaawansowane instrumenty. Jak pokazują przykłady najbardziej konkurencyjnych gospodarek i branż na świecie, ich rozwój był nierzadko synergiczny. Aktywna rola sektora publicznego uzupełniała sektor prywatny w antycypowaniu trendów i tworzyła dla niego innowacyjne technologie, otwierała nowe rynki i rozszerzała pionierskie nisze.

Nowa Ekonomia Strukturalna tworzy ramy konceptualne na rzecz uzupełnienia wachlarza instrumentów polityki gospodarczej w Polsce o branżową politykę przemysłową. Musi ona być prowadzona z poszanowaniem reguł konkurencyjności i wspierać zaangażowanie sił rynkowych, dla których państwo ma za zadanie stworzyć optymalne warunki i usuwać bariery, nie substytuując, lecz wspierając prywatną kreatywność i przedsiębiorczość. Upowszechnienie samochodów elektrycznych stwarza perspektywę na globalny przewrót w stosunkowo ustabilizowanym rynku producentów pojazdów. Wiele wskazuje, że sukces Tesli może być dla tego sektora podobnym w konsekwencjach wydarzeniem do pojawienia się iPhona dla producentów telefonów komórkowych. W efekcie powstanie nowy rynek, na którym dotychczasowe przewagi związane z silnikiem spalinowym przestaną być barierą wejścia dla nowych graczy. Polska posiada rozbudowany przemysł poddostawczy w motoryzacji, zaawansowane kompetencje w kluczowych dla elektromobilności dziedzinach, takich jak elektrotechnika, elektronika, IT. Dzięki pionierskiej pracy przedsiębiorstw produkujących autobusy elektryczne kraj posiada również kompetencje, które predestynują go do wejścia w rewolucję elektromobilności. Jednak, aby stała się ona sukcesem dla polskich przedsiębiorstw i dla całego kraju niezbędne jest przemyślenie polityki gospodarczej. Nowa Ekonomia Strukturalna stanowi dobre ramy odniesienia dla jej przeorientowania na nowe tory.
\end{abstract}

Słowa kluczowe: Nowa Ekonomia Strukturalna, polityka przemysłowa, polityka rozwoju, elektromobilność, samochód elektryczny, polska polityka gospodarcza. 


\section{Dotychczasowa specyfika rozwoju polskiej gospodarki}

Po dwudziestu pięciu latach po odzyskaniu suwerenności Polska jest otwartą i prężną gospodarką, której sukces został zakorzeniony w prorynkowych instytucjach i wysokiej jakości kapitale ludzkim: przedsiębiorczości Polaków i ich wysokim poziomie edukacji.

Na początku 2017 roku bezrobocie obniżyło się, osiaggając kolejny rekord na poziomie 5,3\% (Eurostat, 2017). Prognozy dla wzrostu gospodarczego na 2017 r. na poziomie 3,4\% stawiają Polskę w gronie światowych liderów wzrostu (Bank Światowy, 2017), a wymiana handlowa z zagranicą bije kolejne rekordy. Dynamika eksportu przeważa nad dynamiką importu i w efekcie od 2015 roku kraj odnotowuje dodatnie saldo obrotów z zagranicą ${ }^{1}$. Wskaźniki gospodarcze stale się polepszają. Od 1990 roku PKB per capita wzrósł z 1700 dolarów do 12 500, przebijając nie tylko kraje Europy, lecz także wszystkie kraje OECD (Cipiur, 2017). W ciagu 10 lat obecności w Unii Europejskiej PKB Polski podwoiło się, a PKB na mieszkańca mierzone parytetem siły nabywczej uzyskało prawie 70\% średniej unijnej (GUS, 2014).

Bardzo wysoki jest poziom edukacji, stale poprawia się pozycja Polski mierzona w międzynarodowym badaniu umiejętności uczniów PISA (OECD, 2017). Polacy należą do jednych z najbardziej pracowitych nacji na świecie. Statystyczny Polak przepracował w 2015 roku 1963 godzin, co sytuuje nasz kraj na 7 pozycji wśród 38 krajów przebadanych przez OECD (2017). Są również jednymi z najbardziej aktywnych w Europie przedsiębiorców - jak pokazują badania Gallupa, z samozatrudnienia korzystała blisko połowa Polaków - i chętniej niż inne europejskie nacje deklarują zainteresowanie tą formą pracy (OECD, 2012). Struktura przedsiębiorczości jest stosunkowo elastyczna, gdyż spośród 1,5 mln firm $96 \%$ to mikrofirmy w porównaniu ze średnią europejską na poziomie $92 \%$.

Dominującą rolę w polityce gospodarczej Polski po 1989 roku odegrały działania o charakterze horyzontalnym, niepreferujące konkretnych branż jako katalizatorów wzrostu. Liberalizacja, prywatyzacja, deregulacja to jej słowa klucze. Stosunkowo wcześniej podjęto działania w zakresie zapobieżenia powstawaniu monopoli. Udało się również uniknąć oligarchizacji gospodarki, o wiele bardziej dotkliwej nie tylko dla krajów, takich jak Ukraina i Rosja, lecz także np. dla Czech (Sopoćko, 2017).

Państwo generalnie wycofywało się z życia gospodarczego, a w jego miejsce wkraczała indywidualne inicjatywa i kreatywność, wspierane przyjmowaniem unijnego prawodawstwa (acquis communautaire), perspektywą przystąpienia do Unii Europejskiej, a później jej faktyczną realizacją w 2004 roku. Państwo nie pretendowało do odgrywania aktywnej roli w promowaniu takich czy innych branż. Tam gdzie miał miejsce wzrost gospodarczy, następował on niejako „obok państwa”, a czasem

1 Według wstępnych danych GUS, rok 2016 przyniósł wzrost polskiego eksportu o 2,3\% (do 183,6 mld euro), importu o 0,9\% (do 178,9 mld euro) oraz dalsze znaczące zwiększenie nadwyżki obrotów (ponad 2-krotne, do blisko 4,8 mld euro). Zob. Ministerstwo Rozwoju, 2017. 
nawet „pomimo państwa”, a nie „razem z państwem”. Takie podejście wynikało w dużej mierze z zastanego po okresie 1945-1989 monstrualnego przerośnięcia państwa, ale również z przyjętej filozofii, która uznała je za podstawową barierę do rozwoju gospodarczego per se.

Transformacja i intensywne procesy prywatyzacyjne początku lat 90 . XX wieku doprowadziły do szybkiego i nierzadko bolesnego przeniesienia potencjału wytwórczego z dziedzin mniej produktywnych do bardziej produktywnych bądź eliminacji całych branż gospodarczych. Po zapaści początku lat 90. pod ich koniec odwróciły się proporcje wytwarzania PKB: od dominacji sektora publicznego do dominacji własności i produkcji w sektorze prywatnym.

Jak pokazał Orłowski (2010), zagregowany wzrost produktywności zasobów (Total Factor Productivity - TFP) to klucz do zrozumienia sukcesu gospodarczego Polski i regionu Europy Środkowej i Wschodniej. „Podstawową cechą rozwoju gospodarczego krajów Europy Środkowej i Wschodniej w okresie Nowego Wzrostu [ie. 1990-2007] stało się oparcie go na wzroście produktywności i efektywności wykorzystania czynników produkcji. Czynnikiem uzupełniającym były zwiększone - w dużej mierze dzięki napływowi inwestycji zagranicznych - nakłady kapitału, podczas gdy wzrost nakładów pracy odegrał we wzroście produkcji minimalna rolę" (Orłowski, 2010, s. 171). Nie przybyło znacząco kapitału ani pracy, ale istniejące zasoby zostały lepiej wykorzystane, do czego przyczyniły się zmiany systemowe, co zaś nastąpiło w znacznej mierze dzięki uruchomieniu potencjału drzemiących dotychczas prostych rezerw oraz w stworzeniu prorynkowych ram prawnych. Stworzono możliwość prowadzenia różnego typu działalności gospodarczych; lepsze skomunikowanie ograniczyło koszty logistyki; liberalizacja i deregulacja wielu sektorów otworzyły nowe rynki etc. Do tego doszły wydarzenia o charakterze jednorazowym - jak przystąpienie do Unii Europejskiej i w pełni zmaterializowany od 2004 roku dostęp do jednolitego rynku i trzech pozostałych swobód.

\section{Wyzwania dla polityki gospodarczej Polski i Nowa Ekonomia Strukturalna}

W opisanym kontekście, w Polsce stajemy obecnie przed następującymi pytaniami:

- czy sukces pierwszych dwudziestu pięciu lat może być przekonującym argumentem na rzecz jego powtórzenia w kolejnym okresie?

- czy ten sam zestaw działań, który umożliwił rozwój gospodarczy kraju po 1989 roku, będzie skuteczny w dalszym ciągu?

- czy dalszy wzrost gospodarczy „obok państwa” będzie w długim okresie wystarczający, żeby doścignąć kraje rozwinięte?

- czy państwo powinno/może być instrumentem polityki gospodarczej dodającym wartość? 
Myśląc poważnie o osiągnięciu światowej pozycji gospodarczej przez jakikolwiek kraj świata, nie sposób nie odnieść się do zdolności innowacji gospodarki. Tymczasem zasadniczą bolączką obecnej sytuacji jest to, że nie nastąpiła praktycznie żadna zmiana kluczowych parametrów w zakresie innowacyjności polskiej gospodarki. Pomimo że w przeciagu ostatnich 10 lat na innowacje i badania naukowe została przeznaczona znacząca, jak na polskie możliwości, kwota ${ }^{2}$, nie udało się wypromować żadnej polskiej specjalności ani uzyskać przełomu w żadnej dziedzinie o światowym zasięgu. Do tego środki wydawane na działalność badawczą i rozwojową - zarówno w wielkościach względnych, jak i bezwzględnych - pozostają skromne i nie przekraczają 1\% PKB. W rankingach innowacyjności przygotowanych przez Eurostat w 2012 r. Polska była na 24. miejscu wśród 27 krajów. Trzy lata później Polska wciąż była na tym samym miejscu, ale już w gronie 28 krajów. Podobnie wygląda sytuacja z polskimi uczelniami, gdyż żadna z nich nie osiągnęła znaczącego postępu w światowych rankingach. Nie zmieniła się również znacząco liczba patentów.

Jak pokazuje P. Koryś (2015) Polska osiągnęła znaczący sukces, jeżeli chodzi o wzrost uprzemysłowienia w stosunku tak do sąsiadów, jak i na tle historycznych przykładów państw europejskich i azjatyckich. Od 1989 roku nastąpił spektakularny wzrost uprzemysłowienia Polski, daleko większy niż u, porównywalnych pod względem punktu startu, pozostałych gospodarek środkowo-europejskich, prawie 5-krotnie wzrosła rynkowa wartość dodana przemysłu w porównaniu z 4-krotnym wzrostem w Czechach, a w obydwu wypadkach daleko więcej niż w pozostałych krajach, jak Słowacja, Węgry czy też Rumunia. Jeszcze większa różnica występuje, gdy za punkt startu weźmiemy bardziej reprezentacyjny dla historycznej sytuacji Polski poziom odniesienia z 1970 roku: prawie 8-krotny wzrost wobec 3,3-krotnego dla Czech. Nastąpiła poprawa jakości kapitału ludzkiego w przemyśle.

Jednak mimo tego sukcesu, wciąż jeszcze poziomy produktywności charakterystyczne są bardziej dla krajów peryferyjnych niż dla innowacyjnego centrum Europy.

Polskie przedsiębiorstwa nie przeznaczają wystarczających środków na działalność badawczo-rozwojową, a nawet te środki, które kwalifikowane są jako takie, służą w znacznie większym stopniu poprawie w sektorach, które nie mogą stanowić podstawy do przełomów technologicznych w najbardziej zaawansowanych branżach na świecie. Gros wydatkowanych jest w usługach dla biznesu, a jedynie $40 \%$ wydatków na innowację dotyczy firm o wysokim i średnio wysokim poziomie techniki w porównaniu z prawie $80 \%$ w Niemczach i $70 \%$ w Finlandii. Nie dość zatem, że w wartościach bezwzględnych ich poziom jest niewystarczający, to jeszcze struktura wydatków nie pozwala z optymizmem myśleć, że przyczyni się do transformacji gospodarczej.

Wydaje się, że w wielu branżach polskie firmy osiągnęły światowy poziom. Jednak z indywidualnych przypadków nie daje się na razie wysnuć tezy o systemowym przełomie. Jak pisze o tym Orłowski (2015), „Choć czasem może zdarzyć się inaczej,

2 Ponad 30 miliardów złotych przez samo tylko Narodowe Centrum Badań i Rozwoju, nie licząc budżetów uczelni, instytutów badawczych i innych instytucji wsparcia nauki. 
polskie firmy generalnie lokują się w środku łańcucha tworzenia wartości: koncentrują się na produkcji, wytwarzają produkty na średnim poziomie zaawansowania technologicznego, dostarczają je dla tych, którzy je sprzedają pod własną marką, albo sprzedają je same, ale jako produkty generyczne" (Orłowski, 2015, s. 161). W konsekwencji powstaje ryzyko, że „opisana sytuacja może się utrwalić, uniemożliwiając firmom dalszą ekspansję i zniechęcając je do wzrostu innowacyjności, a krajowi uniemożliwiając budowę marki, wzrost płac i dogonienie zamożniejszych sąsiadów" (Orłowski, 2015, s. 162). W efekcie kraj złapany jest w pułapkę średniego rozwoju.

Rozwój najbardziej zaawansowanych branż w Polsce odbył się w dużej mierze według wspomnianej logiki „obok państwa”. Państwo nie wspierało ich, ale również one same nie oczekiwały od państwa nic dobrego. Postrzegane w najlepszym razie jako mało skuteczne, a w najgorszym razie wręcz jako szkodliwe i przytłaczające swoją ociężałością, państwo nie miało instrumentów, aby przekonać do siebie przedsiębiorców.

Nie ma dzisiaj wystarczająco czytelnej marki gospodarczej „Polska”, która mogłaby wspierać działalność eksportową polskich firm. Jak pokazują przykłady Szwajcarii, Niemiec czy Stanów Zjednoczonych, również wizerunek państwa czy narodu może być znaczącą dźwignią wspierającą swoje przedsiębiorstwa. Co więcej, państwa często kojarzą się z konkretnymi branżami, nawet jeżeli takie skojarzenie pozostaje stereotypowe: szwajcarska jakość - zegarki; niemiecka doskonałość - samochody; amerykański sen - rozrywka i cyfrowa rewolucja. Polskie firmy rzadko były w stanie wykrystalizować rozpoznawalne marki w świecie, zadawalając się rolą poddostawcy lub producenta generycznego. Ale jeżeli byłyby wspierane przez czytelną i pozytywną markę państwa, mogłyby być znacząco skuteczniejsze w wyprawowaniu swojej własnej podmiotowości na światowych rynkach.

Dlatego na drodze do osiągnięcia sukcesu gospodarczego na kolejnym etapie transformacji gospodarczej przynajmniej trzy wyzwania stają się kluczowe, aby w efekcie uniknąć pułapki średniego dochodu:

- zwiększyć nie tylko skalę, ale przede wszystkim produktywność wydatków badawczo-rozwojowych;

- umożliwić komercjalizację wytworzonych innowacji pod własnymi markami, przeskakując na wyższą pozycję w światowym łańcuchu tworzenia wartości dodanej;

- wesprzeć indywidualne wysiłki pojedynczych firm spójną komunikacją państwa jako całości.

Zanim odpowiemy na te wyzwania, warto podkreślić, że dobra polityka gospodarcza nie musi mieć charakteru alternatywy, ale raczej - koniunkcji. Transparentne instytucje, proste regulacje, wzmocnienie systemowych fundamentów gospodarki są warunkiem niezbędnym sukcesu gospodarczego. Jak bowiem zaznaczyli, w swej pasjonującej książce, D. Acemoglu i J.A. Robinson (2013), to z połączenia mechanizmów, które wspierają udział w życiu gospodarczym wszystkich obywateli na równych 
zasadach, co nazwali instytucjami inkluzyjnymi, ze specyficzną ścieżką historyczną danego kraju rodzi się długookresowy sukces gospodarczy. Taki, który faworyzuje przedsiębiorczość i innowacje, daje miejsce na kreatywną destrukcję, nie usztywnia, ale umożliwia zastępowanie starych branż nowymi. Taki, który nie uprzywilejowuje żadnej konkretnej grupy, dając jej przewagę, której obrona może włączać poszukiwanie renty politycznej. Jak pokazał również Olson (1987), mała i zorganizowana grupa będzie bardziej skuteczna w lobbowaniu swoich celów i w efekcie może zdominować model wzrostu, w swoim interesie zamykając kraj w pułapce niewykorzystania pełnego potencjału na długie lata.

$\mathrm{Z}$ pewnością w polskiej gospodarce jest przestrzeń do dalszego obniżania kosztów transakcyjnych zarówno w twardej infrastrukturze, jak i w zakresie jakości instytucji. Niezbędna jest reforma sądownictwa, ograniczenie sztywności biurokratycznych i zwiększenie prawnej pewności prowadzenia działalności gospodarczej. Dalszy rozwój infrastruktury transportowej, włączając transport rzeczny i intermodalny, modernizacja sieci kolejowych to wyzwania już zidentyfikowane i wspierane środkami Unii Europejskiej. Zbyt duże rozwarstwienie może być przeciwskuteczne, dlatego niezbędne jest stałe wyrównywanie nierówności społecznych i terytorialnych, które mogą utrudniać osiągnięcie optymalnego poziomu rozwoju gospodarczego.

Jednak zakres dalszych zmian systemowych i horyzontalnych, jakkolwiek bardzo znaczący, nie może odpowiedzieć na fundamentalne wyzwania związane z przeskoczeniem od kraju efektywnego producenta do kraju innowacyjnego sukcesu. Nie można spodziewać się wystąpienia kolejnego przełomu, którego pozytywne skutki dla gospodarki mogłyby być porównywalne z efektem wejścia do Unii Europejskiej.

Co więcej, rozszerzenie granic rynku, jakikolwiek by on nie był, prowadzi do redefinicji usytuowania centrum i peryferii. Każda integracja niesie za sobą wyzwanie zachowania spójności całej przestrzeni. Niepodjęcie obecnie działań mających na celu zmniejszenie różnic rozwojowych pomiędzy Polską a bogatszymi krajami Europy Zachodniej może, dla takiego kraju jak Polska, w dłuższej perspektywie doprowadzić do negatywnej spirali pogłębiania się modelu peryferyjnego. Brak możliwości rozwojowych, pułapka średniego dochodu będą zniechęcały najbardziej utalentowanych i przedsiębiorczych do zainwestowania swojej przyszłości w kraj, który nie daje im pełnej szansy do wyrażenia swojego talentu, w efekcie będą emigrować do krajów centrum. Odpływ ponad 1 miliona młodych ludzi to jeden z najbardziej dotkliwych efektów ubocznych wejścia Polski do Unii Europejskiej. Jeżeli będzie kontynuowany, peryferyjność stanie się samospełniającą przepowiednią.

Wydaje się, że Nowa Ekonomia Strukturalna, zdefiniowana przez Justina Yifu Lina (2017), dostarcza dobrej podstawy teoretycznej do refleksji na temat ewolucji polskiej polityki gospodarczej. Może być uzupełnieniem do wymienionych działań o charakterze horyzontalnym i instytucjonalnym, ale również całkiem nowego i świeżego spojrzenia na rolę państwa w gospodarce. Poprzez skoncentrowanie wysiłku na wypromowaniu branż o ukrytych przewagach konkurencyjnych możliwe jest wzniesienie kraju na kolejny poziom rozwoju gospodarczego. 
Według mnie odpowiedzią na wymienione trzy wyzwania jest zatem uzupełnienie prowadzonej polityki gospodarczej o komponent branżowy i postawienie na te, które mogą połączyć obecność ukrytych przewag konkurencyjnych ze znaczącymi korzyściami związanymi z ich rozwojem. Niezbędne jest wskazanie konkretnych celów, gdyż, jak pisze Chorowski (2016), „Doświadczenia historyczne oraz współczesne państw-liderów innowacyjności wskazują, że nowoczesność osiąga się poprzez właściwe zdefiniowanie wymagających nowych technologii celów strategicznych Państwa i następnie stworzenie warunków ich realizacji. Cele strategiczne powinny uwzględniać uwarunkowania geopolityczne, możliwości technologiczne, zasoby naturalne, potrzeby państw ościennych". Nośnikiem tych celów mogą być konkretne branże i osiągnięcie w nich określonej przewagi albo ustalonego wyniku.

Odnosząc się raz jeszcze do wymienionych na początku tego fragmentu wyzwań, postawienie w polityce gospodarczej na konkretną branżę pozwala na:

- skoncentrowanie wydatków badawczo-rozwojowych na konkretnym celu, a zatem w perspektywie zwiększenie ich produktywności;

- uruchomienie awansu krajowych przedsiębiorstw w światowym łańcuchu tworzenia wartości dodanej, gdzie skuteczni pionierzy zbudują globalną rozpoznawalność (markę), wspierając z czasem emancypację i rozwój swoich poddostawców;

- a w efekcie poprzez efekt kuli śnieżnej i aktywną politykę promocyjną państwa może udać się osiągnąć synergię pomiędzy wizerunkiem kraju i konkurencyjnością konkretnej branży.

Moim zdaniem, jedną z najciekawszych i najbardziej perspektywicznych opcji dla Polski jest rozwój samochodu elektrycznego i związanej z nim nowej branży na skalę globalną - przemysłu elektromobilności.

\section{Samochody elektryczne i przemysł elektromobilności w Polsce - dlaczego?}

Argumenty przemawiające na rzecz podjęcia projektu samochodu elektrycznego można podzielić na trzy grupy. Po pierwsze, pokazujące, że jest to branża o ukrytych przewagach konkurencyjnych. Po drugie, że może to być szybko rozwijająca się globalna branża przyszłości, a zatem warto skoncentrować na niej siły i środki. I wreszcie po trzecie, że jej rozwój będzie miał korzystny wpływ na całokształt sytuacji gospodarczo-politycznej kraju. Szczęśliwie i zapewne nieco wyjątkowo się składa, że samochód elektryczny kumuluje wszystkie te trzy grupy argumentów, co zostało po raz pierwszy szerzej opisane w książce pt. New Electricity and New Cars napisanej przez autora wspólnie z Leszkiem Jesieniem (Jesień i Kurtyka, 2016).

Znakomita większość komponentów do produkcji samochodów elektrycznych znajduje się już w Polsce. Działa tu ponad 1000 poddostawców i kooperantów trady- 
cyjnego przemysłu samochodowego. Ponad 100 tys. pracowników wytwarza eksport na poziomie prawie 20 miliardów euro. Roczna produkcja pojazdów osobowych sięga 522 tys., dostawczych i specjalnych - 122 tys., a autobusów - 5,5 tys. Szczególnie te ostatnie są ciekawe z punktu widzenia tworzenia przemysłu elektromobilności. Polska stała się jednym z europejskich zagłębi produkcji autobusów - ulokowali tutaj swoją produkcję Volvo, Man i oczywiście polscy producenci, tacy jak Solaris, Ursus, Autosan czy Solbus. Polscy producenci autobusów stosunkowo wcześnie postawili na elektryfikację, a zbiorowy transport publiczny dobrze spełnia warunki wczesnego przejścia z diesla na elektryczność. Działają pierwsze polskie przedsiębiorstwa na skalę globalną produkujące zelektryfikowane środki transportu, takie jak wspomniany wielkopolski Solaris od lat posiadający $10 \%$ udział w rynku niemieckim czy bydgoska Pesa. Zwłaszcza pionierskie zaangażowanie firmy Solaris od początku lat $2000 \mathrm{w}$ rozwój elektromobilności zaowocowało laurem europejskiego autobusu roku 2017 przyznanego konstrukcji Urbino electric. Za wymienionymi przedsiębiorstwami wytworzył się cały łańcuch wytwórczy, wyspecjalizowany w komponentach i infrastrukturze elektrycznych autobusów (zob. http://www.me.gov.pl/ node/26719).

Można dodać, iż w Polsce tradycyjnie silnie rozbudowane są przemysł i wykształcone kompetencje elektromaszynowe i elektryczne kluczowe dla przemysłu elektromobilności w przyszłości. Jak pokazuje przykład Tesli, samochód elektryczny również zogniskował uwagę producentów software’u i hardware’u („komputer na kółkach”), Polska zaś jako kraj o bardzo silnie rozwiniętych kompetencjach w zakresie IT może stanowić dobre zaplecze dla ich rozwoju.

Jednocześnie jednak w Polsce nie działa żaden znaczący rodzimy producent samochodowy. Nieco paradoksalnie argument ten przemawia na korzyść tworzenia nowego przemysłu samochodów elektrycznych, gdyż nie ma żadnych zaszłości ani utopionych kosztów, które wiązałyby krajowe firmy z know-how tradycyjnego silnika spalinowego. Tymczasem, np. zakumulowane w tej ostatniej technologii przez ostatnie 100 lat wiedza i umiejętności inżynierskie stanowią poważne wyzwanie dla niemieckich producentów motoryzacyjnych, dla których zbyt pośpieszne przejście na nowe technologie wiązać się będzie ze znaczącymi kosztami. Dla polskich przedsiębiorstw zaangażowanie w elektromobilność otwiera prawdziwy „błękitny ocean”: nową perspektywę z mniejszą ilością naturalnych konkurentów niż w przypadku „czerwonego oceanu” tradycyjnego przemysłu motoryzacyjnego.

Wiele również wskazuje, że elektromobilność będzie szybko rosnącą branżą przyszłości. Jak podaje np. Bloomberg, w 2040 roku co czwarty samochód na świecie będzie elektryczny, otwiera to w perspektywie rynek dla 500 milionów pojazdów. Według nieco bardziej zachowawczej prognozy Międzynarodowej Agencji Energii w 2030 roku na drogach będzie poruszało się przynajmniej 150 milionów takich pojazdów.

Spośród dziesięciu najbardziej innowacyjnych przedsiębiorstw świata trzy kolejne zaangażowały się w projekty związane $\mathrm{z}$ rozwojem samochodów elektrycznych 
(Apple, Google, Tesla), co stanowi dobry prognostyk na upowszechnienie i rozwój tych pojazdów i technologii.

Samochód elektryczny jest znacznie prostszy w produkcji i utrzymaniu niż klasyczny samochód spalinowy. Na jego wyprodukowanie składa się około 1000 części, na tradycyjny zaś ok. 3500. Ze względu na mniejszą złożoność jest on również około $20 \%$ mniej awaryjny, co powinno przełożyć się na jego atrakcyjność dla użytkowników.

Na koniec zaś, upowszechnienie samochodów elektrycznych to znacząca i wielowymiarowa szansa dla społeczeństwa i gospodarki polskiej.

Samochód elektryczny i rozwój powiązanej z nim infrastruktury stanowią szansę i bodziec do modernizacji polskiego systemu elektroenergetycznego oraz możliwość produktywnego wykorzystania tzw. doliny nocnej. Poprzez potencjalną możliwość magazynowania, jaką oferuje samochód elektryczny, może on stanowić również istotny element stabilizacji systemu energetycznego w przyszłości, gdy rosnącą rolę w systemach europejskich będą odgrywać źródła niestabilne, takie jak moce wiatrowe i solarne. Daje również szansę na zwiększenie rentowności źródeł konwencjonalnych ze względu na potencjał niewykorzystanej produkcji energii w godzinach nocnych (tzw. dolina nocna). Osiągnięcie 1 miliona samochodów elektrycznych ${ }^{3}$ w horyzoncie 2025 roku odpowiadające obecnie ilości 5\% samochodów w Polsce daje możliwość magazynowania ok. 10\% dobowego zużycia energii w kraju oraz zwiększenia produkcji energii elektrycznej o 4-5 TWh.

Elektryfikacja transportu stopniowo prowadzi do ograniczenia zależności od importu ropy naftowej, a potencjalnie zależność tę eliminuje. W latach 2000-2015 Polska wydawała średniorocznie 2,15\% swojego PKB na import ropy naftowej. Suma ta obciąża bilans handlu zagranicznego polskiej gospodarki, podczas gdy elektryfikacja transportu pozwoli zachować część tych środków w kraju.

Co bardzo istotne, pojazdy elektryczne ograniczają szkodliwość środowiskową transportu i przyczyniają się do podniesienia jakości życia miejskiego. W polskich warunkach ogromne znaczenie samochodu elektrycznego polega na potencjale radykalnej poprawy jakości powietrza w miastach, w których nawet $60 \%$ zanieczyszczeń (Warszawa) pochodzi z transportu samochodowego. Miasta, gdzie powietrze zanieczyszczone jest najbardziej (np. Kraków, Warszawa, Aglomeracja Śląska) już wykazały zainteresowanie ich upowszechnieniem. Co więcej, samochód elektryczny jako uzupełnienie transportu publicznego (co pokazuje np. przykład Autolib w Paryżu) może być traktowany jako sposób na zmniejszenie uciążliwości parkowania, wpisuje się w nowy trend bardziej okazjonalnej konsumpcji samochodu.

Z puntu widzenia spójności polityki gospodarczej, skoncentrowanie wysiłków na upowszechnieniu pojazdu elektrycznego to czytelny sygnał dla uczestników życia gospodarczego, który:

Dla porównania w Polsce funkcjonuje około 2,5 miliona samochodów na LPG, co odpowiada jednej z największych flot w Europie i na świecie, a wynika wyłącznie ze stabilności regulacji podatkowych faworyzujących to paliwo kosztem tradycyjnych. 
- daje impuls rozwojowy dla całej gałęzi przemysłu samochodowego i pozwala na intensywny rozwój poddostawców, dając im okazję do budowy samodzielnych marek oraz nowych sieci kooperacyjnych;

- pozwala na skoncentrowanie badań i rozwoju $(\mathrm{R} \& D)$ na najbardziej przyszłościowych technologiach: magazynowaniu energii, sterowaniu sieciami transportowymi (w tym na samochodach samosterujących) oraz automatyzacji procesów produkcyjnych;

- pozwala na ukierunkowanie inwestycji publicznych, podejmowanych przez samorządy lokalne i władze centralne: budowę sieci dystrybucji prądu i ładowania samochodów elektrycznych; zakup samochodów i autobusów do transportu miejskiego i użytku własnego władz publicznych jako krok do naśladowania i uruchomienie koła napędowego rozwoju projektu; wsparcie przedsięwzięć okołoprojektowych, np. budowy sieci kooperantów i klastrów przemysłowych, ośrodków innowacji i inkubatorów start-upów, propagowanie idei transportu elektrycznego.

Podsumowując, samochód elektryczny i rozwój przemysłu elektromobilności to projekt, który pozwoliłby Polsce przeskoczyć na nowy etap rozwoju technologicznego, podnieść obecnych podwykonawców przemysłu motoryzacyjnego na wyższy poziom łańcucha tworzenia wartości dodanej, a może nawet wejść na rynek masowej produkcji samochodów z pominięciem jego fazy opartej na silnikach spalinowych. Daje szansę na przeskoczenie etapu rozwoju technologii i wyprzedzenie tradycyjnych producentów i centrów produkcji wyspecjalizowanych w silnikach poprzedniej generacji, z której rezygnacja jest dla nich kosztowna, a rozwój i promocja nowego standardu nosi znamiona kanibalizacji własnych kompetencji i rynków.

Ponieważ w wielu krajach elektryczny samochód staje się ikoną nowoczesności, połączeniem innowacji technologicznej i troski o otoczenie, może on stać się wizytówką kolejnej fazy transformacji, innowacyjnej reindustrializacji Polski. Własne marki samochodowe to również element narodowej dumy i tożsamości i dobra promocja kraju za granicą.

\section{Program Rozwoju Elektromobilności jako polityka branżowa}

W efekcie przeprowadzonej diagnozy rząd przyjął do realizacji Plan Rozwoju Elektromobilności (www.me.gov.pl), który zakłada całościową koordynację działań nakierowanych na rozwój przemysłu elektromobilności i upowszechnienie pojazdów elektrycznych w Polsce w ramach kompleksowego programu. Jego cele to: (1) upowszechnienie pojazdów elektrycznych i osiągnięcie poziomu 1 miliona pojazdów w 2025 roku; (2) rozbudowa polskiego przemysłu elektromobilności oraz (3) przygotowanie sieci elektroenergetycznej do zabezpieczenia zapotrzebowania na 
moc, jaką pociągnie za sobą potrzeba ładowania pojazdów elektrycznych, zwłaszcza w centrach miast.

Przewidziano zaangażowanie wszystkich agend rządowych w koordynację prac oraz powstanie Komitetu Sterującego Programem Elektromobilności. Realizacja Programu koncentruje się wokół pięciu obszarów działania: przemysłu, rynku, akceptacji, infrastruktury, regulacji.

Jak już wspomniano, jednym z ważnych celów Programu jest stymulowanie produkcji pojazdów elektrycznych i ich komponentów z wysokim udziałem wartości dodanej wytworzonej w Polsce oraz wykreowanie przy tej okazji polskich producentów. Dlatego też przewidziano powstanie całościowego ekosystemu elektromobilności: od działalności wdrożeniowo-badawczej, poprzez zbudowanie sieci kooperacyjnych, aż po wykreowanie innowacyjnych modeli transportu oraz powstanie fabryk pojazdów i kluczowych komponentów.

Ważnym elementem programu jest stopniowe uruchomienie zapotrzebowania na pojazdy elektryczne w Polsce. Optymalne dozowanie i koordynacja wsparcia finansowego wraz z budowaniem korzyści dla użytkowników pojazdów elektrycznych są w tym względzie kluczowe. Szczególnymi instrumentami działania są zwolnienie z akcyzy, zagwarantowanie środków finansowych na dopłaty poprzez stworzenie dedykowanego Funduszu Niskoemisyjnego Transportu, wprowadzenie podwyższonych odpisów amortyzacyjnych, wprowadzenie stref niskoemisyjnych w miastach, wprowadzenie minimalnego udziału autobusów elektrycznych w transporcie miejskim i pojazdów elektrycznych we flotach komunalnych i w administracji.

Zbudowanie społecznej akceptacji dla pojazdów elektrycznych i wypromowanie elektromobilności są niezbędne dla powodzenia przedsięwzięcia. Newralgiczną rolę odgrywają w szczególności mieszkańcy aglomeracji miejskich, dla których mały miejski samochód elektryczny jest dopasowany do profilu potrzeb (przeciętny użytkownik korzysta z samochodu jedynie 23 kilometry dziennie), stanowi odpowiedź na problem hałasu i niskiej emisji, jest idealnym drugim pojazdem w rodzinie. Konieczne jest stworzenie dedykowanych programów pilotażowych pełniących jednocześnie rolę edukacyjną i promocyjną dla elektromobilności. Zbudowanie społecznej akceptacji dla pojazdów elektrycznych jest również okazją do wypromowania współpracy pomiędzy nauką, biznesem, administracją i samorządami.

Powstanie infrastruktury oraz stworzenie rynku ładowania pojazdów elektrycznych są warunkami sine qua non sukcesu programu. W pierwszej fazie programu koniecznie jest aktywne zaangażowanie państwa w powstanie infrastruktury ładowania, które uwiarygodni pojazd elektryczny jako realistyczną alternatywę dla istniejących pojazdów spalinowych, charakteryzujących się w dalszym ciągu większym zasięgiem i krótszym czasem tankowania. Po tej pierwszej fazie zakłada się, że priorytetem powinno być zassanie popytu na pojazdy elektryczne, który pokieruje rozwojem infrastruktury, aby uniknąć błędnej alokacji infrastruktury ładowania i nietrafionego wydatkowania środków publicznych. Konieczne będzie upowszechnienie 
możliwości ładowania pojazdów elektrycznych w istniejących i nowych budynkach, również poprzez nowe standardy budowlane.

Rozwój transportu opartego na pojazdach elektrycznych wymaga kompleksowego dostosowania legislacji. Konieczne jest dostosowanie prawa energetycznego, budowlanego i środowiskowego. Zostaną stworzone ramy prawne dla powstania rynku ładowania i ewentualnych innych działalności towarzyszących, przy stopniowym zawężaniu roli państwa do ograniczenia niepotrzebnego dublowania się działań operatorów rynkowych. Niezbędne jest uruchomienie inicjatyw w zakresie finansowania w wymiarze zarówno systemowym, jak i programów pilotażowych.

Realizacja Planu Rozwoju Elektromobilności przewidziana jest na trzech etapach, które różnicować będzie poziom rozwoju rynku i wymagana w związku z tym intensywność i zakres zaangażowania państwa w jego stymulowanie.

Pierwsza faza ma charakter przygotowawczy. Rozpoczęła się w 2017 roku i ma trwać do 2018 roku. W jej ramach zostaną wdrożone m.in. programy pilotażowe, które skierują zainteresowanie społeczne na elektromobilność oraz stworzone będą warunki rozwoju elektromobilności po stronie regulacyjnej. Wzmocnieniu ulegną zachęty dla samorządów do opracowywania koncepcji rozwoju transportu publicznego, które mają obejmować stopniową elektryfikację kołowego transportu zbiorowego i indywidualnego.

W drugiej fazie (2019-2020), w kluczowych aglomeracjach, zostanie zbudowana infrastruktura zasilania pojazdów elektrycznych i zintensyfikowane zachęty do zakupu samochodów elektrycznych, co będzie skorelowane ze stopniem rozwoju przemysłu elektromobilności. Oczekiwana jest komercjalizacja wyników badań z obszaru elektromobilności rozpoczętych w fazie I oraz wdrożenie nowych modeli biznesowych upowszechnienia pojazdów elektrycznych.

Zakłada się, że w trzeciej fazie (2020-2025) coraz większa popularność pojazdów elektrycznych w gospodarstwach domowych i w transporcie publicznym doprowadzi do wykreowania mody na ekologiczny transport, co w sposób naturalny będzie stymulować popyt. Dodatkowym czynnikiem propopytowym będzie zbudowana infrastruktura ładowania. Sieć będzie w pełni przygotowana na dostarczenie energii dla 1 mln pojazdów elektrycznych i dostosowana do wykorzystania pojazdów jako stabilizatorów systemu elektroenergetycznego. Administracja będzie wykorzystywać pojazdy elektryczne w swoich flotach. Polski przemysł będzie wytwarzał wysokiej jakości podzespoły na potrzeby elektromobilności, a zarejestrowane w Polsce pojazdy elektryczne będą miały wysoki udział podzespołów wytworzonych w naszym kraju.

Niewątpliwie postawienie akcentu na rozwój takich, a nie innych konkretnych branż nie jest wolne od ryzyka. Po pierwsze, wybór może okazać się nietrafiony. Albo kraj - wbrew początkowej diagnozie - nie posiada wystarczającego potencjału w danej branży, albo też jej rozwój będzie przebiegał szybciej w innych krajach, 
przez co uzyskany poziom przewagi konkurencyjnej okaże się relatywnie mniejszy od innych, a może nawet nie uzasadni poniesionego wysiłku.

Po drugie, każda koncentracja zaangażowania publicznego na precyzyjnym celu i konkretnej grupie niesie za sobą ryzyko polityczne. Uprzywilejowanie określonych produktów, a w efekcie konkretnych producentów może skłaniać ich do poszukiwania renty politycznej, aby na trwałe zawłaszczyć owoce polityki rozwojowej na rzecz wąskiej grupy interesu. Ewentualne fiasko projektu może nieść za sobą negatywne skutki dla promotorów politycznych projektu, łącznie z sankcją ze strony wyborców.

Po trzecie wreszcie, i być może najważniejsze, dobra diagnoza nie przesądza o skuteczności polityki gospodarczej. Jak pokazał A.Z. Nowak (2017), w Polsce miały miejsce już co najmniej trzy próby zdefiniowania całościowej koncepcji rozwoju gospodarczego. W dwóch przypadkach na trzy, pomimo relatywnej spoistości postulatów, nie udało się ich w praktyce osadzić w konkretnych instrumentach wdrożeniowych. Sterowanie procesami rozwojowymi wymaga spójnej koordynacji działań wielu agend rządowych w wystarczająco długim okresie.

Jednak w tak pojemnej dziedzinie, jak upowszechnienie transportu elektrycznego, wydaje się, że zbyt dużo argumentów przemawia na korzyść zaangażowania publicznego. Korzyści są wielowymiarowe, ich horyzont pojawiania się bardzo różnorodny i nawet jeśli nie zmaterializują swojego potencjału w każdym z wymiarów ani w szybkim tempie, będą one znaczące.

\section{Podsumowanie - elektromobilność jako perspektywiczna branża i szansa na wyrwanie z pułapki średniego dochodu}

Po dwudziestu pięciu latach od uruchomienia transformacji politycznej i gospodarczej w Polsce przyszedł czas na analizę dotychczasowych źródeł sukcesów i przyczyn niepowodzeń. Wiele wskazuje, że dotychczasowy model rozwoju gospodarczego opierał się na stopniowym wycofywaniu państwa z gospodarki. Miało to uzasadnienie w jednoczesnym niedowładzie i przeroście centralnie sterowanej gospodarki, jaka dominowała do 1989 roku. Było również efektem przyjętej filozofii, niechętnie upatrującej w państwie potencjału na pomnażanie wartości oraz globalnym trendom do liberalizacji i deregulacji zachodzącym wtedy również w Unii Europejskiej.

Podnoszenie jakości instytucji rynkowych oraz poszerzanie ich inkluzyjnego charakteru są niewątpliwie podstawami dla dalszego sukcesu gospodarczego Polski. Jednak przykłady najbardziej zaawansowanych gospodarek na świecie pokazują, że szeroko rozumiane państwo może mieć wymierny wkład w sukces branż tworzących relatywnie największa wartość dodaną. Nie byłoby lądowania na księżycu, Internetu, Doliny Krzemowej, telefonii komórkowej, iPhona bez aktywnej roli państwa w gospodarce (Mazzucato, 2016). Dalszy rozwój gospodarczy Polski, a szczególnie przełamanie „szklanego sufitu” gospodarki imitacyjnej (nawet o najwyższej 
produktywności) i przeobrażenie się w gospodarkę zdolną do kreacji nowych idei, a następnie ich globalnej komercjalizacji wymaga zaangażowania państwa w rozwój konkretnych, perspektywicznych branż.

Rozwój przemysłu elektromobilności może być dla Polski jedną z tych perspektywicznych branż, która pozwoli krajowi na wydobycie się z pułapki średniego rozwoju. Poprzez skoncentrowanie sił, jakie są do dyspozycji państwa, w tym środków na badania, rozwój, innowacyjność na konkretny cel nawet stosunkowo szczupłe na skalę globalną zasoby mogą dać pożądany efekt wykreowania innowacyjnego i konkurencyjnego przemysłu. Dzięki współzależności pomiędzy transportem elektrycznym i elektroenergetyką, samochód elektryczny może stać się dźwignią dla rozwoju wielu nowych modeli biznesowych i technologii, takich jak magazynowanie energii lub transport autonomiczny.

Upowszechnienie pojazdów elektrycznych w kraju, jako jeden z warunków rozwoju branży elektromobilnej, nie byłby możliwy bez aktywnego zaangażowania państwa. W sferze regulacyjnej wymagane jest zdefiniowanie nowego rynku i stworzenie warunków sprzyjających pionierom do testowania nowych rozwiązań. Niezbędne jest również stworzenie wystarczającej infrastruktury do ładowania pojazdów elektrycznych uwiarygadniającej ich powszechne stosowanie. Poprzez swoje zaangażowanie państwo pozwala wydobyć się z dylematu ,jajko czy kura” - musi bowiem istnieć wystarczający poziom infrastruktury dla umasowienia pojazdów elektrycznych, nieosiągnięcie zaś tego punktu spowoduje fiasko całego projektu. A zważywszy na wielkość wyzwania mało jest podmiotów, jak np. Tesla w Stanach Zjednoczonych czy też na mniejszą skalę Autolib w Paryżu, zdolnych podźwignąć obydwa wyzwania jednocześnie - budowy pojazdów i infrastruktury ich ładowania. Choć w obydwu wymienionych przypadkach, należałoby dodać, sukces nie mógł obyć się bez zaangażowanego udziału strony publicznej.

W efekcie elektromobilność jest dobrym przykładem na potencjał synergii pomiędzy sektorem prywatnym i publicznym. Może mieć również charakter prekursorski i testować przeformułowanie sposobu prowadzenia polityki gospodarczej z nastawionej na horyzontalne i systemowe wsparcie na ukierunkowaną na konkretny efekt i wybraną branżę przemysłową. Wreszcie, ze względu na promocję kraju i jego utożsamienie z konkretnymi branżami, rozwój elektromobilności może być atrakcyjny dla takiego kraju, jak Polska oraz dla wielu już istniejących polskich przedsiębiorstw.

\section{Bibliografia}

Acemoglu, D. i Robinson, J.A. (2013). Why Nations Fail. The Origins Of Power, Prosperity and Poverty. CPI Group, Croydon.

Bank Światowy. (2017). Bank Światowy: polska gospodarka przyspiesza. Komunikat prasowy, 20 kwietnia. Pozyskano z: http://www.worldbank.org/pl/news/press-release/2017/04/20/ poland-economic-growth-accelerates-says-world-bank. 
Chorowski, M. (2016). Modernizacje. Polski projekt. Teologia Polityczna Co Tydzień, 23. Pozyskano z: http://www.teologiapolityczna.pl/maciej-chorowski-czy-plan-na-rzeczodpowiedzialnego-rozwoju-moze-stac-sie-zaczynem-innowacyjnej-gospodarki-w-polscetpct-23-.

Cipiur, J. (2017). Polska z największym w OECD i Europie wzrostem PKB na mieszkańca. Obserwator Finansowy, 22 marca. Pozyskano z: https://www.obserwatorfinansowy. $\mathrm{pl} /$ tematyka/makroekonomia/polska-z-najwiekszym-w-oecd-i-europie-wzrostem-pkb-naglowe-mieszkanca/.

Eurostat. (2017). Pozyskano z: http://ec.europa.eu/eurostat/web/main.

GUS. (2014). Polska w Unii Europejskiej 2004-2014. Warszawa: GUS.

Jesień, L. i Kurtyka, M. (2016). New Electricity And New Cars. Warszawa: Wydawnictwo CeDeWu.

Koryś, P. (2015). Zatrudnienie w Polsce 2014. Praca czasu innowacji. Polska uprzemystowiona na nowo. Prezentacja przedstawiona na Wydziale Nauk Ekonomicznych UW, 16 listopada. Warszawa: Warszawski Instytut Studiów Ekonomicznych. Pozyskano z: http://wise-europa. eu/wp-content/uploads/2016/04/ZWP-2014-cz-II.pdf.

Lin, J.Y. (2017). Nowa Ekonomia Strukturalna dla gospodarek doganiających. W: J.Y. Lin, A.Z. Nowak (red.), Nowa Ekonomia Strukturalna wobec krajów mniej zaawansowanych. Warszawa: Wydawnictwa Naukowe Wydziału Zarządzania UW.

Mazzucato, M. (2016). Przedsiębiorcze państwo. Warszawa: Wydawnictwo Ekonomiczne Hetorodox.

Ministerstwo Rozwoju. (2017). Handel zagraniczny Polski w 2016 r. Warszawa: Ministerstwo Rozwoju. Pozyskano z: https://www.mr.gov.pl/strony/aktualnosci/handel-zagraniczny-polski-w-2016-r/.

Nowak, A.Z. (2017). Nowa Ekonomia Strukturalna a dylematy rozwoju polskiej gospodarki. W: J.Y. Lin, A.Z. Nowak (red.), Nowa Ekonomia Strukturalna wobec krajów mniej zaawansowanych. Warszawa: Wydawnictwa Naukowe Wydziału Zarządzania UW.

OECD. (2012). Małe i średnie przedsiębiorstwa oraz polityka przedsiębiorczości w Polsce. Przeglad OECD. Warszawa: OECD i Ministerstwo Gospodarki,.

OECD. (2017). Pozyskano z: https://data.oecd.org/poland.htm.

Olson, M. (1987). Logique de l'action collective. Paris: PUF.

Orłowski, W. (2010). W pogoni za straconym czasem. Wzrost gospodarczy w Europie Środkowo-Wschodniej w latach 1950-2030. Warszawa: PWE.

Orłowski, W. (2015). Czy Polska dogoni Niemcy. Warszawa: PWN.

Sopoćko, A. (2017). Przewaga komparatywna. Stan czy proces. W: J.Y. Lin, A.Z. Nowak (red.), Nowa Ekonomia Strukturalna wobec krajów mniej zaawansowanych. Warszawa: Wydawnictwa Naukowe Wydziału Zarządzania UW. 


\title{
Wybrane koncepcje rozwoju \\ a Nowa Ekonomia Strukturalna. Wnioski dla elektromobilności w Polsce ${ }^{1}$
}

\begin{abstract}
Dorobek ekonomii zapewnia różnorodną gamę teorii, koncepcji i wyników badań empirycznych wykorzystywanych do odpowiedzi na pytanie o czynniki rozwoju i sukcesu gospodarek. Nowa Ekonomia Strukturalna (NES), odwołując się do dorobku teorii wzrostu, teorii konwergencji, ekonomii instytucjonalnej oraz integrując podejście makro- i mikroekonomiczne wielu innych spojrzeń, oferuje obiecujące rekomendacje dla gospodarki na każdym poziomie rozwoju.

Celem poniższego artykułu nie jest bezpośrednia dyskusja z założeniami Nowej Ekonomii Strukturalnej, ale wskazanie jej jako komplementarnej względem kilku innych koncepcji, jak pułapka średniego poziomu rozwoju, inwestycyjna ścieżka rozwoju kraju oraz krzywa dywersyfikacji. Wykorzystując wnioski z wyżej wymienionych nurtów, dokonano również próby oceny rozwoju rynku elektromobilności w Polsce w kontekście podjętych działań publicznych, które uczynily z niego priorytet polityki gospodarczej.
\end{abstract}

Słowa kluczowe: Nowa Ekonomia Strukturalna, pułapka średniego poziomu rozwoju, dywersyfikacja, BIZ, elektromobilność.

\section{Wprowadzenie}

Problem z wykorzystaniem dorobku ekonomii w rozwiązywaniu praktycznych dylematów polityki gospodarczej polega często na tym, że ekonomiści w swoich dociekaniach docierają do punktu, w którym przedstawiają jedynie rekomendacje dotyczące tego „co należy zrobić”. Znacznie rzadziej natomiast pochylają się nad problemem ,jak wdrożyć” zalecane rozwiązania i z jakimi komplikacjami może się to wiązać. Wynika to z pewnej koncentracji funkcjonalnej, instytucjonalnej i merytorycznej w obrębie wąskich specjalności, czego przejawem jest relatywnie mały

1 Artykuł powstał w ramach projektu badawczego realizowanego na Wydziale Zarządzania Uniwersytetu Warszawskiego pt. Konkurencyjność eksportowa sektora motoryzacyjnego a rozwój elektromobilności w Polsce. 
przepływ wiedzy pomiędzy nawet bliskimi dziedzinami, jak choćby biznes międzynarodowy i handel międzynarodowy2.

W myśl podejścia rekomendującego „co należy robić” przyjmuje się, że za ostatni fragment implementacji zaleceń dla stymulowania wzrostu odpowiada polityka gospodarcza, która powinna być realizowana przez rząd i instytucje kooperujące. NES, czerpiąc inspirację z dotychczasowego dorobku ekonomii, podkreśla kluczową i jednocześnie wysublimowaną rolę rządu w kształtowaniu polityki makroekonomicznej oraz ewolucji kraju w procesie wzrostu. Wskazuje jednocześnie dość precyzyjnie na instrumenty, po które można sięgać dla skutecznego realizowania polityki gospodarczej (zapewnienie informacji o trendach rynkowych, poszukiwanie liderów i nisz rynkowych, akceleracja biznesów oraz koncentracja i współpraca w ramach klastrów, stref ekonomicznych i parków przemysłowych etc.).

Celem pierwszej części tekstu jest krótkie przedstawienie trzech relatywnie nowych spojrzeń na czynniki rozwoju oraz ewolucję struktur gospodarek w miarę wzrostu PKB per capita i zestawienie ich z założeniami NES. Są to: pułapka średniego poziomu rozwoju, inwestycyjna ścieżka rozwoju oraz krzywa dywersyfikacji eksportu. Choć można zarzucić, że koncepcje te nie mają silnej podbudowy teoretycznej i dobrane są arbitralnie, to jednak mają istotną cechę wspólną. Podejmują ocenę warunków ewolucji pozycji gospodarki w czasie i w porównaniu z innymi krajami.

Celem drugiej części tekstu jest próba spojrzenia na potencjał rozwoju rynku elektromobilności w Polsce w perspektywie omawianych koncepcji. Przemysł samochodowy ma w Polsce długie tradycje i obecnie, mimo że pod względem masy produkcji i eksportu jest znacząco skoncentrowany w rękach inwestorów zagranicznych, stanowi o dużym zasobie zakumulowanej wiedzy, kompetencji, różnorodności krajowych podmiotów oraz przewag lokalizacyjnych. Jednocześnie działania podjęte po stronie administracji rządowej na rzecz rozwoju elektromobilności skłaniają do refleksji i oceny perspektyw tego rynku w Polsce.

2 W świetle założeń International Business już od lat 70. XX w. podkreślano rolę kosztów transakcyjnych oraz wydajności i wielkości firmy w ich pokonywaniu, jak również zasobów wewnętrznych decydujących o umiędzynarodowieniu. Tzw. Nowa nowa teoria handlu doprowadziła ekonomistów zajmujących się handlem międzynarodowym do podobnych wniosków dopiero w latach 2000. Do tego momentu w teorii handlu zakładano, że to kraje handlują i konkurują ze sobą, podczas gdy w nowym podejściu uwzględniono założenie, naturalne i oczywiste w biznesie międzynarodowym, że to firmy z poszczególnych krajów handlują ze sobą. Podmioty te są jednocześnie bardzo zróżnicowane pod względem wielu cech i zasobów, co powoduje, że tylko nieliczne spośród nich mogą eksportować. Upowszechnienie takiego spojrzenia mogło się dokonać w badaniach dotyczących handlu dopiero, kiedy możliwe stało się ich przeprowadzenie na danych jednostkowych firm. Ogólne wnioski formułowane na bazie tzw. Nowej nowej teorii handlu nie różnią się przy tym znacząco od wniosków formułowanych w podejściu menedżerskim 2-3 dekady wcześniej. 


\section{Ewolucyjne koncepcje spojrzenia na gospodarkę a NES}

\subsection{Pułapka średniego poziomu rozwoju}

Pojęcie „pułapka średniego poziomu rozwoju”, występujące również pod pokrewnymi określeniami, budzi wśród ekonomistów pewne kontrowersje, a część spośród nich wskazuje, że jest to tylko atrakcyjny sposób nazwania problemów i dylematów, z którymi ekonomia wzrostu i rozwoju gospodarczego zmaga się od dawna (szerzej: Wojtyna, 2016, s. 5-22).

W debacie ekonomicznej pojęcie „pułapki średniego poziomu dochodu” upowszechnili I.S. Gill i H. Kharas (2007), którzy sugerują że „gospodarki o średnim poziomie dochodu mogą znaleźć się pomiędzy gospodarkami o niskich dochodach, konkurujących tanią siłą roboczą, a gospodarkami o wysokich dochodach, z przewagami konkurencyjnymi w innowacyjnych branżach". Pojęcie to obejmuje swoim zasięgiem takie propozycje, jak „pułapka imitacji” (Agénor i inni, 2012) czy „pułapka braku konwergencji” (Aghion i Howitt, 2009).

Jak wskazuje A. Wojtyna (2016), Gill i Kharas (2015) zaprezentowali podsumowanie dyskusji wokół pojęcia pułapki, wyodrębniając trzy szerokie jej znaczenia, czyli:

- „błędną diagnozę w ustalaniu strategii wzrostu kraju odpowiadającej strukturalnym cechom gospodarki, trwanie przy strategii wzrostu opartej na eksporcie pracochłonnych towarów przemysłowych, mimo utraty przewagi konkurencyjnej w wyniku wzrostu płac oraz próbę zbyt wczesnego przeskoczenia do gospodarki opartej na wiedzy mimo braku potrzebnej infrastruktury instytucjonalnej”;

- długi okres przebywania przez dany kraj w określonym przedziale PKB per capita;

- zahamowanie procesu konwergencji w stosunku do określonego kraju wysoko rozwiniętego.

Dyskusja dotycząca pojęcia toczy się wokół czynników mogących prowadzić do ryzyka utknięcia w pułapce oraz poziomu PKB per capita, przy jakim może to nastąpić. Poziom ten zazwyczaj wyznacza się przedziałowo, przy czym propozycje prezentowane w literaturze potwierdzają szeroką definicję pułapki, a za właściwsze wydaje się odniesienie PKB per capita porównywanego kraju w relacji do innego wysokorozwiniętego. Agénor i inni (2012) wyznaczają przedział pułapki w relacji do USA, przyjmując że jest to pomiędzy 5 a $45 \%$ PKB per capita w USA33.

Czynnikami sprzyjającymi utknięciu w pułapce mogą być: słabe wyposażenie w kapitał ludzki i fizyczny (infrastruktura), niesprzyjające otoczenie instytucjonalnoregulacyjne, dominacja sektorów o słabych powiązaniach z innymi sektorami i duży udział dóbr nisko przetworzonych, mała otwartość eksportowa i niska dywersyfikacja

3 Przykładowo, Eichengreen (2011) proponuje przedział 10 000-11 000, a następnie Eichengreen i in. (2013) proponują przedział 15 000-16 000USD PKB per capita (1990 r. wg PPP). 
eksportu, wysoki poziom obciążenia demograficznego, nadmiernie wysokie tempo inwestycji, niedowartościowany kurs walutowy, spadające stopy zwrotu z kapitału oraz wyczerpywanie przewag niskich kosztów pracy i imitacji, brak bodźców dla właściwej alokacji talentów i kwalifikacji, brak dostępu do finansowania (Eichengreen, 2011; Felipe i in., 2012; Agénor, 2016).

NES proponuje kilka działań po stronie polityki gospodarczej mogących zapobiegać bądź obniżać ryzyko pułapki średniego poziomu rozwoju (Lin, 2012):

1) poprzez identyfikację i wsparcie branż o ukrytych przewagach komparatywnych (the latent comparative advantage), które mogą zdynamizować rozwój ekonomiczny kraju; w identyfikacji tej powinien pomóc rząd i jego agendy;

2) poprzez aktywną rolę rządu jako animatora, koordynatora i jeśli trzeba organizatora rynku dla obniżenia kosztów transakcyjnych działalności gospodarczej; dlatego też rząd powinien zadbać o jakość infrastruktury miękkiej (np. kapitał ludzki, wiedzę, doświadczenie i umiejętności - tacit knowlegde) oraz twardej (np. sieć komunikacyjna w postaci dróg, sieć telekomunikacyjna);

3) poprzez pragmatyczną ingerencję rządu w mechanizm rynkowy pozostającą w zgodzie z prawami rynku, ale jednocześnie stwarzanie warunków do konkurencji oraz kooperacji; rząd staje się więc graczem nie tylko kształtującym rynek po stronie bodźców regulacyjnych (głównie podażowych), lecz także popytowych.

W kontekście animacji rynku (ale również stymulowania transferu wiedzy od przychodzących BIZ), NES postuluje już wcześniej sugerowane w literaturze instrumenty, jak wspieranie inteligentnych specjalizacji, regionalnych systemów innowacyjności, obniżanie kosztów transakcyjnych, zapewnienie bliskości podmiotów i ich aglomeracji, budowanie relacji różnych sektorów i aktorów, w tym przedsiębiorstw i nauki (Girma i in., 2015, s. 157-169). Sugeruje sięganie po takie instrumenty, jak strefy ekonomiczne, parki przemysłowe, klastry itp.

Choć można uznać, że polska gospodarka wkroczyła wg PKB per capita w obszar ryzyka utknięcia w pułapce, należy jednak pamiętać, że kraje mogą doświadczać trwałego spowolnienia wzrostu również przy znacząco wyższym PKB na głowę (Japonia, Włochy $)^{4}$ (por. rys. 1). Oznacza to, że w procesie identyfikacji ryzyka pułapki

4 Często cytowanym zestawieniem gospodarek, którym udało się uniknąć pułapki jest dokument Agenor, Canuto i Jelenic (2012, s. 1-7), gdzie wskazuje się, że na 101 krajów o średnim poziomie dochodu per capita w 1960 r. jedynie 13 udało się awansować do grupy krajów o wysokim dochodzie w 2008 r. I choć może to sugerować, że sukces osiągnęły jedynie kraje nadzwyczaj efektywne w zakresie kształtowania swojej polityki makroekonomicznej, to jednak przyjrzenie się poszczególnym krajom zmienia nieco wydźwięk tego zestawienia. Są to Gwinea Równikowa, Grecja, Hongkong, Irlandia, Japonia, Mauritius, Portugalia, Portoryko, Korea Południowa, Singapur, Hiszpania, Tajwan i Chiny. Co najmniej kilka, spośród wymienionych, to raje podatkowe: Mauritius oraz Singapur, choć i Irlandia również mogłaby by być do tego grona zaliczona (podobnie Hongkong). Grecja i Portoryko to natomiast kraje, które w okresie kryzysu finansowego stanęły na granicy bankructwa. W gronie krajów UE Portugalię również trudno uważać w ostatnich dekadach za wzór w zakresie jakości polityki makroekonomicznej. 
istotniejszy może być zestaw czynników do niej prowadzących niż sam poziom rozwoju, przy którym to następuje. Na uderzenie w „szklany sufit” w procesie wzrostu narażone są bowiem gospodarki na każdym poziomie rozwoju. Niezależnie od tego czy polska gospodarka dokonała istotnego cywilizacyjnego skoku przez ponad ćwierć wieku transformacji, a w ostatnich latach wzrost gospodarczy wyróżniał się pozytywnie na tle krajów UE, zagrożenie wystąpienia jakiejś formy pułapki imitacji bądź zatrzymania konwergencji jest realne. Aby je przezwyciężyć, należy wykazać zdolność do kreacji własnych specjalności i ich umiędzynarodowienia przy coraz większym udziale krajowej wartości dodanej.

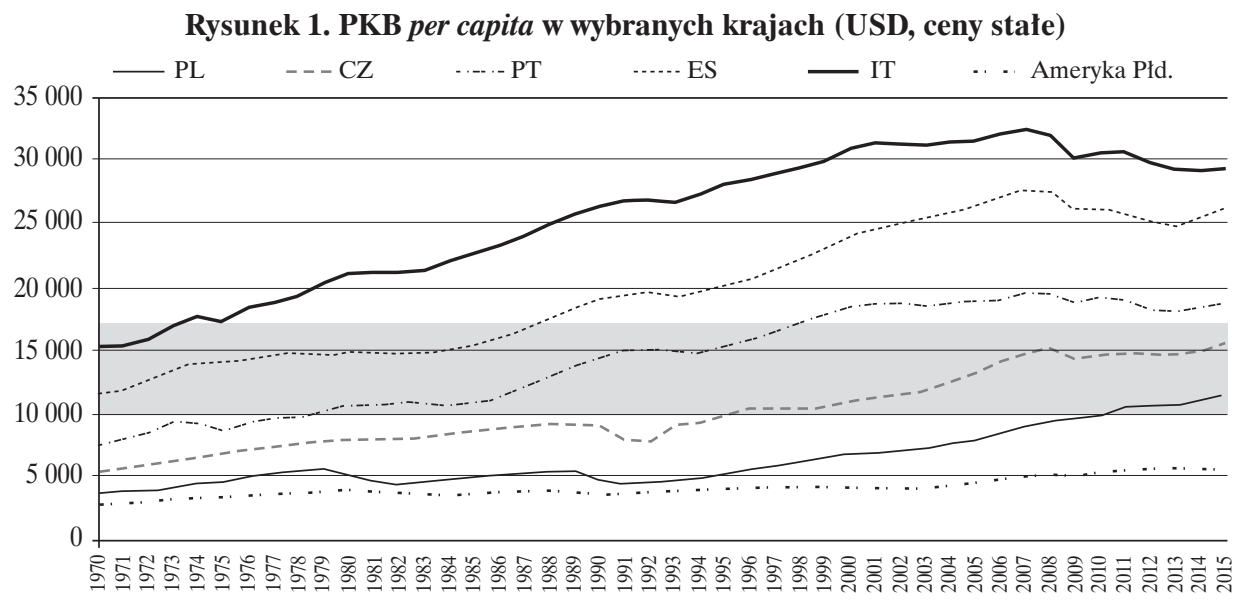

Potencjalna pułapka została wyznaczona dla celów ilustracyjnych w przedziale 10000-17000 USD

Źródło: opracowanie własne na podstawie danych Banku Światowego (15.05.2017).

\subsection{Inwestycyjna ścieżka rozwoju kraju}

Inwestycyjna ścieżka rozwoju (Investment Development Path - IDP) zakłada bezpośrednie relacje między rozwojem mierzonym PKB per capita a pozycją netto w zakresie przepływów BIZ (Gammeltoft i Kokko, 2013, s. 1-20). Ewolucja pozycji kraju wraz z rosnącym PKB per capita jest wynikiem zdolności firm do gromadzenia aktywów materialnych i niematerialnych oraz angażowania się w ekspansję zagraniczną w najbardziej zaawansowanej formie, jaką są BIZ.

Według założeń IDP kraje przechodzą przez kilka etapów rozwoju. Na pierwszym etapie, który dotyczy głównie krajów najsłabiej rozwiniętych, napływy BIZ, a zwłaszcza odpływ jest niewielki z powodu braku przewagi konkurencyjnej kraju i braków instytucjonalnych. Na drugim etapie napływ BIZ wzrasta w wyniku rosną-

Potwierdza to tylko, że nawet jeśli jakiś kraj potrafi sobie poradzić z zapewnieniem wzrostu gospodarczego w przeszłości, nie gwarantuje to sukcesu w przyszłości. 
cej atrakcyjności inwestycyjnej. Z powodu napływu BIZ pozycja netto zazwyczaj się pogarsza, w tej fazie możliwy jest natomiast transfer wiedzy z przychodzących BIZ (spillovere ffects), co prowadzi do podniesienia konkurencyjności lokalnych firm i stymulowania odpływu inwestycji zagranicznych. Warunkiem jest jednak zbudowanie odpowiednich zdolności absorpcyjnych (absorptive capacity) oraz zdolności adaptacyjnych (dynamic capabilities) (szerzej: Meliciani i Tchorek, 2017; Tchorek, 2016, s. 201-212) opartych na czynnikach wytwórczych wysokiej (rosnącej) jakości. Etap trzeci ma zazwyczaj charakter punktu zwrotnego, ponieważ pozycja netto w zakresie zakumulowanych BIZ jest ujemna, ale odpływy BIZ mogą być wyższe niż napływy dzięki rosnącej konkurencyjności firm krajowych. Ten etap wskazuje na większą specjalizację w obszarze produktów wysokiej wartości dodanej. W rezultacie krajowe firmy zaczynają rozwijać własne przewagi. W czwartej fazie pozycja netto jest dodatnia, ponieważ odpływ BIZ przekracza napływ BIZ, a ich zaawansowanie technologiczne wzrasta. W fazie piątej, która jest charakterystyczna dla najbardziej rozwiniętych krajów, pozycja netto, choć zmienna, jest bliska zera.

Inwestycyjna ścieżka rozwoju mówi o konieczności posiadania zdolności do przesuwania się w górę łańcucha wartości w sektorze wraz ze wzrostem dochodu kraju. Jednym z kluczowych czynników wzrostu PKB jest akumulacja inwestycji zagranicznych przy jednoczesnym budowaniu dzięki nim krajowego potencjału do ekspansji i eksportu kapitału.

M. Gorynia, J. Nowak i R. Wolniak (2010, s. 5-26), którzy przeanalizowali IDP dla sześciu krajów Europy Środkowej i Wschodniej (kraje grupy Wyszehradzkiej - V4 plus Bułgaria i Rumunia), sklasyfikowali V4 na drugim etapie. Autorzy wskazują, że polska gospodarka może być najbliżej punktu przejścia na trzeci etap, mimo że jest najmniej rozwinięta wśród V4. J. Klich (2014, s. 19-31), na podstawie danych do końca 2012 r., zauważył, że Polska, Republika Czeska i Słowacja weszły w etap trzeci, do którego Węgry dotarły nieco wcześniej.

W kontekście umiędzynarodowienia, na którym koncentruje się inwestycyjna ścieżka rozwoju, NES postuluje substytucję importu krajową produkcją i przypisuje dużą rolę otwartości handlowej jako kanałowi konkurencyjności i konwergencji. Sugeruje również przyciąganie BIZ w branżach, w których zidentyfikowano ukryte przewagi oraz budowanie zdolności do ekspansji kapitału krajowego na rynki zagraniczne (Lin, 2012).

\subsection{Krzywa dywersyfikacji gospodarki}

Istotną rolę w spojrzeniu na proces ewolucji kraju w zakresie wzrostu PKB w czasie odgrywa tzw. krzywa dywersyfikacji gospodarki i eksportu. Wskazania literatury sugerują, że wraz ze wzrostem poziomu PKB per capita rośnie również dywersyfikacja produktowa gospodarki. Następnie proces ten ulega spowolnieniu, a po przekroczeniu pewnego poziomu dochodu malejąca dynamika dywersyfikacji ustępuje respecjalizacji produktowej. Ilustracją tego procesu jest odwrócona 
krzywa U prezentująca zależność pomiędzy wysokością PKB per capita a dywersyfikacją towarową mierzoną najczęściej liczbą produktów przeznaczonych na eksport (por. rys. 2).

Rysunek 2. PKB per capita i liczba produktów eksportowych (lewy panel) oraz PKB per capita i indeks Theila (prawy panel)
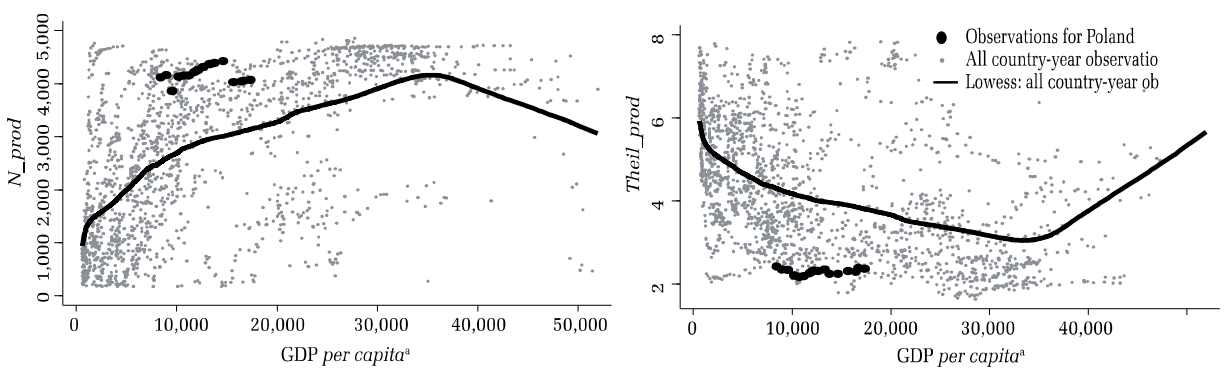

Źródło: Parteka, 2013.

Zależność ta, choć sprzeczna z intuicją, została potwierdzona przez liczne badania empiryczne na różnorodnych pod względem poziomu rozwoju próbach krajów oraz przy użyciu różnorodnych metod. Prekursorzy nurtu, J. Imbs i R. Wacziarg (2003, s. 63-86), na próbie 99 krajów wskazują na U kształtną zależność pomiędzy PKB per capita a stopniem koncentracji (odwrotność dywersyfikacji), podobnie B. Klinger i D. Lederman (2006) zależność tę potwierdzają na próbie 130 krajów. Badania wskazują również na istotną rolę takich czynników, jak wielkość gospodarki oraz zasobność w surowce w procesie dywersyfikacji, które mogą wpływać na jego przebieg. Niemniej, potwierdzają ogólną prawidłowość określaną krzywą dywersyfikacji - wzrost dywersyfikacji wraz ze wzrostem PKB, a następnie proces respecjalizacji ${ }^{5}$.

Zilustrowane na rysunku 3 zmiany liczby produktów eksportowanych w wybranej grupie krajów sugerują występowanie tej zależności. W gronie krajów rozwiniętych zauważalne jest na ogół obniżenie liczby linii produktowych w ostatnich dwudziestu latach, a w gronie krajów rozwijających się ich wzrost.

5 Badania empiryczne dla Europy Środkowo-Wschodniej oparte na analizie poziomu dywersyfikacji państw regionu w latach 1993-2000 wykazały, że punktem zwrotnym może być wartość PKB per capita kształtująca się na poziomie 25000 USD (Funke i Ruhwedel, 2005 s. 25-50). W badaniu Parteki (2013), punkt przegięcia krzywej został wyznaczony dla grupy 163 krajów przy wartość PKB per capita bliskiej 35000 USD. 


\section{Rysunek 3. Liczba eksportowanych produktów w wybranych krajach (wszystkie produkty)}

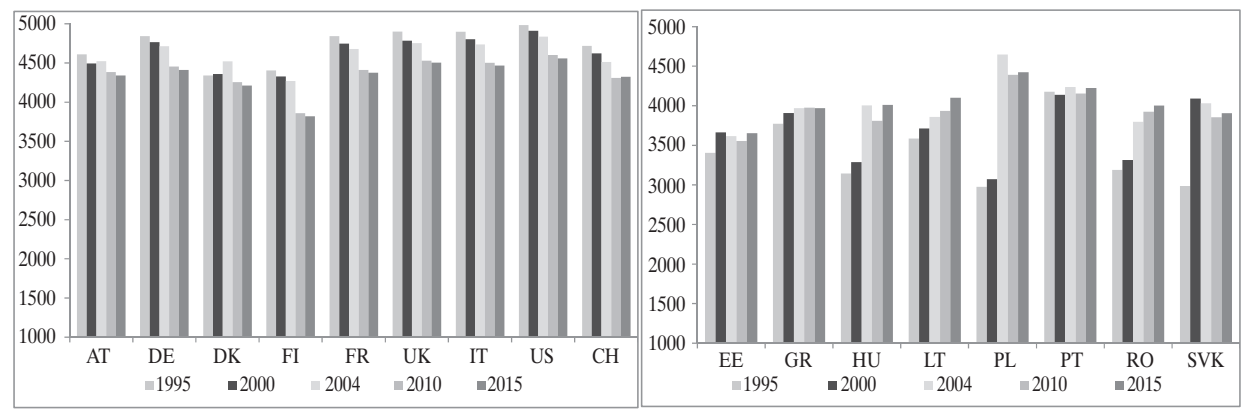

Źródło: opracowanie własne na podstawie danych WITS (15.05.2017).

Mimo że rosnącą specjalizację produktową można uznać za proces rynkowy, stymulowany koncentracją na najbardziej dochodowych produktach i fragmentach łańcucha wartości, to jednak budzi on wątpliwości ekonomistów. Często nawołują oni do większego sterowania tym procesem $\mathrm{z}$ uwagi na ryzyka wynikające $\mathrm{z}$ rosnącej specjalizacji oraz sugerują dążenie do zwiększenia dywersyfikacji gospodarki. Nawet w sektorze prywatnym może dochodzić do niewłaściwej, z punktu widzenia systemowego, alokacji zasobów prowadzącej do pogorszenia kondycji ekonomicznej gospodarki, szczególnie w warunkach szoków. Jednym z głównych postulatów NES jest zwiększenie dbałości polityki rządu o dywersyfikację gospodarki poprzez wykorzystanie polityki przemysłowej. Dywersyfikacji produktowej powinno towarzyszyć zwiększanie krajowej wartości dodanej w eksporcie i korzystne lokowanie pozycji przedsiębiorstw w łańcuchach wartości (poprzez przychodzące i wychodzące BIZ).

Rysunek 4. Dywersyfikacja rynków i produktów (produkty o rocznej wartości eksportu powyżej 10000 USD)

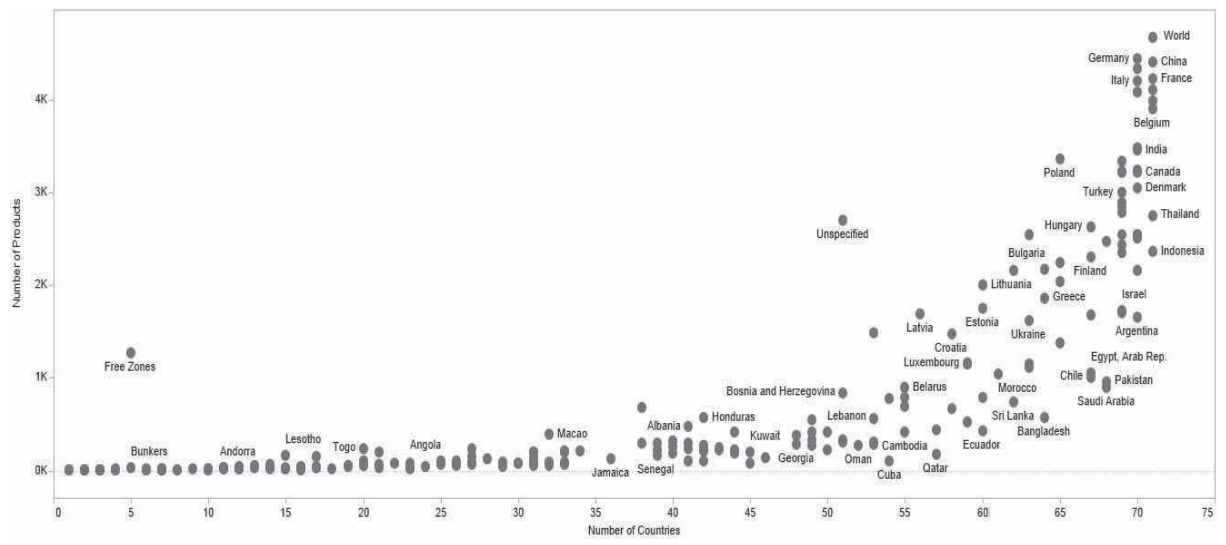

Źródło: opracowanie własne na podstawie danych WITS (15.05.2017). 
Obserwacja przemian polskiego eksportu wskazuje na podążanie ścieżką dywersyfikacji produktowej. Polska jest krajem, który doświadczył wzrostu liczby eksportowanych produktów, szczególnie po wejściu do UE, co było m.in. związane z pojawieniem się w wymianie międzynarodowej nowych wyrobów rolnych i spożywczych. Liczba oferowanych produktów plasuje Polskę na poziomie porównywalnym do krajów wysokorozwiniętych (por. rys. 4). Niemniej jednak, poziom zaawansowania technologicznego polskiej produkcji i eksportu w wielu przypadkach ustępuje konkurencji z Czech i Węgier.

Zestawiając narzędzia realizacji celów gospodarczych wg propozycji NES z przywołanymi trzema koncepcjami ewolucyjnego rozwoju gospodarki, należy zauważyć, że ich pragmatyczne zastosowanie pozwala zmniejszać ryzyko wpadnięcia w pułapkę średniego dochodu oraz ryzyko nadmiernej specjalizacji gospodarki, jak również sprzyja budowie zdolności kraju do przyciągania inwestorów zagranicznych dla podniesienia własnej konkurencyjności (por. tab. 1).

Tabela 1. Nowa Ekonomia Strukturalna a wybrane koncepcje rozwoju

\begin{tabular}{|c|c|c|}
\hline Koncepcja & Główne założenia & $\begin{array}{c}\text { Wskazania NES } \\
\text { dla polityki gospodarczej }\end{array}$ \\
\hline 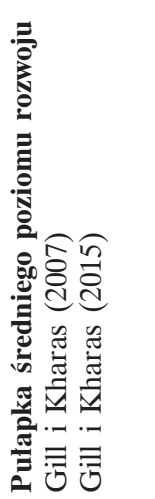 & $\begin{array}{l}\text { w centrum uwagi są czynniki mogące } \\
\text { trwale zatrzymać proces wzrostu } \\
\text { gospodarczego (doganiania); pułapka } \\
\text { może wynikać: } \\
\text { • z błędnej diagnozy w strategii } \\
\text { wzrostu kraju, opartej na } \\
\text { eksporcie pracochłonnych towarów } \\
\text { przemysłowych, mimo utraty } \\
\text { przewagi cenowo-kosztowej } \\
\text { - ze zbyt pospiesznego przeskoczenia } \\
\text { do „gospodarki opartej na wiedzy” } \\
\text { mimo braku potrzebnych zasobów } \\
\text { i instytucji }\end{array}$ & $\begin{array}{l}\text { - polityka gospodarcza ma za zadanie } \\
\text { identyfikację branż o ukrytych } \\
\text { przewagach komparatywnych, } \\
\text { które mogą zdynamizować rozwój } \\
\text { ekonomiczny kraju i sprzyjać } \\
\text { konwergencji } \\
\text { - rola rządu sprowadza się do ważnej } \\
\text { funkcji koordynatora działań, który } \\
\text { musi spojrzeć daleko w przyszłość } \\
\text { i podjąć ryzyko zapewnienia } \\
\text { miękkiej i twardej infrastruktury dla } \\
\text { obniżenia kosztów transakcyjnych } \\
\text { w wyselekcjonowanych branżach/ } \\
\text { sektorach }\end{array}$ \\
\hline 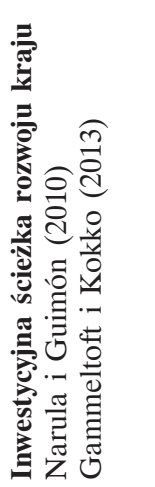 & $\begin{array}{l}\text { zmiany PKB per capita są powiązane } \\
\text { z ewolucją salda netto BIZ (napływu } \\
\text { i wypływu): } \\
\text { - wraz ze wzrostem jakości zasobów, } \\
\text { kraje przyciagając oraz więcej BIZ } \\
\text { - kluczowa może być dbałość } \\
\text { o strukturę BIZ } \\
\text { - osiągając masę krytyczną akumulacji } \\
\text { kapitału krajowego, firmy dokonują } \\
\text { ekspansji za granica, są zdolne } \\
\text { do kreacji własnych Globalnych } \\
\text { Łańcuchów Dostaw i osiągania } \\
\text { w ich hierarchii wysokiej pozycji }\end{array}$ & $\begin{array}{l}\text { - BIZ stanowią najbardziej pożądaną } \\
\text { formę kapitału, kierują się } \\
\text { bowiem najczęściej przewagami } \\
\text { komparatywnymi sektorów, w które } \\
\text { inwestują } \\
\text { - optymalne jest przyjmowanie } \\
\text { inwestycji w sektorze dóbr } \\
\text { wymienialnych (przemysł) } \\
\text { - zachęcanie do napływu BIZ } \\
\text { w zidentyfikowanych przemysłach, } \\
\text { które polityka przemysłowa } \\
\text { zamierza wspierać }\end{array}$ \\
\hline
\end{tabular}


cd. tab. 1

\begin{tabular}{|c|c|c|}
\hline Koncepcja & Główne założenia & $\begin{array}{c}\text { Wskazania NES } \\
\text { dla polityki gospodarczej }\end{array}$ \\
\hline 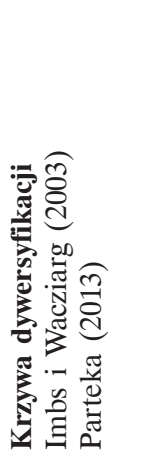 & $\begin{array}{l}\text { - wraz ze wzrostem poziomu rozwoju } \\
\text { rośnie poziom dywersyfikacji } \\
\text { gospodarki mierzony różnorodnością } \\
\text { produkcji (eksportowej) } \\
\text { - po przekroczeniu krytycznego } \\
\text { poziomu następuje proces } \\
\text { respecjalizacji gospodarki } \\
\text { - rosnąca specjalizacja może } \\
\text { eksponować gospodarkę na szoki } \\
\text { zewnętrzne }\end{array}$ & $\begin{array}{l}\text { - wyzwaniem dla polityki strukturalnej } \\
\text { jest stymulowanie różnorodności } \\
\text { produkcji oraz zwiększanie } \\
\text { zaawansowania technologicznego } \\
\text { przemysłu } \\
\text { - rola państwa w tych zabiegach } \\
\text { jest ograniczona do zapewnienia } \\
\text { niezbędnych informacji na temat } \\
\text { stymulowanego przemysłu, } \\
\text { koordynacji inwestycji pomiędzy } \\
\text { firmami wewnątrz przemysłu, } \\
\text { inkubacji nowych przemysłów } \\
\text { i podmiotów }\end{array}$ \\
\hline
\end{tabular}

Źródło: opracowanie własne.

Warto zauważyć, że istotną rolę w procesie kształtowania polityki przemysłowej NES przypisuje rządowi. Podobne spojrzenie na rolę państwa proponuje również Mazzucato (2016), która postuluje zmianę roli rządu jako jednego z najważniejszych aktorów w systemie ekonomicznym. Wskazuje na konieczność uzupełnienia dotychczasowej roli, jaką było usprawnianie mechanizmów rynkowych (fixing market failures) i wyposażenia w dodatkową funkcję w postaci kształtowania i kreowania rynku (shaping and creating market). Według tej koncepcji państwo w swoim działaniu również musi być bardziej kreatywne i przedsiębiorcze (The Entrepreneurial State) oraz powinno ponosić ryzyko działań we wczesnym stadium rozwoju rynku i koncepcji biznesowych. Powinno to sprzyjać akumulacji i akceleracji wiedzy już zgromadzonej i wytworzenia nowej oraz możliwości jej komercjalizacji przez sektor prywatny. Prof. Mazzucato wskazuje, że iPhone został w dużej mierze złożony przez Apple na bazie rozwiązań technologicznych, do których powstania przyczyniły się działania publiczne.

\section{Szanse rozwoju rynku elektromobilności w Polsce}

Zaawansowanie dyskusji i działań w obszarze elektromobilności w Polsce było do niedawna znacząco opóźnione względem innych krajów europejskich ${ }^{6}$, jednak podjęte przez Ministerstwo Energii i Ministerstwo Rozwoju działania w latach 2016-2107 istotnie nadrabiają ten dystans. Wydaje się, że jest to ostatni moment

6 Przykładowo, w Norwegii dyskusja na temat elektromobilności rozpoczęła się w latach 90. XX wieku. W Niemczech plan rozwoju elektromobilności przyjęto w 2009 r., a w Estonii w 2011. 
na uruchomienie rozwoju krajowego rynku, przemysł samochodowy na świecie dojrzał już bowiem do masowej produkcji aut z napędami elektrycznymi i proces ten znacząco przyspieszy w kolejnych latach. Według Bloomberg New Energy Finance (za: Randal, 2017) do 2020 r. pojawi się ok. 120 różnych modeli aut elektrycznych (por. rys. 5).

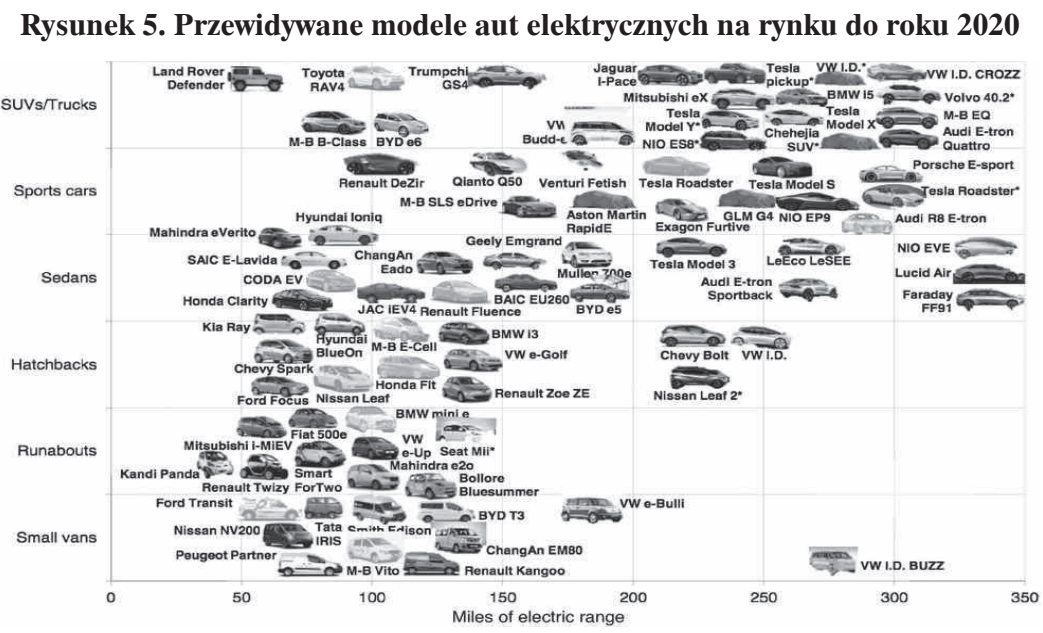

Źródło: Randal, 2017.

Brak zdywersyfikowanej i zaawansowanej krajowej produkcji komponentów (a w optymistycznym wariancie nawet polskiego auta elektrycznego i innych pojazdów związanych z mobilnością) doprowadzi do konieczności ich importu. Należy bowiem zakładać, że popyt na pojazdy napędzane silnikiem elektrycznym będzie wzrastał na skutek rosnącej presji w zakresie ochrony środowiska naturalnego i ograniczenia w dostępie do pojazdów z silnikami spalinowymi w miastach. Problem jakości powietrza zostanie w pewien sposób rozwiązany przez upowszechnienie pojazdów elektrycznych w komunikacji publicznej. Jednak czyste i „mądre” miasta (smart cities) ograniczą możliwość poruszania się pojazdów tradycyjnych do wyznaczonych stref i zwiększą przestrzeń dla ruchu pieszego i rowerowego. Oznacza to, że zwiększy się udział samochodów napędzanych silnikiem elektrycznym. Jednocześnie z punktu widzenia dywersyfikacji rynku warto pamiętać o konieczności testowania i stymulowania różnorodnych odmian produktów związanych z osobistą mobilnością opartą na napędzie elektrycznym (rowery, skutery, wózki inwalidzkie), na które zapotrzebowanie również wzrośnie.

W najbliższych latach proces zastępowania tradycyjnych napędów spalinowych napędami elektrycznymi przyspieszy ze względów technologicznych, ekonomicznych i środowiskowych. W swojej konstrukcji silnik elektryczny jest prostszy, przez co mniej awaryjny dlatego stopniowo zastąpi napęd spalinowy. Koszt energii elektrycz- 
nej jest mniejszy, a emisja zanieczyszczeń może być w większym stopniu kontrolowana (poprzez produkcję energii w jednym miejscu) niż ma to miejsce w przypadku milionów rozproszonych aut o napędzie tradycyjnym.

Za rozwojem rynku pojazdów z napędem elektrycznym w Polsce przemawia kilka kluczowych przesłanek, a najważniejszą jest prawdopodobnie ich kompozycja, która powinna wyzwolić efekty synergiczne i uruchomić endogeniczne rezerwy rozwoju rynku (Kurtyka, 2017). Choć rozwój elektromobilności jest obwarowany wieloma dodatkowymi warunkami i zastrzeżeniami oraz niewątpliwie ryzykiem, można wymienić kilka powodów sprzyjających spojrzeniu na Polskę jako miejsce koncentracji tego przemysłu i przemysłów pokrewnych.

Po pierwsze, rozwój elektromobilności będzie się opierał na bazie relatywnie dobrze rozwiniętego i konkurencyjnego przemysłu samochodowego (zarówno zagranicznych, jak i krajowych producentów) skoncentrowanego w Polsce.

Po drugie, elektromobilność może być impulsem dla systemowego wykorzystania potencjału przemysłowego i innowacyjnego polskiej gospodarki.

Po trzecie, elektromobilność będzie sprzyjać realizacji postulatów zrównoważonego rozwoju i dbałości o ochronę środowiska poprzez rozwiązanie części problemów komunikacyjnych w miastach.

Po czwarte, szanse powodzenia projektu rosną, ponieważ państwo podjęło się roli animatora ekosystemu innowacyjności i dąży do zapewnienia twardej oraz miękkiej infrastruktury rynku w postaci stworzenia regulacji, wsparcia badań, budowania systemów ładowania, zapewnienia finansowych bodźców stymulujących popyt itp.

Po piąte, elektromobilność może być czynnikiem uniezależniającym od zakupu surowców (paliw), zmniejszającym skalę importu tego typu aut, stabilizując saldo handlowe, oraz może być czynnikiem sprzyjającym stabilizacji sieci energetycznej.

\subsection{Przemysł samochodowy dojrzał do masowej produkcji pojazdów elektrycznych}

W badaniu KPMG (2017), Global Automotive ExecutiveSurvey 2017, respondenci z 42 krajów uznali, że kluczowym wyzwaniem związanym z przemianami na rynku samochodów jest rozwój pojazdów elektrycznych (w latach 2014-2015 kwestia ta plasowała się na ok. 10 pozycji). Oznacza to, że rynek wykształcił masę krytyczną zasobów i zdarzeń, które wymuszą konieczność przyspieszonego rozwoju napędu elektrycznego. Sprzyja temu rosnące zaangażowanie największych graczy rynkowych (VW, GM, BMW, ale również firm spoza sektora - Apple, Google, Uber) oraz postęp technologiczny, który doprowadzi do zrównania cen pojazdów elektrycznych i tradycyjnych w perspektywie kilku lat. Popularyzacji aut elektrycznych powinna sprzyjać tendencja do wprowadzania samochodów autonomicznych jako bardziej bezpiecznych. I choć użytkowanie aut autonomicznych jest neutralne względem rodzaju napędu, to w większym stopniu będzie się pojawiało w przypadku samochodów z napędem elektrycznym. 
Branża samochodowa rozpoczyna globalny wyścig w elektromobilności, w którym wykorzystane zostaną osiągnięcia współczesnej elektroniki, telekomunikacji i zarządzania dużymi zbiorami danych (big data). Jednocześnie branżę motoryzacyjną czekają istotne zmiany modelu biznesowego, oparte na optymalnym wykorzystaniu dotychczasowych zasobów, co wg KPMG doprowadzi do zmniejszenia zapotrzebowania na samochody. Wynika to również ze zmiany postaw konsumenckich. Według KPMG do 2025 r. 50\% właścicieli samochodów nie będzie odczuwało potrzeby posiadania auta. Rozwiną się więc różne formy współdzielenia samochodów i ich długoterminowego najmu.

\subsection{Akceleracja oraz wykorzystanie potencjału polskiego przemysłu i innowacyjności}

Udział przemysłu samochodowego w Polsce (ujęty w PKD jako - Produkcja pojazdów samochodowych, przyczep i naczep oraz Produkcja pozostatego sprzętu transportowego) wynosił ok. 10\% całkowitej produkcji przemysłowej, a w 2015 r. znajdowało w nim zatrudnienie ok. 220 tys. pracowników 7 . Obie te kategorie decydowały jednocześnie o ok. $20 \%$ całkowitego eksportu i ok. $20 \%$ udziału w nakładach na B+R całego przemysłu. W latach 2000-2008 wkład do wzrostu eksportu tych dwóch kategorii oraz powiązanego przemysłu elektromaszynowego wynosił ok. 40\%, a od kryzysu spadł do ok. 30\%, co często tłumaczone jest strukturalnym wyhamowaniem handlu wewnątrz GVC (por. rys. 6).

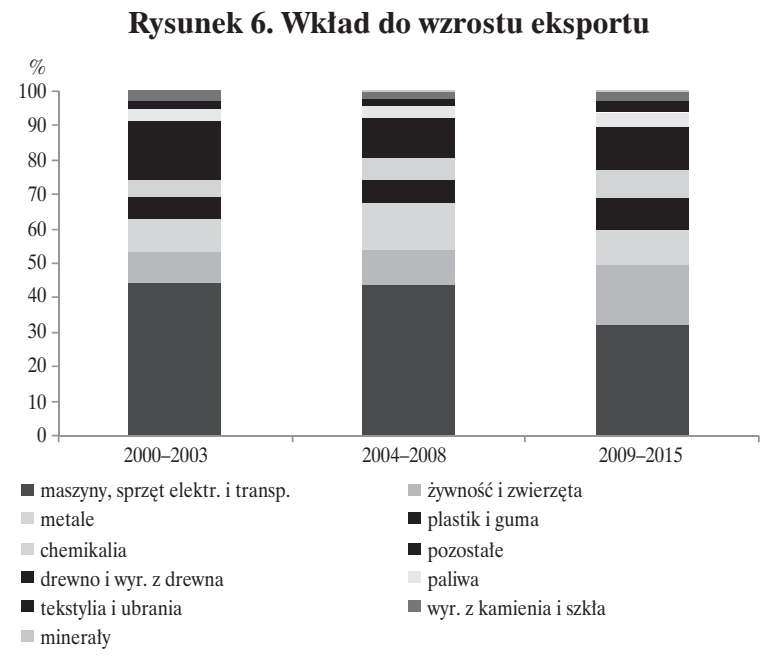

Źródło: opracowanie własne na podstawie danych WITS (15.05.2017).

$7 \quad$ Licząc zatrudnienie w kategoriach Produkcja pojazdów samochodowych, przyczep i naczep oraz Produkcja pozostatego sprzętu transportowego. 
Przemysł samochodowy ma tendencję do jednoczesnej defragmentacji produkcji oraz geograficznej koncentracji, ponieważ produkt finalny (samochód) jest rezultatem złożenia ok. 3500 części, których nie wytwarza ostateczny jego producent. Kluczowe znaczenie w procesie produkcji auta ma skoncentrowana wokół niego sieć dostawców i kooperantów.

Lokalizacja przemysłu samochodowego w krajach Europy Środkowej i Wschodniej, w tym w Polsce, wynika przede wszystkim z włączenia przemysłów motoryzacyjnych w łańcuchy dostaw inwestorów zagranicznych z Niemiec, Francji, Włoch. Oznacza to, że Polska stanowi silne zaplecze produkcyjne dla produktów finalnych, co wynika z tradycji sektora, wysokich kompetencji technicznych, infrastruktury i sieci dostawców (Füzi, Gombos i Tóth, 2012). Około 2/3 z 30 największych światowych koncernów samochodowych ma swoje zakłady w Polsce. Jak ilustruje to rysunek 7, skoncentrowane lokalnie sieci dostawców są wstanie w dużym stopniu zaspokoić potrzeby sektora, dzięki różnorodności i wielonarodowości podmiotów.

\section{Rysunek 7. Przykładowa sieć dostawców zlokalizowana w Specjalnej Strefie Ekonomicznej „Invest-Park”}

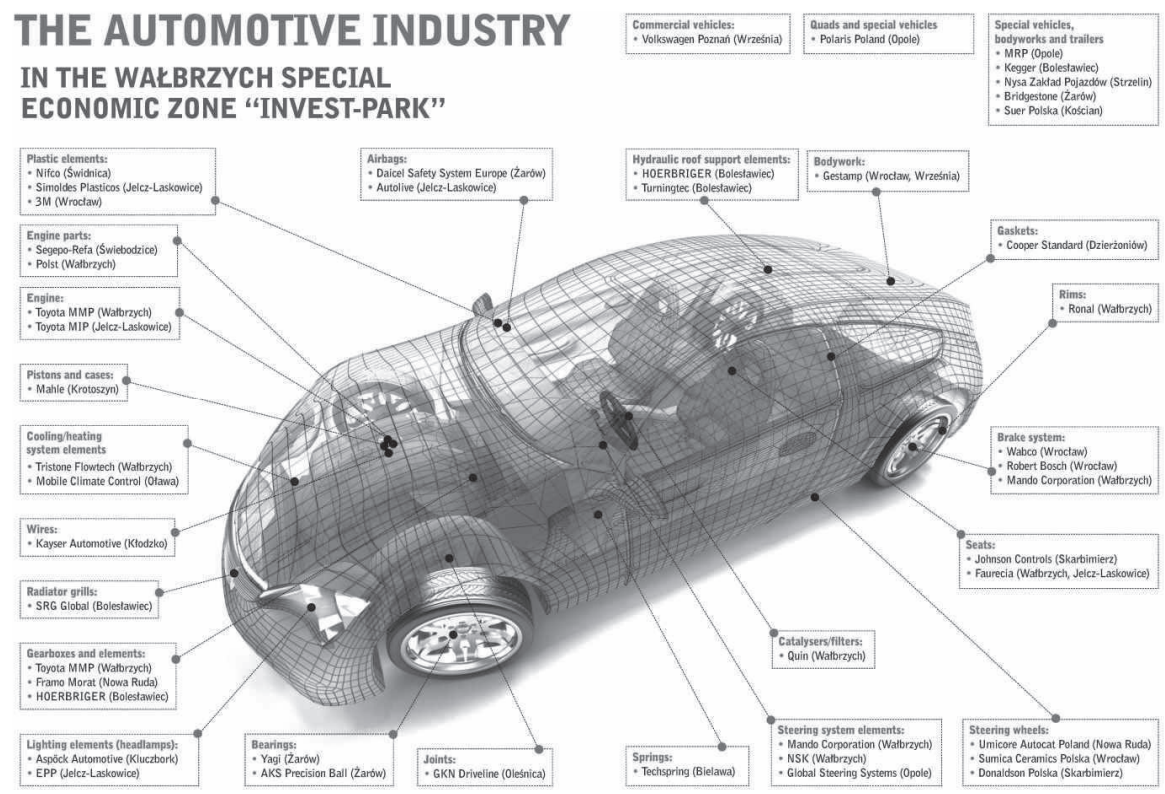

Źródło: https://invest-park.com.pl/en/blog/2015/06/30/zone-of-automotiv/ (20.05.2017).

Nawet jeśli producentami i eksporterami dóbr finalnych z Polski są przede wszystkim podmioty z udziałem kapitału zagranicznego, nie zmienia to faktu, że przemysł ten zakumulował już masę krytyczną wiedzy, technologii i relacji, podnosząc atrakcyjność inwestycyjną regionu i zwiększając jego lokalne kompetencje. 
Analiza Polityka Insight wskazuje, że na tle Czech, Węgier i Słowacji Polska zajmuje pierwsze miejsce w zakresie bliskości do klienta w ramach GVC. O konkurencyjności i dojrzałości sektora świadczy to, że powstało wiele polskich firm, które umiejętnie budują własne sieci wartości i stają się europejskimi liderami, np. Boryszew, Solaris, Wielton, Pesa.

Potwierdzeniem powyższych obserwacji może być indeks $\mathrm{RCA}^{8}$ dla wybranych grup produktowych związanych z przemysłem samochodowym wskazujący na pewne przewagi eksporterów polskich nad niemieckimi (por. rys. 8).

\section{Rysunek 8. Przewagi komparatywne w polskim i niemieckim eksporcie}

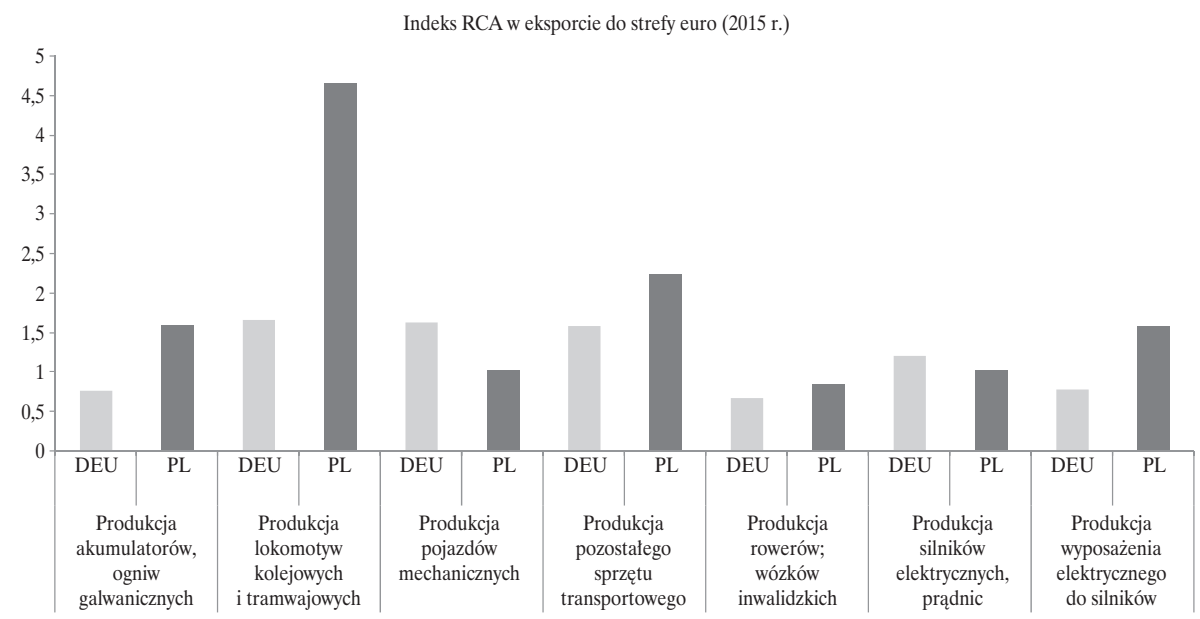

Źródło: Barteczko i Tchorek, 2016.

Bez wątpienia przemysł elektromobilności ma szansę pobudzić inne branże, jak choćby informatyczną, energetyczną, lotniczą i produkcji komponentów szeroko rozumianej mobilności napędzanej silnikiem elektrycznym. Przykładowo, w Danii wiele innowacji o kluczowym znaczeniu wyrosło z tak tradycyjnego sektora, jak rolnictwo (penicylina przyczyniła się do rozwoju branży farmaceutycznej, rolnictwo i przetwórstwo żywności stymulowało rozwój branży urządzeń do przechowywania żywności), a elektrownie wiatrowe stymulowały rozwój branży IT.

8 Wskaźnik RCA (Revealed Comparative Advantage) mierzy ujawnione przewagi komparatywne poprzez ocenę koncentracji eksportu na poszczególnych produktach lub ich grupach. Wskaźnik mierzy intensywność specjalizacji danego kraju w handlu międzynarodowym danym towarem w odniesieniu do reszty świata, regionu bądź innego kraju. Wartość RCA powyżej jedności świadczy o tym, że badany kraj posiada przewagę komparatywną (specjalizację) w eksporcie danej grupy produktów względem grupy odniesienia. 


\subsection{Przedsiębiorcze i innowacyjne państwo}

Doświadczenia w zakresie kształtowania polityki innowacyjności w krajach skandynawskich wskazują, że innowacja, kreatywność i entuzjazm w działaniu mogą być kojarzone z sektorami zarówno prywatnym, jak i publicznym. Sektor publiczny jest tam odpowiedzialny za usprawnianie mechanizmów rynkowych, jak również animowanie rynku w roli pioniera, lidera i przewodnika umiejętnie bodźcującego działanie przedsiębiorstw i aktorów ekosystemu. Doświadczenia krajów, które odniosły sukces w innowacyjności wskazują, że istotnym elementem ekosystemu innowacyjności były klastry, dla których kołem napędowym był często popyt z sektora publicznego oraz partnerstwo publiczno-prywatne. Istotną rolę odgrywały także sieci innowacyjności nakierowane na budowanie więzi i wymianę wiedzy pomiędzy instytucjami naukowo-badawczymi a sektorem przedsiębiorstw, szczególnie w gronie firm małych, w przypadku których koszty transakcyjne mogą być rzeczywiście znaczące (NBP, 2016).

Podjęte działania Ministerstwa Energii i Ministerstwa Rozwoju (przy współudziale Ministerstwa Środowiska, Polskiego Funduszu Rozwoju, Narodowego Funduszu Ochrony Środowiska i Gospodarki Wodnej, Narodowego Centrum Badań i Rozwoju) stanowią znaczący krok na rzecz animacji środowiska podmiotów związanych z produkcją samochodów i komponentów, koncentracji potencjalnego popytu i podaży, redukcji kosztów transakcyjnych i transferu wiedzy.

W latach 2016-2017 wśród wielu istotnych wydarzeń konferencyjnych, seminaryjnych i dyskusji publicznej zmobilizowano znaczący potencjał intelektualny, zbudowano konsensus w obszarze wspólnej wizji rozwoju i podjęto działania na rzecz poszukiwania kierunków i gamy rozwiązań. Zdefiniowano również projekty pilotażowe w kluczowym segmencie nabywców instytucjonalnych, gdzie istotna będzie dalsza pogłębiona ocena możliwości wykorzystania transportu elektrycznego. Ten segment nabywców, również flotowych, ma bowiem szansę rozwinąć się najszybciej9. Konieczne są dalsze badania i konsultacje w zakresie możliwości zastosowania autobusów elektrycznych w zależności od profilu obciążenia dziennego zużycia energii, odległości pomiędzy przystankami w miastach itd. Jednak już sama animacja popytu i podaży oraz nakreślenie ram rynku znacząco zwiększyło zainteresowanie elektromobilnością wśród samorząáów: 41 z nich przystąpiło do programu pilotażowego i planuje zakupić ok. 800 autobusów elektrycznych. Powołano spółkę ElectroMobility Poland, ogłoszono konkurs na koncepcję polskiego samochodu elektrycznego, a docelowo na cały projekt rząd zamierza przeznaczyć ok. 20 mld złotych. Cztery spółki energetyczne mają stworzyć ogólnokrajową infrastrukturę ładowania, co stanowi krytyczny element rozwoju rynku.

9 Przykładowo, obecny zasięg baterii wystarczy dla wielu firm kurierskich, które chętniej będą inwestowały we własne stacje ładowania i rzeczywiście mogą się ładować w nocy (stabilizować sieć energetyczną), co już nie jest takie oczywiste przypadku nabywców indywidualnych skoncentrowanych w aglomeracyjnej zabudowie polskich miast. 


\section{Wnioski dla elektromobilności w Polsce}

\section{Patrzeć z wizją w przyszłość i ją kształtować (czyli uciekać a nie gonić)}

Wśród wielokrotnych prób sformułowania diagnozy stanu i perspektyw polskiej gospodarki w różnych dokumentach ${ }^{10}$, mimo że wielce wartościowych i pożytecznych, nie podjęto ciężaru zdefiniowania kluczowych branż, w których należy oczekiwać potencjału rozwoju. Taką rolę powinna odegrać polityka gospodarcza rządu i wydaje się, że w przypadku Strategii na Rzecz Odpowiedzialnego Rozwoju, której częścią jest Program Rozwoju Elektromobilności w Polsce, mamy do czynienia z przemyślana próbą takiego działania.

Po raz pierwszy od początku transformacji, w naszym planowaniu strategicznym wychodzimy w swojej wizji gospodarczej daleko do przodu i nie działamy reaktywnie. Nie reagujemy na to, co się stało, tylko próbujemy kształtować to, co może nastąpić. Czynnik ten jednak nie wystarczy, jeśli nie będzie oparty na miękkiej (kształcenie kadr, społeczna akceptacja dla nowych rozwiązań), twardej (system ładowania i rosnącego zasięgu baterii) oraz regulacyjnej infrastrukturze (system zachęt finansowych i pozafinansowych do zakupu auta elektrycznego).

Wyrażając to językiem NES, działania publiczne doprowadziły do zidentyfikowania sektora o ukrytych przewagach konkurencyjnych. Będzie on co prawda budowany na bazie tradycyjnego przemysłu samochodowego, ale oparty na większym udziale polskiej myśli technicznej i intelektualnej. Co ważne, Polska wydaje się mieć potrzebne ku temu zasoby, trzeba je tylko odpowiednio zalokować i wyznaczyć regulacyjne ramy działania.

\section{Promować różnorodność i dywersyfikację}

Rozwój rynku elektromobilności w Polsce dotyczy wielu obszarów gospodarki i relacji społecznych. Kluczowe dla uruchomienia skokowej zmiany jest stworzenie ogólnokrajowego systemem ładowania (kompatybilnego w wymiarze krajowym i międzynarodowym). Towarzyszyć temu będzie również rozwój nowych modeli biznesowych opartych na strategii cyfrowej, związanych ze zmianą sposobu użytkowania samochodów (car-sharing), ale również z koniecznością utylizacji baterii zgodnie z koncepcją zrównoważonego rozwoju w ramach circular economy. Umiejętne zarządzanie danymi będzie niezbędne szczególnie w kontekście konieczności pomiarownia poboru prądu i zastosowania inteligentnych liczników oraz wzrostu znaczenia samochodów autonomicznych. Krajowy sektor IT wydaje się być gotowy

10 Jak choćby w raportach Competitive Poland. How to Advance in Global Economic League? opracowanym pod kierownictwem prof. J. Hausnera (2013) oraz Potencjat innowacyjny gospodarki: uwarunkowania, determinanty, perspektywy, pod redakcją prof. A. Sławińskiego i prof. J. Growca (2016). 
na to wyzwanie, ponieważ coraz więcej polskich firm należy do grona europejskich liderów.

Jednocześnie konieczna jest próba wskazania procesu przejścia od przemysłu tradycyjnego. Według M. Kurtyki (2017), zaletą samochodu elektrycznego jest większa łatwość jego produkcji, składa się on bowiem z ok. 1000 różnych części, natomiast samochód o napędzie tradycyjnym - z ok. 3500. Choć sprzyja to obniżeniu awaryjności samochodu o ok. 20\%, to jednocześnie będzie miało istotny wpływ na zmianę modelu funkcjonowania branży, co również wymaga pogłębionej oceny. Pozostaje otwarte pytanie, na ile producenci tych 2500 części, wyeliminowanych z produkcji za sprawą auta elektrycznego, będą w stanie szybko się dostosować do produkcji samochodów elektrycznych. Być może otworzą się przed nimi możliwości nowych specjalizacji i perspektywiczne segmenty rynku, ale jest to warte przedyskutowania i ewentualnego zbadania, szczególnie w kontekście promowania dywersyfikacji.

Dywersyfikacja dotyczy również gamy rozwijanych napędów. Oczekiwania analityków wskazują, że w perspektywie kilku lat podstawowym napędem pozostanie napęd hybrydowy, a nie wyłącznie elektryczny ${ }^{11}$. Różnorodność napędów związana jest również z dywersyfikacją nośników energii. W tym kontekście istotna jest dbałość o stymulowanie gazo mobilności.

\section{Stymulować umiędzynarodowienie}

W kontekście umiędzynarodowienia NES, omawiane koncepcje postulują substytucję importu krajową produkcją i przypisują dużą rolę otwartości jako kanałowi konkurencyjności i konwergencji. Oznacza to, że na rozwój elektromobilności musimy również spojrzeć z perspektywy umiędzynarodowienia badań, eksportu krajowej produkcji i ekspansji kapitałowej. Bez internacjonalizacji działalności, w tym w zakresie BIZ, nie zostaniemy światowym liderem. Obecność na rynkach zagranicznych jest warunkiem zdolności do zdobywania wiedzy i śledzenia zachodzących trendów rynkowych. Z punktu widzenia decyzji przedsiębiorstw wejście na nowy rynek eksportowy i/lub wprowadzenie nowego produktu związane jest z istotnymi kosztami oraz wymaga określonych zasobów materialnych i niematerialnych. Dlatego tak istotne będzie wparcie oferowane w innych obszarach Strategii Odpowiedzialnego Rozwoju w tym zakresie.

Po stronie polityki gospodarczej pozostają do rozwiązania dylematy, jak poradzić sobie z: przyciąganiem BIZ o „lepszej jakości” w przemyśle samochodowym (realizujących $\mathrm{B}+\mathrm{R}$ przy partnerskim i silnym zaangażowaniu krajowych podmiotów); transferem wiedzy od inwestorów i jej rozprzestrzenieniem wśród podmiotów krajowych; jakością czynników produkcji sprzyjających absorpcji wiedzy i technologii oraz budowaniem przewag na zasobach niematerialnych. W tym kontekście warto

11 Wg BCG w 2025 r. w globalnej sprzedaży samochodów ok. 25\% będą stanowiły te z napędami alternatywnymi. W tej puli ok. $65 \%$ będą stanowiły napędy hybrydowe, a czyste elektryczne tylko ok. 1/4 (zob. Kędzierski, 2017). 
również poddać pod dyskusję opcję nawiązania strategicznego partnerstwa technologicznego z jakimś graczem zagranicznym z sektora, który pomógłby przyspieszyć rozwój rynku. Można sobie wyobrazić, że Tesla byłaby skłonna współtworzyć mały, niskobudżetowy samochód miejski na relatywnie duży polski rynek.

Stworzenie krajowej marki samochodów będzie stosunkowo trudne, biorąc pod uwagę około 4-letni cykl takiego procesu oraz brak krajowego doświadczenia w tym zakresie. Niemniej rozwój rynku elektromobilności w Polsce będzie można uznać za korzystny dla gospodarki przy ok. 20-40\% finalnej wartości dodanej wytworzonej w kraju. Istotne jest, aby ta wartość była w coraz większym stopniu oparta na przewagach niematerialnych.

\section{Podsumowanie}

Dokonując próby syntezy omawianych koncepcji - pułapki średniego poziomu rozwoju, inwestycyjnej ścieżki rozwoju, krzywej dywersyfikacji oraz NES w kontekście rozwoju rynku elektromobilności, można sformułować następujące wnioski.

Po pierwsze, warto wzmocnić potencjał państwa, jako podmiotu organizującego rzadkie zasoby i podejmującego ryzyko, w kształtowaniu reguł rynku i jego kreowaniu. Wysłany do rynku wiarygodny sygnał kompleksowego stymulowania branż o zidentyfikowanym dużym potencjale sprzyja stabilizacji planowania i podejmowaniu decyzji inwestycyjnych w perspektywie co najmniej średnioterminowej.

Po drugie, należy zadbać o różnorodność rynku i jego dywersyfikację. Rynek elektromobilności znajduje się na początku swojej ewolucji i nie można przesądzić o jego kształcie nawet w perspektywie nadchodzących lat. Dotyczy to stosowanych technologii, produktów oraz usług dodatkowych. Za sugestią poszukiwania różnorodności kryje się potrzeba stymulowania rynku na rzecz poszukiwania nowych możliwość technologicznych, organizacyjnych i biznesowych. Rosnąca dywersyfikacja powinna sprzyjać zwiększeniu odporności gospodarki na wstrząsy oraz stymulować rozwój różnych branż. Po trzecie, należy promować umiędzynarodowienie polskiego sektora elektromobilności. Stanowi to bowiem jeden z warunków jego konkurencyjności, a więc i powodzenia projektu, który ma charakter trudnego wyzwania społecznego i ekonomicznego. Sięganie po międzynarodowe doświadczenia, w tym zaawansowanych pod względem elektromobilności krajów azjatyckich, przyciąganie BIZ i eksport kapitału oraz wsparcie krajowych championów to istotne wyzwania polityki gospodarczej.

Należy odnotować, że w stosunkowo krótkim okresie zbudowano wizję polskiego rynku elektromobilności. Wyznaczono kierunki rozwoju na następne lata, programując jednocześnie zasoby i kapitał, które będą sprzyjały realizacji celu. Rola państwa podąża w stronę zarówno połączenia wiedzy i kreatywności polskiego przemysłu oraz podjęcia się roli animatora definiującego brzegowe warunki popytu i podaży 
na rynku, jak i podejmowania ryzyka i testowania rozwiązań. Ponadto uruchomiono inicjatywy mające na celu koncentrację $\mathrm{B}+\mathrm{R}$ wokół spokrewnionych branż oraz stworzenie ekosystemu sprzyjającego komercjalizacji badań, co było dotąd jedną z największych bolączek systemu innowacyjności w Polsce. Niezależnie od tego, że stosunkowo szybko zmobilizowano kapitał społeczny i zbudowano wizję rozwoju, należy pamiętać, że jesteśmy na początku mozolnej drogi w zakresie budowy rynku elektromobilności w Polsce. Niestety nawet Nowa Ekonomia Strukturalna nie daje łatwych recept na to, jak działać szybko i jednocześnie rozważnie w warunkach silnej presji rynkowej i globalnego wyścigu, do którego polski przemysł chce dołączyć.

Innowacja, a za taką można uznać rozwój rynku elektromobilności na polu technicznym i społecznym, podąża często skokową i niepozbawioną ryzyka ścieżką. Dlatego próba objaśnienia fenomenu dynamicznego rozkwitu dyskusji, ale również konkretnych działań w zakresie elektromobilności w Polsce oraz dalszego rozwoju rynku wymaga odejścia od liniowego myślenia o rzeczywistości. Tymczasem ekonomiści, choć stanowią prawdopodobnie jedną z grup społeczno-zawodowych, w znacznym stopniu świadomą, że wiele procesów w gospodarce nie przebiega w sposób liniowy, do rozwiązywania problemów gospodarczych wykorzystują często projekcje oparte na zależnościach linearnych.

\section{Bibliografia}

Agénor, P.R., Canuto, O. i Jelenic, M. (2012). Avoiding middle-income growth traps. World Bank-Economic Premise, (98), 1-7.

Agénor, P.R. (2016). Caught in the middle? The economics of middle income traps. Journal of Economic Surveys, 22 August, http://dx.doi.org/10.1111/joes.12175.

Aghion, P. i Howitt, P. (2009). The Economics of Growth. Cambridge, MA: MIT Press.

Barteczko, K. i Tchorek, G. (2016). Wprowadzenie euro a konkurencyjność polskich przedsiębiorstw na rynkach zagranicznych. Baza danych zgromadzona na potrzeby projektu NCN. Grant No. DEC-2011/03/D/HS4/01954. Pozyskano z: http://www.eurocompetitiveness.eu/.

Hausner, J. (red.). (2013). Competitive Poland. How to Advance in Global Economic League?. Kraków: Fundacja GAP.

Eichengreen, B. (2011). Escaping the middle-income trap. Berkeley: Barry Eichengreen University of California. Pozyskano z: http://www.kc.frb.org/publicat/sympos/2011/2011;

Eichengreen, B., Park, D. i Shin, K. (2013). Growth slowdowns redux: New evidence on the middle-income trap. NBER Working Papers from National Bureau of Economic Research, Inc., No. 18673.

Felipe, J. (2012). Tracking the Middle-Income Trap: What is It, Who is in It, and Why. ADB Economics Working Paper Series, No. 306, March.

Funke, M. i Ruhwedel, R. (2005). Export Variety and Economic Growth in East European Transition Economies. The Economics of Transition, 13(1), 25-50;

Füzi, A., Gombos, Sz. i Tóth, T. (2012). Location factors of automotive industry in Central and Eastern Europe. W: J. Rechnitzer, M.Smahó (red.), (2012). Vehicle Industry 
and Competitiveness of Regions in Central and Eastern Europe. Győr: Universitas-Győr Nonprofit Limited.

Gammeltoft, P. i Kokko, A. (2013). Introduction: Outward foreign direct investment from emerging economies and national development strategies: three regimes. International Journal of Technological Learning, Innovation and Development, 6(1/2), 1-20.

Gill, I.S. i Kharas, H. (2007). An East Asian Renaissance: Ideas for Economic Growth. Washington: World Bank.

Gill, I.S. i Kharas, H. (2015).The Middle-Income Trap Turns Ten. Policy Research Working Paper, No. 7403. World Bank Group, August.

Girma, S., Gong, Y., Görg, H. i Lancheros, S. (2015). Estimating direct and indirect effects of foreign direct investment on firm productivity in the presence of interactions between firms. Journal of International Economics, 95(1), 157-169.

Gorynia, M., Nowak, J. i Wolniak, R. (2010). Foreign Direct Investment in Central and Eastern Europe: The IDP trajectories of selected countries. Poznan University of Economics Review, 10(1), 5-26.

Imbs, J. i Wacziarg, R. (2003). Stages of Diversification. American Economic Review, 93(1), 63-86.

Kędzierski, T. (2017). Elektromobilność a energetyka. Prezentacja BCG na Kongresie Ekonomicznym w Katowicach, maj.

Klich, J. (2014). Foreign Direct Investment in the The Visegrad Countries after 2004: Have the The Visegrad Countries` Membership in the European Union Changed Something? Entrepreneurial Business and Economic Review, 2(3), 19-31.

Klinger, B. i Lederman, D. (2006). Diversification, Innovation, and Imitation Inside the Global Technology Frontier. World Bank Policy Research Paper, No. 3872. Washington: The World Bank.

KPMG. (2017). KPMG's Global Automotive Executive Survey 2017.Pozyskano z: https://assets. kpmg.com/content/dam/kpmg/xx/pdf/2017/01/global-automotive-executive-survey-2017. pdf.

Kurtyka, M. (2017). Rozwój elektromobilności w Polsce w kontekście Nowej Ekonomii Strukturalnej. W: J.Y. Lin, A.Z. Nowak (red.), Nowa Ekonomia Strukturalna wobec krajów mniej zaawansowanych. Warszawa: Wydawnictwa Naukowe Wydziału Zarządzania UW.

Lin, J.Y. (2012). New Structural Economics: A Framework for Rethinking Development and Policy. Washington, DC: World Bank Publications.

Mazzucato, M. (2016). Przedsiębiorcze państwo. Warszawa: Wydawnictwo Ekonomiczne Hetorodox.

Meliciani, V. i Tchorek, G. (2017). Global value chains, innovation and firms' performance during the crisis. NBP Working Paper, No. 259.

Narula, R. i Guimón, J. (2010). The investment development path in a globalized world: implications for Eastern Europe. Eastern Journal of European Studies, 1(2), 5-19.

Sławiński, A. i Growiec, J. (red.). (2016). Potencjat innowacyjny gospodarki: uwarunkowania, determinanty, perspektywy. Warszawa: Narodowy Bank Polski. Pozyskano z: https://www. nbp.pl/aktualnosci/wiadomosci_2016/20160530_Raport_innowacyjnosc.pdf.

Parteka, A. (2013). The evolving structure of Polish exports (1994-2010) - diversification of products and trade partners. Bank $i$ Kredyt, 44(5).

Randal, T. (2017). The Electric-Car Boom Is So Real Even Oil Companies Say It's Coming https://www.bloomberg.com/news/articles/2017-04-25/electric-car-boom-seen-triggeringpeak-oil-demand-in-2030s (20.05.2017). 
Tchorek, G. (2016). Foreign Direct Investment and Investment Development Path. The Case of Visegrad Countries. Studia i Materialy WZ UW, 22(2/2), 201-212.

Wojtyna, A. (2016). Kontrowersje teoretyczne wokół koncepcji pułapki średniego poziomu rozwoju. Gospodarka Narodowa, (6), 5-22.

World Integrated Trade Solution (WITS). Pozyskano z: http://wits.worldbank.org/ (15.05.2017). 
BEATA KOZŁOWSKA-CHYŁA

\title{
Jurydyczne aspekty gospodarczej pozycji państwa w sferze dominium
}

\begin{abstract}
Wpływ państwa na gospodarkę realizuje się w szczególności poprzez jego działania władcze podejmowane w sferze imperium. W obszarze prawa publicznego państwo posiada szereg instrumentów prawnych, za pomocą których tworzy i reguluje warunki rozwoju gospodarczego oraz kształt stosunków gospodarczych i społecznych. Doniosły wpływ na gospodarkę posiadają również działania podejmowane w ramach stosunków właścicielskich z udziałem państwa, występującego w osobie Skarbu Państwa. W sferze dominium państwo (Skarb Państwa) jest podmiotem praw i obowiązków o charakterze prywatnoprawnym, wraz z innymi państwowymi osobami prawnymi jest właścicielem mienia państwowego, a jego działania w tym zakresie istotnie wpływają na funkcjonowanie gospodarki. W niniejszym opracowaniu analizie zostaną poddane prawne uwarunkowania pozycji państwa w sferze dominium. Zagadnienie jest szczególnie aktualne w związku z dokonanymi w ostatnim czasie istotnymi zmianami stanu prawnego w zakresie stosunków właścicielskich z udziałem państwa. Kształt zastosowanych rozwiązań normatywnych oraz ich ratio legis stanowi przyczynek do dyskusji o pozycji gospodarczej państwa de lege lata.
\end{abstract}

Slowa kluczowe: państwo, Skarb Państwa, państwowe osoby prawne, mienie państwowe, sfera imperium, sfera dominium.

\section{Wprowadzenie}

Zagadnienie roli państwa jako kreatora warunków rozwoju gospodarczego i uczestnika stosunków gospodarczych, w tym pytanie o granice wpływu państwa na szeroko rozumianą gospodarkę kraju, od dawna stanowią przedmiot debat ekonomiczno-prawnych, w których ścierają się odmienne poglądy dotyczące stopnia dopuszczalnej ingerencji państwa w mechanizmy rynkowe. Państwo, będące złożoną organizacją posiadającą zadania wykraczające poza zakres prawa publicznego, ze swej istoty stanowi niepodzielną całość - będąc osobą prawa publicznego, posiada równocześnie, w postaci Skarbu Państwa, osobowość prawną w obrocie prywatnym (cywilnoprawnym) i wykonuje w ten sposób funkcje właścicielskie w stosunku do posiadanego mienia. W stosunkach prywatnoprawnych Skarb Państwa jako osoba prawna wykonuje swoje uprawnienia właścicielskie sfery dominium w sposób pozba- 
wiony, co do zasady, cech działania publicznoprawnego - imperium, państwo w osobie Skarbu Państwa jest w stosunkach cywilnoprawnych podmiotem praw i obowiązków, które dotyczą mienia państwowego (zob. Całus, 1995, s. 13). W obszarze prawa publicznego państwo wyposażone jest w imperium, występuje w pozycji władczej, realizuje swoje funkcje za pomocą środków przymusu (nakazu i zakazu) w warunkach podporządkowania. Zarówno w sferze imperium, jak i dominium państwo odrywa istotną rolę z jednej strony jako regulator stosunków gospodarczych, z drugiej zaś - jako uczestnik obrotu gospodarczego. Realizacja przyjmowanych założeń polityki gospodarczej państwa następuje w szczególności poprzez kształtowanie systemu normatywnego w obszarze prawa publicznego i prywatnego w sposób wyznaczający ramy prawne dla stosunków gospodarczo-społecznych i ich uczestników. Państwo, realizując przypisane mu funkcje: alokacyjną, redystrybucyjną i stabilizacyjną, działa w sferze imperium poprzez odpowiednie organy władzy ustalające normy prawne w celu regulowania szeroko rozumianej sfery gospodarki. W wymiarze ustawodawczym są to regulacje prawne w szczególności w zakresie prawa własności i jego ochrony, zakresu swobody działalności gospodarczej, ochrony konkurencji, prawa pracy i zabezpieczeń społecznych, prawa ochrony środowiska, prawa budżetowego, podatkowego, administracyjnego, a nawet prawa karnego. Kształt tych regulacji jest wynikiem określonej „filozofii” przyjmowanej przez ustawodawcę w procesie normatywnego definiowania roli państwa w gospodarce. Charakterystyka założeń i rozwiązań jurydycznych w tym zakresie kształtuje de lege lata odpowiedź na pytanie o obecny zakres ingerencji państwa w stosunki gospodarcze, de lege ferenda debata pozostaje wciąż otwartą.

W ostatnim czasie, dzięki przepisom ustawy o zasadach zarządzania mieniem państwowym ${ }^{1}$ oraz ustawy - Przepisy wprowadzające ustawę o zasadach zarządzania mieniem państwowym ${ }^{2}$, dokonane zostały istotne zmiany normatywne w zakresie odnoszącym się do działania państwa w sferze prywatnoprawnych stosunków gospodarczych. Nowe regulacje prawne redefiniują dotychczasową pozycję państwa działającego w sferze dominium, a ich znaczenie dla obrotu gospodarczego ma wymiar kluczowy. Państwo bowiem, co zostało wyżej wskazane, odgrywa w gospodarce nie tylko rolę regulacyjną, lecz także, jako Skarb Państwa, jest podmiotem stosunków gospodarczych, aktywnie uczestnicząc w obrocie cywilnoprawnym na zasadzie równorzędności z innymi przedsiębiorcami, jest podmiotem praw i obowiązków, które dotyczą mienia państwowego nienależącego do innych państwowych osób prawnych (art. 34 k.c.). Wyznaczany regulacjami prawnymi zakres własności państwowej oraz warunki jej „wykonywania” oddziałują w efekcie na strukturę rynku i procesy gospodarcze na nim zachodzące, stanowiąc istotny element polityki gospodarczej państwa.

1 Ustawa z dnia 16 grudnia 2016 r. o zasadach zarządzania mieniem państwowym (Dz.U. 2016, poz. 2259), weszła w życie w dniu 1 stycznia 2017 r.

2 Ustawa z dnia 16 grudnia 2016 r. - Przepisy wprowadzające ustawę o zasadach zarządzania mieniem państwowym (Dz.U. 2016, poz. 2260). 
Jednocześnie, co warte podkreślenia, zarówno analiza obecnie obowiązujących regulacji prawnych we wskazanym zakresie, jak i prześledzenie kierunku dokonywanych zmian normatywnych oraz ratio legis tych zmian stanowią istotny przyczynek do dyskusji nad obecną i przyszłą rolą państwa w gospodarce.

Intencją normodawcy stało się przeprowadzenie wieloaspektowej reformy sfery wykonywania uprawnień właścicielskich Skarbu Państwa (dominium), tj. obszaru, w którym państwo występuje jako właściciel mienia. Uznano, że obowiązujące dotąd regulacje prawne tworzone były na potrzeby procesu transformacji sfery gospodarczej i własnościowej, a w konsekwencji w znacznej części nie przystają one do obecnej rzeczywistości gospodarczej i wymagają głębokich zmian systemowych. Celem dokonywanych zmian normatywnych jest, aby państwo, działając w sferze dominium, położyło główny akcent na efektywne gospodarowanie posiadanym mieniem w celu budowania jego trwałej wartości, a także na jego zabezpieczenie przed możliwymi nadużyciami. Uznano, że dotychczasowy model charakteryzował się istotnymi wadami strukturalnymi, polegającymi na realizacji wykonywania praw w stosunku do mienia państwowego przez znaczną liczbę organów i podmiotów, bez zorganizowanej koordynacji polityki państwa w zakresie zarządzania mieniem państwowym na poziomie Rady Ministrów, w efekcie czego silne ekonomicznie podmioty działały w pojedynkę, nie wykorzystując możliwości, jakie stwarza działanie podobnie jak grupa kapitałowa przy realizacji wspólnych przedsięwzięć, co z kolei generuje koszty utraconych szans rozwojowych, jakie można by osiągnąć efektywniej wykorzystując posiadane zasoby ${ }^{3}$.

Wśród obszarów normatywnych, które zdaniem Autorki w kluczowy sposób redefiniują dotychczasowy model stosunków własnościowych z udziałem państwa i podmiotów państwowych, należy w szczególności wskazać poniższe nowe rozwiązania prawne.

\section{Pojęcie państwowej osoby prawnej}

Struktura własności majątku państwowego opiera się na zasadzie, że własność i inne prawa majątkowe, stanowiące mienie państwowe, przysługują Skarbowi Państwa albo innym państwowym osobom prawnym (art. $44^{1}$ k.c.). W obrocie występuje więc, poza Skarbem Państwa, wiele innych osób prawnych, których majątek w całości jest majątkiem państwa, tyle że z różnych względów - najczęściej z uwagi na efektywność zarządzania - jednostki te w stosunkach cywilnoprawnych występują jako odrębne od Skarbu Państwa osoby prawne (Frąckowiak, 2012, s. 1175 i n.). Obowiązująca do 1 stycznia 2017 r. definicja państwowej osoby prawnej zawarta była w art. 1a ustawy o zasadach wykonywania uprawnień przysługujących Skarbowi

3 Zob. Uzasadnienie do projektu ustawy o zasadach zarządzania mieniem państwowym. Pozyskano z: www.orka.sejm.gov.pl. 
Państwa 4 , w myśl której państwową osobą prawną jest inna niż Skarb Państwa jednostka organizacyjna, posiadająca osobowość prawną, której mienie w całości jest mieniem państwowym.

Obecna, bardzo rozbudowana definicja państwowej osoby prawnej oparta jest na enumeratywnym wyliczeniu jednostek organizacyjnych, zaliczanych do kategorii państwowych osób prawnych, uzupełnionym o dodatkowe kryteria kwalifikujące podmioty nieujęte w wyliczeniu enumeratywnym do tej kategorii. Jednocześnie nowa definicja usuwa dotychczasowy błąd logiczny, zawarty w regulacji wcześniej obowiązującej (idem per idem), gdzie definiowano państwową osobę prawną za pomocą pojęcia mienia państwowego, mienie państwowe zaś - przez pojęcie państwowej osoby prawnej. Zgodnie z art. 3 ust. 1 ustawy o zasadach zarządzania mieniem państwowym, państwową osobą prawną jest:

1) jednostka organizacyjna posiadająca osobowość prawną, utworzona w drodze ustawy lub na podstawie ustawy lub w wykonaniu ustawy przez organ administracji rządowej, w celu realizacji zadań publicznych, w której:

- przewidziane w regulujących ustrój tej osoby prawnej przepisach ustawy prawo nadawania i zmiany statutu przysługuje organowi administracji rządowej albo przepisy te przewidują, że prawo do udziału w organie stanowiącym osoby prawnej, w tym uprawnionym do zmiany statutu, przysługuje w całości Skarbowi Państwa oraz

- przewidziane w regulujących ustrój tej osoby prawnej przepisach ustawy prawo do nadwyżki między przychodami a kosztami tej osoby prawnej, jeżeli podlegają dysponowaniu, przysługują w całości Skarbowi Państwa, chyba że przepisy te przewidują inny niż prawo do nadwyżki sposób dysponowania nią, oraz

- w razie rozwiązania albo innej utraty bytu prawnego przez tę osobę prawną, prawa do jej majątku, w tym prawo do dysponowania tym majątkiem, przysługują wyłącznie Skarbowi Państwa;

2) agencja wykonawcza, o której mowa w ustawie z dnia 27 sierpnia 2009 r. o finansach publicznych (Dz. U. 2016, poz. 1870, 1948 i 1984), w szczególności:

- Agencja Nieruchomości Rolnych,

- Agencja Rynku Rolnego,

- Agencja Mienia Wojskowego,

- Agencja Rezerw Materiałowych,

- Polska Agencja Rozwoju Przedsiębiorczości,

- Narodowe Centrum Nauki,

- Narodowe Centrum Badań i Rozwoju,

- Centralny Ośrodek Badania Odmian Roślin Uprawnych,

- Agencja Restrukturyzacji i Modernizacji Rolnictwa,

- Polska Agencja Kosmiczna;

4 Ustawa z dnia 8 sierpnia 1996 r. o zasadach wykonywania uprawnień przysługujących Skarbowi Państwa (t.j. Dz.U. 2016, poz. 154 z późn. zm.), uchylona z dniem 1 stycznia 2017 r. 
3) instytucja gospodarki budżetowej, o której mowa w ustawie z dnia 27 sierpnia 2009 r. o finansach publicznych;

4) państwowy fundusz celowy posiadający osobowość prawną;

5) państwowa instytucja kultury;

6) Polski Instytut Sztuki Filmowej;

7) Narodowy Instytut Fryderyka Chopina;

8) Zakład Narodowy imienia Ossolińskich;

9) Polska Akademia Nauk i jej jednostki naukowe posiadające osobowość prawną;

10) uczelnia publiczna utworzona przez państwo reprezentowane przez właściwy organ władzy lub administracji rządowej;

11) instytut badawczy w rozumieniu ustawy z dnia 30 kwietnia 2010 r. o instytutach badawczych (Dz.U. 2016, poz. 371, 1079 i 1311);

12) Międzynarodowy Instytut Biologii Molekularnej i Komórkowej w Warszawie;

13) samodzielny publiczny zakład opieki zdrowotnej, dla którego podmiotem tworzącym jest Skarb Państwa reprezentowany przez ministra, centralny organ administracji rządowej albo wojewodę albo uczelnia publiczna, o której mowa w pkt 10 ;

14) park narodowy;

15) przedsiębiorstwo państwowe;

16) bank państwowy;

17) Agencja Oceny Technologii Medycznych i Taryfikacji;

18) Narodowy Fundusz Ochrony Środowiska i Gospodarki Wodnej;

19) Polska Organizacja Turystyczna;

20) Urząd Dozoru Technicznego;

21) Transportowy Dozór Techniczny;

22) Polskie Centrum Akredytacji;

23) Polska Agencja Żeglugi Powietrznej;

24) Zakład Ubezpieczeń Społecznych;

25) Narodowy Fundusz Zdrowia;

26) Rzecznik Finansowy;

27) Polski Klub Wyścigów Konnych;

28) Centrum Polsko-Rosyjskiego Dialogu i Porozumienia;

29) Centrum Doradztwa Rolniczego oraz wojewódzkie ośrodki doradztwa rolniczego;

30) Polski Instytut Spraw Międzynarodowych.

Zgodnie z art. 3 ust. 2 w/w ustawy, jednostka organizacyjna, o której mowa w ust. 1 pkt 1, nie przestaje być państwową osobą prawną z tej przyczyny, że ustawa regulująca ustrój tej osoby prawnej przewiduje, że prawo do udziału w organie stanowiącym osoby prawnej, w tym uprawnionym do zmiany statutu, przysługiwać będzie wyłącznie albo w części innemu podmiotowi lub podmiotom, jeżeli organ administracji rządowej, chociażby inny, niż tworzący osobę prawną, sprawuje nadzór nad taką osobą prawną, wynikający z przepisów tej ustawy. 
Stosownie zaś do art. 3 ust. 3, państwową osobą prawną jest także: 1) jednostka organizacyjna niespełniająca przesłanek, o których mowa w ust. 1 pkt 1 , jeżeli ustawa tak stanowi; 2) spółka, której akcjonariuszami są wyłącznie Skarb Państwa lub inne państwowe osoby prawne.

Mienie należące do Skarbu Państwa oraz do innych państwowych osób prawnych (mienie państwowe) jest miernikiem ,ilości” własności państwowej w gospodarce. Ustalenie właściwych rynkowo proporcji udziału własności państwowej i prywatnej stanowi jedną z osi sporu wokół problematyki prywatyzacji majątku państwowego. W tym obszarze również nastąpiły zasadnicze zmiany stanu prawnego, mające istotne znaczenie z perspektywy oceny roli i pozycji państwa w sferze dominium.

\section{Kwestia prywatyzacji majątku państwowego}

Poważnym zmianom normatywnym poddano ustawę o komercjalizacji i prywatyzacji ${ }^{5}$ Z punktu widzenia analizowanej problematyki kluczowe znaczenie ma uchylenie przepisów o prywatyzacji pośredniej i bezpośredniej oraz zmiana nazwy ustawy na ustawa o komercjalizacji i niektórych uprawnieniach pracowników6. Ustawodawca całkowicie odchodzi od pojęcia prywatyzacji. Z systemu prawnego znika zatem tryb prywatyzacji bezpośredniej, polegającej na rozporządzeniu wszystkimi składnikami materialnymi i niematerialnymi majątku przedsiębiorstwa państwowego przez sprzedaż przedsiębiorstwa, wniesienie przedsiębiorstwa do spółki albo oddanie przedsiębiorstwa do odpłatnego korzystania. Zbycie akcji lub udziałów należących do Skarbu Państwa nie będzie dokonywane w dotychczasowym trybie prywatyzacji pośredniej, lecz na ogólnych zasadach określonych w ustawie o zasadach zarządzania mieniem państwowym (art. 11-12). Jednym z głównych założeń tej ustawy jest zmiana filozofii w zakresie zbywania akcji i udziałów Skarbu Państwa, które staje się jednym z elementów gospodarowania tym mieniem państwowym, a nie głównym procesem w tym zakresie. Dotychczas obowiązywał mechanizm polegający na założeniu, że głównym organem uprawnionym do zbywania w imieniu Skarbu Państwa akcji i udziałów był Minister Skarbu Państwa, zbycie zaś odbywało się na zasadach i w trybach określonych w ustawie o komercjalizacji i prywatyzacji. Odejście od tego modelu polega na przyjęciu zasady, że akcje i udziały w imieniu Skarbu Państwa zbywa, za zgodą Rady Ministrów, organ lub podmiot uprawniony do wykonywania wynikających $\mathrm{z}$ nich praw. Zrezygnowano z enumeratywnego wyliczenia dopuszczalnych trybów prywatyzacji na rzecz rozwiązania, zgodnie z którym organ lub podmiot ubiegający się o wyrażenie zgody na zbycie akcji lub udziałów będzie proponował Radzie Ministrów tryb zbycia. Ostatecznie tryb zbycia określać

5 Ustawa z dnia 30 sierpnia 1996 r. o komercjalizacji i prywatyzacji (t.j. Dz.U. 2016, poz. 981 z późn. zm.).

6 Art. 14 ustawy - Przepisy wprowadzające ustawę o zasadach zarządzania mieniem państwowym. 
będzie Rada Ministrów, z jednoczesnym wyrażeniem zgody na transakcję. Zgodnie z intencją normodawcy, powyższe rozwiązanie stanowi przejaw „urynkowienia” sfery wykonywania uprawnień przysługujących Skarbowi Państwa, jednocześnie zbycie na nowych warunkach musi uwzględniać ochronę interesów Skarbu Państwa7.

Co istotne, nowe regulacje statuują całkowity zakaz zbywania akcji spółek o istotnym znaczeniu dla gospodarki państwa, wyliczonych enumeratywnie w art. 13 ustawy o zasadach zarządzania mieniem państwowym ${ }^{8}$. Sankcją za naruszenie wymogów ustawy (art. 11-15), dotyczących zbycia akcji lub udziałów Skarbu Państwa jest nieważność czynności prawnej mającej za przedmiot zbycie akcji lub udziałów - art. 16 ustawy.

\section{Wykonywanie praw z akcji i udziałów należących do Skarbu Państwa}

W dotychczasowym stanie prawnym funkcje organu odpowiedzialnego w szczególności za ochronę interesów Skarbu Państwa, komercjalizację, prywatyzację, wykonywanie praw z akcji i udziałów w spółkach z udziałem Skarbu Państwa pełnił Minister Skarbu Państwa. Rozwiązanie obecnie obowiązujące polega na zniesieniu działu Skarb Państwa oraz organu ministra właściwego do spraw Skarbu Państwa ${ }^{9}$ i przeniesieniu zasadniczej części kompetencji Ministra Skarbu Państwa na

7 Zob. Uzasadnienie do projektu ustawy o zasadach zarządzania mieniem państwowym, op. cit.

8 Zakazem zbycia objęte są akcje następujących spółek: 1) Agencja Rozwoju Przemysłu Spółka Akcyjna z siedzibą w Warszawie; 2) Enea Spółka Akcyjna z siedzibą w Poznaniu; 3) Energa Spółka Akcyjna z siedzibą w Gdańsku; 4) Giełda Papierów Wartościowych w Warszawie Spółka Akcyjna z siedzibą w Warszawie; 5) Grupa Azoty Spółka Akcyjna z siedzibą w Tarnowie; 6) Grupa Azoty Zakłady Chemiczne „Police” Spółka Akcyjna z siedzibą w Policach; 7) Grupa Azoty „Puławy” Spółka Akcyjna z siedzibą w Puławach; 8) Grupa LOTOS Spółka Akcyjna z siedzibą w Gdańsku; 9) Jastrzębska Spółka Węglowa Spółka Akcyjna z siedzibą w JastrzębiuZdroju; 10) KGHM Polska Miedź Spółka Akcyjna z siedzibą w Lubinie; 11) Polska Grupa Energetyczna Spółka Akcyjna z siedzibą w Warszawie; 12) Polska Grupa Zbrojeniowa Spółka Akcyjna z siedzibą w Radomiu; 13) Polski Fundusz Rozwoju Spółka Akcyjna z siedzibą w Warszawie; 14) Polskie Górnictwo Naftowe i Gazownictwo Spółka Akcyjna z siedzibą w Warszawie; 15) Polski Holding Nieruchomości Spółka Akcyjna z siedzibą w Warszawie; 16) Polski Holding Obronny Spółka z ograniczoną odpowiedzialnością z siedzibą w Warszawie; 17) Polski Koncern Naftowy Orlen Spółka Akcyjna z siedzibą w Płocku; 18) PKP Polskie Linie Kolejowe Spółka Akcyjna z siedzibą w Warszawie; 19) PKP Cargo Spółka Akcyjna z siedzibą w Warszawie; 20) Powszechna Kasa Oszczędności Bank Polski Spółka Akcyjna z siedzibą w Warszawie; 21) Powszechny Zakład Ubezpieczeń Spółka Akcyjna z siedzibą w Warszawie; 22) Polska Wytwórnia Papierów Wartościowych Spółka Akcyjna z siedzibą w Warszawie; 23) Totalizator Sportowy Spółka z ograniczoną odpowiedzialnością z siedzibą w Warszawie; 24) Tauron Polska Energia Spółka Akcyjna z siedzibą w Katowicach.

9 Art. 23 ustawy - Przepisy wprowadzające ustawę o zasadach zarządzania mieniem państwowym, op. cit. 
Prezesa Rady Ministrów. Zgodnie z art. 7 ust. 1 ustawy o zasadach zarządzania mieniem państwowym Prezes Rady Ministrów koordynuje wykonywanie uprawnień przysługujących Skarbowi Państwa w spółkach oraz dąży do zapewnienia jednolitego sposobu wykonywania praw z akcji należących do Skarbu Państwa, wykonuje prawa z akcji należących do Skarbu Państwa, łącznie z wynikającymi z nich prawami osobistymi, o ile przepisy odrębne nie stanowią inaczej, wykonuje uprawnienia z akcji należących do Skarbu Państwa na walnym zgromadzeniu w sprawach, o których mowa w art. $201 \S 4$ oraz art. 368 § kodeksu spółek handlowych ${ }^{10}$, składa w imieniu Skarbu Państwa oświadczenia woli o utworzeniu spółki, przystąpieniu do spółki lub objęciu akcji. Uprawnienia te w zasadniczej części mogą być przekazane przez Prezesa Rady Ministrów innemu członkowi Rady Ministrów, pełnomocnikowi rządu lub państwowej osobie prawnej. Wówczas Rada Ministrów rozporządzeniem ma określić wykaz spółek, w których uprawnienia wykonują inni członkowie Rady Ministrów, pełnomocnicy rządu lub państwowe osoby prawne. W takim przypadku Prezes Rady Ministrów zachowuje (obok organu/osoby upoważnionej w powyższym trybie) prawo zwołania lub żądania zwołania walnego zgromadzenia i umieszczenia poszczególnych spraw w porządku obrad zgromadzenia - art. 8 ustawy.

Rada Ministrów, w trybie wskazanym powyżej, określiła wykaz spółek, w których prawa z akcji Skarbu Państwa wykonują inni niż Prezes Rady Ministrów członkowie Rady Ministrów, kierujący odpowiednimi ze względu na przedmiot działalności spółek resortami ${ }^{11}$.

Dokonaną zmianę modelu wykonywania uprawnień właścicielskich w zakresie wykonywania praw z akcji i udziałów w spółkach Skarbu Państwa należy oceniać na kilku płaszczyznach. Przede wszystkim, formalne przekazanie tych uprawnień Prezesowi Rady Ministrów odczytywać należy jako wzmocnienie nadzoru państwa nad spółkami z udziałem Skarbu Państwa. Co prawda Prezes Rady Ministrów przekazał wykonywanie większości uprawnień względem spółek członkom Rady Ministrów, jednak zachowuje ustawowo ciążący na nim obowiązek koordynacji wykonywania uprawnień przysługujących Skarbowi Państwa w spółkach oraz obowiązek dążenia do zapewnienia jednolitego sposobu wykonywania praw z akcji należących do Skarbu Państwa (art. 7 ust. 1 pkt 1 w zw. z art. 8 ust. 1 ustawy). Zakłada się, że w tym celu Prezes Rady Ministrów będzie podejmował działania standaryzujące w/w proces, np. w postaci wydawania wiążących podległe mu organy i podmioty zarządzeń, określający bądź precyzujących zasady nadzoru właścicielskiego ${ }^{12}$.

Dodatkowo, w obecnie obowiązującym modelu wykonywania praw z akcji i udziałów w spółkach Skarbu Państwa rzeczą charakterystyczną jest przekazanie

10 Ustawa z dnia 15 września 2000 r. - Kodeks spółek handlowych (t.j. Dz.U. 2016, poz. 1578, 1579, 2255).

11 Rozporządzenie Rady Ministrów z dnia 3 stycznia 2017 r. w sprawie wykazu spółek, w których prawa z akcji Skarbu Państwa wykonują inni niż Prezes Rady Ministrów członkowie Rady Ministrów, pełnomocnicy Rządu lub państwowe osoby prawne (Dz.U. 2017, poz. 10).

12 Zob. Uzasadnienie do projektu ustawy o zasadach zarządzania mieniem państwowym, op. cit. 
faktycznego nadzoru nad poszczególnymi spółkami Skarbu Państwa ministrom kierującym działami administracji rządowej, z którymi związana jest specyfika działalności poszczególnych spółek. Nadzór poszczególnych resortów nad spółkami Skarbu Państwa oznacza wzmocnienie realizacji funkcji ekomoniczno-gospodarczych państwa poprzez zadania realizowane przez same spółki. Powyższe rozwiązanie nabiera szczególnego znaczenia w odniesieniu do spółek posiadających istotne znaczenie dla gospodarki kraju ${ }^{13}$. Państwo swoje funkcje publiczne, strategiczne z punktu widzenia funkcjonowania kraju (np. w obszarze obronności, bezpieczeństwa publicznego, zapewnienia infrastruktury, ochrony obywateli czy innych funkcji publicznie użytecznych) realizuje zasadniczo poprzez działania w sferze imperium. Uzupełnieniem tych działań jest aktywność państwa w sferze dominium, realizowana przez Skarb Państwa w spółkach o strategicznym znaczeniu dla gospodarki kraju. Z punktu widzenia instrumentów gospodarczych posiadanych przez państwo, spółki Skarbu Państwa o istotnym znaczeniu dla gospodarki kraju stanowią więc ważny element realizacji przez państwo kluczowych funkcji publicznych. Przyporządkowanie nadzoru nad tymi spółkami ministrom kierującym resortami funkcjonalnie powiązanymi z przedmiotem działalności poszczególnych spółek, bez wątpienia wzmacnia realizację ważnych gospodarczo i społecznie funkcji publicznych państwa.

\section{Zarządzanie mieniem Skarbu Państwa}

Mienie państwowe służy wykonywaniu zadań publicznych, zarządza się nim zgodnie z zasadami prawidłowej gospodarki, z zachowaniem szczególnej staranności (art. 4 ustawy o zasadach zarządzania mieniem państwowym). Ustawa w rozdziale 6 statuuje szczegółowe zasady zarządzania mieniem państwowym innym niż akcje, rozdział 7 poświęcony jest nadzorowi nad czynnościami prawnymi państwowych osób prawnych (zgodnie z art. 3 ust. 4 przepisów ustawy dotyczących państwowych osób prawnych nie stosuje się do spółek). W szczególności warto odnotować wynikający z art. 38 ustawy obowiązek uzyskania zgody właściwego organu na czynność mającą za przedmiot rozporządzenie składnikami aktywów trwałych w rozumieniu ustawy o rachunkowości, zaliczonymi do wartości niematerialnych i prawnych, rzeczowych aktywów trwałych lub inwestycji długoterminowych, w tym wniesienia ich jako wkładu do spółki lub spółdzielni, jeżeli wartość rynkowa tych składników przekracza 200 tys. złotych. Zgody właściwego organu wymaga również dokonanie przez państwową osobę prawną czynności prawnej w zakresie oddania w/w składników do korzystania innemu podmiotowi, na okres dłuższy niż 180 dni w roku

13 Zob. Rozporządzenie Prezesa Rady Ministrów z dnia 13 stycznia 2017 r. w sprawie określenia wykazu spółek o istotnym znaczeniu dla gospodarki państwa (Dz.U. 2017, poz. 95). Zob. też art. 32 i 33 ustawy o zasadach zarządzania mieniem państwowym, statuujące podwyższone rygory wykonywania praw z akcji w takich spółkach. 
kalendarzowym, jeżeli wartość czynności prawnej przekracza 200 tys. złotych. Ustawa określa szczegółowy tryb dokonania powyższych czynności, organ właściwy do wydania zgody, wyłączenia przedmiotowe i podmiotowe. Dokonanie czynności prawnej bez uzyskania wymaganej ustawą zgody właściwego organu dotknięte jest sankcją nieważności. Wskazać również należy na przepisy ustawy o Prokuratorii Generalnej Rzeczypospolitej Polskiej14, które obowiązywać będą od dnia 1 lipca 2017 r., w szczególności art. 18-20 ustawy. Podmioty reprezentujące Skarb Państwa będą obowiązane uzyskiwać opinię prawną Prokuratorii Generalnej o projektach umów, ugód oraz jednostronnych czynności prawnych dokonywanych przez Skarb Państwa, jeżeli wartość przedmiotu czynności prawnej przekracza kwotę 100000000 zł (art. 18 ustawy). Zgodnie z art. 20 ustawy, podmioty reprezentujące Skarb Państwa oraz osoby zastępowane będące państwowymi osobami prawnymi są obowiązane uzyskać opinię prawną Prokuratorii Generalnej w przedmiocie projektu: 1) umowy o doradztwo prawne, jeżeli wysokość wynagrodzenia przewidzianego łącznie za świadczone usługi przekracza kwotę 500000 zł netto, w stosunku rocznym; 2) zmiany umowy o doradztwo prawne podwyższającej wynagrodzenie do kwoty przekraczającej kwotę, o której mowa w pkt 1;3) umowy o doradztwo prawne, w której maksymalna wysokość wynagrodzenia nie jest określona.

W odniesieniu do spółek z udziałem Skarbu Państwa lub z udziałem innych państwowych osób prawnych ustawodawca nie nakłada wprost ustawą obowiązku uzyskania zgód korporacyjnych na określone czynności spółki, obliguje jednak podmioty uprawnione do wykonywania praw z akcji należących do Skarbu Państwa lub państwową osobę prawną, w zakresie wykonywania praw z akcji spółki, do podjęcia działań mających na celu wprowadzenie do statutów (umów) spółek lub uchwałą walnego zgromadzenia (zgromadzenia wspólników) stosownych zapisów, z których wynikać będzie obowiązek uzyskania zgody walnego zgromadzenia (w niektórych przypadkach zgody organu nadzorczego) na określone ustawą czynności prawne. Katalog tych czynności jest szeroki (art. 17 ustawy ${ }^{15}$ ), dotyczy zarówno rozporzą-

14 Ustawa z dnia 15 grudnia 2016 r. o Prokuratorii Generalnej Rzeczypospolitej Polskiej (Dz.U. 2016, poz. 2261).

15 Zgodnie z art. 17 ustawy o zasadach zarządzania mieniem państwowym:

1. Podmiot uprawniony do wykonywania praw z akcji należących do Skarbu Państwa lub państwowa osoba prawna, w zakresie wykonywania praw z akcji w spółce, są obowiązane podejmować działania mające na celu określenie, w drodze uchwały walnego zgromadzenia lub w statucie tej spółki, że zgody walnego zgromadzenia wymaga: 1) rozporządzenie składnikami aktywów trwałych w rozumieniu ustawy z dnia 29 września 1994 r. o rachunkowości (Dz.U. 2016, poz. 1047 i 2255), zaliczonymi do wartości niematerialnych i prawnych, rzeczowych aktywów trwałych lub inwestycji długoterminowych, w tym wniesienie jako wkładu do spółki lub spółdzielni, jeżeli wartość rynkowa tych składników przekracza wartość 5\% sumy aktywów w rozumieniu ustawy z dnia 29 września 1994 r. o rachunkowości, ustalonych na podstawie ostatniego zatwierdzonego sprawozdania finansowego, a także oddanie tych składników do korzystania innemu podmiotowi, na okres dłuższy niż 180 dni w roku kalendarzowym, na podstawie czynności prawnej, jeżeli wartość rynkowa przedmiotu czynności prawnej przekracza $5 \%$ sumy aktywów, przy czym, oddanie do korzystania w przypadku: a) umów najmu, dzierżawy 
dzeń majątkowych, oddania określonych składników majątkowych do korzystania innemu podmiotowi, nabycia składników majątkowych, w tym nabycia lub objęcia akcji lub udziałów w innej spółce, zbycia akcji lub udziałów w innej spółce, zawarcia umowy o usługi prawne, marketingowe, w zakresie PR, komunikacji społecznej oraz doradztwa związanego z zarządzaniem - spełniających warunki szczegółowo określone w ustawie.

Powyższe rozwiązania prawne wyraźnie świadczą o intencji ustawodawcy istotnego wzmocnienia nadzoru nad działaniem spółek z udziałem Skarbu Państwa lub z udziałem innych państwowych osób prawnych. Co istotne, podobny obowiązek nałożony został odnośnie do spółek zależnych od spółek z udziałem Skarbu Państwa lub z udziałem innych państwowych osób prawnych (precyzyjnie ujmując, chodzi o spółki, wobec których spółka z udziałem Skarbu Państwa lub państwowej osoby prawnej jest przedsiębiorcą dominującym w rozumieniu ustawy o ochronie konkurencji i konsumentów ${ }^{16}$ - art. 17 ust. 7 ustawy o zasadach zarządzania mieniem

i innych umów o oddanie składnika majątkowego do odpłatnego korzystania innym podmiotom - przez wartość rynkową przedmiotu czynności prawnej rozumie się wartość świadczeń za: - rok - jeżeli oddanie składnika majątkowego nastąpiło na podstawie umów zawieranych na czas nieoznaczony, - cały czas obowiązywania umowy - w przypadku umów zawieranych na czas oznaczony, b) umów użyczenia i innych nieodpłatnych umów o oddanie składnika majątkowego do korzystania innym podmiotom - przez wartość rynkową przedmiotu czynności prawnej rozumie się równowartość świadczeń, jakie przysługiwałyby w razie zawarcia umowy najmu lub dzierżawy, za: - rok - jeżeli oddanie składnika majątkowego nastąpi na podstawie umowy zawieranej na czas nieoznaczony, - cały czas obowiązywania umowy - w przypadku umów zawartych na czas oznaczony; 2) nabycie składników aktywów trwałych w rozumieniu ustawy z dnia 29 września 1994 r. o rachunkowości, o wartości przekraczającej: a) 100000000 złotych lub b) wartość 5\% sumy aktywów w rozumieniu ustawy z dnia 29 września $1994 \mathrm{r}$. o rachunkowości, ustalonych na podstawie ostatniego zatwierdzonego sprawozdania finansowego; 3) objęcie albo nabycie akcji innej spółki o wartości przekraczającej: a) 100000000 złotych lub b) wartość 10\% sumy aktywów w rozumieniu ustawy z dnia 29 września $1994 \mathrm{r}$. o rachunkowości, ustalonych na podstawie ostatniego zatwierdzonego sprawozdania finansowego; 4) zbycie akcji innej spółki o wartości przekraczającej: a) 100000000 złotych lub b) $10 \%$ sumy aktywów w rozumieniu ustawy z dnia 29 września 1994 r. o rachunkowości, ustalonych na podstawie ostatniego zatwierdzonego sprawozdania finansowego. 2. Podmiot uprawniony do wykonywania praw z akcji należących do Skarbu Państwa lub państwowa osoba prawna, w zakresie wykonywania praw z akcji w spółce, są obowiązane podejmować działania mające na celu określenie, w drodze uchwały walnego zgromadzenia lub w statucie tej spółki, że zgody organu nadzorczego, wymaga zawarcie: 1) umowy o usługi prawne, usługi marketingowe, usługi w zakresie stosunków międzyludzkich (public relations) i komunikacji społecznej oraz usługi doradztwa związanego z zarządzaniem, jeżeli wysokość wynagrodzenia przewidzianego łącznie za świadczone usługi przekracza 500000 zł netto, w stosunku rocznym; 2) zmiany umowy o usługi prawne, usługi marketingowe, usługi w zakresie stosunków międzyludzkich (public relations) i komunikacji społecznej oraz usługi doradztwa związanego z zarządzaniem podwyższającej wynagrodzenie powyżej kwoty, o której mowa w pkt 1; 3) umowy o usługi prawne, usługi marketingowe, usługi w zakresie stosunków międzyludzkich (public relations) i komunikacji społecznej oraz usługi doradztwa związanego z zarządzaniem, w których maksymalna wysokość wynagrodzenia nie jest przewidziana. 3. Podmiot 
państwowym). Wzmocnienie nadzoru realizowane jest również przepisami ustawy dotyczącymi zasad powoływania członków zarządu i organu nadzorczego czy wymogów kwalifikacyjnych dot. tych osób (art. 18 i nast. ustawy) (zob. szerzej Kozłowska-Chyła, 2017, s. 13 i n.).

Podobny cel ma powołanie Rady do spraw spółek z udziałem Skarbu Państwa i państwowych osób prawnych, do której zadań należy przede wszystkim wydawanie opinii dotyczących kandydatów na członków organów nadzorczych wskazanych przez Skarb Państwa albo państwową osobę prawną. Rada opiniuje również kandydatów na członków organów nadzorczych w spółkach, wobec których spółka z udziałem Skarbu Państwa lub państwowej osoby prawnej jest przedsiębiorcą dominującym w rozumieniu przepisów ustawy o ochronie konkurencji i konsumentów (art. 24 pkt 1 ustawy o zasadach zarządzania mieniem państwowym). Należy przy tym podkreślić, że opiniowanie przez Radę wyżej wymienionych kandydatów ma charakter obligatoryjny, Rada fakultatywnie może również opiniować kandydatów

uprawniony do wykonywania praw z akcji należących do Skarbu Państwa lub państwowa osoba prawna, w zakresie wykonywania praw z akcji w spółce, są obowiązane podejmować działania mające na celu określenie, w drodze uchwały walnego zgromadzenia lub w statucie tej spółki, że zgody organu nadzorczego wymaga zawarcie przez spółkę umowy: 1) darowizny lub innej umowy o podobnym skutku o wartości przekraczającej 20000 złotych lub $0,1 \%$ sumy aktywów w rozumieniu ustawy z dnia 29 września 1994 r. o rachunkowości, ustalonych na podstawie ostatniego zatwierdzonego sprawozdania finansowego; 2) zwolnienia z długu lub innej umowy o podobnym skutku o wartości przekraczającej 50000 złotych lub $0,1 \%$ sumy aktywów w rozumieniu ustawy z dnia 29 września 1994 r. o rachunkowości, ustalonych na podstawie ostatniego zatwierdzonego sprawozdania finansowego. 4. Podmiot uprawniony do wykonywania praw z akcji należących do Skarbu Państwa lub państwowa osoba prawna, w zakresie wykonywania praw z akcji w spółce, są obowiązane podejmować działania mające na celu określenie, w drodze uchwały walnego zgromadzenia lub w statucie tej spółki, zasad zbywania składników aktywów trwałych w rozumieniu ustawy z dnia 29 września $1994 \mathrm{r}$. o rachunkowości. Zasady te muszą uwzględniać zastosowanie trybu przetargu oraz wyjątki od obowiązku jego zastosowania, w przypadku zbywania przez spółkę składników aktywów trwałych, o wartości przekraczającej $0,1 \%$ sumy aktywów w rozumieniu ustawy z dnia 29 września 1994 r. o rachunkowości, ustalonych na podstawie ostatniego zatwierdzonego sprawozdania finansowego, chyba że wartość ta nie przekracza 20000 zł. 5. Podmiot uprawniony do wykonywania praw z akcji należących do Skarbu Państwa lub państwowa osoba prawna, w zakresie wykonywania praw z akcji w spółce, mogą podejmować działania mające na celu określenie, w drodze uchwały walnego zgromadzenia lub w statucie tej spółki, surowszych wymagań niż określone w ust. 1-4. 6. Podmiot uprawniony do wykonywania praw z akcji należących do Skarbu Państwa lub państwowa osoba prawna, w zakresie wykonywania praw z akcji w spółce, są obowiązane podejmować działania mające na celu wprowadzenie, w drodze uchwały walnego zgromadzenia lub w statucie tej spółki, obowiązku przedkładania walnemu zgromadzeniu przez organ zarządzający zaopiniowanego przez organ nadzorczy, sprawozdania o wydatkach reprezentacyjnych, a także wydatkach na usługi prawne, usługi marketingowe, usługi w zakresie stosunków międzyludzkich (public relations) i komunikacji społecznej oraz usługi doradztwa związanego z zarządzaniem.

16 Art. 4 pkt 3 ustawy z dnia 16 lutego 2007 r. o ochronie konkurencji i konsumentów (t.j. Dz.U. 2015, poz. 184 z późn. zm.). 
na członków organów zarządzających spółek z udziałem Skarbu Państwa lub państwowej osoby prawnej oraz ich spółek zależnych (art. 26 ustawy) ${ }^{17}$. Ponadto, Rada posiada kompetencje w obszarze wydania opinii dotyczących dokumentów polityki państwa w zakresie zarządzania mieniem państwowym, projektów aktów normatywnych w zakresie zarządzania mieniem państwowym oraz - na wniosek Prezesa Rady Ministrów - spraw związanych z zarządzaniem mieniem państwowym (art. 24 pkt 2, 3 i 5 ustawy).

\section{Podsumowanie}

Dokonany powyżej, w wybranych obszarach, przegląd rozwiązań normatywnych wskazuje na wyraźną intencję ustawodawcy wzmocnienia roli państwa działającego w sferze dominium. W ramach stosunków właścicielskich z udziałem państwa następuje przede wszystkim „utrwalenie” dotychczasowego zakresu własności państwowej, poprzez normatywne odstąpienie od trybów prywatyzacji pośredniej i bezpośredniej majątku państwowego. Obecnie obowiązujący model jurydyczny bazuje na założeniu, że zbycie akcji lub udziałów należących do Skarbu Państwa lub do innej państwowej osoby prawnej wymaga zgody na poziomie Rady Ministrów, z jednoczesnym całkowitym wyłączeniem zbywalności akcji enumeratywnie wskazanych dwudziestu czterech spółek o strategicznym znaczeniu dla gospodarki kraju, m.in. Grupa Azoty S.A., Grupa Lotos S.A., Jastrzębska Spółka Węglowa S.A., KGHM Polska Miedź S.A., PKN Orlen S.A., PZU S.A. czy PKO BP S.A. Wszystkie spółki o istotnym znaczeniu dla gospodarki państwa (obecnie jest to trzydzieści spółek) poddane zostały szczególnemu nadzorowi Prezesa Rady Ministrów. Jednocześnie działania ustawodawcy zmierzają do poprawienia skuteczności działania państwa w ramach stosunków właścicielskich, czyli w sferze dominium, poprzez zwiększenie zakresu i efektywności nadzoru nad mieniem państwowym, szczególnie widoczne w obszarze działania spółek z udziałem Skarbu Państwa lub innych państwowych osób prawnych. Zastosowane instrumenty prawne zwiększają w efekcie zakres zaangażowania państwa w stosunki prywatnoprawne z jego udziałem.

\section{Bibliografia}

Całus, A. (1995). Problematyka prawna Skarbu Państwa. Biuletyn Rady Legislacyjnej, 6. Frąckowiak, J. (2012). W: M. Safjan (red.), System Prawa Prywatnego. Prawo cywilne - część ogólna (t. I, s. 1175 i n.). Warszawa: C.H. Beck.

17 Szerzej o organizacji i sposobie procedowania Rady do spraw spółek z udziałem Skarbu Państwa i państwowych osób prawnych zob. Kozłowska-Chyła, 2017, s. 13 i n. 
Kozłowska-Chyła, B. (2017). Nowe regulacje zasad zarządzania mieniem państwowym w zakresie powoływania i odwoływania członków organów nadzorczego i zarządzającego w spółkach z udziałem Skarbu Państwa. Przegląd Ustawodawstwa Gospodarczego, 2.

Rozporządzenie Prezesa Rady Ministrów z dnia 13 stycznia 2017 r. w sprawie określenia wykazu spółek o istotnym znaczeniu dla gospodarki państwa (Dz.U. 2017, poz. 95).

Rozporządzenie Rady Ministrów z dnia 3 stycznia 2017 r. w sprawie wykazu spółek, w których prawa z akcji Skarbu Państwa wykonują inni niż Prezes Rady Ministrów członkowie Rady Ministrów, pełnomocnicy Rządu lub państwowe osoby prawne (Dz.U. 2017, poz. 10).

Ustawa z dnia 15 grudnia 2016 r. o Prokuratorii Generalnej Rzeczypospolitej Polskiej (Dz.U. 2016, poz. 2261).

Ustawa z dnia 15 września 2000 r. - Kodeks spółek handlowych (t.j. Dz.U. 2016, poz. 1578, $1579,2255)$.

Ustawa z dnia 16 grudnia 2016 r. - Przepisy wprowadzające ustawę o zasadach zarządzania mieniem państwowym (Dz.U. 2016, poz. 2260).

Ustawa z dnia 16 grudnia 2016 r. o zasadach zarządzania mieniem państwowym (Dz.U. 2016, poz. 2259).

Ustawa z dnia 16 lutego 2007 r. o ochronie konkurencji i konsumentów (t.j. Dz.U. 2015, poz. 184 z późn. zm.).

Ustawa z dnia 30 sierpnia 1996 r. o komercjalizacji i prywatyzacji (t.j. Dz.U. 2016, poz. 981 z późn. zm.).

Ustawa z dnia 8 sierpnia 1996 r. o zasadach wykonywania uprawnień przysługujących Skarbowi Państwa (t.j. Dz.U. 2016, poz. 154 z późn. zm.).

Uzasadnienie do projektu ustawy o zasadach zarządzania mieniem państwowym.

www.orka.sejm.gov.pl. 
